\title{
Are Independent Directors Effective Corporate Monitors? \\ - An Analysis of the Empirical Evidence in the USA and Canada
}

\author{
Brian Yiching Lai
}

Thesis submitted to the

Faculty of Graduate and Postdoctoral Studies

in partial fulfillment of the requirements

for the Doctor of Laws (LL.D.) degree

\author{
Faculty of Law \\ University of Ottawa
}

(C) Brian Yiching Lai, Ottawa, Canada, 2014 


\begin{abstract}
This thesis explores whether independent directors in the USA and Canada are effective in holding management accountable by: (1) analyzing how the policy of relying on independent directors developed and operates; (2) introducing the main theoretical critiques of independent directors' monitoring effect; and (3) examining whether empirical studies in the field of management science and financial economics support the policy in both countries of relying on independent directors as corporate monitors.

Empirical evidence shows that boards with a majority of independent directors, in some circumstances, were associated with better firm performance (in the post-SOX period) and fulfilled certain board tasks effectively in the United States. Canadian studies, however, have not shown a positive association with improved firm performance. Audit committees composed entirely of independent directors have been effective in ensuring the quality of financial reporting in the United States, but this effect has not been found in Canada. Compensation committees composed fully of independent directors neither constrained the level of executive compensation nor tied CEO pay to firm performance in either country. US firms with an audit committee member who had accounting expertise, rather than financial analysis or supervisory expertise, were associated with a higher quality of financial reporting, while Canadian firms with an audit committee member who has financial expertise, instead of financial literacy, were associated with a similar effect. Studies also showed that independent directors perform better in certain circumstances.

Based on empirical evidence, US regulators should consider: (1) changing the current mandatory requirements for an independent board and a completely independent compensation committee to a comply-or-explain requirement; (2) narrowing the qualification of a financial expert to an individual who has accounting expertise; and (3) recruiting independent directors who have two or fewer outside directorships, hold more of the corporation's shares, have lower cost of acquiring corporate information, and have no social connections with the CEO. In Canada, weak evidence of the monitoring effectiveness of independent directors supports the existing comply-or-explain approach. Canadian regulators may only need to require or recommend that at least one audit committee member has financial expertise, instead of only financial literacy.
\end{abstract}




\section{Acknowledgements}

I would like to thank my thesis supervisor, Professor VanDuzer, for his wise counsel, encouragement and tremendous patience. He is not only the most important mentor in my academic work but also a considerate advisor in my career development. I am fortunate enough to have such a good supervisor.

I would also like to show gratitude to the members of my committee: Professors Walid Ben Amar, Jennifer A Quaid, P.M. Vasudev, and Poonam Puri, for their precious time and insightful suggestions. I remain indebted to Professors Dongsheng Tu at Queen's University and Zhongjun Qu at Boston University, who provided expert advice for my empirical analysis.

Finally, I am very grateful to my wife, Lynn Guo. She supported the family during my LL.D. journey. Without her indulgence and encouragement, this thesis would not have been finished. I also thank my two lovely sons, Allen and David, who put with their father's busyness to work on his dissertation, mostly without complaint. 


\section{Table of Contents}

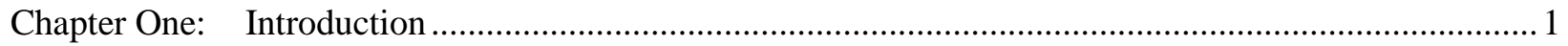

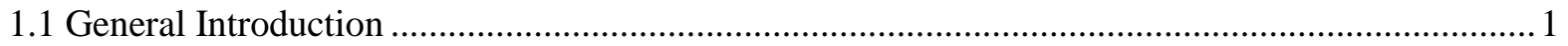

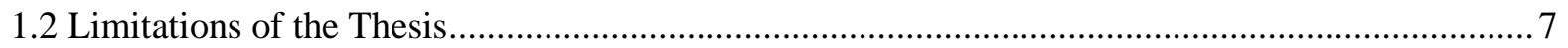

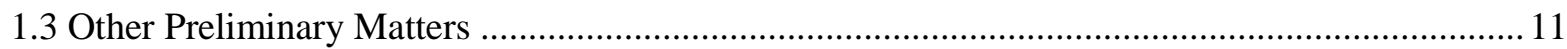

Chapter Two: The Development of the Policy of Relying Independent Directors as Corporate Monitors

2.1 The Historical Roots of the Policy of Relying on Independent Directors................................... 14

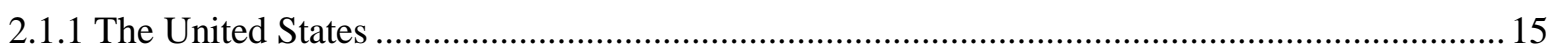

2.1.1.1 The Recognition of Agency Problems and the Initiatives during the 1930s and the 1940s 15

2.1.1.2 The Passiveness of Advisory Boards and Corporate Scandals in the 1970s...................... 18

2.1.1.2.1 Advisory Board in the 1950s and 1960s .............................................................. 18

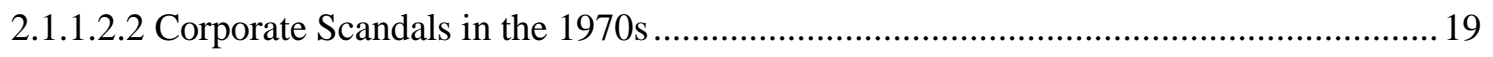

2.1.1.3 The Promotion of the Audit Committee.............................................................................. 22

2.1.1.4 The Promotion of the Monitoring Role of Independent Directors by the Academic, Legal

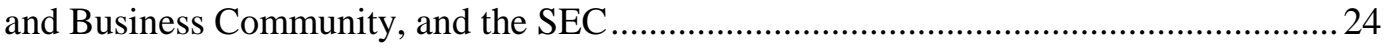

2.1.1.4.1 Professor Melvin Eisenberg's Monitoring Model......................................................25

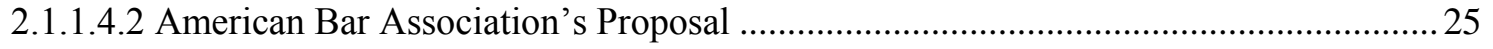

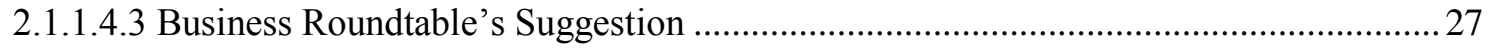

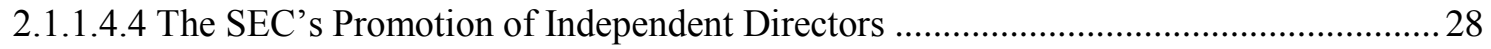

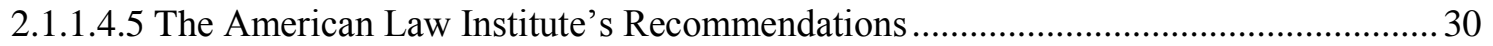

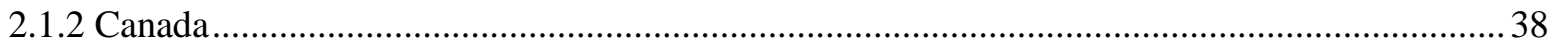

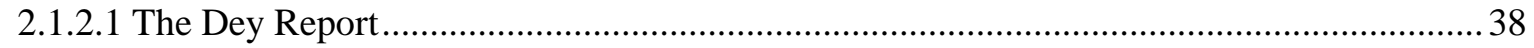

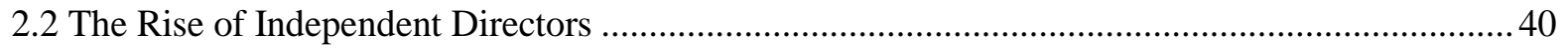

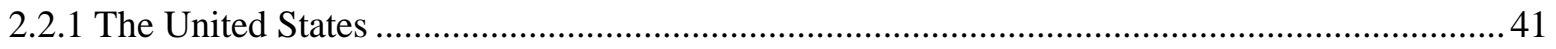

2.2.1.1 The Court and Legislatures Rely on Independent Directors during the 1980s and 1990s .. 41

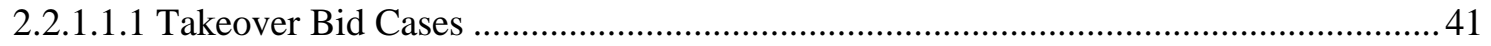

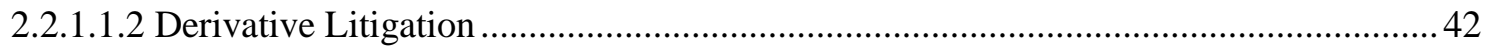

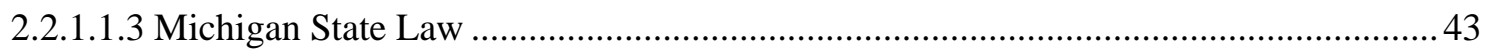

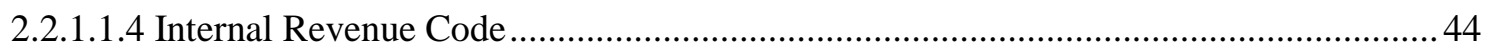

2.2.1.2 The Blue Ribbon Committee, NYSE and NASDAQ Rely on Independent Directors to Ensure the Integrity of Financial Reporting Process in the Late 1990s ............................45 
2.2.1.3 The Sarbanes-Oxley Act and the Related Reforms in Response to Corporate Scandals in the early $2000 \mathrm{~s}$

2.2.1.4 Dodd-Frank Wall Street Reform and Consumer Protection Act Regarding the Compensation Committee Composition ..................................................................5 54

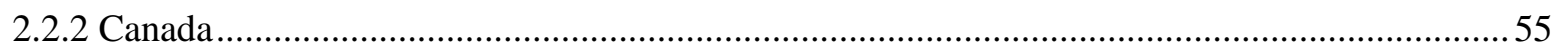

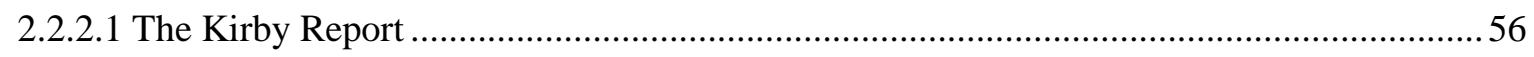

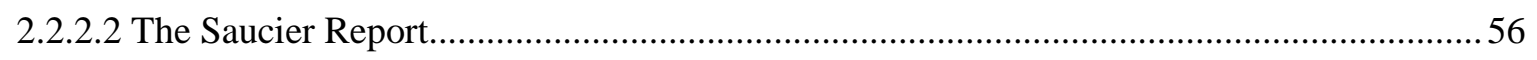

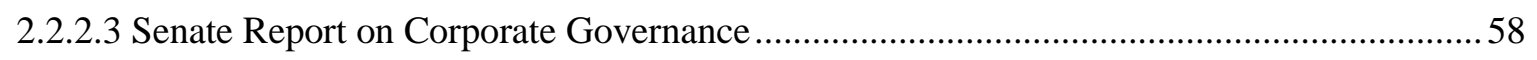

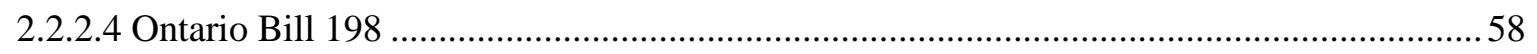

2.2.2.5 CSA Measures in Response to Corporate Scandals in the 2000s ..................................... 61

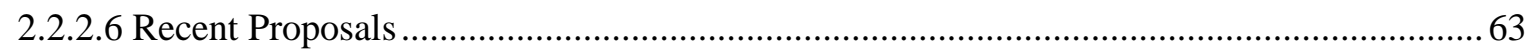

2.3 Theoretical and Empirical Bases for Arguments that Independent Directors are Effective

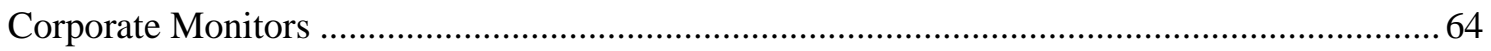

2.3.1 Reputation Capital (The Market for Director Services) Theory ….........................................65

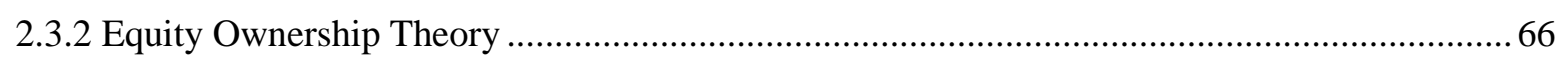

Chapter Three: Critiques of the Effectiveness of Independent Directors as Corporate Monitors ..............70

3.1 A Theory regarding the Ineffectiveness of Independent Directors as Corporate Monitors-

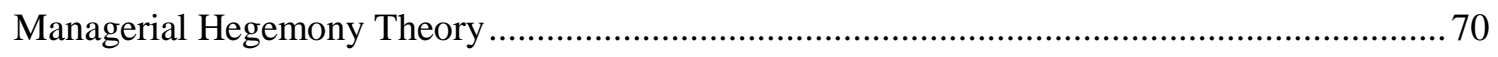

3.1.1 Biases in the Nomination and Selection Process ................................................................. 71

3.1.2 Constraints on Independent Directors' Ability to Monitor Effectively.................................... 72

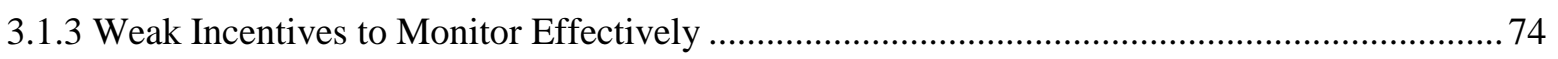

3.2 Specific Critiques Regarding the Ineffectiveness of Independent Directors as Corporate Monitors

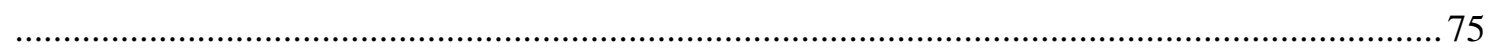

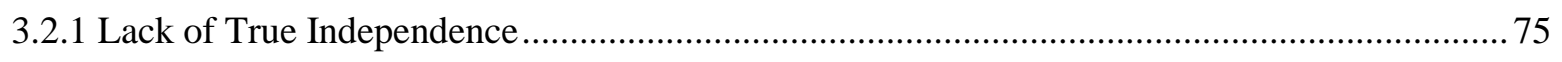

3.2.1.1 The Negative Impact of the Sponsorship Relationship on Enron's Board Members .........76

3.2.1.2 Delaware Cases Showing a Negative Impact of Non-financial Ties and Friendships on

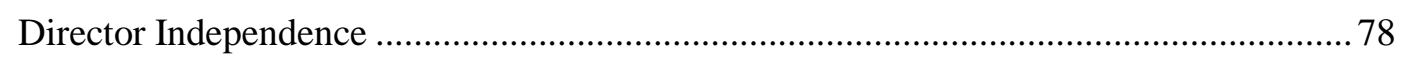

3.2.1.3 Empirical Evidence Showing a Negative Impact of Social Ties on the Effectiveness of

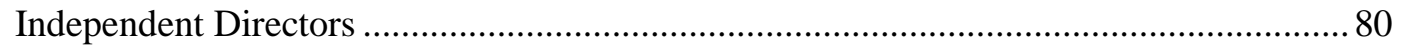

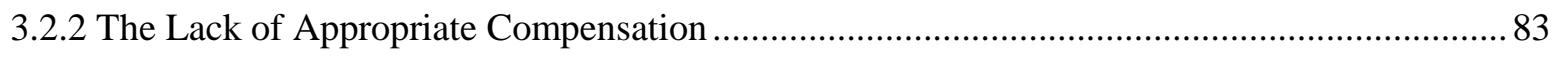

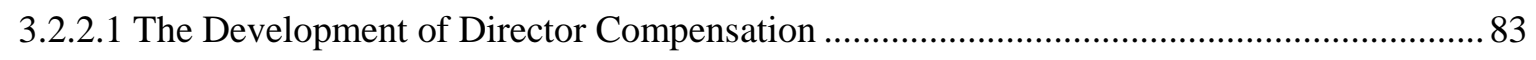

3.2.2.2 The Advantages and Disadvantages of Stock-based Compensation for Independent

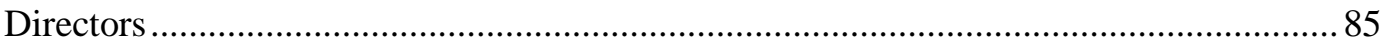




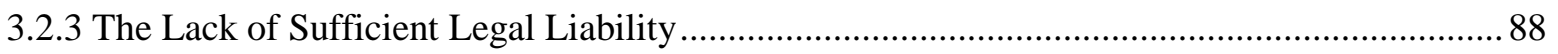

3.2.3.1 Director Legal Liability in the United States ............................................................. 90

3.2.3.1.1 Substantive Liability Rules Regarding Independent Directors ................................. 91

3.2.3.1.2 Protections for Independent Directors against Nominal Liability ............................... 94

3.2.3.1.3 The Out-of-Pocket Liability Exposure of Independent Directors ............................... 95

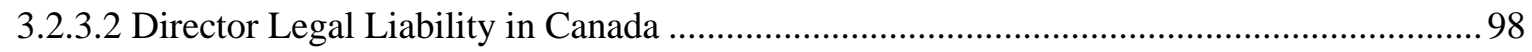

3.2.3.2.1 Substantive Liability Rules Regarding Independent Directors ................................. 98

3.2.3.2.2 Protections for Independent Directors against Nominal Liability.............................. 101

3.2.3.2.3 The Out-of-Pocket Liability Exposure of Independent Directors .............................. 102

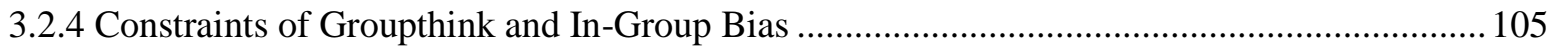

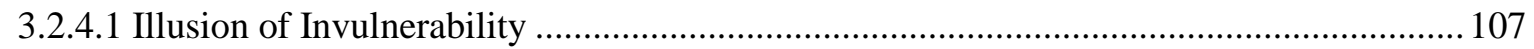

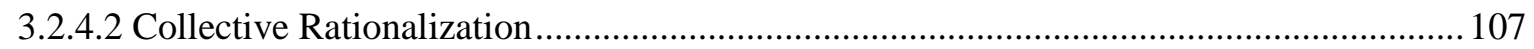

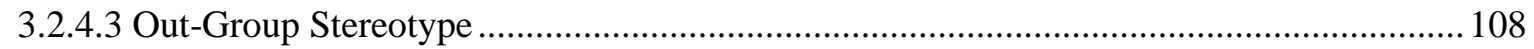

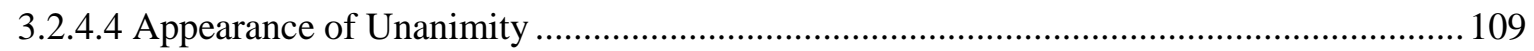

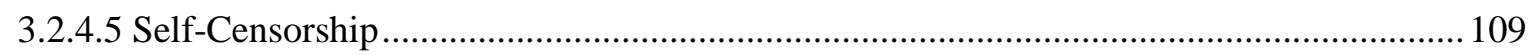

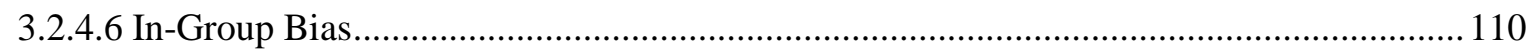

3.2.5 The Overemphasis on Independent Directors' Monitoring Function May Undermine

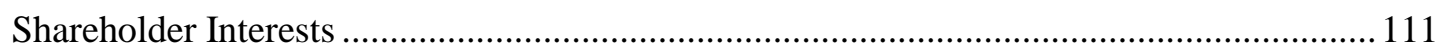

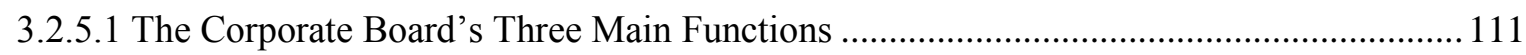

3.2.5.2 The Trade-off between a Board's Monitoring Function and Managing Function ............ 113

3.2.5.3 The Optimal Level of Board Independence Varies with Firm-specific Characteristics ... 115

Chapter Four: How Current Laws and Regulations Rely on Independent Directors as Corporate

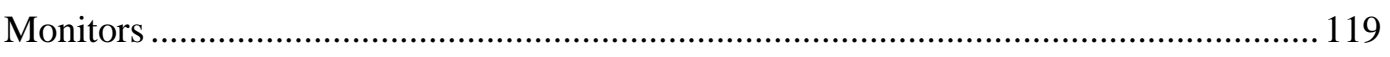

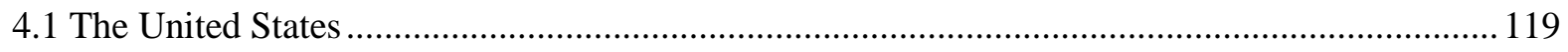

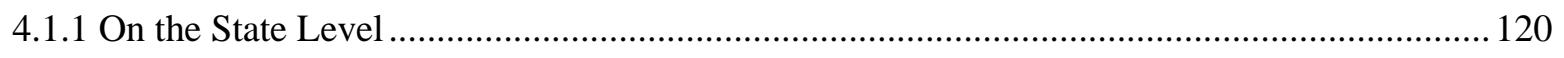

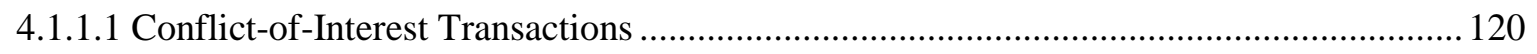

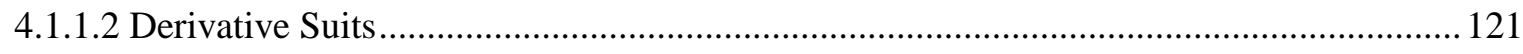

4.1.1.3 Defensive Measures against Hostile Takeovers............................................................. 123

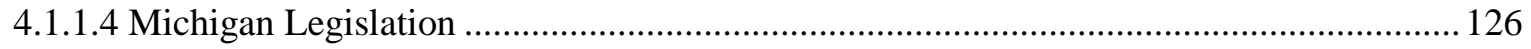

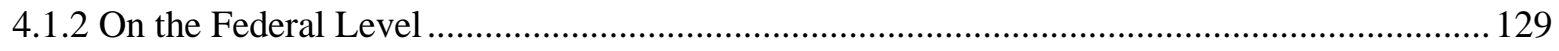

4.1.2.1 Tightening the Definition of Independent Directors ...................................................... 129

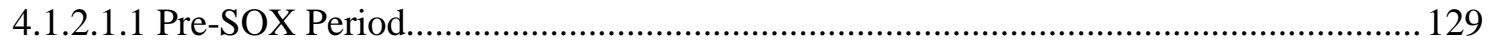

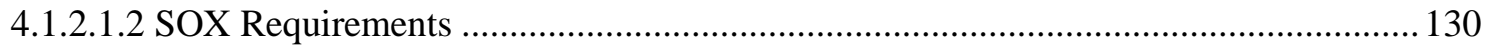




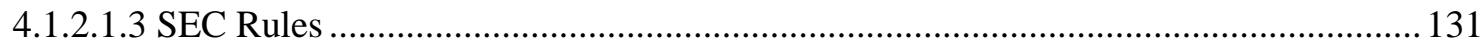

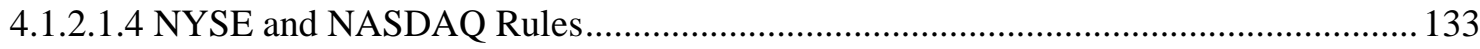

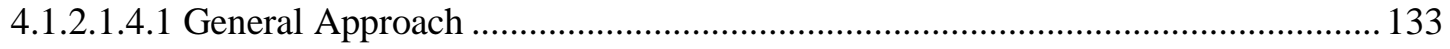

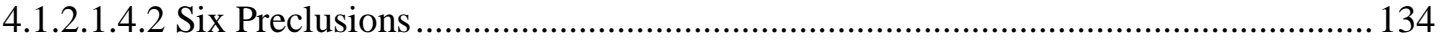

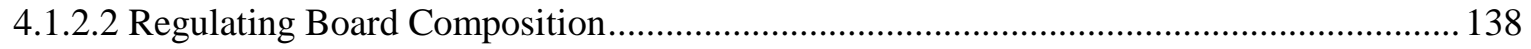

4.1.2.3 Stifling the Influence of Management in the Boardroom .............................................. 139

4.1.2.4 Mandating Three Key Board Functions: Auditing Supervision, Setting Executive

Compensation and Nomination of New Directors ........................................................ 141

4.1.2.4.1 The Board's Financial Reporting Oversight Function ............................................... 141

4.1.2.4.1.1 Composition of the Audit Committee and the Qualification of the Audit

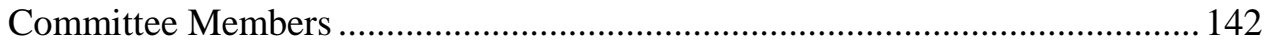

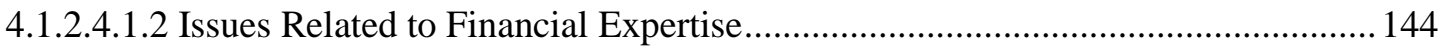

4.1.2.4.1.3 Charter and Responsibilities (of the Audit Committee) ....................................... 150

4.1.2.4.2 The Board's Director Nomination Oversight Function............................................. 154

4.1.2.4.2.1 The Establishment and Composition of the Nominating Committee................... 154

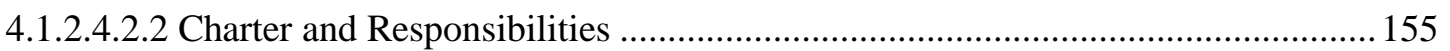

4.1.2.4.3 The Board's Executive Compensation Oversight Function........................................ 156

4.1.2.4.3.1 The Establishment and Composition of the Compensation Committee............... 157

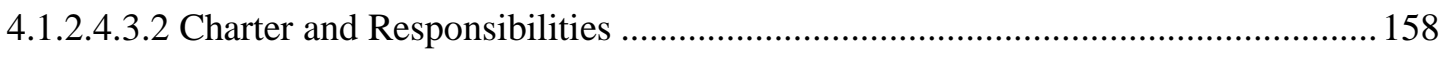

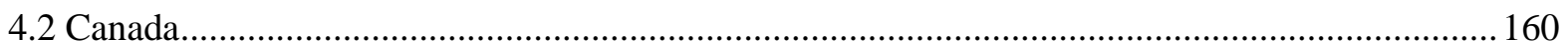

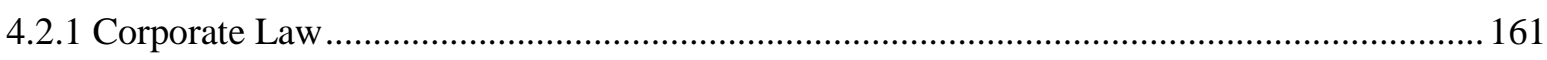

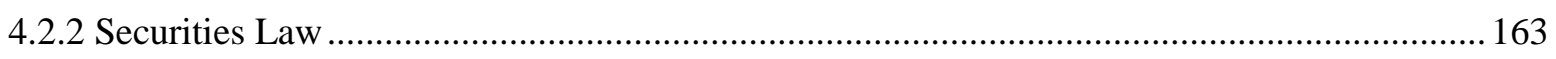

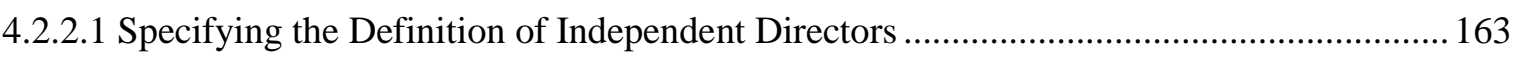

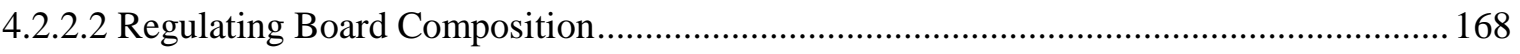

4.2.2.3 Recommending Certain Procedures in the Boardroom to Stifle the Influence of

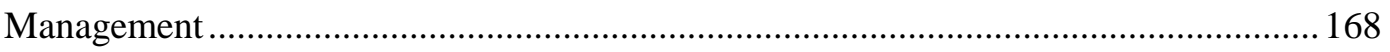

4.2.2.4 Mandating Three Key Board Functions: Oversight of Auditing, Setting Executive

Compensation and Nomination of Directors ............................................................ 170

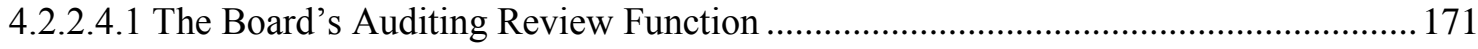

4.2.2.4.1.1 Composition of the Audit Committee and Qualification of the Audit Committee

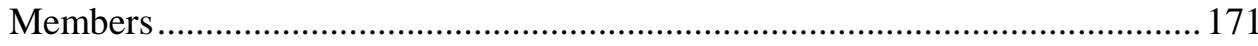

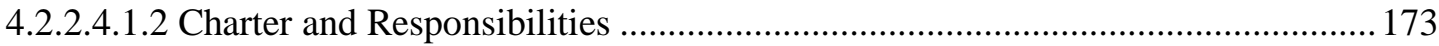

4.2.2.4.2 The Board's Director Nomination Oversight Function........................................... 175

4.2.2.4.2.1 The Establishment and Composition of the Nominating Committee.................. 175 


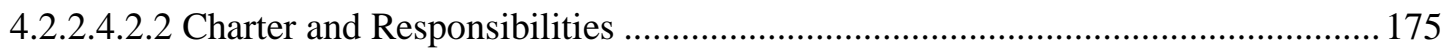

4.2.2.4.3 The Board's Executive Compensation Oversight Function ...................................... 177

4.2.2.4.3.1 The Establishment and Composition of the Compensation Committee............... 177

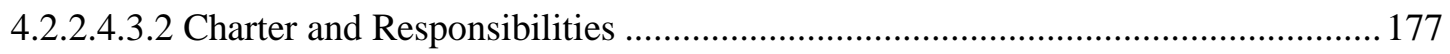

4.2.3 Courts' Reliance on Independent Directors .................................................................... 178

Chapter Five: Empirical Evidence Regarding the Effectiveness of Independent Directors ................. 184

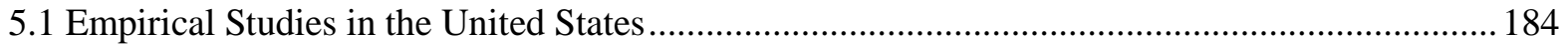

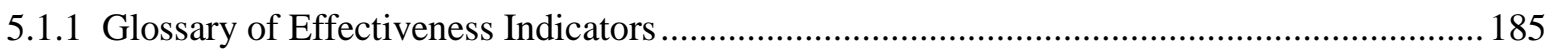

5.1.2 Factors That May Affect the Reliability of Empirical Findings Regarding the Efficacy of

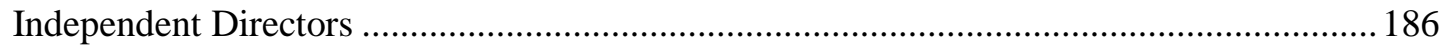

5.1.3 Board Independence and Overall Firm Performance …..................................................... 193

5.1.3.1 Five Studies Reporting Positive Relationship between Director Independence and Firm Performance

5.1.3.2 Five Studies Reporting Negative Relationship between Director Independence and Firm Performance

5.1.3.3 Studies Showing No Relationship between Independent Directors and Firm Performance 201

5.1.4 Board Independence and Performance of Specific Board Tasks ....................................... 207

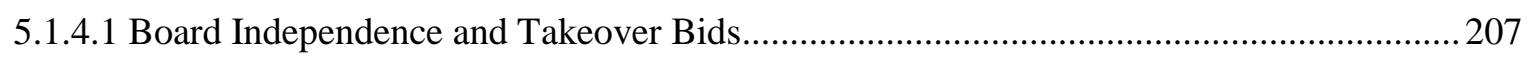

5.1.4.1.1 Board Composition and Shareholder Wealth in Bidding Firms ............................... 208

5.1.4.1.2 Board Independence and Shareholder Interests in Target Firms During a Tender Offer 209

5.1.4.1.3 The Impact of Board Independence on Takeover Defenses and Shareholder Wealth in

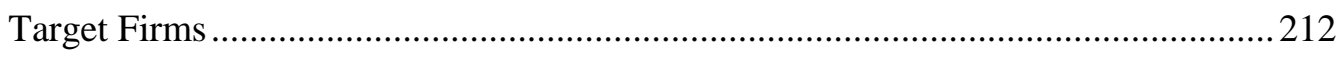

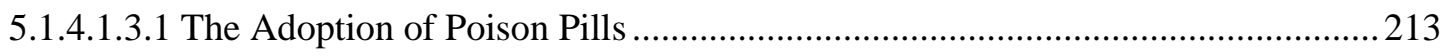

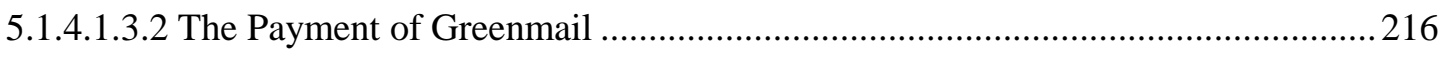

5.1.4.1.3.3 The Adoption of Golden Parachutes ................................................................. 217

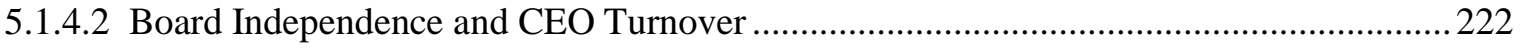

5.1.4.3 Board Independence and Executive Compensation ......................................................... 226

5.1.4.4 Board Independence and Management Buyouts ............................................................. 233

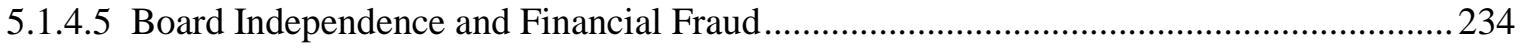

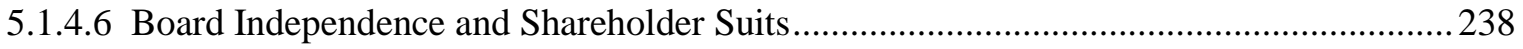

5.1.5 The Effectiveness of Independent Directors on Specific Board Committees ....................... 243 
5.1.5.1.1 The Relationship between Two Audit Committee Characteristics, the Presence of An Audit Committee and Firm Performance. 246

5.1.5.1.2 The Relationship between Two Audit Committee Characteristics, the Presence of An Audit Committee and the Quality of Financial Reporting.

5.1.5.1.2.1 The Impact of the Presence of an Audit Committee on the Quality of Financial

Reporting. 250

5.1.5.1.2.2 The Impact of the Audit Committee Independence on the Quality of Financial Reporting.

5.1.5.1.2.3 The Relationship between Different Types of Financial Expertise and the Quality

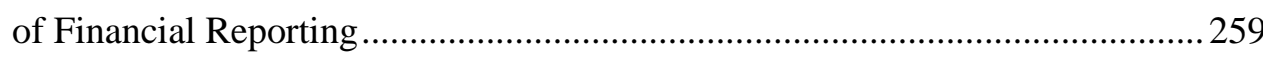

5.1.5.2 The Compensation Committee 266

5.1.5.2.1 The Association between the Existence or the Level of Independence of the Compensation Committee and Firm Performance 267

5.1.5.2.2 The Relationship between the Proportion of Independent Directors on the Compensation Committee and the Level of CEO Compensation .268

5.1.5.2.3 The Correlation between Compensation Committee Independence and the Sensitivity of CEO Pay to Firm Performance 271

5.1.5.3 The Nominating Committee...... 273

5.1.6 Evidence Regarding Other Governance Mechanisms Influencing the Effectiveness of

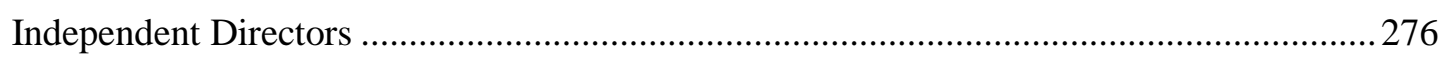

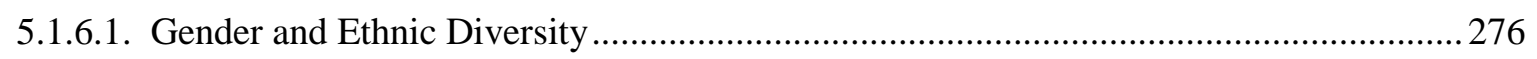

5.1.6.1.1 The Relationship between Ethnic Minority Directors on the Board and Firm Performance .278

5.1.6.1.2 The Association between Ethnic Minority Directors on the Three Monitoring Committees and Firm Performance .................................................................... 278

5.1.6.1.3 The Correlation between Female Directors on the Board and Firm Performance .....279

5.1.6.1.4 The Correlation between Female on the Three Monitoring Committees and Firm

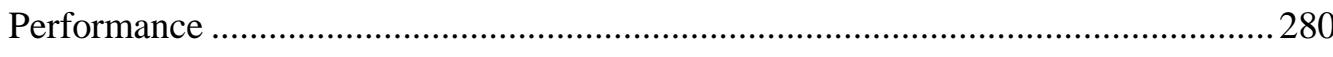

5.1.6.1.5 The Relationship between Female and Other Discrete Board Tasks ....................... 281

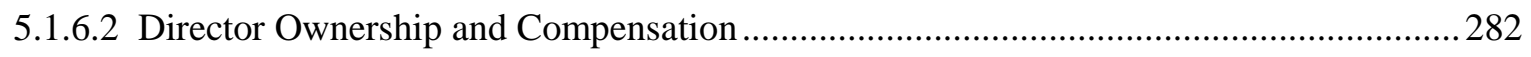

5.1.6.2.1 The Impact of Director Share Ownership on Firm Performance .............................. 283

5.1.6.2.2 The Impact of Director Incentive Compensation on Shareholder Interests ...............285 
5.1.6.2.2.1 The Impact of Stock Options for Independent Directors on Shareholder Interests 286

5.1.6.2.2.2 The Impact of Stock Grants for Independent Directors on Shareholder Interests 288

5.1.6.2.2.3 The Impact of Incentive Plans Combining Stock Options and Stock Grants on Shareholder Interests

5.1.6.2.3 The Relationship between Director Share Ownership (or Incentive Pay) and the Sensitivity of CEO Turnover to Firm Performance 290

5.1.6.3 Multiple Directorships 292

5.1.6.3.1 The Impact of Independent Directors Holding Multiple Directorships on Firm Value 293

5.1.6.3.2 Market Reaction to the Appointment of a Busy Independent Director. 295

5.1.6.3.3 The Correlation between Committee Service and Directors Holding Multiple Board Seats 296

5.1.6.3.4. The Relationship between Other Factors and Independent Directors Holding Multiple Board Seats 297

5.1.6.4 Market for Corporate Control (or Barriers to the Market for Corporate Control) 299

5.1.6.5 Information Cost 304

5.1.6.6 Leadership Structure 307

5.1.6.6.1 The Connection between Firm Performance and Different Types of Leadership Structure (Without Considering the Impact of Independent Directors) 307

5.1.6.6.2 The Relationship between Different Types of Leadership Structure and the Efficacy of

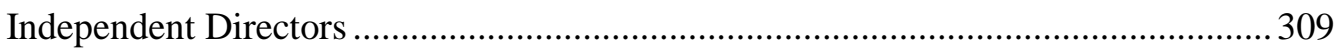

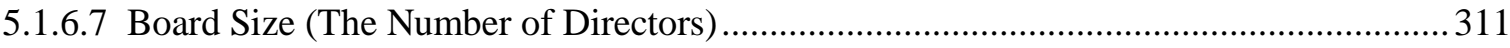

5.1.6.8 Board Meeting Frequency (Board Diligence) ............................................................... 315

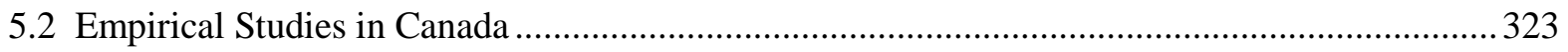

5.2.1 Board Independence and Overall Firm Performance ...................................................... 323

5.2.1.1 The Relationship between Outside Directors and Firm Performance Before 1994 .......... 324

5.2.1.2 The Relationship between Unrelated Directors and Firm Performance After the Dey

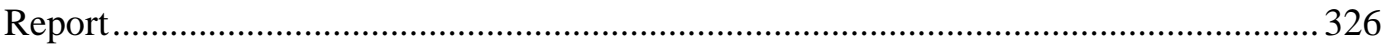

5.2.1.3 The Relationship between Outside Directors and Firm Performance Regarding SOEs ... 329

5.2.1.4 The Correlation between ROB Board Composition Scores and Firm Performance After 2002 
5.2.1.5 The Connection between SOX Director Independence Requirements and Firm

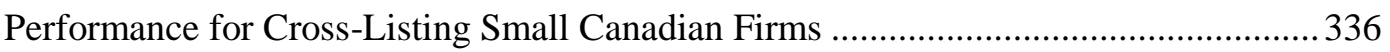

5.2.2 Board Independence and Other Monitoring Mechanisms ................................................... 340

5.2.3 Director Independence and the Quality of Financial Reporting ......................................... 341

5.2.4. Director Independence and Executive Compensation......................................................... 346

5.2.5 Evidence Regarding Other Mechanisms Influencing the Effectiveness of Independent

Directors

5.2.5.1 The Relationship between the Presence of Controlling Shareholders and Independent

Directors

5.2.5.1.1 The Impact of Ownership Concentration on Firm Performance.

351

5.2.5.1.2 The Impact of the Presence of Controlling Shareholders on the Effectiveness of Independent Directors

5.2.5.2 Gender Diversity

5.2.5.3 Board Size 355

5.2.5.4 Leadership Structure 356

Chapter Six: An Analysis of the Effectiveness of Independent Directors in North America 359

6.1 Whether Empirical Findings Support the Current Measures Relying on Independent Directors as

Corporate Monitors? 359

6.1.1 In the United States 361

6.1.1.1 Whether a Board Composed of a Majority of Independent Directors Is More Likely to Benefit Shareholders 362

6.1.1.1.1 Whether a Board Composed of a Majority of Independent Directors Is More Likely to Perform Better. 362

6.1.1.1.2 Whether a Board Composed of a Majority of Independent Directors Is More Likely to

Protect Shareholder Interests in Relation to Discrete Board Tasks...... 366

6.1.1.2 Whether the Level of Independence in the Audit, Compensation and Nominating

Committees Has a Significant Impact on Shareholder Interests 372

6.1.1.2.1 Whether the Level of Audit Committee Independence Has an Impact on Shareholder Interests 372

6.1.1.2.2 Whether the Level of Compensation Committee Independence Has an Impact on Shareholder Interests 375

6.1.1.2.3 Whether the Level of Nominating Committee Independence Has an Impact on Shareholder Interests 378 
6.1.1.3 Whether Financial Literacy and the Types of Financial Expertise Affect the Quality of

Financial Reporting

6.1.1.4 Whether the Current Definition of Director Independence Is Sufficient to Prevent

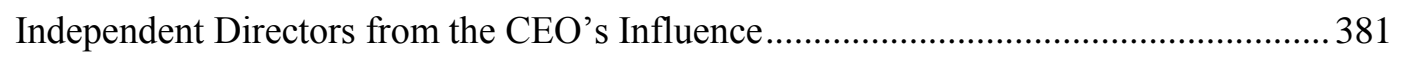

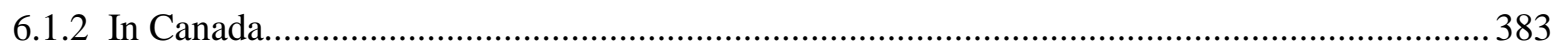

6.1.2.1 Whether a Board Comprised of a Majority of Independent Directors Is More Likely to

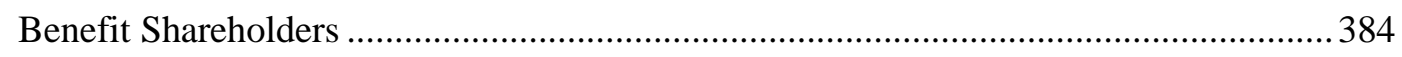

6.1.2.2 Whether Completely Independent Audit and Compensation Committees Have a

Significant Impact on the Achievement of Their Committee Missions ............................ 387

6.1.2.3 Whether Financial Expertise and Financial Literacy Affect the Quality of Financial

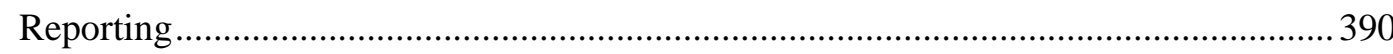

6.2 The Possible Explanations for the Inconsistency Between Empirical Evidence and the

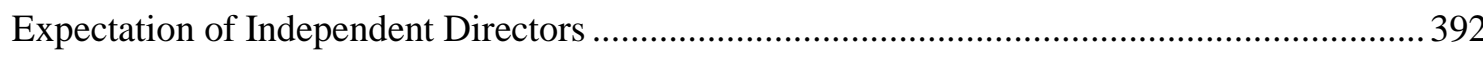

6.3 Other Factors That May Affect the Effectiveness of Independent Directors Have Not Been

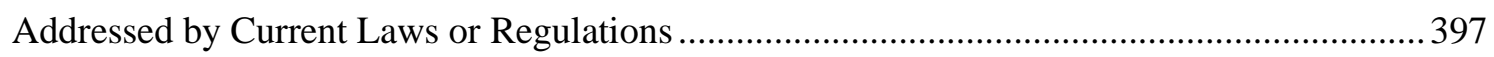

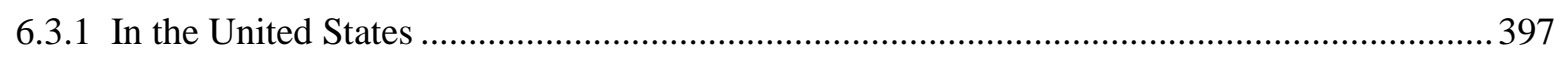

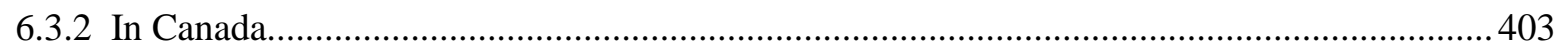

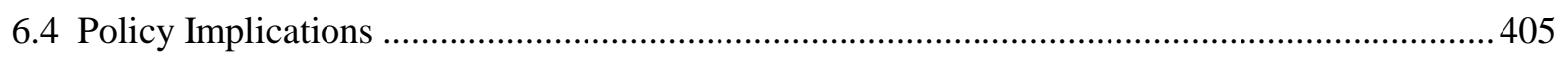

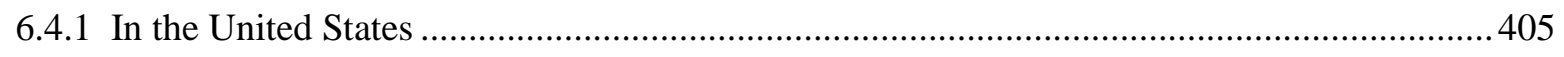

6.4.1.1 The Criteria to Determine Whether a Director Is Independent Should Be Tightened ..... 406

6.4.1.2 The Requirement of Having a Majority of Independent Directors on the Board Needs to

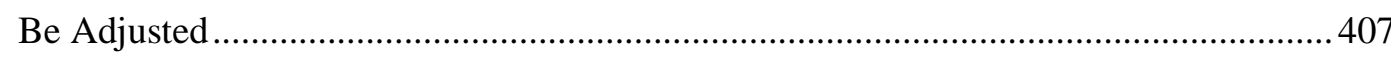

6.4.1.2.1 Problems of the Requirement of Having a Majority of Independent Directors on the

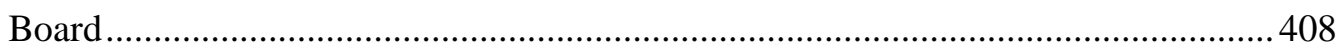

6.4.1.2.2 The US Regulators May Consider Adopting the Comply-or-explain Approach ....... 409

6.4.1.2.3 Regulators May Consider Adopting Supporting Measures to Enhance the

Effectiveness of Independent Directors

6.4.1.3 The Requirement That the Audit Committee Be Composed Entirely of Independent

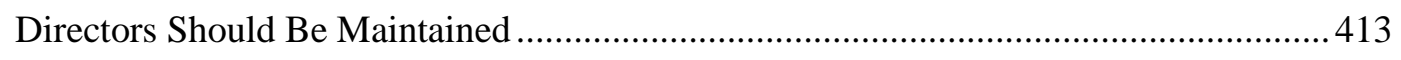

6.4.1.4 The Definition of a Financial Expert Should Be Tightened.......................................... 414

6.4.1.5 The Requirement That the Compensation Committee Be Composed Entirely of Independent Directors May Need to Be Changed to Only a Recommendation and Supporting Measures May Also Be Needed .415 
6.4.1.6 The Requirement That the Nominating Committee Be Composed Entirely of Independent Directors May Need to Be Changed to Only a Recommendation

6.4.1.7 Courts May Need to Examine Relevant Factors That May Impair Independent Directors' Monitoring Effect When Reviewing Decisions Made by Independent Directors ........... 419

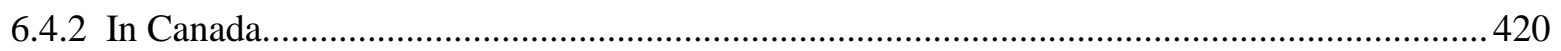

6.4.2.1 The Recommendation of Having a Majority of Independent Directors on the Board Should Be Maintained.

6.4.2.2 The CSA Should Require or Recommend That at Least One Member of the Audit Committee Be a Financial Expert

6.4.2.3 The Requirement of Having an Audit Committee Composed Entirely of Independent Directors May Not Need to Be Changed, But Further Research Is Needed 423

6.4.2.4 The Recommendation of Having a Compensation Committee Composed Entirely of Independent Directors May Not Need to Be Changed, But Further Research Is Needed
6.4.2.5 Ontario Courts May Need to Examine Relevant Factors That May Impair Independent Directors' Monitoring Effect When Reviewing Recommendations Made by Independent Directors 426

Chapter Seven : Conclusion 427

7.1 What Did Empirical Evidence Say About the Effectiveness of Independent Directors 427

7.2 What Regulators Can Do to Make Independent Directors More Effective 428

7.3 Where Further Research Is Needed in the United States and Canada.

Appendix 1 Summary of US Empirical Studies Regarding the Relationship between Board Independence and Firm Performance.

Appendix 2 Summary of US Empirical Studies Investigating the Relationship between Board Independence and the Effects of Takeover Bids. 436

Appendix 3 Summary of US Empirical Studies Investigating the Relationship between Board Independence and CEO Turnover 439

Appendix 4 Summary of US Empirical Studies Investigating the Relationship between Board Independence and Executive Compensation .440

Appendix 5 Summary of US Empirical Studies Investigating the Relationship between Board Independence and Management Buyouts 
Appendix 6 Summary of US Empirical Studies Investigating the Relationship between Board

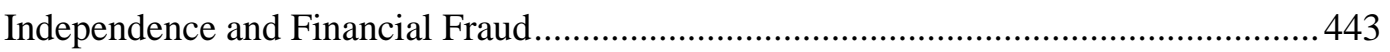

Appendix 7 Summary of US Empirical Studies Investigating the Relationship between Board

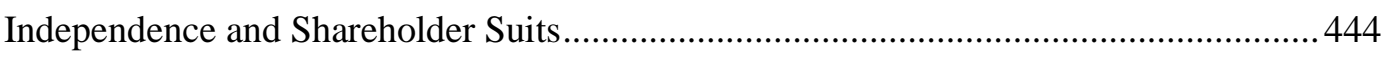

Appendix 8 Summary of US Studies Investigating the Impact of Audit Committee Independence on

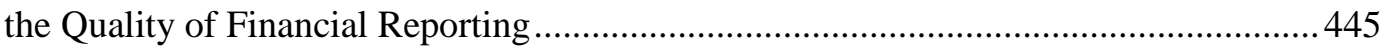

Appendix 9 Summary of US Empirical Studies Investigating the Relation between Different Types of Financial Expertise and the Quality of Financial Reporting .....

Appendix 10 Summary of US Empirical Studies Investigating the Relationship between Compensation Committee Independence and the Missions of the Committee

Appendix 11 Summary of US Empirical Studies Investigating the Correlation between Nominating Committee Characteristics and the Missions of the Committee 455

Appendix 12 Summary of US Empirical Studies Investigating the Impact of Female and Ethnic Minority on the Effectiveness of Independent Directors 456

Appendix 13 Summary of US Empirical Studies Investigating the Impact of Director Ownership on the Effectiveness of Independent Directors

Appendix 14 Summary of US Empirical Studies Investigating the Impact of Multiple Directorships on the Effectiveness of Independent Directors. 470

Appendix 15 Summary of US Empirical Studies Investigating the Relationship between Market (or the Barriers to the Market) for Corporate Control and Board Independence. 474

Appendix 16 Summary of US Empirical Studies Investigating the Relationship between Information Cost and the Effectiveness of Independent Directors. 475

Appendix 17 Summary of US Empirical Studies Investigating the Relationship between the Types of Leadership Structure and the Effectiveness of Independent Directors 476

Appendix 18 Summary of US Empirical Studies Investigating the Relationship between the Board Size and the Effectiveness of Independent Directors 480

Appendix 19 Summary of US Empirical Studies Investigating the Relationship between Directors' Meeting Frequency and Their Efficacy. 482

Appendix 20 Summary of Canadian Empirical Studies Investigating the Relationship between Board Independence and Firm Performance. 486

Appendix 21 Summary of Canadian Empirical Studies Investigating the Relationship between Board Independence and the Adoption of Other Monitoring Mechanisms 491

Appendix 22 Summary of Canadian Empirical Studies Investigating the Relationship between Director Independence (or Financial Expertise) and the Quality of Financial Reporting 492 
Appendix 23 Summary of Canadian Empirical Studies Investigating the Relationship between Director

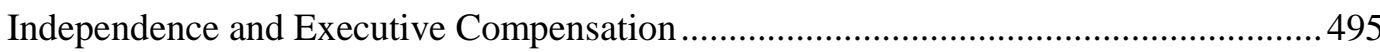

Appendix 24 Summary of Canadian Empirical Studies Investigating the Relationship between Female

Directors on the Board and Firm Performance

Appendix 25 Summary of Canadian Empirical Studies Investigating the Relationship between the

Number of Directors on the Board (Board Size) and Firm Performance

Appendix 26 Summary of Canadian Empirical Studies Investigating the Relationship between

Leadership Structure, Board Independence and Firm Performance

Appendix 27 Summary of Canadian Empirical Studies Investigating the Relationship between

Controlling Shareholders and the Efficacy of Independent Directors 500

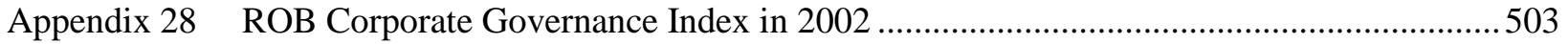

Appendix 29 Problems of 13 Canadian Empirical Studies Exploring the Relationship between Independent Directors and Firm Performance

Appendix 30 Problems of 14 US Empirical Studies Exploring the Relationship between Independent Directors and Firm Performance 


\section{Chapter One Introduction}

\subsection{General Introduction}

Requiring boards to have independent directors has been one of the most important strategies for holding management accountable for more than thirty years. In the United States, independent directors have populated at least two-thirds of board seats of publicly-held corporations since the end of last century. ${ }^{1}$ However, high levels of board independence still failed to either identify or prevent serious accounting misdeeds or managerial misconduct, such as that at Enron ${ }^{2}$, and WorldCom ${ }^{3}$, in the early part of the new millennium. Nevertheless, American legislators' and regulators' reforms in response to these corporate scandals, like Sarbanes-Oxley Act $(\mathrm{SOX})^{4}$ and new rules of stock exchanges ${ }^{5}$, remained focused on relying on the presence of independent directors as the key mechanism to ensure management accountability. Similarly, in Canada, most large listed companies have boards with a majority of

\footnotetext{
${ }^{1}$ Sanjai Bhagat \& Bernard Black, "The Non-Correlation Between Board Independence and Long-Term Firm Performance" (2002) 27 The J Corp L 231 at 232 [Bhagat \& Black 2002]; Jeffrey N Gordon, "The Rise of Independent Directors in the United States, 1950-2005: Of Shareholder Value and Stock Market Prices" (2007) 59 Stan L Rev 1465 at 1565 Table 1 [Gordon, The Rise of Independent Directors].

${ }^{2}$ US The Permanent Subcommittee on Investigations of the Committee on Governmental Affairs United States Senate, The Role of the Board of Directors in Enron's Collapse (S Prt 107-70) (Washington, DC: United States Government Printing Office, 2002) at 3, online: FindLaw <http://news.findlaw.com/hdocs/docs/enron/senpsi70802rpt.pdf > [Senate Enron Report]; Stuart L Gillan \& John D Martin, "Corporate Governance Post-Enron: Effective Reforms, or Closing the Stable Door?" (2007) 13 Journal of Corporate Finance 929, at 930, 934-35, 937 [Gillan \& Martin].

${ }^{3}$ United States Bankruptcy Court Southern District of New York, First Interim Report of Dick Thornburgh, Bankruptcy Court Examiner (4 November 2002), at 1, online: FindLaw <http://fl1.findlaw.com/news.findlaw.com/hdocs/docs/worldcom/thornburgh1strpt.pdf> [Thornburgh Report]; Adam Feuerstein, "WorldCom's Watchdogs Were Asleep" TheStreet.com (27 June 2002), online: TheStreet.com < http://www.thestreet.com/tech/adamfeuerstein/10029259.html > [Feuerstein]; Andrew Buncombe, "The WorldCom Scandal: Directors Asked How They Failed to Spot Fraud” BNET.com (28 June 2002), online: BNET.com <http://findarticles.com/p/articles/mi qn4158/is_ai_n12620440> [Buncombe].

4 Sarbanes-Oxley Act of 2002, Pub L No 107-204, 116 Stat 745 (codified in scattered sections of 11, 15, 18, 28 and 29 USC) [Sarbanes-Oxley Act], online: Findlaw

<http://fl1.findlaw.com/news.findlaw.com/hdocs/docs/gwbush/sarbanesoxley072302.pdf $>$.

${ }^{5}$ New York Stock Exchange, Listed Company Manual §303A (2009), online: NYSE

$<$ http://nysemanual.nyse.com/LCMTools/PlatformViewer.asp?selectednode $=$ chp $\% 5 F 1 \% 5 F 4 \% 5 F 3 \& m a n u a l=\% 2 F l c$

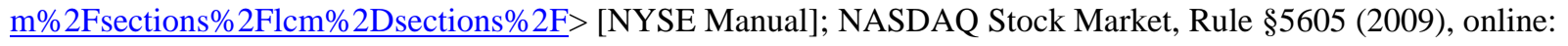
NASDAQ: <http://nasdaq.cchwallstreet.com/NASDAQTools/PlatformViewer.asp?selectednode=chp $\% 5 \mathrm{~F} 1 \% 5 \mathrm{~F} 1 \% 5 \mathrm{~F} 4 \% 5 \mathrm{~F} 2 \&$ manual=\%2Fnasdaq\%2Fmain \%2Fnasdaq\%2Dequityrules\%2F $>$ [NASDAQ Rule].
} 
independent directors following the recommendation of the Dey Committee ${ }^{6}{ }^{7}$ However, Canadian corporate scandals still occur periodically, like Bre- $\mathrm{X}^{8}$ and Nortel ${ }^{9}$, although their magnitude was not comparable to those in the United States. In response to the US corporate scandals and the passage of SOX, regulators in Canada have also continued to rely on independent directors as the main prescription to check managerial abuses. ${ }^{10}$ Such heavy reliance on independent directors as corporate monitors in both countries is problematic if independent directors are not as effective as conventional wisdom predicts. Despite regulators' heavy reliance on independent directors, whether independent directors act as better corporate monitors has been widely debated. ${ }^{11}$

The purpose of this thesis is to explore whether it is a good public policy to rely so heavily on the oversight ability of independent directors. In other words, are independent directors really effective in holding management accountable? The key feature of this thesis is using the findings in the field of management science and financial economics to examine whether legal measures relying on independent directors are justified. To date, only a little legal

\footnotetext{
${ }^{6}$ In 1993, the Toronto Stock Exchange (TSX) appointed a committee chaired by Peter Dey, a former head of the Ontario Securities Commission, to find the root of the current corporate governance problems and to design guidelines for public corporations based on existing best practices.

${ }_{7}^{7}$ Anita Anand, Frank Milne \& Lynnette Purda, "Monitoring to Reduce Agency Costs: Examining the Behavior of Independent and Non-Independent Boards" (2010) 33 Seattle U L Rev 809 at 818, 838 Table 1 [Anand, Milne \& Purda].

${ }^{8}$ Christopher C Nicholls, "The Bre-X Hoax: A South East Asian Bubble” (1999) 32:2 Can Bus L J 173; Belle Kaura, "The Corporate Governance Conundrum: Reinventing the Board of Directors and Board Committees" in Poonam Puri \& Jeffrey Larsen eds Corporate Governance and Securities Regulation in the 21st Century (Markham, ON: LexisNexis Butterworths, 2004) at 15, 18 [Kaura].

${ }^{9}$ In the early 2000s, Nortel's executives manipulated Nortel's books to meet Wall Street's expectations and paid themselves bonuses. Mark Heinzl \& Ken Brown, "Nortel Unveils New Accounting Flubs - Company Details Mistakes, Says Executives Will Return Millions in Bonus Payments" The Wall Street Journal (12 January 2005) A3; James Bagnall, “Archive: Nortel's Numbers: Accounting for the Errors" The Ottawa Citizen (10 January 2012); David Johnston \& Kathleen Doyle Rockwell, Canadian Securities Regulation (Markham, ON: Butterworths, 2006) at 652 [Johnston \& Rockwell].

${ }^{10}$ See National Instrument 52-110, Audit Committees, OSC NI 52-110, 27 OSCB 3252 (26 March 2004), online: CSA <http://www.osc.gov.on.ca/en/13550.htm> [NI 52-110] and National Policy 58-201, Corporate Governance Guidelines, OSC NP 58-201, 28 OSCB 5383 (17 June 2005), online: CSA 〈http://www.osc.gov.on.ca/en/SecuritiesLaw rule_20050415 58-201_gov-practices_2.jsp〉 [NP 58-201]. ${ }^{11}$ Victor Brudney, "The Independent Director- Heavenly City or Potemkin Village?” (1982) 95 Harv L Rev 597 at 622, 654, 659 [Brudney]; Roberta S Karmel, “The Independent Corporate Board: A Mean to What End?” (1984) 52 The Geo Wash L Rev 534 at 551, 556 [Karmel, Independent Board]; Larry E Ribstein, "Market vs. Regulatory Responses to Corporate Fraud: A Critique of the Sarbanes-Oxley Act of 2002" (2002) 28 J Corp L 1 at 27; Roberta Romano, "The Sarbanes-Oxley Act and the Making of Quack Corporate Governance" (2005) 114 Yale L J 1521 at 1533 [Romano, Quack Corporate Governance]; Donald C Langevoort, "The Human Nature of Corporate Boards: Law, Norms, and the Unintended Consequences of Independence and Accountability" (2001) 89 The Geo L J 797 at 798-800 [Langevoort, Human Nature]; Johnston \& Rockwell, supra note 9 at 677; Christopher C Nicholls, "The Outside Director: Policeman or Placebo?” (2003) Can Bus L J 323 at 334-44 [Nicholls].
} 
research $^{12}$ has briefly discussed empirical studies regarding the efficacy of independent directors. ${ }^{13}$ This thesis tries to systematically analyze the empirical evidence concerning the effectiveness of independent directors, and make those studies readily accessible to the legal community, with a view to providing policy recommendations based on a synthesis of empirical research.

Chapter two starts with an analysis of how the policy of relying on independent directors as corporate monitors developed over time. It first introduces the historical roots of the policy of relying on independent directors in the United States and Canada, showing why such a policy was initiated, and how it evolved, and gained public recognition. The thesis then describes the increasing role played by independent directors as courts began to rely on independent directors to deal with situations involving conflicts of interest in the United States, and laws and regulations were revised to rely on independent directors as a check against management abuses in response to several waves of corporate malfeasance in both countries. This section of the thesis also presents theoretical arguments and empirical evidence provided by financial economists to support the view that reputation capital and equity ownership can motivate independent directors to act in shareholders' best interests and monitor management's behavior.

After the discussion of conventional wisdom's reliance on independent directors, chapter three describes misgivings about independent directors' monitoring effect. This chapter shows how proponents of the managerial hegemony theory argue that independent directors are inescapably dominated by management due to: (1) biases in the nomination and selection process; (2) constraints on independent directors' ability to monitor effectively; and (3) weak incentives for independent directors to monitor effectively. The thesis then describes how significant limitations, including flaws in defining independence, the lack of appropriate rewards and compensation (positive incentives), the lack of sufficient civil liability (negative incentives), the

\footnotetext{
${ }^{12}$ There are plenty of empirical studies in the field of management science and financial economics which have explored the effectiveness of independent directors as shown on chapter five of this thesis. However, only a little legal research has used more than 30 pages to systematically analyze empirical evidence regarding the efficacy of independent directors.

${ }^{13}$ See Laura Lin, "The Effectiveness of Outside Directors as a Corporate Governance Mechanism: Theories and Evidence" (1996) 90 Nw UL Rev 898 [Lin]; Gordon, The Rise of Independent Directors, supra note 1 at 1500-05; Robert Charles Clark, "Corporate Governance Changes in the Wake of the Sarbanes-Oxley Act: A Morality Tale for Policymakers Too" (2005) 22 Ga St U L Rev 251 at 298-99 [Clark, Morality Tale]; Stephen M Bainbridge, “A Critique of the NYSE's Director Independence Listing Standards” (2002) 30 Sec Reg L J 370; Romano, Quack Corporate Governance, ibid at 1530-33; Jill E Fisch, "Taking Boards Seriously" (1997) 19 Cardozo L Rev 265 at 276-78 [Fisch].
} 
constraints of groupthink and in-group bias, and the trade-off between a board's monitoring function and managing function, are likely to prevent independent directors from effectively fulfilling their oversight role. These defects cast a doubt on the effectiveness of independent directors to monitor management.

In spite of these defects, however, courts, laws and regulations have relied more and more on independent directors as corporate monitors in the wake of each wave of corporate misconduct in North America. Chapter four describes how current laws and regulations in the United States and Canada rely on independent directors to hold management accountable. The thesis first introduces how the United States state courts and state laws encourage corporations to add independent directors to their boards. It then describes how the current federal network of legal requirements in the United States relies on independent directors to hold management accountable by: (1) regulating board composition; and (2) mandating that three key board functions - oversight of audits, setting executive compensation and nomination of directors - be performed by independent directors. The thesis also depicts how federal legal measures have sought to enhance independent directors' oversight through: (1) tightening the definition of independent directors; (2) requiring certain procedures in the boardroom to stifle the influence of management; and (3) disclosing whether at least one independent director on the audit committee qualifies as a financial expert as defined by the US Securities and Exchange Commission (SEC).

The thesis then shows how Canadian corporate laws specify independent directors' monitoring role in their statutes, and delineates how current Canadian securities regulations rely on independent directors to check managerial abuses through similar measures to their US counterparts, including: (1) regulating board composition; (2) mandating that the same three key board functions, oversight of audits, setting executive compensation and the nomination of directors, be performed by independent directors; (3) tightening the definition of independent directors; and (4) recommending certain procedures in the boardroom. The differences between the two legal frameworks regarding reliance on independent directors are also discussed at the end of this chapter. The main difference is that few of the Canadian requirements are mandatory. After having reviewed how laws and regulations value independent directors' monitoring ability, chapter five reviews the empirical evidence in the United States and Canada, with a view to evaluating the appropriateness of laws and regulations that rely on independent directors. With respect to the empirical findings concerning independent directors in the United States, the 
thesis analyzes empirical studies in the field of management science and financial economics concerning whether independent directors on the board make a difference in enhancing firm performance and in discharging six specific board tasks ${ }^{14}$. It also reviews empirical evidence regarding whether independent directors on key board committees, namely the audit, compensation and nominating committees, are more likely to improve firm performance or fulfill their specific committee tasks, such as ensuring the quality of financial reporting and tying executive compensation to firm performance. This chapter also explores empirical findings regarding factors that may complement, substitute for, or diminish the effectiveness of independent directors. Nine factors are considered, including gender, ethnicity, director ownership and compensation, multiple directorships, the number of independent directors, the meeting frequency of independent directors, antitakeover legislation, costs of acquiring corporate information, and whether the board is chaired by an independent director. As for empirical studies regarding Canadian independent directors, the thesis does a similar analysis as done for the United States. The Canadian discussion is somewhat limited, however, owing to the relative lack of empirical research in Canada.

Finally, chapter six of this thesis analyzes whether independent directors are effective corporate monitors in North America, and identifies policy implications for both legal regimes in light of the review of empirical evidence in chapter five. Chapter six first examines whether empirical findings support the current measures relying on independent directors as corporate monitors in the United States and Canada. It then offers possible explanations for the inconsistency between empirical evidence and the expectations of independent directors. The thesis further, based on the analysis of chapter five, generalizes several factors that can enhance the efficacy of independent directors. The final part of this chapter provides policy recommendations for regulators in the United States and Canada regarding their reliance on independent directors as corporate monitors.

After reviewing more than 160 empirical studies, this thesis concludes that the effectiveness of independent directors in management oversight varies with the type of the task, differs from firm to firm, and depends on the characteristics of independent directors and the firm's governance environment. Boards with a majority of independent directors, in some

\footnotetext{
${ }^{14}$ This thesis explores six specific board tasks, including responding to takeover bids, replacing incompetent CEO, setting executive compensation, preventing financial fraud, reducing shareholder suits and evaluating management buyout, to measure the efficacy of independent directors.
} 
circumstances, appear to enhance firm performance (in the post-SOX period) and fulfill certain board tasks effectively in the United States, but have not been shown to be related to improved firm performance in Canada. Audit committees composed entirely of independent directors appear to be effective in ensuring the quality of financial reporting in the United States, but this effect has not been fully demonstrated in Canada. Compensation committees composed fully of independent directors neither constrain the level of executive compensation nor tie CEO pay to firm performance, regardless of whether evidence in the United States or Canada is examined. In addition, audit committee members in the United States having accounting expertise, rather than financial analysis or supervisory expertise, are associated with a higher quality of financial reporting, while audit committee members in Canada having financial expertise, instead of financial literacy, can reach similar results. Overall, except for a completely independent audit committee in the US, requirements or recommendations regarding independent directors in both countries did not have fully, or even have no, empirical support. Most US empirical findings are based on the observation of pre-SOX samples, except for the results regarding firm performance and tasks of the compensation committee, so there is some question regarding the applicability of these results in the post-SOX period.

Based on the empirical evidence, regulators in the United States may need to consider: (1) changing the current mandatory requirement to have an independent board and a completely independent compensation committee to a comply-or-explain requirement; and (2) narrowing the qualification of a financial expert to an individual who has accounting expertise. In Canada, because most measures regarding independent directors are recommendations (following the comply-or-explain approach), regulators may only need to require or recommend that at least one audit committee member has financial expertise, instead of only financial literacy.

With a view to making independent directors more effective, US regulators may consider adopting measures: (1) to encourage firms to recruit individuals who hold less than three outside board seats, or/and who own a certain proportion of the company's shares to serve as independent directors; (2) to foster a governance environment in which independent directors are well informed; and (3) to prevent a director who has social connections with the CEO from being considered independent, because empirical findings have demonstrated that independent directors in these circumstances were more likely to be associated with better firm performance 
or better protection for shareholder interests. These empirical studies regarding the factors that may enhance or impair the efficacy of independent directors still need to be done for Canada.

\subsection{Limitations of the Thesis}

Before moving a step further, some limitations on the scope of this thesis must be explained in advance. First, the thesis only concentrates on whether independent directors are effective in holding management accountable and how other internal governance mechanisms affect the efficacy of independent directors. The impact of other external governance mechanisms on management oversight is outside the scope of this thesis, as discussed below.

Currently, director liability and director compensation packages are the main direct sanctions (sticks) and rewards (carrots) inside a corporation that motivate independent directors to effectively monitor management. In corporate law, the duty of care requires that directors act diligently and prudently in managing the company's affairs, while the duty of loyalty (or fiduciary duty in Canada) requires that directors place the interests of the company ahead of their own. Shareholders can use derivative actions to sue independent directors on behalf of the company if they breach the duty of care or loyalty. At the securities law level, directors are responsible for the accuracy and disclosure of the registration statement, or in Canada, relating to particular securities. In addition, compensation packages, if well designed, can provide an additional incentive for independent directors to check managerial abuses. Whether these two types of mechanisms effectively motivate independent directors in relation to management oversight is discussed in chapter three (sections 3.2.2 and 3.2.3) of the thesis. However, the discussion of director liability and director compensation packages is not the main focus of this thesis.

In addition to internal oversight by independent directors, market forces (external oversight), including product markets, the market for managers' services, the market for corporate control and capital (securities) markets, as well as other internal mechanisms, like the presence of controlling shareholders, are claimed to act as constraints against managerial 
misdeeds. ${ }^{15}$ The monitoring effect of independent directors may be influenced by these external and internal mechanisms performing the same oversight function. ${ }^{16}$

More specifically, the marketplace plays a role in disciplining management to act in shareholder interests. Corporate management has to ensure that their corporations develop innovative products or deliver desirable services at a reasonable price in order to survive in the intensely competitive marketplace. Corporations with ineffective management will lose market shares to better managed companies. Executives who fail to enable their corporations to compete effectively in the product market face the risk of replacement by their board or job loss precipitated by a corporate bankruptcy. In addition, future promotion and employment opportunities should motivate managers to administer their corporations competently and refrain from directing corporate assets to personal use or otherwise abusing their powers, since corporations are less likely to recruit executives of underperforming firms or those who are suspected of engaging in self-interested behavior to serve on their management teams. ${ }^{17}$

Furthermore, the market for corporate control will encourage management to do its best. All public information about corporate management tends to be efficiently reflected into the price in today's capital (securities) markets. Capital markets respond to incompetent or unfair management practices by discounting the price that investors will pay for a company's stock. A depressed stock price generally would remind executives to implement business reforms in order to secure their positions. If management fails to respond appropriately, the low stock price may attract hostile bidders seeking to acquire a controlling interest in the corporation so that they may change management with a view to increasing share value. The threat of a hostile takeover bid that, if successful, will result in the executives losing their jobs, should discourage management from engaging in the behavior that created the opportunity for the bidder in the first place. ${ }^{18}$

However, in practice, market forces do not operate as effectively and efficiently as scholars assume. Many market participants may not detect whether managers are competent or

\footnotetext{
${ }^{15}$ J Anthony VanDuzer, The Law of Partnerships \& Corporations (Toronto: Irwin Law, 2009) at 528-30 [VanDuzer]; Renee M Jones, "Law, Norms, and the Breakdown of the Board: Promoting Accountability in Corporate Governance" (2006) 92 Iowa L Rev 105 at 119-20 [Jones]; Eugene F Fama, "Agency Problems and the Theory of the Firm" (1980) 88 J Pol Econ 288 at 294-95 [Fama, Agency Problems]; Ralph K Winter, "State Law, Shareholder Protection, and the Theory of the Corporation" (1977) 6 J Legal Stud 251 at 264-66 [Winter].

${ }^{16}$ Stuart L Gillan, Jay C Hartzell \& Laura T Starks, "Tradeoffs in Corporate Governance: Evidence from Board Structures and Charter Provisions" (June 2006) at 1, online: SSRN < http://ssrn.com/abstract=917544> [Gillan, Hartzell \& Starks].

${ }^{17}$ VanDuzer, ibid at 530; Jones, ibid at 120; Winter, ibid at 264.

${ }^{18}$ VanDuzer, ibid ; Jones, ibid; Winter, ibid at 264-66.
} 
effective because of systemic market failures and imperfections. ${ }^{19}$ The antitakeover provisions permitted under some US state laws can severely weaken the disciplinary power of the takeover threat. $^{20}$ Most troubling, executives can easily obscure their own mismanagement for years by falsifying corporate financial reports, which prevent markets from appropriately pricing their securities, as the Enron and WorldCom scandals demonstrate. ${ }^{21}$ Accordingly, the tasks of holding management accountable have to rely on corporate internal governance mechanisms, in addition to external market mechanisms. This thesis only focuses on whether independent directors are effective corporate monitors and how internal governance mechanisms influence the effectiveness of independent directors. The impact of market forces as external governance mechanisms ${ }^{22}$ on management oversight and their relationships with independent directors are left to other scholars to research.

As for the connection between other internal governance mechanisms and independent directors, existing empirical studies have shown a close relationship between independent directors and two internal governance mechanisms, namely the presence of controlling shareholders and antitakeover provisions (or legislation). The impact of controlling shareholders and antitakeover provisions on the efficacy of independent directors will be discussed in chapter five (sections 5.1.6.4 and 5.2.4.4, respectively).

A second limitation is that it is difficult to find a perfect way to appropriately evaluate the "effectiveness" of independent directors as corporate monitors that will not be subject to criticism. So far, firm performance and successful performance of board tasks and committee missions are the main criteria used by empirical studies as benchmarks in assessing independent directors' efficacy. The rationale behind these criteria is that if independent directors are really effective corporate monitors, their firms are more likely to perform better and board or committee tasks are more likely to be fulfilled when boards or committees have more, or a higher proportion of, independent directors. ${ }^{23}$

\footnotetext{
${ }^{19}$ Jones, ibid at 120-21.

${ }^{20}$ Ibid at 121; William W Bratton, "The Economic Structure of the Post-Contractual Corporation" (1992) 87 Nw U L Rev 180 at 195-96; Frank J Easterbrook \& Daniel R Fischel “The Proper Role of a Target's Management in Responding to a Tender Offer" (1981) 94 Harv L Rev 1161 at 1169-70.

${ }^{21}$ Jones, ibid; Lisa M Fairfax, "Spare the Rod, Spoil the Director? Revitalizing Directors' Fiduciary Duty Through Legal Liability" (2005) 42 Hous L Rev 393 at 428-32 [Fairfax, Spare the Rod].

${ }^{22}$ The four external governance mechanisms include product markets, the market for managers' services, the market for corporate control and capital (securities) markets.

${ }^{23}$ Currently, researchers measure firm performance by using accounting or financial indices, such as return on assets (ROA), stock returns or Tobin's Q, while evaluating the fulfillment of board and committee tasks by observing
} 
However, using either firm performance or board (or committee) tasks to measure the efficacy of independent directors has problems. Firm performance, in fact, is influenced by many factors, in addition to director independence. Despite researchers' best efforts, it is difficult to isolate the effect of director independence from other factors that affect firm performance. ${ }^{24}$ In other words, even though greater firm performance may be found to be closely connected to the presence of independent directors, such an effect may not be necessarily attributed solely to the presence of independent directors. Similarly, looking at the performance of board (committee) tasks also has weaknesses. Boards with a higher fraction of independent directors may perform better on specific tasks, like replacing the CEO when needed, but may perform worse on other missions, leading to no net advantages in overall performance. ${ }^{25}$ Nevertheless, although these indicators have drawbacks, in general, they still provide some evidence regarding whether independent directors are effective corporate monitors. Since more innovative indicators have not yet been developed, this thesis, like most empirical studies, employs firm performance and board (committee) tasks to evaluate independent directors' effectiveness.

Third, this thesis aims to analyze comprehensively all the empirical studies concerning the efficacy of independent directors in North America to date; however, it would be impossible to include all new articles into the analysis up to the time of writing. Accordingly, this thesis only reviews empirical studies regarding the effectiveness of independent directors to the end of December $2010 .^{26}$

Finally, this thesis concentrates on Delaware law, the Canada Business Corporations $A c t^{27}$ (the $C B C A$ ) and Ontario Securities $A c t^{28}$ when discussing how corporate law (including case law) in the United States and Canada, as well as securities law in Canada, rely on

\footnotetext{
whether shareholder interests are well safeguarded in specific circumstances, such as by replacing an incompetent $\mathrm{CEO}$, defending against a takeover bid or ensuring the quality of financial reporting. Please refer to chapter five for further details.

${ }^{24}$ Lin, supra note 13 at 925; Gordon, The Rise of Independent Directors, supra note 1 at 1500.

${ }^{25}$ Sanjai Bhagat \& Bernard Black, "The Uncertain Relationship Between Board Composition and Firm Performance" (1999) 54 Bus Law 921 at 923 [Bhagat \& Black 1999]; Bhagat \& Black 2002, supra note 1 at 235.

${ }^{26}$ Nevertheless, this thesis may accidentally omit some articles within this period because of the recent explosion in literature relating to boards of directors. However, such an omission does not mean that these articles are not important. The author of this thesis apologizes for any accidental omission in advance.

${ }_{27}$ Canada Business Corporations Act, RSC 1985, c C-44, as amended by SC 2001, c14 [CBCA].

${ }^{28}$ Ontario Securities Act, RSO 1990, c S5.
} 
independent directors as corporate monitors. ${ }^{29}$ The reason for analyzing cases and corporate law in Delaware, instead of other states, is that Delaware has been chosen as the state of incorporation by more listed companies than any other state, which has allowed for the development of advanced corporate statutes and a sophisticated case law. Because of such development, corporate statutes and judicial opinions regarding independent directors in Delaware are more important than those in other jurisdictions in the United States. ${ }^{30}$ Similarly, in Canada, many provincial corporate statutes and securities laws were inspired by the $C B C A$ and Ontario Securities Act, respectively. ${ }^{31}$ With a view to simplifying the analysis, the thesis focuses on the federal corporate statute, but notes the differences between it and other provincial legislation where relevant.

\subsection{Other Preliminary Matters}

Before entering the discussion of whether independent directors are effective corporate monitors, a preliminary matter has to be addressed. The definition of independent directors needs to be clarified, because several similar terms, such as outside directors, non-executive directors, non-management directors and disinterested directors, are sometimes used interchangeably in different jurisdictions and empirical studies, but, in fact, they do not always describe the same concept. The differences between these terms may cause the misinterpretation of empirical findings if their definitions are not properly distinguished.

Currently, most laws and regulations define an independent director as a board member who has no direct or indirect material relationship with the company in the view of board of directors. ${ }^{32}$ However, the concept of "outside director" is often mentioned in the same breath

\footnotetext{
${ }^{29}$ In Canada, each province and the federal government have enacted their own corporate statutes. Unlike the United States, securities regulation in Canada is a provincial matter. Mark E Gillen, Securities Regulation in Canada, 3rd ed (Toronto: Thomson Carswell, 2007) at 77 [Gillen].

${ }^{30}$ Lewis S Black, Why Corporations Choose Delaware (Delaware Department of State Division of Corporations, 2007) at 2-3, 5-6, online: Delaware Department of State <http://corp.delaware.gov/whycorporations_web.pdf >; M P Dooley \& M D Goldman, "Some Comparisons Between the Model Business Corporation Act and the Delaware General Corporation Law" (2001) 56 Bus Law 737 at 737.

${ }^{31}$ VanDuzer, supra note 15 at 95, 98; Gillen, supra note 29, at 84.

${ }^{32}$ See NYSE Manual, supra note 5, §303A.02; NASDAQ Rule, supra note 5, §5605(a)(2); NI 52-110, supra note 10, s 1.4(1), 27 OSCB 3255.
} 
with that of "independent director." 33 In fact, an outside director means any director who is not a company employee, without regard to whether he/she has any other connection with management (or the company). ${ }^{34}$ The company's lawyers, suppliers, and others who may do a large amount of business with the company are within the scope of outside directors, ${ }^{35}$ but they are not considered independent due to their close ties with management. Thus, the scope of "outside director" is manifestly larger than that of "independent director." An independent director must be an outside director, but an outside director may not necessary be an independent director. Some scholars further term those outside directors, who have a certain relationship with the company, as "affiliated directors" or "gray directors" with a view to differentiating them from independent directors. ${ }^{36}$

In addition, the terms "outside director", "non-management director" and "non-executive director" are frequently used interchangeably in some empirical studies. It is worth noting that their meanings are slightly different and should not be treated as being the same. Essentially, "non-management director" and "non-executive director" represent the same concept: a director who is not a member of current senior management team. ${ }^{37}$ However, "non-management director" or "non-executive director" can include a director who is (or was) an employee, but not an executive-for example, a worker representative. ${ }^{38}$ In this case, the non-management director may not be independent from management, since he/she remains an employee of the company and subject to the influence of executives. As Professor Clarke has mentioned, "[s]uch directors would be neither outside directors, in the sense of being able to bring some special expertise to the board ..., nor independent directors, in the sense of feeling free to oppose management." 39 Accordingly, the concepts of "outside director" and "non-executive director" mostly overlap, but there still exists nuanced differences between the two concepts.

The concept of "disinterested director" is also often described as being comparable to that of "independent director." A director who has no financial interest in a specific transaction is

\footnotetext{
${ }^{33}$ Donald C Clarke, "Three Concepts of the Independent Director" (2007) 32 Del J Corp L 73 at 99 [Clarke, Concepts of Independent Directors].

${ }^{34}$ Ibid.

${ }^{35}$ Ibid at 101 .

${ }^{36}$ Eliezer M Fich \& Anil Shivdasani, "The Impact of Stock-Option Compensation for Outside Directors on Firm Value" (2005) 78:6 Journal of Business 2229 at 2233 [Fich \& Shivdasani 2005]; Langevoort, Human Nature, supra note 11 at 800 .

${ }^{37}$ Clarke, Concepts of Independent Directors, supra note 33 at 79.

${ }^{38}$ Ibid at 99 n 109.

${ }^{39}$ Ibid.
} 
considered as disinterested. ${ }^{40}$ American state law and state courts, especially in Delaware, rely on disinterested directors in judging the conduct of corporate officers and directors where transactions raised conflicts of interest and in deciding how to respond to shareholders seeking to bring derivative actions. ${ }^{41}$ The mission of disinterested directors is to ensure the fairness of the transactions and to protect shareholder interests, which is similar to the monitoring role of independent directors on corporate boards. In fact, independent directors who have no conflicts of interest in particular corporate transactions can also undertake the same responsibility as disinterested directors. The main difference between "disinterested director" and "independent director" is that disinterest has to be examined case-by-case, ${ }^{42}$ but the status of independence must be always maintained for a director to be considered independent. ${ }^{43}$ With a view to correctly evaluating the effectiveness of independent directors, this thesis tries to differentiate between these similar terms carefully when interpreting related empirical findings.

\footnotetext{
${ }^{40}$ Lin, supra note 13 at 905 ; See ibid at 104-05.

${ }^{41}$ Lin, ibid at 904-05, 907. In addition, Investment Company Act of 1940 also use the term "disinterested director." Investment Company Act of 1940, 15 USC $\S 80 \mathrm{a}-2(\mathrm{a})(19)(\mathrm{A})$ (2012) [Investment Company Act].

${ }^{42}$ In other words, "disinterested director" is a term that is used to describe directors' position in relation to particular decisions or actions.

${ }^{43}$ Clarke, Concepts of Independent Directors, supra note 33 at 104-06.
} 


\section{Chapter Two}

\section{The Development of the Policy of Relying Independent Directors as Corporate Monitors}

This chapter describes how reliance on independent directors became a mainstream component of corporate governance in North America. The first part explores how independent directors became the principal corporate monitors in the United States and Canada. The second part introduces the rise of reliance on independent directors, including how states courts in the United States and corporate governance reforms in the two countries have relied on independent directors to check managerial misconduct. The final part explores theoretical foundations and empirical evidence regarding whether independent directors have incentives to act in the best interests of shareholders and to monitor the behavior of management. Collectively, the trend toward reliance on independent directors, in combination with the theoretical and empirical support regarding incentives that encourage independent directors to engage in active monitoring, suggest that independent directors should be an effective mechanism in holding management accountable. Challenges to this conclusion by the work of various scholars are described in chapter three. Chapter four provides a more comprehensive discussion of the current rules regarding independent directors.

\subsection{The Historical Roots of the Policy of Relying on Independent Directors}

The concept of an independent director did not emerge in the history of corporate governance until the late 1930s. Through the promotion by scholars, the American Bar Association, Business Roundtable, the SEC, and American Law Institute in the United States between the mid-1970s and early 1980s, as well as the Toronto Stock Exchange in Canada during mid-1990s, independent directors came to be perceived to be needed in corporate governance and have become the principal device relied on to ensure monitoring of management in North America. The first section starts with early developments in the United States. 


\subsubsection{The United States}

\subsubsection{The Recognition of Agency Problems and the Initiatives during the 1930s and the} 1940s

As early as 1932, Berle and Means in their classic work, The Modern Corporation and Private Property, argued that most publicly-held corporations would mature to an end-stage capital structure characterized by "the separation of ownership and control ${ }^{44}$."45 They observed that shareholders of most large corporations were unable to exert meaningful control over management as equity of these firms became dispersed among an increasing number of small shareholders. With a view to making corporate decisions more efficient, professional management was hired to run the day-to-day affairs of the firms. ${ }^{46}$ Shareholders contributed capital and bore risk, while managers acted as shareholder agents and directed capital in profitmaking ventures. ${ }^{47}$ Theoretically, a business run by management with commercial knowledge and professional skill is beneficial to shareholders, but it gives rise to the problem that the interests of these managers might not be necessarily align with those of shareholders. Management might take advantage of opportunities to increase their own wealth at the shareholders' expense. ${ }^{48}$ They might also be inclined to work at a slack pace and to avoid the effort and time involved in adapting to changing situations, such as the emergence of new technologies. ${ }^{49}$ Potential conflicts of interest between shareholders and their agents (professional managers) occur; ${ }^{50}$ the costs associated with the risk of management misbehavior are referred to as agency costs. A perceived need for a legal mechanism to minimize the agency cost associated with the separation of ownership and control emerged. Consequently, it was argued that there should be a legal safeguard to ensure that management acts in the best interests of shareholders. ${ }^{51}$

\footnotetext{
${ }^{44}$ Adolf A Berle \& Gardiner C Means, The Modern Corporation and Private Property (New York: Harcourt, Brace $\&$ World, 1932) [Berle \& Means].

${ }^{45}$ John C Coffee, "The Rise of Dispersed Ownership: The Role of Law in the Separation of Ownership and Control", Columbia Law School, Working Paper No. 182 (January 2001) at 2, online: SSRN

$<$ http://ssrn.com/abstract=254097>.

${ }^{46}$ Berle \& Means, supra note 44 at 84-89; Mark S Mizruchi, "Berle and Means revisited: The governance and power of large U.S. corporations" (2004) 33:5 Theory and Society 579 at 581-82 [Mizruchi].

47 Alan J Meese, "The Team Production Theory of Corporate Law: A Critical Assessment" (2001-02) 43 Wm \& Mary L Rev 1629 at 1637.

${ }^{48}$ Berle \& Means, supra note 44 at 222-24; Mizruchi, supra note 46 at 582.

${ }^{49}$ Melvin A Eisenberg, "The Mandatory Structure of Corporate Law" (1989) 89 Colum L Rev 1461 at 1471.

${ }^{50}$ Berle \& Means, supra note 44 at 6.

${ }^{51}$ Mizruchi, supra note 46 at 582.
} 
Although the stock market crash of 1929 and the Great Depression of the 1930s led to the adoption of the Securities Act of $1933^{52}$ and the Securities Exchange Act of $1934^{53}$, there was no measure adopted by these Acts to directly hold corporate managers accountable to shareholders. No notion similar to, or related to, director independence was proposed to solve the risk of abuse by management at that time. ${ }^{54}$

After the Acts were passed, an idea similar to the "independent director" was promoted by Justice William O. Douglas. Douglas, who was the first Chairman of the Securities and Exchange Commission and later a Justice of the United States Supreme Court, advocated that large corporations should have "public directors" who are not subservient to management. He contended that the SEC had the power to enforce such a policy. ${ }^{55}$ Although Justice Douglas and other proponents were unable to institute a "public director" requirement through either amendments to, or interpretations of, federal securities laws, their corporate governance ideas were incorporated into discrete areas. ${ }^{56}$ The Investment Company Act of $1940^{57}$ and the establishment of a committee composed of non-officer members of the board of directors to nominate the firm's outside auditor as recommended by the SEC were the most prominent examples.

The Investment Company Act of 1940 was probably the first federal law to require a fixed percentage of non-interested directors (a concept similar to independent director) to serve on the boards of investment companies. Investment companies are companies formed to buy, sell and manage a portfolio of securities for investment purposes, such as mutual funds. ${ }^{58}$ The fund's investment advisers usually organize the fund, sell and manage the fund assets, and

\footnotetext{
${ }^{52}$ Securities Act of 1933, 15 USC 77a et seq, as amended. The 1933 Act focused on truth in new issues. It required prospectuses to be distributed containing all material information regarding corporation issuing securities, and made underwriters and accountants share the liability for the accuracy of prospectus information with the company, in order to increase the scrutiny they would give their clients. Roy C Smith \& Ingo Walter, Governing the Modern Corporation: Capital Markets, Corporate Control and Economic Performance (New York: Oxford University Press, 2006) at 78 [Smith \& Walter].

${ }_{53}$ Securities Exchange Act of 1934, 17 USC 78, as amended. The 1934 Act required fair and honest secondary market conduct that would prevent market manipulating, and created and empowered the SEC to enforce both the 1933 and 1934 Acts. Smith \& Walter, ibid.

${ }^{54}$ Karmel, Independent Board, supra note 11 at 536.

${ }^{55}$ Ibid at 538; Paul W Dickson, Compensation and Duties of Corporate Directors, Studies in Business Policy, No. 16 (New York: National Industrial Conference Board, 1946) at 4 [Conference Board 1946].

${ }_{57}^{56}$ Karmel, Independent Board, supra note 11 at 538.

${ }^{57}$ Investment Company Act of 1940, 15 USC \$80a (2012) [Investment Company Act].

${ }^{58}$ Lin, supra note 13 at 910.
} 
appoint the fund's first board of directors, so potential conflicts of interest ${ }^{59}$ and self-dealing could be prevalent between the investment advisers and the individual fund investors (holding shares in the fund). ${ }^{60}$ In order to control these potential conflicts of interest, the Act requires that the board of a registered investment company consists of at least 40 percent "non-interested" members. ${ }^{61}$

The Act does not directly define the term "non-interested," but it defines "interested person $^{62 "}$ instead. The non-interested directors play an important role in representing and safeguarding the interests of investors. For example, the Act requires non-interested directors of the investment company (by a majority) to appoint other non-interested directors to fill any vacancies among directors, ${ }^{63}$ and to select accountants who file the company's financial statements to the SEC. ${ }^{64}$ These missions are quite similar to what is now known as the "nomination committee" and the "audit committee" which are required to be performed by independent directors under current US rules. In addition, the board has the duty to evaluate contracts between the investment company and its advisers or principal underwriters, and such contracts are required to be approved by a majority of non-interested directors. ${ }^{65}$ As Professor Cox et al. stated, the United States Congress intended these directors to be the "independent

\footnotetext{
${ }^{59}$ Professor Lin provided an example regarding the conflicts of interest. She mentioned that a mutual fund's director who also works for the fund's investment adviser may face competing interests between the advisor and the fund's shareholders, since the adviser who prefers high management fees while the fund shareholders who prefer the fund to pay low management fees. Ibid.

${ }^{60}$ Lin, ibid; Ezio Scaldaferri, Notes, Mutual Fund Independent Directors: Putting a Leash on the Watchdogs, (1979) 47 Fordham L Rev 568 at 570-71; Joseph F Krupsky, "The Role of Investment Company Directors" (1977) 32 Bus Law 1733 at 1737-38 [Krupsky]. The individual fund shareholders refer to individual investors holding shares in the fund. In addition, Professor Lin provided an example of conflicts of interest between investment advisors and individual fund shareholders. She mentioned that the fund's directors who

${ }^{61}$ Section 10(a) provides: "No registered investment company shall have a board of directors more than 60 per centum of the members of which are persons who are interested persons of such registered company." Investment Company Act, supra note 57, § 80a-10(a), Krupsky, ibid at 1744-45.

${ }^{62}$ An interested person is defined as follows: (1) any affiliated person of the investment company; (2) any immediate family member of an affiliated natural person; (3) any interested person of the investment company's investment adviser or principal under writer; (4) any person who has acted as the investment company's legal counsel within the last two fiscal years; (5) any person who has executed portfolio transactions or distributed shares for the investment company; (6) any person who has loaned money or other property to the investment company; (7) any person who the Securities and Exchange Commission considers to be interested because of the person's material business or professional relationship with the investment company within the past two fiscal years. Investment Company Act, ibid, §80a-2(a)(19)(A). Regarding the definition of affiliated person, see ibid, §80a-2(a)(3).

${ }^{63} \mathrm{Ibid}, \S 80 \mathrm{a}-16(\mathrm{~b})$, Lin supra note 13 at 911.

${ }^{64}$ Investment Company Act, ibid, § 80a-32(a); Lin, ibid.

${ }^{65}$ Investment Company Act, ibid, $\$ 80 a-15(c)$; Lin, ibid; Krupsky, supra note 60 at 1743, 1749-52.
} 
watchdogs" for investors and to serve as an independent check on management. ${ }^{66}$ Probably this was the first time that a notion similar to an independent director emerged in a statute in the United States.

In addition to this federal legislation, a predecessor of the audit committee was recommended by the SEC at the end of 1940. The idea originated from the financial scandal of McKesson \& Robbins, a New York Stock Exchange listed company which deceived investors by issuing fraudulent financial statements to overstate its assets and gross profits. The company's outside auditing firm failed to discover the fraud and certified the company's financial statements. In order to prevent similar wrongdoing, the SEC suggested that corporations establish a committee comprised of non-officer members of the board, whose main function would be to nominate the company's auditors and arrange details of their engagement. ${ }^{67}$ This committee was the embryo of audit committees in current companies. Nevertheless, independent directors did not become an important generally applicable mechanism to achieve board or committee accountability until after the corporate scandals of the 1970s.

\subsubsection{The Passiveness of Advisory Boards and Corporate Scandals in the 1970s}

\subsection{Advisory Board in the 1950s and 1960s}

The 1950s and 1960s were the heyday of stakeholder capitalism and corporate managerialism. ${ }^{68}$ Shareholder interests were perceived as only one of several constituencies that the management team had to balance among competing stakeholder objectives. The role of the CEO was considered to be the company's central planner, enjoying the paramount power to

\footnotetext{
${ }^{66}$ James D Cox et al, Securities Regulations: Cases and Materials 3rd ed (New York: Aspen, 2001) at 1199 [Cox et al].

${ }^{67}$ In re McKesson \& Robbins Inc, SEC Securities Exchange Act Release No. 2707, [Accounting Series Release Transfer Binder] Fed Sec L Rep (CCH) 72, 020, at 62,104, 62,108 (5 December 1940) [In re McKesson \& Robbins]; Jeremy Bacon, Corporate Directorship Practices: The Audit Committee (New York: The Conference Board, 1979) at 5-6 [Conference Board 1979, Audit Committee].

${ }^{68}$ Gordon, The Rise of Independent Directors, supra note 1 at 1511; Professor Coffee at Columbia Law School used the other term "managerial capitalism" to describe the relationship between management and its corporation in 1950s. John C Coffee, "What Caused Enron?: A Capsule Social and Economic History of the 1990's", Columbia Law and Economics Working Paper No. 214 (29 January 2003) at 5, online: SSRN <http://ssrn.com/abstract=373581 or DOI: 10.2139/ssrn.10.2139/ssrn.373581 > [Coffee, What Caused Enron]; see Robin Marris, the Economic Theory of Managerial Capitalism (London: Macmillan, 1964).
} 
pursue firm-building goals. ${ }^{69}$ Management teams usually maximized corporate sales, growth and size, but might not maximize a firm's profits or stock price. ${ }^{70}$ In order to achieve the entrusted task in the face of increasing complexity, the senior executives usually organized a board consisting of both insiders and outsiders ${ }^{71}$ who had important economic relationships with the firm, such as bankers, lawyers and suppliers. These knowledgeable outside directors served as advisors or counselors to assist the management team. ${ }^{72}$ Since the CEO dominated all the resources of the corporation and controlled the selection process of board members, outside directors who might question management critically or display an excessive degree of independence typically were not selected by the CEO. ${ }^{73}$ The most desirable outside director was a "yes person," a person with enough sense to recognize the cue from management regarding when to say "yes" and when to say "no." In fact, major corporate decisions were often made by the management team without seeking board review or approval. ${ }^{74}$ At that time, the role of corporate directors was described as an "advisory board," and directors were considered as the passive instruments of management.

\subsection{Corporate Scandals in the 1970s}

In the early 1970s, a series of major corporate bankruptcies and fraud cases emerged. The first shock was the unexpected collapse of Penn Central. The nation's largest railroad company at that time went bankrupt on June $21,1970 .^{75}$ It was the largest corporate bankruptcy

\footnotetext{
${ }^{69}$ Gordon, ibid. at 1513 .

${ }^{70}$ Coffee, What Caused Enron, supra note 68 at 5-6.

${ }^{71}$ Retired or former company officers, CEOs or presidents from other companies, the company's investment bank, financial counselors, and even the company’s law firm were all regarded as outside directors. John R Kinley, National Industrial Conference Board \& American Society of Corporate Secretaries, The Corporate Directorship Practices, Business Policy Study, No. 103 (New York: National Industrial Conference Board, 1962) at 16 Table 8, 22 Table 10 [Conference Board 1962]; Jeremy Bacon, National Industrial Conference Board \& American Society of Corporate Secretaries, The Corporate Directorship Practices, Business Policy Study, No. 125 (New York: National Industrial Conference Board, 1967) at 14-15 Table 4 and Table 5 [Conference Board 1967]. The New York Stock Exchange (NYSE) 1962 statement also adopted the same criteria that an outside director was simply one who is non-management. New York Stock Exchange, The Corporate Director and the Investing Public (1962) at 7, 19-20, cited by Gordon, The Rise of Independent Directors, supra note 1 at 1478.

${ }^{72}$ Gordon, The Rise of Independent Directors, ibid at 1513-14.

${ }^{73}$ Robert W Hamilton, “Corporate Governance in America 1950-2000: Major Changes But Uncertain Benefits”, (2000) 25 J Corp L 349 at 351.

${ }^{74}$ Ibid at 352 .

${ }^{75}$ Staff Report of the Securities and Exchange Commission, The Financial Collapse of the Penn Central Company, (1972) at 1.
} 
in American history up until that time. ${ }^{76}$ Penn Central's board had little inkling of the financial trouble facing the railroad. In fact, Penn Central's working capital deteriorated and its indebtedness continuously rose in the two years before the collapse. However, the board was unaware of the company's poor financial performance and still approved over $\$ 100$ million in dividends. ${ }^{77}$ No wonder Penn Central's directors were criticized for being puppets instead of advisors or monitors. ${ }^{78}$

After the collapse of Penn Central, the Harvard Business School Professor Myles Mace published his influential academic study, Directors: Myth and Reality, exposing the prevalence of directors' passiveness and the failure of the board's advisory function. ${ }^{79}$ Through interviews with corporate executives and directors, Professor Mace found that modern corporate boards of directors, contrary to some generally held notions, did not establish corporate objectives, strategies, and broad policies. ${ }^{80}$ In addition, they failed to select corporate CEOs or attempt to replace those who were incompetent. ${ }^{81}$ Of paramount significance was the fact that CEOs controlled the selection of members of the board. ${ }^{82}$ Those who might ask penetrating, discerning or challenging questions during board meetings would naturally be eliminated by CEOs in advance. ${ }^{83}$ A sizable proportion of directors were retired corporate executives, investment bankers, commercial bankers, or lawyers, who were economically or psychologically dependent on, or tied to, the CEO. ${ }^{84}$ Also, boards did not even meet frequently enough to perform an advisory role for management. ${ }^{85}$ Therefore, Professor Mace concluded that boards of directors could not shoulder the mission to effectively check corporate management. ${ }^{86}$

Another shock in the 1970s was the diversion of corporate funds for illegal domestic campaign contributions and the bribery of foreign government officials. In May 1973, the

\footnotetext{
76 “The Biggest Bankruptcy Ever" Time (06 July 1970), online: Time < http://www.time.com/time/magazine/article/0,9171,878372,00.html>; Joel Seligman, “A Sheep in Wolf's Clothing: The American Law Institute's Principles of Corporate Governance Project" (1987) 55 Geo Wash L Rev 325 at 329330 [Seligman, A Sheep in Wolf's Clothing].

${ }^{77}$ Seligman, ibid at 330; Gordon, The Rise of Independent Directors, supra note 68, at 1515.

${ }_{78}^{78}$ Gordon, The Rise of Independent Directors, supra note 1, at 1515.

${ }^{79}$ Myles L Mace, Directors: Myth and Reality, (Boston: Harvard Business School Press, 1971) [Mace].

${ }^{80}$ Ibid at 43; Larry D Soderquist, "Toward A More Effective Corporate Board: Reexamining Roles of Outside Directors" (1977) 52 NYUL Rev 1341 at 1355; Seligman, A Sheep in Wolf's Clothing, supra note 76 at 331.

${ }^{81}$ Mace, ibid at 29-30, 36-37, 65-68, 70; Seligman, ibid.

${ }^{82}$ Mace, ibid at 94-101; Seligman, ibid.

${ }^{83}$ Mace, ibid at 54, 180; Seligman, ibid at 331-32; Gordon, The Rise of Independent Directors, supra note at 1516.

${ }^{84}$ Mace, ibid at 87-91; Seligman, ibid at 332.

${ }^{85}$ Seligman, ibid.

${ }^{86}$ Mace, supra note 79 at 3,41; Seligman, ibid at 330.
} 
Watergate Special Prosecution Force began to investigate illegal corporate campaign contributions made during the 1972 presidential election. This investigation uncovered "slush funds" created through fictitious or unrecorded transactions that were used to finance illegal corporate campaign contributions during the presidential election. Since slush funds involved the falsification of both corporate internal financial records and the financial statements filed with the SEC, the SEC subsequently started its own investigation. ${ }^{87}$ These investigations later led to the discovery of "questionable foreign payments" cases, involving diverse payments to foreign government officials to obtain or keep business abroad. ${ }^{88}$ More than fifty public corporations became the subject of criminal prosecution or SEC enforcement action. Both the Special Prosecutor and SEC announced an amnesty or voluntary disclosure program, which would mitigate the penalties imposed for corporate officers' misconduct if they confessed their illegal political contributions or questionable payments. Close to 400 firms voluntarily admitted making illegal campaign contributions, or bribing foreign or American political or commercial officials due to the threat of prosecution. ${ }^{89}$

In the aftermath of these events, an SEC report mentioned that such falsification of records and questionable payments had often been known to top management, but was usually concealed from outside or independent directors. ${ }^{90}$ The report revealed the boards' limited information about a company's accounting practices and also the board's inability to ensure a company's compliance with the law. ${ }^{91}$ This report, in addition to the above-mentioned events, led the public to demand a mechanism to effectively monitor corporate management.

It is worth mentioning that the SEC's voluntary disclosure program was typically supervised by the company's independent directors and assisted by the firm's accounting firm and independent outside counsel. ${ }^{92}$ In many cases of potential violations of federal securities law, the appointment of independent directors or a special committee composed of a majority of independent directors was required by the SEC or by courts in order to end the investigation. ${ }^{93}$ It

\footnotetext{
${ }^{87}$ Seligman, ibid at 334.

${ }^{88}$ Karmel, Independent Board, supra note 11 at 540-41.

${ }^{89}$ Seligman, A Sheep in Wolf's Clothing, supra note 76 at 333-35; Gordon, The Rise of Independent Directors, supra note 1 at 1516; Karmel, Independent Board, ibid.

${ }^{90}$ Seligman, A Sheep in Wolf's Clothing, ibid at 335; Gordon, The Rise of Independent Directors, ibid.

${ }^{91}$ Gordon, The Rise of Independent Directors, ibid.

${ }_{92}^{92}$ Seligman, A Sheep in Wolf's Clothing, supra note 76 at 335.

93 Arthur F Mathews, "Recent Trends in SEC Requested Ancillary Relief in SEC Level Injunction Actions" (1976) 31 Bus Law 1323 at 1326-28, 1334-40.
} 
demonstrated that from the perspective of the SEC, boards of directors who had no relation with management or no business ties with the company were in a better position to hold management accountable.

In brief, the passiveness of boards of directors in the 1950s and 1960s contributed to a series of major corporate bankruptcies and fraud cases in the 1970s, which led to a demand for independent directors to hold management accountable.

\subsubsection{The Promotion of the Audit Committee}

Another early source of interest in independent directors was the perceived need for an audit committee. Board members who have no significant relationship with management were thought to be in a better position to select independent auditors in reviewing the company's financial reporting process. As early as 1940, the SEC recommended that issuers set up a committee composed of non-management directors to nominate the company's auditors and arrange details of their engagement. ${ }^{94}$ According to a Conference Board survey, around 5\% of corporations had an audit committee in 1946 and the percentage grew to 15\% in 1962. During the late 1960s and the early 1970s, there was a rapid and widespread increase in the number of companies establishing audit committees. The percentage of corporations having an audit committee rose from $24 \%$ in 1967 to around $45 \%$ in 1972, almost doubling in five years. ${ }^{95}$ This phenomenon was attributed to the mounting pressure for further disclosure of corporate information. The increased exposure of directors to legal liability further heightened the need to validate financial information and to examine financial policy at the board level. ${ }^{96}$ In addition, the American Institute of Certified Public Accountants played an important role in recommending the use of the audit committee. In its 1967 statement, it proposed that publiclyheld corporations appoint a standing committee composed of outside directors to nominate independent auditors and to communicate with independent auditors whenever management could not satisfactorily resolve a question. ${ }^{97}$

\footnotetext{
${ }^{94}$ See In re McKesson \& Robbins, supra note 67.

95 Jeremy Bacon, Membership and Organization of Corporate Boards, The Conference Board 1990 at 33 Table 39 [Conference Board 1990].

${ }^{96}$ Jeremy Bacon, Corporate Directorship Practices: Membership and Committees of the Board (1973) at 51 [Conference Board 1973].

${ }^{97}$ Senate Commission on Banking, Housing \& Urban Affairs, $96^{\text {th }}$ Congress $2^{\text {nd }}$ Session, Staff Report on Corporate Accountability (1980) at 487 [SEC Staff Report 1980]; Jillian M Lutzy, "Analysis of the Proposed NYSE Corporate
} 
Although audit committees have been around for decades, they only began to receive serious attention in the 1970s. In 1972, the SEC issued a release stating that the Commission endorsed the establishment of audit committees composed of outside directors by all publiclyheld companies. ${ }^{98}$ In 1973, the New York Stock Exchange (NYSE) recommended that all listed companies form an audit committee preferably composed of independent directors. ${ }^{99}$ A year later, the SEC restated its support for independent audit committees by revising its proxy rules to require the disclosure in proxy statements regarding the existence and composition of audit committees. ${ }^{100}$

In 1976, in response to the SEC's investigation into questionable corporate payments, the Chairman of the SEC, Roderick Hills, suggested that the NYSE take the lead by amending its listing requirements to require all listed domestic corporations to establish and maintain an audit committee. ${ }^{101}$ American Bar Association's Corporate Director's Guidebook made the same recommendations in the same year. ${ }^{102}$ The New York Stock Exchange subsequently made the change, and the new rule, approved by the SEC, took effect on June 30, $1978 .{ }^{103}$ The new NYSE rule required that every listed company establish an audit committee composed exclusively of directors independent of management and free from any relationship that would interfere with the exercise of independent judgment. ${ }^{104}$ Directors who were (current) affiliates ${ }^{105}$ of the company, or officers or employees of the company or its subsidiaries would not be qualified for

Governance and Audit Committee Listing Requirements" (2003) 2 DePaul Business \& Commercial L J 99 at 101 [Lutzy].

${ }^{98}$ Karmel, Independent Board, supra note 11 at 545; Standing Audit Committees Composed of Outside Directors, [1971-1972 Transfer Binder] Fed Sec L Rep (CCH) 78,670, at 81,424 (No. 9548, 23 March 1972).

${ }_{99}$ Karmel, ibid; SEC Securities Exchange Act Release No. 13346 at 1946 (9 March 1977).

${ }^{100}$ Karmel, ibid; SEC Securities Exchange Act Release 34-14970, [1978 Transfer Binder] Fed Sec L Rep (CCH) 80579 at 81645 (18 July 1978) [SEC, Release No. 34-14970] ; SEC Accounting Series Release No. 165 [Accounting Series Release Transfer Binder] Fed Sec L Rep (CCH) 72,187 at 62,394 (20 December 1974).

${ }^{101}$ Karmel, ibid; Seligman, A Sheep in Wolf's Clothing, supra note 76 at 338.

102 American Bar Association Committee on Corporate Laws, "The Corporate Director's Guidebook" (1976) 32 Bus Law 5 at 35-36 [Director's Guidebook 1976].

${ }^{103}$ Karmel, Independent Board, supra note 11 at 545; Seligman, A Sheep in Wolf's Clothing, supra note 76 at 338; Conference Board 1979, Audit Committee, supra note 67 at 10.

${ }^{104}$ Conference Board 1979, ibid; Roberta S Karmel, "The Future of Corporate Governance Listing Requirements" (2001) 54 SMU L Rev 325 at 340 [Karmel, Listing Requirements]; New York Stock Exchange Listed Company Manual $\$ 303$ \& Supplementary material (1983) [NYSE Manual 1983]; American Bar Association, "Special Study on Market Structure, Listing Standards and Corporate Governance" (2002) 57 Bus Law 1487 at 1507 [American Bar Association, Special Study on Listing Standards].

${ }^{105}$ The SEC defined the term "affiliate" in Rule 405 as "an 'affiliate' of, or a person 'affiliated' with, a specified person, is a person that directly, or indirectly through one or more intermediaries, controls, or is controlled by or is under common control with, the person specified." SEC Securities Act Release No. 33-4790 (13 July 1965), online: The SEC <http://www.sec.gov/rules/interp/33-4790.pdf>. 
the audit committee membership. ${ }^{106}$ The key responsibility of the audit committee is to select the company's outside auditors, to conduct the required review of the company's accounts and financial statements, and to monitor the performance of the company's internal control system. ${ }^{107}$ However, the NYSE permitted exceptions which allowed former employees ${ }^{108}$ and nonmanagement directors who had business relationship with the company, to serve on audit committees. ${ }^{109}$ These exceptions largely reduced the effective independence of the audit committee and remained intact until 1999. ${ }^{110}$ Nevertheless, starting in 1978, a majority of the audit committee members in practice were directors who were not formerly officers of the company or any of its subsidiaries in most cases. ${ }^{111}$ The new NYSE listing standards expressed two important messages: first, the establishment of an audit committee was mandatory for listed companies; second, independent directors were entrusted with the task of ensuring the quality of financial reporting. By the end of the 1970s, nearly $90 \%$ of corporations had established an audit committee, according to a Conference Board's survey. ${ }^{112}$

\subsubsection{The Promotion of the Monitoring Role of Independent Directors by the Academic, Legal and Business Community, and the SEC}

In addition to the promotion of audit committees, the monitoring role of independent directors, including through their participation in the compensation and nominating committees,

${ }^{106}$ Conference Board 1979, ibid at 10, 51.

${ }^{107}$ Ibid at 14, 31; SEC, Release No. 34-14970, supra note 100, 80580 at 81645.

${ }^{108}$ A director who was formerly an officer of the company or any of its subsidiaries may qualify for membership even though he may be receiving pension or deferred compensation payments from the company if, in the opinion of the Board of Directors, such a person will exercise independent judgment and will materially assist the function of the committee. However, a majority of the audit committee members shall be directors who were not formerly officers of the company or any of its subsidiaries. Conference Board 1979, ibid at 10.

109 The NYSE supplementary material stated "...A director who has, or is a partner, officer or director of an organization that has, customary commercial, industrial, banking, or underwriting relationships with the company which are carried on in the ordinary course of business on an arms-length basis may qualify for membership, unless, in the opinion of the board of directors, such director is not independent of management or the relationship would interfere with the exercise of independent judgment as a committee member..." NYSE Manual 1983, supra note 104; Conference Board 1979, ibid; Gordon, The Rise of Independent Directors, supra note 1 at 1479-80.

${ }^{110}$ Gordon, ibid at 1480 .

${ }^{111}$ Conference Board 1979, supra note 103 at 10; Karmel, Listing Requirements, supra note 104 at 340; NYSE Manual 1983, supra note 104; American Bar Association, Special Study on Listing Standards, supra note 104 at 1507.

112 Conference Board 1990, supra note 95 at 33 Table 39; Jeremy Bacon, Corporate Directorship Practices: The Nominating Committee and the Director Selection Process (New York: The Conference Board, 1981) at 7 [Conference Board 1981]. 
was advocated with great force by academics, lawyers, the business community and the SEC after the middle of the 1970s.

\subsection{Professor Melvin Eisenberg's Monitoring Model}

In 1976, Professor Melvin Eisenberg in his influential book, The Structure of the Corporation: A Legal Analysis, ${ }^{113}$ advocated an innovative model-the monitoring board to replace the advisory board model. He observed discrepancies between theoretical models of corporate law and actual working conditions. Under the theoretical model, the board has to participate in selecting officers, setting business policy, supervising executives and generally managing the company. However, under the working model, the board does not do these jobs by itself, but mostly relies on the corporation's executives to do so. ${ }^{114}$ Most of the board members cannot devote enough time, make a substantial effort or gather sufficient information to direct the operation of the company. ${ }^{115}$ The majority of directors are economically or psychologically dependent on or tied to the company's chief executive, ${ }^{116}$ just as Professor Mace discovered in the early 1970s. Therefore, Professor Eisenberg proposed the "monitoring model" to replace the previous "advisory model." He contended that legal rules governing the structure of corporate management should ensure the effectiveness of monitoring functions by the board. These rules must make directors independent of CEOs and ensure that directors receive sufficient and unbiased information to perform their monitoring function. ${ }^{117}$ The monitoring model that Eisenberg actively promoted was the embryo of the current independent director regime. The age of the independent director had begun.

\subsection{American Bar Association's Proposal}

\footnotetext{
${ }^{113}$ Melvin Eisenberg, The Structure of the Corporation: A Legal Analysis (Boston: Little, Brown, 1976) [Eisenberg 1976].

${ }^{114}$ Ibid at 139-41, 319; Karmel, Independent Board, supra note 11 at 542-43.

115 Eisenberg 1976, ibid at 141-48, 170-71.

116 The author indicated that most director in most publicly held companies are closely tied to the CEO, either economically, through an employment, professional, consulting, or supplier relationship with the company, or psychologically, through friendship, prior employment, or the fact that they have been selected and indoctrinated by the CEO and hold their seats at his/her pleasure. Ibid at 144-45, 171-72; Seligman, A Sheep in Wolf's Clothing, supra note 76 at 332 .

${ }^{117}$ Eisenberg, ibid at 170-71, 319; Karmel, Independent Board, supra note 11 at 543.
} 
Around the same time as Eisenberg's proposal, a subcommittee of the Section of Corporation, Banking and Business Law of the American Bar Association published the Corporate Director's Guidebook in order to assist corporate directors in performing their duties. ${ }^{118}$ The Guidebook contended that the role of a corporate director is to oversee the corporation's operation and monitor its senior managers, rather than participating in the day-today management of the corporation. ${ }^{119}$ In order to fulfill this task, the Guidebook recommended that a majority of the board members consist of non-management directors. ${ }^{120}$ The Guidebook divided directors into two categories, namely management directors and non-management directors. A director who devotes substantially their full time and attention to the affairs of the company, its subsidiaries, or any other company controlled by the company is considered to be a management director. A former officer or employee is also regarded as a management director. All other directors are regarded as non-management directors and are further classified into affiliated or unaffiliated non-management directors. Directors are categorized as affiliated nonmanagement directors if they have close familial ties to a key member of management or engage in material transactions with the company. ${ }^{121}$ Commercial bankers, investment bankers, attorneys, and others who supply services or goods to the company are typical examples of affiliated non-management directors. ${ }^{122}$ According to the above classification, unaffiliated nonmanagement directors are similar to what are now called independent directors.

The Guidebook also recommended that companies have at least three working committees-a nominating committee, a compensation committee and an audit committee-to address the most commonly recurring needs for disinterested oversight. ${ }^{123}$ The nominating committee shoulders the responsibility of recommending nominees to fill board vacancies, establishing a procedure for identifying potential nominees, and recommending criteria for board membership. The compensation committee takes the job of approving the compensation arrangements for a company's senior management and adopting the compensation plan for officers and directors. The audit committee has primary responsibility for recommending

\footnotetext{
${ }_{118}$ Director's Guidebook 1976, supra note 102 at 5; Karmel, ibid at 546-47.

${ }^{119}$ Director's Guidebook 1976, ibid at 31.

${ }^{120}$ Ibid at 33; Karmel, Independent Board, supra note 11 at 546-47. However, this sentence was eliminated from the subsequent 1978 revised edition. American Bar Association, “The Corporate Director's Guidebook" (1978) 33 Bus Law 1595 at 1622 [Director's Guidebook 1978].

${ }^{121}$ Director's Guidebook 1976, ibid at 31; Karmel, ibid at 547.

${ }^{122}$ Director's Guidebook 1976, ibid at 32.

${ }^{123}$ Ibid at 35; Karmel, Independent Board, supra note 11 at 547.
} 
independent auditors to the company, reviewing the audit report and supervising the company's internal control mechanisms. ${ }^{124}$ The Guidebook recommended that the nominating committee should be composed exclusively of unaffiliated non-management directors. ${ }^{125}$ As for the compensation committee and the audit committee, both should be composed of non-management directors, a majority of whom should be unaffiliated non-management directors. ${ }^{126}$ The ABA recommendations created another source of the current corporate governance structures related to independent directors. In fact, there is not much difference between the suggestions of the American Bar Association in 1976 and the listing requirements adopted by the NYSE in 2002 regarding independent directors.

\subsection{Business Roundtable's Suggestion}

In 1978, the Business Roundtable ${ }^{127}$ issued a statement discussing the proper role of a board of directors in the conduct of corporate affairs. ${ }^{128}$ Compared to the Corporate Director's Guidebook, this statement was more practical and less legalistic. ${ }^{129}$ The statement suggested that directors should possess critical qualities of integrity, independence, an inquiring mind, vision, an ability to work with others, and broad experience. In order to deal with the changeable business environment, directors with managerial experience in another business or from a source outside the business community were highly desirable. ${ }^{130}$ Although the statement rejected the notion that all members of operating management should be disqualified from serving as directors, except the chief executive officer, ${ }^{131}$ the statement still considered that the number of outside directors should be at least sufficient to have a substantial impact on the board decision-

\footnotetext{
${ }^{124}$ Director's Guidebook 1976, ibid at 35-36.

125 Ibid at 36; Karmel, Independent Board, supra note 11 at 547.

${ }^{126}$ Director's Guidebook 1976, ibid at 36.

127 The Business Roundtable is an association of 180 chief executive officers of leading US corporations. This organization was established in 1972 through the merger of three existing organizations. The Roundtable has two major goals: (1) to enable chief executives from different corporations to work together to analyze specific issues affecting the economy and business, and (2) to present government and the public with knowledgeable, timely information, and with practical, positive proposals for action. See Business Roundtable history, online: Business Roundtable <http://www.businessroundtable.org/aboutUs/history.aspx>.

${ }^{128}$ Statement of the Business Roundtable, "The Role and Composition of the Board of Directors of the Large Publicly Owned Corporation" (1978) 33 Bus Law 2083 at 2085 [Business Roundtable 1978].

${ }^{129}$ Karmel, Independent Board, supra note 11 at 547.

${ }^{130}$ Business Roundtable 1978, supra note 128 at 2105-06.

${ }^{131}$ Ibid at 2107.
} 
making process. ${ }^{132}$ Therefore, the Business Roundtable endorsed the trend that US business corporations should move toward a board structure based on a majority of outside directors. ${ }^{133}$

Furthermore, the statement emphasized that companies should establish three critical committees-the audit, the nominating, and the compensation committees-to assist the full board to better fulfill its functions. ${ }^{134}$ The responsibility of each committee is roughly the same as what the Guidebook claimed. The main difference between the Guidebook and the statement from the Business Roundtable is the composition of the three committees. The statement believed that both the audit and the compensation committees should be solely made up of non-management directors, while the nominating committee should be composed by a majority of nonmanagement directors. ${ }^{135}$ However, the Business Roundtable did not define management directors, non-management directors, or outside directors in its statement.

\subsection{The SEC's Promotion of Independent Directors}

In addition to the legal and business community, the main US administrative authoritythe SEC-played an important role in promoting the monitoring role of independent directors. In 1977, Harold Williams became Chairman of the SEC, he outlined a far-reaching proposal for an ideal board of directors to function as a countervailing force to management. He first suggested that corporations explore the role and number of inside directors on their boards, since directors who have business links to their corporations impose a cost on the accountability process. In addition, he asserted that the chief executive officer should not serve as chairman of the board because top management should not control the substance of the board's deliberations. ${ }^{136}$ On his ideal board, management would not be represented except by the chief executive officer. He recommended that at least the nominating and audit committees of the board, the key elements in corporate governance, should be composed of independent directors. ${ }^{137}$

During Williams' tenure, the Commission held public hearings in four cities to reexamine issues concerning shareholder communications, shareholder participation in the corporate

\footnotetext{
${ }^{132}$ Ibid at 2108 .

133 Ibid.

${ }^{134}$ Ibid at $2108-09$.

135 Ibid at 2108-10.

${ }^{136}$ SEC Staff Report 1980, supra note 97 at 473.

${ }^{137}$ Williams, Corporate Accountability and Corporate Power, in the 1979 Benjamin F. Fairless Memorial Lectures: Power and Accountability: The Changing Role of the Corporate Board of Directors 8, 18-19 (1979), cited in Roberta S Karmel, Independent Board, supra note 11 at 543; Seligman, A Sheep in Wolf's Clothing, supra note 76 at 339.
} 
electoral process, and corporate governance in general. ${ }^{138}$ The well-known Staff Report on Corporate Accountability was published after these hearings. ${ }^{139}$ The report concluded that boards of directors were viewed by the public as a main force to enhance corporate accountability. Companies should provide an environment that enables directors to exercise their independent judgment, while allowing the three main committees-audit, nominating and compensation committees-to fully perform their functions. With an increasing number of truly independent directors and an effectively functioning committee system, an institutionalized process for holding management accountable would be created. ${ }^{140}$ However, the report did not address any legal recommendations regarding whether to establish or how to establish a board composed of independent directors. ${ }^{141}$

The SEC also actively applied its disclosure policies to encourage publicly-held companies to create boards consisting of independent directors and set up committees in which independent directors predominated. In a 1978 rulemaking proposal, the SEC strongly expressed its view that boards should consist of a majority of independent directors. Of paramount significance, this proposal required an issuer to disclose information regarding: (1) whether the corporation had standing audit, nominating and compensation committees of the board of directors; (2) the functions of these committees, if they were different from the customary functions set by the Commission; ${ }^{142}$ and (3) the members of these committees and whether they are management, affiliated non-management or independent directors as defined by the Commission. ${ }^{143}$ The Commission defined the independent director as a person who is neither a management director, nor an affiliated non-management director. A director who is an officer or

\footnotetext{
${ }^{138}$ Seligman, ibid at 340; Karmel, ibid at 545-46.

${ }^{139}$ SEC Staff Report 1980, supra note 97 at 473.

${ }^{140}$ Ibid at 579-85.

${ }^{141}$ Karmel, Independent Board, supra note 11 at 546.

142 The Commission considered that the customary function of the audit committee should include engaging and discharging the independent auditors, reviewing with the independent auditors the plan and results of the auditing engagement, reviewing the scope and results of the issuer's procedures for internal auditing, approving each professional service provided by the independent auditors prior to the performance of such service, reviewing the independence of the independent auditors, considering the range of audit and non-audit fees, and reviewing the adequacy of the issuer's system of internal accounting control. The customary functions of the compensation committee would include approval (or recommendation to the full board) of the remuneration arrangements for senior management and directors, adoption of compensation plans in which officers and directors are eligible to participate and granting of options or other benefits under any such plan. With respect to the nominating committee, its customary functions would include selecting (or recommending to the full board) nominees for election as directors and consideration of the performance of incumbent directors in determining whether to nominate them for re-election. SEC, Release No. 34-14970, supra note 100 at 80,580.

${ }^{143}$ Ibid at $80,579-80$.
} 
employee of the company, or any of its parents or subsidiaries was considered a management director. A director who has a business or personal relationship with the corporation or its management was regarded as an affiliated non-management director. ${ }^{144}$

This proposal eventually became a rule issued by the Commission at the end of 1978; however, the requirement of the categorization of directors in the proposal was dropped, due to the opposition by many commentators. ${ }^{145}$ More specifically, an issuer did not need to disclose whether the members of the audit, nominating and compensation committees were management, affiliated non-management or independent directors, as defined by the Commission. The disclosure of the classification of directors was replaced by a requirement for a brief description regarding whether certain significant economic or personal relationships existed between the director and the issuer. ${ }^{146}$ The disclosure of committees' functions was also replaced by a requirement for a brief description of functions actually performed by the companies' committees, again owing to commentators' objections. ${ }^{147}$ Nevertheless, the overall effect of the rule was to push issuers toward a higher level of director independence in the late 1970s.

\subsection{The American Law Institute's Recommendations}

In the early 1980s, the American Law Institute (ALI) ${ }^{148}$ also joined the line of voices supporting independent directors. Between 1982 and 1986, the ALI published Tentative Drafts No. 1 to 5 of Principles of Corporate Governance. The final version of Principles of Corporate Governance: Analysis and Recommendations, which contained seven parts ${ }^{149}$, was finished in

\footnotetext{
${ }^{144}$ Ibid at 80,577-79.

${ }^{145}$ Some commentators argued that directors identified as other than "independent" would be perceived as incapable of exercising independent judgment. As a result, corporations would be encouraged to select candidates on the basis their lack of certain defined relationships with the issuer, rather than their expertise or experience. SEC Exchange Act Release No. 15384, 81,766 at 81,089 (6 December 1978). The Release only mentioned that almost 600 individuals and organizations submitted letters in response to the Commission's request for public comments, but did not reveal their names. Ibid at 81,087.

${ }^{146}$ Ibid at 81,089 .

${ }^{147}$ Ibid at $81089,81095$.

${ }^{148}$ Founded in 1923, the American Law Institute has a membership consisting of more than 4,000 judges, practicing lawyers, and legal scholars from all areas of the United States as well as some foreign countries. The ALI drafts and then publishes various Restatements of the Law, model codes, and legal studies to promote the clarification and simplification of the law and its better adaptation to social needs, to secure the better administration of justice, and to encourage and carry on scholarly and scientific legal work. About ALI, online: American Law Institute < http://www.ali.org/>.

${ }^{149}$ The seven parts were: I. Definitions; II. The Object and Conduct of the Business Corporation; III. Structure of the Corporation; IV. Duty of Care and the Business Judgment Rule; V. Duty of Fair Dealing; VI. Transactions in Control; VII. Remedies.
} 
May 1992. The rationale behind the ALI Project was the monitoring model for corporations advocated by Professor Eisenberg. ${ }^{150}$ From the perspective of the ALI, the basic function of a board is to select a management team to run the company and to oversee their performance, rather than the inspection of day-to-day activities. In order to ensure the effectiveness of the oversight function, a board should be capable of evaluating the performance of management objectively and be provided with an accurate and a reliable flow of information concerning their performance. The requirement of board independence and the independence of the audit, nominating, and compensation committees were proposed to implement and support the oversight function of the board. ${ }^{151}$ The ALI's proposals are described below.

\subsection{Board Composition}

The Tentative Draft No. $1^{152}$ was the most controversial version in the Project. It gave rise to a corporate governance debate within the legal and business communities. The debate originated from the Draft's endorsement of mandatory requirements for board and specific committee independence. Some commentators considered that the monitoring model and a requirement for independent directors were not necessary. ${ }^{153}$ In the beginning of the Draft, the ALI distinguished corporations into three tiers: large publicly-held corporations, ${ }^{154}$ publicly-held corporations, ${ }^{155}$ and small corporations, ${ }^{156}$ based on differences in capital and ownership

\footnotetext{
${ }^{150}$ Karmel, Independent Board, supra note 11 at 549-50.

${ }^{151}$ The American Law Institute, Principles of Corporate Governance: Analysis and Recommendations, Volume 1 Parts I-VI (1994) at 104-06, 111, 122-23, 128.

${ }^{152}$ The full title of The Tentative Draft No. 1 is Principles of Corporate Governance and Structure: Restatement and Recommendations, which was published in April 1982. The American Law Institute, Principles of Corporate Governance and Structure: Restatement and Recommendations : Tentative Draft No. 1. (1982) [ALI Draft No. 1].

${ }^{153}$ Please refer to the articles in The George Washington Law Review Volume 52 (1984); Daniel R Fischel, "The Corporate Governance Movement” (1982) 35 Vand L Rev 1259 at 1265-71, 1283, 1291-92 [Fischel]; Walter Werner, "Corporation Law in Search of Its Future" (1981) 81 Colum L Rev 1611 at 1643-44 [Werner, Corporation Law Future]; Walter Werner, "Management, Stock Market and Corporate Reform: Berle and Means Reconsidered" (1977) 77 Colum L Rev 388 at 389, 410, 413 [Werner, Berle and Means Reconsidered]; Brudney, supra note 11 at 622, 654, 659; Karmel, Independent Board, supra note11 at 551, 556.

${ }^{154}$ Section 1.15 of ALI Draft No. 1 defines "Large Public Held Corporation" as follows:

"Large public held corporation" means a corporation that has 2000 or more record holders of its equity securities and $\$ 100$ million of total assets; but a large publicly held corporation shall not cease to have that status because its total assets fall below $\$ 100$ million, unless total assets remain below $\$ 100$ million for two consecutive fiscal years. ALI Draft No. 1, supra note 152 at 6.

${ }^{155}$ Section 1.21 of ALI Draft No. 1 defines "Publicly Held Corporation" as follows:
} 
structure. Then, it proclaimed that the functions of the board of directors should be: the selection and removal of senior executives, the review and approval of corporate plans and policies, the oversight of changes in accounting principles, and the avoidance of self-dealing. ${ }^{157}$ In order to fulfill these tasks, the ALI established a black-letter requirement that corporate law should provide that at least a majority of the directors of a large publicly-held corporation must be free of any significant relationships ${ }^{158}$ with the corporation's senior executives. ${ }^{159}$ As for other publicly-held corporations, the ALI only recommended that at least three directors be free of such relationships with the corporation's senior executives, as a matter of good corporate practice $^{160}$.

In fact, between 1977 and 1980, independent directors constituted $36 \%$ to $37 \%$ of the boards of corporations, while affiliated non-management and management (inside) directors made up $29 \%$ to $30 \%$ and $33 \%$ to $35 \%$ of the corporate boards, respectively, according to different empirical studies. ${ }^{161}$ At that time, neither federal nor state statutes in the United States had ever stipulated the composition of boards of directors, except for the Investment Company Act. Furthermore, no statute has tried to set qualifications for directors of publicly-held

"Publicly held corporation" means a corporation that has 500 or more record holders of its equity securities and $\$ 3$ million of total assets; but a publicly held corporation shall not cease to have that status because its total assets fall below \$3 million, unless total assets remain below \$3 million for two consecutive fiscal years. Ibid at 8-9.

${ }^{156}$ Small corporations mean corporations with fewer than 500 shareholders or less than $\$ 3$ million in total assets. Ibid.

${ }^{157}$ See Section 3.02, ALI Draft No. 1, ibid at 57-70.

${ }^{158}$ The significant relationship is defined in Section 1.24:

A director has a significant relationship with the senior executives of a corporation if , as of the time of the annual meeting to elect directors:

(1) He is employed by the corporation, or was so employed within the two preceding years;

(2) He is a member of the immediate family of an individual who is employed by the corporation as an officer or was employed by the corporation as a senior executive within the two preceding years;

(3) He owns an equity interest in a business organization to which the corporation made, or from which the corporation received, during either of the organization's two preceding fiscal years, commercial payments which, when multiplied by his percentage equity interest in the organization, exceeded $\$ 200,000$.

(4) He is a principal manager of a business organization to which the corporation made, or from which the corporation received, during either of the organization's two preceding fiscal years, commercial payments that exceeded 5\% of the organization's consolidated gross revenues, or $\$ 200,000$, whichever is more; or

(5) He is affiliated in a professional capacity with corporate counsel, or which an investment-banking firm that has been retained by the corporation, or acted as a managing underwriter in an issue of the corporation's securities, within two preceding years, or was so affiliated with such a law or investment-banking firm when it was so retained or so acted. Ibid at 10-11.

${ }^{159}$ Section 3.03(a), ibid at 71.

${ }^{160}$ Section 3.03(b), ibid.

${ }^{161}$ Gordon, The Rise of Independent Directors, supra note 1 at 1565 Appendix Table 1; Benjamin E Hermalin \& Michael S Weisbach, The Determinants of Board Composition, (1988) 19 RAND Journal of Economics 589 at 593. [Hermalin \& Weisbach 1988]. 
companies. The trend toward independent directors has been the result of business practice in light of economic and political circumstances, rather than a response to any legal requirement. ${ }^{162}$ This mandatory requirement regarding the proportion of independent directors on the board aroused debate between scholars and business communities. ${ }^{163}$

In comparison with other initiatives, the view of the ALI regarding board composition was not a radical one. The 1976 Corporate Director's Guidebook and the 1978 Business Roundtable statement already recommended that non-management directors should constitute a majority of the full board of directors, ${ }^{164}$ while SEC Chairman Harold Williams had suggested that an ideal board should be composed entirely of independent directors with the exception of its chief executive officer. ${ }^{165}$ Draft No. 1 adopted an in-between standard by recommending that corporate law should require that large publicly-held corporations have at least a majority of independent directors on the board.

\subsection{Composition of the Three Key Monitoring Committees}

In addition to board composition, the establishment of three committees, namely the audit, the compensation and the nominating committees, were recommended by the ALI to implement and support the monitoring function of the board. Regarding the audit committee, the ALI considered that the primary function of the audit committee would be to: select and fire the independent auditor, supervise the relationship between management and the independent auditor, consider the adequacy of a firm's internal accounting controls and choose appropriate accounting principles in the preparation of a firm's financial statements. ${ }^{166}$ Draft No. 1 contended that corporate law should provide that each large publicly-held corporation shall establish an audit committee composed solely of directors without significant relationships with the corporation's senior executives. ${ }^{167}$ As for all other publicly-held corporations, it recommended that their audit committees should be composed solely of directors who are not officers or employees of the corporation, and at least a majority of directors should have no

\footnotetext{
${ }^{162}$ Karmel, Independent Board, supra note at 544, 548.

${ }^{163}$ See ibid at 548-554.

${ }^{164}$ ALI Draft No. 1, supra note 152 at 72.

${ }^{165}$ See Karmel, supra note 11 at 543; Seligman, A Sheep in Wolf's Clothing, supra note 76 at 339.

${ }^{166}$ Section 3.05(a)(2), ALI Draft No. 1, supra note 152 at 82-84.

${ }^{167}$ Section 3.05(a), ibid at 82.
} 
significant relations with the corporation's senior executives, as a matter of good corporate practice (not a binding requirement). ${ }^{168}$

Compared with previously mentioned initiatives, the proposal regarding the audit committee independence in the Draft No. 1 seems to be a radical one. The Business Roundtable only recommended that the audit committee should be comprised of non-management directors, while the Corporate Director's Guidebook suggested that a majority of the committee members should be unaffiliated with the company or top managers. The NYSE 1978 rules, as a consequence of the pressure of the business community, further permitted former employees and affiliated non-management directors to serve on the audit committee. In contrast, the ALI adopted a more stringent standard which requires every audit committee member in large publicly-held companies to be independent of management. Perhaps, the prevalence of the audit committee at that time urged the ALI to further promote a higher level of audit committee independence in order to enhance the quality of financial reporting. In fact, before the NYSE adopted the new requirement in 1978, the independent audit committee had become a widely accepted element of the board structure in more than $90 \%$ of publicly-held companies. ${ }^{169}$ According to the Conference Board's 1979 report, 98\% of the surveyed committees had no employee members as of 1978 , and $83 \%$ had no former employees either. ${ }^{170}$

With respect to the nominating committee, the Draft No. 1 considered that corporate law should stipulate that every large publicly-held company shall establish a nominating committee composed exclusively of directors who are not officers or employees of the corporation, including at least a majority of directors with no significant relationship with the company's senior executive. ${ }^{171}$ As a matter of good corporate governance practice, all other publicly-held corporations were recommended to set up a nominating committee satisfying the same compositional standard. ${ }^{172}$ The function of the nominating committee would be to recommend and evaluate candidates for directorships, to monitor the performance of existing directors, and

\footnotetext{
${ }^{168}$ Section 3.05(b), ibid at 84 .

${ }^{169}$ Seligman, A Sheep in Wolf's Clothing, supra note 76 at 338; the Conference Board 1979, supra note 103 at 1, 52; Gordon, The Rise of Independent Directors, supra note at 1491.

${ }^{170}$ The Conference Board 1979, ibid at 50; Gordon, The Rise of Independent Directors, ibid.

${ }^{171}$ Section 3.06(a)(1), ALI Draft No. 1, supra note 152 at 97.

${ }^{172}$ Section 3.06(b), ibid at 98.
} 
to remove incompetent directors. ${ }^{173}$ It is worth mentioning that the removal of incompetent directors first appeared as a function of the nominating committee in this draft.

In comparison with the aforementioned initiatives, the ALI recommendation was a modest reform. The Corporate Director's Guidebook recommended that corporations establish a nominating committee composed solely of unaffiliated non-management directors, while, in 1978, the Business Roundtable suggested that companies set up a nominating committee only composed of a majority of non-management directors. Draft No. 1 adopted an in-between standard by recommending that corporate law should require that companies have a nominating committee comprised of a majority of directors with no significant relationship with the company's senior executive, in accordance with current business practice. ${ }^{174}$

Compared with the audit and compensation committees, the development of the nominating committee was relatively late. In 1967, only $7 \%$ of companies had a nominating committee, according the Conference Board's report. Even in 1977, by which time the audit committee had been established by $90 \%$ of the firms surveyed, a nominating committee was found in only $15 \%$ of the surveyed corporations. ${ }^{175}$ Probably due to the promotion of the American Bar Association, Business Round Table, and the SEC, the acceptance of the nominating committee changed dramatically during the end of the 1970s. In 1981, the proportion of companies having a nominating committee had increased to $43 \%{ }^{176}$

As for the compensation committee, the establishment of such a committee was not to be a mandatory requirement for companies. Purely as a matter of good corporate governance practice, Draft No. 1 recommended that each large publicly-held company should have a compensation committee composed solely of directors who are not officers or employees of the company, including at least a majority of directors with no significant relationships with the company's senior executives. ${ }^{177}$ The function of the compensation committee is to determine annual salary, bonuses and other benefits of senior management. ${ }^{178}$ By comparison, the Corporate Director's Guidebook in 1976 suggested that a majority of the members of the

\footnotetext{
${ }^{173}$ Section 3.06(a)(2), ibid at 97-98.

${ }^{174}$ See comments in Section 3.06(a)(2), ibid at 99-100.

${ }^{175}$ Conference Board 1981, supra note 112 at 7.

176 The Conference Board 1990, supra note at Table 39.

${ }^{177}$ Section 3.07(a), ibid at 106-07.

${ }^{178}$ Section 3.07(b), ibid. at 107.
} 
compensation committee should be unaffiliated non-management directors, ${ }^{179}$ while the Business Roundtable in 1978 recommended that the compensation committee should be comprised solely of non-management directors. ${ }^{180}$ Compared to these initiatives, Draft No. 1 seems to be relatively conservative (i.e. not significantly out of step with other proposals).

In fact, the rise of the compensation committee was roughly similar to that of the audit committee. According to the Conference Board's survey, around 30\% of corporations in 1962 and $51 \%$ of the companies in 1967 had established a compensation (or salary and bonus) committee to make recommendations to the board regarding the compensation of directors and corporate officers. ${ }^{181}$ The committee's mission even included the supervision or administration of the company's incentive compensation plan. ${ }^{182}$ With a view to avoiding conflicts of interest, the compensation committee in most corporations consisted of a majority of outside directors. In some cases, only directors who were not, and never had been, officers of the company were eligible to serve on the committee. ${ }^{183}$ In 1972, the percentage of corporations with a compensation committee increased to $69 \%$. More than $90 \%$ of compensation committees were composed of a majority of outside (non-management) directors. Around two-thirds of the compensation committees consisted entirely of outside directors at that time. ${ }^{184}$ With the promotion of the American Bar Association, the Business Roundtable, the SEC and the ALI, the percentage of companies with a compensation committee increased slightly to above $80 \%$ in the early 1980s. ${ }^{185}$

\subsection{Response to Critique}

However, in response to criticism from opponents, ${ }^{186}$ the ALI in 1984 published a modified version, Tentative Draft No. 2, that revised, in particular, its position on the composition of the board and its committees. The main characteristic in the latter version is that

\footnotetext{
${ }^{179}$ Director's Guide Book 1976, supra note 102 at 36.

${ }^{180}$ Business Roundtable 1978, supra note 128 at 2108.

${ }^{181}$ Conference Board 1962, supra note 71 at 132; Conference Board 1967, supra note 71 at 158.

${ }^{182}$ Conference Board 1962, ibid at 133; Conference Board 1967, ibid at 158.

${ }^{183}$ Conference Board 1962, ibid at 134; Conference Board 1967, ibid.

${ }^{184}$ Conference Board 1973, supra note 96 at 51, 67 Table 23.

185 The Conference Board 1990, supra note 95 at 33 Table 39.

${ }^{186}$ Fischel, supra note 153 at 1265-71, 1283-85, 1291-92; Werner, Corporation Law Future, supra note 153 at 164344; Werner, Berle and Means Reconsidered, supra note 153 at 389, 410, 413; Brudney, supra note 11 at 622, 654, 659; Karmel, Independent Board, supra note 11 at 551, 556.
} 
the ALI removed most of the mandatory features of the initial version. The major changes regarding independent directors included four parts. Firstly, it replaced the "mandatory requirement" in Draft No. 1's Section 3.03 that large publicly-held corporations have a least a majority of directors free of significant relationships with senior executives, with a "recommendation" in Draft No. 2 in Section 3.04 that "as a matter of corporate practice" the boards have such a composition. Secondly, it retained a mandatory audit committee, but lowered the requirement from "all" directors to "a majority of" directors having no significant relationship with senior executives. Thirdly, it recommended that the establishment of an audit committee be "a matter of corporate practice", rather than "a proposed statutory section." Finally, it reduced the composition of the nominating committee from previously "a proposed statutory section" to "a matter of corporate practice." 187 Nevertheless, despite this retreat, the monitoring role of independent directors gained popularity in the corporate community in the early 1980s.

\subsubsection{Summary}

Independent directors began to be considered as principal corporate monitors in the early 1970s. In fact, the concept of "independent director" was not differentiated from the "outside director" categories until the 1970s. ${ }^{188}$ Through promotion by lawyers, the business community, the SEC, and legal scholars for a decade, the monitoring role of independent directors was widely accepted as an important prescription for holding management accountable in the early 1980s. Most large publicly-held corporations gradually and voluntarily set up boards comprised of a majority of independent directors and established the audit, compensation and nominating committees composed solely of, or of at least a majority of independent directors to fulfill the expected monitoring function. In fact, there is not much difference between the proposals regarding board and committee independence in the late 1970s and the requirements of the NYSE in the $21^{\text {th }}$ century. The idea that directors should exercise independent judgment and ask probing questions of management had become commonplace in the late 1970s.

\footnotetext{
${ }^{187}$ Seligman, A Sheep in Wolf's Clothing, supra note 76 at 360.

${ }^{188}$ Gordon, The Rise of Independent Directors, supra note 1 at 1477.
} 


\subsubsection{Canada}

The concept of "independent director" did not gain public attention in Canada until the early 1990s. In 1991, a raft of governance failures in some major British corporations triggered corporate governance reform in the United Kingdom, and that reform subsequently spurred similar actions taken in Canada. ${ }^{189}$ More specifically, in response to governance failures in some large listed corporations, the British Financial Reporting Council ${ }^{190}$ and London Stock Exchange formed a committee to assess the financial aspect of corporate governance in the United Kingdom. The resulting paper, commonly referred to as the Cadbury Report ${ }^{191}$ after its principal author, was a milestone in thinking on corporate governance. ${ }^{192}$ The Cadbury Report proposed that a properly constituted board should include enough non-executive directors to carry significant weight in the board's decisions, and that a majority of non-executive directors should be independent of management and free from any relationship which could materially interfere with the exercise of their independent judgment. ${ }^{193}$ In addition, all listed corporations should establish an audit committee composed of a minimum of three non-executive directors, a majority of whom should be independent. ${ }^{194}$ The Cadbury Committee's recommendations regarding non-executive directors and the audit committee were highly influential in the development of thinking on independent directors in Canada. ${ }^{195}$

\subsubsection{The Dey Report}

\footnotetext{
${ }^{189}$ Sussex Circle Inc, Corporate Governance and Accountability in Canada (2002) at 22, online:<http://www.aucc.ca/_pdf/english/programs/cepra/Final\%20report_swain.pdf $>$ [Sussex].

190 The Financial Reporting Council is the UK's independent regulator responsible for promoting high quality corporate governance and reporting to foster investment. Financial Reporting Council, online: Financial Reporting Council 〈http://www.frc.org.uk/about/>.

${ }^{191}$ Committee on the Financial Aspect of Corporate Governance, The Financial Aspect of Corporate Governance, (London: Gee and Co Ltd, 1992), online: The European Corporate Governance Institute <http://www.ecgi.org/codes/documents/cadbury.pdf> [Cadbury Report].

192 Sussex, supra note 189 at 22; Sridhar R Arcot \& Valentina G Bruno, "In Letter But Not in Spirit: An Analysis of Corporate Governance in the UK" (May 2006) at 4-5, online: SSRN: <http://ssrn.com/abstract=819784 > [Arcot \& Bruno].

${ }^{193}$ Cadbury Report, supra note 191 at paras 4.11 and 4.12; Arcot \& Bruno, ibid at 6.

${ }^{194}$ Cadbury Report, ibid at para 4.35; Arcot \& Bruno, ibid.

195 Sussex, supra note 189 at 22.
} 
In the early 1990s, there was a growing feeling of dissatisfaction among Canadian investors and other interested parties with regard to the performance of boards of directors. ${ }^{196}$ Influenced by the Cadbury Report, and in response to the above concern, in 1993 the Toronto Stock Exchange (TSX) appointed a committee chaired by Peter Dey, a former head of the Ontario Securities Commission, to find the root of the problem and to design guidelines for public corporations based on existing best practices. One year later, with publication of what is commonly referred to as the Dey Report, Canada began its own modern attempt at assessing and improving the corporate governance practices of publicly-held Canadian firms. The Dey committee proposed 14 guidelines focusing on boards of directors and their relationship with shareholders and management. ${ }^{197}$ The key recommendations concerning independent directors, which the Dey Report termed "unrelated directors", were as follows:

- Each board should have a majority of unrelated directors, that is, directors who are free from any interests and any business or other relationship which could materially interfere with a directors' ability to act with a view to the best interests of the company. ${ }^{198}$

- Each board should have a committee comprised solely of outside directors, with oversight responsibility for management reporting on internal controls and with direct communication channels with the internal and external auditors. ${ }^{199}$

- Each board should appoint a committee composed exclusively of outside nonmanagement directors, a majority of whom are unrelated directors, with the responsibility for proposing to the full board new nominees to the board and for assessing directors on an ongoing basis. ${ }^{200}$

- To ensure that the board can function independently of management, every board should adopt a chair who is not a member of management or assign a lead director, ${ }^{201}$ and directors may meet on a regular basis without management present. ${ }^{202}$

\footnotetext{
${ }^{196}$ Sussex, ibid at 24; Toronto Stock Exchange Committee on Corporate Governance in Canada, Where Were the Directors? (Toronto: Toronto Stock Exchange, 1994) [Dey Report] at preface b.

${ }^{197}$ Sussex, ibid at 24-25; Dey Report, ibid at 4-5.

${ }^{198}$ Dey Report, ibid at 4, 24 (paras 5.7 and 5.8).

${ }^{199} \mathrm{Ibid}$ at 5, 41 (paras 6.20 and 6.21).

${ }^{200}$ Ibid at 4, 27-28 (para 5.25).

${ }^{201}$ Ibid at 5, 39-40 (para 6.16).

${ }^{202} \mathrm{Ibid}$ at 5, 38 (paras 6.10 and 6.11).
} 
In 1995, following the recommendations of the Dey Report, the TSX revised its listing requirements to adopt guidelines and to require corporations to specify, in either their annual report or proxy statement, whether their corporate governance practices complied with the guidelines and to give reasons for any non-compliance. ${ }^{203}$ This "comply or explain" approach, characterized by some as a principles-based model, became the mainstream approach adopted in Canadian corporate governance. The 1995 TSX guidelines have also been effective in raising the consciousness in Canada regarding the importance of unrelated directors. While the monitoring role of independent directors had been actively promoted in the United States since mid-1970s, unrelated directors also became the key foundation of corporate reforms in Canada in mid-1990s. The era of independent directors in Canada had begun.

\subsection{The Rise of Independent Directors}

After the monitoring model of corporate directors gained popularity in the early 1980s, the US state courts and legislation started to rely on independent directors to oversee corporate conduct due to their perceived impartial position. Whenever corporate scandals have emerged in the past two decades, each wave of corporate reforms, regardless of whether they occurred in the US or Canada, focused on independent directors by increasing their proportion on the committee or on the board, and tightening the standards for measuring independence. The differences between the two countries are the extent to which they require corporations to follow the rules regarding independent directors. The US regulators require issuers to comply with detailed legislation, regulations and stock exchange listing requirements in maintaining director independence. In contrast, Canada regulators give listing corporations discretion to follow guidelines regarding independent directors, but require them to explain the extent to which they choose not to comply with the practices set out in the guideline. As discussed in the following sections, the overall effect of courts' and regulators' reliance on independent directors in both countries for more than two decades means that independent directors have become the foundation of current corporate governance.

\footnotetext{
${ }^{203}$ Ibid at 1 (para 1.2).
} 


\subsubsection{The United States}

\subsubsection{The Court and Legislatures Rely on Independent Directors during the 1980s and 1990s}

\subsection{Takeover Bid Cases}

The 1980s is well remembered as the decade of the corporate takeover. ${ }^{204}$ Nearly half of the major companies in the US either received a friendly bid or became the object of a hostile acquisition attempt. ${ }^{205}$ From 1983 to 1988, there was an average of 160 hostile takeover bids per year. ${ }^{206}$ Taking Delaware corporations as examples, ${ }^{207}$ in response to the threat from hostile takeover bids, many of them adopted unexpected, even unprecedented defensive measures. The Delaware Court developed an approach which reviewed the board's deliberation process as well as board independence when the target board was responding to a takeover attempt. ${ }^{208}$ The Court was inclined to hold that the defensive measures adopted by the board were within the scope of the business judgment rule ${ }^{209}$, if the targets could demonstrate that their defensive measures were discussed extensively by all directors in the presence of the company's financial

\footnotetext{
${ }^{204}$ Melissa M Kurp, "Corporate Takeover Defenses After QVC: Can Target Boards Prevent Hostile Tender Offers Without Breaching Their Fiduciary Duties?" (1994) 26 Loy U Chicago L J 29 at 29 [Kurp]; Joseph Kershenbaum, "Corporate Law - A Snapshot of the Takeover Decade: Polaroid Corp. v. Disney - Whether a Target Corporation Has Third Party Standing to Assert a Violation of the All-Holders Rule" (1991) 13 W New Eng L Rev 63 at 63 [Kershenbaum].

${ }^{205}$ Mark Mitchell \& Harold Mulherin, "The Impact of Industry Shocks on Takeover and Restructuring Activity" (1996) 41 Journal of Financial Economics 193 at 199 [Mitchell \& Mulherin].

${ }^{206}$ Harvey Pitt, "On the Precipice: A Reexamination of Directors' Fiduciary Duties in the Context of Hostile Acquisitions" (1990) 15 Del J Corp L 811 at 812 note 7.

${ }^{207}$ The reason for analyzing takeover bid cases in Delaware, instead of other states, is that Delaware has been chosen as the state of incorporation by more listed companies than any other states, which has allowed for the development of a sophisticated case law. Because of such development, judicial opinions regarding independent directors in Delaware is more important than those in other jurisdictions in the United States.

${ }^{208}$ The Delaware courts were facing a trilemma in dealing with these cases. Theoretically, the courts could decide to: (1) prohibit these defensive measures and leave the matter of corporate control to shareholder action, which Delaware law strongly constrained; or (2) give managers uncontrolled discretion to resist tender offers, which raised obvious conflicts of interest; or (3) make a decision on the appropriateness of defensive tactics in a particular case, which would transform the court into an economic regulator. None of these was a good idea. By contrast, placing the burden on the board of directors had a statutory foundation. Delaware corporate law clearly provides that "business and affairs of a corporation shall be managed by or under the direction of a board of directors." Thus, the Delaware court developed such a strategy mentioned in the text. Gordon, The Rise of Independent Directors, supra note 1 at $1523-24$.

${ }^{209}$ The business judgment rule is a legal principle that makes directors of a corporation immune from liability to the corporation for loss incurred in corporate transactions within their authority, as long as the transactions are made in good faith and with reasonable skill and prudence. Usually, the courts are reluctant to interfere with or second-guess business decisions of corporate boards. Unocal Corp v Mesa Petroleum Co, 493 A 2d 946 at 954 (Del Supr 1985)

[Unocal]; Lisa M Fairfax, "Sarbanes-Oxley, Corporate Federalism, and the Declining Significance of Federal Reforms on State Director Independence Standards" (2005) 31 Ohio N U L Rev 381 at 392 [Fairfax, Corporate Federalism].
} 
advisors and counsel, and the independent directors constituted a clear majority of the board members. ${ }^{210}$ Unocal Corp. v. Mesa Petroleum Co. ${ }^{211}$ and Moran v. Household Int'l Corp. ${ }^{212}$ in the 1980 s as well as Paramount Communications Inc. v. Time, Inc. ${ }^{213}$ in the early 1990s are typical examples. Further details are discussed in section 4.1.1.3. The judicial deference to independent directors in the takeover bid cases demonstrated the growing importance of independent directors as corporate monitors.

\subsubsection{Derivative Litigation}

In addition to sustaining defensive measures made by independent directors in hostile takeover cases, director independence was promoted by courts in derivative litigation, especially in Delaware. Generally speaking, prior to filing a derivative claim, a shareholder must make a demand on the corporation's board of directors to request them to remedy the situation that is the subject of the shareholder's concern. ${ }^{214}$ In Delaware, a shareholder plaintiff can bring a derivative action without making a demand, if such a demand on directors would be futile. The standard, set forth in Aronson v. Lewis, for determining "demand futility" requires the pleading of particularized facts raising a reasonable doubt regarding whether (1) a majority of directors lack independence; or (2) the challenged transaction was a valid exercise of the business judgment by directors. ${ }^{215}$ Usually, courts defer to directors' corporate decisions under the business judgment rule ${ }^{216}$, so establishing demand futility under the second standard is very difficult. Unless shareholders can prove that a majority of directors lacked independence, their

\footnotetext{
${ }^{210}$ Unocal, ibid at 950; Moran v Household Int'l Corp, 500 A 2d 1346 at 1348 (Del 1985) [Moran]; Paramount Communications Inc v Time Inc, 571 A 2d 1140 at 1147-48 (Del 1990) [Paramount]; Gordon, The Rise of Independent Directors, supra note 1 at 1524-26.

${ }^{211}$ Unocal, ibid.

${ }^{212}$ Moran, supra note 210 at 1348.

${ }^{213}$ Paramount, supra note 210 at $1147-48$.

${ }^{214}$ Dennis J Block, Stephen A Radin \& Michael J Maimone, "Derivative Litigation: Current Law Versus the American Law Institution" (1993) 48 Bus Law 1443 at 1451 [Block, Radin \& Maimone]; Lin, supra note 13 at 907. ${ }^{215}$ Block, Radin \& Maimone, ibid at 1456; Lin, supra note 13 at 907; Grobow v Perot, 539 A 2 d 180 at 186 (Del 1988) [Grobow] (citing Aronson v Lewis, 473 A 2d 805 at 814 (Del 1984)).

216 The business judgment rule is an acknowledgment of the managerial prerogatives of Delaware directors under Section 141(a) of Delaware General Corporation Law. It is a presumption that the directors of a corporation acted on an informed basis, in good faith and in the honest belief that the action taken was in the best interests of the company, when they were making a business decision. Zapata Corp v Maldonado, 430 A 2d 779 at 782 (Del 1981) [Zapata]; Aronson v. Lewis, 473 A 2d 805 at 814 (Del 1984) [Aronson]; Lisa M Fairfax, "The Uneasy Case for the Inside Director” (2010) 96 Iowa L Rev 127 at 141 [Fairfax, Inside Director], see also supra note 209.
} 
derivative suits cannot move forward on the basis of demand futility. ${ }^{217}$ Further details are discussed in the section 4.1.1.2. Corporations may have incentives to maintain a majority of independent directors on the boards, since independent directors play a critical role in preventing shareholders from bringing a derivative action before the court. The court's reliance on independent directors in response to derivative suits demonstrates the courts' faith in their effectiveness as corporate monitors in the field of corporate governance.

\subsection{Michigan State Law}

Besides judicial deference, a state legislature endorsed independent directors as corporate monitors at the end of the 1980s. In 1989, Michigan introduced a role for independent directors in its Business Corporation Act ${ }^{218} .^{219}$ Corporations in Michigan are able to choose whether to appoint statutory independent directors. ${ }^{220}$ In order to encourage corporations to appoint statutory independent directors, incentives are built into the statute. Independent directors are given the statutory power to make determinations in three areas of corporate actions: interested director transactions, indemnification of directors and officers, and termination of shareholder derivative suits. ${ }^{221}$ To qualify as an independent director in Michigan, a director must be elected by the corporation's shareholders, be designated by its board or its shareholders as independent, and meet both competence and independence requirements. ${ }^{222}$ The competence requirement requires a minimum of five years' business, legal or financial experience. The independence requirement requires the absence of any disqualifying relationship ${ }^{223}$ with the corporation for three years prior to designation (a cooling-off period) and a limitation of the director's term to

\footnotetext{
${ }^{217}$ Fairfax, Inside Director, ibid at 143.

2181972 Mich Pub Acts 284 (codified as amended at Mich Comp Laws Ann $§ \S 450.1101-450.3192$ (1973)).

${ }^{219}$ Cyril Moscow et al, Michigan's Independent Director (1990) 46 Bus Law 57 at 57 [Moscow et al]. In addition, Michigan is the first state in the United States to use the term "independent director" in its statute. Scott J Gorsline, "Statutory 'Independent' Directors: A Solution to the Interested Director Problem?" (1989) 66 U Det L Rev 655 at 673 [Gorsline].

${ }^{220}$ Moscow et al, ibid at 65; Gorsline, ibid at 675.

${ }^{221}$ Mich Comp Laws Ann $§ 450.1545 a, \S 450.1564 a, \S 450.1495$; Moscow et al, ibid at 58-59, 61-62; Gorsline, ibid at 675-76.

${ }^{222}$ Mich Comp Laws Ann $\$ 450.1107(3)$; Moscow et al, ibid at 58; Gorsline, ibid at 673.

${ }^{223}$ The three disqualifying relationships include employment relationship, business relationship and family member relationship. Mich Comp Laws Ann \$450.1107(3)(d) (f). Please refer to infra note 746 for further details.
} 
three years. ${ }^{224}$ Further details regarding an independent director in Michigan are discussed in section 4.1.1.4.

The Michigan statute explicitly gives independent director approval special effect. Scholars consider that courts will not second-guess the judgment of independent directors in relation to the approval of transactions in which other directors have an interest, indemnification, and derivative suits, since the decisions of independent directors have gained statutory recognition. ${ }^{225}$ Corporations in Michigan have incentives to have more independent directors on the board. The Michigan legislation reveals that one state legislature, to some extent, started to rely on independent directors as corporate monitors from the late 1980s.

\subsection{Internal Revenue Code}

In 1993, the reform of Internal Revenue Code (IRC) Section $162(\mathrm{~m})^{226}$ also joined the line of policy initiatives relying on independent directors ${ }^{227}$, in this case to tie executive remuneration to firm performance. The new law denied publicly-held corporations the right to deduct executive compensation greater than $\$ 1$ million for corporate tax purposes, ${ }^{228}$ unless the compensation is performance-based and determined by a compensation committee composed solely of two or more independent directors. ${ }^{229}$ The purpose of the law is to encourage the adoption of performance-based compensation for executives, ${ }^{230}$ while independent directors on the compensation committee are relied on to ensure that the performance-based executive remuneration in excess of $\$ 1$ million is closely related to firm performance. A director who is not a current or former employee of the company, or who does not receive directly or indirectly remuneration from the company other than as a director, is considered as an independent

\footnotetext{
${ }^{224}$ Mich Comp Laws Ann \$450.1107(3); Moscow et al, supra note 219 at 58; Gorsline, supra note 219 at 674.

${ }^{225}$ See Moscow et al, ibid at 61-62, 65; Gorsline, ibid at 675-76.

${ }^{226}$ Internal Revenue Code, 26 USC §162(m) (1993); Omnibus Revenue Reconciliation Act of 1993, Pub L No 10366, 107 Stat 312 (2006).

${ }^{227}$ The original term used in the Internal Revenue Code Section $162(\mathrm{~m})$ is "outside director."

${ }^{228}$ Ibid; James E Heard, "Executive Compensation: Perspective of the Institutional Investor" (1995) 63 U Cin L Rev 749 at 756; Bengt Holmstrom \& Steven N Kaplan, "Corporate Governance and Merger Activity in the United States: Making Sense of the 1980s and 1990s" (2001) 15 Journal of Economic Perspectives 121 at 136; Gordon, Independent Directors, supra note at 1531; Jerry W Markham, "Regulating Excess Executive Compensation - Why Bother?" (2007) 2 J Bus \& Tech L 277 at 293-94 [Markham].

${ }^{229}$ Internal Revenue Code, 26 USC $\$ 162(\mathrm{~m})(4)(\mathrm{c})(\mathrm{i})(1993)$; Markham, ibid.

${ }^{230}$ Markham, ibid at 294; James S Wallace \& Kenneth R Ferris, "IRC Section 162(m) and the Law of Unintended Consequences" (November 2006) at 3, online: SSRN <http://ssrn.com/abstract=942667>.
} 
director. $^{231}$ This legislation demonstrates that the reliance on independent directors to check on managerial abuses has extended to the federal level in the early 1990s.

\subsubsection{The Blue Ribbon Committee, NYSE and NASDAQ Rely on Independent Directors to Ensure the Integrity of Financial Reporting Process in the Late 1990s}

In 1998, Arthur Levitt, the Chairman of the SEC, expressed concerns in an address at New York University that the US business community was witnessing a gradual, but noticeable, erosion in the quality of financial reporting, and the emergence of a gray area where accounting practices are perverted and where earnings reports reflect the desires of management rather than underlying financial performance of the company. He indicated that some corporations practiced inappropriate earnings management in order to meet analysts' forecasts or to respond short-term market pressure. Such a phenomenon could distort the market's perception of a company's true financial condition and results of operations; misleading investors and resulting in a substantial loss to shareholders. ${ }^{232}$

In response to Mr. Levitt's concerns, the Blue Ribbon Committee (BRC) on Audit Committee Effectiveness was established jointly by the NYSE and National Association of Securities Dealers (NASD) in September 1998. The BRC issued its recommendations regarding the appropriate make-up and function of the audit committee in February 1999. The BRC report contained ten recommendations, which could be categorized into three parts: audit committee membership requirements (Recommendations 1 to 3), audit committee structure and function (Recommendations 4 and 5), and audit committee relationships and communications with the outside auditor and management (Recommendations 6 to 10). ${ }^{233}$

With respect to the audit committee membership requirements, Recommendation 1 suggested that both the NYSE and the NASD tighten their current definition regarding the independence of audit committee members to include only those who have no relationship to the

\footnotetext{
${ }^{231}$ Income Tax Regulation, $\$ 1.162-27(\mathrm{e})(3)(\mathrm{i}) ; 26$ CFR $\$ 1.162-27(\mathrm{e})(3)(\mathrm{i})$.

${ }^{232}$ Blue Ribbon Committee on Improving the Effectiveness of Corporate Audit Committees, "Report and Recommendations of the Blue Ribbon Committee on Improving the Effectiveness of Corporate Audit Committees" (1999) 54 Bus Law 1067 at 1076-77 [BRC Report]; L Murphy Smith, "Audit Committee Effectiveness: Did the Blue Ribbon Committee Recommendations Make A Difference?” (2006) 3 International Journal of Accounting, Auditing and Performance Evaluation 240 at 240-41, 243, online: SSRN <http://ssrn.com/abstract=1001531> [Smith].

${ }^{233}$ Smith, ibid at 243.
} 
corporation that may interfere with the exercise of their independence from management and the corporation. In addition, the Recommendation gave five examples of the relationships, in which audit committee members should not be considered independent, including employment relationships, ${ }^{234}$ compensation relationships, ${ }^{235}$ immediate family relationships, ${ }^{236}$ business relationships, ${ }^{237}$ and cross-compensation committee links. ${ }^{238}$ Recommendation 2 suggested that corporations listed in the NYSE and the NASD have an audit committee comprised solely of independent directors subject to the definition in Recommendation 1. Recommendation 3 proposed that each audit committee should consist of a minimum of three directors, each of whom is financially literate ${ }^{239}$, and further that at least one member of the audit committee have accounting or related financial management expertise ${ }^{240} \cdot 241$

Regarding the audit committee structure and function, Recommendation 4 suggested that the audit committee of each listed corporation adopt a formal written charter, specifying the scope of the committee's responsibilities, and how it carries out those responsibilities and reviews the adequacy of the audit committee charter on an annual basis. Recommendation 5 recommended that the SEC promulgate rules that require each listed company to disclose its audit committee's activities in the proxy statement, including whether it had adopted a written charter, and fulfilled its responsibilities. ${ }^{242}$

As for the audit committee's relationships and communication with the outside auditor and management, Recommendation 6 suggested that the audit committee have the ultimate

\footnotetext{
${ }^{234}$ An employment relationship refers to a director being employed by the corporation or any of its affiliates for the current year or any of the past years. BRC Report, supra note 232 at 1080.

${ }^{235}$ A compensation relationship refers to a director accepting any compensation from the corporation or any of its affiliates other than compensation for board service or benefits under a tax-qualified retirement plan. Ibid.

${ }^{236}$ An immediate family relationship refers to a director being a member of the immediate family of an individual who is, or has been in any of the past five years, employed by the corporation or any of its affiliates as an executive officer. Ibid.

${ }^{237}$ A business relationship refers to a director being a partner in, or a controlling shareholder or an executive officer of, any for-profit business organization to which the corporation made, or from which the corporation received, payments that are or have been significant to the corporation or business organization in any of the past five years. Ibid.

${ }^{238}$ A cross-compensation committee link refers to a director being employed as an executive of another company where any of the corporation's executives serves on that company's compensation committee. Ibid.

${ }^{239}$ BRC defines financial literacy as the ability to read and understand fundamental financial statements, including a company's balance sheet, income statement, and cash flow statement. Ibid at 1081.

${ }^{240} \mathrm{BRC}$ defines financial expertise as past employment experience in finance or accounting, requisite professional certification in accounting, or any other comparable experience or background which results in the individual's financial sophistication, including being or having been a CEO or other senior officer with financial oversight responsibilities. Ibid.

${ }^{241}$ Ibid at 1072-73, 1080-82.

${ }^{242}$ Ibid at 1073-74, 1083-85.
} 
authority and responsibility to select, evaluate and replace the outside auditor. Recommendation 7 proposed that the audit committee should be responsible for ensuring its receipt of a written statement from the outside auditors delineating all relationships between the outside auditors and the company, and taking appropriate action to ensure the independence of the outside auditor. Recommendation 8 recommended Generally Accepted Auditing Standards to require that each listed company's outside auditor have discussions with the audit committee regarding the quality of the company's accounting principles as applied in its financial reporting, including the degree of aggressiveness or conservatism. Recommendation 9 proposed that the SEC require each listed company's audit committee to send an annual letter to stockholders regarding a discussion of the audited financial statements between the audit committee and management, and a confirmation of financial statements which fairly present the financial position of the corporation in conformity with Generally Accepted Accounting Principles. Recommendation 10 suggested that the SEC should require that each listed company's outside auditor conducts SAS 71 Interim Financial Reviews ${ }^{243}$ at each quarter. ${ }^{244}$

In response to the BRC's recommendation, the NYSE and NASD quickly proposed to amend their listing standards regarding audit committee requirements. ${ }^{245}$ The SEC approved the proposals with full speed. ${ }^{246}$ The NYSE's 1999 rule changes specify four requirements for a qualified audit committee, including a formal charter, the composition requirement, the expertise requirement, and the independence requirement. ${ }^{247}$ With respect to a formal charter, the NYSE's requirements were copied from the BRC's Recommendations 4, 6, and $7^{248}$ with a minor

\footnotetext{
${ }^{243}$ SAS 71 Interim Financial Reviews refers to Statement on Auditing Standards No. 71, which is promulgated by the Auditing Standards Board of the American Institute of Certified Public Accountants (AICPA) in May 1992 (superseded by SAS 100 in November 2002). This Statement (SAS 71) provides guidance on the nature, timing, and extent of procedures to be applied by the independent accountant in conducting a review of interim financial information and on the reporting applicable to such engagements. Interim Financial Information, online: University of Mississippi Library 〈http://umiss.lib.olemiss.edu:82/record=b1038094> .

${ }^{244}$ Ibid at 1073-76, 1085-89.

${ }^{245}$ Smith, supra note 232 at 241.

${ }^{246}$ The NYSE and NASDAQ proposed amendments to their listing requirements regarding the audit committee on September 1999, and the SEC approved the proposals on December 1999. Self-Regulatory Organizations, Order Approving Proposed Rule Change by the New York Stock Exchange, Inc. Amending Its Audit Committee Requirements and Notice of Filing and Order Granting Accelerated Approval of Amendments No. 1 and No. 2 Thereto, Exchange Act Release No. 34-42233 (14 December 1999) [NYSE 1999 Rules]; Self-Regulatory Organizations, Order Approving Proposed Rule Change by the National Association of Securities Dealers, Inc. Amending Its Audit Committee Requirements and Notice of Filing and Order Granting Accelerated Approval of Amendments No. 1 and No. 2 Thereto, Exchange Act Release No. 34-42231 (14 December 1999) [NASD 1999 Rules].

${ }^{247}$ NYSE 1999 Rules, ibid.

${ }^{248}$ The content of BRC's Recommendations 4, 6, and 7 can be found in text accompanying supra notes 242-244.
} 
adjustment. As for the composition and expertise requirements, the NYSE followed the recommendation of the BRC without making any significant changes. ${ }^{249}$ However, regarding the independence requirements, the NYSE only listed four relationships which restricted directors from being considered independent, eliminating the compensation relationship proposed by the Blue Ribbon Committee. ${ }^{250}$ In addition to independence requirements, in comparison with the BRC's report, the NYSE's listing requirements are looser in other ways as well. The cooling-off period $^{251}$ is reduced from five years to three years. As well, a director who accepts any compensation from the company or any of its affiliates, other than compensation for board service or benefits under a tax-qualified retirement plan, may still be considered independent. ${ }^{252}$

The 1999 NASDAQ rule changes covered three general areas: the audit committee charter; the structure and membership of the audit committee; and the definition of independence. $^{253}$ With respect to the audit committee charter and the structure and membership of the audit committee, the NASDAQ requirements are roughly the same as those of NYSE, both cite the BRC's recommendations. ${ }^{254}$ Regarding the definition of "independence," the NASDAQ adopted a similar approach as the NYSE, which described the meaning of "independent director" and excluded some directors who have certain relationships with the company from being considered independent. ${ }^{255}$ The main differences between the NYSE rules and the NASDAQ rules are that the NASDAQ standards were more detailed and specific ${ }^{256}$, and the NASDAQ enumerated five exclusions from independent directors, which wholly followed the BRC's suggestions, ${ }^{257}$ in comparison with only four required by the NYSE. ${ }^{258}$

\footnotetext{
${ }^{249}$ NYSE 1999 Rules, supra note 246; BRC's Recommendations regarding composition and expertise requirements (i.e. Recommendations 2 and 3) can be found in text accompanying supra notes 239-241.

${ }^{250}$ NYSE 1999 Rules, ibid; BRC's Recommendations regarding independence requirements (i.e. Recommendation 1) can be found in text accompanying supra notes 234-238.

${ }^{251}$ A cooling-off period here refers to that a director who is considered not independent by the NYSE rules has to wait for a specific period (such as three years) to be reconsidered independent. Lutzy, supra note 97 at 114; NYSE Manual, supra note 5, §303A.02(b).

${ }^{252}$ Ibid.

${ }^{253}$ NASD 1999 Rules, supra note 246.

${ }^{254}$ Ibid.

${ }^{255}$ Ibid.

${ }^{256}$ For example, the NASDAQ specifies that the standard of considering not independent is the receipt of compensation from the company exceeding $\$ 60,000$ per year, while the NASDAQ clearly defines "business relationship" as any for-profit organization to which the corporation made or from which the corporation received payments that exceed 5\% of the corporation's or business organization's consolidated gross revenues in a year, or $\$$ 200,000 , depending on which is more. Ibid.

${ }^{257}$ Ibid.

${ }^{258}$ Please refer to text accompanying supra notes 234-238 and infra notes 756-758 for further details.
} 
Collectively, the 1999 NYSE and NASDAQ amendments to their audit committee requirements demonstrated that the market regulators, after the mandatory establishment of audit committees for two decades, relied on independent directors to oversee the financial reporting process and deter fraud, with a goal of providing accurate and high-quality financial information to the public market and shareholders. In comparison with the 1978 listing requirements, the 1999 amendments further tightened the definition of independent directors and required directors who sit on the audit committee to have a certain level of financial knowledge.

\subsubsection{The Sarbanes-Oxley Act and the Related Reforms in Response to Corporate Scandals in the early 2000s}

Starting with Enron, a wave of reported corporate debacles was revealed in the early 2000s. In October 2001, one of the most acclaimed and innovative companies in the United States, Enron, reported a shocking quarterly loss of \$618 million. Within two months, this seventh-largest publicly traded corporation in the United States declared bankruptcy. ${ }^{259}$ According to the US Senate report, the collapse of Enron was due to its engaging in high-risk accounting, inappropriate transactions tainted by conflicts of interest, excessive compensation and extensive undisclosed off-the-books activities, in combination with the failure of Enron's board of directors to prevent management from doing the aforementioned inappropriate activities. ${ }^{260}$ In fact, the Enron board had been ranked as one of the five best corporate boards by Chief Executive Magazine in 2000. ${ }^{261}$ Twelve out of Enron's fourteen board members, including five CEOs and four academics, claimed to be independent in $2001 .^{262}$ Furthermore, Enron's audit committee charter, which was considered state-of-the-art, allowed the committee to retain other accountants, consultants, or lawyers, as it thought advisable. ${ }^{263}$ Its chairman, Robert Jaedicke, was even a well-known financial expert, an accounting professor and the former dean at the Stanford University Graduate School of Business. Enron's three key

\footnotetext{
${ }^{259}$ Senate Enron Report, supra note 2 at 1, 6; R William Ide, "Post-Enron Corporate Governance Opportunities: Creating a Culture of Great Board Collaboration and Oversight" (2003) Mercer L Rev 829 at 829 [Ide, Post-Enron].

${ }^{260}$ Senate Enron Report, ibid at 3.

${ }^{261}$ Gillan \& Martin, supra note 2 at 932.

262 Ibid at 952-955.

${ }^{263}$ Ibid at 935; Jeffrey N Gordon, "What Enron Means for the Management and Control of the Modern Business Corporations: Some Initial Reflections” (2002) 69 U Chicago L Rev 1233 at 1241[Gordon, Enron Reflection].
} 
monitoring committees-audit, compensation and nominating committees-were also comprised solely of independent directors. ${ }^{264}$ However, the allegedly solid and independent board and committees still could not restrain Enron's management from engaging in risky behavior that led to the firm's destruction.

On June 25, 2002, WorldCom announced that it had improperly accounted for over $\$ 3.8$ billion in expenses during the previous five quarters, which resulted in the largest earnings restatement in business history. On July 21, 2002, WorldCom filed for bankruptcy, just less than one month after the outbreak of its accounting scandal. This was the biggest bankruptcy in American history at that time. ${ }^{265}$ According to the subsequent investigation, WorldCom's problem originated from accounting fraud by its CFO, Scott Sullivan, who listed charges paid to telephone companies as capital expenditure rather than operating costs, and thus disguised WorldCom's loss as its profit. ${ }^{266}$ WorldCom's board of directors, mostly claimed to be independent, failed to detect this simple, but catastrophic accounting discrepancy, which brought the company to bankruptcy. ${ }^{267}$

These and other corporate scandals during 2001 and 2002 caused US shareholders to worry about whether the current corporate governance system could effectively monitor the behavior of managers and protect their interests. Significant pressure mounted on the regulators and legislators for dramatic changes in corporate governance structures in order to prevent a repeat of such collapses. After the eruption of the Enron scandals, the NYSE and NASDAQ started to prepare their next round of corporate governance reforms. Their reform proposal, mainly relying on independent directors, included two parts: (1) enhancing the role and authority of independent directors; ${ }^{268}$ and (2) tightening the definition of independent directors and adding

\footnotetext{
${ }^{264}$ Gillan \& Martin, ibid.

${ }^{265}$ Simon Romero \& Riva D Atlas, "WorldCom Files for Bankruptcy; Largest U.S. Case”, Wall Street Journal (22 July 22 2002) A3; Ide, supra note 259 at 830.

${ }^{266}$ Thornburgh Report, supra note 3 at 105-09; Kathleen F Brickey, "From Enron To WorldCom and Beyond: Life and Crime After Sarbanes-Oxley" (2003) 81 Wash U L Q 357 at 369-70; Feuerstein, supra note 3; Buncombe supra note 3.

${ }^{267}$ Thornburgh Report, ibid at 37; Feuerstein, ibid; Buncombe, ibid. WorldCom's board consisted of eleven directors, and eight of them were considered independent, according to the National Association of Securities Dealers' definition. The questioned financial statements were reviewed by the company's audit committee comprised of four independent members who only met five times in 2001. Feuerstein, ibid; Buncombe, ibid.

${ }^{268}$ The proposed new standards required that listed companies must possess boards with a majority of independent directors, and that every listed company must have an audit committee, a nominating committee and a compensation committee, each comprised solely of independent directors. Boards must convene regular executive sessions in which non-management directors meet in the absence of management. Audit committees must have sole responsibility for hiring and firing the corporation's independent auditors, and for approving any significant non-
} 
new audit committee qualification requirements. ${ }^{269}$ The US Congress also heeded the pressure from the public and moved quickly. The Sarbanes-Oxley Act of $2002^{270}$ was passed within only a month after the WorldCom scandal, with the goal of protecting investors and restoring the confidence of the nation's financial markets.

The Sarbanes-Oxley Act was described as "the most far-reaching reforms of American business practices since the time of Franklin Delano Roosevelt," by President Bush. ${ }^{271}$ The newly-appointed Commissioner of the SEC, Harvey J. Goldschmid, called the Act the "most sweeping reform since the Depression-era securities laws." 272 Unlike the proposed Exchange listing requirements that were notable for their concentration on board independence generally, the Act focuses on director independence requirements related to audit committees and corporate financial oversight by the accounting profession. ${ }^{273}$ With a view to enhancing the effectiveness of audit committees, the Act requires that each audit committee of a public corporation be composed solely of independent directors. ${ }^{274}$ The criteria of independence for the audit committee members requires that these directors may neither accept any consulting, advisory, or other compensation fees from the corporation, nor be affiliated with persons of the corporation or any of its subsidiaries. ${ }^{275}$ In addition, each listed company has to disclose whether at least one of

audit work by the auditors. The chair of the audit committee must have accounting or financial management experience. NYSE, "New York Stock Exchange Corporate Accountability and Listing Standards Committee" (6 June 2002) at 2, online: NYSE <www.iasplus.com/resource/nysegovf.pdf> [Corporate Accountability Report 2002]; NASDAQ, Press Release, "NASDAQ Submits First Round of Corporate Governance Rule Changes to the SEC; Announces Plan for Additional Issues for Review This Month" (5 June 2002), online: NASDAQ <http://www.nasdaq.com/newsroom/news/pr2002/ne_section02_121.html_> [NASDAQ 2002 Reform]; Ide, supra note 259 at 846 .

${ }^{269}$ As for the definition of independence and the new audit committee qualification requirements, directors must have no material relationship with the listed company and be certified by the board to satisfy the definition "independent." There is also a five-year cooling-off period for former employees, independent auditors, or other related person to be reconsidered "independent" of the company. In addition, for an audit committee member, director compensation must be the sole remuneration received from the listed company. The goal of these new rules seeks to increase the objectivity and quality of board oversight in order to protect shareholder interests. NYSE, Corporate Accountability Report 2002, ibid; NASDAQ, 2002 Reform, ibid; Ide, ibid.

${ }^{270}$ Sarbanes-Oxley Act, supra note 4.

${ }^{271}$ Lawrence A Cunningham, "The Sarbanes-Oxley Yawn: Heavy Rhetoric, Light Reform (And It Just Might Work)" (2003) 35 Conn L Rev 915 at 917 [Cunningham].

${ }^{272}$ Ibid.

${ }^{273}$ Charles M Elson \& Christopher J Gyves, "The Enron Failure and Corporate Governance Reform" (2003) 38 Wake Forest L Rev 855 at 879 [Elson \& Gyves].

${ }^{274}$ See Sarbanes-Oxley Act, supra note 4, §201-\$301; Cunningham, supra note 271 at 946-47; Elson \& Gyves, ibid.

${ }^{275}$ See Sarbanes-Oxley Act, supra note 4, §301(3). 
its audit committee members, through education and experience, qualifies as a financial expert. $^{276}$

In addition, the Act expands audit committee authority. The audit committee is required to be directly responsible for the appointment, compensation and oversight of the auditing firm hired by the corporation to prepare and issue audit reports. ${ }^{277}$ This responsibility includes the authority to hire and fire auditors, ${ }^{278}$ and pre-approve all audit and non-audit services. ${ }^{279}$ Moreover, the audit committee must act as a fraud watchdog by establishing confidential and anonymous procedures for employees to report any questionable accounting or audit matters. ${ }^{280}$

Because Enron and WorldCom had independent boards meeting best practice standards but remained unable to detect managerial abuses, the Act adopted other measures to hold management accountable, such as prohibitions on loans to corporate officers and directors (SOX $\S 402$ ), certification of the effectiveness of internal controls by the CEO and CFO (SOX $\S 404)$, and disclosure of the corporation's code of ethics (SOX §406).

Following the enactment of Sarbanes-Oxley, both the NYSE and NASDAQ took additional steps. The central theme of the new NYSE listing requirements for corporate governance focused on the enhanced role of independent directors. ${ }^{281}$ The new listing requirements necessitate that each listed company have a majority of independent directors on its board, ${ }^{282}$ and establish audit, nominating/corporate governance and compensation committees comprised solely of independent directors. ${ }^{283}$ No director can qualify as being independent, unless the board of directors determines that the director has no material relationship with the company. ${ }^{284}$ The new requirements tightened the definition of independent director by adding two specific preclusions-compensation relationships ${ }^{285}$ and relationships with auditors-that are

\footnotetext{
${ }^{276}$ See Sarbanes-Oxley Act, ibid, $\$ 407(a),(b)$; Elson \& Gyves, ibid at 879

${ }^{277}$ See Sarbanes-Oxley Act, ibid, $\$ 301(2)$.

${ }^{278}$ Ibid.

${ }^{279}$ Ibid, $\$ 201-\$ 202$.

${ }^{280}$ Ibid, \$301(4).

${ }^{281}$ Ide, supra note 259 at 850.

${ }^{282}$ NYSE Manual, supra note 5, §303A.01

${ }^{283}$ Ibid, §303A.04, §303A.05, §303A.06.

${ }^{284}$ Ibid, §303A.02(a).

${ }^{285}$ The NYSE 1999 rules did not preclude a director from being considered independent even if he/she accepts compensation from the listed company. However, the NYSE 2003 rules tightened the definition of independent directors by adding a preclusion that a director is not independent if he/she (or his/her immediate family member) has received more than $\$ 120,000$ in direct compensation during any 12-month period, other than director and committee fees and pension. NYSE 1999 Rules, supra note 246; NYSE Manual, ibid, §303A.02(b)(ii).
} 
presumed to interfere with the exercise of independent judgment in carrying out their responsibilities. ${ }^{286}$ With a view to preventing negative interference from executives, the new rules also required that independent directors must meet regularly without the presence of management (so-called executive sessions). ${ }^{287}$ Moreover, each of these three committees must have a publicly disclosed written charter that stipulates the individual committee's purpose, goals and responsibilities, and each committee is responsible for undertaking annual committee performance evaluations. ${ }^{288}$

Regarding NASDAQ's reform, most NASDAQ rules regarding independent directors are similar to those of the NYSE, but less demanding. ${ }^{289}$ Every NASDAQ-listed company is also required to have a majority of independent directors sitting on its board. ${ }^{290}$ Any relationship that would interfere with the exercise of independent judgment in carrying out director's duty disqualifies a director from being considered "independent" under the new rules. ${ }^{291}$ Unlike the NYSE, the NASDAQ rules do not require listed companies to establish compensation and nominating committees. It only requires independent directors to approve director nominees and executive officer compensation either through an independent committee or through a majority of independent directors. ${ }^{292}$ The NASDAQ rules also require independent directors to meet regularly without management (i.e. executive sessions). ${ }^{293}$

As for the audit committee, much like the NYSE, each listed company must have an audit committee ${ }^{294}$ with a formal written charter ${ }^{295}$ and must have at least three independent members in accordance with the NASDAQ's definition. ${ }^{296}$ At least one member of the audit committee must have financial expertise. ${ }^{297}$ The audit committee must also be granted more authority and

\footnotetext{
${ }^{286} \mathrm{Ibid}, \S 303 \mathrm{~A} .02(\mathrm{~b})(\mathrm{ii})$-(iii).

${ }^{287}$ Ibid, \$303A.03.

${ }^{288} \mathrm{Ibid}$, §303A.04, §303A.05, §303A.07; Ide, supra note at 850-51.

${ }^{289}$ Joel Seligman, "A Modest Revolution in Corporate Governance" (2005) 80 Notre Dame L Rev 1159 at 1174 [Seligman, Corporate Governance].

${ }^{290}$ NASDAQ Rule, supra note 5, §5605(b)(1).

${ }^{291}$ Ibid, $\S 5605(\mathrm{a})(2)$.

${ }^{292}$ Ibid, §5605(d), §5605(e).

${ }^{293} \mathrm{Ibid}, \$ 5605(\mathrm{~b})(2)$.

${ }^{294} \mathrm{Ibid}, \S 5605(\mathrm{c})(2)(\mathrm{A})$.

${ }^{295} \mathrm{Ibid}, \$ 5605(\mathrm{c})(1)$.

${ }^{296} \mathrm{Ibid}, \S 5605(\mathrm{c})(2)(\mathrm{A})$.

${ }^{297}$ Ibid.
} 
responsibility to address internal accounting control and audit matters in compliance with the regulations and the Securities Exchange Act of $1934 .^{298}$

In summary, several high-profile companies involved in corporate scandals in the early new millennium had already populated their boards with a majority of independent directors or had audit committees comprised entirely of independent directors. However, the subsequent reforms in response to these corporate debacles, including SOX, the NYSE and NASDAQ listing requirements, still centered on enhancing the role of independent directors to prevent similar collapses in the future. It seems that securities regulators and stock exchanges still considered the monitoring role of independent directors to be the main prescription for curbing managerial abuses.

\subsubsection{Dodd-Frank Wall Street Reform and Consumer Protection Act Regarding the Compensation Committee Composition}

In 2008, a wave of bank and insurance corporation failures in the US triggered a financial crisis that effectively halted global credit markets and required unprecedented government intervention. ${ }^{299}$ On September, Lehman Brothers declared bankruptcy after failing to find a buyer and Merrill Lynch was sold to Bank of America. ${ }^{300}$ American International Group (AIG) was saved by a bailout of more than $\$ 170$ billion from the US federal government. ${ }^{301}$ However, just four days before its declaration of bankruptcy, Lehman Brothers still approved payments for two fired executives worth \$18.2 million and another \$5 million payment for an executive who was leaving voluntarily. In early 2009, AIG even planned to pay about $\$ 165$ million in bonuses to executives in the same business unit that brought the corporation to the brink of collapse.

\footnotetext{
${ }^{298}$ Ibid, $\$ 5605(\mathrm{c})(3)$.

${ }^{299}$ Linda M Beale, "In the Wake of Financial Crisis", Wayne State University Law School Research Paper No. 1007, (2010) at 1-3, online: SSRN < http://ssrn.com/abstract=1681577> [Beale]; Austin Murphy, "An Analysis of the Financial Crisis of 2008: Causes and Solutions" (4 November 2008) at 2, online: SSRN $<$ http://ssrn.com/abstract $=1295344>$.

${ }^{300}$ Beale, ibid at 2.

${ }^{301}$ Steven M Davidoff \& David Zaring, "Regulation by Deal: The Government's Response to the Financial Crisis" (2009) 61:3 Admin L Rev 463 at 499.
} 
Investors were furious with executives' greed and the inappropriateness of these compensation packages. $^{302}$

In order to control executive compensation, the bailout fund, known as the Troubled Asset Relief Program (TARP), required that the compensation committees of corporations receiving its funding be composed of independent directors. ${ }^{303}$ On July 2010, US Congress passed the Dodd-Frank Wall Street Reform and Consumer Protection Act, ${ }^{304}$ a comprehensive financial reform in response to the 2008-2009 financial crisis. With respect to executive compensation, the Act, again, focused on independent directors to ensure that executive remuneration was properly determined in an environment free of conflicts and based on the receipt of unbiased advice. ${ }^{305}$ Section 952 in the Act mandates the SEC to direct self-regulatory organizations, such as the NYSE and NASDAQ, to adopt listing standards requiring that each member of an issuer's compensation committee be independent. ${ }^{306}$ The standards for determining the definition of "independence" are almost identical to those of SOX. ${ }^{307}$ The regulators believed that requiring the independence of compensation committees should serve to prevent undue consideration of management interests in deciding on executive compensation. ${ }^{308}$ The key role of independent directors in corporate governance thus remains unchanged in the wake of the financial crisis.

\subsubsection{Canada}

After the creation of an important role for independent directors in corporate governance was proposed by the Dey Report, several subsequent studies, such as the Kirby Report and the

\footnotetext{
${ }^{302}$ Edmund L Andrews \& Peter Baker, “A.I.G. Planning Huge Bonuses After $\$ 170$ Billion Bailout” The New York Times (15 March 2009) A1; Carl Hulse \& David M Herszenhorn, "House Approves 90\% of Tax on Bonuses After Bailouts" The New York Times (20 March 2009).

${ }^{303}$ See TRAP Standards for Compensation and Corporate Governance, 31 CFR pt 30 (2009) cited by Lisa M Fairfax, Inside Director, supra note 216 at 137 n 42.

${ }^{304}$ Dodd-Frank Wall Street Reform and Consumer Protection Act, Pub L No 111-203, 124 Stat 1376 (2010) [DoddFrank Act].

${ }^{305}$ Stephen M Bainbridge, "Dodd-Frank: Quack Federal Corporate Governance Round II", UCLA School of Law, Law-Econ Research Paper No. 10-12 (7 September 2010) at 25-26, Online: SSRN

<http://ssrn.com/abstract=1673575>; Stephen M Bainbridge, "The Corporate Governance Provisions of DoddFrank", UCLA School of Law, Law-Econ Research Paper No. 10-14 (27 October 2010) at 6-7, online: SSRN < http://ssrn.com/abstract=1698898>.

${ }^{306}$ Ibid; see Dodd-Frank Act, supra note 304, §952(a)(2).

${ }^{307}$ See Dodd-Frank Act, ibid, §952(a)(3); See Sarbanes-Oxley Act, supra note 4, §301(3).

${ }^{308}$ Simone M Sepe, "Making Sense of Executive Compensation” Arizona Legal Studies Discussion Paper No. 10-42

(7 December 2010) at 43-44, online: SSRN <http://ssrn.com/abstract=1721131>.
} 
Saucier Report, also endorsed independent directors as having a key role to play in the governance of publicly-held companies. Even following the Enron scandals, the Ontario legislature and Canadian Securities Administrators continued to embrace the view that independent directors could be relied on to resolve corporate-agency problems. Currently, Canadian corporate governance mechanisms rely heavily on independent directors to hold management accountable.

\subsubsection{The Kirby Report}

Following the completion of the update in governance regulation initiated by the Dey Committee, the Senate Standing Committee on Banking, Trade and Commerce of the federal parliament held hearings and released a report in 1998 on new measures to improve the governance practices of institutional investors. ${ }^{309}$ The document, referred to as the Kirby Report after the Committee Chairman, Sen. Michael Kirby, recommended that each mutual fund be required to have a majority of independent directors on its board. The Kirby Committee considered that independent status leaves directors free to focus on issues of fairness, conflicts of interest, and procedural and monitoring issues. ${ }^{310}$ In its review, the interests of the unit holders in the funds are more likely to be looked after when a mutual fund has an independent board. ${ }^{311}$

\subsubsection{The Saucier Report}

In 2001, six years after the Dey Report had been released; a successor to the Dey Committee was established. The Joint Committee on Corporate Governance was formed with a view to reviewing the efficacy of the Dey recommendations, reevaluating corporate governance in light of a new political and economic landscape, and updating the TSX listing requirements on

\footnotetext{
${ }^{309}$ The Standing Committee on Banking, Trade and Commerce, Government of Canada, "The Governance Practices of Institutional Investors" (Ottawa: Government of Canada, 1998), online:

<http://www.parl.gc.ca/36/1/parlbus/commbus/senate/com-e/bank-e/rep-e/rep16nov98-e.htm> [Kirby Report];

Sussex, supra note 189 at 26-27.

${ }^{310}$ Kirby Report, ibid; Sussex, ibid at 27.

${ }^{311}$ Kirby Report, ibid.
} 
corporate governance. ${ }^{312}$ A number of high-profile corporate scandals had occurred following the implementation of the Dey recommendations, ${ }^{313}$ and a recent study had showed that $51 \%$ of 324 public companies surveyed did not report their practices against all of the TSX Guidelines. $^{314}$

The Committee's report, named after its Chair, Guylaine Saucier, paid more attention to the competencies and functions of the board, and focused less on its structure. With respect to independent directors, in addition to the existing TSX guidelines, the Saucier Report further recommended that a board should be chaired by an independent director; if it is not feasible, at least a board should have an independent lead director who is responsible for ensuring the capacity of the board to act independently of management. ${ }^{315}$ The most controversial part in the recommendation is that the Saucier Report upgraded this standard to a listing requirement from merely a voluntary guideline in the Dey Report. ${ }^{316}$ Moreover, influenced by the Blue Ribbon Committee, the Saucier Report favored an expanded role for audit committee members. Compared to the Dey Report, the Saucier Committee recommended that audit committees should consist entirely of independent directors instead of only outside directors. ${ }^{317}$ Furthermore, the audit committee members should have a basic level of financial literacy, and at least one of them should have accounting or related financial expertise, which was not proposed in the Dey Report. $^{318}$ Consistent with prior reports, it seems that independent directors, again, were considered to be critical in holding management accountable. However, the TSX did not adopt the above recommendations made by the Saucier Committee, and, therefore, TSX's "comply-orexplain" guidelines were not changed. ${ }^{319}$

\footnotetext{
312 Joint Committee on Corporate Governance, Beyond Compliance: Building a Governance Culture (November 2001) [Saucier Report], online: ECGI < http://www.ecgi.org/codes/documents/beyond_compliance.pdf >; Sussex, supra note 189 at 28.

${ }^{313}$ Sussex, ibid.

${ }^{314}$ Patrick O'Callaghan and Associates in partnership with Korn/Ferry International, "Corporate Board Governance and Director Compensation in Canada: A Review of 2000" (2000) at 8 cited by Saucier Report at 8 . A similar result was also reported by Bujaki and McConomy (2002) that a very few firms disclose that they have fully implemented the TSX guidelines, and that the extent of disclosure of practices implemented varied widely among the firms. Merridee Bujaki \& Bruce J McConomy, "Corporate Governance: Factors Influencing Voluntary Disclosure by Public Traded Canadian Firms" (2002) 1:2 Canadian Accounting Perspectives 105 at 123, 127 [Bujaki \& McConomy].

${ }^{315}$ Saucier Report, supra note 312 at 18-19.

${ }^{316}$ Ibid at 18; Sussex, supra note 189 at 29.

${ }^{317}$ Saucier Report, ibid at 29.

${ }^{318}$ Ibid at 27-30.

${ }^{319}$ Carol Hansell, “Governance Regulation - The Right Balance” (Paper delivered at the Queen's Business Law Symposium, 2004) at 13.
} 


\subsubsection{Senate Report on Corporate Governance}

Before the OSC issued new rules in response to the US corporate scandals, the Standing Senate Committee on Banking, Trade and Commerce published a report entitled "Navigating Through 'the Perfect Storm': Safeguards to Restore Investor Confidence” in June 2003. ${ }^{320}$ The Senate Committee Report, which suggested that Canada adopt a SOX-like approach, recommended that requirements for board and committee independence, as well as director expertise, should be introduced into legislation, including boards composed of a majority of independent directors, compensation committees composed entirely of non-management members, audit committee members being fully independent and financially literate, and at least one audit committee members being a financial expert. ${ }^{321}$ However, no recommendation was adopted by the TSX.

\subsubsection{Ontario Bill 198}

As discussed above, following the eruption of a series of corporate scandals, including Enron, WorldCom and other corporations, a wave of stringent sweeping corporate governance reforms were introduced in the United States starting from the middle of 2002. As noted, with respect to independent directors, the Sarbanes-Oxley Act, in combination with proposed NYSE listing requirements, obliges all issuers to have audit, compensation and nominating committees composed solely of independent directors, and requires all members of the audit committee to be financially literate and at least one of them to be a financial expert. In August 2002, the Chairman of the Ontario Securities Commission wrote an open letter to the President and CEO of the TSX to seek analysis and views as to whether it would be appropriate: (1) to adopt measures in Canada mirroring SOX and the proposed NYSE listing requirements; (2) to implement such measures as mandatory requirements in Canada; (3) to reformulate some, or all,

\footnotetext{
${ }^{320}$ The Standing Senate Committee on Banking, Trade and Commerce, Navigating Through “The Perfect Storm”: Safeguards to Restore Investor Confidence (June 2003), online:< http://www.parl.gc.ca/37/2/parlbus/commbus/senate/com-e/bank-e/rep-e/rep12jun03-e.pdf>.

${ }^{321}$ Ibid at 8, 11-12, 14 .
} 
TSX corporate governance guidelines, as well as additional guidelines recommended by the Saucier Report as mandatory requirements. ${ }^{322}$ The letter again revived a long-existing debate concerning whether the Canadian corporate governance regime should follow a "principlesbased" approach or a "rules-based" approach.

As noted, Canada's traditional approach to corporate governance following the Dey Report is characterized as a "principles-based" approach that is established through guidelines in combination with mandatory disclosure as to the extent of compliance with the guidelines and with an explanation regarding why any guidelines have not been followed. ${ }^{323}$ The Toronto Stock Exchange had followed this approach, which originated from the recommendations of the Cadbury Report, since 1995. In contrast, the US adopts a model characterized as a "rules-based" approach that is heavily oriented toward mandatory compliance with highly-detailed legislation, regulations and stock exchange listing requirements, and with a much greater emphasis on regulatory enforcement rather than voluntary compliance. ${ }^{324}$

In response to the impact of the US corporate scandals, Canadian regulators were forced to reassess the efficacy of the traditional principles-based approach of corporate governance against the rules-based US model, and to weigh the costs and benefits of harmonizing their securities laws with SOX and its related reforms. ${ }^{325}$ Some still favored a principles-based approach, including the head of the securities commission in British Columbia, ${ }^{326}$ the chief officer of the TSX, ${ }^{327}$ and the Canadian Council of Chief Executives. ${ }^{328}$ They contended that: (1) the cost of compliance with mandatory rules is disproportionately higher for Canadian corporations due to their scale; ${ }^{329}(2)$ the relatively small pool of potential independent directors and the inability to pay significant director fees would make it difficult for issuers to fully

\footnotetext{
322 J A Levin, “Canadian Corporate Governance Development” (Paper delivered at the Queen's Business Law Symposium, 2004), at 92 [Levin]; Sukanya Pillay, "Forcing Canada's Hand? The Effect of the Sarbanes-Oxley Act on Canadian Corporate Governance Reform" (2004) 30:3 Man L J 285 at 302 [Pillay].

${ }^{323}$ Levin, ibid at 136; VanDuzer, supra note 15 at 508; Johnston \& Rockwell, supra note 11 at 671-72; Erinn B Broshko \& Kai Li, "Corporate governance Requirements in Canada and the United States: A Legal and Empirical Comparison of the Principles-Based and Rules-Based Approaches", Sauder School of Business Working Paper (February 2006) at 3-4, online: SSRN:<http://ssrn.com/abstract=892708 $>$ [Broshko \& Li].

${ }^{324}$ Levin, ibid ; Broshko \& Li, ibid.

${ }^{325}$ Levin, ibid at 137; Pillay, supra note 322 at 301.

${ }^{326}$ Levin, ibid; VanDuzer, supra note 15 at 508; Broshko \& Li, supra note 323 at 4-5; Pillay, ibid at 300.

${ }^{327}$ Levin, ibid at 138-39; VanDuzer, ibid at 508-09; Pillay, ibid.

${ }^{328}$ Levin, ibid at 137-38; VanDuzer, ibid at 509.

${ }^{329}$ Levin, ibid at 137; VanDuzer, ibid; Johnston \& Rockwell, supra note 11 at 676; Pillay, supra note 322 at 300.
} 
comply with mandatory independence requirements for boards and committees; ${ }^{330}(3)$ the findings of no serious evidence of wrongdoing for 517 listed Canadian companies in an OSC review demonstrated that the current Canadian corporate governance system is working well; ${ }^{331}$ (4) mandatory rules are inclined to encourage compliance with the letter of the law rather than its underlying principles, and rules tend to lag as circumstances change. ${ }^{332}$ Thus, they only accepted some additional mandatory obligations but preferred to maintain the principles-based approach.

In contrast, some questioned the efficacy of principles-based approach, such as the chair of the OSC ${ }^{333}$ and the Saucier Report. They argued that: (1) the failure of Bre-X, Livent, YBM and Phillip Services demonstrated that a principles-based approach is not a panacea; ${ }^{334}$ (2) several studies had indicated that a large percentage of corporations listed on the TSX were not fully in compliance even with the relatively soft obligation to disclose the extent to which they met the suggested guidelines; ${ }^{335}$ (3) maintaining a principles-based approach at that time may cause investors to perceive Canada as being "soft" on corporate governance issues; ${ }^{336}$ (4) principles (or guidelines) tend to breed inconsistency as issuers pick and choose the extent to which they comply or issuers interpret provisions that are non-mandatory in a way that undermines confidence in the Canadian capital market; ${ }^{337}$ (5) the effectiveness of a firm's corporate governance policies is left solely to the judgment of investors who are often uninformed. $^{338}$ No general consensus between the two positions was reached.

In December 2002, Ontario passed Bill 198, which incorporated some prescriptive approaches from SOX and many suggestions made by previous corporate governance reform committees, into the Ontario Securities Act. Regarding independent directors, the Bill gave the Ontario Securities Commission (OSC) the power to make rules governing the composition and conduct of audit committees, and require corporations to adopt systems of internal control as

\footnotetext{
${ }^{330}$ Levin, ibid at 136; VanDuzer, ibid.

${ }^{331}$ Levin, ibid at 138 .

${ }^{332}$ Levin, ibid; Broshko \& Li, supra note 323 at 5.

${ }^{333}$ VanDuzer, supra note 15 at 509; Johnston \& Rockwell, supra note 11 at 675; Pillay, supra note 322 at 300.

${ }^{334}$ Levin, supra note 322 at 140.

${ }^{335}$ Levin, ibid; VanDuzer, supra note 15 at 509; Bujaki \& McConomy, supra note 314 at 123, 127; Saucer Report, supra note 312 at 8.

${ }^{336}$ Levin, ibid at 136; Johnston \& Rockwell, supra note 11 at 677; Broshko \& Li, supra note 323 at 5; Pillay, supra note 322 at 300 .

${ }^{337}$ Levin, ibid at 140.

${ }^{338}$ Broshko \& Li, supra note 323 at 4-5.
} 
well as disclosure controls and procedures. ${ }^{339}$ At that time, except for British Columbia, ${ }^{340}$ the other eleven provinces and territories agreed to implement similar or identical regulations through Canadian Securities Administrators (CSA), an umbrella organization representing securities regulators, in their respective securities markets. ${ }^{341}$ Currently, all twelve securities regulators have implemented the same regulations approved by the CSA.

\subsubsection{CSA Measures in Response to Corporate Scandals in the 2000s}

During June 2003 and January 2004, the CSA released a series of rules and guidelines in response to financial scandals, which again mainly relied on independent directors. The CSA adopted a hybrid system, combining the elements of the existing "comply or explain" approach and the mandatory compliance model in the US. More specifically, the CSA included some mandatory rules regarding audit committees under National Instrument 52-110 Audit Committees (NI 52-110) ${ }^{342}$, but also employed a principles-based approach in other corporate governance practices through implementation in National Policy 58-201 Corporate Governance Guidelines (NP 58-201) $)^{343}$ in combination with National Instrument 58-101 Disclosure of Corporate Governance Practices (NI 58-101) ${ }^{344}$ as to the extent of compliance with the guidelines. If an issuer's practices depart from the guidelines, it has to describe the procedures implemented to meet the same governance objective. ${ }^{345}$ The rationale of this approach is: (1) to reduce the cost of compliance with rigid mandatory standards in order to avoid undermining the competitiveness of Canadian firms; and (2) to be responsive to the distinctive characteristics of the Canadian market. $^{346}$

\footnotetext{
${ }^{339}$ VanDuzer, supra note 15 at 510; Pillay, supra note 322 at 305-06; Allison Dabbs Garrett, "Themes and Variations: the Convergence of Corporate Governance Practices in Major World Market” (2004) Denv J Int'l L \& Pol'y 147 at 164.

${ }^{340}$ British Columbia later agreed to implement the identical regulations through Canadian Securities Administrators.

${ }^{341}$ Pillary, supra note 322 at 305.

${ }^{342}$ NI 52-110, supra note 10 at 27 OSCB 3252.

${ }^{343}$ NP 58-201, supra note 10 at 28 OSCB 5383.

${ }^{344}$ National Instrument 58-101, Disclosure of Corporate Governance Practices, OSC NI 58-101, 28 OSCB 3634

(15 April 2005), online: CSA <http://www.osc.gov.on.ca/en/SecuritiesLaw_rule_20050415_58-201_govpractices_1.jsp $>$ [NI 58-101].

${ }^{345}$ VanDuzer, supra note 15 at 510 ; Broshko \& Li, supra note 323 at 3-4.

${ }^{346}$ Ibid; Pillay, supra note 322 at 304; Levin, supra note 323 at 138.
} 
National Instrument 52-110, influenced by SOX and NYSE listing requirements, requires all audit committee members to be "independent" and "financially literate." "I47 "Independence" of an audit committee member is defined to mean the member has no material connection to the issuer, which could reasonably interfere with the member's independent judgment in the view of the issuer's board of directors. ${ }^{348}$ The financial literacy obligation requires all audit committee members to have the ability to read and understand financial statements of comparable breadth and complexity to those of the issuer's. ${ }^{349}$ It is worth noting that NI 52-110 does not require that every audit committee have a "financial expert", in contrast to SOX.

As for voluntary corporate governance practices regarding independent directors, NP 58201 recommends that issuers adopt best practices as follows: (1) boards should have a majority of independent directors who have no material relationship with management or the corporation as defined in NI $52-110 ;{ }^{350}$ (2) the chair of the board should be an independent director or the board has a lead director who is an independent director, ${ }^{351}$ (3) the independent directors should meet regularly on their own; ${ }^{352}$ (4) the board should have a nominating committee comprised solely of independent directors with a written charter to assess existing directors and make recommendations to new nominees to the board; ${ }^{353}$ (5) the board should have a compensation committee composed entirely of independent directors with a written charter that is responsible for evaluating the CEO's performance, determining the CEO's compensation and making recommendations concerning the compensation of other executives and directors. ${ }^{354}$ Simultaneously, NI 58-101 requires issuers to disclose how they comply with the aforementioned best practices or explain what they do in their practices to achieve the same results. ${ }^{355}$ The emphasis on disclosure is not only to give the issuers the flexibility to tailor their corporate governance practices to their specific circumstances, but also to provide investors with relevant information to evaluate such practices. ${ }^{356}$

\footnotetext{
${ }^{347}$ NI 52-110, supra note 10, s 3.1 (3)-(4), at 27 OSCB 3257-58.

${ }^{348} \mathrm{Ibid}$, s 1.4 , at 27 OSCB 3255.

${ }^{349} \mathrm{Ibid}, \mathrm{s} 1.5$, at 27 OSCB 3256.

${ }^{350}$ NP 58-201, supra note 10, s 2.1 and s 3.1, at 28 OSCB 5383.

${ }^{351} \mathrm{Ibid}$, s 3.2, at 28 OSCB 5383.

${ }^{352} \mathrm{Ibid}, \mathrm{s} 3.3$, at 28 OSCB 5383.

${ }^{353} \mathrm{Ibid}$, ss 3.10 and 3.11, at 28 OSCB 5385.

${ }^{354} \mathrm{Ibid}$, ss 3.15 and 3.16, at 28 OSCB 5384.

${ }^{355}$ Form 58-101F1 Corporate Governance Disclosure, OSC Form 58-101F1, 28 OSCB 3636 (15 April 2005), at 3636-37.

${ }^{356}$ VanDuzer, supra note 15 at 510; Broshko \& Li, supra note 323 at 3-4.
} 


\subsubsection{Recent Proposals}

In December 2008, the CSA proposed revisions to current corporate governance requirements, including an overhaul of NP 58-201, and minor modifications of NI 58-101 and NI 52-110. ${ }^{357}$ More specifically, three main changes to the current corporate governance regime were recommended: (1) replacing current specific guidelines for corporate governance with nine broad corporate governance principles and commentary explaining those principles (NP 58-201); (2) replacing existing comply-or-explain disclosure requirements with more general disclosure obligations (NI 58-101); (3) replacing the current prescriptive approach in the independence requirements for audit committee members that provide some bright-line tests for independence with a more principles-based approach that leaves assessments of independence for the board itself (NI 52-110). ${ }^{358}$ The purpose of the proposed revisions is to provide greater flexibility for issuers regarding the adoption of specific governance practices, and enhanced transparency with respect to their practices.

Regarding the practices related to independent directors, previous specific guidelines, including board and committee composition as well as having an independent board chair and lead director, became examples of practices under the proposed principles. ${ }^{359}$ The composition of the nomination committee was even downgraded from "entirely" independent directors to "a majority" of independent directors. ${ }^{360}$ The previous bright-line tests of disqualifying directors as non-independent in the current NI 52-110 were removed, and the authority of assessing independence was left solely to the board. ${ }^{361}$

However, in late 2009, the CSA, after consulting with the issuer community, announced that it was not the right time to introduce significant change in corporate governance, since issuers were focused on business sustainability in the wake of the 2009 financial crisis. The

\footnotetext{
357 Request for Comment - Proposed Repeal and Replacement of NP 58-201 Corporate Governance Guidelines, NI 58-101 Disclosure of Corporate Governance Practices, and NI 52-110 Audit Committees and Companion Policy 52-110CP Audit Committees, OSC Request for Comment, 31 OSCB 12158 (19 December 2008).

${ }^{358} \mathrm{Ibid}$ at 31 OSCB 12159.

${ }^{359}$ Ibid at 31 OSCB 12174.

${ }^{360}$ Ibid at 31 OSCB 12175.

${ }^{361}$ Ibid at 31 OSCB 12189-90.
} 
CSA stated that it would not implement any change until at least the 2011 proxy season. ${ }^{362}$ Nothing has been changed to date.

\subsubsection{Summary}

Independent directors started to play a key role in the Canadian corporate governance regime after the introduction of the Dey Report in 1994. The Kirby Report, the Saucier Report, Ontario Bill 198, and the Senate Report on Corporate Governance, which followed, continued to focus on independent directors to monitor management and protect shareholder interests. So far, NI 52-110 requires every issuer to establish a fully independent audit committee. The CSA's national corporate governance policies still recommend that each issuer has a board composed of a majority of independent directors, a compensation committee comprised entirely of independent directors and a nominating committee composed solely of independent directors. Although the extent of reliance on director independence in Canada is not as strong as that in the US (i.e. the proportion of independent directors on the board, the compensation committee and the nominating committee are only recommendations rather than requirements), the importance of independent directors in Canadian corporate governance is substantial.

\subsection{Theoretical and Empirical Bases for Arguments that Independent Directors are Effective Corporate Monitors}

An effective legal mechanism must be built on the reasonable expectations of human nature and sufficient incentives. Although the monitoring role of independent directors had been proposed in mid-1970s, advocates did not provide satisfactory arguments regarding whether independent directors would be able, and willing, to fulfill this job. Starting in the 1980s, some scholars, mostly in the field of financial economics, tried to provide theoretical arguments to support the view that independent directors have incentives to act in shareholders' best interests and to monitor management's behavior. They contended that reputation capital and equity

\footnotetext{
${ }^{362}$ CSA Staff Notice 58-305 - Status Report on the Proposed Changes to the Corporate Governance Regime, OSC CSA Notice, 32 OSCB 9347 (13 November 2009), online: CSA <http://www.osc.gov.on.ca/documents/en/Securities-Category5/csa 20091113 58-305-gov-regime.pdf> [CSA Staff Notice 58-305].
} 
ownership motivate independent directors to be competent corporate monitors. Their main arguments can be summarized as follows.

\subsubsection{Reputation Capital (The Market for Director Services) Theory}

Some scholars in the field of financial economics believe that independent directors value their own reputations and will devote themselves to effectively monitoring management as a way of preserving and enhancing their reputations. According to their arguments, independent directors typically hold, or are interested in, multiple directorships. ${ }^{363}$ They usually act as professional referees of management actions and have invested a significant effort in cultivating their reputation as experts in corporate decision monitoring. ${ }^{364}$ Thus, independent directors have incentives to be good monitors because being directors of well-run corporations signals their value to the external labor market, which rewards their labor with directorships on the boards of other firms. $^{365}$ If the performance of companies is (or becomes) poor during the time that an independent director is serving on the board, the director's reputations will be tarnished, and the end result will be that the director will hold fewer board seats in the future. ${ }^{366}$ Hence, this disciplinary effect of the market for independent directors' services gives them a strong incentive to develop and protect their own reputation as effective monitoring specialists. ${ }^{367}$

A few empirical studies have suggested that independent directors of underperforming firms suffer from tarnished reputations in the market for directors. Gilson (1990) found that outside directors who leave the boards of financially distressed firms held approximately onethird fewer directorships three years after their departure, ${ }^{368}$ while Kaplan and Reishus (1990) reported that top executives of firms that cut dividends were $50 \%$ less likely to obtain additional

\footnotetext{
${ }^{363}$ John W Byrd \& Kent A Hickman, "Do Outside Directors Monitor Managers?: Evidence from Tender Offer Bids" (1992) 32 Journal of Financial Economics 195 at 203 [Byrd \& Hickman]; Lewis D Solomon, "Restructuring the Corporate Board of Directors: Fond Hope-Faint Promise?" 76 Mich L Rev 581 at 585 [Solomon]; see also Stuart C Gilson, "Bankruptcy, Boards, Banks, and Blockholders: Evidence on Changes in Corporate Ownership and Control When Firms Default" (1990) 27 Journal of Financial Economics 355 at 375-76 [Gilson].

${ }^{364}$ Eugene F Fama \& Michael C Jensen, "Separation of Ownership and Control" (1983) 26 JL \& Econ 301 at 315 [Fama \& Jensen 1983]; Lin, supra note 13 at 917.

${ }^{365}$ Anil Shivdasani, "Board Composition, Ownership Structure, and Hostile Takeovers" (1993) 16 Journal of Accounting and Economics 167 at 175 [Shivdasani 1993]; Fama \& Jensen 1983, ibid.

${ }^{366}$ Rita Ricardo-Campbell, "Comments on the Structure of Ownership and the Theory of the Firm" (1983) 26 Journal of Law and Economics 391 at 392; Lin, supra note 13 at 917-18.

${ }^{367}$ Lin, ibid at 918.

${ }^{368}$ Gilson, supra note 363 at 375-76.
} 
directorships. ${ }^{369}$ Similarly, Brickley, Linck and Coles (1999) observed that the number of board seats held by retiring CEOs was associated with firm performance prior to their retirement, ${ }^{370}$ while Shivdasani (1993) found that independent directors of firms that are the targets of hostile bids were likely to hold fewer directorships than independent directors of non-target firms, if firms become targets due to poor performance. ${ }^{371}$ Taken together, it appears that empirical research supports the reputation capital theory that independent directors have incentives to develop reputations as monitoring specialists.

\subsubsection{Equity Ownership Theory}

In addition to reputation capital, financial economists argue that equity ownership gives independent directors an even greater incentive to take action in firm decisions. They consider that if independent directors own equity in the company they serve, they will have a direct incentive to monitor managerial decisions in order to protect the value of their stake in the company. ${ }^{372}$ In other words, these shareholder-directors would increase their time commitment and make a greater effort to understand and supervise the operation of the company, and would vigilantly oppose unprofitable managerial decisions with a view to maintaining their personal stake in the corporation's profitability. ${ }^{373}$ According to this convergence-of-interests hypothesis, the greater the equity holdings that independent directors have in the firm, the more their interests would be aligned with those of shareholders. ${ }^{374}$ Many institutional investors and influential stockholder activists, like National Association of Corporate Director and CalPERS, have called for minimum shareholdings or appropriate incentive programs, especially stock-

\footnotetext{
${ }^{369}$ Steven N Kaplan \& David Reishus, “Outside Directorships and Corporate Performance” (1990) 27 Journal of Financial Economics 389 at 399, 401, 405.

${ }^{370}$ James A Brickley, James S Linck \& Jeffery L Coles, "What Happens to CEOs after They Retire? New Evidence on Career Concerns, Horizon Problems, and CEO Incentives" (1999) 52 Journal of Financial Economics 341 at 343.

${ }^{371}$ Shivdasani 1993, supra note 365 at 182-83, 195-96.

${ }^{372}$ Rita D Kosnik, "Greenmail: A Study of Board Performance in Corporate Governance" (1987) 32 Administrative Science Quarterly 163 at 171 [Kosnik 1987]; Byrd \& Hickman, supra note 363 at 198; Charles M Elson, "Executive Overcompensation-A Board-Based Solution" (1993) 34 BCL Rev 937 at 939 [Elson 1993]; Lin, supra note 13 at 918 .

${ }^{373}$ Lin, ibid.

${ }^{374}$ Randall Morck, Andrei Shleifer \& Robert W Vishny, "Management Ownership and Market Valuation: An Empirical Analysis" (1988) 20 Journal of Financial Economics 293 at 294 [Morck, Shleifer \& Vishny]; Lin, ibid.
} 
based compensation, for independent directors to increase their willingness to engage in management oversight. ${ }^{375}$

Empirical evidence has suggested that firms were more likely to perform better when their outside (or independent) directors had higher equity ownership or stock-option compensation plans. More specifically, Morck, Shleifer and Vishny (1988) found a significant correlation between outside director share ownership and current and next year's firm performance, ${ }^{376}$ while Hambrick and Jackson (2000) reported that outside directors in firms that successively outperformed their industries had greater equity holdings than their counterparts in firms that apparently lagged behind their industries. ${ }^{377}$ In addition, Fich and Shivdasani (2005) and Cordeiro, Veliyath and Neubaum (2005) both observed that the presence of a stock-option plan for independent directors was significantly and positively correlated with several firm performance indicators. ${ }^{378}$ Empirical research also reported that independent directors were more likely to replace incompetent CEOs when they had higher equity holdings. Perry (2000) found that the sensitivity of CEO turnover to firm performance was inclined to be enhanced when independent directors were awarded with incentive compensation (combining stock options and stock grants). ${ }^{379}$ It seems that empirical studies support the equity ownership theory that independent directors are more likely to actively oversee management when they have sufficient financial incentives.

\section{Summary of Chapter Two}

Taking the development of independent directors in the US and Canada together, independent directors were expected to be corporate monitors with a view to preventing corporate wrongdoing and to serving as a check on managerial abuses of authority. Widespread

\footnotetext{
${ }^{375}$ James J Corderio, Rajaram Veliyath \& Donald O Neubaum, "Incentives For Monitors: Director Stock-Based Compensation and Firm Performance" (2005) 21:2 The Journal of Applied Business Research 81 at 82 [Corderio, Veliyath \& Neubaum, 2005]; Mason Gerety, Chun-Keung Hoi \& Ashok Robin, "Do Shareholders Benefit from the Adoption of Incentive Pay for Directors" (2001) 30:4 Financial Management 45 at 45 [Gerety, Hoi \& Robin].

${ }^{376}$ Morck, Shleifer \& Vishny, supra note 374 at 302.

${ }^{377}$ Donald C Hambrick \& Eric M Jackson, "Outside Directors with a Stake: The Linchpin in Improving Governance" (2000) 42:4 California Management Review 111 at 114, 116 [Hambrick \& Jackson].

${ }^{378}$ Fich \& Shivdasani 2005, supra note 36 at 2240, 2243; Cordeiro, Veliyath \& Neubaum, 2005, supra note 375 at 86.

${ }^{379}$ Tod Perry, "Incentive Compensation for Outside Directors and CEO Turnover" (June 2000) at 17-19, presented at Tuck-JFE Contemporary Corporate Governance Conference, online: SSRN <http://ssrn.com/abstract=236033 or doi:10.2139/ssrn.236033> [Perry].
} 
corporate misconduct in the early 1970s prompted academics and the law and business communities, as well as securities administrators and stock exchanges in the United States to insist on greater independence for corporate directors with a view to enhancing their role as monitors. Corporate malfeasance during the late 1980s and the early 1990s encouraged Canadian administrators to follow the push for director independence. The mainstream of corporate governance believes that boards and critical committees, including the audit, compensation and nominating committees, should be populated by a certain proportion of directors independent of management to ensure the accuracy of financial statements, to set the appropriate remuneration for executives, and to reduce CEO's influence in director selection and retention. However, there were some differences among the different initiatives involving the definition of independence, and the level of independence for the board and the three critical committees. Except for the NYSE audit committee requirements, all corporate governance proposals relating to independent directors were voluntary before the 1980s.

After independent directors became more prevalent in the 1980s, the US courts started to rely on independent directors to address conflict-of-interest transactions, and in takeover bid cases and derivative suits. In response to corporate misconduct in the late 1990s, the NYSE and NASDAQ began to require every listing company to have a fully independent and financially literate audit committee. Facing corporate scandals in the new millennium, SOX and stock exchange rules continued to emphasize increasing the number of independent directors on the board and specific critical committees, as well as tightening the criteria for director independence. US federal rules passed in the wake of the recent financial meltdown also required an entirely independent compensation committee to review executives' remuneration.

In Canada, a series of corporate governance studies following the Dey Report mirrored the US trend regarding independent directors. In response to Enron and other corporate scandals, the Canadian Securities Administrators continuously followed the same pattern to focus on increasing director independence. A completely independent and financially literate audit committee, mimicking SOX, became a mandatory requirement for Canadian listing corporations. Boards with a majority of independent directors and entirely independent compensation and nominating committees also became core values of current Canadian corporate governance guidelines, although they are not compulsory. Collectively, independent directors have become regarded as a key mechanism to hold management accountable in the US and Canada. 
Theories of reputation capital and equity ownership, as well as related empirical studies, provide a solid foundation to support the view that independent directors do have incentives to prevent corporate officers from self-dealing or shirking their responsibilities. In combination with the above developments, it would seem that independent directors represent an ideal solution to agency problems. However, some scholars think otherwise. They contend that independent directors are not an effective instrument to oversee executives' performance and integrity. The subsequent chapter will discuss how certain factors may influence independent directors not to behave objectively and impede their ability to be truly independent. 


\title{
Chapter Three
}

\section{Critiques of the Effectiveness of Independent Directors as Corporate Monitors}

\begin{abstract}
Although the mainstream of corporate governance thinking considers independent directors as a cure for agency problems, many scholars have questioned the effectiveness of independent directors in holding management accountable since the monitoring role of director was first proposed. The proponents of the managerial hegemony theory ${ }^{380}$ argue that independent directors are inescapably dominated by management because they do not have sufficient time, professional knowledge or relevant information to fulfill their monitoring responsibilities. Some scholars also contend that at least six factors, namely defects in defining independence, ${ }^{381}$ the lack of appropriate compensation, ${ }^{382}$ the lack of sufficient civil liability, ${ }^{383}$ the constraints of groupthink and in-group bias, ${ }^{384}$ the trade-off between board's monitoring and managing functions, ${ }^{385}$ as well as the need for board independence varying with firm-specific operating environments, ${ }^{386}$ combine to make independent directors an ineffective instrument to oversee executives' performance and integrity. The following sections describe these critiques.
\end{abstract}

\subsection{A Theory regarding the Ineffectiveness of Independent Directors as Corporate Monitors - Managerial Hegemony Theory}

In the previous chapter, theories and empirical studies regarding reputation capital and equity ownership were argued to provide a solid foundation to support the concept that independent directors do have incentives to prevent corporate officers from self-dealing or shirking their responsibilities. However, some academics contend that independent directors do

\footnotetext{
${ }^{380}$ A scholar uses the term "optimal contracting theory" to describe a similar concept. Kaura, supra note 8 at 22.

${ }^{381}$ Please refer to section 3.2.1 of this thesis.

${ }^{382}$ Please refer to section 3.2 .2 of this thesis.

${ }^{383}$ Please refer to section 3.2 .3 of this thesis.

${ }^{384}$ Please refer to section 3.2.4 of this thesis.

${ }^{385}$ Please refer to section 3.2 .5 of this thesis.

${ }^{386}$ Ibid.
} 
not make any difference as monitors of management. The most famous theory describing the ineffectiveness of independent directors is the managerial hegemony theory.

According to the managerial hegemony theory, boards of directors, no matter how independent they are, are powerless to control abuse by management because the boards are inescapably dominated by management. ${ }^{387}$ Supporters of this view argue that the board is an appendage of management, ${ }^{388}$ so independent directors are ineffectual in providing managerial oversight and consequently act merely as "ceremonial rubber stamps."389 One scholar compiles reasons given by this theory into three categories to explain the ineffectiveness of independent directors: (1) biases in the nomination and selection process; (2) constraints on independent directors' ability to monitor effectively; and (3) weak incentives to monitor effectively. ${ }^{390}$

\subsubsection{Biases in the Nomination and Selection Process}

In most publicly-held corporations, shareholders are only able to vote for nominees proposed by the incumbent board or the company's nomination committee, because the current proxy mechanism is tilted heavily in favor of the company's slate ${ }^{391}$ and the high expenses associated with distribution of proxy statements prevent shareholders from nominating their own candidates. $^{392}$ Although nomination committees composed entirely of independent directors are

\footnotetext{
${ }^{387}$ Paul Mallette \& Karen L Fowler, "Effects of Board Composition and Stock Ownership on the Adoption of 'Poison Pills"' (1992) 35 Academy of Management Journal 1010 at 1014 [Mallette \& Fowler]; Kosnik supra note 372 at 166-67; Lin, supra note 13 at 912; Kaura, ibid.

${ }^{388}$ Kosnik 1987, ibid at 166.

${ }^{389}$ Ibid; Mallette \& Fowler, supra note 387 at 1014.

${ }^{390}$ Lin, supra note 13 at 913.

${ }^{391}$ In the United States, no statute explicitly gives management the authority to nominate directors for election to the board. However, Rule 14a-8(i)(8) of the Exchange Act allows incumbent management and directors to exclude any shareholder proposal regarding director candidates from the company's proxy statement. Although shareholders can distribute their own proxy statements, the expenses associated with such a distribution can be prohibitive, therefore, making it extremely difficult for most shareholders to nominate and elect their own candidates. See Exchange Act Rule 14a-8, 17 CFR \$240.14a-8(i)(8) (2010); Fairfax, Inside Director, supra note 216 at 157; Elizabeth Cosenza, "The Holy Grail of Corporate Governance Reform: Independence or Democracy?" (2007) 2007:1 BYU L Rev 1 at 43 [Cosenza]. Similar situation happens in Canada. Incumbent management and directors decide director nominees and control the proxy-solicitation process. Only shareholders with more than $5 \%$ of the shares are entitled to nominate their own director candidates. VanDuzer, supra note 15 at 266, 524.

392 Stuart Rosenstein \& Jeffrey G Wyatt, “Outside Directors, Board Independence, and Shareholder Wealth” (1990) 26 Journal of Financial Economics 175 at 176-77 [Rosenstein \& Wyatt]; Fairfax, Inside Director, ibid; Leo E Strine, "Derivative Impact? Some Early Reflections on the Corporation Law Implications of the Enron Debacle" (2002) 57 Bus Law 1371 at 1377 [Strine].
} 
increasing in number, ${ }^{393}$ the chief executives of companies still play an important role in board selection. ${ }^{394}$ Such influence often results in the selection of directors with social and ideological ties to management, rather than those dedicated to the protection of shareholders. ${ }^{395}$

In addition, a desire to continue to serve on the board compromises the willingness of independent directors to check managerial abuses. ${ }^{396}$ Since the CEO has a substantial influence over the nomination of board members, ${ }^{397}$ independent directors, who depend largely on the chief executive for their tenure on the board, ${ }^{398}$ are unlikely to make a decision that displeases management. ${ }^{399}$ Moreover, one leading criterion for selecting a board member is his or her “probable identification with and acceptance of the company's goals and methods of operation." 400 When independent directors are chosen on this basis, they are more likely to passively consent to management's policies and decisions rather than actively challenge them. ${ }^{401}$

\subsubsection{Constraints on Independent Directors' Ability to Monitor Effectively}

Moreover, the passiveness of independent directors is exacerbated by various constraints on these board members. First, more than a majority of CEOs also hold the board chair. ${ }^{402}$ They often determine the agenda of board meetings and control the quality, volume and timing of the information given to the board. ${ }^{403}$ Since it is difficult for independent directors to verify the

\footnotetext{
${ }^{393}$ Lynn L Dallas, “The Relational Board: Three Theories of Corporate Board of Directors” (1996) 22:1 The J Corp L 1 at 5 [Dallas, Relational Board]; The Conference Board 1990, supra note 95 at 33 Table 39; Gordon, The Rise of Independent Directors, supra note 1 at 1498; Lin, supra note 13 at 913.

394 James D Cox \& Harry L Munsinger, "Bias in the Boardroom: Psychological Foundations and Legal Implications of corporate Cohesion" (1985) 48 Law and Contemporary Problems 83 at 97-98 [Cox \& Munsinger]; Arch Patton \& John C Baker, "Why Won’t Directors Rock the Boat?" (1987) Nov.-Dec. Harvard Business Review 10 at 12 [Patton \& Baker]; Lin, ibid; Dallas, Relational Board, ibid; Kaura, supra note 8 at 23.

${ }^{395}$ Strine, supra note 392 at 1377-78; Ronald J Gilson \& Reinier Kraakman, "Reinventing the Outside Directors: An Agenda for Institutional Investors" (1991) 43 Stan L Rev 863 at 884 [Gilson \& Kraakman].

${ }^{396}$ Strine, ibid at $1378-79$.

${ }^{397}$ Cox \& Munsinger, supra note 394 at 97-98; Patton \& Baker, supra note 394 at 12.

${ }^{398}$ Gilson \& Kraakman, supra note 395 at 875; Solomon, supra note 363 at 584; Dallas, Relational Board, supra note 393 at 6 .

${ }^{399}$ Strine, supra note at 1378.

${ }^{400}$ Cox \& Munsinger, supra note 394 at 91; Lin, supra note at 913-14.

${ }^{401}$ Lin, ibid at 914; Kosnik, supra note 372 at 167.

402 Steven T Petra, "Do Outside Independent Directors Strengthen Corporate Boards" (2005) 5 Corporate Governance 55 at 57.

${ }^{403}$ Marleen A O'Connor, “The Enron Board: The Perils of Groupthink” (2003) 71 U Cin L Rev 1233 at 1245 [O’Connor]; Michael C Jensen, "The Modern Industrial Revolution, Exit, and the Failure of Internal Control System" (1993) 48:3 Journal of Finance 831 at 864 [Jensen, Industrial Revolution]; Patton \& Baker, supra note 394 at 12; Kosnik 1987, supra note 372 at 167; Solomon, supra note at 586; Dallas, Relational Board, supra note 393 at 4.
} 
accuracy of the information due to their outsider status, ${ }^{404}$ it is believed that independent directors may only receive selective information that supports management's desired position on the matter. ${ }^{405}$ Therefore, independent directors may see major issues confronted by the company only through the executives' eyes, rather than being permitted to develop an independent assessment of management's strategies. ${ }^{406}$

Second, even if independent directors receive all the relevant information they need, they may not have sufficient expertise to understand or analyze complex business, financial or technical issues. ${ }^{407}$ Studies reveal that few directors have knowledge concerning the particular industry on whose board they sit, and even fewer have knowledge about the specific corporation on whose board they sit. ${ }^{408}$ Such a lack of knowledge and expertise impedes the efficacy of independent directors' oversight. Even if independent directors have the knowledge and expertise, they may not devote sufficient time to review management's proposals and evaluate executives' performance due to their busy schedules. ${ }^{409}$ Moreover, independent directors are often given meeting materials shortly before or at a board meeting. It is almost impossible for them to digest the information in such a short amount of time. ${ }^{410}$

Third, the board culture of politeness and courtesy undermines independent directors' ability to monitor top managers' decisions. Boardroom norms or board culture in many companies discourages directors from openly questioning or criticizing the chief executive's proposals or decisions. ${ }^{411}$ In addition, many independent directors are also CEOs of other corporations. They may be unwilling to challenge management energetically because they hope that they will not be treated similarly on their own boards. ${ }^{412}$ Thus, in a boardroom environment that rewards consent and discourages conflict, independent directors are less likely to question

\footnotetext{
${ }^{404}$ Fairfax, Inside Director, supra note 216 at 161.

${ }^{405}$ Solomon, supra note 363 at 585; Patton \& Baker, supra note 394 at 12; Lin, supra note 13 at 914; Kaura, supra note 8 at 31 .

${ }^{406}$ Lin, ibid at 914.

${ }^{407}$ Solomon, supra note 363 at 586; Fairfax, Inside Director, supra note 216 at 165-66.

${ }^{408}$ Margaret A Bancroft, "Knowledge Is Power: What Went Wrong in the Mutual Fund Industry" (2006) 1 J Bus \& Tech L 145 at 155; Fairfax, ibid at 165.

${ }^{409}$ Lin, supra note 13 at 914-15; Solomon, ibid at 585; Fairfax, ibid; Brudney, supra note 11 at 609.

${ }^{410}$ Solomon, ibid at 585.

${ }^{411}$ Lin, supra note 13 at 915; Jensen, Industrial Revolution, supra note 403 at 863; Solomon, ibid at 586; Dallas, Relational Board, supra note 393 at 5-6.

412 Gilson \& Kraakman, supra note 395 at 875; Cox \& Munsinger, supra note 394 at 105-07; Lin, ibid.
} 
managerial decisions even though such passiveness is not in the best interests of the shareholders. ${ }^{413}$

\subsubsection{Weak Incentives to Monitor Effectively}

Even if independent directors have the ability to monitor management's decisions, the small incentive they are given may discourage them from doing so. ${ }^{414}$ Before the $1990 \mathrm{~s}$, independent directors were typically compensated by a fixed, nominal fee for attending board meeting and serving on committees. ${ }^{415}$ Their compensation is usually unaffected by their performance in monitoring management. ${ }^{416}$ Since a majority of independent directors are chief executives of other companies, ${ }^{417}$ the token director fees, compared to what they earn in their primary position, cannot provide them with sufficient incentives to diligently curb management's abuses. $^{418}$ Although the compensation packages of independent directors typically include a certain proportion of stock grants and stock options since the mid-1990s, ${ }^{419}$ independent directors usually only own a nominal amount of stock in the company on whose board they sit. ${ }^{420}$ Their financial interests are not closely connected to a firm's performance. Therefore, the proponents of the managerial hegemony theory believe that the small size of their financial incentives do not strongly encourage independent directors to devote their time and energy to monitoring the company, not to mention taking an active role in crisis prevention. ${ }^{421}$

\footnotetext{
${ }^{413}$ Lin, supra note 13 at 916; Jensen, Industrial Revolution, supra note 403 at 863.

${ }^{414}$ Lin, ibid.

415 Charles M Elson, "Director Compensation and the Management-Captured Board - The History of A Symptom and A Cure" (1996) 50 SMU L Rev 127 at 132, 146-47 [Elson 1996].

${ }^{416}$ Katherine M Brown, "Notes: New Demands, Better Boards: Rethinking Director Compensation in an Era of Heightened Corporate Governance?” (2007) 82 NYU L Rev 1102 [Brown] at 1121-22; Gilson, supra note 363 at 377; Robert Charles Clark, Corporate Law (Boston: Little, Brown, 1986) at 108-09 [Clark, Corporate Law]; Lin, supra note 13 at 916.

${ }^{417}$ Gilson \& Kraakman, supra note at 875; L Rechner \& Dan R Dalton, “CEO Duality and Organizational Performance: A Longitudinal Analysis" (1991) 12:2 Strategic Management Journal 155 [Rechner \& Dalton] at 156; James A Brickley, Jeffrey L Coles, \& Gregg Jarrell, "Leadership Structure: Separating the CEO and Chairman of the Board" (1997) 3 Journal of Corporate Finance 189 [Brickley, Coles \& Jarrell] at 197.

${ }^{418}$ Lin, supra note at 916.

${ }^{419}$ Corderio, Veliyath \& Neubaum, supra note 375 at 81-82; Gerety, Hoi \& Robin, supra note 375 at 45 ; Fich \& Shivdasani 2005, supra note 36 at 2229.

${ }^{420}$ Jensen, Industrial Revolution, supra note 403 at 864; Gilson, supra note at 377; Chun I Lee et al, "Board Composition and Shareholder Wealth: The Case of Management Buyouts" (1992) 21 Financial Management 58 at 62 [Chun I Lee et al]; Shivdasani 1993, supra note 365 at 175; Gordon, The Rise of Independent Directors, supra note 1 at 1488 .

${ }^{421}$ Lin, supra note 13 at 917.
} 


\subsection{Specific Critiques Regarding the Ineffectiveness of Independent Directors as Corporate Monitors}

In addition to the managerial hegemony theory that depicts independent directors as ineffective in holding management accountable, some scholars contend that many additional existing significant limitations, including flaws in defining independence, the lack of appropriate positive rewards (compensation), the lack of sufficient civil liability (negative incentives), the constraints of groupthink and in-group bias, and the trade-off between independent directors' monitoring function and managing function, prevent independent directors from effectively fulfilling their oversight role. These limitations are analyzed as follows.

\subsubsection{Lack of True Independence}

The rationale for independent directors to be considered as a cure for agency problems is that independent directors are believed to have an objective viewpoint, no conflicts between their obligation to the corporation and their self-interest, and, as a result, are more likely to make unbiased judgments. However, the flaws in defining independence hinder independent directors from fulfilling this expected role. The failure of the Enron board, two Delaware lower court decisions, ${ }^{422}$ and the findings of empirical studies ${ }^{423}$ demonstrate that the traditional definition of director independence, which focuses on directors' financial ties and familial ties with the company or the chief executive, may fail to identify directors who can possess a truly independent viewpoint in curbing managerial abuses. In contrast, social connections, including personal, professional, sponsorship, and philanthropic ties, which are traditionally excluded from the requirements to determine whether a director is independent, play an important role in limiting a director's exercise of independent judgment. Many independent directors as traditionally defined may not be truly independent.

In practice, laws, regulators and stock exchanges must adopt standards to permit boards to decide whether a director is independent in actual cases. Since true "independence" is difficult to define through precise and specific language, the current definition that the law, regulators and stock exchanges have adopted is perceived to be highly abstract and difficult to

\footnotetext{
${ }^{422}$ Further details are discussed in infra text accompanying notes 440-461.

${ }^{423}$ Further details are discussed in infra text accompanying notes 463-483.
} 
operationalize. "No material relationship with the company" adopted by the NYSE 424 and "no relationship would interfere with the exercise of independent judgment in carrying out the duties of a director" used by the NASDAQ are typical examples. ${ }^{425}$ In order to solve the problem of determining whether a director is independent, stock exchanges also define an independent director by reference to a bright-line test that excludes a director from being considered independent in specific circumstances. For example, the NYSE and NASDAQ enumerates six relationships that disqualify a person from serving as an independent director, namely employment relationships, compensation relationships, relationships with auditors, business relationships, immediate family relationships and cross compensation committee links, ${ }^{426}$ while Companion Policy 52-110CP in Canada lists first five of these relationships for the same purpose. $^{427}$

However, these preclusions only focus on directors' financial ties and familial ties with the company or the chief executive without considering social, sponsorship or professional ties. $^{428}$ Corporations' intent on selecting directors who are attached to them could develop strategies to circumvent these laws and regulations. Top executives can easily nominate directors who are independent according to regulatory definitions, but still unduly influenced by

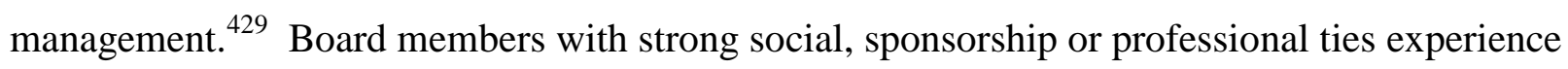
challenges in impartially assessing one another's behavior. ${ }^{430}$ Enron's board is a typical example.

\subsubsection{The Negative Impact of the Sponsorship Relationship on Enron's Board Members}

Enron's board of directors was what most experts would have called ideal. The board had been ranked as one of the five best corporate boards in 2000 by Chief Executive

\footnotetext{
${ }^{424}$ NYSE Manual, supra note 5, §303A.02(a)

${ }^{425}$ NASDAQ Rule, supra note 5, §4200(a)(15). NI 52-110 uses similar wording to define "independence.” NI 52110 , supra note $10, \mathrm{~s} 1.4$, at 31 OSCB 12189.

${ }^{426}$ Please refer to infra text accompanying notes 779-796.

${ }^{427}$ Companion Policy 52-110CP to National Instrument 52-110 Audit Committee, OSC CP 52-110, 31 OSCB 12200 (19 December 2008), at 12200-01.

${ }^{428}$ Fairfax, Inside Director, supra note 216 at 149-50; Rachel A Fink, "Social Ties in the Boardroom: Changing the Definition of Director Independence to Eliminate 'Rubber-Stamping Boards"' (2006) 79 S Cal L Rev 455 at 457 [Fink]; Developments in the Law - Corporations and Society, (2004) 117 Harv L Rev 2169 at 2198 [Developments in the Law].

${ }^{429}$ Ran Duchin, John G Matsusaka \& Oguzhan Ozbas, "When Are Outside Directors Effective?” (2010) 96 Journal of Financial Economics 195 at 196 [Duchin, Matsusaka \& Ozbas]; Cosenza, supra note 391 at 15.

${ }^{430}$ Fairfax, Inside Director, supra note 216 at 150; O’Connor, supra note 403 at 1233.
} 
Magazine. $^{431}$ Of the 14 board members in 2001, only two were Enron executives (Kenneth L. Lay, Chairman of the Board and former CEO and Jeffrey K. Skilling, CEO). ${ }^{432}$ Even deducting three board members who had business relationships with Enron (Robert Belfer, Charles Walker and Herbert Winokur), nine directors (64\% of board members) still claimed to be independent, according to 1999 NYSE listing standards. ${ }^{433}$ However, the independence of Enron's board of directors was substantially compromised by certain under-the-table connections, especially the sponsorship relationship.

Enron made donations to organizations managed or favored by its directors. Dr. LeMaistre and Dr. Mendelsohn, on the board from 1985 to 1999, respectively, ${ }^{434}$ both served as president of the M.D. Anderson Cancer Center in Texas. Enron and Kenneth Lay, Chairman of the board and former CEO, donated nearly \$600,000 to the Cancer Center between 1997 and 2002. In 1993, the Enron Foundation also pledged $\$ 1.5$ million to the Cancer Center. ${ }^{435}$ Although these two directors did not directly receive contributions from Enron, this sponsorship relationship may have discouraged them from expressing different opinions in the boardroom.

Moreover, Enron board member Dr. Wendy Gramm, ${ }^{436}$ a former head of the Commodity Futures Trading Commission, was employed for some time at George Mason University. Beginning in 1996, Enron and the Lay Foundation donated more than \$50,000 to George Mason University and its Mercatus Center in Virginia. ${ }^{437}$ In addition, Ms. Gramm's husband, Senator Phil Gramm, received political contribution totaling \$97,350 from Enron from 1989 to $2001{ }^{438}$ A politician's wife may have been reluctant to offend his sponsor and give the sponsor a hard time when they were meeting in the boardroom. ${ }^{439}$ The examples suggest that directors who conform to the stock exchanges' independent requirements may not be truly independent.

\footnotetext{
${ }^{431}$ Gillan \& Martin, supra note 2 at 932; Gordon, Enron Reflection, supra note 263 at 1242.

${ }^{432}$ Gillan \& Martin, ibid at 952-55; Gordon, ibid.

${ }^{433}$ Gillan \& Martin, ibid at 932-35.

${ }^{434}$ Dr. Lemaistre served on Enron's executive committee and chaired the compensation committee. Dr. Mendelsohn was on Enron's audit committee and nominating and corporate governance committee. Ibid at 938.

${ }^{435}$ Ibid; Senate Enron Report, supra note 2 at 55; Paul Windolf, "Corruption, Fraud, and Corporate Governance: A Report on Enron" in Anna Grandori ed Corporate Governance and Firm Organization: Microfoundations and Structural Forms (Oxford; New York: Oxford University Press, 2004) at 179; Elson \& Gyves, supra note 273 at 873.

${ }^{436}$ Ms. Gramm served on Enron's board from 1993. In 2001, she was on the audit and the nominating and corporate governance committees. Gillan \& Martin, ibid.

${ }^{437}$ Ibid; Senate Enron Report, supra note 2 at 55.

${ }^{438}$ Gillan \& Martin, ibid.

${ }^{439}$ See Strine, supra note 392 at 1381.
} 


\subsubsection{Delaware Cases Showing a Negative Impact of Non-financial Ties and Friendships on Director Independence}

In addition to corporate scandals, two Delaware lower court decisions demonstrate that non-financial ties and friendships could impede director independence and cause bias that would preclude a director from objectively evaluating corporate decisions. In In re Oracle Derivative Litigation, shareholders brought a derivative action against four Oracle board members, including Lawrence Ellison, Michael Boskin, and Donald Lucas, alleging that they had engaged in insider trading by selling some of their holdings prior to an unfavorable earnings announcement. ${ }^{440}$ The company responded to the suit by establishing a special litigation committee (SLC), composed of two Stanford University professors, Joseph Grundfest and Hector Garcia-Molina, to determine whether Oracle should press shareholders' claims, settle the case, or terminate it. ${ }^{441}$ After an extensive investigation with the engagement of independent financial and legal advisors, ${ }^{442}$ the SLC advised Oracle to terminate the case. ${ }^{443}$

The Delaware court reviewed the SLC' termination decision under the requirements set forth in Zapata Corp v. Maldonado ${ }^{444}$, placing the burden on the SLC had to prove that (1) its two members were indeed independent; (2) it acted in good faith; and (3) there existed a reasonable explanation for its conclusions. ${ }^{445}$ The Delaware Court of Chancery ruled that the two directors in the SLC were not independent because of various connections between defendants, Stanford University and the two SLC members. ${ }^{446}$ First, Boskin (a defendant) was a Stanford professor and fellow as well as a committee member of the Stanford Institute for Economic Policy Research. ${ }^{447}$ Grundfest (one of the SLC members) was also a senior fellow of the Institute. $^{448}$ Boskin even taught Grundfest when Grundfest was a Ph.D. candidate at Stanford. ${ }^{449}$ Second, Lucas (a defendant), obtaining both his undergraduate and graduate degrees from Stanford, donated \$50,000 to Stanford Law School to show his appreciation for Grundfest

\footnotetext{
${ }^{440}$ In re Oracle Corp Derivative Litig, 824 A 2d 917 at 920-21 (Del Ch 2003) [Oracle].

${ }^{441}$ Ibid at $923-24$.

442 Ibid at 925.

443 Ibid at 928.

${ }^{444}$ Zapata, supra note 216.

${ }^{445}$ Ibid at 788-89; Cosenza, supra note 391 at 37.

${ }^{446}$ Oracle, supra note 440 at 937-38.

${ }^{447}$ Ibid at 930-31; Fink, supra note 428 at 478.

${ }^{448}$ Oracle, ibid at 931.

${ }^{449}$ Ibid at 931.
} 
(one of the SLC members) giving a speech at his request. ${ }^{450}$ His foundation had also donated $\$ 11.7$ million to Stanford since 1981. ${ }^{451}$ Third, Ellison (a defendant), the CEO and chairman of Oracle, had donated over $\$ 0.3$ million to Stanford and was in negotiations to make another $\$ 170$ million donation in 2001. ${ }^{452}$ Fourth, the two SLC members were recruited to the board primarily by defendant Lucus, with help from defendant Boskin. ${ }^{453}$ The court concluded that these ties among the SLC members, defendants and Stanford were so substantial, that they raised a reasonable doubt about the SLC's ability to impartially consider whether the defendants should face suit. $^{454}$

In Bean v. Martha Stewart, a shareholder brought a derivative action against Martha Stewart and other directors, alleging breaches of fiduciary duty stemming from the sale of ImClone stock in 2001. ${ }^{455}$ In Delaware, prior to filling a derivative litigation, a shareholder must make a demand on the firm's directors to remedy the complaint, unless it can be proved that making such a demand would be futile. ${ }^{456}$ As noted previously, according to Aronson v. Lewis, a shareholder must raise a reasonable doubt that: (1) directors were independent, and (2) directors exercised proper business judgment in approving the challenged transaction, in order to prove demand futility. ${ }^{457}$ The shareholder in this case claimed that the demand would be futile, because close personal and social ties between Stewart and other directors undermined the directors' independence. ${ }^{458}$

The Delaware Court of Chancery gave significant weight to the personal ties between Stewart and Moore, a defendant director of the firm who was a longstanding friend of Stewart. ${ }^{459}$ The court considered the following allegations "quite a close call" as to the director's independence: (1) Moore attended a wedding reception hosted by Stewart's personal lawyer; (2) Fortune magazine described Stewart and Moore as close personal friends; (3) Moore was selected to serve on the board of Martha Stewart Living Omnimedia, Inc. after Stewart's

\footnotetext{
${ }^{450}$ Ibid.

451 Ibid.

452 Ibid at 933.

${ }^{453}$ Ibid at 924.

${ }^{454}$ Ibid at 942.

${ }^{455}$ Beam ex rel Martha Stewart Living Omnimedia, Inc v Stewart, 833 A 2d 961 at 968 (Del Ch 2003) [Beam].

${ }^{456}$ See context accompanying notes 707-713, Fairfax, Corporate Federalism, supra note 209 at 392.

${ }^{457}$ Aronson v Lewis, 473 A 2d 805 at 814.

${ }^{458}$ Fairfax, Corporate Federalism, supra note 209 at 401.

${ }^{459}$ Ibid at 402.
} 
longtime friend resigned. ${ }^{460}$ The decision appears to reveal that some personal relationships, like moving in the same social circles, attending the same weddings, and being described as friends, may hinder a director's independence, especially when the director is called on to impose civil or criminal liability on close friends. ${ }^{461}$ Some scholars also support this view. ${ }^{462}$

\subsubsection{Empirical Evidence Showing a Negative Impact of Social Ties on the Effectiveness of Independent Directors}

Moreover, two recent empirical studies showed that independent directors with social ties, including education institution, regional origin, military service, and professional similarity ${ }^{463}$ to the firm's CEOs, were less effective in enhancing shareholder wealth and in fulfilling their monitoring roles. More specifically, firms with independent directors with such connections to their CEOs are inclined to have poorer financial performance, award a higher level of compensation to their CEOs, exhibit a lower sensitivity to the CEO's performance in deciding on the CEO's compensation and deciding whether the CEO should be removed, and have a lower quality of financial reporting. ${ }^{464}$

Hwang and Kim (2009) examined whether taking into account certain omitted ties (social ties) into the definition of board independence ${ }^{465}$ would affect the monitoring and disciplinary efficacy of independent directors by using a sample of Fortune 100 firms from 1996 to $2005 .{ }^{466}$ The effectiveness of independent directors was measured by whether independent directors were likely to (1) control the level of CEO compensation; (2) tie CEO pay to firm performance; and (3) remove poorly performing CEOs. In their study, a director is classified as socially dependent if

\footnotetext{
${ }^{460}$ Beam, supra note 455 at 980; Fairfax, ibid at 402.

${ }^{461}$ Beam, ibid at 979 ; Fairfax, ibid at 401.

462 Julian Velasco, "Structure Bias and the Need for Substantive Review" (2004) 82 Wash U L Q 821 at 858-60 [Velasco]; Brudney, supra note 11 at 613.

${ }^{463}$ Professional similarities are defined as whether an independent director is also a C-level executive (such as CEO, $\mathrm{CFO}$, and $\mathrm{COO}$ ) of another corporation. The authors consider that professional similarities and shared experiences facilitate interactions between these directors and their CEOs, and, in turn, establish personal connections between parties. Aiyesha Dey \& Xiaohui Liu, "Social Connections, Stock-Based Compensation, and Director Oversight" (2010) at 2, 23, online SSRN: <http://ssrn.com/abstract=1581212〉 [Dey \& Liu].

${ }^{464}$ Byoung-Hyoun Hwang \& Seoyoung Kim, "It Pays to Have Friends" (2009) 93 Journal of Financial Economics 138 at 139 [Hwang \& Kim]; Dey \& Liu, ibid at 4.

${ }^{465}$ In this study, a director is considered as conventionally independent if he or she is not a current or former employee of the firm, a relative of an executive officer, a customer of or a supplier to the firm, a provider of professional services, a recipient of charitable funds, a designee under a documented agreement by a significant shareholder or group, or interlocked with an executive of the firm. Hwang \& Kim, ibid at 142.

${ }^{466}$ Ibid at 141.
} 
the director and CEO have two or more of the following characteristics in common: "(1) served in the military; (2) graduated from the same university (and were born no more than three years apart); (3) were born in the same US region or the same non-US country; (4) have the same academic discipline; (5) have the same industry of primary employment; (6) share a third-party connection through another director to whom each is directly dependent ${ }^{467}$.,468

The authors found that CEO compensation (salary plus bonus) was lower by approximately $\$ 0.8$ million when a board was conventionally and socially independent of the CEO (average salary plus bonus is $\$ 3.8$ million) in comparison with a board only conventionally independent. ${ }^{469}$ CEO total compensation ${ }^{470}$ was also $\$ 3.3$ million lower when a conventionally and socially independent board was present (average total compensation is \$12.8 million), compared to a board only conventionally independent. ${ }^{471}$ In addition, the sensitivity of a CEO's pay-for-performance relation was lower for firms with conventionally independent boards, compared to firms with both conventionally and socially independent boards. ${ }^{472}$ The probability of CEO turnover was also less sensitive to firm performance when firms had boards that were not conventionally and socially independent. ${ }^{473}$ These results suggest that independent directors with social connections to their CEOs are likely to be less effective monitors.

One year later, Dey and Liu's (2010) research confirmed Hwang and Kim's findings. The authors investigated whether social connections between independent directors ${ }^{474}$ and their CEOs were related to a firm's operating performance and financial reporting quality by using a

\footnotetext{
${ }^{467}$ The authors provided an example for this situation. "Suppose that the CEO is a 55-year-old, Stanford-educated, business major who served in the military and was born in the Northeast, and director A is a 55-year-old, Stanfordeducated, electrical engineering major born in the South. Although the director and CEO share only one direct tie (through mutual alma mater), if there is third-party director B who is a 57-year-old Stanford graduate who studied electrical engineering and served in the military, then we consider director A socially dependent to the CEO (because in addition to their mutual alma mater connection, the two are socially connected to a mutual third party with whom each shares two direct ties)." Ibid at 142.

${ }^{468}$ Ibid at 142 .

${ }^{469}$ Ibid at 146.

${ }^{470}$ CEO total compensation in this study includes the sum of base salary, bonus, long-term incentive payouts, the value of restricted stock grants and the value of option grants. Ibid at 146 Table 4.

${ }^{471}$ Ibid at $139,146$.

${ }^{472}$ Ibid at $139,150,154$.

${ }^{473}$ Ibid at $139,151,155$.

${ }^{474}$ In this study, a director is classified as independent, if he or she is neither affiliated nor currently an employee of the corporation. An affiliated director is a director who: (1) is a former employee of the firm or of a majority-owned subsidiary; (2) is a provider of professional services, such as legal, consulting, or financial to the firm or an executive; (3) is a customer of supplier to the firm; (4) is a designee, such as a significant shareholder, under a documented agreement between the firm and a group; (5) controls more than $50 \%$ of the firm's voting power; (6) is a family member of an employee; or (7) is an employee of an organization or institution that receives charitable gifts from the firm. Dey \& Liu, supra note 463 at 15.
} 
sample of 210 US firms over the period 1996 to $2006 .^{475}$ An independent director was considered to be socially connected to the CEO if he or she overlapped with the CEO in the past for two or more years in at least one of the following situations: (1) served in the military; (2) graduated from the same university; (3) worked in the same corporation or (corporations) in the past. In addition, an independent director is considered to have social connections with the CEO, if he or she: (1) is a member of one or more clubs of which the CEO is also a member; (2) serves in one or more charities with the CEO; and (3) is a member of any other similar type of organization that the CEO also attends. ${ }^{476}$

The results demonstrated that firms (that did not comply with the board independence requirements before $\mathrm{SOX}$ ) experienced lower operating performance (as measured by return on assets) and a poorer quality of financial reporting (as measured by three different indicators) ${ }^{477}$ in the post-SOX period, when they added independent directors to the board (in order to comply with new board independence requirements) but where the directors had social connections to the CEO. ${ }^{478}$ Similar results also held for the same increase in independent directors with social ties to the CEO on the audit committee. ${ }^{479}$ The authors also found that firms (that did not comply with the board independence requirements before SOX) experienced a greater decrease in operating performance and financial reporting quality, when they had increases in professionally connected ${ }^{480}$ directors on the board after the passage of SOX. ${ }^{481}$ Similar results held for the increase in professionally connected directors on the audit committee. ${ }^{482}$ The authors concluded that similarities in professional roles and social connections between directors and the CEO make independent directors identify more with the CEO and adopt a more sympathetic view, thereby lowering their monitoring effectiveness. ${ }^{483}$

Collectively, corporate scandals, court decisions and these empirical results suggest that

\footnotetext{
475 Ibid at 4, 10 .

${ }^{476}$ Ibid at 2, 7 .

${ }^{477}$ The authors used value relevance, accruals quality and the frequency of restatements made by the firm to measure the quality of financial reporting. Ibid at 13-15.

${ }^{478}$ Ibid at 4, 21-22, 41. In this study, the authors focused on the firms that were not in compliance with the SOX independence requirements prior to the passage of SOX in order to ensure that the empirical results will not be affected by unobservable firm and CEO characteristics, since their change of board composition in the post-SOX period is mostly attributed to the new rules under SOX rather than unobservable factors. Ibid at 3-4.

${ }^{479}$ Ibid at 4, 22, 42 .

${ }^{480}$ Profession connection is defined as a director who has served or currently serves as a C-level executive (such as $\mathrm{CEO}, \mathrm{CFO}, \mathrm{COO}$, etc.) in his primary employment. Ibid at 7, 33.

${ }^{481}$ Ibid at 4, 23, 44.

${ }^{482}$ Ibid at $4,23,45$.

${ }^{483}$ Ibid at 23.
} 
personal ties and other social connections between independent directors and the CEO or the company do affect the monitoring effectiveness of independent directors. Directors who are independent under the conventional definition may not be truly independent. Therefore, independent directors as currently defined may not effectively serve as a check on managerial abuses and further protect shareholder interests.

\subsubsection{The Lack of Appropriate Compensation}

In addition to the lack of true independence, the lack of an appropriate director compensation mechanism to align the interests of directors with those of shareholders further contributes to the ineffectiveness of independent directors as checks on managerial abuses. Independent directors have been increasingly relied on to hold management accountable since the 1990s. However, if there are no appropriate rewards, they may not have sufficient motivation to commit time and energy to fulfill their increasing monitoring responsibilities. With a view to enhancing monitoring quality, the business community has developed several compensation mechanisms to motivate independent directors to devote themselves to diligent monitoring. However, no model has been proven to achieve this goal successfully so far.

\subsubsection{The Development of Director Compensation}

Originally, corporate directors received no direct remuneration for their services. During the nineteenth and the early twentieth century, most companies were closely held by a relatively small group of investors. Directors at that time were usually major shareholders (or their representatives) and the goal of their board service was to protect and enhance the value of their investment. Hence, no compensation was necessary or desirable. Having the opportunity to monitor management was reward enough for a substantial shareholder. ${ }^{484}$

This concept did not substantially change until around the 1950s. As of the 1950s, director compensation gradually became an accepted part of the American corporate landscape. ${ }^{485}$ According to a 1962 Conference Board report, a substantial majority of the largest public companies paid compensation to their outside directors. Their remuneration usually took one of the following forms: (1) a simple fee per board meeting attended; (2) an annual fee; or (3)

\footnotetext{
${ }^{484}$ Elson 1996, supra note 415 at 135-36; Gordon, The Rise of Independent Directors, supra note 1 at 1487.

${ }^{485}$ Elson 1996, ibid at 146.
} 
a combination of annual retainer and a stated fee per meeting. ${ }^{486}$ However, compared to what an inside director was paid, this flat fee compensation for outside directors was a relatively modest sum.

Around the middle of the 1980s, the amount of director compensation substantially shifted. Two factors contributed to the increase of remuneration. One was the concept that boards should be independent of management in order to exercise a proper monitoring function to ensure maximum corporate performance. To attract the independent directors, an increase in director compensation was necessary. The other reason was the increasing threat of director liability. Before 1985, director decisions were seldom challenged for the violation of the duty of care which might result in director liability. Even though actions against directors for poor decisions were filed or threatened, directors were usually protected under the business judgment rule and were rarely liable to make out-of-pocket payments. ${ }^{487}$ However, in 1985, the Delaware Supreme Court's ruling in Smith v. Van Gorkom ${ }^{488}$ tightened the duty of care standard, which therefore increased the risk of director liability. In order to compensate for directors' risk of liability and enhance candidates' willingness to accept board positions, the business community developed much richer and more varied compensation package for directors, along with greater directors' and officers' (D\&O) insurance coverage and other indemnification arrangements. ${ }^{489}$

In the early 1990s, a typical director compensation package consisted of many or all of the following items: (1) annual retainer (generally in cash, plus supplements for chairing any board committee); (2) fees for attending board and committee meetings; (3) defined benefit retirement arrangements; (4) life insurance/medical insurance; (5) charitable contribution arrangements; (6) directors' and officers' liability insurance. ${ }^{490}$ According to a Conference Board report, the median total annual director compensation among the nation's most substantial manufacturing companies was $\$ 31,000$ in 1995 . The largest companies paid a median of $\$ 60,000$, with a range of $\$ 35,000$ to $\$ 95,000$. These figures did not include the value of the other assorted benefits granted to directors, such as pension plans and charitable contributions on their behalf, which substantially increased the average total compensation. ${ }^{491}$ At first glance, the

\footnotetext{
4861962 Conference Board, supra note 71 at 31-32; Elson 1996, ibid at 146-47.

${ }^{487}$ Elson 1996, ibid at 148-51.

${ }^{488}$ Smith v Van Gorkom, 488 A 2d 858 (Del 1985).

${ }^{489}$ Elson 1996, supra note 415 at 151-53.

${ }^{490}$ Ibid at 154.

${ }^{491}$ Kay Worrell, Corporate Directors' Compensation 1, Conference Board Report No. 1140-95-RR (1996).
} 
director compensation seems munificent. However, compared with a CEO's median total compensation-1.8 million in $1994^{492}$, the director compensation was only a modest sum. Since a substantial majority of independent directors were CEOs of other companies at that time, ${ }^{493}$ such a slim director compensation package might not provide sufficient incentives for independent directors to hold management accountable.

\subsubsection{The Advantages and Disadvantages of Stock-based Compensation for Independent Directors}

The rise of stock-based compensation was one of the governance innovations in the 1990s. Stock grants ${ }^{494}$ and stock options ${ }^{495}$ were introduced to director compensation packages, in addition to the traditional cash retainer and attending fees. ${ }^{496}$ In 1992, only around 200 firms in the Fortune 1000 list offered stock-option remuneration for corporate directors, ${ }^{497}$ but by 1997 , almost 500 firms in the same list had stock-based compensation (including stock grants and stock options) in place for outside directors. ${ }^{498}$ The rationale behind the stock grants and options is to bring directors' interests in line with those of shareholders. ${ }^{499}$ These two types of equity compensation are used as vehicles to induce independent directors to monitor management and to think and act in a way that is representative of shareholders. ${ }^{500}$ The ultimate goal is to make independent directors work harder to increase shareholder value.

The use of equity-based remuneration as an incentive for independent directors has found some empirical support. Empirical studies found that firms were more likely to perform better

\footnotetext{
${ }^{492}$ Lin, supra note 13 at 916 n 101.

${ }^{493}$ Lin, ibid.

${ }^{494}$ Stock grants can be deferred or restricted stocks. Deferred stock is usually delivered at the end of a board member's service on the board. The purpose of doing this way is providing incentives for directors to participate fully in the growth (or decline) in the stock price throughout their tenure on the board. Restricted stock compensation plans normally provide for an annual grant of a pre-specified number of shares, or an amount of shares equal to a pre-specified amount of money. Brown, supra note 416 at $1122 \mathrm{n} 130$.

495 Stock options grant the director, often annually, a right to purchase the company's stock with an exercise price equal to the fair market value on the date of the grant. The options typically become exercisable in annual installments and expire a certain years from the issue date. Ibid at 1123 .

${ }^{496}$ Corderio, Veliyath \& Neubaum 2005, supra note 375 at 84.

${ }^{497}$ Fich \& Shivdasani 2005, supra note 36 at 2229. According to the authors, some firms have also used restricted stocks and phantom stocks to award outside directors. Ibid at n 1.

${ }^{498}$ Ibid.

${ }^{499}$ Ibid at 2231; Gordon, The Rise of Independent Directors, supra note 1 at 1487; Brown, supra note 416 at $1124-$ 25, 1129.

${ }^{500}$ Brown, ibid at 1124; Kaura, supra note 8 at 35.
} 
when their independent or outside directors had a higher proportion of shareholdings. ${ }^{501}$ Financial economists further reported that stock options for outside directors had an even stronger positive impact on subsequent firm performance than stock grants. ${ }^{502}$ It seems that stock options and shareholdings provide incentives for independent directors to monitor management with the goal of maximizing shareholder value. Further details are discussed in sections 5.1.6.2.1 and 5.1.6.2.2.

However, the effectiveness of stock-based compensation as an incentive for independent directors has been doubted. Most independent directors seldom acquired a great enough equity interest to generate a strong incentive in monitoring management, according to Professor Gordon. ${ }^{503}$ Independent directors usually obtained their stocks through annual stock-based compensation rather than an initial grant of stock options. ${ }^{504}$ It may take a few years to reach an amount that leads independent directors to really care. Such a slow incentive may not generate sufficient motivations for independent directors in holding management accountable.

Even if some independent directors accumulate sufficient stocks over time, their independence may be undermined, especially when the CEO has influence over director retention. More importantly, they may choose to keep silent in the boardroom in order to

\footnotetext{
${ }^{501}$ Morck, Shleifer and Vishny (1988) found a significant correlation between outside director ownership and current and next year's firm performance (as measured by Tobin's Q), but the correlation was not monotonic. Morck, Shleifer \& Vishny, supra note 374 at 308. Hambrick and Jackson (2000) reported that outside directors in firms that successively outperformed their industries had greater equity holdings than their counterparts in firms that apparently lagged behind their industries. Hambrick \& Jackson, supra note 377 at 116 . Moreover, Klein (1998) found that the presence of at least one independent director holding at least 5 percent of a firm's equity was marginally related to one out of three firm performance indicators (significant for Jensen Productivity, but not for ROA and market return), while Bhagat and Black (2002) observed that independent directors who hold significant stock positions enhanced firm performance, but other independent directors did not. April Klein, "Firm Performance and Board Committee Structure" (1998) 54 JL \& Econ 275 at 277, 293 [Klein 1998]; Bhagat \& Black 2002, supra note 1 at 265-66. Please also refer to section 5.1.6.2 of this thesis.

502 Cordeiro, Veliyath and Neubaum (2005) found that stock options for outside directors was significantly and positively related to two subsequent firm performance measures (stock return and Jensen's Alpha), while stock grants was only significantly and positively associated with one subsequent performance measure (stock returns). Corderio, Veliyath \& Neubaum 2005, supra note 375 at 86. Cordeiro, Veliyath and Romal (2007) further observed that the same results also held for firms with greater investment opportunities (was measured by market-to-book ratio of the firm's assets). James J Cordeiro, Rajaram Veliyath \& Jane B Romal, "Moderators of the Relationship Between Director Stock-Based Compensation and Firm Performance" (2007) 15:6 Corporate Governance 1384 at 1388-90 [Cordeiro, Veliyath \& Romal 2007].

${ }^{503}$ Gordon, The Rise of Independent Directors, supra note 1 at 1488; Cosenza, supra note 391 at 25; see Jensen, Industrial Revolution, supra note 403 at 864; Gilson, supra note 363 at 377; Chun I Lee et al, supra note 420 at 62; Shivdasani 1993, supra note 365 at 175.

${ }^{504}$ Gordon, ibid at 1488; Frederic W Cook \& Co Inc, 2011 Director Compensation (November 2011) at 4, online: Deloitte $<$ http://www.fwcook.com/alert_letters/2011_Director_Compensation_\%20NonEmployee Director_Compensation_Across_Industries_and_Size.pdf>
} 
maintain benefits from their directorships. ${ }^{505}$ Even if director nomination is free from the CEO's involvement, a too generous stock-based compensation may induce some independent directors to accept management's aggressive accounting practices, especially if they are designed to inflate stock prices. ${ }^{506}$ Taking Enron's board as an example, each independent director earned over $\$ 300,000$ in one year from stock options alone. ${ }^{507}$ Such luxurious compensation may render independent directors unable to act independently of executives and reluctant to challenge management's risky accounting decisions from which they benefit. The use of stock-based remuneration as incentives for director monitoring is not necessarily beneficial.

Several studies have reported that equity-based compensation for independent directors had negative effects on shareholder wealth in some circumstances. Ronen, Tzur \& Yaari $(2006)^{508}$ argued that incentive compensation (including stock grants and stock options) induces directors to tacitly collude with executives in the manipulation of earnings, ${ }^{509}$ while Bédard, Chtourou and Courteau (2004) reported that the percentage of stock options that can be exercised in the short term by independent director serving on the audit committee was related to a higher likelihood of the manipulation of earnings. ${ }^{510}$ Bebchuk, Grinstein and Peyer (2010) also observed that independent directors were less likely to constrain CEO total compensation when they also received lucky option grants ${ }^{511}$ (opportunistically timed option grants) that were like those that CEO received. ${ }^{512}$ In other words, when a company's CEO and independent directors both received lucky option grants, independent directors were less inclined to provide a check on executive compensation decisions. ${ }^{513}$ In addition, the findings of Byard and Li (2003) showed that stock options compromised directors' ability to limit the CEO’s timing opportunism.

\footnotetext{
${ }^{505}$ Gordon, ibid; Gordon, Enron Reflection, supra note at 1242; Lin, supra note 13 at 916-17; Brown, supra note 416 at 1113.

${ }^{506}$ Gordon, ibid.

${ }^{507}$ Strine, supra note 392 at 1378.

${ }^{508}$ The authors examined the effect of insider trading by directors on the likelihood of earnings management (by management), on the value of the firms, and on the stock price. Joshua Ronen, Joseph Tzur \& Varda Yaari, "The Effect of Directors' Equity Incentives on Earnings Management” (2006) 25 J Acct \& Pub Pol'y 359 at 360 [Ronen, Tzur \& Yaari].

509 Ibid at 362, 380.

${ }^{510}$ Jean Bédard, Sonda Marrakchi Chtourou \& Lucie Courteau, "The Effect of Audit Committee Expertise, Independence, and Activity on Aggressive Earnings Management” (2004) 23:2 Auditing: A Journal of Practice \& Theory 13 at 14, 29 [Bédard, Chtourou \& Courteau].

${ }^{511}$ Lucky grants in this study are defined as grants for which the exercise price is based on the lowest trading price of securities during a month. Lucian A Bebchuk, Yaniv Grinstein \& Urs Peyer, "Lucky CEOs and Lucky Directors" (2010) 65:6 Journal of Finance 2363 at 2364, 2368 [Bebchuk, Grinstein and Peyer].

512 Ibid at 2365, 2387, 2399.

${ }^{513}$ Ibid at 2365.
} 
Timing opportunism refers to the opportunistic practice where CEOs increase the value of their option grants by lowering their firms' stock prices on days when they receive option grants ${ }^{514} .515$ Usually independent directors receive options on the same day with their CEOs. They are unlikely to constrain CEO timing opportunism, since they also benefit from timing opportunism. ${ }^{516}$ Collectively, these findings reveal that granting equity-based remuneration to independent directors, especially when the same approach is used to compensate management, increases the likelihood of collusion between executives and independent directors, and thus can undermine independent directors' monitoring integrity. Shareholder wealth may therefore suffer. Although some proposals have called for restrictions on the sale of stock until after the director's departure from the board to reduce the negative impact of stock compensation, ${ }^{517}$ the effect of such a suggestion has not been reported yet (some firms have implemented such proposals, but it is too early to see the results).

\subsubsection{Summary}

From the above analysis, it appears that the business community has not found a way to provide appropriate compensation to motivate independent directors to monitor management. Although the evidence is somewhat inconsistent, it shows that the rewards are either too trivial to attract the independent director's attention or so lavish as to induce them to collude with management. The interests of independent directors are seemingly not closely aligned with those of shareholders under the current director compensation packages. The lack of appropriate compensation undermines the effectiveness of independent directors in holding management accountable.

\subsubsection{The Lack of Sufficient Legal Liability}

A lack of sufficient legal liability for independent directors may also reduce their

\footnotetext{
${ }^{514}$ Donal Byard \& Ying Li, “The Impact of Directors' Option Compensation on Their Independence" (September 2005) at 1, online: China Center for Financial Research <http://www.ccfr.org.cn/cicf2006/cicf2006paper/20060201123102.pdf > [Byard \& Li].

${ }^{515}$ Ibid at $1-2,29$.

${ }^{516}$ Ibid at 2.

${ }^{517}$ Brown, supra note 416 at 1123, 1125; Cosenza, supra note 391 at 26.
} 
incentives to curb management abuses. In fact, laws and regulations impose an increasing amount of responsibilities on independent directors, but, so far, they may fail to impose sufficient legal sanctions to deter directors from shirking their obligations. When there is no significant risk associated with failing to perform oversight responsibilities, independent directors may not be properly motivated to carry out their monitoring roles. ${ }^{518}$

In North America, laws impose various duties on corporate directors. At the corporate law level, those duties encompass the duty of care, which demands directors to act diligently and prudently in managing the company's affairs, and the duty of loyalty (or the fiduciary duty in Canada), which requires directors to be loyal to the company and avoid situations where their personal interests conflict with those of the company. At the securities law level, directors are responsible for the accuracy and public disclosure relating to the corporation and its underlying securities. In theory, shareholder voting and shareholder litigation serve as the enforcement mechanisms for holding independent directors accountable for these duties. However, in practice, neither mechanism is able to provide meaningful accountability. ${ }^{519}$

Corporate statutes provide that shareholders elect directors who appoint corporate executives. In reality, shareholders in publicly-held corporations have little practical ability to influence the selection of board nominees. Executives and incumbent directors control the proxy-solicitation process and determine board nominees. It is difficult for most shareholders to nominate and elect their own candidates due to the high expenses associated with distributing their own proxy statements. Shareholders usually can only vote on nominees on management slate with no alternative choices. ${ }^{520}$ As one scholar described, "year after year incumbent directors renominate themselves, virtually ensuring their perpetual reelection." ${ }^{, 521}$ Although such a situation may be changing recently, ${ }^{522}$ shareholder voting, so far, remains not an effective

\footnotetext{
${ }^{518}$ Fairfax, Inside Director, supra note 216 at 167.

519 Jones, supra note 15 at 118 ; VanDuzer, supra note 15 at 522-23.

${ }^{520}$ Jones, ibid; VanDuzer, ibid at 524.

521 Jones, ibid.

${ }^{522}$ For example, the policy of majority voting has been proposed by institutional investors and corporate governance organizations for several years. A majority voting policy refers to a policy that a director is required to promptly submit his or her resignation to the board of directors, if the number of votes withheld for a particular director nominee is greater than the votes in favor of such nominee in an uncontested director election. The Toronto Stock Exchange is now proposing to make the majority voting policy a requirement for listing. Several US corporate governance organizations, such as the Council of Institutional Investors, requested just on July this year that the US exchanges propose such a rule. David Milstead, "Corporate Governance: The Curse of Zombies in the Boardroom", The Globe and Mail, (24 July 2013), online: The Globe and Mail <http://www.theglobeandmail.com/globeinvestor/investment-ideas/lets-get-rid-of-zombie-directors/article13399769/\#dashboard/follows/> .
} 
mechanism to monitor corporate directors.

With respect to shareholder lawsuits, shareholders, theoretically, can seek leave of a court to commence a derivative action on behalf of the company for directors' breach of duty of care or duty of loyalty (or fiduciary duty). In addition, shareholders can claim damages for any misrepresentation in public disclosure, or, in Canada, seek relief directly under the oppression remedy, when independent directors oppress the interests of shareholders, including by failing to fulfill their duties under corporate and securities law. ${ }^{523}$ However, in reality, independent directors rarely face liability, either civil or criminal, for breaching their aforementioned duties, according to Professors Black, Cheffins, and Klausner's studies and the US Department of Justice Corporate Fraud Task Force's Report ${ }^{524} .{ }^{525}$ In the United States, the demand requirement ${ }^{526}$ of derivative actions, the deference to the decision of a special litigation committee, the business judgment rule, indemnification, directors' and officers' liability insurance (D\&O insurance), and exculpatory provisions ${ }^{527}$ all work to protect independent directors from the consequences of their actions. ${ }^{528}$ Similarly, in Canada, the business judgment rule, indemnification, directors' and officers' liability insurance, and the loser-pays litigation rule also play an important role in protecting independent directors from making out-of-pocket payment. $^{529}$ Since the deterrents of director legal liability are slightly different between the US and Canada, the following analysis discusses separately regarding: (1) what liability risks independent directors bear; and (2) why the possibility of making out-of-pocket payment for independent directors is very low.

\subsubsection{Director Legal Liability in the United States}

\footnotetext{
${ }^{523}$ Jones, ibid at 118-19; VanDuzer, ibid at 522-23.

${ }^{524}$ U.S. Department of Justice, News Release, “Fact Sheet: President's Corporate Fraud Task Force Marks Five Years of Ensuring Corporate Integrity" (17 July 2007), online: Department of Justice <http://www.justice.gov/opa/pr/2007/July/07_odag_507.html>.

${ }^{525}$ See Fairfax, Inside Director, supra note 216 at 169; Gordon, The Rise of Independent Directors, supra note 1 at 1484.

${ }^{526}$ Please refer to supra notes 214-215 and infra notes 707-714, as well as their accompanying text, for further details regarding the demand requirement of derivative actions.

${ }^{527}$ Please refer to infra note 548 and accompanying text for further details regarding exculpatory provisions.

${ }^{528}$ See Bernard Black, Brian Cheffins \& Michael Klausner, "Outside Director Liability” (2006) 58 Stan L Rev 1055 at 1060 [Black, Cheffins \& Klausner, Liability].

${ }^{529}$ See Brian R Cheffins \& Bernard S Black, "Outside Director Liability across Countries" (2006) 84:6 Tex L Rev 1385 [Cheffins \& Black, Liability across Countries] at 1441-51.
} 


\subsubsection{Substantive Liability Rules Regarding Independent Directors}

In the United States, lawsuits against independent directors of public companies can be roughly divided into two categories. One is class actions brought by shareholders under securities laws. The other is suits for breach of the duty of loyalty or duty of care under state corporate law. ${ }^{530}$ In securities lawsuits, there are two common causes of action. One is a claim under section 11 of the Securities Act of 1933, which provides that those responsible for a registration statement regarding a public offering may be liable, if there is a material misrepresentation or omission in the registration statement. ${ }^{531}$ The other is a claim under section 10(b) of the Securities Exchange Act of 1934, which provides that those responsible for material misstatements or omission on which investors have relied in secondary trading may incur liability. ${ }^{532}$

In a section 11 case, the company, all directors and those who signed the registration statement are all potential defendants. Usually, the company is the most attractive defendant because the company bears strict liability; unlike individual defendants, the company has no due diligence defense. ${ }^{533}$ Independent directors have to prove the following three facts in order to succeed in due diligence defense: (1) they conducted a reasonable investigation; (2) they had no reasonable grounds to believe, and did not believe, that the expertised portions ${ }^{534}$ of the statement were untrue and misleading; (3) they had reasonable grounds to believe, and did believe, that the non-expertised portion ${ }^{535}$ of the statement was true or not misleading. ${ }^{536}$ The assessment of "reasonable investigation" and "reasonable grounds" is based on a negligence standard. ${ }^{537}$ So far, courts, in most cases, are inclined to hold that independent directors had established their due diligence defense, in comparison with inside directors, since independent

\footnotetext{
${ }^{530}$ Black, Cheffins \& Klausner, Liability, supra note at 1077.

${ }^{531}$ Securities Act of $1933 \S 11,15$ USC $\$ 77 \mathrm{k}$.

532 Exchange Act of 1934 \$10(b), 15 USC \$78j(b) (2008); Exchange Act Rule 10b-5, 17 CFR 240.10b-5 (2008).

${ }^{533}$ Black, Cheffins \& Klausner, Liability, supra note 528 at 1078.

534 The expertised portions mean the portions purported to be made on the authority of an expert, like an accountant, so the lower reliance standard applies requiring no investigation. 15 USC $\$ 77 k(b)(3)(A)$; William K Sjostrom Jr, "The Due Diligence Defense Under Section 11 of the Securities Act of 1933" (2006) 44 Brandeis L J 549 at 565 [Sjostrom].

${ }^{535}$ Since the non-expertised portions were not purporting to be made on the authority of an expert, the higher reasonable investigation standard applies to independent directors. Sjostrom, ibid.

${ }^{536}$ Securities Act of $1933 \S 11(\mathrm{a})(2),(\mathrm{b})(3), 15 \mathrm{USC} \$ 77 \mathrm{k}(\mathrm{a})(2),(\mathrm{b})(3)(2008)$; Cox et al, supra note 66 at $612-27$.

${ }^{537}$ Black, Cheffins \& Klausner, Liability, supra note 528 at 1078.
} 
directors do not devote substantial time to the daily operation of the corporation. ${ }^{538}$ Such a trend significantly reduces the risk for independent directors' section 11 liability.

Under section 10(b), a plaintiff must prove that a defendant responsible for a material misstatement had scienter. The proof of scienter usually requires a high degree of recklessness regarding the truth, approaching conscious disregard of truthfulness or conscious knowledge of untruthfulness. ${ }^{539}$ The company itself and all directors are potential defendants. However, the "proportionate liability rule" under section 10(b) reduces the attractiveness of independent directors as targets of section 10(b) suit. An independent director is liable solely for his/her "percentage of responsibility" "540, unless he/she knowingly committed a violation, in which case he/she shall be jointly and severally liable. ${ }^{541}$ In determining the percentage of responsibility, the court must consider the nature of independent directors' conduct and the nature and extent of the causal relationship between the conduct and the damages. ${ }^{542}$ Since independent directors are ordinarily not involved in the day-to-day operation of the corporation, a plaintiff is less likely to establish a strong case against independent directors for misstatement or omission. ${ }^{543}$ As a result, they usually bear less risk than inside directors for section 10(b) liability.

With respect to suits under state corporate law, a plaintiff can claim against a director for breach of the duty of care or breach of the duty of loyalty. The duty of care, involving a negligence standard, requires a director to exercise reasonable skill, diligence and care in taking or refraining from board action that a reasonable person would exercise in comparable circumstances. ${ }^{54}$ The duty of loyalty necessitates directors to act in the best interest of the corporation and therefore prohibits them from preferring their own interests over the interests of the corporation. ${ }^{545}$ Suits against independent directors for breach of the duty of loyalty or the

\footnotetext{
538 See Sjostrom, supra note 534 at 577-82.

${ }^{539}$ Exchange Act of $1934 § 10($ b), 15 USC $\$ 78$ j(b) (2008); Black, Cheffins \& Klausner, Liability, supra note 528 at 1078-79.

${ }^{540}$ The "percentage of responsibility" is measured by "a percentage of the total fault of all persons who caused or contributed to the loss incurred by the plaintiff." Securities Exchange Act of 1934 §21D(f)(3)(A), 15 USC §78u4(f)(2) (2008).

${ }^{541}$ Securities Exchange Act of $1934 \S 21 \mathrm{D}(\mathrm{f})(2)(\mathrm{B}), 15 \mathrm{USC} \S 78 \mathrm{u}-4(\mathrm{f})(2)(2008)$.

542 Securities Exchange Act of $1934 \$ 21 \mathrm{D}(\mathrm{f})(3)(\mathrm{C}), 15 \mathrm{USC} \S 78 \mathrm{u}-4(\mathrm{f})(2)(2008)$.

${ }^{543}$ Black, Cheffins \& Klausner, Liability, supra note 528 at 1079.

544 See Lyman P Q Johnson \& Mark A Sides, "The Sarbanes-Oxley Act and Fiduciary Duties" (2004) 30 Wm Mitchell L Rev 1149 at 1197, 1200 [John \& Sides]; Roberta Romano, "Corporate Governance in the Aftermath of the Insurance Crisis" (1990) 39 Emory LJ 1155 at 1156 [Romano, Insurance Crisis]; Jones, supra note 15 at 110-11; Nadelle Grossman, "Director Compliance With Elusive Fiduciary Duties in A Climate of Corporate Governance Reform" (2007) 12 Fordham J Corp \& Fin L 393 at 402 [Grossman].

${ }^{545}$ Romano, Insurance Crisis, ibid; Jones, ibid at 110, 112; Grossman, ibid at 407.
} 
duty of care are usually pursued through derivative suits.

Most common types of breach of the duty of loyalty by independent directors are selfdealing, preferential treatment of a controlling shareholder, or conflicts of interest. State law imposes a stricter liability in relation to the duty of loyalty compared to the duty of care, because the burden of proof is placed on the defendant-the director, rather than on the plaintiff-the shareholder-once a conflict of interest is shown. ${ }^{546}$ Usually independent directors face duty of loyalty claims not because they enriched themselves but because they favored a controlling shareholder, the CEO or inside managers over minority shareholders. ${ }^{547}$

As to litigation against independent directors for breaches of duty of care, most cases allege their failure of oversight. However, establishing liability against independent directors for a breach of duty of care is extremely difficult because most states allow public companies to adopt an exculpatory provision ${ }^{548}$ in their charters. Under most exculpatory provisions, a court must dismiss a suit seeking damages from independent directors in the light of a breach of duty of care, unless the plaintiff can demonstrate that the defendant engaged in intentional misconduct or failed to act in good faith. ${ }^{549}$ Even if a plaintiff's allegations withstand a motion to dismiss, independent directors are still protected under the business judgment rule ${ }^{550}$, as long as they acted in good faith, on an informed basis and believed that the decision was in the best interests of the company. ${ }^{551}$ As a scholar has noted, "the business judgment rule is essentially designed to

\footnotetext{
${ }^{546}$ Romano, ibid at 1156; Black, Cheffins \& Klausner, Liability, supra note 528 at 1089-90.

${ }^{547}$ Ibid at 1090 .

548 The first exculpatory provision originated from Delaware General Corporation Law section 102(b)(7), which immediately responded to the visible enhanced liability standard in Smith v. Van Gorkom case. See 488 A 2 d 858 (Del 1985). The provision allows a corporation to limit or eliminate personal liability for directors who breach their duty of care. Fairfax, Spare the Rod, supra note 21 at 412. Most states followed Delaware's step, adopting similar or even broader provisions. Black, Cheffins \& Klausner, Liability, ibid at 1090-91, 1094.

${ }^{549}$ Black, Cheffins \& Klausner, Liability, ibid at 1090-91; Fairfax, Spare the Rod, ibid; M Martin Boyer, "Three Insights from the Canadian D\&O Insurance Market: Inertia, Information and Insiders” (2008) 14:1 Conn Ins L J 75 at 77 [Boyer].

${ }^{550}$ The rationale of this rule is that board members are better-suited than courts to make business decisions due to their business background and experience. Thus, courts are reluctant to interfere with or second guess business decisions of boards. Fairfax, ibid. at 410; Unocal, supra note 209 at 954.

${ }^{551}$ Black, Cheffins \& Klausner, Liability, supra note 528 at 1091; Fink, supra note 428 at 462-63; Aronson, supra note 216 at 812 . In re Walt Disney Co. Derivative Litigation, the Delaware court delivered a message that even though independent directors were negligent in connection with the hiring and the approval of the president's employment agreement, they were still protected by statutory exculpation and the business judgment rule, as long as they did not act in bad faith. This decision confirmed that establishing liability against independent directors for a breach of duty of care is extremely difficult. In re Walt Disney Co. Derivative Litigation, 907 A 2 d 693 at 760 (Del Ch 2005); Carter G Bishop, “A Good Faith Revival of Duty of Care Liability in Business Organization Law” (2006) 41 Tulsa L Rev 477 at $477-78$.
} 
immunize corporate business decisions from accountability through the judicial process. ${ }^{, 552}$

\subsection{Protections for Independent Directors against Nominal Liability}

In order to protect current directors or encourage potential directors to serve on their boards, large public corporations usually provide indemnification and directors' and officers' liability insurance for directors, which shield them from the residual risk of out-of-pocket liability. Under Delaware corporate law, a corporation has power to indemnify a director for damages, amounts paid in settlement and legal expenses, as long as the director acted in good faith and in a manner the director reasonably believed to be in the best interests of the company. ${ }^{553}$ Self-dealing and a conscious neglect of one's duty are typical examples of lack of good faith. ${ }^{554}$ Delaware corporate law also permits a company to reimburse a director in advance and on an ongoing basis for legal expenses that the director incurs in any civil, criminal or administrative litigation. ${ }^{555}$ According to Black, Cheffins \& Klausner's study, almost all public companies have bylaws or indemnification agreements protecting independent directors, in which the company shall indemnify directors against damages, amounts paid in settlement and legal fees, and shall pay legal expenses in advance to the fullest extent permitted by law. ${ }^{556}$ However, the SEC may preclude any indemnification when it considers that the indemnification in a section 11 claim is against public policy. ${ }^{557}$

In addition to indemnification, $\mathrm{D} \& \mathrm{O}$ insurance provides an additional layer of protection for independent directors, since indemnification sometimes may become unavailable if the company is insolvent or a director's conduct falls outside the scope for indemnification. ${ }^{558}$ D\&O insurance often covers damages paid pursuant to judgments, amounts paid in settlement and directors' legal expenses. However, D\&O insurance also has its exclusions. Criminal behavior, deliberate fraud, and taking illegal profits are not covered by D\&O policies. Nevertheless, in comparison with the good faith limitation on indemnification, the deliberate fraud and illegal

\footnotetext{
${ }^{552}$ Irwin Borowski, “Corporate Accountability: The Role of the Independent Director” (1984) 9 J Corp L 455 at 468.

${ }^{553}$ Del Code Ann tit $8 \S 145$ (a); Boyer, supra note 549 at 77.

${ }^{554}$ Black, Cheffins \& Klausner, Liability, supra note 528 at 1084.

${ }^{555}$ Del Code Ann tit 8 \$145(e); Black, Cheffins \& Klausner, ibid at 1083.

${ }^{556}$ Black, Cheffins \& Klausner, ibid at 1083; Del Code Ann tit $\$ 145(f)$.

${ }^{557}$ Regulation S-K, 17 CFR $\$ 229.510$ (2008); Black, Cheffins \& Klausner, ibid at 1084.

${ }^{558}$ Black, Cheffins \& Klausner, ibid at 1085; Gordon, The Rise of Independent Director, supra note 1 at 1484.
} 
profit exclusions in D\&O insurance are considerably narrower. ${ }^{559}$ Virtually all public companies purchase D\&O insurance for their directors and officers, according to a survey in the US. ${ }^{560}$

Moreover, the rules governing derivative litigation provide additional protection for independent directors in the regime of state corporate law. Before filing a derivative litigation, a shareholder must make a demand on the corporation's board that the corporation pursue the suit against its own directors or persuade the court that making such a demand would be futile. ${ }^{561}$ Usually plaintiffs adopt the latter approach. ${ }^{562}$ Even if a plaintiff succeeds at the demand stage, the corporation may establish a special litigation committee ${ }^{563}$ comprised of independent directors to consider whether the corporation should move to dismiss the case. If the special committee does suggest dismissal, as long as the court finds that the committee was independent and its reviewing procedure followed a reasonable deliberative process to reach its conclusion, the court usually will not challenge the committee's determination. ${ }^{564}$

\subsection{The Out-of-Pocket Liability Exposure of Independent Directors}

According to Professors Black, Cheffins and Klausner, independent directors' risk of outof-pocket liability depends on: (1) whether the company is solvent; (2) the ability of the company to indemnify its independent directors; and (3) the sufficiency of the company's D\&O insurance coverage relative to the damages awarded. In practice, the risk of liability is low.

\footnotetext{
${ }^{559}$ Black, Cheffins \& Klausner, ibid at 1086.

${ }^{560}$ Ibid at 1085. It is worth noting that most D\&O policies have significant deductibles that directors must pay. Some litigation costs, such as the time spent on the lawsuit, may not be compensated by insurance proceeds. In addition, reputational damage incurred by the litigation cannot be compensated by insurance proceeds.

${ }^{561}$ Block, Radin \& Maimone, supra note 214 at 1451; Lin, supra note 13 at 907; Fairfax, Inside Director, supra note 216 at 143; Fairfax, Corporate Federalism, supra note 209 at 392-93; Cosenza, supra note 391 at 31; Antony Page, "Unconscious Bias and the Limits of Director Independence" (2009) 2009:1 U Ill L Rev 237 at 244 [Page].

562 In order to demonstrate futility, a plaintiff must allege particularized facts to raise a reasonable doubt regarding: (1) "director disinterest or independence" or (2) "whether the director exercised proper business judgment in approving the challenged transaction." Aronson, supra note 216 at 814. Please refer to section 4.1.1.2 Derivative Suits for further details.

${ }^{563}$ In the United States, establishing a special litigation committee to determine whether to litigate, settle or terminate the court action has been recognized in most jurisdictions, although courts afford varying degrees of deference to the committee's recommendation. Jones, supra note 15 at 115, n 35. In Delaware, courts review the committee's termination decision under Zapata Corp. v. Maldonado, which has two prongs. First, the corporation shoulders the burden to prove that the special litigation committee was independent and acted in good faith. Second, the court can apply its own judgment to determine whether the action should be dismissed. Zapata, supra note 216 at 788-89.

${ }^{564}$ Black, Cheffins \& Klausner, Liability, supra note 528 at 1091-92; Lin, supra note13 at 907; Block, Radin \& Maimone, supra note 214 at 1456; Fairfax, Inside Director, supra note 216 at 144; Fairfax, Corporate Federalism, supra note 209 at 393; Page, supra note 214 at 245.
} 
In securities class action, the risk of independent directors incurring out-of-pocket liability is very low, if a corporation is able to pay the maximum amount of indemnification for its independent directors. There is almost no economic incentive for a lead plaintiff to sue independent directors of a solvent corporation, because the corporation is a more attractive defendant. Even if a lead plaintiff were to sue them and the independent directors were held liable under either section 10(b) of the Exchange Act or section 11 of the Securities Act, the independent directors would usually be indemnified, as long as they did not engage in selfdealing or consciously neglect their duty. Even if the independent directors are not eligible for indemnification, a state-of-the art $\mathrm{D} \& \mathrm{O}$ insurance policy will cover their misconduct under either section 10 (b) or section 11 , so long as they did not engage in deliberate fraud or the taking of illegal profits. ${ }^{565}$

However, a lead plaintiff with a view to increasing recovery may sue independent directors, when a corporation is insolvent or insufficiently solvent to cover damages. Independent directors' risk in such a suit is limited to cases in which they have committed deliberate fraud or taken illegal profits (because insurance does not cover directors in these circumstances), if the policy limits are high enough to cover potential damages. When the D\&O insurance is not sufficient to cover potential damages, independent directors may make out-offpocket payments if they are held liable under section 10(b) or section 11. Independent directors can take comfort from the high scienter standard for section 10(b) liability. However, because the standard for liability under section 11 is mere negligence, independent directors do bear significant risks. ${ }^{566}$

Regarding state corporate lawsuits, the solvency of the corporation has less impact on the independent directors' risk of out-of-pocket liability in a breach of duty of loyalty situation, compared to the securities lawsuits. Since almost all public corporations adopted exculpatory charter provisions, as long as independent directors have acted in good faith, they will not be held liable in either a direct or derivative suit. Thus, indemnification by the corporation for damage payments is not needed. ${ }^{567}$ Even if an independent director has engaged in a gross

\footnotetext{
${ }^{565}$ Black, Cheffins \& Klausner, ibid at 1095.

${ }^{566}$ Ibid at 1096.

${ }^{567}$ The exclusions of an exculpatory provision and indemnification are roughly the same, both include failure to act in good faith and engaging in intentional misconduct. Self-dealing and a conscious neglect of one's duty are typical examples of lack of good faith. See supra text accompanying notes 548-549 and notes 553-554. It is worth noting that there is no exculpation provision in Canadian corporation law.
} 
oversight violation that constitutes a conscious disregard of duty (meeting the requirement for the exclusion of indemnification), so long as he/she has not committed deliberate fraud or taken illegal profits, D\&O insurance will offer coverage up to the policy limit (subject to the deductible which can be very high). ${ }^{568}$

When a corporation's D\&O insurance is inadequate, its independent directors will be financially responsible for breaches of duty of loyalty and for breaches of duty of care. In addition, the insolvency of a corporation will increase risks for independent directors in two situations regarding making out-of-pocket payments. First, under normal situations, independent directors may derive protection in derivative suits from the formation of a special litigation committee, but this procedure will not be available if the corporation is in bankruptcy. ${ }^{569}$ Second, if $\mathrm{D} \& \mathrm{O}$ insurance is also not available, independent directors have to pay their own legal expenses regardless of the outcome of the litigation. ${ }^{570}$

Based on the above analysis, it appears that independent directors' exposure to out-ofpocket liability is limited to certain situations as a result of the protection of indemnification, D\&O insurance and certain procedural hurdles for plaintiffs. Independent directors almost have no risk of being forced to make out-of-pocket payments, so long as they do not commit deliberate fraud or take illegal profits. According to Black, Cheffins and Klausner, independent directors made out-of-pocket payments in only 13 cases between 1980 and 2005, including the Enron and WorldCom settlements. ${ }^{571}$ Many cases involved insolvent companies in combination with no or insufficient insurance that would not arise today, if these companies had a state-ofthe-art D\&O policy and standard indemnification agreements for independent directors. ${ }^{572}$

The main concern for independent directors is whether an Enron or WorldCom type of settlement will happen to them. Independent directors in WorldCom and Enron paid \$25 million and $\$ 13$ million, respectively, to settle litigation with their plaintiffs. ${ }^{573}$ According to Black, Cheffins \& Klausner's observation, both Enron and WorldCom settlements had three common features. First, the company was insolvent or the company's net assets plus the net policy limit was less than the net expected damage award. Second, the plaintiff had strong evidence to prove

\footnotetext{
${ }^{568}$ Ibid at $1096-97$.

${ }^{569}$ A bankrupt firm may not be able to afford to pay the expense of forming a special litigation committee.

${ }^{570}$ Ibid at 1097.

571 Ibid at 1055 .

${ }^{572}$ Ibid at 1060.

${ }^{573}$ Ibid at 1118.
} 
independent directors' culpability. Third, independent directors were wealthy. When all three conditions are met, the authors called it "the perfect storm." 574 Under the perfect storm, even though independent directors have D\&O insurance, as long as the lead plaintiff refuses to settle within the policy limits, independent directors are more likely to make out-of-pocket payments. ${ }^{575}$ However, perfect storms are very uncommon. As a result, independent directors need not worry about the exposure to out-off-pocket liability under normal circumstances. The above findings demonstrate that the current US liability regime does not provide a significant threat of sanction for independent directors, and therefore reduces their incentives to engage in effective monitoring.

\subsubsection{Director Legal Liability in Canada}

Although the liability system for independent directors in Canada is slightly different from that in the United States, the out-of-pocket liability risk faced by independent directors of Canadian publicly-held companies is similar to that in the United States-very small. In Canada, each province and the federal government have enacted their own corporate statutes. Unlike the United States, securities regulation in Canada is a provincial matter. ${ }^{576}$ With a view to simplifying the analysis, the following sections focus on the federal corporate legislation-the Canada Business Corporations Act (CBCA) and the Ontario Securities Act.

\subsubsection{Substantive Liability Rules Regarding Independent Directors}

In Canada, lawsuits against independent directors of public-held companies can be roughly divided into four categories. The first category is suits by the corporation or its shareholders for breach of fiduciary duty ${ }^{577}$ and duty of care under corporate law. The second is claims for direct relief by a shareholder on the grounds of oppressive or unfairly prejudicial corporate conduct (oppression remedy). The third category is actions for a misrepresentation in prospectus, takeover circulars and secondary market disclosure brought by shareholders under the provincial securities laws. The final one is suits for breach of duties imposed by other

\footnotetext{
${ }^{574}$ Ibid at 1107,1123 .

575 Ibid at 1107-08.

${ }^{576}$ Gillen, supra note 29 at 77; VanDuzer, supra note 15 at 466.

${ }^{577}$ In Canada, the courts and academic use the term "fiduciary duty" to refer the concept "duty of loyalty" in the United States.
} 
regulatory statutes, such as liability for up to six-month unpaid wages under corporate law.

Under the $C B C A$, a director owes a duty to exercise "the care, diligence and skill that a reasonably prudent person would exercise in comparable circumstances."578 The Supreme Court of Canada, in BCE Inc. v. 1976 Debentureholders, made clear that the duty of care is not just owed to the corporation but could also inform the standard owed to corporate stakeholders. ${ }^{579}$ Like the United States, Canadian courts also apply the business judgment rule in assessing whether a board's decision constitutes a breach of duty of care. ${ }^{580}$ However, unlike the United States where board decisions are presumed not to be a breach of duty of care, Canadian courts only defer to board decisions when certain preconditions are met. ${ }^{581}$ The $C B C A$ also imposes a fiduciary duty (similar to the duty of loyalty in the US) on directors to "act honestly and in good faith with a view to the best interests of the corporation." 582 Suits against independent directors for breach of both duties are mostly taken through direct suits by the company or derivative suits by shareholders (on behalf of the company). However, the probability of derivative suits is relatively low because any remedy granted will be awarded to the company rather than directly to the shareholders. An oppression remedy is a better alternative in most cases, as discussed below. ${ }^{583}$ The proportionate liability ${ }^{584}$ for directors adopted in the $C B C A$ in 2001 also reduces independent directors' risk of making out-of-pocket payments. ${ }^{585}$

In addition, the $C B C A$ provides minority shareholders, but not only shareholders, with an "oppression remedy" in which a complainant can seek direct relief against the corporation when

${ }^{578}$ CBCA, supra note 27, s 122(1)(b); VanDuzer, supra note 15 at 375.

${ }^{579}$ VanDuzer, ibid at 339, 343; BCE Inc v 1976 Debentureholders, [2008] 3 SCR 560.

${ }^{580}$ Cheffins \& Black, Liability across Countries, supra note at 1442, VanDuzer, ibid at 382-83.

${ }^{581}$ The business judgment rule in Canada appears to be different from that in the United States. In the United States, business decisions are presumed not to be a breach of duty of care as long as directors act in good faith, on an informed basis and believe that the decision are in the best interests of the company. In Canada, there is no presumption in favor of the business decision. In general, the business judgment rule applies when the board decision has been exercised prudently, honestly, in good faith, and on reasonable grounds. Directors are not required to make a perfect decision, as long as their decision is within the range of reasonable alternatives. VanDuzer, ibid at 383-84, Cheffins \& Black, ibid at 1442.

${ }^{582}$ CBCA, supra note 27, s 122(1)(a); VanDuzer, ibid at 340.

${ }^{583}$ Cheffins \& Black, Liability across Countries, supra note 529 at 1444; Edward M Iacobucci \& Kelvin E Davis, "Reconciling Derivative Claims and the Oppression Remedy" (2000) 12 Sup Ct L Rev 87 at 90-92.

${ }^{584}$ Before 2001, a corporate director is jointly and severally liable for claims for financial loss under CBCA. In 2001, the joint and several liability was partially replaced with proportionate liability. A director is only responsible for the portion of the financial loss that corresponds to his/her degree of responsibility for the loss when the loss arising by reason of an error, omission, or misstatement. Joint and several liability continue to apply to claims made against a director who knowingly or intentionally engaged in fraudulent or dishonest conduct. CBCA, supra note 27 , s 237.3(1), 237.4(1); Cheffins \& Black, ibid at 1443.

${ }^{585}$ CBCA, ibid, s $237.3(1)$. 
the conduct of the corporation is oppressive, unfairly prejudicial, or unfairly disregards the interests of a complainant. ${ }^{586}$ An oppression remedy is launched usually because the actions of the directors are inconsistent with the reasonable expectations of the complaint. ${ }^{587}$ However, according to Ben-Ishai and Puri's research, only $8 \%$ of proceedings (six out of 71 cases) brought under the oppression remedy between 1995 and 2001 involved publicly-held corporations. Of the six cases involving publicly-held corporations, only two (33\%) were successful, in comparison with a success rate of $54 \%$ for closely-held corporations. ${ }^{588}$

In addition, the Ontario Securities Act regulates prospectuses for public offerings, imposes continuous disclosure obligations on publicly-traded corporations (secondary market disclosure), and mandates a target corporation in a takeover situation to issue a circular to its shareholders. ${ }^{589}$ Independent directors, in addition to the issuer, are also liable for the losses of investors, if the prospectus, continuous (secondary market) disclosure, or circular is false or misleading. ${ }^{590}$ Similar to the United States, the issuer is the most attractive defendant in Ontario, since its only defence is that the purchaser had the knowledge of the misrepresentation when he or she purchased the securities. ${ }^{591}$ In contrast, independent directors have a due diligence defence in respect of misrepresentation in the prospectus and takeover bid documents. ${ }^{592}$

The most often mentioned personal liability imposed by statute for independent directors is the unpaid wages of employees. ${ }^{593}$ Independent directors of an insolvent corporation which fails to pay its staff can end up being jointly and severally liable for up to six-month unpaid

\footnotetext{
${ }^{586}$ Ibid s 241; VanDuzer, supra note 15 at 413-14.

587 Stephanie Ben-Ishai \& Poonam Puri, "The Canadian Oppression Remedy Judicially Considered: 1995-2001" (2004) Queen's L J 79 at 88-89 [Ben-Ishai \& Puri]. 
wages and related employment benefits. ${ }^{594}$ However, Professors Cheffins and Black indicated that they did not find a single decision by a Canadian court or employment tribunal which held independent directors in a publicly-held corporation liable for unpaid wages between 1980 and $2005 .^{595}$ Even if an independent director is held liable, the company's D\&O insurance would probably protect him/her from making out-of-pocket payment on such a claim as discussed below. ${ }^{596}$

\subsubsection{Protections for Independent Directors against Nominal Liability}

Similar to the situation in the US, Canadian publicly-held corporations also provide indemnification and $\mathrm{D} \& \mathrm{O}$ insurance for directors with a view to reducing the disincentives of becoming an independent director. The $C B C A$ allows a corporation to indemnify independent directors all costs, charges and expenses in respect of any civil, criminal, administrative or investigative proceeding for breaches of their duties, so long as the director fulfilled his or her fiduciary duty to act honestly and in good faith with a view to the best interests of the corporation, and, in the case of a criminal or administrative action or proceeding, had reasonable grounds for believing that his or her conduct was lawful. ${ }^{597}$ With respect to the costs of derivative litigation against a director, indemnification can only be made with court approval. ${ }^{598}$ Usually independent directors in publicly-held companies are able to meet the above conditions. $^{599}$ As a practical matter, Canadian public companies routinely indemnify independent directors to the maximum extent permitted by the corporate statute. ${ }^{600}$ In addition, mandatory indemnification is provided for in some circumstances. ${ }^{601}$

Moreover, D\&O insurance provides an additional layer of protection for independent directors. Nearly all Canadian public corporations purchase D\&O insurance, ${ }^{602}$ with the average

\footnotetext{
${ }^{594}$ VanDuzer, ibid; Cheffins \& Black, ibid.

${ }^{595}$ Cheffins \& Black, ibid.

${ }^{596}$ Ibid at 1451.

${ }^{597}$ CBCA, supra note 27, s 124(1)(3)(5).

${ }^{598}$ Ibid s 124(4).

${ }^{599}$ Cheffins \& Black, Liability across Countries, supra note 529 at 1448.

${ }^{600} \mathrm{Ibid}$; VanDuzer, supra note 15 at 384.

${ }^{601}$ Ontario Business Corporations Act, RSO 1990, c B16, s 136(4.2) [OBCA]; CBCA, supra note 27, s 124(5); VanDuzer, ibid at 286.

${ }^{602}$ Cheffins \& Black, ibid.
} 
policy limits around $\$ 71$ million, according to a 2006 survey. ${ }^{603}$ Although many practitioners have argued that $\mathrm{D} \& \mathrm{O}$ insurance is not a complete answer for Canadian independent directors due to the coverage limits and exclusions, ${ }^{604}$ there is little evidence that insurers have contested D\&O coverage offered to public corporations in Canada. ${ }^{605}$ In addition, the Ontario Securities Act has also capped damages for an independent director at the greater of $\$ 25,000$ or half of his/her annual remuneration (the average total outside director compensation for 100 leading Canadian publicly-traded corporations was around $\$ 119,500$ in 2010) in violations of Securities Act $^{606}$ These caps on Securities Act liability make the potential recovery from independent directors too small to be attractive to plaintiffs and make independent directors easier to protect through D\&O insurance. ${ }^{607}$

Most importantly, the loser-pays litigation rule ${ }^{608}$ in Canada substantially reduces the exposure of out-of-pocket liability for Canadian independent directors. Shareholders are reluctant to sue independent directors without solid legal foundations, since they may be ordered to reimburse some or all legal expenses to defendants when they fail at trial. ${ }^{609}$ In the United States, even though independent directors have merit in their cases, they may be forced to settle by making out-of-pocket payments if the company they serve is insolvent or the D\&O insurance is inadequate to cover their litigation expenses through trial. ${ }^{610}$ The loser-pays litigation rule further shields Canadian independent directors from for their liability.

\subsection{The Out-of-Pocket Liability Exposure of Independent Directors}

Similar to the situations in United States, the risk of out-of-pocket liability for Canadian

\footnotetext{
${ }^{603}$ Insurance-Canada.ca, "HUNTERS Completes Secondary Annual Study of D\&O Insurance Limits for the TSX/S\&P 300” Business of Insurance Information in Canada (14 November 2006), online: Insurance-Canada.ca < http://www.insurance-canada.ca/business/canada/HUNTERS-DO-Insurance-Limits-611.php>.

${ }^{604}$ Cheffins \& Black, Liability across Countries, supra note 529 at 1448; Nicholls, supra note 11 at 344.

${ }^{605}$ Cheffins \& Black, ibid at 1448. It is worth mentioning that Chubb Insurance Co. of Canada filed a lawsuit in 2005 for seeking to rescind the D\&O policy of Nortel on grounds of misrepresentation. Ibid at 1448-49.

${ }^{606}$ Ontario Securities Act, supra note 589, s 138.1 liability limit (b); Spencer Stuart, "Canadian Spencer Stuart Board Index: Board Trend and Practices of Leading Canadian Companies 2010” (2010) at 20, online: Spencer Stuart <http://content.spencerstuart.com/sswebsite/pdf/lib/CSSBI2010.pdf>.

${ }^{607}$ Cheffins \& Black, Liability across Countries, supra note 529 at 1446-47.

${ }^{608}$ The rules governing who pay the litigation costs in Canada are different from those in the United States. In Canada, there is a general rule that the party who loses litigation must pay the winning party's legal costs. Ibid at $1444,1446$.

${ }^{609}$ Ibid at 1444 .

${ }^{610}$ Black, Cheffins \& Klausner, Liability, supra note 528 at 1109.
} 
independent directors also depends on: (1) the ability of the company to indemnify its independent directors; (2) the sufficiency of the company's D\&O insurance coverage; and (3) whether the company is solvent. In addition to the above three factors, the loser-pays rule in Canada further reduces the exposure to out-of-pocket liability for Canadian independent directors.

With respect to corporate (derivative) lawsuits, there has been only a handful of cases brought involving Canadian directors where the main allegation was a failure to meet the duty of care, according to Professors Cheffins and Black. ${ }^{611}$ Canadian shareholders are deterred from suing independent directors for breaches of fiduciary duty and duty of care because damages in derivative suits will be paid to the company rather than shareholders and the losers-pay rule regarding litigations costs. ${ }^{612}$ Even if independent directors are sued and held liable, the indemnification from the company or/and the $\mathrm{D \& O}$ insurance policy will cover their misconduct and protect them from making out-of-pocket payments. ${ }^{613}$ Although the $C B C A$ provides an oppression remedy for minority shareholders, most remedies granted by the courts are share purchase, liquidation and dissolution, orders against other shareholders, or compliance with the statute, rather than damages against directors. ${ }^{614}$ There have been few oppression cases involving damage claims against directors of publicly-held companies. No case has been reported granted damages against an independent director, according to Professors Cheffins and Black's survey. ${ }^{615}$

As for provincial securities litigation, cases involving liability for independent directors have been very rare. Professors Cheffins and Black only found two reported decisions regarding a misleading prospectus in which independent directors were named as defendants. ${ }^{616}$ It is worth mentioning that the two cases only involved preliminary motions rather than full trials. ${ }^{617} \mathrm{~A}$

\footnotetext{
${ }^{611}$ Cheffins \& Black, Liability across Countries, supra note 529 at 1443.

${ }^{6}$ Ibid at 1443-44.

${ }^{613}$ Even if indemnification is not available where the fiduciary duty has been breached, the D\&O insurance policy may still shield independent directors from making out-of-pocket payments.

${ }^{614}$ Ibid at 1444-45; VanDuzer, supra note 15 at 447-50.

${ }^{615}$ Cheffins \& Black, ibid at 1445. Professors Cheffins and Black listed three cases between 1998 and 2001 seeking relief against directors of public corporations. In each of these cases, the proceedings were dismissed. Ibid at 1445 n 359.

616 Ibid.

${ }^{617}$ CC\&L Dedicated Enterprise Fund (Trustee of) v Fisherman, [2002] 55 OR (3d) 794; Montreal Trust Co of Canada v ScotiaMcLeod Inc, [1995] 26 OR (3d) 48; ibid.
} 
similar situation exists for allegations of misleading periodic disclosure. ${ }^{618}$ A report published by Toronto Stock Exchange in 1997 mentioned that the remedies of misleading disclosure in secondary trading markets are difficult for investors to pursue; as a result, the remedies are "as a practical matter largely academic." ${ }^{\prime 619}$ Professors Cheffins and Black attributed the paucity of securities class actions in Canada to the prevalence of the loser-pays litigation rule and difficulties associated with paying plaintiffs' lawyers in multiparty litigation. ${ }^{620}$ In addition, as mentioned above, the liability limit for a director in securities law further reduces a plaintiff's incentive to file a suit against independent directors.

Between mid-1980s and 2006, there had been only four cases involving Canadian independent directors paying damages out of their own pocket regarding their liability. All of them were related to corporate bankruptcy. ${ }^{621}$ In the mid-1980s, the Canadian Commercial Bank and Northland Bank, two Alberta-based financial institutions, went bankrupt. The Canada Deposit Insurance Corporation (CDIC) and Department of Finance of the federal government, after bailing out depositors, sought to recover damages against the directors (including independent directors) for negligent misrepresentations. ${ }^{622}$ Settlements were reached with defendant directors of Canadian Commercial Bank in 1990 and Northland Bank in 1998, respectively. ${ }^{623}$ According to Professors Cheffins and Black, some independent directors of the two banks did personally pay damages, while some independent directors with full-time employment benefited from reimbursement by their employers. ${ }^{624}$

In 1998, YBM Magnex International Inc., a company trading on the TSX involved in the manufacture and global distribution of magnets, computer software and bicycles, collapsed. ${ }^{625}$ The Ontario Securities Commission, based on findings of inadequate disclosure of investment risk by the company, banned five Magnex ex-directors, including three independent directors, from acting as a director of any reporting issuer for a certain period of time. Simultaneously, the

\footnotetext{
${ }^{618}$ Cheffins \& Black, ibid.

${ }^{619}$ Committee on Corporate Disclosure, Final Report: Responsible Corporate Disclosure: A Search for Balance, (Toronto: Toronto Stock Exchange, 1997); Cheffins \& Black, ibid at 1445-46.

${ }^{620}$ Cheffins \& Black, ibid at 1446.

${ }^{621}$ Ibid at $1449-50$.

${ }^{622}$ Canada Deposit Insurance Corp v Prisco, [1991] 120 AR 35; Canada Deposit Insurance Corp v Canadian Commercial Bank, [1989] 98 AR 353; Cheffins \& Black, ibid at 1449.

${ }^{623}$ Northland Bank v Willson, [1999] 249 AR 201, at paras 14-19; Cheffins \& Black, ibid.

${ }^{624}$ Cheffins \& Black, ibid at 1449-50.

${ }^{625}$ Lisa C Munro, "YBM Case Study: Anatomy of A Securities Class Action Settlement" Lerner LLP at 1, online: Lerners <http://lernersclassactiondefence.ca/@assets/uploads/articles25/ybmcasestudyanatomyofasecuritiesclassactionsettlement.pdf $>$.
} 
three independent directors were also ordered to pay investigation and hearing costs in the amount of $\$ 400,000{ }^{626}$ This is the third case of independent directors making out-of-pocket payments related to their obligation of periodic disclosure.

In addition, independent directors of Canadian companies cross-listed on US stock market may face additional risk of paying out of their own pocket under US securities law. According to Professors Black, Cheffins and Klausner's investigation, several independent directors of a bankrupt Canadian cross-listed corporation paid personally to settle a lawsuit that following a major accounting fraud which resulted in the corporation's insolvency. ${ }^{627}$

Based on the above analysis, it seems that Canadian independent directors' exposure to out-of-pocket liability is limited to certain situations as a result of the protection of indemnification, D\&O insurance, liability limits under securities law and the loser-pays litigation rule. Independent directors in Canada have almost no risk of being forced to make out-of-pocket payments, if the companies they serve are solvent. According to the investigation by Black and Cheffins described above, independent directors have only made out-of-pocket payments in four cases as of 2006, and three of them were launched by provincial (OSC) or federal government (CDIC). ${ }^{628}$ It appears that public enforcement is the primary source of risk for Canadian independent directors to make out-of-pocket payment. ${ }^{629}$ However, the possibility is still very low. Such results demonstrate that the current Canadian liability systems impose weak legal sanctions on independent directors, which may therefore reduce their incentive to effective oversight.

\subsubsection{Constraints of Groupthink and In-Group Bias}

The constraints of groupthink and in-group bias (structural bias) ${ }^{630}$ may also prevent independent directors from objectively serving as a check on managerial abuses. Boards of

\footnotetext{
${ }^{626}$ Re YBM Magnex International Inc (2003), 26 OSCB 5285; Cheffins \& Black, Liability across Countries, supra note 529 at 1447.

${ }^{627}$ Cheffins \& Black, ibid; Black, Cheffins \& Klausner, Liability, supra note 528 at 1069 . However, the authors did not disclose further details due to confidentiality restrictions.

${ }^{628}$ Cheffins \& Black, ibid at 1451.

${ }^{629}$ Ibid.

${ }^{630}$ Professor Fairfax, Cox and Munsinger, Cosenza, and Velasco use the term "structural bias" to describe the concept what Professor Page and O'Connor call it "in-group bias." Please refer to the text accompanying notes 649652.
} 
directors are a type of small group; as such, they may be subject to similar social and psychological influences as in other small groups. ${ }^{631}$ According to psychological research, groupthink and in-group bias are prevalent phenomena that exist in small groups with a high level of cohesiveness. ${ }^{632}$ The term "groupthink" refers to the tendency of cohesive groups implicitly or subconsciously to censor non-preferred points of view and any information inconsistent with what the group prefers. ${ }^{633}$ "In-group bias" refers to the tendency of collegial groups implicitly or subconsciously to favor their own group members over non-members in evaluation and behavior. ${ }^{634}$ Both groupthink and in-group bias are inclined to generate subtle but powerful prejudice, which may undermine independent directors' judgment in monitoring management's behavior. ${ }^{635}$

Corporate boards are typical cohesive groups. They provide identity and a sense of superiority for their members. Directors not only enjoy associating with other successful people, but also provide each other with access to key informal and social networks that promote their career advancement. The process of being singled out for a board membership further enhances a director's self-esteem in the business community. These features not only attract directors to serve on boards but also intensify the cohesiveness among board members. ${ }^{636}$ However, such cohesiveness may also impair independent directors' willingness to challenge their fellow directors' business decisions due to the fear of damaging their friendship or social connections.

According to Professor O'Connor, at least five symptoms of groupthink may occur during board meetings or board decisions, namely (1) illusion of invulnerability; (2) collective rationalization; (3) out-group stereotype; (4) appearance of unanimity; (5) and self-censorship. These symptoms, in combination with in-group bias, may prevent independent directors from asking discerning or probing questions, and therefore result in dysfunction in the role of independent directors in holding management accountable. ${ }^{637}$ The following sections introduce these symptoms and in-group bias, and indicate how they are likely to influence independent directors' judgment.

\footnotetext{
${ }^{631}$ O'Connor, supra note 403 at 1237.

${ }^{632}$ Cox \& Munsinger, supra note 394 at 99.

${ }^{633}$ Langevoort, Human Nature, supra note 11 at 810; O'Connor, supra note at 1238; Irving Janis, Groupthink: Psychological Studies of Policy Decisions and Fiascoes (Boston: Houghton Mifflin, 1982) at 78 [Janis, Groupthink].

${ }^{634}$ Page, supra note 561 at 249; Velasco, supra note 462 at 861.

${ }^{635}$ Velasco, ibid at 862; Cox \& Munsinger, supra note 394 at 85.

${ }^{636}$ O'Connor, supra note 403 at 1262; Velasco, ibid at 862-63; Cox \& Munsinger, ibid at 104-06.

${ }^{637}$ O'Connor, ibid at 1259-60; Fink, supra note 428 at 468.
} 


\subsubsection{Illusion of Invulnerability}

The first symptom of groupthink is the illusion of invulnerability. When a group is powerful and has achieved success in the past, group members may become overconfident and therefore engage in risky activities. The feature of their belief is that luck is on the group's side. Usually certain successful individuals in the group spread this bias to other group members through emotional contagion in order to relieve stress and foster a "can do" atmosphere. ${ }^{638}$ For example, Jeffrey K. Skilling, Enron's CEO, once boasted that there is no trading company in the world has reported twenty straight quarters of increasing income, like Enron. ${ }^{639}$

Sometimes this optimism can turn into a self-fulfilling prophecy, because it promotes higher morale and aggressiveness among employees. However, this bias may also cause group members to ignore important indications that point toward limits to their competence, which may possibly lead to the collapse of their institution. ${ }^{640}$ Enron's directors are a typical example. They were infected by a culture of invincibility and supported management's ambitious plans, allowing them to use complicated transactions with convoluted financing and accounting structures that contributed to the downfall of the corporation. ${ }^{641}$

\subsubsection{Collective Rationalization}

Another symptom of groupthink is collective rationalization. A group may make efforts to rationalize warning signs that reveal something wrong regarding their previous decisions. Where red flags indicate the need for change, some group members may interpret negative data in a way to preserve the status quo as if everything is still normal. The situation may be even worse, when certain group members refuse to face the real situation because they fear a loss of self-esteem, and therefore throw more resources into dealing with the problem. ${ }^{642}$ Discovering a red flag may put independent directors in the unpleasant position that they have to question senior managers who are probably their fellow members. To avoid destroying the trust between

\footnotetext{
${ }^{638}$ Ibid at $1270-71$.

${ }^{639}$ Bethany McLean, "Why Enron Went Bust” Fortune (24 December 2001) at 32; O’Connor, ibid at 1272.

${ }^{640}$ O'Connor, ibid at 1270-71.

${ }^{641}$ Ibid at $1270-73$.

${ }^{642}$ Ibid at 1279; Donald C Langevoort, "Selling Hope, Selling Risk: Some Lessons for Law from Behavioral Economics About Stockbrokers and Sophisticated Customers" (1996) 84 Cal L Rev 627 at 645 [Langevoort, Selling Hope] .
} 
them, independent directors may accept senior managers' explanations at face value without making efforts to further investigate. Once such rationalizations occur, independent directors may gradually neglect a red flag. ${ }^{643}$ Again, taking Enron as an example, Skilling's abrupt departure after only six months of serving as CEO raised a red flag regarding Enron's operation. However, the Enron Board still trusted the new CEO's interpretation that there were no accounting or trading issues regarding Enron. ${ }^{644}$ The case illustrates how collective rationalization undermines independent directors' vigilance.

\subsubsection{Out-Group Stereotype}

The third symptom of groupthink is out-group stereotype. A cohesive group may stereotype those who ask questions or oppose decisions within the group as weak-minded for "not getting it." Through such negative stereotyping, the group fosters the belief "either you are with us or against us." Within the group, these questioners or opposers may face intense social disapproval and may become outcasts. This may encourage many intelligent and experienced independent directors who are unfamiliar with the company's operation not to challenge management. Since most people, especially professionals, do not want to risk embarrassment by displaying their ignorance in public, independent directors, for the same reason, may subconsciously avoid such humiliation by pretending to understand complicated issues. They concur with the board's decisions not because they understand the problem but because they do not dare to challenge their fellows. Under the influence of the out-group stereotype, independent directors may try to appear sophisticated in the presence of management while discussing complex financial matters. Once such stereotyping happens, independent directors are less likely to discover management's problems. ${ }^{645}$ This symptom may have occurred in Enron's boardroom, such that Enron's independent directors were unwilling to inquire about the complicated relatedparty transactions adopted by Enron's management. ${ }^{646}$ As a result, they were unable to check on managerial abuses in Enron.

\footnotetext{
${ }^{643}$ O'Connor, ibid; Langevoort, ibid at 693.

${ }^{644}$ O'Connor, ibid at 1282.

${ }^{645}$ Ibid at 1283-84; Langevoort, supra note 642 at 656.

${ }^{646}$ O'Connor, ibid at 1285.
} 


\subsubsection{Appearance of Unanimity}

The appearance of unanimity is another symptom of groupthink. Under this symptom, the appearance of a group consensus may pressure group members to accept decisions that they disagree with. A group leader, with a view to reaching a quick concurrence, may release a message that "it appears the group has reached a consensus regarding a proposal." Such information may lead to self-censorship by group members for fear of rocking the boat. Group members who have not made up their mind may be inclined to sense "which way the wind is blowing" and then adopt the same view. There is no doubt that a certain degree of concurrence seeking is necessary for a group to reach a decision. However, pushing group members to reach a quick concurrence may lead to premature decisions that could be detrimental to the whole institution. This tendency can lead to a situation in which many group members know where problems are, but none are willing to discuss them openly. ${ }^{647}$ If the symptom of appearance of unanimity often occurs during board deliberation, it is difficult to expect independent directors to hold management accountable and protect shareholder interests.

\subsubsection{Self-Censorship}

The fifth symptom of groupthink is self-censorship by members of the group. Selfcensorship means group members may self-censor their ideas before sharing with other members in order to avoid divergence. To maintain the appearance of harmony, group members may remain silent even if they disagree; or they may deemphasize their disagreement when the group appears to favor a decision. A group member may choose to conform to the group opinion rather than suffering the costs of being the lone objector. Therefore, group members may publicly agree or remain silent even when they privately disagree. As Professor O'Connor said, “[i]n essence, they go along to get along", because they do not want to be noticed for their difference. Usually, group members who do not like confrontation or opposition are more likely to have this psychological need for seeking concurrence. ${ }^{648}$ This symptom also reveals the pressures for conformity in boardrooms. Self-censorship may hinder the curiosity of independent directors to discover the CEO's or senior managers' problems.

\footnotetext{
${ }^{647}$ Ibid at $1286-87$.

${ }^{648}$ Ibid at 1288; Janis, Groupthink, supra note 633 at 34.
} 


\subsubsection{In-Group Bias}

In addition to the impact of groupthink, in-group bias may affect independent directors' impartiality in evaluating their fellow directors' behavior. According to in-group bias theory, directors are naturally empathetic to and collegial with other board members after working together on a board, since they share the same corporate culture reflecting the underlying ideology and ethos of the institutions they oversee. As such, they are reluctant to assign blame to colleagues for poor performance or malfeasance. ${ }^{649}$ In fact, directors may explicitly know they should impartially assess the actions of other board members, but they cannot escape from a situation in which their decisions will not be free from bias. ${ }^{650}$

The impact of in-group bias was acknowledged by the Delaware court in Zapata Corp. v. Maldona, as early as 1981. The court recognized that independent directors might find it difficult to be neutral when faced with the decisions regarding whether to allow their fellow directors to be sued. ${ }^{651}$ Professors Cox and Munsinger, in their 1985 research, also found that ingroup bias undermines an independent director's ability to be critical of their fellow directors. They examined whether in-group bias has an impact on independent directors' behavior in the context of serving on a special litigation committee and evaluating a demand to the board during derivative suits. They concluded that in-group bias can have subtle, but powerful, effects on decision-making within a boardroom, which result in independent directors seeking to insulate their colleagues from legal sanctions. ${ }^{652}$

\subsubsection{Summary}

Corporate boards are typical of small groups with certain cohesiveness. Board members, including independent directors, can hardly make their decisions without the influence of groupthink and in-group bias. They are subject to the impact of illusions of invulnerability,

\footnotetext{
${ }^{649}$ Cosenza, supra note 391 at 27-29; Fairfax, Inside Director, supra note 216 at 152; Page, supra note 561 at 249.

${ }^{650}$ Velasco, supra note 462 at 861 ; Fairfax, ibid.

${ }^{651}$ Zapata, supra note 216 at 787; Fairfax, ibid at 152-53.

${ }^{652}$ Cox \& Munsinger, supra note 394 at 84-85; Fairfax, ibid at 153; Velasco, supra note 462 at 862-63; Page, supra note 561 at 252-53; Cosenza, supra note 391 at 27-29.
} 
collective rationalization, out-group stereotype, appearance of unanimity, and self-censorship, and are more likely to favor their fellow directors when making corporate decisions as a result. Independent directors, despite the absence of employment and financial ties with the company, are not truly impartial according the above analysis. Thus, they are not likely to be effective corporate monitors in holding management accountable, contrary to the perception of conventional wisdom.

\subsubsection{The Overemphasis on Independent Directors' Monitoring Function May Undermine Shareholder Interests}

Even assuming that independent directors are not subject to the above constraints, the overemphasis on their monitoring function can also undermine the overall interests of shareholders. In practice, an independent director may undertake both managing and monitoring functions with a view to enhancing and protecting shareholder interests. However, trade-offs between the two functions can prevent an independent director from simultaneously serving the monitoring role and the managing role. The benefits of independent directors' oversight function may come at the expense of independent directors' managing function. The overall benefits to shareholder interests may not increase, but may decrease. In addition, several empirical studies in the new millennium have found that the optimal level of board independence varies with firmspecific characteristics and operating environments. As a result, any mandatory uniform requirements for board independence, like those in SOX and stock exchange reforms, ${ }^{653}$ may impair the effectiveness of independent directors. The following paragraphs analyze this view.

\subsubsection{The Corporate Board's Three Main Functions}

Generally speaking, corporate boards serve three roles: monitoring, strategic/advising and resource gathering roles. ${ }^{654}$ The monitoring role originates from the need to reduce agency costs. The separation of ownership and control in the modern public corporation gives managers

\footnotetext{
${ }^{653}$ Please refer to 4.1.2.2.

${ }^{654}$ O'Connor, supra note 403 at 1242; Langevoort, Human Nature, supra note 11 at 801-03; Jonathan L Johnson, Catherine M Daily \& Alan E Ellstrand, "Boards of Directors: A Review and Research Agenda" (1996) 22 Journal of Management 409 at 411 [Johnson, Daily \& Ellstrand]; Shaker A Zahra \& John A Pearce II, "Boards of Directors and Corporate Financial Performance: A Review and Integrative Model” (1989) 15 Journal of Management 291 at 303-04.
} 
opportunities to increase their own wealth at the shareholders' expense. In order to hold management accountable, laws and regulations require board members to be responsible for selecting and compensating the CEO as well as certain senior managers, and further ensuring that their retention depends on their performance. In addition, directors are required to review and address conflicts of interest in transactions between management and the corporation with a view to protecting shareholder interests. Moreover, to ensure that investors and stakeholders can properly assess the performance of the corporation and its management, the board of directors also has the responsibility to oversee the corporation's process of accounting, financial reporting and auditing. In short, the essence of the monitoring role of the board is to prevent management self-dealing and shirking. ${ }^{655}$

The second role of the board is resource gathering, namely securing and protecting the corporation's external resources. According to resource dependence theory, the survival of a corporation is deeply influenced by the external environment. In order to reduce environmental uncertainty, one of the main missions of the board is to secure, manage and even bring essential resources to the corporation. ${ }^{656}$ A person who possesses the ability to build relationships and secure resources for the corporation is an ideal director for this purpose. To increase the corporation's likelihood of survival, a board usually chooses its members carefully to make the corporation more legitimate and attractive in the eyes of key resource providers, such as government and labor. ${ }^{657}$ From this perspective, board members play a role in facilitating the acquisition of resources critical to the corporation's success. ${ }^{658}$

The board's third role is its strategic/advising role. Traditionally, boards are established to provide advice and guidance to the CEO and top managers in making major policy decisions. ${ }^{659}$ Currently, directors are also required to play a role in initiating and formulating corporate strategy. ${ }^{660}$ Sometimes, board members may, displacing management's position, take control of a strategic decision in a significant merger or acquisition transaction as if they were

\footnotetext{
${ }^{655}$ Fisch, supra note 13 at 268-70; O’Connor, ibid at 1242; Langevoort, ibid at 802.

${ }^{656}$ Amy J Hillman, Albert A Cannella \& Ramona L Paetzold, "The Resource Dependence Role of Corporate Directors: Strategic Adaptation of Board Composition in Response to Environmental Change" (2000) 37 Journal of Management Studies 235 at 236.

${ }^{657}$ Ibid at 238; Langevoort, supra note 11 at 802.

658 Johnson, Daily \& Ellstrand, supra note 654 at 411.

${ }^{659}$ O'Connor, supra note 403 at 1242.

${ }^{660}$ Johnson, Daily \& Ellstrand, supra note 654 at 411.
} 
the primary actors in the drama. ${ }^{661}$ According to Johnson, Daily and Ellstrand, firm performance improves when board members contribute to the strategic decision process. ${ }^{662}$ It appears that directors also act as a sounding board for management.

\subsubsection{The Trade-off between a Board's Monitoring Function and Managing Function}

According to Professor Fisch, a board's resource-gathering role and strategic/advisory role are considered as a board's managing function, rather than monitoring function. ${ }^{663}$ Traditionally, the board of directors enjoyed managerial authority in the company. Early statutes expressly granted the board, not management, the power to run the company. ${ }^{664}$ Even at the time that Berle and Means proposed the concept "the separation of ownership and control", directors were defined as a part of the management structure rather than shareholder representatives. ${ }^{665}$ Although there is no bright line to distinguish between the board's managing function and its monitoring function, the duties of the modern board continue to carry a managing component. ${ }^{666}$ Independent directors are able to undertake all three corporate board roles (resource gathering, strategic/advising, and monitoring), ${ }^{667}$ while inside directors and affiliate directors can only take the first two roles due to their connections with management. An inside director who is a member of management team is unsuitable to evaluate himself/herself as a matter of course. Even if affiliated directors are not the company's employees, their relationships with the company (or management) may prevent them from objectively monitoring executives' behavior. $^{668}$

Although independent directors can play board's managing and monitoring roles, they cannot fulfill monitoring and managing duties at the same time, because the effectiveness of both roles is mutually exclusive. There are distinct trade-off effects between a board's monitoring function and managing function. As Professor Fisch describes the trade-off as follows:

\footnotetext{
${ }^{661}$ Langevoort, supra note11 at 802-03.

662 Johnson, Daily \& Ellstrand, supra note 654 at 426; Fink, supra note 428 at 460.

${ }^{663}$ Fisch, supra note 13 at 274.

${ }^{664}$ Larry E Ribstein, "Limited Liability and Theories of the Corporation” (1991) 50 Md L Rev 80 at 93 note 52.

${ }^{665}$ Berle \& Means, supra note 44 at 196.

${ }^{666}$ Fisch, supra note 13 at 272.

${ }^{667}$ See ibid at 273-74.

${ }^{668}$ See NYSE Manual, supra note 5, §303A.02(b)(i) (v); NASDAQ Rule, supra note 5, §5605(a)(2)(A) (F).
} 
As a board participates actively in corporate decision-making, it sacrifices the capacity to monitor those decisions independently. A board that has negotiated the structure of a merger is unable to evaluate the transaction neutrally. The board that works closely to advise the CEO and other top executives sacrifices the distance necessary to assess executive performance critically. ... [T] he board undertakes an affirmative role in strategic planning, the performance that the board evaluates is its own. Should a board judge a CEO deficient who adheres to the board's strategic plan for the corporation when that plan produces poor results? ${ }^{669}$

Under the same rationale, when an independent director has been designated to undertake the responsibilities with respect to the board's advisory and resource-gathering function, he or she is not suitable to perform the monitoring role because what he (or she) evaluates are the suggestions of himself (herself). Therefore, benefits associated with the board's monitoring function (offered by independent directors) may come at the expense of the substantial value offered by the directors as a management resource. ${ }^{670}$ Although independent directors can take strategic/advisory and resource-gathering roles in a board, ${ }^{671}$ conventional wisdom believes that their main function is to serve as a check on managerial abuses. ${ }^{672}$ Since the 1990 s, independent directors have populated at least two-thirds or even three-quarters of board seats of publicly-held companies in the United States. ${ }^{673}$ The phenomenon implies that only the small remaining portion of directors is fulfilling the board's managing function.

When a corporate board focuses its role on monitoring (such as with a high percentage of independent directors on the board), the corporation is less likely to benefit from the management expertise of talented executives. ${ }^{674}$ It is worth noting that the survival of a corporation depends largely on its business strategies and how to secure its essential resources instead of on active monitoring. Although good monitoring provided by independent directors can prevent management from self-dealing and indulging in risk-taking, it can only passively save money rather than actively making profits for shareholders. Defenders of independent directors may fail to recognize that managing and monitoring roles are distinct components of board function, and therefore ignore the trade-off effect between monitoring and managing

\footnotetext{
${ }^{669}$ Fisch, supra note 13 at $280-81$.

${ }^{670}$ Ibid at 281.

${ }^{671}$ Nicholls, supra note 11 at 338-39.

${ }^{672}$ Bhagat \& Black, 2002, supra note 1 at 232.

${ }^{673}$ Ibid.

${ }^{674}$ Fisch, supra note 13 at 281.
} 
effectiveness. $^{675}$

\subsubsection{The Optimal Level of Board Independence Varies with Firm-specific Characteristics}

Moreover, many scholars have indicated that firm-specific characteristics may cause corporations to have different needs from their independent directors. Companies with a controlling shareholder appear to require less monitoring by their independent directors. ${ }^{676}$ On the other hand, a firm with a large free cash reserve and a dispersed shareholder body may need an enhanced internal monitoring structure to prevent self-dealing. ${ }^{677}$ A growth corporation in a developing field may need to rely on directors' managerial expertise to get through that difficult time, when it is faced with a variety of strategic decisions and an inexperienced CEO. ${ }^{678}$ Several empirical findings in the new millennium support this view. ${ }^{679}$

Financial economists have found that the optimal level of board independence varied with a broad combination of firm-specific characteristics and operating environments. A least six factors were reported to be significantly related to the level of board independence ${ }^{680}$, namely

\footnotetext{
675 Ibid at 283.

${ }^{676}$ Bernard S Black, "The Value of Institutional Investor Monitoring: The Empirical Evidence" (1992) 39 UCLA L Rev 895 at 917. In Canada, Erickson et al. (2005) found that board independence was highly negatively associated with dominant shareholder ownership, while Bozec and Bozec (2007) reported that the ROB Board Composition scores were significantly and negatively related to the level of ownership concentration, especially when a dominant shareholder held more than $25 \%$ of voting rights. Collectively, the findings seem to suggest a potential substitution effect between director independence and controlling shareholders. Further details are discussed in section 5.2.5.4. John Erickson et al, "Board Composition and Firm Value under Concentrated Ownership: The Canadian Evidence" (2005) 13 Pacific-Basin Finance Journal 387 at 402 [Erickson et al]; Yves Bozec \& Richard Bozec, "Ownership Concentration and Corporate Governance Practices: Substitution or Expropriation Effects?” (2007) 24 Canadian Journal of Administration Sciences 182 at 185 [Bozec \& Bozec].

${ }^{677}$ Fisch, supra note 13 at 285; See Roberta Romano, "A Guide to Takeover: Theory, Evidence, and Regulation" (1992) 9 Yale J on Reg 119 at 131-32.

${ }^{678}$ Fisch, ibid.

${ }^{679}$ Kenneth Lehn, Sukesh Patro \& Mengxin Zhao, "Determinants of the Size and Structure of Corporate Boards: 1935-2000" (November 2003), online: SSRN <http://ssrn.com/abstract=470675 or doi:10.2139/ssrn.470675> [Lehn, Patro and Zhao]; Audra L Boone et al, "The Determinants of Corporate Board Size and Composition: An Empirical Analysis" (2007) 85 Journal of Financial Economics 66 [Boone et al]; Jeffrey L Coles, Naveen D Daniel \& Lalitha Naveen, "Boards: Does One Size Fit All” (2008) 87 Journal of Financial Economics 329 [Coles, Daniel \& Naveen]; Yixi Ning, Wallace N Davidson III \& Ke Zhong, "The Variability of Board Size Determinants: An Empirical Analysis" (2007) Fall/ Winter Journal of Applied Finance 46 [Ning, Davidson \& Zhong]; James Linck, Jeffry Netter \& Tina Yang, "The Determinants of Board Structure" (2008) 87 Journal of Financial Economics 308 at 313 [Linck, Netter \& Yang].

${ }^{680}$ Lehn, Patro and Zhao (2003), Coles, Daniel and Naveen (2008), and Linck, Netter and Yang (2008) used the proportion of outside directors on the board as a proxy for board independence, while Boon et al (2007) adopted the proportion of independent directors on the board to measure board independence. Lehn et al, ibid at 13; Coles, Daniel \& Naveen, ibid at 336; Linck, Netter \& Yang, ibid at 311; Boone et al, ibid at 78 Table 5, 85 Table 8.
} 
firm size ${ }^{681}$ firm complexity, ${ }^{682} \mathrm{CEO}$ 's influence and the constraints of such influence, ${ }^{683}$ growth opportunities, ${ }^{684}$ R\&D intensity, ${ }^{685}$, and managers' opportunities for private benefits. ${ }^{686}$ Existing

studies have consistently reported that firms were inclined to have more independent boards when they were larger, ${ }^{687}$ more complex,${ }^{688}$ and had less CEO influence (more constraints on CEO influence $)^{689}$. In contrast, firms with high growth opportunities seemingly did not choose boards with higher independence. ${ }^{690}$ In addition, the connection between board independence

${ }^{681}$ In Lehn, Patro and Zhao (2003), firm size is defined as market value of equity. Lehn, Patro and Zhao, ibid at 17. In Boone et al, firm size is measured as the natural log of the market value of equity as of each fiscal year-end. Boone et al, ibid at 76. In Ning, Davidson and Zhong (2007), firm size is defined as the book value of total debt over the market value of firm's equity. Ning, Davidson \& Zhong, ibid at 50. In Linck, Netter and Yang (2008), firm size is measured by (the logarithm of) market value of equity. Linck, Netter \& Yang, ibid at 316, 321 Table 4.

${ }^{682}$ Boon et al (2007) used firm size, firm age and the number of business segments as proxies for firm complexity, while Coles, Daniel and Naveen (2008) adopted firm size, diversification and financial leverage as proxies to measure firm complexity. Linck, Netter and Yang (2008) used firm size, the proportion of debt in capital structure, the number of business segments and firm age to represent firm complexity. Boone et al, ibid at 71; Coles, Daniel \& Naveen, ibid at 332; Linck, Netter \& Yang, ibid at 311.

${ }^{683}$ The CEO's influence is measured by the CEO's job tenure and the CEO's stock ownership, while outside director ownership, venture capital presence and Carter-Manaster underwriters ranking are used as proxies for the constraints of the CEO's influence. Boone et al, ibid at 70-72.

${ }^{684}$ Lehn, Patro and Zhao (2003) used the ratio of the market to book value of assets and the ratio of property plant and equipment to total assets to measure growth opportunities, while Boon et al. (2007) and Linck, Netter and Yang (2008) did not directly define growth opportunities. Since Boon et al. (2007) mentioned that firms with high log market-to-book ratios tend to have significant growth opportunities, I use market-to-book ratio as a proxy for growth opportunities in Boon et al. (2007) and Linck, Netter and Yang (2008). Lehn, Patro and Zhao, supra note 679 at 17 18 ; Boone et al, ibid at 81 .

${ }^{685}$ Boon et al. (2007) defined firms with high R\&D expenditures as firms in the top quartile of R\&D expenditures relative to firm size, while Coles, Daniel and Naveen (2008) consider R\&D intensity is high if the firm's R\&D to asset ratio is greater than $75^{\text {th }}$ percentile value. The intensity of R\&D in Linck, Netter and Yang (2008) is defined as R\&D expenses over total assets. Boone et al, ibid at 84 Table 7; Coles, Daniel \& Naveen, supra note 679 at 337 , 345 Table 6; Linck, Netter \& Yang, supra note 679 at 321 Table 4.

${ }^{686}$ This factor refers to the opportunities for managers to increase their own wealth at the shareholders' expense. Boon et al (2007) used the firm's free cash flow, industry concentration and takeover defense (G-index) to measure managers' opportunities for private benefits, while Linck, Netter and Yang (2008) only adopted firm's free cash flow as a proxy for opportunities for managers to pursue their private benefits. Boone et al, ibid at 80; Linck, Netter \& Yang, ibid at 311.

${ }^{687}$ Four studies consistently observed that the proportion of outside (independent) directors on the board increased when firm size became larger. Lehn, Patro and Zhao, supra note 679 at 20, 23; Coles, Daniel \& Naveen, supra note 679 at 341 Table 4; Boone et al, ibid. at 80; Linck, Netter \& Yang, supra note 679 at 320, 321 Table 4.

${ }^{688}$ Boon et al (2007), Coles, Daniel and Naveen (2008) and Linck, Netter and Yang (2008) all reported that firm complexity was positively associated with board independence, suggesting that board independence increased when firm operations grew, matured and became more complex. Coles, Daniel \& Naveen, ibid at 340; Boone et al, ibid at 79-80; Linck, Netter \& Yang, ibid at 320.

${ }^{689}$ Boon et al. (2007) observed that board independence was negatively related to the CEO influence but was positively associated with the constraints of CEO influence. The results demonstrated that the level of board independence reflected the outcome of negotiations between the CEO and independent directors. Boone et al, ibid at 87.

${ }^{690}$ Lehn, Patro and Zhao (2003) observed that growth opportunities decreased with the proportion of outside directors on the board, while Boon et al (2007) reported that the proportion of independent directors on the board was significantly and negatively related to market-to-book ratio. Linck, Netter and Yang (2008) reported the same results when board independence was measured by the fraction of outside directors on the board. Lehn, Patro and 
and the last two factors are inconsistent. Some studies observed that firms with higher R\&D expenditure or greater managers' opportunities to pursue their private benefits were more likely to choose more independent boards, while some studies found no such correlation. ${ }^{691}$

Collectively, there seems to be no ideal level of board independence that fits all companies.

To sum up, monitoring is only one of the main functions of the board. Firms should be very cautious to ensure that their level of board independence optimally suits their unique competitive environment, since there is a distinct trade-off effect between the board's monitoring and managing functions. The conventional wisdom that the more independent directors on the board the higher shareholder benefits may not be applicable to all corporations. Sometimes, too many independent directors on the board make the firm perform even worse.

\subsection{Summary of Chapter Three}

From the time that the monitoring role of independent directors was proposed to serve as a cure for agency problems, many scholars began questioning the effectiveness of independent directors in fulfilling this job. The managerial hegemony theory believes that boards of directors, no matter how independent they are, are inescapably dominated by management, because: (1) biases in the nomination and selection process; (2) constraints on directors' ability; and (3) weak incentives prevent independent board members from effectively monitor corporate executives.

In addition to managerial hegemony theory, academics argue that at least six defects make independent directors an ineffective instrument to oversee management integrity. First, the difficulty of giving a complete definition for independence provides opportunities for corporations to appoint directors who meet the legal requirements but are not truly independent.

Zhao, supra note 679 at 20, 23; Boone et al, ibid at 84-85, 84 Table 7; Linck, Netter \& Yang, supra note 679 at 321 Table 4.

${ }^{691}$ Boon et al. (2007) and Linck, Netter and Yang (2008) observed that board independence was significantly and positively associated with R\&D expenditures, while Coles, Daniel and Naveen (2008) found that firms with high R\&D intensity benefited from having a lower (higher) proportion of outside (inside) directors on the board but firms with low R\&D intensity were neutral to board independence. Boone et al., ibid at 84-85; Linck, Netter \& Yang, ibid at 320; Coles, Daniel \& Naveen, supra note 679 at 344. In addition, Linck, Netter and Yang (2008) reported that managers' opportunities for private benefits were positively correlated with board independence, while Boon et al (2007) observed that managers' opportunities for private benefits was not significantly related to the proportion of outside directors on the board. Since Boon et al (2007) used three proxies to represent managers' opportunities for private benefits, while Linck, Netter and Yang (2008) only employed one of them, the differences may cause the inconsistent results. Linck, Netter \& Yang, ibid at 322; Boone et al., ibid at 84-85. 
Second, the reward system (director compensation) does not provide appropriate incentives to urge independent directors to devote themselves to management oversight. Third, the legal system's (law's and courts') reluctance to impose liability on independent directors indirectly encourages them to shirk their monitoring obligations. Fourth, the in-group bias and influence of groupthink further impair the motivation of independent directors to ask probing questions in the boardroom. Finally, the trade-off between a board's monitoring function and managing function, as well as the need for board independence varying with firm-specific operating environments, also undermine the utility of uniform rules requiring independent directors for all firms because mandatory board composition will not be beneficial for all firms. Empirical findings support the first three contentions and the need for board independence varying with firm-operating environments at least to some extent.

Although the defects regarding independent directors have been identified for a period of time, the existing laws and regulations seemingly do not take these problems seriously and continue to rely on independent directors to serve as a check on executive behavior for all firms. The subsequent chapter will discuss how laws, regulations and courts rely on independent directors as corporate monitors, including how courts defer to decisions made by independent directors, how laws and regulations require independent directors to fulfill their duties and responsibilities as corporate monitors, and how director independence is defined. This discussion will reveal that current laws and regulations regarding independent directors have not fully addressed the problems mentioned in this chapter, which may affect the effectiveness of independent directors. 


\section{Chapter Four}

\section{How Current Laws and Regulations Rely on Independent Directors as Corporate Monitors}

Although the effectiveness of independent directors has been questioned since the monitoring role of director was first proposed, laws and regulations in North America have continuously relied on independent directors as a cure for agency problems in the past three decades. As noted, the way laws and regulations rely on independent directors in corporate governance is slightly different between the United States and Canada. Regulators in the United States require every listed corporation to comply with highly-detailed rules regarding independent directors, while Canadian administrators, with the exception of requirements regarding audit committees, only establish guidelines concerning independent directors. Each issuer in Canada must disclose whether it complies with the guidelines, and give the reasons for any non-compliance. The following sections analyze how the compulsory approach operates in the United States and how the comply-or-explain approach functions in Canada.

\subsection{The United States}

After academics and the SEC promoted independent directors as corporate monitors in the mid-1970s, the NYSE began to require that every listed company establish an audit committee composed exclusively of directors independent of management in 1978. US state courts, in the 1980s, also relied on independent directors in judging the conduct of corporate officers and directors in conflict-of-interest situations, such as takeover bid cases and derivative actions, within the regime of state corporation law. In 1999, the NASDAQ, following the NYSE, started to require independent directors to sit on the audit committee to ensure the quality of financial reporting. In response to corporate scandals in the new millennium, federal law, especially SOX, the SEC and stock exchanges largely relied on independent directors to serve as a check on management in the interests of shareholders. The following sub-sections analyze how the current state and federal laws, as well as stock exchange rules, count on independent 
directors to hold management accountable in the United States.

\subsubsection{On the State Level}

Except for few states, such as Michigan, most states have no statutory requirements for director independence. However, state courts, especially Delaware courts, have crafted an analytical framework that encourages corporations to add independent directors to their boards. ${ }^{692}$ Delaware courts apply a nuanced case-by-case approach to define director independence, ${ }^{693}$ and defer to decisions made by independent directors with respect to situations involving risks of managerial abuse. ${ }^{694}$ This deference is reflected in at least three areas discussed below: conflict-of-interest transactions, shareholder derivative actions, and takeover bids. In addition, the Michigan Business Corporation Act gives independent directors statutory power to make determinations in the first two areas of the aforementioned corporate actions. The following analysis starts with conflict-of-interest transactions.

\subsubsection{Conflict-of-Interest Transactions}

A conflict-of-interest transaction refers to a transaction between a corporation and its directors or officers in which a director or officer may receive a benefit that is not shared equally with others in the corporation. ${ }^{695}$ Conflict-of-interest transactions were historically voidable by shareholders. ${ }^{696}$ Since these transactions may benefit the corporation, state corporate law ${ }^{697}$ and state courts provide several ways to legitimize these conflict-of-interest transactions. The disputed transactions may be legalized after going through a certain test or procedure as proof of the fairness of the transaction. ${ }^{698}$

Taking Delaware as an example, the courts may review the disputed transactions by

\footnotetext{
${ }^{692}$ Lin, supra note 13 at 904.

${ }^{693}$ Page, supra note 561 at 242; Fairfax, Inside Director, supra note 216 at 134.

${ }^{694}$ Fairfax, ibid at 142.

${ }^{695}$ Ibid; Lin, supra note 13 at 904.

${ }^{696}$ Fairfax, ibid; James D Cox, "Managing and Monitoring Conflicts of Interests: Empowering the Outside Directors with Independent Counsel” (2003) 48 Vill L Rev 1077 at 1082.

${ }^{697}$ At least 47 states have a statutory provision similar to Delaware's section 144. Lin, supra note 13 at 904 n 30.

${ }^{698}$ Lin, supra note 13 at 904; See Fairfax, Inside Director, supra note 216 at 142-43.
} 
applying the "entire fairness" test ${ }^{699}$ to decide whether the transaction is fair to the corporation. $^{700}$ Simultaneously, section 144 of the Delaware General Corporation Law also provides a channel of legalization, if the transaction is: (1) disclosed to the board of directors (or the appropriate committee) including all material facts and its terms; and (2) approved by a majority of independent (disinterested) directors. "Independent" in this context is narrowly defined under the same provision as a lack of financial interest in the transaction. ${ }^{701}$ When a disputed transaction is brought before a state court, if it has been approved by independent directors, the court would review the transaction under the business judgment rule, thereby abandoning the more rigorous standard of the entire fairness test. ${ }^{702}$ This phenomenon reveals that the law tends to be more lenient in its review of conflict-of-interest transactions when they are approved by independent directors. ${ }^{703}$ This statutory authority may encourage large publiclyheld corporations to add independent directors to their boards. ${ }^{704}$

\subsubsection{Derivative Suits}

Courts also defer to independent directors in the context of shareholder actions. As noted, a derivative suit refers to a lawsuit brought by one or more minority shareholders on behalf of a corporation to assert that directors, management or other shareholders allegedly caused harm to the corporation, and request that the alleged wrong be remedied to the corporation. ${ }^{705}$ Derivative suits provide the primary channels for shareholders to impose liability on officers and directors who breach their fiduciary duties to the corporation. ${ }^{706}$ However, bringing a derivative action must meet certain requirements.

Taking Delaware as an example, before filing a derivative claim, a shareholder must make a demand on the corporation's board of directors to remedy the situation or demonstrate

\footnotetext{
${ }^{699}$ The test focuses on the fairness of both the transaction's price and the process of approval. The two prongs are fair price and fair dealing. Weinberger $v$ UOP Inc, 457 A 2d 701 at 710 (Del 1983).

${ }^{700}$ Ibid; Fairfax, Inside Director, supra note 216 at 142.

${ }^{701}$ Del Code Ann tit $8 \$ 144(a)(1)$; Lin, supra note 13 at 904-05.

${ }^{702}$ Fairfax, ibid at 142-43.

${ }^{703}$ Lin, supra note 13 at 904.

${ }^{704}$ Ibid at 905.

${ }^{705}$ Block, Radin \& Maimone, supra note 214 at 1443, 1450; Fairfax, Inside Director, supra note 216 at 143.

${ }^{706}$ Fairfax, Corporate Federalism, supra note 209 at 393; Fairfax, Inside Director, ibid; Daniel R Fischel \& Michael Bradley, "The Role of Liability Rules and the Derivative Suit in Corporate Law: A Theoretical and Empirical Analysis" (1986) 71 Cornell L Rev 261 at 286.
} 
"demand futility",707 708 To prove demand futility, the shareholder has to satisfy at least one component of a two-pronged test set forth in Aronson v. Lewis, ${ }^{709}$ which requires the pleading of particularized facts raising a reasonable doubt regarding: (1) whether a majority of directors were disinterested and independent ${ }^{710}$; or (2) whether the directors exercised proper business judgment in approving the challenged transaction. ${ }^{711}$ Since courts defer to directors' corporate decisions under the business judgment rule, establishing demand futility under the second prong is particularly difficult. ${ }^{712}$ Consequently, if shareholders cannot prove that a majority of directors lacked independence, typically their derivative suits cannot move forward on the basis of demand futility. ${ }^{713}$ From this perspective, the presence of independent directors reduces shareholders' ability to avoid making a demand. ${ }^{714}$

In several Delaware cases, the court stated that the approval of the challenged transaction by a majority of independent, disinterested directors usually supports a presumption that an appropriate business judgment was made, which has created significant hurdles for shareholders seeking to show demand futility. As a result, when a plaintiff alleges that making such a demand is futile, a heavy burden would be placed on the plaintiff. ${ }^{715}$ For example, in Polk v. Good, the Delaware Supreme Court stated "[t]he presence of the 10 outside directors on the Texaco board, coupled with the advice rendered by the investment banker and legal counsel, constitute a prima facie showing of good faith and reasonable investigation. With 10 of the 13 directors being independent, the plaintiffs thus bore a heavy burden of overcoming the presumptions thus attaching to the board's decisions." ${ }^{716}$ In an early 1990s federal case, RCM Sec. Fund, Inc. v.

\footnotetext{
${ }^{707}$ Demand futility means a shareholder plaintiff is permitted to bring a derivative litigation without making a demand.

${ }^{708}$ Block, Radin \& Maimone, supra note 214 at 1451; Lin, supra note at 907; Fairfax, Inside Director, supra note 216 at 143; Fairfax, Corporate Federalism, supra note 209 at 392-93; Cosenza, supra note 391 at 31; Page, supra note 561 at 244.

${ }^{709}$ Aronson, supra note 216 at 814; Lin, supra note at 907; Fairfax, Inside Director, ibid; Fairfax, Corporate Federalism, ibid; Cosenza, supra note 391 at 31.

${ }^{710}$ However, the standard for director independence in this context is less clear. The Delaware courts interpreted lack of independence for demand futility purposes to mean that the board is dominated or otherwise controlled by an officer, director, or other individual, such as a controlling shareholder, who is the proponent of the challenged transaction. Grobow v Perot, 539 A2d 180 at 186 (Del 1988) [Grobow]; Aronson, ibid at 815-16; Lin, ibid at 90708.

${ }^{711}$ Block, Radin \& Maimone, supra note 214 at 1456; Lin, ibid at 907; Grobow, ibid, citing Aronson v Lewis, 473 A 2d 805 at 814 (Del 1984).

${ }^{712}$ Fairfax, Inside Director, supra note 216 at 143.

${ }^{713}$ Fairfax, Corporate Federalism, supra note 209 at 392.

${ }^{714}$ Ibid.

${ }^{715}$ Block, Radin \& Maimone, supra note 214 at 1456; Lin, supra note at 907; Grobow, supra note 710 at 190.

${ }^{716}$ Polkv Good, 507 A 2d 531 at 537 (Del 1986).
} 
Stanton, the Second Circuit also mentioned "Delaware law, of course, requires us to accord considerable deference to the judgment of an independent board, and plaintiffs bear the burden of pleading particularized facts establishing a reasonable doubt as to the adequacy of the terms of the transaction ${ }^{717}$."718 These cases reveal that companies may have an incentive to maintain a majority of independent directors on their boards with the purpose of obtaining judicial deference to their business decisions, and simultaneously reducing the probability of derivative suits. $^{719}$

Even if corporations cannot prevent shareholders from bringing derivative actions through demonstrating demand futility under Aronson, they can still seek dismissal of shareholder derivative actions under another route by establishing a special litigation committee that decides that the corporation should not take action. Courts review the committee's decisions under the test from Zapata Corp. v. Maldonado, which has two prongs. ${ }^{720}$ First, the corporation shoulders the burden to prove that the special litigation committee was independent and acted in good faith. Second, the court can apply its own judgment to determine whether the action should be dismissed. $^{721}$ Because courts overwhelmingly defer to the decisions of special litigation committees composed of independent directors, such deference encourages corporations to populate their boards with independent directors. ${ }^{722}$

In summary, as the above discussion reveals, no matter whether a demand is made or excused, independent directors have tremendous power over the fate of a shareholder's derivative suit. $^{723}$ This is one way that the law and courts rely on independent directors as corporate monitors to hold management accountable.

\subsubsection{Defensive Measures against Hostile Takeovers}

\footnotetext{
${ }^{717}$ The Delaware court considers that exercising "the adequacy of the terms of the transaction" is equivalent to exercising "proper business judgment". "...Under Delaware law, proper business judgment means the exercise of substantive due care-the terms of the transaction-and procedural due care-an informed decision." RCM Sec Fund, 928 F 2d 1318 at 1331 (2d Cir 1991).

${ }^{718}$ Ibid.

${ }^{719}$ Lin, supra note 13 at 907; Fairfax, Inside Director, supra note 216 at 143-44; Fairfax, Corporate Federalism, supra note 209 at $392-93$.

${ }^{720}$ Fairfax, Inside Director, ibid at 144; Fairfax, Corporate Federalism, ibid at 393; Cosenza, supra note 391 at 37-38.

${ }^{721}$ Zapata, supra note 216 at $788-89$.

722 Ibid at 784; Fairfax, Inside Director, supra note 216 at 144; Fairfax, Corporate Federalism, supra note 209 at 393.

${ }^{723}$ Fairfax, Inside Director, ibid.
} 
In addition to conflict-of-interest transactions and shareholder derivative actions, courts similarly defer to independent directors in the context of hostile takeover cases. This approach was first adopted in the 1980s. The 1980s is well remembered as the decade of the corporate takeover. ${ }^{724}$ In response to the pressure of hostile takeovers, many Delaware corporations adopted unexpected, even unprecedented defensive measures, against the acquirer. In order to ensure that the interests of shareholders are well protected and avoid second guessing the appropriateness of defensive tactics in a particular case, the Delaware courts developed a strategy which reviewed the board's deliberation process as well as director independence in takeover cases. The examination of the board's deliberation process was to ensure that directors had tried their best and exercised independent judgment in determining what their defensive tactics would be. The review of board independence focused on whether a decision to adopt the defensive measure was made by a board comprised of a majority of independent directors. ${ }^{725}$

In a series of cases, ${ }^{726}$ the Delaware Courts repeatedly invoked the role of independent directors in the board's evaluation of the raider's bid and in the formation of its defensive measures. As long as the defensive measures were discussed extensively by all directors in the presence of the company's financial advisors and counsel, and independent directors constituted a clear majority of the board members in reviewing and approving the defensive undertaking, ${ }^{727}$ the courts were inclined to hold that the defensive measures adopted by the board were within the scope of the business judgment rule. ${ }^{728}$

For example, in Unocal Corp. v. Mesa Petroleum Co., the target board used a selftender $^{729}$ to resist a raider's cash tender offer. The Delaware Supreme Court articulated a twoprong test for determining the validity of such defenses. First, the target board must demonstrate that "they had reasonable grounds for believing that a danger to corporate policy and effectiveness existed." Second, directors must show that their defensive measures were

\footnotetext{
${ }^{724}$ Please refer to supra note 204.

${ }^{725}$ Gordon, The Rise of Independent Directors, supra note 1 at 1523-24.

726 Two pivotal cases in 1980s, Unocal Corp. v. Mesa Petroleum Co. and Moran v. Household Int'l Corp., as well as one famous case in the early 1990s, Paramount Communications Inc. v. Time, Inc., demonstrated the court's reliance on independent directors. Unocal, supra note 209; Moran, supra note 210; Paramount, supra note 210.

${ }^{727}$ Unocal, ibid at 950; Moran, ibid at 1348; Paramount, ibid at 1147-48.

${ }^{728}$ Gordon, The Rise of Independent Directors, supra note 1 at 1524-26.

${ }^{729}$ A corporation buys back a certain percentage of its own shares for a price well above fair market price through a tender offer. Usually, it is an attempt to prevent a real or suspected hostile takeover. When a corporation becomes its own majority or plurality shareholder, it either makes a hostile takeover impossible or much more expensive for the firm attempting to buy it out. Gillen, supra note 29 at 459.
} 
reasonable in relation to the threat posed. ${ }^{730}$ Then, the defensive measures could be recognized within the scope of the business judgment rule. In Unocal, the independent directors ${ }^{731}$ met separately with financial advisors and legal counsel, and the board unanimously agreed on the defensive measure. The eight independent directors constituted a clear majority of the thirteen board members present. ${ }^{732}$ Thus, the court held that the board satisfied the above burden by showing good faith and reasonable investigation. Moreover, such proof was materially enhanced by the approval of a board comprised of a majority of independent directors. ${ }^{733}$

Similarly, in Moran v. Household Int'l Corp., the defendant's board adopted a shareholder rights $\operatorname{plan}^{734}$ as a defensive mechanism to ward off a possible future takeover. During the deliberation, all directors participated in an extensive discussion of shareholder rights plan with the company's financial advisors and counsel, ${ }^{735}$ and then approved the rights plan. A majority of them, ten of sixteen, were independent. ${ }^{736}$ In addition, a particular director who opposed the plan had fully expressed his opinions during the board meeting. ${ }^{737}$ Therefore, the court held that the defendant's board, consisting of a majority of independent directors, had acted in accordance with the Unocal standards. ${ }^{738}$

In Paramount Communications Inc. v. Time Inc., the defendant's (Time's) board rejected the plaintiff's tender offer. The target board consisted of sixteen directors with twelve of them being independent. ${ }^{739}$ Corporate counsel and financial advisors were also present during their meetings, and, from time to time, the management directors were asked to leave the board sessions. In addition, independent directors met frequently without the presence of management

\footnotetext{
${ }^{730}$ Unocal, supra note 209 at 955.

${ }^{731}$ The court in Unocal did not elaborate on the definition of "independent directors". Lin, supra note 13 at 909.

${ }^{732}$ Unocal, supra note 209 at 950-51.

${ }^{733} \mathrm{Ibid}$ at 955.

${ }^{734}$ A shareholder rights plan is a document that often contains the provision that a takeover bid must be approved by the target's board, and that the board has the right to remove the plan if it negotiates an acceptable arrangement with the bidder. When board approval cannot be obtained, the plan is activated. Usually the target's management calls it a "shareholder rights plan", while their opponents call it a "poison pill." John A Pearce II \& Richard B Robinson, "Hostile Takeover Defenses that Maximize Shareholder Wealth" (2004) 47 Business Horizons 15 at 19-20 [Pearce \& Robinson]; Mary G Condon, Anita I Anand \& Janis P Sarra, Securities Law in Canada: Cases and Commentary (Toronto: Emond Montgomery Publications, 2005) at 509-10 [Condon, Anand \& Sarra, 2005]; Gillen supra note 29 at 460 .

${ }^{735}$ Moran, supra note 210 at 1349, 1356.

${ }^{736}$ Ibid at 1348.

${ }^{737}$ Ibid at 1349 .

${ }^{738}$ Ibid at 1356.

${ }^{739}$ Paramount, supra note 210 at 1147.
} 
and inside directors. ${ }^{740}$ The deliberation process showed that the board, comprised of a majority of independent directors, was the chief architect of Time's strategy and choices, rather than Time's CEO or management team. Thus, the court held that Time's response was reasonable and proportionate, and the decision of Time's board demonstrated a valid exercise of a board's independent judgment. $^{741}$

In short, a series of cases demonstrated that the Delaware courts rely on independent directors to determine the validity of defensive measures. Such deference to director independence may encourage corporations to maintain a majority of independent directors on their boards, and demonstrates the courts' reliance on independent director as corporate monitors.

\subsubsection{Michigan Legislation}

Michigan introduced a role for independent directors in its Business Corporation Act in 1989 under the influence of the SEC's promotion of independent directors and the ALI's Corporate Governance Project. ${ }^{742}$ It was the first state in the United States to use the term "independent director" in its statute. ${ }^{743}$

In Michigan, to qualify as an independent director, a director must be elected by its shareholders, be designated by its board or its shareholders as independent, and meet both competence and independence requirements. ${ }^{744}$ The competence requirement demands a minimum of five years' business, legal or financial experience. For corporations with publiclytraded securities, "experience" means experience as a senior executive, director, attorney or other equivalent experience. ${ }^{745}$ The independence requirement requires the absence of any disqualifying relationship ${ }^{746}$ with the corporation for three years prior to designation (a cooling-

\footnotetext{
${ }^{740}$ Ibid at $1147-48$.

${ }^{741}$ Ibid at 1142 .

${ }^{742}$ Moscow et al, supra note 219 at 57.

${ }^{743}$ Gorsline, supra note 219 at 673.

${ }^{744}$ Mich Comp Laws Ann \$450.1107(3); Moscow et al, supra note 219 at 58; Gorsline, ibid.

${ }^{745}$ Mich Comp Laws Ann $\$ 450.1107(3)(c)$; Moscow et al, ibid.

${ }^{746}$ Michigan Business Corporation Act section $\$ 450.1107(3)$ states:

"Independent director" means a director who meet all of the following requirements:

(d) Is not and during the 3 years prior to being designated as an independent director has not been any of the following:

(i) An officer or employee of the corporation or any affiliate of the corporation.

(ii) Engaged in any business transaction for profit or series of transactions for profit, including banking, legal, or consulting services, involving more than $\$ 10,000.00$ with the corporation or any affiliate of the corporation.
} 
off period) and a limitation of the director's term to three years, including employment relationship, business relationship and family member relationship. ${ }^{747}$

A unique feature of the Michigan independent director rules is that there is no obligation for corporations to have independent directors. ${ }^{748}$ Corporations in Michigan are free to choose whether to appoint statutory independent directors. In order to attract corporations to appoint statutory independent directors, however, incentives are built into the statute. Independent directors are given the statutory power to make determinations in three areas of corporate actions: interested director transactions, indemnification and termination of shareholder derivative suits. First, a transaction in which a director or officer has an interest shall be allowed if the material facts of the transaction were disclosed to independent directors, and independent directors approved or ratified the transaction. ${ }^{749}$ Second, indemnification of various persons is allowed if statutory standards of conduct are met. Whether the statutory standards are met may be decided by all independent directors who are not parties or threatened to be made parties to the action, suit or proceeding. ${ }^{750}$ Third, a shareholder derivative suit can be dismissed by the court if all

(iii) An affiliate, executive officer, general partner, or member of the immediate family of any person that had the status or engaged in a transaction described in subparagraph (i) or (ii).

(e) Does not propose to enter into a relationship or transaction described in subdivision (d)(i) through (iii).

(f) Does not have an aggregate of more than 3 years of service as a director of the corporation, whether or not as an independent director. Mich Comp Laws Ann §450.1107(3).

${ }_{747}$ Moscow et al, supra note 219 at 58; Gorsline, supra note 219 at 674; Mich Comp Laws Ann $\$ 450.1107(3)$. ${ }_{748}^{748}$ Moscow et al, ibid at 65; Gorsline, ibid at 675.

${ }^{749}$ Moscow et al, ibid at 58-59, 61; Gorsline, ibid at 675-76; Michigan Business Corporation Act section 545a states:

(1) A transaction in which a director or officer is determined to have an interest shall not, because of the interest, be enjoined, set aside, or give rise to an award of damages or other sanctions, in a proceeding by a shareholder or by or in the right of the corporation, if the person interested in the transaction establishes any of the following:

(b) The material facts of the transaction and the director's or officer's interest were disclosed or known to the board, a committee of the board, or the independent director or directors, and the board, committee, or independent director or directors authorized, approved, or ratified the transaction.

(2) For purposes of subsection (1)(b), a transaction is authorized, approved, or ratified if it received the affirmative vote of the majority of the directors on the board or the committee who had no interest in the transaction, though less than a quorum, or all independent directors who had no interest in the transaction. ...

Mich Comp Laws Ann $\$ 450.1545$ a.

${ }^{750}$ Moscow et al, ibid at 58-59, 62; Gorsline, ibid; Michigan Business Corporation Act Section 564a states:

(1) Except as otherwise provided in subsection (5), an indemnification under section 561 or 562, unless ordered by the court, shall be made by the corporation only as authorized in the specific case upon a determination that indemnification of the director, officer, employee, or agent is proper in the circumstances because he or she has met the applicable standard of conduct set forth in sections 561 and 562 and upon an evaluation of the reasonableness of expenses and amounts paid in settlement. This determination and evaluation shall be made in any of the following ways: 
disinterested independent directors determine that the suit is not in the best interests of the corporation after conducting a reasonable investigation. ${ }^{751}$

In order to encourage independent directors to be effective monitors of management, the statute mandates the reimbursement of expenses reasonably related to services as an independent director, including counseling fees and lawyers' expenses. ${ }^{752}$ The statute allows directors to communicate with shareholders at the corporation's expense in any report ${ }^{753}$ sent to shareholders to strengthen the influence of independent directors. The act also authorizes corporations to pay compensation to independent directors beyond the compensation paid to other directors in recognition of their special burdens. ${ }^{754}$

In contrast to the above three areas in which Delaware courts defer to decisions made by independent directors regarding situations involved risks of managerial abuse, the Michigan legislation institutionalizes the role of independent directors in holding management accountable. The above results reveal that state courts and, in the case of Michigan, the legislature rely on independent directors to act as impartial judges to look out for the best interests of shareholders. Although state law has not imposed a mandatory board structure on corporations, judicial interpretation and Michigan legislation may encourage corporations to add independent directors to their boards.

(d) By all independent directors who are not parties or threatened to be made parties to the action, suit, or proceeding. Mich Comp Laws Ann \$450.1564a.

${ }^{751}$ Moscow et al, ibid; Gorsline, ibid; Michgan Business Corporation Act Section 495 (Dismissal of derivative proceeding; determination) states:

(1) The court shall dismiss a derivative proceeding if, on motion by the corporation, the court finds that 1 of the groups specified in subsection (2) has made a determination in good faith after conducting a reasonable investigation upon which its conclusions are based that the maintenance of the derivative proceeding is not in the best interests of the corporation. ...... If the determination is made pursuant to subsection (2)(c) or (d), the plaintiff shall have the burden of proving that the determination was not made in good faith or that the investigation was not reasonable.

(2) A determination under subsection (1) may be made by any 1 of the following:

$\cdots$

(d) By all disinterested independent directors. Mich Comp Laws Ann $§ 450.1495$.

${ }^{752}$ Moscow et al, ibid at 58, 63; Michgan Business Corporation Act Section 505(3) states: $\cdots$

(3) The shareholders or board may designate 1 or more directors as an independent director. Any director so designated shall be entitled to reasonable compensation in addition to compensation paid to directors generally, as determined by the board or shareholders, and reimbursement for expenses reasonably related to service as an independent director. An independent director may communicate with shareholders at the corporation's expense, as part of a communication or report sent by the corporation to shareholders. An independent director shall not have any greater duties or liabilities than any other director. Mich Comp Laws Ann §450.1505(3).

${ }^{753}$ Michigan corporations are required to send annual financial statements to shareholders, so the independent directors will have access to shareholders at least annually. Moscow et al, ibid at 63 .

${ }^{754}$ Moscow et al, ibid at 58, 63; Mich Comp Laws Ann \$450.1505(3). 


\subsubsection{On the Federal Level}

In 1978, the NYSE began to require that every listed company establish an audit committee exclusively composed of directors independent of management. Two decades later, the NASDAQ started to require all listed companies to have an audit committee composed solely of independent directors with a view to ensuring the quality of financial reporting. In response to several high-profile corporate scandals, like Enron and WorldCom, SOX institutionalized the 1999 NYSE and NASDAQ requirements regarding audit committee independence in 2003. Subsequently, the NYSE and NASDAQ further tightened the definition of "director independence" and required all listed corporations to have a majority of independent directors on their boards. The NYSE also requires its listing companies to have completely independent compensation and nominating committees. In 2010, Dodd-Frank Wall Street Reform and Consumer Protection Act, a comprehensive financial reform in response to the 2008-2009 financial crisis, continued to rely on independent directors to ensure that the executive remuneration is decided in an environment free of conflicts and based on the receipt of unbiased advice. The development of corporate governance at the federal level reveals that current law and stock market regulators rely heavily on independent directors' monitoring role to check on managerial abuses.

The current network of US legal requirements, which relies on independent directors as corporate monitors, has four dimensions: (1) tightening the definition of independent directors; (2) regulating board composition; (3) requiring certain procedures in the boardroom to stifle influence of management; (4) mandating that three key board functions in the field of oversight of auditing, executive compensation and the nomination of directors be performed by independent directors.

\subsubsection{Tightening the Definition of Independent Directors}

\subsection{Pre-SOX Period}

The NYSE and NASDAQ have been relying on independent directors on the audit 
committee to ensure the quality of financial reporting since 1978 and 1999 , respectively. ${ }^{755}$ Both exchanges leave the authority to the board to determine whether a director is independent. Beginning in 1999, both exchanges adopt the same pattern for defining director independence. First, they offer a broadly worded definition and require that the board members affirmatively determine whether each independent director meets the given definition. Second, they require the board of the listed corporation to disclose such determination in its annual proxy statement or Form 10-K. Finally, they set forth a fairly lengthy list of relationships that preclude a director from being considered independent. ${ }^{756}$ The 1999 NYSE rules listed four conditions which restrict directors from being considered independent, including employment relationships, business relationships, cross-compensation committee links and immediate family relationships, ${ }^{757}$ while the 1999 NASDAQ rules enumerated five restrictions, including the above four and the compensation relationship. ${ }^{758}$

However, the corporations at the center of the Enron and WorldCom scandals in the early 2000s had audit committee members that met independence requirements of the NYSE 1999 and NASDAQ 1999 listing standards, respectively, ${ }^{759}$ but in the subsequent investigation were found either to have been involved in potential conflicts of interest or too incompetent to detect accounting misbehavior. ${ }^{760}$ Thus, Congress, the regulator and stock exchanges acknowledged that the definition of "independent director" should be tightened in order to ensure that no relationship between directors and management would influence these directors to exercise their independent judgment in carrying out their duties impartially.

\subsection{SOX Requirements}

In comparison with the NYSE and NASDAQ, the Sarbanes-Oxley Act and the related SEC rules use a different approach to define director independence that applies only to

\footnotetext{
${ }^{755}$ Smith, supra note 232 at 241.

756 "Developments in the Law, supra note 428 at 2188; BRC Report, supra note 232 at 1073; NYSE 1999 Rules, supra note 246; NASD 1999 Rules, supra note 246.

${ }^{757}$ NYSE 1999 Rules, ibid.

758 NASD 1999 Rules, supra note 246.

${ }^{759}$ Lutzy, supra note 97 at 103.

${ }^{760}$ Senate Enron Report, supra note 2 at 55; Gillan \& Martin, supra note 2 at 938; Thornburgh Report, supra note 3 at 37 .
} 
independent directors on the audit committee ${ }^{761} .^{762}$ Their definitions are, in some ways, more stringent, though more vague, than the definitions used by the 2003 NYSE and NASDAQ listing standards. ${ }^{763}$ The Sarbanes-Oxley Act adopted two criteria to determine audit committee independence. One is the compensation relationship, namely whether an audit committee member accepts any compensatory fee from the company. The other is the affiliated relationship, namely whether a member is closely connected to, or controlled by, the company. Section 301 of SOX provides that

....in order to be considered to be independent..., a member of an audit committee... may not ...

(i) accept any consulting, advisory, or other compensation fee from the issuer; or

(ii) be an affiliated person of the issuer or any subsidiary thereof. ${ }^{764}$

In order to ensure that every audit committee member is independent of management, SOX gave the SEC the authority to promulgate new rules to achieve this goal. In April 2003, the SEC promulgated Rule 10A-3 under the Exchange Act, in which the SEC added a minor modification to the definition of "independence" under SOX $\$ 301$ and explained in more detailed regarding the two criteria.

\subsection{SEC Rules}

With respect to the compensation relationship, the SEC considered that any "direct or indirect" compensatory fee from the company, other than compensation as a director, might influence independent directors' ability to make decisions impartially. Thus, the rule proscribed any indirect acceptance of compensatory payments, including payments to spouses, minor children or stepchildren, or children or stepchildren sharing a home with the audit committee member. Under the same rationale, any payments for services to law firms, accounting firms, consulting firms, investment banks or financial advisory firms, in which audit committee members are partners, members, executive officers or hold similar positions are also prohibited

\footnotetext{
${ }^{761}$ It is worth noting that the subsequent the 2003 NYSE and NASDAQ requirements regarding director independence apply to all independent directors.

762 Clarke, Concepts of Independent Directors, supra note 33 at 87.

${ }^{763}$ Developments in the Law, supra note 428 at $2188-89$.

${ }^{764}$ Sarbanes-Oxley Act, supra note 4.
} 
by this rule. ${ }^{765}$ However, the independence requirement of SOX only applies to current relationships; unlike the NYSE or NASDAQ rules, which both have a three-year cooling-off period for employees of a corporation. ${ }^{766}$ In addition, the rule clarified that compensatory fees do not include the receipt of fixed amounts of compensation under a retirement plan (including deferred compensation) for prior service with the listed company, because the rule applies only to current relationships and the receipt of retirement compensation is not contingent on any continued service. $^{767}$

As for the affiliated relationship, the SEC rule defines "affiliate" of, or a person "affiliated" with, a specified person, to mean "a person that directly, or indirectly through one or more intermediaries, controls, or is controlled by, or is under common control with, the person specified." The term "control" is interpreted as "the possession, direct or indirect, of the power to direct or cause the direction of the management and policies of a person, whether through the ownership of voting securities, by contract, or otherwise." However, a determination of "affiliated person" must be made on a case-by-case basis after considering the particular facts in any given situation. In order to introduce some certainty in this area, the SEC has created a safe harbor under which any person who is not an executive officer or a holder of $10 \%$ or more of the company's shares is deemed not to control the company. Nevertheless, executive officers, general partners, employee-directors and managing members of an affiliated person are themselves deemed to be affiliated persons by the SEC. ${ }^{768}$ It is worth noting that the NYSE and NASDAQ do not view ownership of a significant amount of stock, by itself, as a bar to an independence finding. ${ }^{769}$ However, audit committee members of corporations listed on the NYSE and NASDAQ must meet both the SOX's and their exchange's definition of director

\footnotetext{
${ }^{765}$ Standards Relating to Listed Company Audit Committee, Exchange Act Release No 33-8220 (9 April 2003), online: SEC <http://www.sec.gov/rules/final/33-8220.htm> [SEC, Release 33-8220]; 17 CFR §240.10A-3 (b)(1)(ii).

${ }^{766}$ A director who is considered not independent by NYSE and NASDAQ rules has to wait for three years to be reconsidered independent. This is what is meant by a cooling off period. Lutzy, supra note 97 at 114; NYSE Manual, supra note 5, §303A.02(b); NASDAQ Rule, supra note 5, §5605(a)(2)(A) (F).

${ }^{767}$ The SEC only added "directly or indirectly" before "accept any consulting, advisory fee" and restricted the scope of compensatory fees that the receipt of fixed amounts of compensation under a retirement plan for prior service is not included. SEC, Release 33-8220, supra note 765.

${ }^{768}$ Ibid.

${ }^{769}$ NYSE Manual, supra note 5, §303A.02(a) Commentary; NASDAQ, IM-5605 Definition of Independence - Rule 5605(a)(2); Lutzy, supra note 97 at 121; Clarke, Concepts of Independent Directors, supra note 33 at 93 . It should be noted that the NASDAQ imposes additional, more stringent requirements that apply to directors serving on audit committees, as specified in Rule 5605(c). NASDAQ, ibid.
} 
independence. ${ }^{770}$ The stock exchanges' requirements are set out in more detail below.

\subsection{NYSE and NASDAQ Rules}

\subsection{General Approach}

In response to the Enron and WorldCom scandals, both the NYSE and NASDAQ filed their proposed rule changes regarding independent directors with the SEC. After the proposals were amended several times, the final rules were approved by the SEC in November $2003 .{ }^{771}$ The current NYSE and NASDAQ rules regarding director independence are still the same as those in 2003. The new rules tighten the definition of "independent director" and apply the new definition to the entire board rather than just the audit committee. Following their 1999 pattern, both exchanges offer a broadly worded definition for "director independence" and leave the authority to the board to determine whether a director is independent. The definitions of the two exchanges differ slightly. The NYSE Listed Company Manual §303A.02 states that "no director will qualify as independent unless the board affirmatively determines that the director has no material relationship with the listed company", while the NASDAQ Rule 5605(a)(2) requires independent directors to have no "relationship which, in the opinion of the issuer's board of directors, would interfere with the exercise of independent judgment in carrying out the responsibilities of a director." Material relationships, according to NYSE's commentary, include, but are not limited to, commercial, industrial, banking, consulting, legal, accounting, charitable, and familial relationships among others. ${ }^{772}$ In this regard, a board may adopt and disclose standards to assist it in making determinations of independence and may make a general disclosure if a director meets these standards. ${ }^{773}$

In addition to providing a direct definition of independence, the current rules of the NYSE and NASDAQ list six relationships that would prevent a director from being considered independent. The five preclusions of the NYSE and six preclusions of the NASDAQ focus on six types of relationships, namely employment relationships, compensation relationships, relationships with auditors, cross-compensation committee links, business relationships and

\footnotetext{
${ }^{770}$ Developments in the Law, ibid.

${ }^{771}$ John \& Sides, supra note 544 at 1159-60, 1168.

772 NYSE Manual, supra note 5, §303A.02(a) Commentary; SEC, Release 33-8220, supra note 765.

${ }^{773}$ Clarke, Concepts of Independent Directors, supra note 33 at 88.
} 
immediate family relationships, each including a three-year look-back period to ensure that the effects of prior relationships are caught. The NYSE rules combined immediate family relationships into the other five types of relationships in its preclusions, while NASDAQ rules combined some immediate family relationships into other types of relationships in its preclusions but still maintained the preclusion of immediate family relationships.

Both the five NYSE preclusions and the six NASDAQ preclusions originated from the Blue Ribbon Committee's 1999 recommendations. ${ }^{774}$ However, the 2003 NYSE preclusions were more advanced, detailed and specific than the 1999 version. ${ }^{775}$ The 2003 NASDAQ preclusions also expanded the 1999 content and described it in more specific detail. ${ }^{776}$ The contents of the preclusions have remained unchanged since 2003. In comparison with the NYSE, the NASDAQ preclusions are similar, but less demanding. ${ }^{777}$ For example, NASDAQ Rule 5605(a)(2)(D) adopts a less stringent standard in determining a director's business ties to the other company. A payment received by the company exceeding 5\% of the other company's annual gross revenues is considered as being a business tie between two companies, compared to $2 \%$ in the NYSE's standard. ${ }^{778}$

\subsection{Six Preclusions}

The six types of relationships that prevent a director from being considered independent by both stock exchanges are analyzed as follows.

First, regarding the employment relationship, both exchanges disqualify directors who are currently, or were, at any time in the prior three years, employed by the issuer or its parent or subsidiaries from being considered independent. ${ }^{779}$ The commentary of the NYSE

\footnotetext{
${ }^{774}$ Please refer to supra notes 234-238 and the accompanying text.

775 The differences between the Blue Ribbon Committee's recommendations and the 2003 NYSE rules are: (1) a new type of relationship-relationships with auditors-was added into the 2003 NYSE preclusions; (2) the immediate family relationship is no more listed separately and is combined into the other types of relationship in the 2003 NYSE preclusions. NYSE Manual, supra note 5, §303A.02(b).

${ }^{776}$ Besides adding a new type of preclusion-"relationship with auditors", the 2003 NASDAQ rules combined some immediate family relationships into other types of relationships in its new preclusions, but still maintained its original preclusion of immediate family relationships. NASDAQ Rule, supra note 5, §5605(a)(2).

777 Seligman, Corporate Governance, supra note 289 at 1174.

${ }^{778}$ The example is the result in comparison with NYSE Manual §303A.02(b)(v) and NASDAQ Rule §5605(a)(2)(D).

779 The NYSE Listed Company Manual provides“.... a director is not independent, if: (i) the director is, or has been within the last three years, an employee of the listed company." NYSE Manual, supra note 5, §303A.02(b)(i). The NASDAQ rule states: “...the following persons shall not be considered independent: (A) a director who is, or at any
} 
accompanying this preclusion does not exclude a director from being considered independent after his/her employment as an interim chairman, CEO or other executive officer of the listed company, ${ }^{780}$ while the NASDAQ has a similar commentary permitting an independent director to have served as an interim executive officer (but not interim officer). ${ }^{781}$

Second, with respect to the compensation relationship, both exchanges consider a director "not independent", if he/she has accepted a certain level of compensation from the listed company in any of the prior three fiscal years, other than board or committee fees or certain types of deferred compensation. Both exchanges set the same maximum compensation at $\$ 120,000$ in a given year. ${ }^{782}$ However, the NYSE provides two exceptions for this preclusion: (1) compensation received by a director for former service as an interim chairman, CEO, or other executive officer; (2) compensation received by an immediate family member for service as an employee of the listed company (other than an executive officer). ${ }^{783}$ In contrast, the NASDAQ only provides an exception for serving as an interim executive officer. In addition, political contributions to the campaign of a director or a family member of the director would be considered indirect compensation under this preclusion by the NASDAQ. ${ }^{784}$ In comparison with SOX, the NYSE and NASDAQ restrictions for the compensation relationship are relatively loose. Under SOX definition, a director may not accept any compensation from the issuer other than for his/her services as a director, ${ }^{785}$ but the NYSE and NASDAQ rules allow some levels of such compensation without automatically precluding independence. ${ }^{786}$

time during the past three years was, employed by the company." NASDAQ Rule, supra note $5, \S 5605(\mathrm{a})(2)(\mathrm{A})$; Developments in the Law, supra note 428 at 2189.

${ }^{780}$ NYSE Manual, ibid, §303A.02 (b)(i) commentary.

${ }^{781}$ NASDAQ Rule, IM-5605 Definition of Independence - Rule 5605(a)(2).

${ }^{782}$ NYSE Listed Company Manual states: “...a director is not independent, if: ... (ii) The director has received, or has an immediate family member who has received, during any twelve-month period within the last three years, more than $\$ 120,000$ in direct compensation from the listed company, other than director and committee fees and pension or other forms of deferred compensation for prior service (provided such compensation is not contingent in any way on continued service)." NYSE Manual, supra note 5, §303A.02 (b)(ii).

NASDAQ rule provides: “...the following persons shall not be considered independent: ... (B) a director who accepted or who has a family member who accepted any compensation from the company in excess of $\$ 120,000$ during any period of twelve consecutive months within the three years preceding the determination of independence, other than the following: (i) compensation for board or board committee service; (ii) compensation paid to a family member who is an employee (other than an executive officer) of the company; or (iii) benefits under a tax-qualified retirement plan, or non-discretionary compensation.” NASDAQ Rule, ibid, §5605(a)(2)(B).

${ }^{783}$ NYSE Manual, supra note 5, §303A.02 (b)(ii) commentary.

${ }^{784}$ NASDAQ Rules, supra note 5, IM-5605 Definition of Independence - Rule 5605(a)(2).

${ }_{785}^{785}$ Sarbanes-Oxley Act, supra note 4.

${ }^{786}$ Developments in the Law, supra note 428 at 2188-89 n 32; Clarke, Concepts of Independent Directors, supra note 33 at 87-88; see NYSE Manual, supra note 5, §303A.02(b)(ii) and (v); NASDAQ Rule, supra note 5, 
Third, as for the relationship with auditors, the NYSE and NASDAQ each include a provision disqualifying directors who have certain relationships with the issuer's auditors, but the provision of the NYSE is stricter than that of the NASDAQ. Both exchanges preclude a director from being considered as independent, if the director or his/her family member is a current partner of the issuer's outside auditor, or was a partner or employee of the issuer's outside auditor who worked on the issuer's audit during the past three years. However, the NASDAQ does not disqualify a director from being considered independent, when he/she is a current employee of the issuer's auditor, or whose family member is currently employed by the issuer's auditor. On the contrary, the NYSE bars such a director from being considered independent. $^{787}$

Fourth, regarding the cross-compensation committee link, both exchanges contain provisions to reduce the impact of interlocking directorates. A director is considered not independent, if he/she is an executive officer of another corporation where any executive officer of the issuer served on the compensation committee of that corporation for the past three years. The wording of the two exchanges is different, but the spirit of their provisions remains the same. $^{788}$

$\S 5605(a)(2)(B), \S 5605(a)(2)(D)$. The two exceptions only apply to independent directors who do not serve on the audit committee and SOX only applies to audit committee members.

${ }^{787}$ NYSE Listed Company Manual §303A.02(b)(iii) states:

"... a director is not independent, if:

...

(iii) (A) The director is a current partner or employee of a firm that is the company's internal or external auditor; (B) the director has an immediate family member who is a current partner of such a firm; (C) the director has an immediate family member who is a current employee of such a firm and personally works on the listed company's audit; or (D) the director or an immediate family member was within the last three years a partner or employee of such a firm and personally worked on the listed company's audit within that time." NYSE Manual, supra note 5, §303A.02(b)(iii).

NASDAQ Rule $§ 5605(\mathrm{a})(2)(\mathrm{F})$ states:

"...the following persons shall not be considered independent:

$\cdots$

(F) a director who is, or has a family member who is, a current partner of the company's outside auditor, or was a partner or employee of the company's outside auditor who worked on the company's audit at any time during any of the past three years." NASDAQ Rule, supra note 5, §5605(a)(2)(F).

It does not make sense that the NASDAQ does not disqualify a director from being considered independent when he/she (or his/her family member) is a current employee of the issuer's outside auditor. The NASDAQ has barred a director from being considered independent for his/her previous employment of the issuer's outside auditors. Since the current employment of the issuer's outside auditors is more likely to raise the issue of conflict-of-interest than the previous employment, the current employment of the issuer's outside auditors should also be a cause to exclude a director from being considered independent.

${ }^{788}$ NYSE Listed Company Manual §303A.02(b)(iv) states:

"....a director is not independent, if: $\ldots$ 
Fifth, with respect to business relationships, both exchanges have added or enhanced provisions dealing with business connections between the issuer and other entities with which a director is affiliated. ${ }^{789}$ Nevertheless, the restrictions only apply to past payments between the issuer and other entity, rather than a director's past employers. A director becomes independent under the "business relationship" provision immediately upon ceasing to be employed by the other entity. ${ }^{790}$ However, SOX does not restrict significant business relationships between the issuer and any corporation with which the director is employed or serves as an executive officer. These differences reveal an inconsistency between SOX and stock exchange rules.

In addition, the NYSE and NASDAQ provisions regarding business relationships differ substantially in three ways. First, the NYSE restricts the scope of "other entities" to “companies" (excluding charitable organizations), while the NASDAQ considers that "any" organization (including, but not limited to, charitable organizations) is included in "other entities."791 Second, the NASDAQ provision only applies to a director (or his/her family

(iv) The director or an immediate family member is, or has been with the last three years, employed as an executive officer of another company where any of the listed company's present executive officers at the same time serves or served on that company's compensation committee." NYSE Manual, ibid, $\S 303$ A.02(b)(iv).

The NASDAQ Rule §5605(a)(2)(F) states:

"...the following persons shall not be considered independent:

...

(E) a director of the issuer who is, or has a family member who is, employed as an executive officer of another entity where at any time during the past three years any of the executive officers of the issuer serve on the compensation committee of such other entity" NASDAQ Rule, ibid, §5605(a)(2)(F).

${ }^{789}$ NYSE Listed Company Manual 303A.02(b)(v) states:

".... director is not independent, if:

(v) The director is a current employee, or an immediate family member is a current executive officer, of a company that has made payments to, or received payments from, the listed company for property or services in an amount which, in any of the last three fiscal years, exceeds the greater of $\$ 1$ million, or $2 \%$ of such other company's consolidated gross revenues." NYSE Manual, ibid, §303A.02(b)(v).

The NASDAQ Rules 5605(a)(2)(D) states:

"...the following persons shall not be considered independent:

(D) a director who is, or has a family member who is, a partner in, or a controlling shareholder or an executive officer of, any organization to which the company made, or from which the company received, payments for property or services in the current or any of the past three fiscal years that exceed $5 \%$ of the recipient's consolidated gross revenues for that year, or $\$ 200,000$, whichever is more, other than the following:

(i) payments arising solely from investments in the company's securities; or

(ii) payments under non-discretionary charitable contribution matching programs." NASDAQ

Rule, ibid, $\S 5605(\mathrm{a})(2)(\mathrm{D})$.

${ }^{790}$ Developments in the Law, supra note 428 at 2190, n 40.

${ }^{791}$ See ibid. NASDAQ interpretive material explicitly states that charitable organizations are included in the "organization" of the Rule $\S 5605$ (a)(2)(D), while the NYSE commentary states that charitable organizations "shall 
member) who is in a position to exert some control over the other organization (like a partner, a controlling shareholder or an executive officer), while the NYSE provision further extends the scope to a current employee of other organizations. ${ }^{792}$ Finally, the NYSE sets a higher threshold of being considered to have a business relationship between the issuer and other entities than the NASDAQ. The NYSE threshold is $\$ 1$ million or 2\% of the other organization's consolidated gross revenues (whichever is greater), while the NASDAQ threshold is $\$ 200,000$ or $5 \%$ of the other organization's consolidated gross revenues. ${ }^{793}$

Six, as for family member relationships, both exchanges include provisions to extend the above five preclusions to a director's family member. In other words, if a director's family member is involved in one of the five aforementioned relationships, the director is not considered independent. ${ }^{794}$ Both exchanges' definitions of "family member" cover the director's spouse, parents, children, siblings, in-laws of all types, and anyone residing in the director's home, ${ }^{795}$ although the NYSE exempts domestic employees. ${ }^{796}$

\subsubsection{Regulating Board Composition}

In addition to tightening the definition of independent directors, one of the most notable reforms in the post-Enron era is that both the NYSE and NASDAQ, through modifying their listing standards, require public corporations to have a majority of independent directors on their boards, though there is an exception for controlled corporations.

It is worth mentioning that the idea-requiring a board to be comprised of a majority of independent directors-had been proposed by the regulator, scholars and many organizations for more than twenty years, but no such law had been enacted on the national level. Even though corporate scandals, such as Enron and WorldCom, seriously damaged investors' confidence, the

not be considered "companies"” for the purposes of section 303A.02(b)(v). NASDAQ Rule, supra note 5, IM-5605

Definition of Independence - Rule 5605(a)(2); NYSE Manual, supra note 5, §303A.02(b)(v) Disclosure

Requirement.

${ }_{792}$ See NASDAQ Rule, ibid; NYSE Manual, ibid; Developments in the Law, ibid at 2190, n 39.

${ }^{793}$ NYSE Manual, ibid, §303A.02(b)(v) ; NASDAQ Rule, ibid, §5605(a)(2)(D).

${ }^{794}$ See NYSE Manual, ibid, §303A.02(b)(i) (v); NASDAQ Rule, ibid, §5605(a)(2)(A) (F); Developments in the Law, supra note 428 at 2191 \& 2191, n 44. Both the NYSE and NASDAQ apply their employment relationship rule, compensation relationship rule, auditor relationship rule, cross compensation committee link rule, and business relationship rule equally to a director's family member.

${ }^{795}$ Developments in the Law, ibid. at 2191; NASDAQ Rule, ibid, §5605(a)(2); NYSE Manual, ibid, \$303A.02 General Commentary.

${ }^{796}$ NYSE Manual, ibid, §303A.02 General Commentary. 
responding law, the Sarbanes-Oxley Act of 2002, only requires that every public company' audit committee be comprised solely of independent directors. ${ }^{797}$ There is no requirement for a majority of the board members to be independent in SOX.

However, the Act required the SEC to enact rules to direct national securities exchanges and national securities associations in amending their listing rules to ensure that listed corporations comply with certain requirements for audit committees. ${ }^{798}$ In April 2003, the SEC promulgated a new rule, Rule 10A-3, under the Exchange Act, in which each self-regulatory organization (SRO), like the NYSE or NASDAQ, was required to implement standards for audit committees consistent with that rule. Although a number of commentators requested the SEC to impose requirements beyond SOX, the SEC determined not to replace the SRO's role in setting additional criteria, but allowed them to adopt more stringent governance requirements with appropriate Commission oversight. ${ }^{799}$ The SROs took this charge from the SEC and proposed and adopted significant changes that go beyond the audit committee focusing on section 301 and Rule 10A-3. Since 2003, the NYSE and NASDAQ rules both require each listed company to maintain a majority of independent directors on its board. ${ }^{800}$ This was the first time that board composition was required by formal regulation at the national level.

It is worth mentioning that publicly-traded corporations had increasingly adopted the practice of majority-independent boards of directors before the collapse of Enron and WorldCom. ${ }^{801}$ By 2001, at least $75 \%$ of corporations listed on the NYSE or NASDAQ had populated their boards with a majority of independent directors. ${ }^{802}$ Therefore, the board composition required by both exchanges, in fact, enacted already-existing corporate governance practices in a new federal guise. ${ }^{803}$

\subsubsection{Stifling the Influence of Management in the Boardroom}

\footnotetext{
${ }^{797}$ Sarbanes-Oxley Act, supra note 4, §301.

${ }^{798}$ Sarbanes-Oxley Act, ibid, $\$ 301(1)(\mathrm{A})$.

799 Johnson \& Sides, supra note 544 at 1158-59; SEC, Release 33-8220, supra note 765.

${ }^{800}$ NYSE Manual §303A.01 states “[1]isted companies must have a majority of independent directors”, while NASDAQ Rule $\$ 5605(b)(1)$ states: “[a] majority of the board of directors must be comprised of independent directors as defined in Rule 5605(a)(2).” NYSE Manual, supra note 5, §303A.01; NASDAQ Rule, supra note 5, $\S 5605(\mathrm{~b})(1)$.

${ }^{801}$ Cosenza, supra note 391 at 8.

${ }^{802}$ Developments in the Law, supra note 428 at 2182; Bhagat \& Black 2002, supra note 1 at 232-33.

${ }^{803}$ Cosenza, supra note at 8 .
} 
With a view to counteracting the social and psychological forces that currently dampen independent directors' voices, the NYSE and NASDAQ both require boards to hold regular "executive sessions" without any managers in attendance to supplement the independent directors' ability to exercise independent judgment. ${ }^{804}$ The NYSE further recommends that, at each of these executive sessions, the board of directors designate a "lead director" or "presiding director" who is a non-management or independent director to run the meeting. ${ }^{805}$

The purpose of scheduling such a meeting is to promote open discussion among independent directors and prevent any negative inference from attaching to the calling of executive sessions. ${ }^{806}$ Through such an arrangement, independent directors may feel more comfortable raising questions and exploring sensitive issues because they do not have to worry about offending or threatening management, or embarrassing themselves by their relative lack of knowledge. Individual independent directors may, therefore, discover that they are not alone in their questions or concerns, thereby facilitating coalition-building among independent directors in fulfilling their monitoring roles. ${ }^{807}$

It is worth noting that the range of participants in executive sessions required by both exchanges is different. The NYSE rule expands the participants of executive sessions to all nonmanagement directors, ${ }^{808}$ while the NASDAQ rule explicitly limits attendance at such executive sessions to independent directors. ${ }^{809}$ Since non-management directors (referring to those who are not executive officers) may include directors who are not independent by virtue of a material relationship, former status or family membership, or for any other reason, ${ }^{810}$ the goal of having executive sessions-promoting open discussion among independent directors-may not be fulfilled. Therefore, the NYSE requires that each listed company hold an executive session at least once a

\footnotetext{
${ }^{804}$ NYSE Manual, supra note 5, §303A.03; NASDAQ Rule, supra note 5, 5605 (b)(2); Developments in the Law, supra note at 2196.

${ }^{805}$ NYSE Manual, ibid; §303A.03 Commentary; Cosenza, supra note 391 at 13.

${ }^{806}$ NYSE, ibid.

${ }^{807}$ Developments in the Law, supra note 428 at 2196, 2196 n 65.

808 The NYSE Listed Company Manual 303A.03 provides that

"[t]o empower non-management directors to serve as a more effective check on management, the nonmanagement directors of each listed company must meet at regularly scheduled executive sessions without management." NYSE Manual, supra note 5, §303A.03.

${ }^{809}$ The NASDAQ Rule 5605 (b)(2) states: "[i]ndependent directors must have regularly scheduled meetings at which only independent directors are present ("executive sessions")." NASDAQ Rule, supra note 5, 5605 (b)(2).

${ }^{810}$ NYSE Manual, supra note 5, §303A.03 Commentary. With respect to the differences between non-management directors and independent directors, please refer to supra notes 32-39 and accompanying text.
} 
year for only independent directors. ${ }^{811}$ In order to encourage and enhance communication among independent directors, the NASDAQ requires that executive sessions must be held at least twice a year. $^{812}$

With respect to a "lead director", the NYSE requires that each executive session of nonmanagement directors must be presided over by a non-management director designated by the board of directors, while executive sessions of independent directors must be in the charge of an independent director. ${ }^{813}$ If one director is chosen to preside at all of these meetings, his or her name must be revealed in the listed company's website or its annual proxy statement. In order to encourage interested parties to make their concerns known to non-management directors, the NYSE required that each listed company disclose a method for such parties to communicate directly with the presiding director or with the non-management directors as a group. Such disclosure must be provided in the listed company's website or its annual proxy statement. ${ }^{814}$

\subsubsection{Mandating Three Key Board Functions: Auditing Supervision, Setting Executive Compensation and Nomination of New Directors}

One of the distinctive features of the post-SOX reforms is that stock exchanges assign three key board functions, namely the review of auditing, director nomination and setting executive compensation, explicitly to independent directors only. In other words, all decisions regarding the three functions must be made (or recommended to the board) by independent directors. The difference between the two exchanges is that the NYSE requires such decisions (or recommendations) to be made by standing fully independent committees, while NASDAQ gives listed corporations the option of approval by a majority vote of all independent directors or entirely independent committees. ${ }^{815}$ The following analysis starts with the board's financial reporting oversight function.

\subsection{The Board's Financial Reporting Oversight Function}

The establishment of a board's financial reporting oversight function can be traced back

\footnotetext{
${ }^{811}$ Ibid.

${ }^{812}$ NASDAQ Rule, supra note 5, IM-5605-2 Executive Sessions of Independent Directors.

${ }^{813}$ NYSE Manual, supra note 5, §303A.03 Commentary.

${ }^{814}$ NYSE Manual, supra note 5, §303A.03 Disclosure Requirements.

${ }^{815}$ Developments in the Law, supra note 428 at 2192.
} 
to a 1939 NYSE report. ${ }^{816}$ In 1978 , the NYSE started to require its listed corporations to establish and maintain an audit committee with a minimum of two directors who are independent from the corporation. ${ }^{817}$ In 1999, in response to the Blue Ribbon Committee's recommendations, both the NYSE and the NASDAQ further amended their listing requirements to require that each listed company maintain an audit committee composed of a minimum of three members, each of whom is financially literate and entirely independent of management, and at least one of whom has financial expertise. The audit committee and the board of directors are granted the ultimate authority and responsibility to select, evaluate and replace the outside auditors. ${ }^{818}$ The current legal regime regarding a board's auditing oversight is built on this foundation.

\subsection{Composition of the Audit Committee and the Qualification of the Audit Committee Members}

In response to corporate scandals in the new millennium, SOX adopted five measures to enhance the oversight function of the audit committee, in addition to director independence. ${ }^{819}$ First, the audit committee must be directly responsible for appointing, remunerating, and monitoring outside auditors. ${ }^{820}$ Second, the committee must be empowered to retain independent counsel and other advisors. ${ }^{821}$ Third, the issuer must provide sufficient funding, as the committee determines, to pay outside auditors and committee advisors. ${ }^{822}$ Four, the SEC must

\footnotetext{
${ }^{816}$ The report acknowledged that corporate directors should nominate or select independent auditors in order to ensure the independence of outside auditors. The process could be through a special committee of the board composed of directors who were not officers. Lutzy, supra note 97 at 100.

${ }^{817}$ Karmel, Listing Requirements, supra note at 104 at 340-41; American Bar Association, Special Study on Listing Standards, supra note 104 at 1507; Lutzy, ibid at 101.

${ }^{818}$ BRC Report, supra note 232 at 1074.

${ }^{819}$ Cunningham, supra note 271 at 946-47.

${ }^{820} \mathrm{SOX} \S 301(2)$ provides that "[t]he audit committee of each issuer, in its capacity as a committee of the board of directors, shall be directly responsible for the appointment, compensation, and oversight of the work of any registered public accounting firm employed by that issuer (including resolution of disagreements between management and the auditor regarding financial reporting) for the purpose of preparing or issuing an audit report or related work, and each such registered public accounting firm shall report directly to the audit committee." Sarbanes-Oxley Act, supra note $4, \S 301(2)$.

${ }^{821}$ SOX $\$ 301(5)$ provides that "[e]ach audit committee shall have the authority to engage independent counsel and other advisers, as it determines necessary to carry out its duties." Sarbanes-Oxley Act, supra note 4, §301(5).

${ }^{822}$ SOX $\$ 301(6)$ provides that "[e]ach issuer shall provide for appropriate funding, as determined by the audit committee, in its capacity as a committee of the board of directors, for payment of compensation-

(A) to the registered public accounting firm employed by the issuer for the purpose of rendering or issuing an audit report; and
} 
adopt rules requiring quarterly and annual disclosure of whether at least one audit committee member is a "financial expert" and, if not, why not. ${ }^{823}$ Five, committees must establish procedures to promote employee reporting of misconduct and protect reporting employees. ${ }^{824}$ Except for the last one, all measures merely formalized the existing stock exchange rules or current state law provisions as federal requirements. ${ }^{825}$ In fact, SOX did not mandate the composition of audit committees or the qualification of audit committee members (except for the financial expert aforementioned).

With respect to stock exchange rules, although both the NYSE and the NASDAQ amended their listing requirements after the wave of corporate scandals, nothing has been changed regarding the audit committee's composition, financial experts and financial literacy, in comparison with their 1999 rules. As noted, since 1999, the NYSE and NASDAQ have required each listed company to maintain an audit committee composed of a minimum of three members, each of whom shall be financial literate, and at least one of whom must have financial expertise. ${ }^{826}$ Whether an audit committee member meets those requirements is left to the judgment of the board of directors. ${ }^{827}$ The NYSE does not specify the content of financially literate or financial expertise, ${ }^{828}$ but the NASDAQ defines "financially literate" as the ability to read and understand a company's balance sheet, income statement, and cash flow statement fundamentally. ${ }^{829}$ The latter also interprets "financial expertise" as "past employment experience in finance or accounting, requisite professional certification in accounting, or any other comparable experience or background which results in the individual's financial sophistication."

(B) to any advisers employed by the audit committee under paragraph (5)." Sarbanes-Oxley Act, supra note $4, \S 301(6)$.

${ }^{823}$ Sarbanes-Oxley Act of 2002, Pub L No 107-204, §407, 116 Stat 790 (codified in scattered sections of 11, 15, 18, $28 \& 29$ USC [Sarbanes-Oxley Act §407]; Cunningham, supra note 271 at 948.

${ }^{824}$ SOX§301(4) provides that "[e]ach audit committee shall establish procedures for-

(A) the receipt, retention, and treatment of complaints received by the issuer regarding accounting, internal accounting controls, or auditing matters; and

(B) the confidential, anonymous submission by employees of the issuer of concerns regarding questionable accounting or auditing matters." Sarbanes-Oxley Act, supra note 4, §301(4).

${ }^{825}$ In fact, appointing outside auditors and the qualification of a financial expert has been included in both the NYSE and NASDAQ audit committee rules since 1999. Some state laws allow audit committees to hire outside advisors and to compensate them and auditors. Cunningham, supra note 271 at 947.

${ }^{826}$ NYSE Manual, supra note 5, §303A.07(a) and its commentary; NASDAQ Rule, supra note 5, §5605 (c)(2)(A).

${ }^{827}$ NYSE Manual, ibid, \$303A.07(a) commentary; See NASDAQ Rule, ibid, $\$ 5605$ (c)(2)(B).

${ }^{828}$ The NYSE only uses "accounting or related financial management expertise" to describe "financial expertise". NYSE Manual, ibid, \$303A.07(a) Commentary.

${ }^{829}$ NASDAQ Rule, supra note 5, §5605 (c)(2)(A)(iv). 
Experience as a chief executive officer, chief financial officer or other senior officer with financial oversight responsibilities is all considered as "financial expertise" by the NASDAQ. ${ }^{830}$

As mentioned previously, all audit committee members must satisfy the requirements for independence mandated by SOX, the SEC rules and the stock exchange's listing criteria. However, the NASDAQ allows an exception permitting a director who does not meet the independence requirements, but conforms to certain criteria, to be appointed to the audit committee, if the board determines that it is the best interests of the company ${ }^{831}$ In contrast, the NYSE does not have a similar provision. Furthermore, the NASDAQ has an additional requirement that each audit committee member must not have participated in the preparation of the financial statements of the company, or any current subsidiary of the company, at any time during the past three years. ${ }^{832}$

Taken together, current law and regulations, including SOX, the SEC regulations and stock exchange rules, are based on the belief that the independence and financial expertise of the audit committee members are the main determinants of whether an audit committee can effectively ensure the quality of financial reporting. The independent director(s) who has (have) financial expertise is (are) supposed to undertake the key responsibility to lead the committee members to detect whether there is management misconduct in the financial reporting process. As a result, whether current rules regarding financial expertise can achieve this goal are worth discussing. This thesis explores this important issue in the subsequent subsection.

\subsection{Issues Related to Financial Expertise}

As stated previously, SOX mandated that each public corporation disclose in its annual

\footnotetext{
${ }^{830}$ NASDAQ Rule, ibid, $\$ 5605$ (c)(2)(A).

${ }^{831}$ The NASDAQ Rule 5605(c)(2)(B) states: “...one director who: (i) is not independent as defined in Rule 5605(a)(2); (ii) meets the criteria set forth in Section $10 \mathrm{~A}(\mathrm{~m})(3)$ under the Act and the rules thereunder; and (iii) is not a current officer or employee or a family member of such officer or employee, may be appointed to the audit committee, if the board, under exceptional and limited circumstances, determines that membership on the committee by the individual is required by the best interests of the company and its shareholders. A company...that relies on this exception must comply with the disclosure requirements... A member appointed under this exception may not serve longer than two years and may not chair the audit committee."

${ }^{832}$ The NASDAQ Rule 5605(c)(2)(A) states

"[e]ach issuer must have, and certify that it has and will continue to have, an audit committee of at least three members, each of whom must:

(iii) not have participated in the preparation of the financial statements of the company or any current subsidiary of the company at any time during the past three years;"
} 
report or proxy statement whether its audit committee has at least one financial expert defined by the SEC. If the corporation does not have a financial expert, it must explain why in its periodic reports. ${ }^{833}$ Thus, having a financial expert on the audit committee is not mandatory under SOX. Unlike SOX, both NYSE and NASDAQ require that at least one independent director in the audit committee have financial expertise. However, the definition of "financial expert" has not been sufficiently specified by either stock exchange; therefore, issuers must rely on the SEC criteria to select a financial expert to sit on their audit committees. ${ }^{834}$

SOX has provided the SEC with guidance in determining how a director qualifies as a financial expert. ${ }^{835}$ In defining the term "financial expert," the SEC is required to consider:

...whether a person has, through education and experience as a public accountant or auditor or a principal financial officer, comptroller, or principal accounting officer of an issuer, or from a position involving the performance of similar functions-

(1) an understanding of general accepted accounting principles and financial statements;

(2) experience in-

(A) the preparation of auditing of financial statements of generally comparable issuers; and

(B) the application of such principles in connection with the accounting for estimates, accruals and reserves;

(3) experience with internal accounting controls; and

(4) an understanding of audit committee functions. ${ }^{836}$

However, the SEC's final rules adopt a relatively loose definition of "financial expert" and provide safe harbors to protect financial experts from liability, which raise a concern that the new rules may diminish the significance of having a financial expert on the audit committee and deprive investors of the additional layer of oversight of financial reporting imposed by SOX. ${ }^{837}$ The related issues are discussed in the following subsections.

\subsection{The Definition of Financial Experts}

Originally, the SEC focused on a director's actual experience with accounting matters at a

\footnotetext{
${ }^{833}$ See Sarbanes-Oxley Act $\$ 407$, supra note 823.

${ }^{834}$ Congress directs the SEC to adopt rules to implement the section 407 of SOX and provided the SEC with guidance in determining how a director qualifies as a financial expert. Sarbanes-Oxley Act $\$ 407$ (a), ibid.

835 Sarbanes-Oxley Act $\$ 407(\mathrm{a})$, ibid.

${ }^{836}$ Sarbanes-Oxley Act $\$ 407(\mathrm{~b})$, ibid.

${ }^{837}$ Jeffrey M McFarland, "Good News Investors! You've Got A Financial Expert on the Board The Bad News? It Doesn’t Mean Anything” (2006) 2 Hastings Business L J 165 at 191, 201[McFarland].
} 
public company. As a result, its proposed definition required a person to have five attributes ${ }^{838}$, which must have been gained through education and experience as an accountant or auditor, or as a principal financial officer, controller or principal accounting officer of an Exchange Act reporting company. ${ }^{839}$ In determining whether a potential financial expert has all of the requisite attributes, the board of directors must evaluate the totality of an individual's education and experience, and consider ten factors ${ }^{840}$ in making such evaluation. Under this definition, only directors who currently have (or have previously had) work experience as certified public accountants, auditors, or principal/chief financial officers, controllers or principal/chief

${ }^{838}$ To qualify as a financial expert, a person have to possess all of the following attributes:

1. An understanding of generally accepted accounting principles and financial statements;

2. Experience applying such generally accepted accounting principles in connection with the accounting for estimates, accruals, and reserves that are generally comparable to the estimates, accruals and reserves, if any, used in the registrant's financial statements;

3. Experience preparing or auditing financial statements that present accounting issues that are generally comparable to those raised by the registrant's financial statements;

4. Experience with internal controls and procedures for financial reporting; and

5. An understanding of audit committee functions.

SEC, Proposed Rule: Disclosure Required by Sections 404, 406 and 407 of the Sarbanes-Oxley Act of 2002, Exchange Act Release No. 34-46701 (22 October 2002), online: SEC < http://www.sec.gov/rules/proposed/338138.htm>.

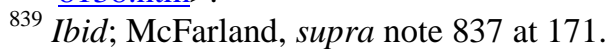

${ }^{840}$ The SEC requires a company to consider a variety of factors in making that evaluation, including:

1. The level of the person's accounting or financial education, including whether the person has earned an advanced degree in finance or accounting;

2. Whether the person is a certified public accountant, or the equivalent, in good standing, and the length of time that the person actively has practiced as a certified public accountant, or the equivalent;

3. Whether the person is certified or otherwise identified as having accounting or financial experience by a recognized private body that establishes and administers standards in respect of such expertise, whether that person is in good standing with the recognized private body, and the length of time that the person has been actively certified or identified as having this expertise;

4. Whether the person has served as a principal financial officer, controller or principal accounting officer of a company that, at the time the person held such position, was required to file reports pursuant to Section 13(a) or 15(d) of the Exchange Act, and if so, for how long;

5. The person's specific duties while serving as a public accountant, auditor, principal financial officer, controller, principal accounting officer or position involving the performance of similar functions;

6. The person's level of familiarity and experience with all applicable laws and regulations regarding the preparation of financial statements that must be included in reports filed under Section 13(a) or 15(d) of the Exchange Act;

7. The level and amount of the person's direct experience reviewing, preparing, auditing or analyzing financial statements that must be included in reports filed under Section 13(a) or 15(d) of the Exchange Act;

8. The person's past or current membership on one or more audit committees of companies that, at the time the person held such membership, were required to file reports pursuant to Section 13(a) or 15(d) of the Exchange Act;

9. The person's level of familiarity and experience with the use and analysis of financial statements of public companies; and

10. Whether the person has any other relevant qualifications or experience that would assist him or her in understanding and evaluating the registrant's financial statements and other financial information.

SEC, ibid. 
accounting officers of reporting companies can be considered financial experts.

After contemplating many commenters' opinions, the SEC issued its final rule in implementing section 407 of the Sarbanes-Oxley Act regarding the definition of "financial expert" in early 2003. ${ }^{841}$ In order to ensure a sufficient pool of available candidates who are financial experts and reduce the misgivings that serving as a "financial expert" may increase risk of personal liability under section 11 of the Securities Act of $1933^{842}$ and state law fiduciary duty and duty of care, the SEC broadened the definition of audit committee "financial expert" and added safe harbors to protect financial experts from liability. ${ }^{843}$ (The issues regarding the safe harbors will be discussed in the next subsection.)

The final rule specifies that a person must have the following attributes to qualify a financial expert:

(1) An understanding of generally accepted accounting principles and financial statements;

(2) The ability to assess the general application of such principles in connection with the accounting for estimates, accruals and reserves;

(3) Experience preparing, auditing, analyzing or evaluating financial statements that present a breadth and level of complexity of accounting issues that are generally comparable to the breadth and complexity of issues that can reasonably be expected to be raised by the registrant's financial statements, or experience actively supervising one or more persons engaged in such activities;

(4) An understanding of internal controls and procedures for financial reporting; and

(5) An understanding of audit committee functions. ${ }^{844}$

In addition, the final rule required that a person must have the above attributes through one or more of the following channels:

(1) Education and experience as a principal financial officer, principal accounting officer, controller, public accountant or auditor or experience in one or more positions that involve the performance of similar functions;

(2) Experience actively supervising a principal financial officer, principal accounting officer, controller, public accountant, auditor or person performing similar functions;

(3) Experience overseeing or assessing the performance of companies or public accountants with respect to the preparation, auditing or evaluation of financial statements; or Other relevant experience. ${ }^{845}$

\footnotetext{
${ }^{841}$ SEC, Disclosure Required by Sections 404, 406 and 407 of the Sarbanes-Oxley Act of 2002, Exchange Act Release No. 34-47235 (23 January 2003), online: SEC <http://www.sec.gov/rules/final/33-8177.htm> [SEC, Financial Expert Final Rule]; McFarland, supra note 837 at 166.

${ }^{842}$ Section 11 of the Securities Act imposes liability for material misstatements and omissions in a registration statement signed by certain "experts," but provides a defense to liability for those who perform adequate due diligence. Escott v BarChris Construction Corp, 283 F Supp 643 (SDNY 1968). For example, accountants would be subject to liability under section 11 for signing off on misleading financial statements included in a registration statement. In order to avoid a "financial expert" to be considered as an "expert" under federal securities law, the SEC provides a safe harbor for financial experts in the audit committee. SEC, ibid.; McFarland, ibid at 176.

${ }^{843}$ McFarland, ibid at 190-91.

${ }^{844}$ SEC, Financial Expert Final Rule, supra note 841.
} 
The SEC rules give the board of directors the discretion to decide whether a person qualifies under the definition of "financial expert." After the company's board determines that at least one of the audit committee members qualifies as an expert, the company must disclose the expert's name. $^{846}$

In contrast to the SEC's proposed rules, the SEC's final rules manifestly loosen the requirements of "financial expert." For example, the proposed rules only allowed a person who has experience "preparing or auditing" financial statements in the reporting company to qualify as a financial expert, but the final rules broaden the experience to "analyzing or evaluating" financial statements, in addition to the experience of "preparing or auditing" financial statements. The final rules also allowed supervision of financial personnel to substitute for that experience. ${ }^{847}$ These changes may permit people who may not have sufficient accounting knowledge or experience, such as some CEOs or securities analysts, to qualify as financial experts with the required attributes. ${ }^{848}$ Under such a definition, directors who currently have (or have previously had) work experience as investment bankers, venture capitalists, financial analysts, financial consultants, even chief executive officers, chief operating officers, company presidents (or vice presidents), or chairpersons of the board are all qualified as financial experts.

In addition, the proposed rules required the board to evaluate ten factors to determine whether a person has the attributes of a financial expert, but the final rules shortened these standards to one of four attributes. Both the proposed rules and the final rules adopted a catch-all provision for determining whether a person has acquired the attributes of a financial expert, but the final one used the simple phrase "other relevant experience" to replace the more detailed description $^{849}$ in the proposed one, significantly deleting the key words "that would assist him in understating and evaluating financial information." This may open a back door for some marginally-qualified candidates. Although the final rules require the board to disclose a person's relevant experience if the catch-all category is used, this requirement can simply be satisfied by

\footnotetext{
${ }^{845}$ Ibid.

${ }^{846}$ Ibid.

${ }^{847}$ McFarland, supra note 837 at 192-93.

${ }^{848}$ Several later empirical studies have supported this point of view. Please refer to section 5.1.5.1.2.3 regarding the connection between financial expertise and the quality of financial reporting.

${ }^{849}$ The proposed rules stated "any other relevant qualifications or experience that would help him in understanding and evaluating financial information and making knowledgeable and thorough inquiries about the integrity of the financial reporting process."
} 
including the director biography that the company is already required to provide under the proxy statement rules. ${ }^{850}$ Based on the aforementioned defects, Professor McFarland believes that the final rules give investors the illusion that they have additional safeguards through financial experts, but in fact nothing has changed. ${ }^{851}$

\subsection{2 Safe Harbor}

In addition to the definition issue of financial experts, the safe harbors adopted by the SEC final rules may deprive investors of the additional layer of oversight of financial reporting that SOX originally intended to provide. ${ }^{852}$ With a view to increasing the incentives for directors to serve as financial experts on the audit committee, the SEC adopted safe harbors to clarify that audit committee financial experts would not be subject to a higher degree of individual responsibility or obligation than other audit committee members. The final SEC rules provide that:

(1) A person who is determined to be an audit committee financial expert will not be deemed an "expert" for any purpose, including without limitation for purposes of Section 11 of the Securities Act, as a result of being designated or identified as an audit committee financial expert pursuant to the new disclosure item;

(2) The designation or identification of a person as an audit committee financial expert pursuant to the new disclosure item does not impose on such person any duties, obligations or liability that are greater than the duties, obligations and liability imposed on such person as a member of the audit committee and board of directors in the absence of such designation or identification; and

(3) The designation or identification of a person as an audit committee financial expert pursuant to the new disclosure item does not affect the duties, obligations or liability of any other member of the audit committee or board of directors. ${ }^{853}$

However, Professor McFarland raised an issue about such safe harbors. He supported the safe harbor that the audit committee experts are not "experts" for purposes of section 11 of the Securities Act of 1933, because it was never the intent of section 407 of SOX to elevate the financial expert to the expertise level of certified public accountants. However, he disagreed with the SEC rules that financial experts do not have any duties, obligations or liabilities greater than those imposed on other members of the audit committee or board. ${ }^{854}$

He believes that the SEC's safe harbor has invaded the territory of the state law duty of

\footnotetext{
${ }^{850}$ McFarland, supra note 837 at 192-93.

${ }^{851} \mathrm{Ibid}$ at 191.

${ }^{852}$ Ibid.

${ }^{853}$ SEC, Financial Expert Final Rule, supra note 841.

${ }^{854}$ McFarland, supra note 837 at 199.
} 
care, in which the SEC has no authority. An audit committee member who has significant financial expertise should shoulder a higher standard of care than those who do not. The safe harbor should leave the liability of a financial expert where it belongs. The purpose of section 407 of SOX is to provide an additional layer of oversight of financial reporting and additional protection of investors. If the financial expert has no duties, obligations or liabilities greater than that of the other audit committee members, then the designation of a financial expert appears to do nothing to the investment protection landscape. It is worth noting that if financial experts are expected to pay more attention to their responsibilities, some additional incentives, such as a higher remuneration, should be provided to encourage them to be attentive to their duties. ${ }^{855}$

\section{Summary of Issues Related to Financial Expertise}

Although current rules regarding financial experts have attracted criticism, there is no doubt that the independent directors who have the financial expertise have been entrusted with key role of ensuring the quality of financial reporting.

\subsection{Charter and Responsibilities (of the Audit Committee)}

In addition to the committee composition and member qualification, adopting a formal written audit committee charter has been required by the NYSE and NASDAQ since $1999 .{ }^{856}$ SOX did not require the adoption of a written charter for any committee under the board, but mandated certain missions for audit committees of public corporations. ${ }^{857}$ In 2003, the NYSE and the NASDAQ, accommodating the content of SOX and related interpretation of the SEC, revised their listing requirements regarding written committee charters. The NYSE requires that all three key committees, namely the audit, compensation and nominating committees, must have their own formal written charters addressing the committee's purposes, responsibilities and

\footnotetext{
${ }^{855}$ Ibid at 198-200.

${ }^{856}$ NYSE 1999 Rules, supra note 246; NASD 1999 Rules, supra note 246.

${ }^{857}$ In addition to director independence, SOX $\$ 301$ requires that an audit committee must: (1) be directly responsible for appointing, remunerating, and monitoring outside auditors; (2) be empowered to retain independent counsel and other advisors; (3) be provided sufficient funding to pay outside auditors and committee advisors; (4) establish procedures to promote employee reporting of misconduct and protect reporting employees. Please refer to section 4.1.2.4.1.1.
} 
annual performance evaluation, ${ }^{858}$ while the NASDAQ only mandates that the audit committee must have a written charter addressing similar issues. ${ }^{859}$

However, the current mandatory content of the audit committee between the NYSE and NASDAQ is slightly different. The NYSE focuses on the committee's purpose, annual performance evaluation, and its duties and responsibilities, ${ }^{860}$ while the NASDAQ emphasizes the scope and implementation of the committee's responsibilities, and the committee's purpose, especially the responsibilities for ensuring the independent status of outside auditors. ${ }^{861}$ In comparison with their 1999 version, the requirements regarding the purpose of the committee are new for companies listed in both stock exchanges.

With respect to the content of committee purposes, the NYSE requires, at minimum, that two purposes-assisting board oversight of accounting matters and preparing an audit committee report-must be included in the charter. ${ }^{862}$ In contrast, the NASDAQ only used a few concise words to delineate the purpose of the audit committee. It considers that "overseeing the accounting and financial reporting processes of the issuers and the audits of the financial statements of the issuer" defines the committee's purpose. ${ }^{863}$

Moreover, the NYSE adds a new requirement-an annual performance evaluation-in its audit committee charter, while the NASDAQ states nothing about such a review. According to best practices, such self-review should be done each year. ${ }^{864}$ However, there is no specific guidance in the listing requirements as to what this self-evaluation should do. Four possible topics are suggested to be included in the review, namely: (1) a comparison of the committee's activities vs. the charter; (2) a comparison of the committee's activities vs. formal industry recommendations and rules; (3) a comparison against best practices as provided in industry

\footnotetext{
${ }^{858}$ NYSE Manual, supra note 5, §303A.07(b), §303A.04(b), §303A.05(b).

${ }^{859}$ NASDAQ Rule, supra note $5, \S 5605(\mathrm{c})(1)$.

${ }^{860}$ NYSE Manual, supra note 5, $\$ 303$ A.07(b)(i)-(iii).

${ }^{861}$ NASDAQ Rule, supra note 5, §5605(c)(1)(A)-(D).

862 The NYSE Listed Company Manual \$303A.07(b)(i) states:

(i) the committee's purpose which, at minimum, must be to:

(A) assist board oversight of (1) the integrity of the listed company's financial statements, (2) the listed company's compliance with legal and regulatory requirements, (3) the independent auditor's qualifications and independence, and (4) the performance of the listed company's internal audit function and independent auditors; and

(B) prepare an audit committee report as required by the SEC to be included in the listed company's annual proxy statement. NYSE Manual, supra note 5, §303A.07(b)(i).

${ }^{863}$ NASDAQ Rule, supra note $5, \S 5605(\mathrm{c})(1)(\mathrm{C})$.

${ }^{864}$ Lutzy, supra note 97 at 111-12.
} 
guidelines; and (4) the level of involvement and performance by each member in the committee's activities. ${ }^{865}$ It is worth noting that audit committees may be reluctant to document this evaluation because it may lead to possible liability implications. ${ }^{866}$

As for the approach of mandating audit committee responsibilities, the two stock exchanges adopt different methods. The NYSE precisely delineates the duties and responsibilities of the audit committee, while the NASDAQ only repeats what SOX and the SEC rules have required. The duties and responsibilities required by the NYSE are compiled as follows. The first two are duties required by SOX. The rest of them are duties required by the NYSE only. In fact, most of these duties have been complied with in practice for years.

The duties and responsibilities of the audit committee for firms listed in the NYSE are to:

(1) select, compensate and oversee the independent auditor; ${ }^{867}$

(2) establish a complaint procedure for reporting questionable accounting or auditing matters; ${ }^{868}$

(3) obtain and review a required report by the independent auditor; ${ }^{869}$

(4) discuss annual and quarterly financial statements with management and the independent auditor; ${ }^{870}$

${ }_{865}^{865}$ Ibid at 112.

${ }^{866} \mathrm{Ibid}$.

${ }^{867}$ SOX $\$ 301(2)$ provides that " $[\mathrm{t}]$ he audit committee of each issuer... shall be directly responsible for the appointment, compensation, and oversight of the work of any registered public accounting firm employed by that issuer... and each such registered public accounting firm shall report directly to the audit committee." SarbanesOxley Act, supra note 4, $\$ 301(2)$.

${ }^{868}$ SOX $\$ 301(4)$ states:

"each audit committee shall establish procedure for:

(A) the receipt, retention, and treatment of complaints received by the issuer regarding accounting, internal accounting controls, or auditing matters; and

(B) the confidential, anonymous submission by employees of the issuer of concerns regarding questionable accounting or auditing matters.” Sarbanes-Oxley Act, supra note 4, §301(4).

${ }^{869}$ The NYSE Listed Company Manual §303A.07(b)(iii) states:

"the duties and responsibilities of the audit committee...must include...(A) at least annually, obtain and review a report by the independent auditor describing: the firm's internal quality-control procedures; any material issues raised by the most recent internal quality-control review, or peer review, of the firm, or by any inquiry or investigation by governmental or professional authorities, within the preceding five years, respecting one or more independent audits carried out by the firm, and any steps taken to deal with any such issues; and (to assess the auditor's independence) all relationships between the independent auditor and the listed company.” NYSE Manual, supra note, §303A.07(b)(iii).

${ }^{870}$ The NYSE Listed Company Manual 3303 A.07(b)(iii) states:

"the duties and responsibilities of the audit committee...must include...(B) meet to review and discuss the listed company's annual audited financial statements and quarterly financial statements with management and the independent auditor, including reviewing the company's specific disclosures under "Management's Discussion and Analysis of Financial Condition and Results of Operations." Ibid. 
(5) discuss earnings press releases and earnings guidance provided to analyst and rating agencies; ${ }^{871}$

(6) discuss risk assessment policies and procedure with management; ${ }^{872}$

(7) periodically meet separately with management, internal auditors and external auditors; ${ }^{873}$

(8) review with the independent auditor any audit problems; ${ }^{874}$

(9) establish and review hiring policies for current and former employees of the independent auditor ${ }^{875}$ and

(10) regularly report to the board of directors ${ }^{876}$

\section{Summary of the Board's Financial Reporting Oversight Function}

The rules regarding the establishment, member qualification, composition, the financial expertise, content of charter, and responsibilities of the audit committee are largely alike except for slight differences between the NYSE and NASDAQ. There seems to be a common thread running through these rules that independent directors are relied on as corporate monitors to ensure the accuracy of financial statements and the quality of financial reporting.

${ }^{871}$ The NYSE Listed Company Manual §303A.07(b)(iii) states: "the duties and responsibilities of the audit committee...must include...(C) discuss the listed company's earnings press releases, as well as financial information and earnings guidance provided to analysts and rating agencies." Ibid.

${ }^{872}$ The NYSE Listed Company Manual §303A.07(b)(iii) states: "the duties and responsibilities of the audit committee...must include...(D) discuss policies with respect to risk assessment and risk management." Ibid.

${ }^{873}$ The NYSE Listed Company Manual §303A.07(b)(iii) states: "the duties and responsibilities of the audit committee...must include...(E) meet separately, periodically, with management, with internal auditors (or other personnel responsible for the internal audit function) and with independent auditors." Ibid.

${ }^{874}$ The NYSE Listed Company Manual \$303A.07(b)(iii) states: "the duties and responsibilities of the audit committee...must include...(F) review with the independent auditor any audit problems or difficulties and management's response." Ibid.

875 The NYSE Listed Company Manual §303A.07(b)(iii) states: "the duties and responsibilities of the audit committee...must include...(G) set clear hiring policies for employees or former employees of the independent auditors." Ibid.

${ }^{876}$ The NYSE Listed Company Manual §303A.07(b)(iii) states: "the duties and responsibilities of the audit committee...must include...(H) report regularly to the board of directors." Ibid. 


\subsection{The Board's Director Nomination Oversight Function}

The rationale for an independent nominating committee is to nominate directors who are truly independent of management, and who are able and willing to ask incisive and probing questions in the boardroom. Since CEOs, especially in the pre-SOX period, usually dominated the director nomination and selection process, directors chosen in this way were inclined to passively consent to management's policies and decisions, rather than actively challenge them. ${ }^{877}$ In order to reduce or even exclude the CEO's substantial influence over the nomination, such a job should be done by a group of people who are free from financial or social ties, friendship or any type of control or influence by the CEO or the company. So far, independent directors are considered as the best candidates to implement this mission. ${ }^{878}$

However, the experience of the Enron and WorldCom scandals demonstrates that nominating committees, before SOX reforms, did not fulfill their responsibilities to nominate proper candidates capable of monitoring management. These directors were either attached to management and failed to ask any discerning questions in the boardroom or were unable to uncover senior manager's accounting misconduct. ${ }^{879}$ The ineffectiveness of the previous nominating committees caused regulators to reconsider how to establish an effective nominating committee.

\subsection{The Establishment and Composition of the Nominating Committee}

SOX did not mandate that a reporting company must have a nominating committee. The SEC left the discretion to the stock exchanges to determine whether a listing company must have a nominating committee. The NYSE requires that listed companies have a nominating/corporate governance committee composed solely of independent directors, ${ }^{800}$ while the NASDAQ left it up to the discretion of each company. If a NASDAQ-listed company decides to have a nominations committee ${ }^{881}$, however, the committee must be composed entirely of independent

\footnotetext{
${ }^{877}$ Please refer to section 3.1 "Biases in the Nomination and Selection Process"; Kaura, supra note 8 at 40-42.

${ }^{878}$ Please refer to section 2.1.1.4 of this thesis; Kaura, ibid.

${ }^{879}$ Please refer to section 2.2.1.3 of this thesis.

${ }^{880}$ NYSE Manual, supra note 5, §303A.04(a).

${ }^{881}$ It is worth mentioning that the NASDAQ uses the term "a nominations committee" to address matters regarding director nominee selection, not the term "a nominating committee" that is used more popularly. See NASDAQ Rule, supra note 5, §5605(e)(1)(B).
} 
directors. ${ }^{882}$ However, the NASDAQ allowed an exception for a nomination committee with at least three members. Under such a special circumstance, one director, who does not meet the "independence" requirements, but is in conformity with certain criteria, may be appointed to such a nominating committee, if the board determines that it is in the best interests of the company. ${ }^{883}$ In contrast, the NYSE does not have any similar exception. This exception seems to open the back door for affiliated directors and the independence of the nominating committee may be compromised.

\subsection{Charter and Responsibilities}

The way of mandating charter and responsibilities of the nominating committee between the NYSE and NASDAQ is different. The NASDAQ only briefly requires that the nominations process and related matters be addressed through its formal written charter or board solution, but says nothing regarding duties and responsibilities. ${ }^{884}$ In contrast, the NYSE precisely delineates the duties and responsibilities of the nominating committee and what must be included in the nominating committee charter. ${ }^{885}$

The NYSE requires that the nominating/corporate governance committee have a written charter addressing two missions: (1) the committee's purpose and responsibilities, and (2) an annual performance evaluation of the committee. With respect to nomination responsibilities, the nominating committee is required to identify qualified director candidates consistent with the board's criteria and recommend appropriate nominees for the next annual shareholder meeting. Regarding corporate governance duties, the committee must develop and recommend to the board a set of corporate governance guidelines suitable for the company and then monitor the

\footnotetext{
${ }^{882}$ NASDAQ Rule $§ 5605(\mathrm{e})(1)$ states:

"[d]irector nominees must either be selected, or recommended for the Board's selection, either by:

(A) independent directors constituting a majority of the board's independent directors in a vote in which only independent directors participate, or

(B) a nominations committee comprised solely of independent directors.” Ibid, §5605(e)(1).

${ }^{883}$ NASDAQ Rule $\$ 5605(\mathrm{e})(3)$ states:

"... if the nominations committee is comprised of at least three members, one director, who is not independent as defined in Rule 5605(a)(2) and is not a current officer or employee or a family member of an officer or employee, may be appointed to the nominations committee if the board, under exceptional and limited circumstances, determines that such individual's membership on the committee is required by the best interests of the company and its shareholders." Ibid, §5605(e)(3).

${ }^{884} \mathrm{Ibid}, \S 5605(\mathrm{e})(2)$.

${ }^{885}$ NYSE Manual, supra note 5, §303A.04(b).
} 
evaluation of management. $^{886}$

In addition to the aforementioned responsibilities, the commentary accompanying this requirement suggests that the nominating committee charter should address: (1) committee member qualifications; (2) committee member appointment and removal; (3) committee structure and operations (including authority to delegate to subcommittees); and (4) committee reporting to the board. In order to support the committee in fulfilling its duties, the charter should give the nominating/corporate governance committee sole authority to retain a search firm to identify director candidates, including sole authority to approve the search firm's fees and other retention terms. ${ }^{887}$

It is worth mentioning that the authority of the nominating committee may be restricted. When a listed company provides a legal right for third parties to nominate directors, such as through preferred stock rights to elect directors or other legal rights, the selection and nomination of such directors need not be subject to the process of the nominating committee. ${ }^{88}$ The NASDAQ has a similar provision. ${ }^{889}$

\section{Summary of the Board's Director Nomination Oversight Function}

Although the rules regarding the establishment, composition, content of charter and responsibilities of the nominating committee are different between the NYSE and NASDAQ, there exists a common thread between these rules that independent directors have been entrusted with the role of nominating directors who are truly independent of management and who are able and willing to ask probing questions in the boardroom.

\subsection{The Board's Executive Compensation Oversight Function}

${ }^{886}$ NYSE Listed Company Manual 303A.04(b) states:

[t]he nominating/corporate governance committee must have a written charter that addresses:

(i) the committee's purpose and responsibilities which, at minimum, must be to: identify individuals qualified to become board members, consistent with criteria approved by the board, and to select, or to recommend that the board select, the director nominees for the next annual meeting of shareholders; develop and recommend to the board a set of corporate governance guidelines applicable to the corporation; and oversee the evaluation of the board and management; and

(ii) an annual performance evaluation of the committee. Ibid.

${ }^{887}$ Ibid, §303A.04 Commentary.

${ }^{888}$ Ibid.

${ }^{889}$ NASDAQ Rule, supra note 5, §5605(e)(4), IM-5605-7. 
The rationale behind having an independent compensation committee is the formulation of a reasonable and fair compensation mechanism for rewarding executives' effort based on their performance. Due to the powerful influence of the CEO and senior executives inside the company, this job should be granted to a group of people who have no material relationship with the CEO, senior executives or the company. The regulator, stock exchanges and many scholars consider independent directors to be the best candidates to fulfill this job. ${ }^{890}$ Therefore, the NYSE and NASDAQ, since 2003, have required that executive compensation be determined by a compensation committee comprised entirely of independent directors or a board composed of a majority of independent directors.

However, cases regarding unreasonable compensation packages for executives have continued to be common in the post-SOX period, such as Lehman Brothers in 2008 and AIG in $2009 .{ }^{891}$ Nevertheless, the current law and stock exchange rules continue to rely on independent directors to decide executive compensation.

\subsection{The Establishment and Composition of the Compensation Committee}

Similar to the situation regarding the nominating committee, SOX does not mandate that a reporting company must have a compensation committee. The SEC left the discretion to stock exchanges to determine whether a listing company must have such a committee. The NYSE requires that each listed company must have a compensation committee composed solely of independent directors, ${ }^{892}$ while the NASDAQ left it for companies to decide. If a NASDAQlisted company decides to have a compensation committee, the committee must be composed entirely of independent directors. ${ }^{893}$ The 2010 Dodd-Frank Wall Street Reform and Consumer Protection Act institutionalized the composition of a listed company's compensation committee

\footnotetext{
${ }^{890}$ Please refer to section 2.1.1.4 of this thesis; see Kaura, supra note 8 at 49-51.

${ }^{891}$ Please refer to section 2.2.1.4 of this thesis.

${ }^{892}$ NYSE Manual, supra note 5, §303A.05(a).

${ }^{893}$ NASDAQ Rule $\$ 5605(\mathrm{~d})(1)$ states:

" [c] ompensation of the chief executive officer of the company must be determined, or recommended to the Board for determination, either by:

(A) independent directors constituting a majority of the board's independent directors in a vote in which only independent directors participate; or

(B) a compensation committee comprised solely of independent directors. NASDAQ Rule, supra note 5, $\S 5605(d)(1)$.
} 
and requires that each compensation committee member be independent. ${ }^{894}$

It is worth mentioning that NASDAQ also allowed an exception for a compensation committee with three or more members. A director, who does not meet the "independence" requirements but is in conformity with certain criteria, may be appointed to the compensation committee, if the board determines that it is in the best interests of the company. ${ }^{895}$ However, the NYSE does not have any similar exception. This exception appears to open the back door for affiliated directors; the independence of the compensation committee may therefore be compromised.

\subsection{Charter and Responsibilities}

The manner of mandating charter and responsibilities of the compensation committee is totally different between the NYSE and NASDAQ. The NYSE precisely delineates the duties and responsibilities of a compensation committee and what must be included in its committee charter. However, the NASDAQ does not require a formal written charter or any specific responsibilities for the compensation committee.

The NYSE requires that a compensation committee have a written charter addressing two missions: (1) the committee's purpose and responsibilities; and (2) annual performance evaluation of the committee. Regarding the committee's responsibilities, the key mission of the committee is to establish a fair and reasonable mechanism to compensate the CEO and senior managers for their contributions. The NYSE requires that the committee must first formulate corporate goals relevant to the CEO's compensation, evaluate the CEO's performance according

${ }^{894}$ Dodd-Frank Wall Street Reform and Consumer Protection Act $\S 952(a)(2)$ provides that :

"[t]he rules of the Commission under paragraph (1) shall require that each member of the compensation committee of the board of directors of an issuer be-

(A) a member of the board of directors of the issuer; and

(B) independent." Dodd-Frank Act, supra note 304.

However, there seems to be disagreement regarding whether section 952 mandates that SRO listing standards requires all listed corporations to have an independent compensation committee. See Stephen M Bainbridge, "A Question re Compensation Committees Under Dodd Frank 952" (14 September 2010), online:

ProfessorBainbridge.Com <http://www.professorbainbridge.com/professorbainbridgecom/2010/09/a-question-recompensation-committees-under-dodd-frank-952.html $>$.

${ }^{895}$ NASDAQ Rule $\$ 5605(d)(3)$ states:

"... if the compensation committee is comprised of at least three members, one director who is not independent as defined in Rule 5605(a)(2) and is not a current officer or employee or a family member of an officer or employee, may be appointed to the compensation committee if the board, under exceptional and limited circumstances, determines that such individual's membership on the committee is required by the best interests of the company and its shareholders." NASDAQ Rule, supra note 5, §5605(d)(3). 
to these goals, and finally determine the CEO's compensation based on this evaluation. The NYSE also requires the committee to make recommendations regarding other senior executive officer's compensation, and any other incentive-compensation or equity-based plans which are subject to board approval. ${ }^{896}$

The comments to this requirement suggest that the committee should consider three items in determining the long-term incentive component of CEO compensation: (1) the listed company's performance and relative shareholder return; (2) the value of similar incentive awards to CEOs at comparable companies; and (3) the awards given to the listed company's CEO in past years. In order to ensure the smooth operation of the committee, the commentary suggested that the compensation committee charter should also address: committee member qualifications; committee member appointment and removal; committee structure and operations (including authority to delegate to subcommittees); and committee reporting to the board. ${ }^{897}$ To support the compensation committee in carrying out its duties, as with the nominating committee requirement, the committee charter should give the committee sole authority to retain a consulting firm to assist with the evaluation of director or executive compensation, including sole authority to approve the firm's fees and other retention terms. ${ }^{898}$

\section{Summary of the Boards Executive Compensation Oversight Function}

The rules regarding the establishment, composition, content of charter and responsibilities of the compensation committee are different between the NYSE and NASDAQ, but there is a general consensus between these rules that independent directors undertake the role

${ }^{896}$ NYSE Listed Company Manual $\$ 303 A .05(b)$ states:

"[t]he compensation committee must have a written charter that addresses:

(i) the committee's purpose and responsibilities- which, at minimum, must be to have direct responsibility to:

(A) review and approve corporate goals and objectives relevant to CEO compensation, evaluate the CEO's performance in light of those goals and objectives, and, either as a committee or together with the other independent directors (as directed by the board), determine and approve the CEO's compensation level based on this evaluation; and

(B) make recommendations to the board with respect to non-CEO executive officer compensation, and incentive-compensation and equity-based plans that are subject to board approval; and

(C) prepare the disclosure required by item 407(e)(5) of Regulation S-K;

(ii) an annual performance evaluation of the compensation committee." NYSE Manual, supra note 5, $\S 303 \mathrm{~A} .05(\mathrm{~b})$.

${ }^{897}$ NYSE Manual, ibid, §303A.05 Commentary.

${ }^{898}$ Ibid. 
of establishing a reasonable compensation mechanism to reward executives based on their performance.

\subsubsection{Summary of How Laws and Regulations Rely on Independent Directors as Corporate Monitors in the United States}

At the state law level, Delaware courts defer to decisions made by independent directors regarding shareholders' derivative suits and situations involved risk of managerial abuses. The Michigan corporate legislation further institutionalizes the status of independent directors in holding management accountable. These results demonstrate that US state courts, especially Delaware courts, and at least one state legislature, in the case of Michigan, rely on independent directors to act as impartial judges to look out for the best interests of shareholders. This trend of relying on independent directors as corporate monitors is also extended to the federal law level. Federal law, SEC regulations or stock exchange rules have required that: (1) a listed firm have a majority of independent directors on its board; and (2) the functions of auditing supervision, establishment of executive compensation and nomination of directors of a listed firm be performed by committees composed entirely of independent directors or by a board composed of a majority of independent directors. Taken together, relying on independent directors to check on managerial misconduct seems to have become a prevailing trend in the United States, regardless of the state or federal level.

\subsection{Canada}

Similar to the situation in the United States, courts, laws and regulations in Canada also rely on independent directors to hold management accountable. One of the main differences between two legal regimes is that securities laws and related regulations are a provincial matter in Canada, while, in the United States, they are under the authority of the federal legislature and the federal government. In addition, corporations in Canada can be incorporated under either federal or provincial law, while, there is no federal corporate statute in the United States.

Currently, laws and regulations regarding the role and responsibilities of independent directors in Canada are mostly delineated in the securities law regime. Corporate law only stipulates 
whether a board or an audit committee shall have a certain number or percentage of outside directors.

In Canada, stock exchange rules started to rely on independent directors as corporate monitors in the mid-1990s. In 1995, the Toronto Stock Exchange, following the recommendation of the Dey Committee, adopted extensive corporate governance guidelines, which largely focused on the oversight role of independent directors. The guidelines concerning independent directors recommended that: (1) each board should have a majority of independent directors; (2) each board should have an audit committee composed entirely of outside directors responsible for the integrity of financial reporting; (3) each board should have a nominating committee composed of a majority of independent directors with the responsibilities of nominating and assessing board members; (4) each board should have a lead director, if the board chair is a member of management; (5) outside directors may meet on a regular basis without the presence of management. ${ }^{899}$ Whether to comply with the guidelines was left to the discretion of the listed companies, but listed companies must give reasons for any noncompliance in either an annual report or proxy statement, if they choose not to follow the guidelines. ${ }^{900}$ This "comply or explain" approach has the goal of giving firms the flexibility to tailor their corporate governance practices in their specific circumstances. It became the mainstream model in the Canadian corporate governance regime.

In contrast to the legal framework for corporate governance in the United States, the Toronto Stock Exchange appeared to take the lead in relying on independent directors to hold management accountable. Stock exchanges in the United States did not formally require an independent board or an independent nominating committee until 2003. The following analysis starts with how Canadian corporate laws rely on independent directors as corporate monitors.

\subsubsection{Corporate Law}

Similar to the United States, corporate laws in Canada do not stipulate in their statutes the monitoring role independent directors should play in detail. However, most Canadian corporate statutes have an outside director requirement for distributing or offering corporations. For

\footnotetext{
${ }^{899}$ Dey Report, supra note 196 at 4-5.

${ }^{900}$ Anand, Milne \& Purda, supra note 7 at 810, 815-16.
} 
example, the Canada Business Corporations Act requires distributing companies to have at least two outside directors on the board, ${ }^{901}$ while the Ontario Business Corporations Act mandates that at least one-third of the directors of an offering corporation shall be outsiders. ${ }^{902}$ The Alberta Business Corporations Act also has a similar provision to that of Ontario. ${ }^{903}$ In addition, the Canada Business Corporations Act further requires that a distributing company have an audit committee composed of at least three members, a majority of whom are outside directors, with responsibilities for reviewing the financial statements of the company. ${ }^{904}$ It is worth mentioning that the aforementioned outside directors refer to directors who are not officers or employees of the corporation or its affiliates. ${ }^{905}$ Retired employees of the company, outside counsel, investment bankers, representatives of a controlling shareholder, major creditors, customers or suppliers of the company would qualify as outside directors, notwithstanding their potential conflicts of interest. ${ }^{906}$ The monitoring effects of these outside directors may be questionable, compared to those of independent directors. So far, federal or provincial legislators have not followed in the steps of securities regulators as analyzed in the following section and have not

${ }^{901}$ Section 102 (2) of Canada Business Corporations Act states:

"[a] corporation shall have one or more directors but a distributing corporation, any of the issued securities of which remain outstanding and are held by more than one person, shall have not fewer than three directors, at least two of whom are not officers or employees of the corporation or its affiliates." $C B C A$, supra note 27 , s 102 (2); see VanDuzer, supra note 15 at 163; Robert Yalden et al, Business Organizations: Principles,

Policies and Practice (Toronto: Emond Montgomery Publications, 2008) at 540 [Yalden].

902 Ontario Business Corporations Act section 115(3) provides:

"[a]t least one-third of the directors of an offering corporation shall not be officers or employees of the corporation or any of its affiliates." OBCA, supra note 601, s 115(3); See VanDuzer, ibid.

903 Alberta Business Corporations Act section 101(2) states:

"A corporation shall have one or more directors but a distributing corporation whose shares are held by more than one person shall have not fewer than 3 directors, at least 2 of whom are not officers or employees of the corporation or its affiliates." Alberta Business Corporations Act, RSA 2000 cB-9, s 101(2).

It is worth noting that there is no requirement for such "outside directors" in the corporate statutes of Prince Edward Island, Quebec, or British Columbia. VanDuzer, ibid n 42.

904 Canada Business Corporations Act section 171 states:

“(1) Subject to subsection (2), a corporation described in subsection 102(2) shall, and any other corporation may, have an audit committee composed of not less than three directors of the corporation, a majority of whom are not officers or employees of the corporation or any of its affiliates.

(3) An audit committee shall review the financial statements of the corporation before such financial statements are approved under section 158." CBCA, supra note 27, s 171; see VanDuzer, ibid at 511. 905 See Canada Business Corporations Act, RSC 1985, c C-44, s 102 (2); Ontario Business Corporations Act, RSO 1990, c B16, s 115(3); Alberta Business Corporations Act, RSA 2000 cB-9, s 101(2).

${ }^{906}$ Osler, Hoskin \& Harcourt LLP, Corporate Governance in Canada: A Guide to the Responsibilities of Corporate Directors in Canada (2009) at 22, online: Osler:

<http://www.osler.com/uploadedFiles/News_and_Resources/Publications/Guides/Corporate_Governance_In_Canad a/Corporate_Governance in_Canada_2009_Aug2011.pdf> [Osler, Hoskin \& Harcourt LLP]; Yalden et al, supra note 901 at 541 . 
precluded those who have certain relationships with management or the corporation from playing the monitoring role.

\subsubsection{Securities Law}

As discussed above, during 2002 to 2003, the Sarbanes-Oxley Act and related reforms were enacted in response to a series of corporate scandals beginning with Enron. Canadian securities regulators, after contemplating opinions both favoring and opposing the US approach, adopted a hybrid system, which combined elements of the pre-existing "comply or explain" approach and the mandatory compliance model in the US. More specifically, Canadian securities regulators included some mandatory rules regarding audit committees under National Instrument 52-110, but also employed a principles-based approach to other corporate governance practices through implementation in National Policy 58-201 (Corporate Governance Guidelines) in combination with National Instrument 58-101 (Disclose of Corporate Governance Policies) which requires disclosure regarding the extent of compliance with the guidelines. In the late 2008, the Canadian Securities Administrators tried to overhaul NP58-201 (Corporate Governance Guidelines), but gave up due to inappropriate timing. Essentially firms complained that the financial crisis was not the time to introduce new corporate governance requirements. ${ }^{907}$

Because of the similarity of the corporate governance framework adopted by the two countries, I follow the same structure used in the US discussion above to analyze how the Canadian legal framework relies on independent directors as corporate monitors. The measures adopted by the Canadian securities regulators regarding independent directors as corporate monitors are discussed in four categories: (1) specifying the definition of independent directors; (2) regulating board composition; (3) requiring certain procedures in the boardroom to stifle influence of management; (4) mandating three key board functions related to oversight of auditing, executive compensation and nomination of directors.

\subsubsection{Specifying the Definition of Independent Directors}

${ }^{907}$ CSA Staff Notice 58-305, supra note 362. 
Since 1995, the Toronto Stock Exchange has recommended that each board should have a majority of independent directors, which the Dey Report termed as "unrelated directors." Independent directors are defined as directors who are free from any interests and any business or other relationship that could materially interfere with a directors' ability to act with a view to the best interests of the company. ${ }^{908}$ However, the Toronto Stock Exchange only gave several examples of "related" directors, such as the issuer's legal or financial consultants, but did not provide clear standards for deciding director independence. ${ }^{909}$ Whether a director is considered "independent" is left to the discretion of the entire board of directors. ${ }^{910}$

In response to corporate scandals in the new millennium, the Canadian Securities Administrators (CSA), following the US approach, set forth a long list of relationships that preclude a director being considered independent, in addition to offering a traditional general definition of director independence. According to National Instrument $52-110,{ }^{911}$ a director is considered independent, if he/she does not have any direct or indirect material relationship with the issuer, which, in the view of board of directors, would reasonably interfere with the exercising of a director's independent judgment. ${ }^{912}$ In fact, this definition is not substantially different from what the TSX adopted in 1995.

In addition to the general definition of director independence, NI 52-110 provides six preclusions that define when a director is considered to have a material relationship with an issuer.

First, regarding the employment preclusion, NI 52-110 disqualifies directors from being considered independent if they are or have been, at any time in the prior three years, employed by or acted as an executive officer ${ }^{913}$ of the issuer. ${ }^{914}$ However, this preclusion does not exclude

\footnotetext{
${ }^{908}$ Dey Report, supra note 196 at 4, 24 (para 5.8).

${ }^{909}$ Ibid at 24 (para 5.10).

${ }_{910}^{91 b i d}$ at 26 (paras 5.18 and 5.19).

${ }^{911}$ Subsection 1.2(1) of National Instrument 58-101 (Corporate Governance Guidelines) states that a director is independent if he or she qualifies as the definition within section 1.4 of National Instrument 52-110 (Audit Committee). NI 58-101, supra note 344, s 1.2(1), at 28 OSCB 3634.

${ }_{912}$ NI 52-110, supra note 10 , s 1.4(2), at 27 OSCB 3255.

${ }^{913}$ The NI 52-110 defines executive officer of an entity as an individual who is: (a) a chair of the entity; (b) a vicechair of the entity; (c) the president of the entity; (d) a vice-president of the entity in charge of a principal business unit, division or function including sales, finance or production; (e) an officer of the entity or any of its subsidiary entities who performs a policy-making function in respect of entity; or (f) any other individual who performs a policy-making function in respect of the entity. Ibid, s 1.1, at 27 OSCB 3253. It is worth mentioning that the CSA specifically lists executive officers as one of the employment relationships, while the NYSE and NASDAQ do not. Ibid, s 1.4(3)(a), at 27 OSCB 3255. In fact, executive officers, by interpretation, should be considered as employees of the issuer.
} 
a director from being considered independent when he/she only previously acted as an interim chief executive of the issuer, or currently acts (or previously acted) as a part-time (rather than full-time) board or committee chair (or vice-chair) of the issuer. ${ }^{915}$

Second, with respect to the relationship with auditors, the preclusions of the NI 52-110 are slightly stricter than those of the NYSE and NASDAQ. NI 52-110 precludes a director from being considered independent if the director or his/her immediate family member is, or was, an affiliated entity of, a partner of, or employed by, the issuer's current or former internal or external auditor during the past three years, except for an immediate family member who is not or was not employed to engage in auditing work. ${ }^{916}$ In other words, a director is still considered to be independent if the director's immediate family member is hired by the issuer's auditor to engage in non-professional work. Moreover, the "partner" here "does not include a fixedincome partner whose interest in the internal or external auditor is limited to the receipt of fixed amounts of compensation." 917

In comparison with the NYSE and NASDAQ preclusions, NI 52-110 extends the scope of the auditor to "former" internal or external auditors and bars a director from being considered independent, if he/she was employed by the issuer's auditor for the past three years, regardless of whether that person engaged in the issuer's auditing. However, like the NYSE and NASDAQ, Canadian preclusions allow a director to be considered independent when his/her immediate family member is or was hired by the issuer's auditor, as long as the family member does not or did not work on the issuer's audit during his/her employment.

${ }^{914}$ NI 52-110 section 1.4(3) states: "[d] espite subsection (2), the following individuals are considered to have a material relationship with an issuer:

(a) an individual who is, or has been, an employee or executive officer of the issuer, unless the prescribed period has elapsed since the end of the service of employment." Ibid, at 27 OSCB 3255.

915 Ibid, s 1.4(8), at 27 OSCB 3256.

${ }^{916}$ NI 52-110 section 1.4(3) states: "[d] espite subsection (2), the following individuals are considered to have a material relationship with an issuer:

‥

(c) an individual who is, or has been, an affiliated entity of, a partner of, or employed by, a current or former internal or external auditor of the issuer, unless the prescribed period has elapsed since the person's relationship with the internal or external auditor, or the auditing relationship, has ended; (d) an individual, whose immediate family member is, or has been, an affiliated entity of, a partner of, or employed in a professional capacity by, a current or former internal or external auditor of the issuer, unless the prescribed period has elapsed since the person's relationship with the internal or external auditor, or the auditing relationship, has ended." Ibid, at 27 OSCB 3255.

${ }^{917}$ Ibid, s 1.4(6), at 27 OSCB 3256. 
Third, as for the preclusion for the cross-compensation committee link, NI 52-110, following the NYSE and NASDAQ, disqualifies a director from being considered independent, if he/she is an executive officer of an entity where any of the issuer's current executive officers served on the entity's compensation committee for the past three years. ${ }^{918}$ The purpose of this preclusion is to reduce the impact of interlocking directorates.

Four, regarding the compensation preclusion, NI 52-110 considers a director "not independent", if he/she: (1) currently accepts any direct or indirect consulting, advisory or other compensatory fee from the issuer; or (2) received more than $\$ 75,000$ in direct compensation from the issuer in any of the prior three fiscal years, other than remuneration for acting as a board or committee member, or as a part-time board or committee chair or vice-chair. ${ }^{919}$ The acceptance of indirect compensatory fee includes payment to a director's spouse, minor child or stepchild, or a child or stepchild who shares the director's home. ${ }^{920}$ Under the same rationale, any payments for services to law firms, accounting firms, consulting firms, investment banks or financial advisory firms, in which the director is a partner, member, executive officer or holds a similar position, are also considered as indirect compensation by NI 52-110. ${ }^{921}$ It is worth noting that compensatory fees and direct compensation "do not include the receipt of fixed amounts of compensation under a retirement plan" for prior service with the issuer. ${ }^{922}$

\footnotetext{
${ }^{918}$ NI 52-110, section 1.4(3) states: "[d]espite subsection (2), the following individuals are considered to have a material relationship with an issuer:

(e) an individual who is, or has been, or whose immediate family member is or has been, an executive officer of an entity if any of the issuer's current executive officers serve on the entity's compensation committee, unless the prescribed period has elapsed since the end of the service or employment." Ibid, at 27 OSCB 3255.

${ }^{919}$ NI 52-110, section 1.4(3) states:

"[d]espite subsection (2), the following individuals are considered to have a material relationship with an issuer:

(f) an individual who

(i) has a relationship with the issuer pursuant to which the individual may accept, directly or indirectly, any consulting, advisory or other compensatory fee from the issuer or any subsidiary entity of the issuer, other than as remuneration for acting in his or her capacity as a member of the board of directors or any board committee, or as a part-time chair or vice-chair of the board or any board committee; or

(ii) receives, or whose immediate family member receives, more than $\$ 75,000$ per year in direct compensation from the issuer, other than as remuneration for acting in his or her capacity as a member of the board of directors or any board committee, or as a part-time chair or vice-chair of the board or any board committee, unless the prescribed period has elapsed since he or she ceased to receive more than $\$ 75,000$ per year in such compensation." Ibid.

${ }^{920} \mathrm{Ibid}$, s 1.4(7)(a), at 27 OSCB 3256.

${ }^{921} \mathrm{Ibid}$, s 1.4(7)(b), at 27 OSCB 3256.

${ }^{922} \mathrm{Ibid}, \mathrm{s}$ 1.4(6), at 27 OSCB 3256.
} 
Five, with respect to the preclusion related to relationships with affiliated entities, NI 52110, mimicking section 301 of SOX, excludes a director from being considered independent, if he/she is an affiliated entity of the issuer or any of its subsidiary entities. ${ }^{923}$ NI 52-110 considers a director to be an affiliated entity of the issuer, if the director is controlled by the issuer or both the director and the issuer are controlled by the same person or company. ${ }^{924}$ The term "control" here is interpreted as "the direct or indirect power to direct or cause the direction of the management and policies of a person or company, whether through ownership of voting securities or otherwise." 925 With a view to introducing some certainty in this area, NI 52-110 specifies that a person is not considered to be an affiliated entity of an issuer, if the person is not an executive officer or owns, directly or indirectly, less than $10 \%$ shareholdings of the issuer. ${ }^{926}$

Six, as for the preclusion related to immediate family member relationships, NI 52-110 extends the above first four preclusions to a director's immediate family member. ${ }^{927}$ In other words, if a director's family member is involved in one of the first four relationships, the director is not considered independent. NI 52-110's definition of "immediate family member" covers the director's spouse, parents, children, siblings, in-laws of all types, and anyone who shares the director's home. ${ }^{928}$

Generally speaking, the new definition of independent directors, including preclusions, offered by the NI 52-110 is more comprehensive and specific than those provided by the Toronto

\footnotetext{
${ }^{923}$ NI 52-110, section 1.4(3) states:

"[d] espite subsection (2), the following individuals are considered to have a material relationship with an issuer:

(g) an individual who is an affiliated entity of the issuer or any of its subsidiary entities." Ibid, at 27 OSCB 3255 .

${ }^{924}$ NI 52-110, section 1.3(1) states:

"For the purpose of this Instrument, a person or company is considered to be an affiliated entity of another person or company if

(a) one of them controls or is controlled by the other or if both persons or companies are controlled by the same person or company, or

(b) the person or company is

(i) both a director and an employee of an affiliated entity, or

(ii) an executive officer, general partner or managing member of an affiliated entity. Ibid, s 1.3(1), at 27 OSCB 3254.

${ }^{925}$ Ibid, s 1.3(3), at 27 OSCB 3255.

${ }^{926} \mathrm{Ibid}$, s 1.3(4), at 27 OSCB 3255. The SEC adopted similar interpretation for this issue. However, the NYSE and NASDAQ do not view ownership of a significant amount of stock as a bar to an independence finding. NYSE Manual, supra note 5, §303A.02(a) Commentary; NASDAQ, IM-5605 Definition of Independence - Rule 5605(a)(2); Lutzy, supra note 97 at 121; Clarke, Concepts of Independent Directors, supra note 33 at 93.

${ }_{927} \mathrm{Ibid}, \mathrm{s} 1.4(3)(\mathrm{a}),(\mathrm{c})-(\mathrm{f})$, at 27 OSCB 3255.

${ }^{928}$ Ibid, s 1.1, at 27 OSCB 3253.
} 
Stock Exchange (as recommended by the Dey Committee) in 1995. However, the preclusions of the NI 52-110, similar to those in the NYSE and NASDAQ, only focus on financial and family ties, and neglect to address non-financial forces that may compromise director independence. In fact, social connections, including personal, professional, sponsorship and philanthropic ties, also can play an important role in affecting a director's exercise of independent judgment as mentioned in section 3.2.1. Thus, directors who have no relationships with the issuer or its management enumerated by NI 52-110 may not be truly independent.

\subsubsection{Regulating Board Composition}

As noted, even though the United States did not require public corporations to have a majority of independent directors on boards until 2003, the Toronto Stock Exchange recommended that each board be constituted of a majority of unrelated directors as early as 1995. ${ }^{929}$ National Policy 58-201 (Corporate Governance Guidelines) maintains the same policy and advice that "the board should have a majority of independent directors." recommendation of Toronto Stock Exchange, around 82\%-87\% of the corporations listed in the TSX had a majority of independent directors on the board during the years 1999 to 2003, according to Professors Anand, Milne and Purda's research. ${ }^{931}$

\subsubsection{Recommending Certain Procedures in the Boardroom to Stifle the Influence of Management}

With a view to fostering a boardroom climate that supports asking probing questions and encourages exploring suspect practices, the TSX recommended that issuers should adopt two measures, namely executive sessions and a non-management board chair (or a lead director) in 1995. ${ }^{932}$ The NYSE and NASDAQ, following this trend, also adopted similar provisions in their listing requirements in 2003. Currently, the CSA maintain the same policy and delineates more

\footnotetext{
${ }^{929}$ Dey Report, supra note at 4, 24 (para 5.7).

${ }^{930}$ NP 58-201 section 3.1 states "[ $\mathrm{t}$ ] he board should have a majority of independent directors." NP 58-201, supra note 10, s 3.1, at 28 OSCB 5383.

${ }_{931}$ Anand, Milne \& Purda, supra note 7 at 818, 838 Table 1.

932 Dey Report, supra note 196 at 5, 38, 39-40 (paras 6.10, 6.11, 6.16).
} 
details in section 3.3 of National Policy 58-201.

Executive sessions, sometimes called "in camera meetings", are meetings regularly scheduled at which non-independent directors and members of management are not in attendance. $^{933}$ Executive sessions aim at creating a spirit of independent deliberation among directors. $^{934}$ During such meetings, independent directors are given opportunities to discuss sensitive issues without worrying about offending or threatening management. ${ }^{935}$ In addition, independent directors can take advantage of such a forum to talk about certain practices that they find suspect. ${ }^{936}$ Originally, the TSX allowed affiliated directors to attend executive sessions, since the guidelines only mentioned "the board meetings ... without management present". Currently, NP 58-201 restricts participants at the executive sessions to independent directors. The NASDAQ currently adopts the same perspective as NP 58-201, but the NYSE still allows outside directors who may have some connection with management or the issuer to participate executive sessions. ${ }^{937}$

With respect to the issue of having an independent board chair, the Canadian securities regulators seem to have a higher standard than the US regulators. The former TSX guidelines had suggested that each board appoints a chair of the board who is not a member of management (but may have certain connections with management). ${ }^{938}$ NP 58-201 further recommends that the chair of the board should be an independent director. If such an appointment is not available, the board should appoint an independent director to act as a "lead director". 939 It appears that NP 58-201's first choice is to have an independent director acting as the board chair. An independent "lead director" is merely NP 58-201's second priority when the former is not applicable. The purpose of separating the position of CEO and board chair is to ensure the board

\footnotetext{
${ }^{933}$ NP 58-201 section 3.3 states:

"[T] and members of management are not in attendance." NP 58-201, supra note 10, s 3.3, at 28 OSCB 5383.

934 Thierry Dorval, The Role of Corporate Governance in Reducing Agency Problems and Assisting Directors in the Discharge of Their Fiduciary Duties (LLD Thesis, University of Ottawa, 2007) at 109 [Dorval].

${ }^{935} \mathrm{Ibid}$ at 241 .

936 Ibid at 109.

${ }^{937}$ Please refer to section 4.1.2.3 of this thesis.

${ }^{938}$ Dey Report, supra note 196 at 5, 39-40 (para 6.16).

${ }^{939}$ NP 58-201 section 3.2 states:

"[T] he chair of the board should be an independent directors. Where this is not appropriate, an independent director should be appointed to act as "lead director". However, either an independent chair or an independent lead director should act as the effective leader of the board and ensure that the board's agenda will enable it to successfully carry out its duties." NP 58-201, supra note 10, s 3.2, at 28 OSCB 5383.
} 
functions independently of management ${ }^{940}$ and increase the likelihood of a genuine second opinion during board discussion. ${ }^{941}$ When the CEO is also sitting in the boardroom as chair, such goals are less likely to be achieved. ${ }^{942}$ It is worth mentioning that the NYSE and NASDAQ rules say nothing regarding whether a board chair should be an independent director. The NYSE even allows a non-management director (who may have certain relationships with management) to be a lead director. ${ }^{943}$

\subsubsection{Mandating Three Key Board Functions: Oversight of Auditing, Setting Executive Compensation and Nomination of Directors}

Similar to the United States, one of the most striking Canadian corporate governance reforms in the post-Enron period is that the three key board functions, namely the review of auditing, director nomination and executive compensation, are required or recommended to be performed solely by independent directors, in addition to an independent board. In fact, in Canada, the TSX had recommended as early as 1995 that a board's auditing and director nomination function should be performed by outside directors. ${ }^{944}$ Canadian securities regulators, influenced by SOX and related reforms, require that every issuer have an audit committee composed solely of independent directors, and recommend that each board should appoint a nominating and a compensation committee comprised entirely of independent directors. The difference between the former TSX guidelines and the current Canadian rules is that the TSX guidelines allowed each issuer to decide whether to follow its guidelines and the issuer must give reasons for any non-compliance, while current rules require each issuer to comply with requirements regarding the audit committee, but continue to adopt "comply-or-explain" approach for issuers to decide whether to follow the guidelines concerning the nominating and the compensation committees. The following analysis begins with the board's audit review function.

\footnotetext{
${ }^{940}$ Dey Report, supra note 196 at 39-40 (para 6.16).

941 Dorval, supra note 934 at 238-39.

${ }^{942}$ Generally speaking, directors are unlikely to pursue problem areas in depth in front of a chairman who is also the CEO. Ibid.

${ }^{943}$ NYSE Manual, supra note5, §303A.03 Commentary.

${ }^{944}$ As for board's executive compensation review function, the TSX guidelines did not mention whether it should be performed by a specific committee. The TSX's Guideline 8 provides that " $[t]$ he board of directors should review the adequacy and form of the compensation of directors and ensure the compensation realistically reflects the responsibilities and risk involved in being an effective director." Dey Report, supra note 196 at 5, 32 (para 5.51).
} 


\subsubsection{The Board's Auditing Review Function}

The establishment of the audit committee has been required by the Canada Business Corporations Act for distributing corporations ${ }^{945}$ since at least $1985 .{ }^{946}$ Since that time, the main duties of the audit committee were reviewing and approving the financial statements of the corporation. ${ }^{947}$ In 1995, the TSX corporate governance guidelines expanded the audit committee's responsibilities to include the oversight of management reporting on internal controls. The audit committee was required to have direct communication channels with the internal and external auditors to discuss and review specific auditing issues. ${ }^{948}$ In response to corporate scandals in the new millennium, NI 52-110 and related rules, combining the previous Canadian practices and some post-SOX measures, further imposed more oversight duties on issuers' audit committees, including a mandatory committee charter, composition and member qualification requirements, and some specific responsibilities, which were not mandatory previously.

\subsection{Composition of the Audit Committee and Qualification of the Audit Committee Members}

The former TSX corporate governance guidelines merely recommended that the audit committee should be composed only of outside directors, ${ }^{949}$ but did not state anything regarding the number of the committee members, and whether its members should be financially literate or any member should be a financial expert. NI 52-110, mimicking the US post-Enron reforms, requires each issuer to maintain an audit committee composed of at least three members, ${ }^{950}$ each

\footnotetext{
945 A distributing corporation means a corporation: (1) is a reporting issuer under provincial securities laws and has filed a prospectus or similar document to permit its shares to be publicly traded in Canada or foreign jurisdiction; or (2) whose shares are listed on a stock exchange inside or outside of Canada. A distributing corporation is subject to a higher level of obligation. VanDuzer, supra note 15 at 596; See Canada Business Corporations Act, RSC 1985, c C-44, s 2(1).

946 See Canada Business Corporations Act, RSC 1985, c C-44, s 171(1).

947 Canada Business Corporations Act, RSC 1985, c C-44, s 171(3).

${ }^{948}$ Dey Report, supra note 196 at 5, 41 (para 6.21).

949 Ibid.

${ }^{950}$ NI 52-110 section 3.1 (1) states "[a]n audit committee must be composed of a minimum of three members." NI 52-110, supra note 10, s 3.1, at 27 OSCB 3257.
} 
of whom shall be independent ${ }^{951}$ and financially literate ${ }^{952}$. Canadian securities regulators consider an individual as being financially literate if he/she has the ability to read and understand financial statements of comparable breadth and complexity to those of the issuer. ${ }^{953}$ However, unlike the NYSE and NASDAQ rules, NI 52-110 does not require any audit committee member to have financial expertise, ${ }^{954}$ but investors can acquire information regarding the education and experience of each audit committee member through mandatory disclosure. ${ }^{955}$

It is worth mentioning that NI 52-110, similar to the NASDAQ rules, allows directors who do not meet the "independence" requirement, but conform with certain criteria, to be appointed to the audit committee, ${ }^{956}$ if the issuer's board has determined that doing so will not affect the ability of the audit committee to act independently. ${ }^{957}$ For example, an individual who sits on the board of, or has a certain relationship with, a company controlled by the issuer may serve as an audit committee member of the issuer under certain circumstances. ${ }^{958}$ In addition, an

${ }^{951}$ NI 52-110 section 3.1 (3) provides that "[s]ubject to sections 3.2, 3.3, 3.4, 3.5 and 3.6, every audit committee member must be independent." Ibid, s 3.1(3), at 27 OSCB 3257.

${ }^{952}$ NI 52-110 section 3.1 (4) states "[s]ubject to sections 3.5 and 3.8, every audit committee member must be financially literate." Ibid, s 3.1(4), at 27 OSCB 3258.

${ }^{953}$ NI 52-110 section 1.5 provides that "[f]or the purposes of this Instrument, an individual is financially literate if he or she has the ability to read and understand a set of financial statements that present a breadth and level of complexity of accounting issues that are generally comparable to the breadth and complexity of the issues that can reasonably be expected to be raised by the issuer's financial statements." Ibid, s 1.5, at 27 OSCB 3256.

${ }^{954}$ Osler, Hoskin \& Harcourt LLP, supra note 906 at 32.

${ }^{955}$ NI 52-110 section 5.1 states "[e]very issuer must include in its AIF the disclosure required by Form 52-110F1". Ibid, s 5.1, at 27 OSCB 3259. Section 3 of Form 52-110F1 provides

"[d] escribe the education and experience of each audit committee member that is relevant to the performance of his or responsibilities as an audit committee member and, in particular, disclose any education or experience that would provide the member with:

(a) an understanding of the accounting principles used by the issuer to prepare its financial statements;

(b) the ability to assess the general application of such accounting principles in connection with the accounting for estimates, accruals and reserves;

(c) experience preparing, auditing, analyzing or evaluating financial statements that present a breadth and level of complexity of accounting issues that are generally comparable to the breadth and complexity of issues that can reasonably be expected to be raised by the issuer's financial statements, or experience actively supervising one or more persons engaged in such activities; and

(d) an understanding of internal controls and procedures for financial reporting."

${ }^{956}$ NI 52-110, ibid, ss 3.2, 3.3, 3.4, 3.5 and 3.6, at 27 OSCB 3258-59.

${ }^{957}$ NI 52-110 section 3.9 states

"[t]he exemptions in sections $3.2,3.4,3.5$ and 3.8 are not available to a member unless the issuer's board of directors has determined that the reliance on the exemption will not materially adversely affect the ability of the audit committee to act independently and to satisfy the other requirements of this Instrument." Ibid, s 3.9, at 27 OSCB 3259.

${ }^{958}$ NI 52-110 section 3.3 provides

"(1) An audit committee member that sits on the board of directors of an affiliated entity is exempt from the requirement in subsection 3.1(3) [Requirements of Independence] if the member, except for being a director (or member of a board committee) of the issuer and the affiliated entity, is otherwise independent of the issuer and the affiliated entity. 
individual who only acts as an audit committee member for a certain period or temporarily may be exempted from complying with the requirements of "independence.",959

\subsection{Charter and Responsibilities}

The former TSX corporate governance guidelines did not recommend the adoption of a written charter for any committee of the board. Canadian securities regulators, following the NYSE and NASDAQ, now require each audit committee to have a written charter that sets out its mandate and responsibilities. Under NI 52-110, the audit committee's responsibilities must include:

(1) recommending the nomination and compensation of the external auditor; 960

(2) overseeing the work of the external auditor, including resolving disputes between

(2) Subject to section 3.7, an audit committee member is exempt from the requirement in subsection 3.1(3) if:

(a) the member would be independent of the issuer but for the relationship described in paragraph $1.4(3)(\mathrm{g})$;

(b) the member is not an executive officer, general partner or managing member of a person or company that

(i) is an affiliated entity of the issuer, and

(ii) has its securities trading on a marketplace;

(c) the member is not an immediate family member of an executive officer, general partner or managing member referred to in paragraph (b), above;

(d) the member does not act as the chair of the audit committee; and

(e) the board determines in its reasonable judgement that

(i) the member is able to exercise the impartial judgement necessary for the member to fulfill his or her responsibilities as an audit committee member, and

(ii) the appointment of the member is required by the best interests of the issuer and its shareholders. Ibid, s 3.3, at 27 OSCB 3258.

${ }^{959}$ NI 52-110 section 3.4 states

"[s]ubject to section 3.9, if an audit committee member ceases to be independent for reasons outside the member's reasonable control, the member is exempt from the requirement in subsection 3.1(3) for a period ending on the later of :

(a) the next annual meeting of the issuer, and

(b) the date that is six months from the occurrence of the event which caused the member to not be independent." Ibid, s 3.4, at 27 OSCB 3258.

NI 52-110 section 3.5 states

"[s]ubject to section 3.9, if the death, disability or resignation of an audit committee member has resulted in a vacancy on the audit committee that the board of directors is required to fill, an audit committee member appointed to fill such vacancy is exempt from the requirements in subsections 3.1(3) and (4) for a period ending on the later of:

(a) the next annual meeting of the issuer, and

(b) the date that is six months from the day the vacancy was created." Ibid, s 3.5, at 27 OSCB 3258.

${ }^{960}$ Subsection 2.3(2) of NI 52-110 provides

"[a]n audit committee must recommend to the board of directors:

(a) the external auditor to be nominated for the purpose of preparing or issuing an auditor's report or performing other audit, review or attest services for the issuer; and

(b) the compensation of the external auditor." Ibid, s 2.3(2), at 27 OSCB 3256. 
management and the auditor regarding financial reporting; ${ }^{961}$

(3) pre-approving all non-audit services provided by the external auditor; ${ }^{962}$

(4) reviewing financial statements, $M D \& \mathrm{~A}^{963}$ and earnings press releases prior to public disclosure ${ }^{964}$

(5) providing adequate procedures for the review of public disclosure of financial information; ${ }^{965}$

(6) establishing a complaint procedure for reporting questionable accounting or auditing matters by employees; ${ }^{966}$ and

(7) reviewing and approving hiring policies for current and former employees and partners of the external auditor. ${ }^{967}$

It is worth noting that the audit committee in Canada is only allowed to recommend the nomination and compensation of the outside auditor to the board. In the United States, the authority to appoint the auditor is solely granted to the audit committee. ${ }^{968}$ In order to support the audit committee in fulfilling its duties, NI 52-110 also gives the committee the authority to engage independent counsel and other advisors, and to set and pay compensation for those

\footnotetext{
${ }^{961}$ Subsection 2.3(3) of NI 52-110 states "[a]n audit committee must be directly responsible for overseeing the work of the external auditor engaged for the purpose of preparing or issuing an auditor's report or performing other audit, review or attest services for the issuer, including the resolution of disagreements between management and the external auditor regarding financial reporting." Ibid, s 2.3(3), at 27 OSCB 3256.

${ }^{962}$ Subsection 2.3(4) of NI 52-110 provides "[a]n audit committee must pre-approve all non-audit services to be provided to the issuer or its subsidiary entities by the issuer's external auditor." Ibid, s 2.3(4), at 27 OSCB 3257. 963 "MD\&A" means Management's Discussion \& Analysis. It is a section of a company's annual report in which management discusses numerous aspects of the company, both past and present. In NI 52-110, MD\&A is "a completed Form 51-102F1 Management's Discussion \& Analysis or, in the case of an SEC issuer, a completed Form 51-102F1 or management's discussion and analysis prepared in accordance with Item 303 of Regulation S-K under the 1934 Act." National Instrument 51-102, Continuous Disclosure Obligations - for financial years beginning on or after January 1, 2011, OSC NI 51-102, at 7, online: OSC <https://www.osc.gov.on.ca/en/13342.htm>.

${ }^{964}$ Subsection 2.3(5) of NI 52-110 states "[a]n audit committee must review the issuer's financial statements, MD\&A and annual and interim earnings press releases before the issuer publicly discloses this information." Ibid, $\mathrm{s}$ 2.3(5), at 27 OSCB 3257.

${ }^{965}$ Subsection 2.3(6) of NI 52-110 provides "[a]n audit committee must be satisfied that adequate procedures are in place for the review of the issuer's public disclosure of financial information extracted or derived from the issuer's financial statements, other than the public disclosure referred to in subsection (5), and must periodically assess the adequacy of those procedures." Ibid, s 2.3(6), at 27 OSCB 3257.

${ }^{966}$ Subsection 2.3(7) of NI 52-110 states "[a]n audit committee must establish procedures for:

(a) the receipt, retention and treatment of complaints received by the issuer regarding accounting, internal accounting controls, or auditing matters; and

(b) the confidential, anonymous submission by employees of the issuer of concerns regarding questionable accounting or auditing matters." Ibid, s 2.3(7), at 27 OSCB 3257.

${ }^{967}$ Subsection 2.3(8) of NI 52-110 provides "[a]n audit committee must review and approve the issuer's hiring policies regarding partners, employees and former partners and employees of the present and former external auditor of the issuer." Ibid, s 2.3(8), at 27 OSCB 3257.

${ }^{968}$ See Sarbanes-Oxley Act, supra note 4, §301(2).
} 
advisors. $^{969}$

\section{Summary of the Board's Auditing Review Function}

The above rules regarding the audit committee demonstrate that independent directors in Canada have been entrusted with the role of ensuring the quality of financial reporting.

\subsubsection{The Board's Director Nomination Oversight Function}

\subsection{1 The Establishment and Composition of the Nominating Committee}

The recommendation of establishing a nomination committee for Canadian issuers can be traced back to the 1995 TSX corporate governance guidelines. ${ }^{970}$ The goal of having a nomination committee is to eliminate the influence of the CEO as a recruiter of directors. Canadian securities regulators, in response to SOX related reforms, recommend that each issuer should have a nominating committee with the responsibility for nominating directors independent of management. ${ }^{971}$ However, the composition requirement is different from the former TSX guidelines. NP 58-201 recommends an entirely independent nominating committee, while the TSX only suggested that the committee be composed solely of outside directors, though a majority of them should be independent directors. ${ }^{972}$ In the United States, the NYSE and NASDAQ both require that the nominating committee be composed entirely of independent directors. ${ }^{973}$ Except for independence, there is no additional requirement for nominating committee members recommended by NP 58-201.

\subsubsection{2 .2 Charter and Responsibilities}

\footnotetext{
${ }^{969}$ NI 52-110 section 4.1 provides

"[a]n audit committee must have the authority

(a) to engage independent counsel and other advisors as it determines necessary to carry out its duties,

(b) to set and pay the compensation for any advisors employed by the audit committee, and ..." NI 52110 , supra note, s 4.1 , at 27 OSCB 3259.

${ }^{970}$ Dey Report, supra note 196 at 4, 27-28 (paras 5.23-5.26).

${ }^{971}$ Section 3.10 of NP 58-201 states "[ $\left.\mathrm{t}\right]$ he board should appoint a nominating committee composed entirely of independent directors." NP 58-201, supra note 10, s 3.10, at 28 OSCB 5385.

972 Dey Report, supra note 196 at 4, 27-28 (paragraph 5.25).

${ }^{973}$ NYSE Manual, supra note 5, §303A.04(a); NASDAQ Rule, supra note 5, §5605(e)(1)(B).
} 
The former TSX corporate governance guidelines did not recommend the adoption of a written charter for nominating committees. NP 58-201, mirroring the NYSE rules, ${ }^{974}$ suggests that each nominating committee should have a written charter that establishes the committee's purposes, responsibilities, member qualifications, member appointment and removal, structure and operations, and the manner of reporting to the board. ${ }^{975}$ With respect to the nomination responsibilities, the nominating committee is expected to identify qualified candidates consistent with the board's criteria and then recommend to the board appropriate director nominees for the next annual shareholder meeting. ${ }^{976}$ NP 58-201 further suggests that the nominating committee should consider the competencies and skills that each existing director possesses or a new nominee will bring to the boardroom, when making its recommendations. In addition, whether each new nominee can devote sufficient time and resources to his/her duties as a board member should be assessed prior to his/her nomination. ${ }^{977}$

Similar to the NYSE and NASDAQ rules, the authority of the nominating committee may be restricted. If an issuer is legally required by contract or otherwise to provide third parties with the right to nominate directors, the selection and nomination of such directors need not involve the approval of the nominating committee. ${ }^{978}$ Moreover, with a view to supporting the nominating committee in fulfilling its duties, NP 58-201 also gives the committee the authority to engage and compensate outside advisors, when it determines that it is necessary. ${ }^{979}$

\section{Summary of Board's Nomination Oversight Function}

\footnotetext{
${ }^{974}$ NYSE Manual, ibid, §303A.04 Commentary.

${ }^{975}$ Section 3.11 of NP 58-201 states " [t] $]$ he nominating committee should have a written charter that clearly establishes the committee's purpose, responsibilities, member qualifications, member appointment and removal, structure and operations (including any authority to delegate to individual members and subcommittees), and manner of reporting to the board." NP 58-201, supra note 10, s 3.11, at 28 OSCB 5385.

${ }^{976}$ See Section 3.13 of NP 58-201. This section provides " $[\mathrm{t}]$ he nominating committee should be responsible for identifying individuals qualified to become new board members and recommending to the board the new director nominees for the next annual meeting of shareholders." Ibid, s 3.13, at 28 OSCB 5386.

${ }^{977}$ Section 3.14 of NP 58-201 provides

"[i]n making its recommendations, the nominating committee should consider:

(a) the competencies and skills that the board considers to be necessary for the board, as a whole, to possess;

(b) the competencies and skills that the board considers each existing director to possess; and

(c) the competencies and skills each new nominee will bring to the boardroom.

The nominating committee should also consider whether or not each new nominee can devote sufficient time and resources to his or her duties as a board member." Ibid, s 3.14, at 28 OSCB 5386.

${ }^{978} \mathrm{NP}$ 58-201 section 3.11 states “...If an issuer is legally required by contract or otherwise to provide third parties with the right to nominate directors, the selection and nomination of those directors need not involve the approval of an independent nominating committee." Ibid, s 3.11, at 28 OSCB 5385.

${ }^{979}$ Ibid.
} 
Taken together, the rules regarding the nominating committee show that the role of recommending qualified candidates of board is entrusted to independent directors.

\subsection{The Board's Executive Compensation Oversight Function}

\subsection{The Establishment and Composition of the Compensation Committee}

Unlike the nominating committee, the former TSX corporate governance guidelines did not recommend that issuers should establish a compensation committee, but merely suggested that the entire board should review the adequacy and form of the compensation of directors (rather than the CEO). ${ }^{980}$ NP 58-201, influenced by the NYSE rules ${ }^{981}$ and best practices, suggests each issuer to have a compensation committee composed solely of independent directors with responsibility for reviewing CEO and executive remuneration. ${ }^{982}$ Except for independence and the chapter, there is also no additional requirement for compensation committee members recommended by NP 58-201.

\subsection{Charter and Responsibilities}

The former TSX corporate governance guidelines did not state anything about the compensation committee, not to mention the adoption of a written charter for such a committee. After the enactment of SOX, NP 58-201, mirroring the NYSE rules, ${ }^{983}$ recommends that each compensation committee should have a written charter that establishes the committee's purposes, responsibilities, member qualifications, member appointment and removal, structure and operations, and the manner of reporting to the board. ${ }^{984}$

As for the committee's responsibilities, NP 58-201 suggests that the compensation committee should be responsible for: (1) evaluating the CEO's performance; (2) reviewing and

\footnotetext{
${ }^{980}$ Dey Report, supra note 196 at 5, 32 (para 5.51).

${ }^{981}$ NYSE Manual, supra note 5, §303A.05(a).

${ }^{982}$ NP 58-201, supra note 10, s 3.15, at 28 OSCB 5386.

${ }^{983}$ NYSE Manual, supra note 5, §303A.05 Commentary.

${ }^{984}$ Section 3.16 of NP 58-201 states " $[\mathrm{t}]$ he compensation committee should have a written charter that establishes the committee's purpose, responsibilities, member qualifications, member appointment and removal, structure and operations (including any authority to delegate to individual members and subcommittees), and the manner of reporting to the board..." NP 58-201, supra note 10, s 3.16, at 28 OSCB 5386.
} 
approving CEO remuneration; (3) making recommendations regarding the compensation of nonCEO officers and directors; (4) reviewing executive compensation disclosure. ${ }^{985}$ In addition, in order to support the compensation committee in carrying out its duties, NP 58-201 also recommends that the committee have the authority to engage and compensate outside advisors, when it determines to be necessary. ${ }^{986}$

\section{Summary of the Board's Executive Compensation Oversight Function}

Collectively, the rules regarding compensation committee reveal that independent directors are relied on as corporate monitors to establish reasonable compensation for corporate executives.

\subsubsection{Courts' Reliance on Independent Directors}

Courts in Canada typically defer to the recommendations made by a special committee composed of independent directors. Usually a special committee is established to review a particular issue where conflicts of interest are present and make a recommendation to the board. $^{987}$ The mandate of a special committee is to ensure that its recommendations are in the best interests of the corporation, which may include the protection of minority shareholders. ${ }^{988}$ The establishment of a special committee has long been considered as a matter of good corporate governance. ${ }^{989}$ Taking cases in courts or securities commissions between 1995 and 2002 for

${ }^{985}$ Section 3.17 of NP $58-201$ provides

"[t]he compensation committee should be responsible for:

(a) reviewing and approving corporate goals and objectives relevant to CEO compensation, evaluating the CEO's performance in light of those corporate goals and objectives, and determining (or making recommendations to the board with respect to) the CEO's compensation level based on this evaluation;

(b) making recommendations to the board with respect to non-CEO officer and director compensation, incentive-compensation plans and equity-based plans; and

(c) reviewing executive compensation disclosure before the issuer publicly discloses this information." Ibid, $\mathrm{s}$ 3.17, at 28 OSCB 5386.

${ }^{986} \mathrm{Ibid}, \mathrm{s} 3.16$, at 28 OSCB 5386.

${ }^{987}$ Dorval, supra note 934 at 232-33; Michael St Patrick Baxter, "The Fiduciary Obligations of Directors of a Target Company in Resisting an Unsolicited Takeover Bid" (1988) 20 Ottawa L Rev 63 at 90, 92 [Baxter]; CW

Shareholdings Inc $v$ WIC Western International Communications Ltd, 1998 CarswellOnt 1891 (WL Can) at paras 23, 27 [WIC]; Pente Investment Management Ltd v Schneider Corp, 1998 CarswellOnt 4035 at paras 11, 14 [Schneider]. ${ }_{988}$ Schneider, ibid at paras 33, 37-38.

${ }^{989}$ Osler, Hoskin \& Harcourt LLP, supra note 906 at 34. 
example, seven out of eight target boards involved in hostile takeover bids had established a special committee. ${ }^{990}$ Multilateral Instrument 61-101 also recommends the use of a special committee where the company is considering certain transactions with a related party. ${ }^{991}$

In several cases involving conflicts of interest or/and oppression remedy, Ontario courts invoked the role of a special committee in the evaluation of a proposed transaction or a takeoverbid and in the formation of the committee's recommendations. Like all directors, the members of the special committee (i.e. independent directors) have an obligation to act honestly and in good faith with a view to the best interests of the corporation, ${ }^{992}$ and must exercise the care, diligence and skill that a reasonably prudent person would exercise in comparable circumstances. ${ }^{993}$ As well, if the actions of committee members unfairly disregard the interests of a shareholder, unfairly prejudice those interests, or are oppressive to him/her, the shareholder may request the court to grant any remedy it thinks fit. ${ }^{994}$ Generally, however, courts would not

990

Table 1: Cases of Courts Establishing a Special Committee in a Hostile Takeover Situation

\begin{tabular}{|l|c|c|}
\hline Case Name & $\begin{array}{l}\text { Year of } \\
\text { Decision }\end{array}$ & $\begin{array}{l}\text { Special } \\
\text { Committee }\end{array}$ \\
\hline $\begin{array}{l}\text { CW Shareholdings Inc. v. WIC Western International } \\
\text { Communications Ltd. }\end{array}$ & 1998 & Yes \\
\hline Pente Investment Management Ltd. v. Schneider Corp. (Maple Leaf) & 1998 & Yes \\
\hline Gazit Inc v. Centrefund Realty Corp & 2000 & Yes \\
\hline
\end{tabular}

See CW Shareholdings Inc v WIC Western International Communications Ltd (1998), 39 OR (3d) 755; Pente Investment Management Ltd v Schneider Corp (1998), 42 OR (3d) 177; Gazit Inc v Centrefund Realty Corp, [2000] OJ No 3070.

Table 2: Cases of Securities Regulators Establishing Special Committee in a Hostile Takeover Situation

\begin{tabular}{|l|c|c|}
\hline Case Name & $\begin{array}{l}\text { Year of } \\
\text { Decision }\end{array}$ & $\begin{array}{l}\text { Special } \\
\text { Committee }\end{array}$ \\
\hline Re CW shareholdings Inc. & 1998 & Yes \\
\hline Re Ivanhoe III Inc. & 1999 & Yes \\
\hline Re Royal Host Real Estate Investment Trust & 1999 & Yes \\
\hline Re Chapters Inc. & 2001 & N/A \\
\hline Re Cara Operations Ltd. & 2002 & Yes \\
\hline
\end{tabular}

See Re CW shareholdings Inc (1998), 21 OSCB 2899; Re Ivanhoe III Inc (1999), 22 OSCB 1327; Re Royal Host Real Estate Investment Trust (1999), 22 OSCB 7819; Re Cara Operations Ltd (1999), 22 OSCB 7819.

${ }^{991}$ See Multilateral Instrument 61-101, Protection of Minority Security Holders in Special Transactions, subsections 2.3(2), 3.3(2), 4.3(3) , 5.4(3), section 7.1, and section 1.6 "Independent Committee", (2008) 31 OSCB 1321.

${ }_{992}$ See $C B C A$, supra note 27, s 122(1)(a); OBCA, supra note 601, s 134(1)(a).

${ }_{993}^{99}$ See $C B C A$, ibid, s 122(1)(b); OBCA, ibid, s 134(1)(b).

${ }^{994}$ See CBCA, ibid, s 241; OBCA, ibid, s 248. 
substitute their own judgment for those of the board, as long as the board adopts the committee's recommendations after adequate deliberation and the committee's recommendations were made honestly, in good faith and on reasonable grounds. The committee must have made reasonable efforts to ensure that it had the information and advice necessary to make the recommendations. The recommendations do not have to represent the best possible decision but must be within the range of reasonable alternatives based on the circumstances that existed at the time the decision was made. This is the Canadian version of the business judgment rule. ${ }^{995}$

For example, in Brant Investments Ltd. v. KeepRite Inc., KeepRite's CEO proposed to its board that KeepRite acquires certain assets from some subsidiaries of its major shareholder, Inter-City Gas Corporation (ICG). ${ }^{996}$ KeepRite's board formed a special committee composed of directors who were independent of ICG to consider the matter. ${ }^{997}$ The special committee reported to KeepRite's board that the acquisition would be desirable. ${ }^{998}$ After the acquisition was completed, some KeepRite minority shareholders brought an oppression action claiming the corporation's decision was oppressive or unfairly prejudicial to their interests. The main reasons the Court gave for concluding that the transaction was not oppressive to the minority shareholders were: (1) the matter had been considered by a special committee composed of members who are truly independent (i.e. independent from the major shareholder rather than only independent from management); ${ }^{999}$ and (2) the transaction recommended by the committee was fair to the minority shareholders as well as in the best interests of the corporation as a whole. ${ }^{1000}$ When these directors have acted honestly and reasonably, the court was unwilling to substitute its own judgment for that of the board of directors. ${ }^{1001}$

In Pente Investment Management Ltd. v. Schneider Corp., Maple Leaf Foods Inc. made an unsolicited takeover bid for Schneider Corp. which was controlled by the Schneider family. The Schneider board established a special committee consisting of five independent non-family directors and the CEO, and supported by independent financial advisors and legal counsel to

\footnotetext{
995 Brant Investments Ltd v KeepRite Inc, 1987 CarswellOnt 135 (WL Can) at paras 79, 109 [KeepRite]; Schneider, supra note 987 at paras 36-38.

${ }^{996}$ KeepRite, ibid at paras at 7, 9, 13.

${ }^{997}$ Ibid at paras 13, 25, 58, 74 .

${ }^{998}$ Ibid at paras 33-35.

${ }^{999}$ Ibid at paras 58, 74.

${ }^{1000}$ Ibid at paras 63, 106.

${ }^{1001}$ Ibid at paras 74, 79.
} 
review the bidder's offer and to consider other alternatives. ${ }^{1002}$ The special committee recommended to the board that the board accepted a third party offer, which was greater than market value of its shares but less than a subsequent bid by Maple Leaf. ${ }^{1003}$ Minority shareholders brought action against the company under oppression remedy claiming an order that would permit them to accept the highest bid. The main issues in this case were whether the special committee was independent and whether the advice given by the committee to the board was in the best interests of the corporation. The Ontario Court of Appeal held that it does not require independent directors in the special committee to make a perfect decision but only a reasonable one. ${ }^{1004}$ As long as the decision was within a range of reasonable alternatives and the committee consisted of members who have no conflicts of interest, acted independently and in good faith, it would not second-guess the special committee's decision. ${ }^{1005}$ The creation of a special committee composed of independent directors was part of the process to obtain the best transaction available in the circumstances and may shield target board's decisions made reasonably and in good faith. ${ }^{1006}$

It is worth mentioning that establishing a special committee is not, of course, sufficient to discharge the board's duty to carefully and independently review a matter. Whether independent directors in the special committee properly exercise their duty of care and fiduciary duty in making business decisions is the key to fulfilling such a responsibility. Other related factors, including the time it has to consider the matter, its access to information and its use of advisors, are also essential in determining whether the board has discharged its duty through the use of the special committee. ${ }^{1007}$

\footnotetext{
1002 Schneider, supra note 987 at paras 3, 11-12.

${ }^{1003}$ Ibid at para 3.

1004 Ibid at para 36.

${ }^{1005}$ Ibid at paras 36-38, 53; Naizam Kanji, "Business (Mis)judgment: Corporate Governance and the Role of Courts and Securities Regulators in Reviewing Target Defensive Tactics" in Poonam Puri \& Jeffrey Larsen, eds, Corporate Governance and Securities Regulation in the 21st Century (Markham, ON: LexisNexis Butterworths, 2004) at 243 [Kanji].

${ }_{1006}$ Schneider, ibid at para 53; Kanji, ibid.

${ }^{1007}$ In UPM-Kymmene Corp. v. UPM-Kymmene Miramichi Inc. (sometimes referred to as the Repap case), the court did not defer to the board's approval of a very generous compensation package recommended by the compensation committee composed of independent directors, because these independent directors failed to make reasonable efforts to ensure that they had the sufficient information and necessary advice to make their recommendation. The compensation committee members did not properly make use of the compensation consultant or give adequate consideration to the decision to recommend the compensation package to the board. UPM-Kymmene Corp. v. UPMKymmene Miramichi Inc., [2002] OJ No 2412 at paras 88-90, 124, 127-28, 214 DLR (4th) 496, 27 BLR (3d) 53; Osler, Hoskin \& Harcourt LLP, supra note 906 at 34.
} 


\subsection{Summary of Chapter Four}

According to the above analysis, courts, laws and regulations in the United States and Canada all count on independent directors as a check on managerial abuses. The content and legal frameworks regarding independent directors are similar but there are some differences between the two countries. Under current rules, the regulators in the United States and Canada both rely on independent directors as corporate monitors through four types of measures: (1) tightening the definition of independent directors; (2) regulating board composition; (3) requiring certain procedures in the boardroom to stifle the influence of management; (4) mandating three key board functions relating to the review of auditing, executive compensation and the nomination of directors. It is important to note that listed companies in the United States are required to comply with highly-detailed rules regarding the aforementioned measures (without any discretion), while the issuers in Canada enjoy the flexibility to decide whether to comply with the guidelines regarding the last three types of measures; however, they are required to give reasons for any non-compliance, with the exception of requirements regarding the definition of independent director and the audit committee which are mandatory. The main difference between the two legal regimes is mandatory compliance versus comply-or-explain regarding the monitoring role of independent directors in corporate governance. In addition to laws and regulations, courts in the US and Canada defer to decisions or recommendations made by independent directors with respect to (but not limited to) situations involving conflicts of interest. US courts are inclined to favor decisions made by a board composed of a majority of independent directors, while Canadian courts defer to decisions made by a board on the adoption of the recommendation of a separate independent committee.

Despite this apparent consensus among courts and regulators on both sides of the border regarding the fundamental importance of independent directors as corporate monitors, many scholars have questioned the effectiveness of independent directors as corporate monitors, as mentioned in chapter three of this thesis. Therefore, whether these costly reforms are justified is worth exploring. The next chapter will analyze empirical evidence regarding the effectiveness of independent directors in terms of improving firm performance, the performance of specific board tasks, quality of financial reporting, controlling executive compensation and the process of 
nominating board members. In addition, evidence regarding other mechanisms that may influence the effectiveness of independent directors is also investigated. 


\section{Chapter Five}

\section{Empirical Evidence Regarding the Effectiveness of Independent Directors}

The importance of board independence has been addressed by academia and securities regulators since the 1970s. Independent directors are expected to effectively monitor management, with the ultimate goal of protecting shareholder interests. Although some critics contend that the ability of, or the incentives for, independent directors may be insufficient to support or motivate them to wield their expected function, the law has relied on independent directors as corporate monitors for several decades. Financial economists have conducted many empirical studies by using statistical models to investigate the correlation between the presence of independent directors and different indices to measure the effectiveness of independent directors since the 1980s. Their results, to some extent, provide fair and objective evidence regarding the effectiveness of independent directors. In the following sections, I compile and analyze the results of these empirical studies, and try to reach some general conclusions regarding the effectiveness of independent directors.

Due to the different governance culture, legal environment and shareholder ownership patterns between the USA and Canada, the empirical findings of the USA may not be applicable to Canada, and vice versa. Thus, the results of empirical studies are discussed and analyzed separately by their sample areas. First, I explore the empirical findings in the United States. The empirical studies regarding Canadian corporations are analyzed in the following section.

\subsection{Empirical Studies in the United States}

Empirical studies regarding the effectiveness of independent directors in the United States can be roughly divided into four categories. The first category directly examines the correlation between board composition and overall firm performance measured by financial or accounting indicators. ${ }^{1008}$ The second category investigates whether independent directors fulfill their responsibilities in relation to discrete board tasks, such as replacing an incompetent CEO,

${ }^{1008}$ Bhagat \& Black 1999, supra note 25 at 923-24. 
responding to a takeover bid, or setting executive compensation. ${ }^{1009}$ The third category examines the monitoring function of independent directors in three key board committees: the audit committee (for the quality of financial reporting), the compensation committee (for remuneration of management), and the nominating committee (for director candidates). The final category explores whether other governance mechanisms (for example, leadership structure $^{1010}$ and outside directorships ${ }^{1011}$ ) or director characteristics (such as gender and race) influence the efficacy of independent directors. With a view to enhancing the comprehensibility of the discussion of empirical findings, this section of the thesis begins with a glossary of indicators of the effectiveness of independent directors and explains some of the factors that may affect the reliability of the empirical findings concerning the efficacy of independent directors, before analyzing the empirical results. In addition, the summary of empirical studies discussed in this chapter is provided in Appendix 1 to Appendix 27.

\subsubsection{Glossary of Effectiveness Indicators}

Independent directors are expected to hold management accountable and, hence, enhance shareholders' wealth. If they are really effective corporate monitors, their efforts should be captured by certain objective indicators. Scholars in the field of financial economics have developed their own or used existing (accounting) indices, such as return on equity, return on assets and Tobin's Q, as effectiveness indicators to evaluate the impact of board (or committee) independence on shareholder interests. The goal of these indicators describes the relationship between the presence of independent directors and some aspect of firm (or committee) performance. With a view to avoiding repeatedly explaining the same indicators in the text and to enhancing the comprehension of the correlation between director independence and shareholder interests, I provide a glossary of related accounting, financial terms or indicators, which are used in this chapter, for the readers' reference. Some indicators, which are employed

\footnotetext{
1009 Ibid at 923.

${ }^{1010}$ Leadership structure refers to whether a firm should bestow CEO and board chair duties on one individual or whether a firm should have different people to hold the two positions.

${ }^{1011}$ Outside directorships refer to whether a director holds multiple directorships. Some scholars contend that the more directorships a director holds, the higher quality the director signals. However, opponents argue that a director holding multiple board seats may be overcommitted and may be unable to perform their monitoring function effectively.
} 
only one or two times in this thesis, are explained in the footnotes accompanying the relevant study.

Return on Assets (ROA) is the ratio of net income to the book value of a firm's total assets. It shows how many dollars of earnings a company derives from each dollar of assets it controls. It is a useful ratio for comparing competing companies in the same industry.

Return on Equity (ROE) is the ratio of net income to shareholder's equity. It shows how much profit a company generates with the money shareholders have invested.

Return on Sales (ROS) is the ratio of net income (before interest and tax) to net sales. It shows how much profit is being produced per dollar of sales. It is also known as a firm's “operating profit margin." It also demonstrates the effectiveness of management in managing costs.

Tobin's $\mathbf{Q}$ is the ratio of the firm's market value to the replacement cost (book value) of its physical assets. Tobin's Q is high when the firm has valuable intangible assets in addition to physical capital, such as monopoly power, goodwill, a stock of patents, good managers, or effective independent directors. A high Tobin's Q suggests that a firm's managers or directors have produced greater market value from the same assets. ${ }^{1012}$

Abnormal Returns (ARs) are measured by the difference between the expected return of a security or portfolio and the actual return over a period of time. Abnormal returns are sometimes triggered by a special event, such as an appointment of independent directors, or a tender offer. Abnormal returns are usually used as an indicator of market reaction to events affecting the corporation, which can be either negative or positive.

\subsubsection{Factors That May Affect the Reliability of Empirical Findings Regarding the Efficacy of Independent Directors}

Before entering the discussion of the efficacy of independent directors, several common factors that may affect the reliability of empirical results have to be identified. First, the

\footnotetext{
${ }^{1012}$ Bhagat \& Black 2002, supra note 1 at 236; Morck, Shleifer \& Vishny, supra note 374 at 296; Romano, Quack Corporate Governance, supra note 11 at 1604; Benjamin E Hermalin \& Michael S Weisbach, "Boards of Directors as An Endogenously Determined Institution: A Survey of the Economic Literature" (2003) 9:1 Economic Policy Review 7 at 12 [Hermalin \& Weisbach 2003]; Yves Bozec \& Claude Laurin, "Large Shareholders Entrenchment and Performance: Empirical Evidence from Canada" (2008) 35: 1 \& 2 Journal of Business Finance \& Accounting 25 at 32 [Bozec \& Laurin].
} 
definition of independent directors may affect the reliability of empirical outcomes. Some studies use the term "independent director" to represent board members who are independent of the firm and management, while some studies adopt the term "outside director" to indicate the same situation. However, the expression "outside director" in some studies not only includes board members who are independent of the firm but also covers affiliated (or so-called gray) directors, who are not full-time employees but have certain business ties with the company. Since affiliated directors may not monitor management as diligently as independent directors due to their conflicts of interest, studies that only examine the role of outside directors may not fully capture the monitoring effect of independent directors. Their results may not represent the real effect of independent directors if their findings include the impact of affiliated directors.

The findings of two empirical studies in the 1990s have demonstrated this problem. Byrd and Hickman (1992) found that tender offer bidders with a majority of independent directors had less negative abnormal returns than those with less than $50 \%$ of independent directors, suggesting that shareholder interests were better served by boards dominated by independent directors. However, no similar effect was found for outside directors on boards (i.e. combining the effect of affiliated and independent directors). ${ }^{1013}$ Brickley, Cole and Terry (1994) reported that stock markets reacted positively for the adoption of poison pills for boards dominated by independent directors, compared to a negative reaction for boards dominated by inside directors. Similarly, the significant connection between the market reaction and board independence disappeared if outside directors took the place of independent directors. ${ }^{1014}$ Such results suggest that the effectiveness of independent directors is very sensitive to how an independent director is defined.

For this reason, studies showing the negative or neutral relationship between outside directors and their performance may not represent the real monitoring effect of independent directors, to the extent that these studies did not differentiate affiliated directors from outside directors. Had only independent directors been looked at, the results might have been different. Consequently, one must be very cautious in applying these results.

Second, changes in law or regulations regarding independent directors may have a significant impact on the effectiveness of independent directors. As discussed, corporate

\footnotetext{
1013 Byrd \& Hickman, supra note 363 at 198, 207, 219-20.

1014 James A Brickley, Jeffery L Coles \& Rory L Terry, "Outside Directors and the Adoption of Poison Pills" (1994) 35 Journal of Financial Economics 371 at 379 [Brickley, Coles \& Terry].
} 
scandals in the early 2000s led to a wave of reform aimed at enhancing requirements for director independence with the goal of holding management accountable. A complete independent audit committee required by the 1999 NYSE and NASDAQ listing rules became a part of SOX. ${ }^{1015}$ The NYSE and NASDAQ in 2003 further tightened the definition of "director independence"1016 (compared to the definition in 1999) and required all listed firms to have a majority of independent directors on the board. ${ }^{1017}$ With a view to fostering an environment for exercising independent judgment, the NYSE and NASDAQ both require that boards hold regular “executive sessions" without any managers in attendance. ${ }^{1018}$ Collectively, independent directors are less likely to be influenced by management and are required to be involved in more critical corporate decisions after these reforms because they improve the likelihood of independent action. As a consequence, independent directors may be more effective in protecting shareholder interests in the post-SOX period than those in the pre-SOX period. ${ }^{1019}$

Empirical findings support this point of view. A comparison between Professors Bhagat and Bolton's 2008 and 2009 studies provides an example of this situation. Bhagat \& Bolton (2008) reported that firms with a higher percentage of independent directors on the board are more likely to perform poorly using a sample across the SOX related reforms (1990-2004). ${ }^{1020}$ However, in their 2009 study, they found a similar result only for firms in the pre-SOX period (1998-2001). ${ }^{1021}$ On the contrary, they observed that greater board independence led to better firm performance after the enactment of SOX (2003-2007). ${ }^{1022}$ This comparison reveals that the change of law or regulations regarding independent directors did have a significant impact on the effectiveness of independent directors. If empirical evidence includes sample periods that straddle the implementation of SOX, and does not separate findings into pre-SOX results and

\footnotetext{
${ }^{1015}$ Sarbanes-Oxley Act, supra note 4, §301(3). Please refer to section 4.1.2.4.1.1 for further details.

${ }^{1016}$ NYSE Manual, supra note 5, §303A.02; NASDAQ Rule, supra note 5, §5605(a)(2). Please refer to section 4.1.2.1 for further details.

${ }^{1017}$ NYSE Manual, ibid, §303A.01; NASDAQ Rule, ibid, §5605(b)(1). Please refer to section 4.1.2.2 for further details.

${ }^{1018}$ NYSE Manual, ibid, §303A.03; NASDAQ Rule, ibid, §5605(b)(2). Please refer to section 4.1.2.3 for further details.

${ }^{1019}$ It is worth noting that the definition of independent directors is not significantly different between the pre-SOX and post-SOX empirical studies (most studies do not consider directors who have any business or family ties with the company as independent, no matter whether before or after the implementation of SOX). Nevertheless, the entire SOX reforms provide a better environment for independent directors to fulfill their monitoring duties.

${ }^{1020}$ Sanjai Bhagat \& Brian Bolton, "Corporate Governance and Firm Performance" (2008) 14 Journal of Corporate Finance 257 at 258, 266 Table 4, 271 [Bhagat \& Bolton 2008].

${ }^{1021}$ Sanjai Bhagat \& Brian J Bolton, "Sarbanes-Oxley, Governance and Performance" (17 March 2009) at 3, 17, 25, 36-37 Table III, online: SSRN <http://ssrn.com/abstract=1361815> [Bhagat \& Bolton 2009].

${ }^{1022}$ Ibid at 3-4, 17, 25, 38 Table III, 39 Table IV.
} 
post-SOX results, it may provide false conclusions regarding the effectiveness of independent directors, because poor performance by independent directors in the pre-SOX period may dilute their efficacy. ${ }^{1023}$ One must be very cautious in applying the empirical finding with sample periods that straddle significant relevant reform and in differentiating between empirical results with pre-SOX samples and those with post-SOX samples.

It is worth noting that most empirical research analyzed in this thesis does not explore the impact of SOX related reforms. Of around 80 US studies that explore the relationship between independent directors and firm performance, as well as performance of board tasks (or three key committee tasks), six studies ${ }^{1024}$ have post-SOX samples and only four ${ }^{1025}$ of them investigated whether the effectiveness of independent directors was influenced by SOX-related reforms. The lack of post-SOX evidence raises an issue that whether the findings with pre-SOX samples can be applicable to post-SOX period.

This thesis considers that whether the empirical findings with pre-SOX samples can be applicable to post-SOX period depends on the results of their findings. Studies with pre-SOX samples that show a positive relationship between independent directors and some indicators of monitoring effectiveness seem more likely to be reliable evidence of the role of independent directors in the post-SOX era. Because the monitoring environment prepared for independent directors has been largely enhanced in the post-SOX period, it is unlikely that the SOX reforms would reduce the monitoring effect of independent directors. On the contrary, studies with preSOX samples that show a neutral or negative relationship seem less likely to be reliable evidence, because the SOX reforms may enhance the monitoring effect of independent directors in the post-SOX period. The impact of independent directors on firm performance was significantly improved from negative or neutral in the pre-SOX period to positive in the post-SOX period is a typical example. As a result, unless studies with post-SOX samples report otherwise, studies with pre-SOX samples that show a positive result regarding independent directors' monitoring effect seem likely to be reliable evidence.

\footnotetext{
1023 See Bhagat \& Bolton 2008, supra note 1020 at 258, 271.

${ }^{1024}$ Please refer to Chhaochharia and Grinstein (2007) and Bhagat and Bolton (2009) in section 5.1.3.1, Bhagat \& Bolton (2008) in section 5.1.3.2, Duchin, Matsusaka and Ozbas (2010) in section 5.1.3.3, and Chhaochharia and Grinstein (2009) and Wan (2009) in section 5.1.4.3.

1025 Please refer to Chhaochharia and Grinstein (2007) and Bhagat and Bolton (2009) in section 5.1.3.1, and Chhaochharia and Grinstein (2009) and Wan (2009) in section 5.1.4.3.
} 
The lack of studies examining the monitoring effect of independent directors in the postSOX period may be because the degree of variability of board (or committee) independence is limited after the implementation of SOX because listed companies have to follow the board (or committee) independence requirements set by SOX or listing regulations. It is difficult for researchers to detect the correlation between board (or committee) independence and performance indicators, since the level of board (or committee) independence is similar among most of the listed firms. So far, only a few studies have explored whether the effectiveness of independent directors was influenced by SOX-related reforms by comparing the performance of same firms between pre-SOX period and post-SOX periods. More research is needed to confirm whether the effectiveness of independent directors is different between pre-SOX and post-SOX period. Where there are no studies with post-SOX findings, this thesis employs pre-SOX results that are less likely to be subject to the impact of SOX-related reforms to evaluate whether independent directors are effective corporate monitors.

Third, the problem of endogeneity may reduce the reliability of empirical findings. The problem of endogeneity arises when there is a loop of causality between the independent and dependent variables of a regression model. ${ }^{1026}$ For example, many financial economists have indicated that board independence and firm performance are endogenously determined. ${ }^{1027}$ That is, the proportion of independent directors on the board and firm performance are determined simultaneously or affected by some third factors. ${ }^{1028}$ More specifically, the proportion of independent directors on the board may influence firm performance; at the same time, firm performance may influence the percentage of independent directors serving on the board. ${ }^{1029}$ Thus, finding a positive relationship between board composition and firm performance implies two possibilities regarding the direction of causation: (1) firms with a higher proportion of

\footnotetext{
${ }^{1026}$ In addition, the problem of endogeneity may come from an uncontrolled variable which both affects the independent and dependent variables.

${ }^{1027}$ Hermalin \& Weisbach 2003, supra note 1012 at 8; Wallace N Davidson III \& Wei Rowe, "Intertemporal Endogeneity in Board Composition and Financial Performance" (2004) 1:4 Corporate Ownership \& Control 49 [Davidson \& Rowe] at 49-50; Ning, Davidson \& Zhong, supra note 679 at 47-48; Lawrence D Brown \& Marcus L Caylor, "Corporate Governance and Firm Valuation" (2006) 25 Journal of Accounting and Public Policy 409 at 424 25 [Brown \& Caylor 2006].

${ }^{1028}$ Michael R Roberts \& Toni M Whited, "Endogeneity in Empirical Corporate Finance" (30 August 2011), Simon School Working Paper No. FR 11-29, at 6, online: SSRN <http://ssrn.com/abstract=1748604 or http://dx.doi.org/10.2139/ssrn.1748604>; Frederick Tung, "The Puzzle of Independent Directors: New Learning" (2011) 91 BUL Rev 1175 at 1186 [Tung].

${ }^{1029}$ Hermalin \& Weisbach 2003, supra note 1012 at 8; Davidson \& Rowe, supra note 1027 at 49; Bhagat and Black 2002, supra note 1 at 243.
} 
independent directors enhance firm performance; or (2) firms with better firm performance choose to have a higher percentage of independent directors on their boards. Similarly, finding a negative correlation between board composition and firm performance also suggests two possible scenarios: (1) firms with higher proportions of independent directors have poor firm performance; or (2) firms with poor firm performance choose to add more independent directors to their boards. As a result, the causality between board independence and firm performance cannot be identified without further investigation.

Some financial economists use "lagged effects" to overcome the problem of causality. ${ }^{1030}$ More specifically, using lagged effects permits conclusions regarding whether board composition in one period influences firm performance in later periods or firm performance in one period influences the proportion of independent directors on the board in later periods. In this way, the causality between board independence and firm performance can be identified. ${ }^{1031}$ Some empirical studies seek to control causation using this approach to identify the relationship between board composition and firm performance, ${ }^{1032}$ while some scholars adopt different approaches to solve this issue. ${ }^{1033}$

Since "lagged effects" may exist between board composition and firm performance, the absence of a contemporaneous correlation between board composition and firm performance does not exclude the possibility that their relationship may be present in later periods. ${ }^{1034}$ The findings of Baysinger and Butler (1985) are a typical example. They did not find any current correlation between board composition and firm performance; however, they reported that firms with more independent directors in the early 1970s enjoyed greater financial performance in the late 1970s. ${ }^{1035}$ Similarly, Hermalin and Weisbach (1991) did not observe any significant

${ }^{1030}$ Klein 1998, supra note 501 at 292-93; Brown \& Caylor 2006, supra note 1027 at 424-25; Lawrence D Brown \& Marcus L Caylor, "Corporate Governance and Firm Operating Performance" (2009) 32 Review of Quantitative Finance and Accounting 129 at 132-33 [Brown \& Caylor 2009]; Bhagat and Black 1999, supra note 25 at 949; Bhagat and Black 2002, supra note 1 at 243-44; Bhagat \& Bolton 2008, supra note 1020 at 258; Bhagat \& Bolton 2009, supra note 1021 at $14-15$.

${ }^{1031}$ Hermalin \& Weisbach 2003, supra note 1012 at 12; Davidson \& Rowe, supra note 1027 at 50-51.

${ }^{1032}$ Please refer to supra note 1030 .

${ }^{1033}$ Some scholars used simultaneous equations methods and three-stage least squares (3SLS) to address the problem of endogeneity. Bhagat and Black 2002, supra note 1 at 244; David A Carter et al, "The Diversity of Corporate Board Committees and Financial Performance" (2008) at 6-9, online: SSRN < http://ssrn.com/abstract=1106698> [Carter et al 2008].

${ }^{1034}$ See Klein 1998, supra note 501 at 293.

${ }^{1035}$ Barry D Baysinger \& Henry N Butler, "Corporate Governance and the Board of Directors: Performance Effects of Changes in Board Composition” (1985) 1 JL Econ \& Org 101 at 115-16 [Baysinger \& Butler 1985]. 
relationship between board composition and current firm performance, ${ }^{1036}$ but they found that firms with poor performance in the past added outside directors to their boards in the later period. ${ }^{1037}$ Thus, empirical studies reporting no contemporaneous connection between board composition and firm performance need to be further examined because lag effects may exist.

Under this same rationale, empirical studies reporting a contemporaneous negative correlation between board composition and firm performance do not necessarily demonstrate the ineffectiveness of independent directors. It is possible that poorly performing firms add more independent directors to their boards, rather than that boards with more independent directors cause their firms to perform poorly. Therefore, studies showing a negative relationship between director independence and poor performance also need to be further examined to confirm causality.

Since the concentration of this thesis is the efficacy of independent directors, I focus on how the change in board composition causes the improvement (or deterioration) of firm performance (because this can demonstrate whether independent directors are effective), rather than whether firm performance influences board composition. After controlling for the problem of causation, the efficacy of independent directors on firm performance seemingly can be demonstrated in the following two situations: (1) a higher proportion of independent directors on the board correlates with better firm performance in later periods; (2) firms with poor performance add independent directors to their boards; leading to improved firm performance in later periods.

It is worth mentioning that causation and lagged effects are often examined in studies of the relationship between board independence and firm performance, but they are seldom investigated in studies looking at the relationship between independent directors and board (or committee) tasks. Nevertheless, not addressing causation or lagged effects does not mean there are no such issues in these studies. The results of these studies (those that do not control for causation or lagged effects) may have an alternative interpretation or risk missing an important

\footnotetext{
${ }^{1036}$ Benjamin E Hermalin \& Michael S Weisbach, "The Effects of Board Composition and Direct Incentives on Firm Performance" (1991) 20 Financial Management 101 at 106 [Hermalin \& Weisbach 1991].

${ }^{1037}$ Hermalin \& Weisbach 1988, supra note 161 at 602, 605. Professors Hermalin and Weisbach' 1988 and 1991 studies both investigated the relationship between board independence and firm performance by using a sample of 142 NYSE companies in the years 1971, 1974, 1977, 1980 and 1983. Their 1991 study reported no contemporaneous connection between board composition and firm performance (Tobin's Q), while their 1988 study observed that the fraction of outside directors on large corporate boards increased slightly after corporations performed poorly. Hermalin \& Weisbach 1988, ibid at 591; Hermalin \& Weisbach 1991, ibid at 105, 107 Exhibit 1.
} 
connection between independent directors and the performance of board (or committee) tasks. However, the impact of the causation (or lagged effects) on the efficacy of independent directors is a complex issue in empirical research and even financial economists may not address them properly. This thesis will not, and should not, comment on studies that did not control for causation or lagged effects unless other scholars have raised these issues. The analysis of empirical studies starts with the correlation between board independence and overall firm performance.

\subsubsection{Board Independence and Overall Firm Performance}

Overall firm performance has been used as the main proxy for measuring the effectiveness of independent directors since the 1980s. The rationale behind this approach is that if firms with a higher proportion of independent directors on the board are associated with better overall performance, the efficacy of independent directors in ensuring the promotion of shareholder interests is demonstrated. However, at a glance, the results of empirical studies concerning the relationship between director independence and overall firm performance are divergent. Five studies found that firms with a higher proportion of independent directors were correlated with better firm performance, while five studies observed the opposite results. Another 11 studies reported that firm performance was unrelated to the fraction of independent directors on the board. It seems that there is no common thread running through the results of these empirical studies.

However, from my observation, after considering three factors aforementioned: (1) the effect of definition of independent directors; (2) the effect of SOX and related reforms; and (3) the problem of endogeneity, in combination with that evidence of three studies in the pre-SOX period was unpersuasive, it appears that independent directors were not effective in enhancing firm performance before the implementation of SOX, but became effective corporate monitors in some circumstances after the enforcement of new rules. In the following sections, I address how these three factors influence the effectiveness of independent directors and the reliability of empirical results, and then explain why the ostensibly mixed empirical results turn out to demonstrate a clear trend as described. The first part examines five findings that reported a positive relationship between the presence of independent directors and firm performance. 


\subsubsection{Five Studies Reporting Positive Relationship between Director Independence and Firm Performance}

There are five studies reporting a positive relationship between the presence of independent directors and firm performance. Three had sample periods before 1990, while two had sample periods after the implementation of SOX. Baysinger and Butler (1985) ${ }^{1038}$ reported that corporations with relatively more independent directors ${ }^{1039}$ on their boards in the early $1970 \mathrm{~s}$ enjoyed better firm performance (as measured by adjusted ROE) in the late 1970s, compared to corporations with less independent boards. However, they did not find any contemporaneous correlation between board composition and firm performance. ${ }^{1040}$ Interestingly, the study also revealed that firm performance in the late 1970s was improved by adding independent directors up to the point where independent directors accounted for around $30 \%$ of the board. Beyond this percentage, adding more independent directors resulted in diminishing firm performance. ${ }^{1041}$ Schellenger, Wood and Tashakori (1989) ${ }^{1042}$ found that the fraction of outside directors ${ }^{1043}$ on the board was positively correlated with contemporaneous firm performance (as measured by risk-adjusted market return ${ }^{1044}$ and return on assets), but found an insignificant

\footnotetext{
${ }^{1038}$ The authors studied the relationship between board composition and financial performance (as measured by adjusted ROE) across 266 major US corporations listed in Forbes during the 1970-80 period. Baysinger \& Butler 1985, supra note 1035 at 111.

${ }^{1039}$ The definition of independent director is a board member who is not currently employed by the firm or does not have any strong psychological or economic dependence on its managers. Ibid at 109-110.

${ }^{1040}$ Ibid at 115-16.

${ }^{1041}$ Barry D Baysinger \& Henry N Butler, "Revolution Versus Evolution in Corporation Law: The ALI's Project and the Independent Director" (1984) 52 The George Washington L Rev 557 at 573-75 [Baysinger \& Butler 1984]. The findings drew to an implication that the optimal percentage of independent directors was well below the majority threshold, and above average firm performance was achieved by corporations with less than a majority of independent directors on their boards. Baysinger \& Butler 1984, ibid at 575; Baysinger \& Butler 1985, supra note 1035 at 119.

1042 The authors conducted a study regarding the relationship between board composition and financial performance by employing a sample of 526 randomly selected corporations that were listed on both the Compustat Industrial tape and the Center for Research in Security Prices (CRSP) daily price files in 1986. Michael H Schellenger, David D Wood \& Ahmad Tashakori, "Board of Director Composition, Shareholder Wealth, and Dividend Policy" (1989) 15:3 Journal of Management 457 at 461 [Schellenger, David \& Tashakori]. This study used four indices to measure firm performance, namely return on assets (ROA), return on equity (ROE), shareholder's annualized total market return on investment (RET), and risk-adjusted shareholder's annualized total market return on investment (RET/STD).

${ }^{1043}$ Outside directors in this study are defined as directors who are not current employees of the company. Ibid. ${ }^{1044}$ The term "risk-adjusted market return" means risk-adjusted shareholder's annualized total market return on investment. Ibid.
} 
relationship between board composition and other performance indices (as measured by return on equity and $\left.\mathrm{RET}^{1045}\right) .{ }^{1046}$

Rosenstein and Wyatt (1990) ${ }^{1047}$ observed that average abnormal returns for shareholders increased by $0.2 \%$ during the two-day announcement period when companies announced the appointment of an additional independent director ${ }^{1048} \cdot 1049$ The positive abnormal returns during the announcement period suggest that shareholders perceive the appointments of independent directors will increase their wealth. ${ }^{1050}$ In contrast, in a follow-up study, the same authors found that the price reaction to the appointment of inside directors was close to zero, implying that independent directors were perceived more beneficially than inside directors. ${ }^{1051}$

At a glance, the above three studies seemingly show that independent directors were associated with enhanced corporate performance before 1990. However, upon digging deeper, the supporting evidence seemingly becomes unpersuasive. With respect to Baysinger and Butler (1985), Professors Fosberg, Bhagat and Black questioned why the time lag (nearly 10 years) was so long for the benefits of independent director monitoring to manifest itself on firm performance. ${ }^{1052}$ In addition, independent directors were useful only when their proportion on the board was lower than 30\%. Regarding Rosenstein and Wyatt (1990), Professors Bhagat and Black indicated that the $0.2 \%$ stock prices increase was statistically significant, but economically small, and could only reflect a signaling effect. This means that appointing an additional independent director merely signals that the company plans to address its business problems, but whether board independence can really enhance the company's ability to address these problems is still unknown. ${ }^{1053}$ Moreover, stock market reaction is susceptible to investor anticipation. It

\footnotetext{
${ }^{1045}$ RET is the abbreviation for shareholder's annualized total market return on investment. Ibid.

1046 Schellenger, David \& Tashakori, ibid at 463.

1047 The authors examined 1251 announcements of an independent director appointment for firms listed on the New York Stock Exchange (NYSE) or the American Stock Exchange (AMEX) from 1981 to 1985. Rosenstein \& Wyatt, supra note 392 at $176-78$.

${ }^{1048}$ This study defines independent directors as directors who are not a present or former employee of the firm and whose only formal connection with the firm is their duties as directors. Ibid at 177-78. The term "independent directors" here is identical to the term "outside directors" used by the original authors in their study.

1049 Ibid at 184.

${ }^{1050}$ Ibid at 186-87.

${ }^{1051}$ Stuart Rosenstein \& Jeffrey G Wyatt, “Inside Directors, Board Effectiveness, and Shareholder Wealth” (1997) 44 Journal of Financial Economics 229 at 231, 248.

1052 Bhagat \& Black, 2002, supra note 1 at 236; Richard H Fosberg, "Outside Directors and Managerial Monitoring” (1989) 20:2 Akron Business and Economic Review 24 at 25 [Fosberg].

${ }^{1053}$ Bhagat \& Black 1999, supra note 25 at 941; Bhagat \& Black 2002, supra note 1 at 237; Hermalin \& Weisbach 2003, supra note 1012 at 13.
} 
may not capture actual improvements in shareholder interests for the long term. ${ }^{1054}$ Finally, in the study of Schellenger, Wood and Tashakori (1989), the findings-a positive relationship between the proportion of independent directors and current firm performance-did not control for the problem of endogeneity. Whether higher board independence caused better firm performance or firms with better performance added more independent directors to their boards was still unclear. In addition, the results did not differentiate affiliated directors from outside directors. The real effect of independent directors on firm performance was not addressed. Taken together, these pre-SOX findings seemingly do not provide reliable evidence that independent directors were effective.

In the new millennium, corporate scandals led to a wave of reform aimed at improving director independence in holding management accountable. The new stock exchange rules further tightened the definition of director independence and required all listed corporations to have a majority of independent directors. Chhaochharia and Grinstein (2007) ${ }^{1055}$ hypothesized that if the relative effect of the rules ${ }^{1056}$ on firms (that were less compliant with SOX related reforms in the pre-SOX period) ${ }^{1057}$ is positive, then the portfolio of these less compliant firms should outperform the portfolio of more compliant firms ${ }^{1058} \cdot{ }^{1059}$ The authors found that the announcement of the new rules was associated with higher abnormal returns for large and medium-sized firms ${ }^{1060}$ that were less compliant with board independence provisions, compared to those more compliant ones. However, small firms with low director independence (less compliant with independence requirements) earned lower returns during the rule announcement

1054 Bhagat \& Bolton 2008, supra note 1020 at 264.

1055 The authors studied whether the new director independence rules had an impact on firm value (as measured by abnormal returns), and whether there was a difference in the announcement effect across small and large firms. They constructed portfolios of 1,101 S\&P 1500 firms based on the extent to which they are compliant with the SOX rules, and then compared the stock returns of these portfolios between November 2001 and October 2002. Vidhi Chhaochharia \& Yanv Grinstein, "Corporate Governance and Firm Value: The Impact of the 2002 Governance Rules" (2007) 62:4 Journal of Finance 1789 [Chhaochharia \& Grinstein 2007] at 1790, 1800.

${ }^{1056}$ SOX and related stock exchange rules include four requirements associated with board and committee independence: (1) a majority of independent directors on the board; (2) a fully independent audit committee; (3) an entirely independent compensation committee; and (4) a solely independent nominating committee. Ibid at 1793-94. ${ }^{1057}$ Less compliant firms are defined as firms that have only one or none of the aforementioned independence requirements in place before the SOX and related reforms became effective. Ibid at 1800 .

${ }^{1058}$ More compliant firms are defined as firms that have at least three of the four aforementioned independence requirements in place. Ibid.

${ }^{1059}$ Ibid at 1790, 1794. The authors chose the period between November 2001 and October 2002 to capture the entire effect of the events related to the legislation on corporate value. Ibid at 1794 .

${ }^{1060}$ The authors do not provide a clear standard to differentiate large, medium and small firms. According to the statistics of Table VII, large firms have an average market capitalization between 17 to 25 billion, 2.0 to 2.8 billion for median firms and 0.59 to 0.67 billion for small firms. Ibid at 1812 . 
period, in comparison with other small firms with high director independence. The results suggest that the requirement of director independence enhanced firm value, but only for large and medium-sized corporations. Small firms seem to suffer from the implementation of new independence requirements. ${ }^{1061}$ It is worth mentioning that the results only captured investors' perception in relation to the new governance rules. It did not look at actual improvements in shareholder interests for the long term. Whether the new rules actually enhance corporate performance was not addressed. ${ }^{1062}$

Bhagat and Bolton (2009) ${ }^{1063}$ also explored the impact of SOX and the related regulations on the correlation between board independence and firm performance. The unique feature of this study is that the authors separated the sample into pre-2002 and post-2002 periods to examine the effect of SOX, an approach which had never been adopted in an empirical study in this field. ${ }^{1064}$ The authors found a significant and negative relationship between the proportion of independent directors ${ }^{1065}$ on the board and contemporaneous and future ${ }^{1066}$ firm performance (ROA), consistent with most prior research for the pre-SOX period, which suggests that greater independence leads to poorer performance. However, they observed the opposite result for the post-SOX period. More specifically, board independence had a positive and significant effect on contemporaneous and future firm performance (ROA) during the 2003 to 2007 period. ${ }^{1067}$ This implies that the new requirements regarding director independence may have had some desired effect. ${ }^{1068}$ Having a more independent board seems to be a better way to generate a higher return for capital suppliers on their investment where there are supporting rules, such as those in the

\footnotetext{
${ }^{1061}$ Ibid at 1791, 1814, 1817, 1822. The authors addressed two possible explanations for the results. The first one is that potential costs of having independent directors on the boards were lower in large and medium corporations, compared to that of small corporations. The second possibility is that the market considered the scandals between 2000 and 2001 as mainly a large-firm problem, so the oversight rules were more applauded in large companies than in small companies. Ibid at 1818 .

1062 Ibid at 1822 .

1063 The authors explored the impact of SOX and related regulations on the relationship between corporate governance mechanisms (including board independence, director ownership, and CEO duality) and firm performance by using a sample including approximately 1,500 large US firms from 1998 to 2007. Bhagat \& Bolton 2009, supra note 1021 at 11.

1064 Ibid at 17.

${ }^{1065}$ The authors define independent directors as directors who are unaffiliated with the sample firm. This includes directors who are neither employees of the firm nor affiliated with the firm. Ibid at 12 .

${ }^{1066}$ With a view to controlling the problem of endogeneity, the authors also investigated the correlation between board independence and the next year's ROA as well as ROA for the next two years. Ibid at 18, 39 Table IV.

${ }^{1067}$ Ibid at 3-4, 17, 25, 38 Table III, 39 Table IV.

${ }^{1068}$ It is also possible that the other reforms resulted in independent directors being more effective.
} 
SOX reforms. ${ }^{1069}$ It is worth mentioning, however, that the authors did not find any significant relationship between board independence and other firm performance indicators (Tobin's Q and stock return). ${ }^{1070}$ This suggests that the correlation between board independence and firm performance was not robust and was sensitive to how firm performance is measured.

Collectively, investors seem to feel that the SOX-related reforms had a positive impact on shareholder wealth for medium and large firms as founded by Chhaochharia \& Grinstein (2007) and this investor perception was partially supported by the findings of Bhagat \& Bolton (2009). It seems that stricter director independence requirements did matter and achieved some desired effect. Considering the evidence that reported a positive relationship between board independence and firm performance as a whole, independent directors seem to be not truly effective in enhancing shareholder wealth in the pre-SOX period, but seemingly became firm value enhancers in some circumstances in the post-SOX period.

\subsubsection{Five Studies Reporting Negative Relationship between Director Independence and Firm Performance}

Five studies reported that a higher fraction of independent directors on the board were associated with lower firm performance. Four had sample periods before the enactment of SOX, while one had a sample period that straddles the implementation of SOX.

Hermalin \& Weisbach $(1988)^{1071}$ found that the fraction of outside directors ${ }^{1072}$ on large corporate boards increased slightly after corporations perform ${ }^{1073}$ poorly. ${ }^{1074}$ More specifically, corporations with performance in the bottom decile increased their proportion of outside

\footnotetext{
${ }^{1069}$ Ibid at 4.

${ }^{1070}$ Ibid at $17-18,39$.

${ }^{1071}$ The authors studied whether firm performance, CEO tenure and changes in market structure led to changes in board composition by surveying 142 firms listed on NYSE from 1972 to 1983. Hermalin \& Weisbach 1988, supra note 161 at 591 .

${ }^{1072}$ In this study, directors who do not work full-time for companies are classified as "outside directors." Inside directors mean directors who are full-time employees of the company. Directors who are closely associated with the firm, but are not full-time employees, are designated as "gray directors." Ibid at 591. According to the above classification, the authors seemingly do not differentiate the effect of independent directors from that of outside directors when they analyze the relationship between board composition and firm performance.

${ }^{1073}$ In this study, firm performance is measured by the change of EBIT (earnings before interests and taxes weighted by the book value of assets in the most recent fiscal year) and the return on the company's stock for 12 months. Ibid at 597.

${ }^{1074}$ Ibid at 602, 605.
} 
directors by around $1 \%$ in the following year. ${ }^{1075}$ In other words, firms with poor performance in the past added independent directors to their boards in the later period. ${ }^{1076}$ Interestingly, the authors did not find any significant relationship between board composition and current firm performance in their later study. ${ }^{1077}$

Eight years later, Agrawal and Knoeber (1996) ${ }^{1078}$ reported a significant and negative relationship between the proportion of outside directors ${ }^{1079}$ on the board and current firm performance (as measured by Tobin's Q). The authors further found that outside directors caused firms to perform poorly, rather than that poorly performing firms added outsiders to the boards. ${ }^{1080}$ It is worth noting that an important limitation on the reliability of Hermalin \& Weisbach (1988) and Agrawal and Knoeber (1996) is that the two studies looked at outside directors only rather than independent directors.

In the late 1990s and the early 2000s, Bhagat and Black $(1999,2002)^{1081}$ published two articles regarding the correlation between board independence ${ }^{1082}$ and firm performance. Both studies reported a significant and negative correlation between board independence and three

\footnotetext{
${ }^{1075}$ Michael S Weisbach, "Outside Directors and CEO Turnover" (1988) 20 Journal of Financial Economics 431 at 454 [Weisbach, CEO Turnover]. In this study, Professor Weisbach mentioned that Hermalin and Weisbach (1988) had noticed the lagged effect between board independence and firm performance.

1076 The findings imply that the corporation thought (or perceived) that more independent directors would help improve firm performance. However, whether the more independent board can really enhance firm performance is still unknown.

${ }^{1077}$ Hermalin \& Weisbach 1991, supra note 1036 at 106. Professors Hermalin and Weisbach' 1988 and 1991 studies both investigated the relationship between board independence and firm performance by using a sample of 142 NYSE companies in the years 1971, 1974, 1977, 1980 and 1983. Their 1991 study reported no contemporaneous connection between board composition and firm performance (Tobin's Q), while their 1988 study observed that the fraction of outside directors on large corporate boards increased slightly after corporations perform poorly. Hermalin \& Weisbach 1988, supra note 161 at 591; Hermalin \& Weisbach 1991, ibid at 105, 107 Exhibit 1.

${ }^{1078}$ The authors studied the effect of seven governance mechanisms in controlling agency problems between managers and shareholders by using a sample of 383 Forbes 800 firms in 1987. Anup Agrawal \& Charles R Knoeber, "Firm Performance and Mechanisms to Control Agency Problems between Managers and Shareholders" (1996) 31 Journal of Financial and Quantitative Analysis 377 at 385-87 [Agrawal \& Knoeber].

${ }^{1079}$ In this study, outside directors are defined as directors who are not employees of the company. Ibid at 386.

${ }^{1080}$ Ibid at 393.

${ }^{1081}$ The authors examined the correlation between board independence and firm performance in their 1999 and 2002 studies by surveying around 930 of the largest corporations in the United States. The samples of the two studies are almost identical, consisting of board composition data in early 1991 and data of four or five financial performance measures from 1985 to 1995. The differences between two studies are that: (1) Bhagat and Black (2002) used an extensive set of control variables and robustness checks, and also ran additional three-stage least squares regressions, but Bhagat and Black (1999) did not; (2) Bhagat and Black (1999) employed five indices-Tobin's Q, ROA, ratio of sales to assets, operating margin, and sales per employee-to measure firm performance, while Bhagat and Black (2002) mainly used the first three as their performance indicators. Bhagat \& Black 2002, supra note 1 at 240-42, 246 Table 2 and Table 3, 247 Table 4; Bhagat \& Black 1999, supra note 25 at 945, 946 Table 3.

${ }_{1082}$ Board independence is measured by the proportion of independent directors minus the proportion of inside directors. Bhagat \& Black 1999, ibid at 944-45; Bhagat \& Black 2002, ibid at 239.
} 
firm performance measures (Tobin's Q, ROA and ratio of sales to assets). More specifically, firms with lower performance from 1988 to 1990 were correlated with a higher percentage of independent directors ${ }^{1083}$ on their boards in the later period (1991). ${ }^{1084}$ The authors concluded that low-profitability firms responded to their business trouble by increasing the proportion of independent directors on their boards. ${ }^{1085}$

Most importantly, they further found that firms did not perform better (and may even perform worse), after more independent directors were added to the boards. ${ }^{1086}$ More specifically, firms with poor performance from 1988 to 1990 added independent directors to their boards in 1991, but their performance was not, therefore, enhanced, ${ }^{1087}$ and even became worse, ${ }^{1088}$ during the 1991 to 1993 period. ${ }^{1089}$ It seems the conventional wisdom that greater board independence leads to improved corporate performance is not supported by Professors Bhagat and Black's studies using a pre-SOX sample. ${ }^{1090}$

In 2008, Bhagat \& Bolton (2008) ${ }^{1091}$ found that the percentage of independent directors ${ }^{1092}$ on the board was negatively associated with current and next year's ROA and Tobin's $\mathrm{Q}^{1093}$. This means that adding an additional independent director to the board will not increase shareholder wealth, but harm corporate value for the moment and in the future. ${ }^{1094}$ Since most of the sample period in this study was before the implementation of SOX and the

\footnotetext{
${ }^{1083}$ In this study, inside directors refer to persons who are currently officers of the company. Affiliated directors mean relatives of officers; persons who are likely to have business relationships with the company, such as investment bankers and lawyers, and persons who were officers in the recent past. Independent directors refer to outside directors without such affiliations. Bhagat \& Black 1999, ibid at 923; Bhagat \& Black 2002, ibid at 239.

1084 Bhagat \& Black 1999, ibid at 935, 944-45, 946 Table 3.

1085 Bhagat \& Black 2002, ibid at 233, 248.

1086 Ibid at 249, 263.

${ }^{1087}$ ROA became insignificant in the later period (1991 to 1993) in both studies, while ratio of sales to assets was only significant and negative in Bhagat and Black (1999) in the later period (1991 to 1993) but became insignificant in Bhagat and Black (2002) in the later period (1991 to 1993)]. Ibid at 247 Table 4, 250 Table 5; Bhagat \& Black 1999, supra note 25 at 946 Table 3.

1088 Tobin's Q remained significant and negative in the later period (1991 to 1993). Bhagat \& Black 1999, ibid; Bhagat \& Black 2002, ibid.

1089 Bhagat \& Black 2002, ibid at 248-49, 252, 263.

1090 Ibid at 263.

${ }^{1091}$ The authors examined the relationship between corporate governance mechanisms (including board independence, stock ownership of board members, and CEO-chair separation) and firm performance (as measured by ROA and Tobin's Q) by surveying more than 10,000 firms during the period 1990 to 2004. Bhagat \& Bolton 2008, supra note 1020 at 260-61.

1092 The authors did not define independent directors in the study. However, they mentioned that board independence was measured by the proportion of unaffiliated independent directors on the board, which suggests that independent directors are those who have no affiliation with the firm they serve. Ibid at 261 Table 1.

${ }^{1093}$ In this study, firm performance is measured by current and next year's ROA and Tobin's Q, with a view to controlling the problem of endogeneity. Ibid at 264, $264 \mathrm{n} 13$.

${ }^{1094}$ Ibid at 258, 266 Table 4, 271.
} 
related reforms, the results seem to reconfirm the previous findings that the addition of independent directors did not necessarily enhance firm value in the pre-SOX period.

Taken together, the findings reported by Hermalin \& Weisbach (1988) and Agrawal and Knoeber (1996) may not be fully reliable because neither study differentiated effect between outside and independent directors. The remaining three studies, nevertheless, showed that lowprofitability firms responded to their business trouble by increasing the level of board independence, but their performance was not therefore enhanced, and in some cases became even worse, in the later period. Such results were observed mostly from pre-SOX samples.

\subsubsection{Studies Showing No Relationship between Independent Directors and Firm Performance}

Eleven studies reported that the proportion of independent directors on the board was not related to firm performance. Except for Duchin, Matsusaka and Ozbas (2010), all these studies had sample periods before the enactment of SOX. After taking the definition of independent directors and the lagged effect into account, the eleven studies can be divided into four groups.

The first group includes Mehran (1995), Yermack (1996), Fogel and Geier (2007) and Duchin, Matsusaka and Ozbas (2010), which do not control for a possible lagged effect. In the mid-1990s, Mehran (1995) ${ }^{1095}$ found no significant relationship between contemporaneous firm performance and the percentage of independent directors ${ }^{1096}$ on the board, ${ }^{1097}$ while Yermack $(1996)^{1098}$ observed that the percentage of independent directors ${ }^{1099}$ on the board was not correlated with current return on assets, return on sales and ratio of sale to assets (as proxies for

\footnotetext{
1095 The author investigated the determinants of executive compensation structure and the association between board composition and firm performance (as measured by Tobin's Q and ROA) by using compensation data for 153 randomly selected manufacturing firms during the period from 1973 to 1983. Hamid Mehran, "Executive Compensation Structure, Ownership, and Firm Performance" (1995) 38 Journal of Financial Economics 163 at 16869 [Mehran].

${ }^{1096}$ In this study, independent directors are members of the board who are neither top executives, retired executives, or former executives of the company nor relatives of the CEO. Outside corporate lawyers who are employed by the firm and also serve on the board are considered insiders. Ibid at 169-70. The term "independent directors" here is identical to the term "outside directors" used by the original author in his study.

${ }^{1097}$ Ibid at 180.

${ }^{1098}$ The author investigated the relationship between board size and firm value in a sample of 452 large industrial firms during 1984 to 1991 period. David Yermack, "Higher Market Valuation of Companies with a Small Board of Directors" (1996) 40:2 Journal of Financial Economics 185 at 189 [Yermack 1996].

${ }^{1099}$ In this study, directors who are current or former officers of the firm and nonemployee directors who have personal or business relationships with the company are considered not independent. Ibid at 193-94.
} 
firm performance), ${ }^{1100}$ but significantly and negatively related with contemporaneous Tobin's Q. ${ }^{1101}$ The findings of both studies imply that independent directors may not enhance shareholder wealth.

In the new millennium, Fogel and Geier $(2007)^{1102}$ found that the worst return on equity (ROE) performers in each of fifty industries had about the same proportion of independent directors ${ }^{1103}$ on their boards as the best ROE performers in each of the same fifty industries. Whether firms had a higher or lower degree of board independence seemed to make no difference to shareholders' financial return. In some industries, the worst ROE firms even have more independent directors on the board than the best ones. ${ }^{104}$ Moreover, Duchin, Matsusaka and Ozbas (2010) ${ }^{1105}$ reported that an increase in the percentage of independent directors ${ }^{1106} \mathrm{did}$ not significantly improve or harm contemporaneous corporate performance between 2000 and 2005 (as measured by ROA, Tobin's Q and stock returns) on average, ${ }^{1107}$ when not taking into account the impact of information costs. ${ }^{1108}$ The results suggest that board independence had no impact on current firm performance in the new millennium. ${ }^{1109}$

${ }^{1100}$ Ibid at 202 Table 4.

${ }^{1101}$ Ibid at 195 Table 2. It is worth mentioning that this negative effect disappeared in a fixed-effects regression model. Ibid.

1102 The authors investigated whether more independent directors can enhance a firm's financial performance for the benefit of shareholders by reviewing the returns on equity (ROE) for 254 public corporations in the year 2000 across fifty separate industries and across different equity capitalizations. Eric M Fogel \& Andrew M Geier, "Strangers in the House: Rethinking Sarbanes-Oxley and the Independent Board of Directors" (2007) 32 Del J Corp L 33 at 51 [Fogel \& Geier].

1103 The authors define a director as independent, if the director or his/her family member has no current or former ties whatsoever with the company, whether by employment, business, consulting or otherwise. Ibid at 52 .

${ }^{1104}$ Ibid.

${ }^{1105}$ The authors examined nearly 2,900 firms covering the period from 1996 to 2005 to test whether the effectiveness of independent directors on firm performance was influenced by their cost of acquiring information. Duchin, Matsusaka \& Ozbas, supra note 429 at 200-01.

${ }^{1106}$ A director is considered independent, if he or she is not an employee of the company and is not linked to firm. For example, the director must not be a former employee, an employee of an organization that receives charitable gifts from the company, an employee of a customer or supplier to the company, or a relative of an executive director, and so on. Ibid at 197.

${ }^{1107} \mathrm{Ibid}$ at 204 . The authors addressed the endogeneity problem by considering the SOX related reforms as exogenous change. Ibid at 203.

${ }^{1108}$ The authors reported that the effectiveness of independent directors depends on how costly it was for independent directors to acquire information about the firm. When the cost of acquiring information was low, adding independent directors to the board was associated with better firm performance. In contrast, when the cost of acquiring information was high, an increase in the percentage of independent directors was connected with worse firm performance. However, if not taking information costs into account, an increase in the percentage of independent directors did not significantly improve or harm firm performance. Ibid at 196, 204, 212.

${ }^{1109}$ Unlike most studies considering that the impact of most new requirements concerning independent directors started from 2003, the authors of this study consider that regulatory reforms began a fewer years earlier (1999) when the NYSE and NASDAQ required audit committees to consist entirely of independent directors. Therefore, the 
At a glance, the studies in the first group seemingly demonstrate that firms' current performance was not associated with the level of board independence. However, upon digging deeper, the four studies appear to neglect the possible time lag between board independence and firm performance shown to be relevant in Baysinger and Butler (1985). That is, the effect of board independence on firm performance may be delayed and emerge in the later period. ${ }^{1110}$ Had the possibility of lagged effect been examined, the results might have been different. Therefore, empirical studies reporting no (contemporaneous) connection between board composition and firm performance may not be fully reliable, unless the possibility of lagged effects has been excluded. In addition to lagged effect, the insignificant relationship between independent directors and firm performance reported by Duchin, Matsusaka and Ozbas (2010) may come from the authors not separating their findings into pre-SOX and post-SOX results. ${ }^{111}$ As noted earlier, the efficacy of independent directors in the post-SOX period may be offset by their poor performance in the pre-SOX period, leading to no net advantages in overall performance.

The second group includes Chaganti, Mahajan and Sharma (1985), Fosberg (1989), Hermalin \& Weisbach (1991), and Ferris, Jagannathan and Pritchard (2003), which focused on the connection between outside directors and firm performance. Chaganti, Mahajan and Sharma $(1985)^{1112}$ found no significant difference in the proportion of outside directors ${ }^{1113}$ on the board between firms filing for bankruptcy and firms not filing for bankruptcy, ${ }^{114}$ while Fosberg $(1989)^{1115}$ reported no significant correlation between the fraction of outside directors ${ }^{1116}$ on the

sample periods (2000-2005) adopted in this study to measure the impact of independent directors on firm performance are considered as post-SOX periods (by the authors), rather than periods across SOX. Ibid at 200. ${ }^{1110}$ Baysinger \& Butler 1985, supra note 1035 at 115-16.

${ }^{1111}$ Duchin, Matsusaka and Ozbas (2010) used the year 2000 as a benchmark to measure the impact of new rules regarding independent directors on firm performance. Duchin, Matsusaka \& Ozbas, supra note 429 at 200. However, the requirements concerning stricter director independence and having a majority of independent directors on the board started in 2003, rather than 2000. Adopting such a non-traditional benchmark may cause a false conclusion regarding the effectiveness of independent directors because independent directors may perform better in the post-SOX period (after mid-2002) than in the pre-SOX period.

1112 The authors studied whether board composition and board size can guarantee better governance by comparing 21 pairs of failed and non-failed retailing firms between 1970 and 1976. The term "failed firm" is defined as a firm which has filed for bankruptcy under Chapter XI of the Bankruptcy Act. A non-failed firm means a firm which has remained in existence. Rajeswararao S Chaganti et al, "Corporate Board Size, Composition and Corporate Failures in Retailing Industry" (1985) $22 \mathrm{~J} \mathrm{Mgmt} \mathrm{Stud} 400$ at 408-09 [Rajeswararao S Chaganti et al].

${ }_{1113}$ An outside director refers to a director who was not an officer in the company. Ibid at 411.

${ }^{1114}$ Ibid at 411-12, 413.

${ }^{1115}$ The authors conducted a study to ascertain whether outside directors could effectively monitor management by comparing around 200 firms with and without a majority of outside directors on their boards between 1979 and 1983. Fosberg, supra note 1052 at 27. 
board and several financial measures (including return on equity and ratio of sales to total assets). ${ }^{1117}$ Hermalin \& Weisbach $(1991)^{1118}$ also observed that there was no relationship between board composition ${ }^{1119}$ and current firm performance (as measured by Tobin's Q), ${ }^{1120}$ suggesting that inside and outside directors ${ }^{1121}$ were equally bad or good at representing shareholders' interests. In addition, Ferris, Jagannathan and Pritchard (2003) ${ }^{1122}$ reported no significant relationship between the proportion of outside directors ${ }^{1123}$ on the board in 1995 and firm performance (as measured by a firm's market-to-book ratio) in 1997, ${ }^{124}$ showing that previous board composition had no impact on later corporate performance. Since these four studies did not differentiate independent directors from outside directors and the first three studies did not examine the possible lagged effect, their findings may not be completely reliable in relation to the effectiveness of independent directors.

The third group of studies consists of Brown and Caylor (2006), and Brown and Caylor (2009), which have controlled for the problem of endogeneity. Brown and Caylor (2006) ${ }^{1125}$ found that a board controlled by a majority of independent directors ${ }^{1126}$ was not associated with

\footnotetext{
${ }^{1116}$ Outside directors in this study refers to directors who are not current or former members of the company's management or their relatives. Ibid.

${ }^{1117}$ Ibid at 32.

${ }^{1118}$ The authors examined the differences in firm performance (as measured by Tobin's Q) caused by board composition and CEO ownership by surveying 142 firms traded on the NYSE during the period from 1971 to 1983. Hermalin \& Weisbach 1991, supra note 1036 at 104-05.

${ }^{1119}$ Board composition is measured the proportion of outside directors on the board. Ibid. at $106 \mathrm{n} 16$.

${ }^{1120} \mathrm{Ibid}$ at 106, 111.

${ }^{1121}$ In this study, employees and former employees of the firms are classified as insiders. Non-employee directors are classified as outside directors. Ibid at 105.

${ }^{1122}$ The authors investigated whether directors serving on multiple boards influenced their quality of monitoring management for a sample of around 3,000 firms between 1995 and 2002. Stephen P Ferris, Murali Jagannathan and A C Pritchard, "Too Busy to Mind the Business? Monitoring by Directors with Multiple Board Appointments" (2003) 58:3 The Journal of Finance 1087 at 1090 [Ferris, Jagannathan \& Pritchard 2003].

${ }^{1123}$ Outside directors in this study refer to directors who are not currently employed by the firm, including both independent and gray directors. See ibid at $1091 \mathrm{n} 1,1102$ Table 5.

${ }^{1124}$ Ibid at 1102 Table 5.

${ }^{1125}$ Brown and Caylor examined the correlation between 51 corporate governance provisions and contemporaneous, as well as subsequent firm performance in their 2006 and 2009 studies by using the same sample composed of 2,363 firms from Institutional Shareholder Services database in 2003 (just before the enactment of new rules). They employed three different econometric approaches to identify which of 51 governance factors are linked to firm performance (or firm value). The difference between the two studies is that Brown and Caylor (2009) used return on assets (ROA) and return on equity (ROE) as firm performance indicators, while Brown and Caylor (2006) employed Tobin's Q to measure firm value. With a view to controlling the problem of endogeneity, both studies include the lagged value of performance measures in their regression models. Brown \& Caylor 2006, supra note 1027 at 414-15, 424-25; Brown \& Caylor 2009, supra note 1032 at 132-33.

${ }^{1126}$ The authors do not define independent directors in their 2003 or 2006 studies. However, according to the term they used-independent outside directors and they mentioned that board composed of a majority of independent
} 
improved current or subsequent firm performance (as measured by Tobin's Q). ${ }^{1127}$ The results remained unchanged after the authors employed different indicators (ROA and ROE) to measure firm performance in their later study [Brown and Caylor (2009)]. ${ }^{1128}$ The findings of the two studies show that boards with a majority of independent directors before the enactment of SOX related rules ${ }^{1129}$ had no impact on contemporaneous and subsequent firm performance or firm value. Since these two studies have considered the possible lagged effects and have differentiated independent directors from outside directors, their findings are more reliable than previous studies.

The fourth group includes only one study, which does not fully address the problem of endogeneity. Klein (1998) ${ }^{1130}$ reported that the proportion of independent directors ${ }^{1131}$ on the board was significantly and negatively associated with one out of three current firm performance indicators (Jensen Productivity ${ }^{1132}$ ). ${ }^{1133}$ Taken at face value, the results suggest that board independence had little effect on firm performance. The author addressed the problem of endogeneity by examining whether poor past firm performance led to subsequent higher board independence; ${ }^{1134}$ however, she did not further investigate the relationship between board composition and changes in firm performance in the later period. Whether independent directors are effective in enhancing firm performance remains unclear in this study, because the possibility of lagged effects was not been examined.

directors has been required by major US stock exchanges, "independent director" in their studies refers to directors who have no affiliation with the firm. Brown \& Caylor 2006, ibid at 429; Brown \& Caylor 2009, ibid at 141.

${ }^{1127}$ Brown \& Caylor 2006, ibid at 419 Table 3, 421 Table 4, 422 Table 5.

${ }_{1128}$ Brown \& Caylor 2009, supra note 1032 at 129-30, 142.

${ }^{1129}$ Although Brown and Caylor's studies were published after the enactment of SOX related reforms, they used data before the enactment of new rules. The reason for choosing pre-SOX data is that the board independence requirement (a majority of independent directors on the board) would become mandatory in the post-SOX period, which exhibits little variation to conduct empirical test. Brown \& Caylor 2006, supra note 1027 at 414 n 12.

${ }^{1130}$ The author conducted a survey evaluating the link between board composition and firm performance (as measured by ROA, Jensen Productivity, and market return) for nearly 500 corporations listed on the S\&P in 1992 and 1993. Klein 1998, supra note 501 at 281.

${ }^{1131}$ Independent directors are defined as directors who have no affiliation with the firm beyond being a member of the firm's board. Affiliated directors refer to directors who are former employees, relatives of the CEO or those who have significant transactions and/or business relationship with the firm. Ibid at 282. The term "independent directors" here is identical to the term "outside directors" used by the original author in her study.

1132 Jensen Productivity is an index, adapted by Professor Klein from Professor Jensen's 1993 research, to measure the investment strategies and productivity of firms' long-term assets. It is equal to the change in market value of equity minus a benchmark return on investment. Ibid at 287. Please also refer to Jensen, Industrial Revolution, supra note 403.

${ }^{1133}$ Ibid at 287.

${ }^{1134}$ The author found no evidence that firms in the lowest (or highest) quintile of performance (as measured by ROA, raw stock returns and beta-adjusted stock returns) over the period 1988 to 1991 were more likely to change the proportion of independent directors on their boards between 1992 and 1993. Ibid at $292 \mathrm{n} 41$. 
In total, among the eleven studies that reported a lack of connection between board composition and firm performance, only two studies (studies in Group Three) provided reliable evidence that the level of board independence had no impact on current or future firm performance. The remaining nine studies (studies in Group One, Two and Four) either did not differentiate independent directors from outside directors or did not investigate the possibility of lagged effects between board independence and firm performance, so their findings might not be fully reliable. Given that the findings of these nine studies are considered reliable, the conclusion that higher board independence did not lead to better firm performance remain unchanged.

\subsubsection{Summary}

Taken at face value, the results of empirical studies concerning the relationship between director independence and overall firm performance are divergent. However, after considering three factors that may influence the reliability of empirical findings [(1) the effect of the definition of independent directors; (2) the impact of SOX and the related reforms; and (3) the problem of causation and lagged effects] and that the evidence of three studies in the pre-SOX period was unpersuasive, the impact of independent directors on firm performance becomes clearer. It appears that independent directors had no impact on, or might even have worsened, current or future firm performance in the pre-SOX period. In contrast, in the post-SOX period, firms with a higher proportion of independent directors, in some circumstances, were more likely to enhance current and future performance.

It is worth noting that board independence is only one of many factors that affect a firm's performance. It is difficult to isolate the effect of director independence from other factors that affect firm performance despite researchers' best efforts. Greater firm performance may be found to be closely connected to the presence of independent directors, but such an effect may not be necessarily attributed solely to the presence of independent directors. Perhaps, studying distinct board tasks may provide more reliable evidence regarding whether independent directors can do a better job than non-independent directors. The next part of the thesis analyzes studies regarding the role of independent directors in relation to particular tasks. 


\subsubsection{Board Independence and Performance of Specific Board Tasks}

In contrast to the prior section that focuses on the correlation between board independence and overall firm performance, this section concentrates on whether independent directors protect shareholder interests in connection with particular board tasks. This section of the thesis examines the relationship between board independence and situations in which the potential conflicts of interests between management and shareholders are great, including: (1) responding to takeover bids; (2) replacing incompetent CEOs; (3) setting executive compensation; and (4) evaluating management buyouts. In addition, this thesis investigates the connection between independent directors and events involving the protection of shareholder interests, including: (1) preventing financial fraud; and (2) reducing shareholder suits. In all these situations, the presence of independent directors is expected to enhance the effectiveness of the board. In general, at least half of the studies in relation to most board tasks show that firms with a greater fraction of independent directors on the board had a positive impact on protecting shareholder interests, but firms with a higher level of board independence were unable to control CEO compensation.

It is worth noting that no empirical study analyzed in this section (section 5.1.4) addresses the issues of causation or lagged effects. However, not examining or discussing causation or lagged effects does not mean there are no such issues in these studies. Since causation and lagged effects are complicated issues in empirical research and out of the scope of this thesis, this thesis will discuss the impact of causation or lagged effects on empirical results regarding the efficacy of independent directors only when scholars have made criticism.

\subsubsection{Board Independence and Takeover Bids}

Nearly half of major companies in the US either received a friendly bid or became the object of a hostile acquisition attempt during the 1980s. ${ }^{1135}$ Since boards cannot avoid being involved in takeover attempts or in responding to takeover bids, how independent directors respond in a takeover situation is a good indicator to measure their efficacy in protecting

${ }^{1135}$ See Kurp, supra note 204 at 29; Kershenbaum, supra note 204 at 63; Mitchell \& Mulherin, supra note 205 at 199. 
shareholder interests. The following sections discuss this topic from three different perspectives: (1) the relationship between board independence and shareholder wealth in bidding firms; (2) the correlation between board independence and shareholder wealth in target firms during tender offers; and (3) the link between defensive tactics and shareholder wealth in target firms. I start with whether board independence in acquiring firms is correlated with investor's wealth.

\subsection{Board Composition and Shareholder Wealth in Bidding Firms}

Only one study exploring the relationship between board composition and shareholder wealth in bidding firms was found. Byrd and Hickman (1992) ${ }^{1136}$ reported that tender offer bidders with a majority of independent directors ${ }^{1137}$ on their boards had roughly zero abnormal return $(-0.07 \%)$ on average, while bidders without such boards had significantly negative abnormal returns $(-1.86 \%)$ on average. ${ }^{1138}$ The results suggest that shareholder interests were better served by boards dominated by independent directors.

It is worth mentioning that the results of this study were sensitive to the classification of directors. The foregoing results were based on a three-way classification identifying directors as insiders, affiliated outsiders, and independent directors ${ }^{1139}$. When this study used the conventional inside-outside categories, instead of independent versus non-independent directors, no significant association was found between board composition and shareholder wealth effects of tender offers. Important relationships might be missed if director categories were not properly differentiated. ${ }^{1140}$

Similar to the finding of Baysiner and Butler (1985), Byrd and Hickman also found a curvilinear relationship between the percentage of independent directors on the board and

\footnotetext{
${ }^{1136}$ The authors examined the association between the board composition of bidding firms and the shareholder wealth effects of tender offer bids (as measured by two-day announcement-date abnormal return) by using a sample consisting of 128 acquisition bids made by 111 firms listed on the NYSE or American Stock Exchange during the period from 1980 to 1987. Byrd \& Hickman, supra note 363 at 199-200.

${ }^{1137}$ The term "independent directors" mean directors who have no affiliation with the firm other than their directorship, including academics, business executives and decision-makers from the public sector. Ibid at 199.

${ }^{1138}$ Ibid at 207.

${ }^{1139}$ In this study, inside directors are defined as directors who are corporate officers or retirees and members of their families; affiliated outside director refers to directors who are not full-time employees of the firm but are associated with it in some way, such as investment bankers, company's lawyers and directors of the company's suppliers. Ibid at 199.

${ }^{1140}$ Ibid at 198, 207, 219-20.
} 
bidding firms' abnormal returns. This relationship was positive over most of the range (from $0 \%$ to $60 \%)$, ${ }^{1141}$ but was significantly negative when independent directors held more than $60 \%$ of board seats. The marginal utility of adding an additional independent director reached the peak when the fraction of independent directors occupied $40 \%$ to $60 \%$ of board seats. Because returns to shareholders decreased when independent directors held more than $60 \%$ of board seats, this study suggests that it is possible for a board to have too many independent directors. ${ }^{1142}$

In brief, this study revealed that independent directors were useful only when their proportion on the board was below $60 \%$ during acquisitions. This suggests that modern corporate boards require a diverse set of talents to undertake a variety of responsibilities, so merely emphasizing one area of expertise, such as managerial monitoring by having high proportions of independent directors, may reduce a board's overall effectiveness. ${ }^{1143}$

\subsection{Board Independence and Shareholder Interests in Target Firms During a Tender Offer}

Takeover bids are considered to be an important external corporate governance mechanism to discipline management. ${ }^{1144}$ When a takeover bid is made, the target directors face a conflict between acting in the best interests of the company and protecting their own position. ${ }^{145}$ On the one hand, directors are obliged to act in the best interests of the company under corporate law. On the other hand, the target board and management may possibly lose their positions if the bid is successful. ${ }^{1146}$ However, compared to inside and affiliated directors, independent directors are less likely to resist possible tender offers that are in shareholders' interests, because they have less to lose. As a result, many firms rely on independent directors in takeover bid situations to minimize such conflicts of interest and enable a fair, appropriate, and efficient response that maximizes the interests of shareholders. ${ }^{1147}$ Two empirical studies

\footnotetext{
${ }^{1141}$ Ibid at 213-16.

${ }^{1142}$ Ibid at 216.

${ }^{1143}$ Ibid at 199.

1144 Andrei Shleifer \& Robert W Vishny, "A Survey of Corporate Governance” 52 (1997) Journal of Finance 737 at 756.

${ }^{1145}$ Condon, Anand \& Sarra, 2005, supra note 734 at 509; Baxter, supra note 987 at 74, 93.

${ }^{1146}$ VanDuzer supra note 15 at 364; Condon, Anand \& Sarra, 2005, ibid at 508.

1147 Jeffrey G MacIntosh, “The Poison Pill: A Noxious Nostrum for Canadian Shareholders” (1989) 15 Canadian Business Law Journal 276 at 325-26 [MacIntosh].
} 
examined the effectiveness of independent directors in such a situation. However, the findings were contradictory.

Cotter, Shivdasani and Zenner (1997) ${ }^{1148}$ reported that shareholder gains ${ }^{1149}$ were roughly $20 \%$ higher for targets with independent boards ${ }^{1150}$ than they were for other targets. ${ }^{1151}$ In evaluating the source of these gains, the authors found that targets with independent boards extracted both higher initial tender offer premiums and higher revised bid premiums than targets without independent boards. ${ }^{1152}$ Furthermore, the findings showed that if targets resisted tender offers or adopted poison pills, shareholder gains were higher when the board was independent than when it was not. ${ }^{1153}$ This suggests that targets with independent boards extracted a greater premium for target shareholders, rather than entrenching the position of incumbent management, when they decided to resist tender offers. ${ }^{1154}$ It seems that independent directors play an important role and enhance shareholder wealth during tender offers.

However, Professors Bhagat and Black considered that higher premiums were not unequivocally beneficial. ${ }^{1155}$ In this study, the higher returns to targets with independent boards were found to come at the expense of lower bidder returns. ${ }^{1156}$ If both bidder and target were publicly traded, a higher takeover price was simply a wealth transfer from the bidder's shareholders to the target's shareholders. Furthermore, if shareholders were diversified, over a number of transactions, shareholders (investors) would hold shares in both bidders and targets. ${ }^{1157}$ Based on a "rational expectations" "1158 equilibrium, bidders would realize that targets

\footnotetext{
${ }^{1148}$ The authors investigated the role of a target firm's independent directors during takeover attempts by surveying a sample of 169 tender offer targets traded on the NYSE, AMEX, or NASDAQ from 1988 to 1992. James F Cotter, Anil Shivdasani \& Marc Zenner, "Do Independent Directors Enhance Target Shareholder Wealth During Tender Offers?" (1997) 43 Journal of Financial Economics 195 at 197-98 [Cotter, Shivdasani \& Zenner]. Independent directors are defined as directors who are not current or past employees of the firms and do not have substantial business or family ties with management. Ibid at 198-99.

${ }^{1149}$ The target shareholder gain is the percentage price change from 30 days before the first tender offer rumor to the final tender bid price if the bid is successful, or to the stock price 90 days after the resolution of the tender offer if the bid is not successful. Ibid at 206 Table 2 .

${ }^{1150}$ This study considers boards to be independent if independent directors comprise at least $50 \%$ of the board. Ibid at 199.

${ }^{1151}$ Ibid at 205.

1152 Ibid at 210, 216.

${ }^{1153}$ Ibid at 213-14, 216.

1154 Ibid at 216.

1155 Bhagat \& Black 1999, supra note 25 at 926.

${ }^{1156}$ Cotter, Shivdasani \& Zenner, supra note 1148 at 208.

${ }^{1157}$ Bhagat \& Black 1999, supra note 25 at 926.

${ }^{1158}$ Rational expectations theory assumes that, over time, unexpected events will cancel out each other and that on average people's expectations about the future will be accurate. This is because they form their expectations on a
} 
with independent boards would extract higher takeover premiums and, therefore, make fewer takeover bids for firms with independent boards. This would reduce the overall efficiency gains from takeovers. ${ }^{1159}$

In my opinion, in the long run, the criticism of Bhagat and Black may be valid. Capital suppliers sometimes are shareholders of target firms and sometimes may hold shares in bidding firms, so they would not actually get higher premiums extracted by independent directors for the long term. However, in the short term, shareholder gains in target firms do seem to be significantly enhanced by the presence of independent directors. The contributions of independent directors cannot be ignored. Moreover, some investors only focus on short-term interests; what Professors Bhagat and Black argue may not be relevant to these people. Even accepting the criticism of Bhagat and Black, findings of Cotter, Shivdasani and Zenner (1997) show that independent directors make a difference.

In contrast to the positive findings of Cotter, Shivdasani and Zenner (1997), Bange and Mazzeo (2004) $)^{1160}$ reported that firms with a higher level of board independence did not enhance shareholder wealth in target firms during the tender offer period. More specifically, when target boards were occupied by a majority of independent directors ${ }^{1161}$, targets received a lower initial offer premium, compared to other targets with less than $50 \%$ of independent directors. ${ }^{1162}$ In addition, no evidence showed that boards with a majority of independent directors were associated with higher total shareholder gains (as measured by cumulative abnormal returns). ${ }^{1163}$

The authors also observed that a takeover bid was less likely to succeed if the target was dominated by independent directors. More specifically, the likelihood of the success of the initial offer was lower when target boards had a majority of independent directors. The same

rational basis, using all the information available to them optimally, and learn from their mistakes. Research Tool Economics A-Z, online: Economist.com < http://www.economist.com/economics-a-to-z/r\#node-21529875>.

${ }^{1159}$ Ibid.

${ }^{1160}$ The authors examined whether the type of initial offer was related to the target's board structure by using a sample of 436 proposed negotiated mergers and bypass offers (tender offers) that were listed on the NYSE and AMEX between 1979 and 1990. Mary M Bange \& Michael A Mazzeo, "Board Composition, Board Effectiveness, and the Observed Form of Takeover Bids" (2004) 17 The Review of Financial Studies 1185 at 1189-91. A bypass offer is defined as an unsolicited tender offer for a controlling majority interest in a target that is outwardly unanticipated by management and the board directors. Ibid at 1185 .

${ }^{1161}$ Independent directors are defined as directors who are non-employee directors without ties to the firm other than their directorships. Ibid at 1187 . The term "independent directors" here is identical to the term "outside directors" used by the original authors in their study.

${ }_{1162}$ Ibid at $1204-05$.

${ }^{1163}$ Ibid at $1210-11$. 
correlation still existed, even when the initial offer had been modified. ${ }^{1164}$ This implies that boards dominated by independent directors perform more poorly than those controlled by inside directors in protecting shareholder interests. Possibly, this is because independent directors might discourage bidders who feared that they would negotiate a higher premium. The likelihood of replacing incompetent management teams would be reduced as a result. This seems to support the critique of Professors Bhagat and Black.

Taken together, the evidence regarding whether higher board independence in target firms provides greater protection for shareholders is mixed. Cotter, Shivdasani and Zenner (1997) found that a majority of independent directors serving on the target board extracted higher tender offer premiums, while Bange and Mazzeo (2004) demonstrated contradictory results. It seems that there is no conclusive evidence regarding the impact of board independence on shareholder wealth in response to takeover bids. However, scholars have not provided possible explanations for such a contradiction. Whether target boards dominated by independent directors can increase value for their shareholders during an acquisition attempt is still unclear. $^{1165}$

Another approach is to look at defensive tactics adopted by boards with a majority of independent directors compared to those of insider-dominated boards. The next section of the thesis analyzes studies regarding the impact of independent directors on takeover defenses in target firms in relation to shareholder interests.

\subsection{The Impact of Board Independence on Takeover Defenses and Shareholder Wealth in Target Firms}

Takeover defenses, such as poison pills, greenmail, golden parachutes, etc., can be either beneficial or detrimental to shareholders, depending on how management uses them. There are two competing hypotheses concerning the function and purpose of takeover defenses, which may be described as the "shareholder interest" and "managerial entrenchment" hypotheses. ${ }^{1166}$ According to the shareholder interest hypothesis, takeover defenses can benefit shareholders

\footnotetext{
${ }^{1164}$ Ibid at 1207-08.

1165 Perhaps, the longer sample periods and investigating the additional effect of negotiated mergers explain why the results of Bange and Mazzeo (2004) contradict those of Cotter, Shivdasani and Zenner (1997).

${ }^{1166}$ Michael Ryngaert, "The Effect of Poison Pill Securities on Shareholder Wealth" (1988) 20 Journal of Financial Economics 377 at 383 .
} 
because the defenses enable management to bargain for a higher price for the target's shares in the event of a takeover bid. On the other hand, under the managerial entrenchment hypothesis, takeover defenses raise the cost of displacing inefficient management and thus reduce shareholder wealth by entrenching managers against value-increasing takeovers. ${ }^{1167}$ However, empirical studies do not conclusively support either hypothesis. The next subsections discuss whether the connection between board independence and shareholder wealth varies with the three types of takeover defenses, namely poison pills, greenmail and golden parachutes.

\subsection{The Adoption of Poison Pills}

The most popular defensive tactic that targets adopt to discourage a takeover bid is what management calls "shareholder rights plans," which their opponents call "poison pills."1168 A typical shareholder rights plan often contains the provision that a takeover bid must be approved by the target or its board, and that the board has the right to remove the plan if it negotiates an acceptable arrangement with the bidder. When the board approval cannot be obtained, the poison pill is activated. Once the pill is activated, stockholders are given the right to purchase additional shares in the target company at a substantially lower price than the current offering. The shares will be issued to all shareholders except the bidder. The effect of this tactic is to dilute the bidder's holding and to make it much more difficult to complete the takeover bid. ${ }^{1169}$ As mentioned above, the poison pill is one of many defensive tactics taken in response to a takeover bid that may either be beneficial or harmful to shareholders. Two studies exploring whether independent directors were able to enhance shareholder interests by adopting poison pills reached inconsistent results.

Brickley, Cole and Terry (1994) ${ }^{1170}$ hypothesized that if independent directors ${ }^{1171}$ represented shareholder interests, the likelihood of using poison pills to harm shareholders

\footnotetext{
${ }^{1167}$ Ibid at 384; MacIntosh, supra note 1147 at 278-81; Lin, supra note 13 at 932.

${ }^{1168}$ VanDuzer, supra note 15 at 365.

${ }^{1169}$ Pearce \& Robinson, supra note 734 at 18-20; Condon, Anand \& Sarra, 2005, supra note 734 at 509-10; Gillen, supra note 29 at $460-61$.

${ }^{1170}$ The authors tested the connection between board independence and shareholder wealth in adopting poison pills by examining 247 publicly-traded firms that adopted poison pills over the period 1984 to 1986 . Brickley, Coles \& Terry, supra note 1014 at 375.

${ }^{1171}$ This study adopted a three-way classification, directors under which are divided into inside directors, affiliated directors and independent directors. Independent directors are defined as directors who are executives of other firms that do not have extensive business relations with the company, as well as public directors, professional directors,
} 
should decrease with the proportion of independent directors on the board. Since the market could observe board composition, the effect should be incorporated into the initial stock price reaction to the adoption of poison pills. ${ }^{1172}$ On the contrary, if independent directors represented managerial interests, the probability of using poison pills to harm shareholders would not vary with the proportion of independent directors on the board. In this situation, the stock market reaction would not depend on board composition. ${ }^{1173}$

The authors found that the proportion of independent directors on the board was significantly and positively correlated with stock-market reaction to a poison pill. ${ }^{1174}$ During the period that companies announced the adoption of poison pill defenses, the average stock-price reaction was significantly positive (average abnormal returns were $0.94 \%$ ) when the company had a majority of independent directors on the board, and was significantly negative (average abnormal returns were $-0.31 \%$ ) when it did not. ${ }^{1175}$

However, the relation between board composition and stock-market reaction was not monotonic. It was initially downward-sloping and then upward-sloping with the turning point at $26.5 \%$ for the percentage of independent directors on the board. ${ }^{1176}$ The relation became flat, after independent directors held a majority of board seats (above 50\%). This suggests when independent directors are a majority of the board, adding additional independent directors would not alter the market's expectations, because a majority of independent directors were sufficient to ensure that the board acts in the interests of shareholders. ${ }^{117}$ Moreover, for corporations that had adopted poison pills, the probability that the corporations would use the bargaining power resulting from the poison pill to induce an auction (with a higher price) among competing bidders during a control contest was higher when boards were controlled by independent

and private investors. Ibid at 375-76. The term "independent directors" here is identical to the term "outside directors" used by the original authors in their study.

1172 Ibid at 372-74.

${ }^{1173}$ Ibid at $372-73$.

1174 Ibid at 381 .

${ }^{1175}$ Ibid at 379. The detailed evidence further revealed that the results were largely driven by independent directors who were retired executives from other companies and who listed their occupation as directors. The authors divided independent directors' occupations into four categories and examined whether the types of independent directors affect shareholder wealth. The four categories include: (1) executives of other firms without extensive business ties to sample firm, (2) private investors, (3) educators, government officials, and clergy, and (4) professional directors (retired business executives and those who list their occupation as being a director). Ibid at 381-82.

${ }^{1176} \mathrm{Ibid}$ at 384. However, the authors did not provide clear explanation regarding why the negative effect associated with adding independent directors up to $26.5 \%$. Ibid at 384-86.

1177 Ibid at 386. 
directors. ${ }^{1178}$ The study confirms that firms with a majority of independent directors enhanced shareholder wealth.

Again, the results of this study were sensitive to the classification of directors. The above results were based on the classification of directors as insiders, affiliated outsiders, and independent directors. When the inside-outside categories was adopted in this study, no significant association was found between board composition and stock-market reaction to the adoption of poison pills. ${ }^{1179}$

In addition, Mallette and Fowler (1992) ${ }^{1180}$ reported that the proportion of independent directors $^{1181}$ on the target boards was not associated with the likelihood of the adoption of poison pills. Based on the assumption that poison pills would be detrimental to shareholders, the authors hypothesized that the higher the proportion of independent directors on the board, the lower the likelihood of adoption of poison pills. ${ }^{1182}$ However, their findings indicated that there was no significant relationship between the proportion of independent directors and the probability that a firm will adopt a poison pill. ${ }^{1183}$ It suggests that there was no difference between independent directors and other directors in protecting shareholder interests.

In total, although the focus of the two studies was slightly different, ${ }^{1184}$ these results, to some extent, provide insight regarding whether independent directors could enhance shareholder wealth when targets adopted poison pills as a defensive tactic. Brickley, Cole and Terry (1994) found that firms with a majority of independent directors was correlated with positive stockmarket reaction to the adoption of poison pills, while Mallette and Fowler (1992) reported that the proportion of independent directors on the board was not related to the incidence of poison pill adoption (assumed detrimental to shareholders). Nevertheless, at least no evidence showed that the adoption of poison pills in firms with a majority independent director would harm

\footnotetext{
${ }^{1178}$ Ibid at $386-87$.

${ }^{1179}$ Ibid at 379.

${ }^{1180}$ The authors investigated 226 firms with poison pills and 447 firms without such pills listed on Standard \& Poor's COMPUSTAT 1988 Industrial Files between 1985 and 1988. Mallette \& Fowler, supra note 387 at $1020-21$.

${ }^{1181}$ Independent directors in this study are defined as directors who have no business ties to a company. Ibid at 1015 .

${ }^{1182}$ Ibid at 1016. In fact, this hypothesis is debatable, since poison pills can be used to either benefit or harm target shareholders.

1183 Ibid at 1023 .

${ }^{1184}$ Brickley, Cole and Terry (1994) focused on the relationship between market reaction and board independence, while Mallette and Fowler (1992) concentrated on the connection between independent directors and the likelihood of the adoption of poison pills.
} 
shareholder interests. It seems that it is possible that firms with a majority of independent directors enhance shareholder wealth when they adopted poison pills.

\subsection{The Payment of Greenmail}

Greenmail involves the target of a takeover bid repurchasing its shares at a premium from the bidder in exchange for an agreement that the bidder will no longer target the company for takeover. The nature of this defensive tactic is equivalent to a payoff, and is sometimes referred to as a "targeted repurchase." 1185 The payment of greenmail to a hostile bidder may have two possible effects on shareholder wealth. Shareholders may benefit, if the target board believes that there will be another bidder who will pay more than the current bidder, and the premium will more than offset the greenmail because this subsequent bidder is unwilling to enter into an auction with the current bidder. ${ }^{1186}$ On the contrary, shareholders may be harmed, if the target board is merely paying off the current bidder in order for management to secure its position in the company and further shield itself from the disciplinary influence of the market when it does not expect a subsequent bidder. ${ }^{1187}$

So far, only two studies investigated the connection between board composition and the payment of greenmail. Kosnik (1987) ${ }^{1188}$ found that the boards which effectively resisted greenmail had a higher proportion of outside directors ${ }^{189}$ and a higher proportion of outside directors who held executive positions in other companies than did boards of companies that paid greenmail. The results remained unchanged when the author used a different statistical method in her later study [Kosnik (1990)]. ${ }^{1190}$ The finding seems to imply that a certain proportion of

\footnotetext{
1185 John H Farrar, "Business Judgment and Defensive Tactics in Hostile Takeover Bids" (1989) 15 Can Bus L J 15 at 42 [Farrar]; Pearce \& Robinson, supra note 734 at 20.

1186 Jonathan R Macey \& Fred S McChesney, "A Theoretical Analysis of Corporate Greenmail” (1985) 95 Yale Law Journal 13 at 17-19; Lin, supra note 13 at 934.

${ }^{1187}$ Kosnik 1987, supra note 372 at 165 ; Lin, ibid.

${ }^{1188}$ The author examined whether certain characteristics of the board affected the target firms' decision to pay greenmail on the assumption that the payment of greenmail was harmful to shareholders. She compared the boards of 53 publicly-traded companies paying greenmail to 57 listed corporations resisting greenmail between 1979 and 1983. Kosnik 1987, ibid at 171-73.

${ }^{1189}$ In this study, outside directors are defined as directors who are not current or former employees of the company. Ibid at 175 .

${ }^{1190}$ Rita D Kosnik, "Effects of Board Demography and Directors' Incentives on Corporate Greenmail Decisions" (1990) 33 Academy of Management Journal 129 [Kosnik, 1990]. The previous study used discriminant analysis and the current research adopts logistic regression analysis.
} 
outside directors on the board may make a difference in the greenmail decisions and protect shareholders' interests (assuming that the payment of greenmail is bad for shareholders).

It is worth mentioning that the analysis in the two studies combined the effect of independent directors and affiliated directors. It is possible that either independent directors outweighed affiliated directors in the effect of monitoring management or affiliated directors in this study were not partial to top managers, so that the presence of outside directors on the board might still enhance the probability in resisting greenmail. Had only independent directors been examined, the results might have been different.

\subsection{The Adoption of Golden Parachutes}

So-called "golden parachutes" are severance agreements that provide cash and non-cash compensation to senior executives on a special event, such as termination or resignation following a change in control. ${ }^{1191}$ The agreements protect senior executives from the consequences of a hostile bid and typically can be established by board members alone without shareholder approval. ${ }^{1192}$ Usually golden parachutes are arranged as lump-sum payments of cash. $^{1193}$

Whether golden parachutes are able to benefit shareholders is still controversial. Critics consider that such compensation may discourage potential bidders by making an acquisition more costly, and entrenching the management team. Shareholders' wealth would therefore be adversely affected and the disciplinary effects of the takeover mechanism would also be diluted. ${ }^{1194}$ To make matters worse, in order to collect benefits under its golden parachutes, the

\footnotetext{
${ }^{1191}$ Pearce \& Robinson, supra note 734 at 19-20; Farrar supra note 1185 at 42; Paul Gompers, Joy Ishii, \& Andrew Metrick, "Corporate Governance and Equity Prices" (2003) 118 Quarterly Journal of Economics 107 at 148 [Gompers, Ishii \& Metrick].

1192 Wallace N Davidson III, Theodore Pilger \& Andrew Szakmary, "Golden Parachutes, Board and Committee Composition, and Shareholder Wealth" (1998) 33 The Financial Review 17 at 18 [Davidson, Pilger \& Szakmary]. ${ }^{1193}$ Pearce \& Robinson, supra note 734 at 19-20; Farrar supra note 1185 at 42.

${ }^{1194}$ Richard A Lambert \& Donald F Larcker, "Golden Parachutes, Executive Decision-making and Shareholder Wealth" (1985) 7 Journal of Accounting and Economics 179 at 183-85 [Lambert \& Larcker]; Philip L Cochran, Robert A Wood \& Thomas B Jones, "The Composition of Boards of Directors and the Incidence of Golden Parachutes" (1985) 28 Academy of Management Journal 664 at 665 [Cochran, Wood \& Jones]. In re Walt Disney Co. Derivative Litigation provides an example of an independent board failing to act effectively in approving a golden parachute. In this case, shareholders challenged Disney's independent board's approval of the CEO's golden parachute. The Delaware court, however, determined that the board's decision should be upheld despite finding that the board had been negligent in approving the parachute. In re Walt Disney Co. Derivative Litigation, 907 A 2d 693 (Del Ch 2005).
} 
target board may have an incentive to accept an inadequate bid instead of seeking the best price available for the shareholders. ${ }^{1195}$ However, the proponents argue that since target shareholders stand to make substantial gains in the event of a takeover, golden parachutes can align the target board's interests with those of shareholders by giving board members financial incentives to accept a takeover bid, so that they will not resist the takeover in order to preserve their jobs. ${ }^{1196}$ So far, empirical evidence revealed that the adoption of golden parachutes was significantly and positively related to the presence of independent directors, but the size of the individual golden parachute payments would not be expanded by the presence of independent directors. Cochran, Wood and Jones (1985) ${ }^{1197}$ hypothesized that the greater the percentage of insiders on the board, the higher the probability that the board would give their management golden parachutes. ${ }^{1198}$ However, contrary to expectation, the findings revealed that the probability of giving management golden parachutes was higher when firms had a higher percentage of independent or outside directors ${ }^{1199}$ on the board. ${ }^{1200}$

Similarly, Singh and Harianto (1989a) ${ }^{1201}$ hypothesized that the higher the proportion of outside directors (not defined) ${ }^{1202}$ on the boards, the lower the likelihood that boards would adopt golden parachutes. ${ }^{1203}$ However, the results were also contrary to their assumption and

${ }^{1195}$ Philip L Cochran \& Steven L Wartick, "Golden Parachutes: A Closer Look” (1984) 26 California Management Review 111 at 123; Lin, supra note 13 at 935.

${ }^{1196}$ Lambert \& Larcker, supra note 1194 at 185; Cochran, Wood \& Jones, supra note 1194 at 665; Lin, ibid.

${ }^{1197}$ The authors examined the relationship between board composition and the probability of the adoption of golden parachutes by using a sample consisting of 52 corporations selected from Fortune 500 firms as of 1982. Cochran, Wood \& Jones, ibid at 666-67.

${ }^{1198}$ Ibid at 665 .

${ }^{1199}$ In this study, the authors do not directly define independent directors. They only define an inside director as a director who is a current employee, former employee, employee of a customer or a supplier, employee of a firm's investment bank or corporate counsel, employee of its parent company or a subsidiary. All affiliated directors are considered insiders. Ibid at 666.

${ }^{1200}$ Ibid at 667-68. The original wording used by the authors to describe the findings is that"the incidence of golden parachute agreement was negatively correlated with the percentage of a board who were insiders". The results held for three different types of insider measures, including a type that includes affiliated directors. In other words, the probability of giving management golden parachutes was higher when firms had a higher percentage of outside directors, and the results also held for independent directors.

${ }^{1201}$ The authors investigated 79 Fortune 500 corporations that adopted golden parachutes as of December 1985. Harbir Singh \& Farid Harianto, "Management-Board Relationships Takeover Risk, and the Adoption of Golden Parachutes" (1989) 32 Academy of Management Journal 7 at 16 [Singh \& Harianto, 1989a].

${ }^{1202}$ The authors did not specifically define "outside directors" in their study. Some studies before the new millennium used the term "outside directors" to describe what are currently called "independent directors", so the effect of these undefined outside directors may refer to either the effect of independent directors (directors who have no direct or indirect material relationship with the company) or the effect of outside directors (directors who are not the company's employee, but without regard to whether they have any other connection with management or the firm).

${ }^{1203}$ Singh \& Harianto, 1989a, supra note 1201 at 14. 
consistent with the findings of Cochran, Wood and Jones (1985), showing that firms that adopted golden parachutes had a higher proportion of outside directors (not defined) on the boards than those that did not adopt golden parachutes. ${ }^{1204}$

Scholars have suggested that the foregoing results may be less significant in the debate over whether independent directors oversee management in shareholder's interests, if we accept the assumption that golden parachutes are used to align shareholder interests with those of management. ${ }^{1205}$ Under this assumption, independent directors should not find any difficulty adopting reasonable golden parachutes for management. ${ }^{1206}$ Management may also have an incentive to maintain an independent board in order to lessen legal scrutiny of these compensation packages, since management can avoid future challenges on the basis of managerial self-dealing. ${ }^{1207}$ This argument may help to explain the finding that firms with golden parachutes had a higher proportion of independent directors serving on their boards. Around the same time, Singh and Harianto (1989b) ${ }^{1208}$ further reported that the number of executives covered by golden parachutes was significantly and positively correlated with the proportion of outside directors (not defined) ${ }^{1209}$ who sat on the compensation committee. ${ }^{1210}$ However, no significant relationship was found between the size of golden parachutes (the number of years' salary) and the fraction of outside directors (not defined) on the board or on a compensation committee. ${ }^{1211}$ The authors provided a possible explanation for the finding: outside directors (not defined) chose to adopt reasonable golden parachutes with a view to aligning management interests with those of shareholders. In other words, outside directors (not defined) on the compensation committee tended to support a wider distribution of the contractual protection for executives (i.e. more executives are covered by golden parachutes) but did not

\footnotetext{
1204 Ibid at 20.

${ }^{1205}$ Harbir Singh \& Farid Harianto, “Top Management Tenure, Corporate Ownership Structure and the Magnitude of Golden Parachutes” (1989) 10 Strategic Management Journal 143 at 154 [Singh \& Harianto, 1989b]; Lin, supra note 13 at 936 .

${ }^{1206}$ Singh \& Harianto, 1989b, ibid; Lin, ibid.

${ }^{1207}$ Lin, ibid at 936, 905-06.

${ }^{1208}$ The authors used the same sample to examine the correlation between board and subcommittee composition and two parameters of golden parachutes (coverage and size). Singh \& Harianto, 1989b, supra note 1205 at 148.

1209 The authors did not specifically define "outside directors" in this study.

${ }^{1210}$ Singh \& Harianto, 1989b, supra note 1205 at 151 , 154. It is worth mentioning that there was no connection between the number of executives covered by golden parachutes and the proportion of outside directors on the board. Ibid at 151, 152 Table 3 .

1211 Ibid at 152 .
} 
expand the size of individual payments. ${ }^{1212}$ This interpretation seems to clarify the previous unexpected finding that firms with a higher proportion of outside directors were more likely to adopt a golden parachute. Outside directors (not defined) seemingly protected shareholder interests by not awarding excessive contractual protection to management.

It is worth noting that some studies before the new millennium used the term "outside director" to describe what is currently called "independent director". Since Singh and Harianto (1989a \& 1989b) did not define outside directors, their results might represent either the effect of independent directors or the effect of outside (independent plus affiliated) directors which might not be the same as that of independent directors.

Around a decade later, Davidson, Pilger and Szakmary (1998) ${ }^{1213}$ used stock market reaction to the announcement of a golden parachute adoption (as measured by cumulative abnormal returns) to examine whether a golden parachute benefits shareholders. ${ }^{1214}$ Negative abnormal returns were thought to suggest that shareholders perceived that the parachute entrenches the management team, while positive abnormal returns were thought to suggest that the parachute is aligned with shareholder interests.

The evidence revealed that the proportion of independent directors ${ }^{1215}$ on the board did not significantly correlate with positive or negative abnormal returns when a company announced the adoption of a golden parachute. ${ }^{1216}$ This suggests that board composition had no impact on shareholder interests during the adoption of golden parachutes. However, the findings also showed that firms whose share price reacted positively to the parachute announcement had compensation committees with majority control by independent directors. In contrast, firms whose share price reacted negatively to the announcement had compensation committees that were numerically dominated by inside and affiliated ${ }^{1217}$ directors. ${ }^{1218}$ Since a compensation committee's responsibility is considered to include reviewing and making recommendations on

\footnotetext{
1212 Ibid at 154 .

1213 The authors examined the relationship between boards of directors and whether golden parachutes were aligned with shareholder interests or were a means of entrenching management by surveying a sample consisting of 86 firms selected from The Investor Responsibility Research Center (IRRC) between June 1984 and January 1990. Davidson, Pilger \& Szakmary, supra note at 20-21.

1214 Ibid at 21.

${ }^{1215}$ Independent directors are defined as directors who are not affiliated with the firm or only have limited economic relations with the company. Ibid at 22.

${ }^{1216}$ Ibid at 27 and table 2.

${ }^{1217}$ In this study, affiliated directors are defined as directors who are closely associated with the firm, but are not full-time employees. Ibid at 22.

${ }^{1218}$ Ibid at 28-29.
} 
compensation for senior management, the results imply that investors perceived that compensation committees with more independent directors better protect shareholder interests.

\section{Analysis}

Evidence seems to be consistent concerning whether independent directors can effectively protect shareholder interests in the adoption of golden parachutes. Cochran, Wood and Jones (1985) and Singh and Harianto (1989a) found that the proportion of independent (or outside) directors on the board was positively related to the probability of the adoption of golden parachutes, while Singh and Harianto (1989b) observed that outside directors (not defined) on the compensation committee did not expand the size of individual golden parachute payments but supported an increase of the number of executives covered by the golden parachutes. Davidson, Pilger and Szakmary (1998) further reported that the market reacted positively to the announcement of golden parachutes if independent directors dominated compensation committees.

Although whether golden parachutes benefit shareholder interests is contested, the latter two studies show that independent directors did not support golden parachutes without reservation, and that their efforts were perceived positively by shareholders. The stock market's positive reaction to the adoption of golden parachutes confirmed the value of independent directors. Therefore, the evidence of empirical studies tends to support the conclusion that independent directors fulfill a monitoring duty in the adoption of golden parachutes, if we consider golden parachutes as a mechanism to align managerial interests with those of shareholders.

\subsection{Summary of the Relationship between Board Independence and Takeover Bids}

Regarding whether independent directors can effectively protect shareholder interests in relation to takeover, the empirical findings seem to vary depending on whether bidding firms or target firms are examined and the types of defensive tactics adopted by the target board. In bidding firms, boards with up to $60 \%$ of independent directors had less-negative returns to shareholders than boards without such a composition during tender offers. However, in target 
firms, there is no conclusive evidence that boards with a majority of independent directors would be more likely to increase shareholder wealth. Where target boards adopted poison pills, shareholder wealth at least was not reduced and might even be enhanced, if target boards were controlled by independent directors. In addition, target firms were more inclined to adopt golden parachutes for their senior managers, if their boards were staffed by a higher proportion of independent or outside directors or their compensation committees were dominated by independent directors. However, the size of individual golden parachute payments was limited and was perceived by shareholders in a positive way where compensation committees were controlled by independent directors. Finally, assuming that payment of greenmail is harmful to shareholders, target firms were more likely to resist greenmail when their boards had a higher proportion of outside directors. Taken together, independent directors generally meet the expectation of protecting shareholder interests in relation to defensive tactics adopted but studies that looked at the performance of target boards subject to tender offers did not consistently show that the presence of independent directors was likely to enhance shareholder wealth.

\subsubsection{Board Independence and CEO Turnover}

The role of the Chief Executive Officer (CEO) in modern corporations is to use firm resources properly to generate maximum returns for their shareholders. In contrast, boards of directors undertake the responsibility of supervising CEOs by reviewing their performance. Independent directors, without business or personal ties with management, are widely believed to be the best candidates to fulfill this monitoring job. When firms suffer deteriorating financial performance, boards dominated by independent outsiders are supposed to replace their ineffective CEOs to protect shareholders' interests. Thus, the effectiveness of independent directors in replacing poorly performing CEOs is often thought to be a good indicator of the effectiveness of independent directors.

Empirical evidence regarding whether independent directors were likely to replace poorly performing CEOs is inconsistent. Before the enactment of SOX and the related regulations, two studies reported that CEO turnover was not sensitive to board independence when firms 
performed poorly. More specifically, Mikkelson and Partch (1997) ${ }^{1219}$ reported that there was no significant correlation between firm performance ${ }^{1220}$ or the proportion of independent directors $^{1221}$ on the board and CEO turnover ${ }^{1222}$ during the low takeover period of 1989 through 1993. ${ }^{1223}$ During the active takeover period of 1984 to 1988 , the authors found a significant and negative relation between CEO turnover and firm performance, but still no correlation between the percentage of independent directors on the board and CEO turnover. ${ }^{1224}$ Around the same time, Geddes and Vinod (1997) ${ }^{1225}$ observed that a CEO was less likely to be replaced when there were a greater proportion of independent directors ${ }^{1226}$ on the board, after controlling the effect of CEO tenure and CEO age. ${ }^{1227}$ However, after firm performance ${ }^{1228}$ was taken into account, independent directors seemed to have no significant impact on CEO turnover. ${ }^{1229}$ These two studies provide no evidence that board independence is related to the turnover of poorly performing CEOs.

In contrast, five studies reported that independent directors were effective in removing CEOs of poorly performing firms. Weisbach $(1988)^{1230}$ found that CEO turnover was more

${ }^{1219}$ Wayne H Mikkelson \& M Megan Partch, "The Decline of Takeovers and Disciplinary Managerial Turnover” (1997) 44 The Journal of Financial Economics 205 at 208-11. The authors tested how prior firm performance and board composition affect the likelihood of management turnover by using a sample comprising 227 firms listed in the NYSE or AMEX during the period between 1984 and 1988, and 218 firms listed on the same exchanges during the period from 1989 to 1993 .

${ }^{1220}$ Firm performance is measured by stock returns, market to book value of assets, and pretax operating income before interest and depreciation scaled by assets. Ibid at 214 .

${ }^{1221}$ An independent director is defined as a director who is neither a current nor former employee of the firm and has no business ties with the firm reported in the proxy statement. Ibid at 221 Table 5, at 223 Table 6. The term "independent directors" here is identical to the term "outside directors" used by the original authors in their study. ${ }^{1222} \mathrm{CEO}$ turnover is defined as a change in the identity of the individual who holds the office of CEO. Ibid at 213. ${ }^{1223}$ Ibid at 221-22, 226.

${ }^{1224}$ Ibid at 207, 221-22, 226.

${ }^{1225}$ R Richard Geddes \& Hrishikesh D Vinod, "CEO Age and Outside Directors: A Hazard Analysis" (1997) 12 Review of Industrial Organization 767 at 773 . The authors explored the relationship between the board of directors, managerial turnover and a number of variables by surveying 367 corporations from 1974 to 1983.

${ }^{1226}$ Independent directors are defined as directors who are not officers of the firm and who do not have extensive dealings with it. Ibid at 769. The term "independent directors" here is identical to the term "outside directors" used by the original authors in their study.

${ }^{1227}$ Ibid at 776 . The same result can also be interpreted as that the more independent directors on the board, the higher inclination of the board to hire a CEO who remains in his position longer. Ibid at 776,778.

${ }^{1228}$ Firm performance is measured by the market-adjusted return (RET) and earnings before interests and taxes (EBIT). Ibid at 773 .

${ }^{1229} \mathrm{Ibid}$ at 776.

${ }^{1230}$ Weisbach, CEO Turnover, supra note 1075 at 435-36. The author examined how board independence affects the relation between poor corporate performance and chief executive turnover by using a sample consisting of 367 NYSE firms between 1974 and 1983. 
sensitive to firm performance when firms had at least $60 \%$ independent directors ${ }^{1231}$ on the board, in comparison with those dominated by inside directors (with less than $40 \%$ of independent directors). This result held regardless of whether firm performance was measured by stock returns or by accounting earnings. ${ }^{1232}$ However, Professors Bhagat and Black questioned the economic significance of Weisbach's study. In fact, the CEO turnover rate of poorly performing companies (ranked in the bottom decile for stock price performance) was only $1.3 \%$ higher for firms with at least $60 \%$ independent directors than for firms with $40 \%$ or few independent directors. The effectiveness of independent directors replacing underperforming firms' CEOs may not be significant.

Around a decade later, Perry's research $(2000)^{1233}$ revealed that board independence and incentive-based compensation ${ }^{1234}$ both influenced the sensitivity of CEO turnover ${ }^{1235}$ to performance. ${ }^{1236}$ Independent boards ${ }^{1237}$, regardless of whether or not they received incentive pay, and inside boards with incentive pay, were more likely to replace CEOs of poorly performing firms. Only inside boards without incentive compensation seemed to have no impact on whether CEO would be replaced when their firms performed poorly. ${ }^{1238}$ Boards having at least $60 \%$ of independent directors (i.e. independent boards) with incentive pay were most strongly associated with the turnover of CEOs of the poorly performing firms. ${ }^{1239}$ These results suggest that board independence was the main contributor to the protection of shareholders interests by removing CEOs of poorly performing firms. With the addition of director incentive pay, the effectiveness of independent directors was likely to be greater.

\footnotetext{
${ }^{1231}$ In this study, independent directors are defined as directors who neither work for the corporation nor have extensive dealings with the company. Ibid at 436.

1232 Ibid at 447.

${ }^{1233}$ The author examined whether the structure of director compensation affected CEO turnover by surveying director compensation data of around 1,600 firms between 1992 and 1995. Perry, supra note 379 at 5.

${ }^{1234}$ Incentive plans in this study include stock grants and stock options. Ibid at 4.

${ }^{1235}$ CEO turnover is defined as a change in the identity of the individual who hold the office of CEO. The author does not distinguish between disciplinary turnover and normal retirement. Ibid at 7.

1236 Ibid at 19.

${ }^{1237}$ The author classified boards with at least $60 \%$ independent directors as independent boards, and boards with less than $60 \%$ independent directors as inside boards. Ibid at 14. Directors who are employees of the firm are defined as inside directors. Affiliated directors are nonemployee directors who are either related to an executive officer of the firm, former employees of the firm, or are consultants, lawyers at other firms that have or may have significant business dealings with the firms. All other directors are classified as independent directors. Ibid at 8 .

${ }^{1238} \mathrm{Ibid}$ at 19. In a different regression model, the author reported that only independent boards with incentive compensation are significantly sensitive to performance in replacing a CEO; the remaining three situations are statistically insignificant. Ibid at 17-18.

${ }^{1239}$ Ibid at $17-18,19$.
} 
In the middle of the first decade of the 2000s, Fich and Shivdasani (2006) ${ }^{1240}$ also found that the sensitivity of CEO turnover to firm performance was stronger when firms had a majority of independent directors ${ }^{1241}$ on the board. ${ }^{1242}$ Two years later, Bhagat and Bolton (2008) ${ }^{1243}$ reported that greater board independence (as measured by the percentage of independent directors on the board) increased the likelihood of disciplinary CEO turnover ${ }^{1244}$ when firms performed poorly. ${ }^{1245}$ Since most of the sample periods (1993-2003) in this study were before the enactment of SOX-related reforms, the results may not reflect the situation in the post-SOX period.

With a view to exploring the impact of SOX and related regulations on corporate governance mechanisms, Bhagat and Bolton (2009) used the identical methodology as in their $2008^{1246}$ study to examine the relationship between five corporate governance mechanisms (including board independence) and disciplinary CEO turnover by separating the sample periods into pre-2002 and post-2002 sub-periods. In their pre-2002 sub-sample, the findings were identical to the authors' 2008 research. A higher level of board independence was found to increase the likelihood of disciplinary CEO turnover when firms performed poorly. ${ }^{1247}$ However, the authors found that the impact of board independence on CEO turnover became insignificant after SOX and related regulations were enacted. ${ }^{1248}$ The results indicate that independent directors indeed played an important role in maintaining the sensitivity of CEO turnover to firm

\footnotetext{
${ }^{1240}$ The authors examined whether busy boards had an impact on firm performance and CEO turnover by using a sample of 508 Forbes 500 firms in 1992 during the period from 1989 to 1995. Eliezer M Fich \& Anil Shivdasani, “Are Busy Boards Effective Monitors?" (2006) 61:2 Journal of Finance 689 at 695 [Fich \& Shivdasani 2006].

${ }^{1241}$ In this study, inside directors are full-time employees of the firm. Gray directors are defined as directors who are associated with the firm, who are former employees, who have existing family or commercial ties with the firm other than their directorship, and who have interlocking directorships with the CEO. Directors who do not fit the description for inside or gray directors are classified as independent directors. Ibid.

${ }^{1242}$ Ibid at 714.

${ }^{1243}$ The authors examined the relationship between CEO turnover, past firm performance and the proportion of independent directors on the board by using a sample of 1,923 CEO changes from 1993 to 2003. Bhagat \& Bolton 2008, supra note 1020 at 270

${ }^{1244} \mathrm{CEO}$ turnover is considered disciplinary, if the CEO resigned to pursue other interests, if the CEO was terminated or if no specific reason is given. Ibid.

${ }^{1245}$ Ibid.

${ }^{1246}$ Bhagat \& Bolton 2008, supra note 1020. The difference between this study and their 2008 research is that the current study adopts a dissimilar observation period (from 1998 to 2007), in comparison with the observation period (1993 to 2003) in their 2008 study; however, the sample size in both studies is similar (1,923 CEO changes in 2008 study vs. 1,951 CEO changes in 2009 research). Ibid at 11, 21.

${ }^{1247}$ Bhagat \& Bolton 2009, supra note 1021 at 23.

${ }^{1248}$ Ibid at 24.
} 
performance in the pre-2002 period, but their influence seems to be reduced in the post-SOX period. However, the authors did not provide an explanation for such findings. ${ }^{1249}$

\section{Analysis}

Taken together, the findings regarding whether independent directors can replace poorly performing CEOs appear to be inconsistent. In the pre-SOX period, Mikkelson and Partch (1997) and Geddes and Vinod (1997) found no evidence that CEO turnover was sensitive to board independence when firms performed poorly, while five studies ${ }^{1250}$ reported that independent directors are an effective mechanism in maintaining the sensitivity of CEO turnover to firm performance. However, among the five studies that support the efficacy of board independence, their thresholds of board independence for retaining the significant effect of the sensitivity of CEO turnover to firm performance were different. Weisbach (1988) and Perry (2000) observed that the independence threshold to maintain such sensitivity was 60\%, while Fich and Shivdasani (2006) found that it was 50\%. In contrast, Bhagat and Bolton (2008) and Bhagat and Bolton (2009) only reported that "a higher proportion" of independent directors on the board was sufficient to reach the significant effect. There seems to be no consensus regarding how much independence is enough to achieve the sensitivity. Nevertheless, board independence had an impact on the sensitivity of CEO turnover to firm performance in the pre-SOX period, since five out of seven existing studies have shown so. In the post-SOX period, the connection between board independence and the sensitivity of CEO turnover to firm performance became insignificant. It may be that listed firms have been required to have a majority of independent directors on the board, so the impact of independent directors on the sensitivity of CEO turnover to firm performance becomes difficult to observe. Taken together, maintaining greater independence in a corporate board meant that the board was more likely to dismiss the CEOs of poorly performing firms.

\subsubsection{Board Independence and Executive Compensation}

\footnotetext{
${ }^{1249}$ Perhaps, the level of board independence has been significantly improved in the post-SOX period, so the impact of independent directors on CEO turnover becomes more difficult to observe or less significant.

${ }^{1250}$ Please refer to Weisbach (1988), Perry (1999), Fich and Shivdasani (2006), Bhagat and Bolton (2008), and Bhagat and Bolton (2009).
} 
Ideally, CEO remuneration should not be so high as to damage shareholder wealth. On the other hand, it cannot be too low so that it does not provide incentives for executives to maintain the quality of their management. The better scenario is to establish a compensation package that aligns the interests of a CEO with those of shareholders. Since CEOs control all corporate resources, they may exert their influence over the board or compensation committee to establish compensation packages favorable to themselves. Where CEOs behave opportunistically to extract excessive remuneration from corporations, their compensation contracts are likely to be suboptimal and will not serve shareholders' interests. Independent directors who have no business or personal ties with the CEO and the firm are thought to be the best candidates for ensuring that CEO compensation is optimal. Thus, the association between board independence and top manager pay is a good indicator to test whether independent directors fulfill their job of protecting shareholder interests. However, existing empirical research seems to provide a pessimistic answer regarding the effectiveness of independent directors in setting appropriate CEO compensation.

So far, existing empirical studies have examined the impact of board independence on CEO compensation from two perspectives: (1) the relationship between the proportion of independent directors on the board and the level of CEO compensation; (2) the correlation between the proportion of independent directors on the board and the likelihood that compensation packages tie CEO pay to performance.

Three studies in the pre-SOX period reported that firms with a higher fraction of outside directors were more likely to reward executives with higher remuneration. More specifically, Boyd (1994) $)^{1251}$ and Core, Holthausen and Larcker (1999) ${ }^{1252}$ both reported that the proportion of inside directors on the board was negatively associated with the level of CEO

\footnotetext{
${ }^{1251}$ Brian K Boyd, "Board Control and CEO Compensation” (1994) 15 Strategic Management Journal 335 [Boyd, CEO Compensation]. The sample of this study consists of 193 firms in 12 industry groups in 1980. Ibid at 337. CEO compensation is measured by base salary, bonus and long-term or deferred income. Ibid. Inside directors are defined as directors who are also members of a firm's management. Ibid at 338.

1252 John E Core, Robert W Holthauesn \& David F Larcker, "Corporate Governance, Chief Executive Officer Compensation, and Firm Performance" (1999) 51 Journal of Financial Economics 371 [Core, Holthauesn \& Larcker]. The authors examined the correlation between CEO compensation and a set of board and ownership structure variables concerning 205 publicly-traded US firms between 1982 and 1984. Ibid at 377. Total CEO compensation is the sum of salary, annual bonus, stock options, performance plans, phantom stock and restricted stock. Ibid at 380. Inside directors are defined as directors who are managers, retired managers, or family members of present or past management. Ibid at 382 .
} 
compensation. ${ }^{1253}$ Since directors who are not classified as insiders are considered as outsiders, the above results imply that the more outsiders on the board, the higher CEO compensation will be. Core, Holthausen and Larcker also found that a higher proportion of less independent outside directors, as proxied by outside directors ${ }^{1254}$ who are appointed by the $\mathrm{CEO}^{1255}$, who are gray directors ${ }^{1256}$ and who are interlocked ${ }^{1257}$, were all associated with higher CEO compensation. ${ }^{1258}$ This suggests that these less independent outside directors do not create a more effective (and may even a worse) board than inside directors.

Five years later, Conyon and $\mathrm{He}(2004)^{1259}$ observed that a compensation committee with higher proportions of inside directors ${ }^{1260}$ was not associated with the level of CEO pay or the use of CEO equity incentives as a way of aligning CEO interests with those of shareholders. ${ }^{1261}$ In contrast, a board with a greater percentage of inside directors was correlated with a lower total CEO compensation level but larger CEO equity incentives. ${ }^{1262}$ It appears that it was inside directors on the board, rather than inside directors on the compensation committee, that had a significant impact on CEO remuneration decisions. It is worth mentioning that the definition of outside directors in the above three studies was very broad. Directors who are gray, and who are interlocked with the company are all included in the definition of outside directors. If these studies only looked at the effect of real independent directors, the results might be different. Therefore, one must be very careful in applying the results of these three studies.

After corporate scandals emerged in 2001 and 2002, major US stock exchanges issued new rules regarding independent directors with a view to enhancing the quality of corporate

\footnotetext{
${ }^{1253}$ Ibid at 385; Boyd, CEO Compensation, supra note 1251 at 340-41.

1254 This study does not define outside directors, but it indicates that outside directors who have been appointed by the CEO, who are gray, and who are interlocked with the corporation are less effective monitors.

1255 Outside directors are assumed to have been appointed by the CEO if they joined the board after the CEO took office. Core, Holthauesn \& Larcker, ibid at 382.

${ }^{1256}$ An outside director is defined to be 'gray' if he or his employer received payments from the company in excess of his board pay. Ibid.

${ }^{1257}$ An outside director is considered as 'interlocked' if an inside director of the firm serves on the board of that outside director's firm. Ibid.

${ }^{1258}$ Ibid at 388 .

${ }^{1259}$ Martin J Conyon \& Lerong He, “Compensation Committees and CEO Compensation Incentives in U.S. Entrepreneurial Firms" (2004) 16 Journal of Management Accounting Research 35 [Conyon \& He]. The authors investigated the relation between the compensation committee, CEO compensation and CEO incentives by using a sample of 455 US firms completing an initial public offering in 1999. Ibid at 40-41.

${ }^{1260}$ Inside directors are defined as directors who currently or previously work for the firm. Ibid at 47, 49, 52.

${ }^{1261}$ Ibid at 46, 48, 49, 52. CEO compensation is calculated as the sum of base salary, annual bonus, long-term incentive, restricted stock, stock option grants and other compensation. CEO equity incentives are measured by stock and stock options, which directly link CEO wealth to shareholder value. Ibid at 41.

${ }^{1262}$ Ibid at 50 .
} 
governance. Corporate boards were required to have a majority of independent directors to decide top executive compensation or review compensation packages proposed by the compensation committee. Two studies tested whether the new requirements regarding independent directors had an effect on executive compensation decisions.

Chhaochharia and Grinstein (2009) ${ }^{1263}$ hypothesized that if the board and committee independence requirements set by SOX or stock exchanges influenced CEO compensation ${ }^{1264}$, then firms that did not comply with these requirements (prior to the enactment of the new rules) should respond more to the rules than firms that did comply with them. ${ }^{1265}$ They found that CEO compensation was reduced by $17 \%$ in the post-SOX period for firms that did not comply with board independence requirement ${ }^{1266}$ in the pre-SOX period, compared to firms that complied with the requirement before the enactment of SOX. ${ }^{1267}$ The significantly lower CEO pay came from the decrease in bonus and the equity-based compensation. ${ }^{1268}$ However, CEO compensation seems not to be influenced by the requirement of compensation committee independence between non-complying firms and complying firms. ${ }^{1269}$ The results of Chhaochharia and Grinstein (2009) appear to show that the requirement of board independence, rather than compensation committee independence, had a significant impact on executive compensation decisions. ${ }^{1270}$

However, the findings of Chhaochharia and Grinstein (2009) seem to be challenged by Professor Wan's 2009 research. Wan reexamined the impact of the new board and committee requirements on CEO compensation by using the identical methodology, observation period and

\footnotetext{
${ }^{1263}$ Vidhi Chhaochharia \& Yaniv Grinstein, "CEO Compensation and Board Structure" (2009) 64:1The Journal of Finance 231 [Chhaochharia \& Grinstein 2009]. The authors investigated 865 firms in the S\&P 1500 index for the years 2000 to 2005 . Ibid at 237.

${ }_{1264}$ Total CEO compensation includes base salary, bonuses, options, restricted stocks and other compensation. Equity-based is defined as the total value of options and restricted stock awarded to the CEO. Nonequity-based is the total compensation to the CEO minus the equity-based compensation. Ibid at 241-42.

${ }^{1265} \mathrm{Ibid}$ at 243. Their measure of the level of compliance is whether the corporation had a majority of independent directors, a fully independent compensation committee and a fully independent nominating committee before the requirements were announced (before 2002). Ibid.

${ }^{1266}$ Board independence requirement refers to the requirement that listed firms must have a majority of independent directors on the board. Ibid at 236.

${ }^{1267}$ Ibid at 232, 244.

1268 Ibid at 232, 247-48.

${ }^{1269}$ Ibid at 232, 244.

${ }^{1270}$ The authors attributed the results to the phenomenon that the board nominates the members of the compensation committees and then approves the recommendation of those committees. Ibid at 244.
} 
sample firms. ${ }^{1271}$ The main difference is that he excluded the exceptionally low compensations of Apple's CEO (Steven Jobs) and Fossil's CEO (Kosta Kartsotis) in the post-regulation period from his sample, because the substantial reduction in their pay was likely motivated by other factors other than board or committee independence requirements. ${ }^{1272}$

Professor Wan found that board independence requirements were not related to CEO total compensation, contrary to the findings of Chhaochharia and Grinstein (2009). He considered that the results of Chhaochharia and Grinstein (2009) were driven by those two unusually low CEO pay packages, rather than the effect of board independence requirements. ${ }^{1273}$ Moreover, in sharp contrast to conventional wisdom, the author found that the requirement for compensation committee independence had a significant and positive effect on CEO remuneration. This requirement was associated with CEO total compensation that was higher by $7.25 \%$ for firms not complying with compensation committee independence requirement in the pre-SOX period, compared to complying firms. ${ }^{1274}$ Taking the two studies in the post-SOX period together, the new board independence requirements seem to have had no influence on the level of CEO total compensation. The new compensation committee independence requirements may even contribute to increased CEO total pay for firms not complying with new requirements, in comparison with those complying firms. The effectiveness of these new requirements thus seems doubtful in terms of their effect on CEO pay.

The two post-SOX studies purposely avoided measuring the likelihood of CEO pay being linked to performance and the effect of compensation on firm performance. ${ }^{1275}$ Only one study in the pre-SOX period has addressed this issue. Based on previous empirical findings that the better way to tie executives' pay to firm performance is to make a greater percentage of their

\footnotetext{
${ }^{1271}$ Kam-Ming Wan, “Can Boards with a Majority of Independent Directors Lower CEO Compensation?” (3 June 2009) at 4, online: SSRN: 〈http://ssrn.com/abstract=1421549> [Wan].

${ }_{1272}$ Ibid at 4-5. The total pay to Kosta Kartsotis (the CEO of Fossil) was around $\$ 255,000$ in each of the five fiscal years between 2000 and 2004, but his pay dropped to $\$ 180$ (salary: $\$ 0$ plus other compensation: \$180) in 2005 . Similarly, the total compensation to Steven Jobs (the CEO of Apple) exceeded $\$ 74.7$ million in each of the four fiscal years between 2000 and 2003, but his remuneration declined to only $\$ 1$ in the fiscal year of 2004 and 2005 . Since Apple and Fossil did not comprise a majority of independent directors in 2002, the substantial drop in their CEO compensation during the post-regulation period might be affected by the board or committee independence requirements or might be just a pure coincidence related to other factors. In Mr. Kartsotis' case, it was he, rather than the board or compensation committee, who initiated and insisted that his base salary should be cut from $\$ 255,000$ to $\$ 0$ in 2005 . In Mr. Job's case, he took just $\$ 1$ per year as salary since he rejoined the company in October 1997. The decrease of compensation for both CEOs was seemingly triggered by factors other than board independence requirements. Ibid at 19-24.

${ }^{1273}$ Ibid at 4-5, 12-13, 18.

${ }^{1274}$ Ibid at 5,14 .

${ }^{1275}$ Chhaochharia \& Grinstein 2009, supra note 1263 at 242.
} 
compensation equity-based, ${ }^{1276}$ Mehran (1995) found that firm performance was positively related to the percentage of executive compensation ${ }^{1277}$ that is equity-based, ${ }^{1278}$ and was negatively related to total compensation in cash. ${ }^{1279}$ Significantly, he found that firms with a higher proportion of independent directors ${ }^{1280}$ on the board had a higher percentage of their executives' compensation in an equity-based form. ${ }^{1281}$ The results seem to show that independent directors on the board, in comparison with inside directors, are more likely to set executive pay in a manner that is sensitive to firm performance and, thus, align managers' interests with increasing shareholder wealth. However, four similar studies that looked at outside or independent directors on the compensation committee regarding the same issue found no such effects.

\section{Analysis}

Taken together, the findings seem to show that greater board independence is not necessarily associated with lower executive compensation. In the pre-SOX period, Boyd (1994), Core, Holthausen and Larcker (1999) and Conyon and He (2004) found that firms with a higher proportion of outside directors were more likely to have a higher level of CEO remuneration. However, these conclusions were based on the effects of outside directors, rather than independent directors. If these studies only looked at real independent directors, the results might be different. It is worth noting that the findings of these three studies are different from those of two post-SOX studies ${ }^{1282}$ which examined only independent directors between board independence and the level of CEO compensation. One may interpret these earlier studies as suggesting that either independent or outside directors were ineffective in controlling the level of

\footnotetext{
${ }^{1276}$ Mehran, supra note 1095 at 166.

${ }^{1277}$ Compensation in this study is measured by three indices: (1) compensation that is in grants of new stock options, (2) compensation that is equity-based and (3) compensation that is in salary plus bonus. Ibid at 169.

${ }^{1278} \mathrm{Ibid}$ at 164, 178. Equity-based compensation is defined as awards from grants of new stock options, restricted stocks, phantom stocks and performance shares. Ibid at 169.

${ }^{1279}$ Ibid at 178. Cash compensation includes salary and bonus. Ibid at 169 .

${ }^{1280}$ In this study, independent directors are members of the board who are not top executives, retired executives, former executives of the company, nor relatives of the CEO. Outside corporate lawyers who are employed by the firm and also serve on the board are considered insiders. Ibid at 169-70. The term "independent directors" here is identical to the term "outside directors" used by the original author in his study.

1281 Ibid at 173 .

1282 Please refer to Chhaochharia and Grinstein (2009) and Wan (2009), as well as text accompanying supra notes 1271-1274.
} 
CEO compensation. To this extent, the results of these earlier studies that fail to look only at the effect of independent directors are consistent with the later studies.

In the post-SOX period, Chhaochharia and Grinstein (2009) reported that CEO compensation reduced significantly after the enactment of SOX-related regulations (regarding board independence), while Wan (2009) observed that boards with a majority of independent directors had no impact on CEO total compensation. Since the main results of Chhaochharia and Grinstein (2009) seem to be driven by two unusually low CEO compensation packages, it appears that the new board independence requirements were not as effective as reformers expected in reducing the level of CEO pay. However, in comparison with the negative effect of outside directors in controlling CEO remuneration before the implementation of SOX, new board independence requirements-with neutral effect in controlling CEO compensation-may in fact provide better protection to shareholders.

With respect to the correlation between the proportion of independent directors on the board and the sensitivity of CEO pay to firm performance, only Mehran (1995) reported that boards with more independent directors had a higher proportion of executive compensation in equity-based form. Since the value of equity-based pay is sensitive to firm performance through stock price, corporate CEOs have incentives to perform well in order to obtain greater rewards. The findings of Mehran (1995) appear to show that more independent directors on the board were more successful in tying CEO compensation to firm performance.

In total, empirical evidence shows that having a majority of independent (or a higher proportion of outside) directors on the board may not be an effective approach to control the level of executive compensation. Although independent directors may be more likely to establish appropriate incentive compensation plans that tie executive pay to firm performance, there is no evidence to show that this results in decreasing the level of total CEO remuneration.

It is worth mentioning that lower levels of CEO remuneration are not necessarily better for shareholders. If CEOs can make more profit for their shareholders, shareholders usually would not spare rewarding CEOs for their effort. The major concern of shareholders is whether the executive compensation fits their performance. Thus, the better indicator to measure the effectiveness of independent directors appears to be their effect on the likelihood that CEO compensation will be structured as pay-for-performance, rather than the level of CEO pay. 


\subsubsection{Board Independence and Management Buyouts}

Management buyouts refer to transactions whereby a group of investors, that includes top managers, acquire all or a dominant equity interest in a company. ${ }^{1283}$ Management buyouts raise conflicts of interest between shareholders and management. On the one hand, management has a fiduciary duty to obtain the highest price for shareholders, but, on the other hand, it has an incentive to make the acquisition by paying the lowest possible price. ${ }^{1284}$ Since independent directors are expected to provide a check on managerial abuses and protect shareholder interests, the management buyout situation is a good indicator for evaluating the effectiveness of independent directors.

Lee et al. (1992) ${ }^{1285}$ investigated market reaction to management buyouts based on whether independent directors were on the board. The results varied with the types of management buyouts-going-private transactions vs. unit management buyouts. A going private transaction means a transaction or series of transactions that convert a publicly-traded company into a closely-held company, ${ }^{1286}$ while a unit management buyout refers to the sale of a division, subsidiary, or other operating unit of a parent firm to members of management of either the parent or the subunit being diverted. ${ }^{1287}$

The authors found that in going-private transactions firms with a majority of independent directors ${ }^{1288}$ on the board were associated with larger shareholder returns (as measured by cumulative abnormal returns), compared to those dominated by non-independent directors (insiders and affiliated outsiders). ${ }^{1289}$ However, there is no evidence to support the same

${ }^{1283}$ Chun I Lee et al, supra note 420 at 58; Clark, Corporate Law, supra note 416 at 500.

${ }^{1284}$ Chun I Lee et al, ibid.

${ }^{1285}$ The authors examined the correlation between board independence and shareholder wealth by surveying a sample consisting of 58 going-private transactions and 74 unit management buyouts for firms listed on the NYSE and AMEX over the years 1983 to 1989. Ibid at 61.

${ }^{1286}$ Its process can be triggered by major shareholders, management, or a third party by buying out the public's stockholdings. Once a company goes private, its shareholders are no longer able to trade their stocks in the open market. See Black's Law Dictionary, 8th ed, sub verbo "going private".

${ }^{1287}$ Gailen Hite \& Michael Vetsuypens, "Management Buyouts of Divisions and Shareholder Wealth" (1989) 44:4 Journal of Finance 953 at 954.

${ }^{1288}$ Independent directors in this research include directors who are not former or current employees of the company and who do not have business ties with management. Ibid at 61-62. The term "independent director" here is identical to the term "independent outside director" used by the original authors in their study.

${ }^{1289}$ Chun I Lee et al, supra note 420 at 66-68. 
conclusion in unit management buyouts. ${ }^{1290}$ The authors attribute the results to differences in agency costs between going-private transactions and unit management buyouts. They suggest that senior inside directors may not generally have a personal stake in unit management buyouts, but would generally benefit by purchasing assets at a low price at the expense of shareholders in going-private transactions. ${ }^{1291}$ The findings show that independent directors tend to fulfill their duties in enhancing shareholder wealth during going-private situations, but may not be effective in unit management buyouts.

\subsubsection{Board Independence and Financial Fraud}

Financial fraud, a general concept of corporate wrongdoing, is committed when public corporations or their management intentionally manipulate earnings, issue materially misleading financial statement information, misappropriate corporate assets, or violate federal or state regulations, all of which usually results in losses to shareholders. Since independent directors shoulder the responsibility to protect shareholders' interests, the incidence of financial fraud should be lower if they can effectively monitor management's misbehavior. Empirical studies have used earnings manipulation, financial statement fraud, SEC sanctions, fraud on stakeholders, and other events as indicators of financial fraud to examine the effectiveness of independent directors. So far, six studies of financial fraud have reported inconsistent results regarding this issue.

Dechow, Sloan and Sweeney (1996) ${ }^{1292}$ found that firms inclined to manipulate earnings were less likely to have outsider-dominated ${ }^{1293}$ boards, compared to those without such a board. The results imply that corporations with more outside directors on the board had a higher

\footnotetext{
${ }^{1290}$ Ibid at 71. The relationship between a majority of independent directors on the board and the unit management buyout is positive but insignificant. Ibid at 69-70.

1291 Ibid.

1292 Patricia M Dechow, Richard G Sloan \& Amy P Sweeney, "Causes and Consequences of Earnings Manipulation: An Analysis of Firms Subject to Enforcement Actions by the SEC” (1996) 13 Contemporary Accounting Research 1 [Dechow, Sloan \& Sweeney]. The authors tested whether the incidence of earnings manipulation is related to a firm's weak governance structure by investigating 92 firms subject to accounting enforcement actions by the SEC for alleged violation of Generally Accepted Accounting Principles (GAAP) and 92 control firms with similar industry and size between April 1982 and December 1992. Ibid at 7-8.

${ }^{1293}$ This study does not directly define outside directors. It indirectly defines inside directors as directors who are officers on the board. Ibid at 15 .
} 
probability of deterring financial fraud. ${ }^{1294}$ Around the same period, Beasley (1996) ${ }^{1295}$ also reported that firms experiencing financial statement fraud ${ }^{1296}$ had a significantly lower proportion of independent directors ${ }^{1297}$ on the board, compared to firms without such fraud. ${ }^{1298}$ A similar relationship also existed between outside directors ${ }^{1299}$ and firms with fraud. ${ }^{1300}$ The results of Beasley (1996) are thus not sensitive to the definition of outside (or independent) director and that gray directors play a similar role in deterring financial fraud. As a result, the failure of Dechow, Sloan and Sweeney (1996) to look only at the effect of independent directors may not undermine the relevance of the study, because Beasley (1996) reported that both outside and independent directors were effective in controlling financial fraud. The findings of Uzen, Szewczyk and Varma (2004), discussed below, also support this view. ${ }^{1301}$

Several years later, Beasley et al. (2000) ${ }^{1302}$ observed that the percentage of firms accused of fraud within the technology, healthcare and financial services industries was much lower for firms with a majority of independent directors ${ }^{1303}$. More specifically, only thirty-three percent $(33 \%)$ of firms accused of fraud had a majority of independent directors, while seventyfour percent (74\%) of firms without fraud allegations had a majority of independent directors in the three industries. ${ }^{1304}$ The results imply that independent directors were more likely to prevent the occurrence of fraudulent financial reporting. However, around the same period, Abbott, Park

\footnotetext{
1294 Ibid at 21.

${ }^{1295}$ Mark S Beasley, "An Empirical Analysis of the Relation between the Board of Director Composition and Financial Statement Fraud" (1996) 71 The Accounting Review 443 [Beasley]. The author examined the relation between board composition and the occurrence of financial statement fraud by surveying a sample comprised of 75 fraud and 75 no-fraud publicly-traded firms during the period from 1980 to 1991. Ibid at 448-49.

${ }^{1296}$ Two types of financial statement fraud are examined in this study. The first type includes occurrences in which management intentionally issues materially misleading financial statement information to outside users. The second type includes occurrence of misappropriations of assets by top management. Ibid at 445 .

${ }^{1297}$ In this study, independent directors are defined as outside directors who have no affiliation with the firm other than his or her directorship. Ibid at 448.

1298 Ibid at 454-55.

${ }^{1299}$ In this study, outside directors are defined as directors who are not employees of the firm. Gray directors are included in the scope of outside directors. Gray directors are outside directors who have some non-board affiliation with the firm. Ibid at 447-448.

1300 Ibid at 455.

${ }^{1301}$ Please refer to infra text accompanying notes 1309-1310.

${ }^{1302}$ Mark S Beasley et al, "Fraudulent Financial Reporting: Consideration of Industry Traits and Corporate Governance Mechanisms" (2000) 14:4 Accounting Horizons 441 [Beasley et al]. The authors investigated the correlation between corporate governance mechanisms and financial statement fraud within three volatile industries (technology, healthcare and financial services) by surveying 66 companies accused of fraudulent financial reporting by the SEC and a control group from 1987 to 1997. Ibid at 445-46.

${ }^{1303}$ In this study, independent directors are defined as directors who have no disclosed relationship, other than stock ownership, between the director and the company or its officers. Ibid at 450.

${ }^{1304}$ Ibid at 452.
} 
and Parker (2000) ${ }^{1305}$ did not find any significant relationship between the percentage of independent directors ${ }^{1306}$ on the board and the incidence of corporate fraud ${ }^{1307} .^{1308}$

In the new millennium, Uzen, Szewczyk and Varma (2004) ${ }^{1309}$ reported that the percentage of outside and independent directors ${ }^{1310}$ were both lower for firms with corporate fraud $^{1311}$ than firms without corporate fraud. ${ }^{1312}$ The findings suggest that independent and outside directors were both an effective mechanism to hold management accountable and their effectiveness was not sensitive to the definition of independent director.

Instead of corporate fraud, Agrawal and Chadha $(2005)^{1313}$ used a restatement of earnings ${ }^{1314}$, a rare and serious accounting event, as an index to measure the monitoring quality of independent directors in modern corporations. ${ }^{1315}$ They observed that neither board composition ${ }^{1316}$ nor audit committee composition ${ }^{1317}$ had a significant impact on the incidence of

${ }^{1305}$ Lawrence Abbott, Young Park \& Susan Parker, "The Effect of Audit Committee Activity and Independence on Corporate Fraud" (2000) 26:11 Managerial Finance 55 [Abbott, Park \& Parker]. The authors examined the role of the audit committee in mitigating the likelihood of corporate fraud by investigating a sample of 78 firms that were sanctioned by the SEC for fraud or aggressive accounting and 78 non-sanctioned firms between 1980 and 1996. Ibid at 57-58.

${ }^{1306}$ Independent directors refer to directors who have no disclosed business ties (other than service on the board) with the firm or its management. Ibid at 59.

${ }^{1307}$ Corporate fraud in this study is measured by whether a firm was sanctioned by the SEC for fraud or aggressive accounting. Ibid at 57.

${ }^{1308} \mathrm{Ibid}$ at 60 . It is worth mentioning that similar results also held for outside directors. The findings of Abbott, Park and Parker (2000) demonstrated that the proportion of outside directors or independent directors on the board was not associated with the incidence of corporate fraud. Ibid.

${ }^{1309}$ Hatice Uzun, Samuel Szewczyk \& Raj Varma, "Board Composition and Corporate Fraud" (2004) May/June Financial Analysts Journal 33 [Uzun, Szewczyk \& Varma]. The authors examined how various characteristics of directors and other governance features affected corporate fraud by surveying a sample of 133 pairs of firms with and without fraud matched by industry and size during the period 1978 through 2001. Ibid at 33-34.

${ }^{1310}$ In this study, outside directors are further separated into independent directors and gray directors. Outside directors who have no affiliation with company other than being on the board are considered as independent. Outside directors who have some non-board affiliation with the company are considered as gray, such as lawyers, investment bankers, consultants, executives of advertising agencies, former employees and family members. Ibid at 34,36 .

${ }^{1311}$ Corporate fraud in this study includes fraud on shareholders, fraud on the government, financial reporting fraud and regulatory violations. Ibid at 33 .

${ }^{1312}$ Ibid at $39,41$.

${ }^{1313}$ Anup Agrawal \& Sahiba Chadha, "Corporate Governance and Accounting Scandals" (2005) 48 Journal of Law and Economics 371 [Agrawal \& Chadha]. They analyzed whether the incidence of earning restatements correlated with corporate governance mechanisms (as measured by board composition, audit committee composition, director's financial expertise, CEO duality, ownership structure, and outside auditors). They surveyed a sample of 159 firms that restated earnings and an industry-size matched sample of control firms from 2000 to 2001 . Ibid at $379-80$.

${ }^{1314}$ The authors do not define earnings restatement.

${ }^{1315}$ Ibid at 373 .

${ }^{1316}$ Board composition is measured by the proportion of independent directors on the board. Ibid at 390 .

${ }^{1317}$ Audit committee composition is measured by the proportion of independent directors on the audit committee. Ibid. 
earning restatements. ${ }^{1318}$ However, the authors found that when a firm had an independent director $^{1319}$ with financial expertise ${ }^{1320}$ on its board or audit committee, the incidence of earning restatements was significantly lower. Statistically speaking, a firm whose board had a member with financial expertise was $31 \%$ less likely to restate earnings than other firms, while a firm that had an audit committee member with financial expertise was $23 \%$ less likely to restate earnings than other firms. ${ }^{1321}$ Their findings suggest that it is independent directors who have financial expertise on the boards or the audit committees that result in a reduction in the incidence of earning restatements, rather than board independence or audit committee independence on its own.

\section{Analysis}

According to the above empirical findings, the impact of independent directors on financial fraud is inconsistent. Beasley (1996), Beasley et al. (2000) and Uzen, Szewczyk and Varma (2004) reported that a higher proportion of independent directors on the board was associated with a lower likelihood of financial statement fraud or corporate fraud, while Dechow, Sloan and Sweeney (1996) found a similar result for boards dominated by outside directors. However, the failure of Dechow, Sloan and Sweeney (1996) to look only at the effect of independent directors may not undermine the relevance of the study, because Beasley (1996) and Uzen, Szewczyk and Varma (2004) reported that outside and independent directors were both effective in controlling financial fraud. By contrast, Abbott, Park and Parker (2000) and Agrawal and Chadha (2005) found that the percentage of independent directors on the board had no impact on the likelihood of SEC sanctions for fraud or earnings restatements. Taking the accumulated evidence as a whole, firms with a higher proportion of independent directors on the board would not increase, and might reduce, the likelihood of financial fraud. Independent

\footnotetext{
${ }^{1318}$ Ibid at 389-92, 395.

${ }^{1319}$ The authors divided directors into three groups: inside, gray and independent directors. Inside directors are employees of the firm. Gray directors are ex-employees, family members of the CEO, or outsiders who have a business tie with the firm, such as consultants, lawyers, bankers, accountants, customers, suppliers, and other service providers. The remaining directors are classified as independent. Ibid at 386.

${ }^{1320}$ Director's financial expertise is measured by whether a board or an audit committee includes an independent director with financial expertise. Ibid at 394. Directors are considered having financial expertise, if they currently have (or have previously had) work experience as a CPA, CFA or in corporate financial management (for example, as a chief financial officer, treasurer, controller, or vice presidents of finance). This definition is similar in spirit to what the SEC initially adopted. Ibid at 386.

${ }^{1321}$ Ibid at 394-95.
} 
directors may be able to deter management from committing financial fraud in some circumstances.

Interestingly, Beasley (1996) and Uzen, Szewczyk and Varma (2004) reported that the effectiveness of directors in controlling financial fraud was not sensitive to the degree of director independence. It appears that gray directors who have certain business or personal ties with the firm or management were able to deter financial fraud as well as independent directors.

It is worth noting that the findings that the more (fewer) independent directors the less (more) financial fraud did not demonstrate causation. It is possible that a firm that inclines to engage in financial fraud chooses to have a less independent board. This is why Professors Bhagat and Black suggest that executives who are prone to commit fraud may resist oversight by independent boards. It may be the executives' propensity for fraud that drives both the likelihood of fraud and the degree of board independence. ${ }^{1322}$ Although the above findings may have different interpretations due to the direction of causation, either interpretation suggests that independent directors are more likely to detect fraud and take action against it.

\subsubsection{Board Independence and Shareholder Suits}

Laws and regulations, mainly in the regime of securities laws and state corporate laws, impose increasing responsibilities on corporate officers and directors to protect shareholder interests. ${ }^{1323}$ When officers and directors fail to fulfill their duties, shareholders may file a lawsuit by themselves or on behalf of the company to recover their loss. Since independent directors and shareholder litigation are both part of the corporate governance mechanism to hold management accountable, the frequency of shareholder suits should be lower when independent directors are effective in carrying out their monitoring duties. In other words, corporations with proportionally more independent directors should theoretically experience less shareholder litigation than those with fewer independent directors. As a result, the relationship between the proportion of independent directors on the board and the likelihood of shareholder litigation may

\footnotetext{
1322 Bhagat \& Black 1999, supra note 25 at 933.

${ }^{1323}$ Roberta Romano, “The Shareholder Suit: Litigation with Foundation?” (1991) 7 The Journal of Law, Economics \& Organization 55 at 55-56 [Romano, Shareholder Suit]; Jones, supra note 15 at 118; VanDuzer, supra note 15 at $522-23$.
} 
be a good indicator of the efficacy of independent directors. Four empirical studies have addressed this issue.

Jones $(1986)^{1324}$ reported that the percentage of outside directors (not defined) ${ }^{1325}$ on the board was negatively correlated to the incidence of shareholder suits ${ }^{1326} \cdot{ }^{1327}$ However, after boards were divided into three categories: inside (40\% or less outside directors), balanced (40\% to $60 \%$ ) and outside (60\% or more), an inverted U-shaped relationship was found between the fraction of outside directors and the incidence of shareholder suits. Inside boards were less likely to experience shareholder suits than balanced boards, but both were far more likely than outside boards to experience these suits. This implies that the reduced likelihood of shareholder suits may be associated with a threshold proportion of outside directors on the board-around $60 \%{ }^{1328}$

Four years later, Kesner and Johnson (1990) ${ }^{1329}$ observed that boards that were sued by their shareholders tended to have a greater (lower) proportion of inside (outside) directors ${ }^{1330}$ than those firms that were not sued. ${ }^{1331}$ However, there was no evidence to suggest that the outcome of these suits was correlated to board composition. In other words, boards receiving favorable outcomes of shareholder suits did not inevitably have a larger proportion of outside directors than those receiving unfavorable outcomes. The findings of Kesner and Johnson (1990) suggest that firms with a higher percentage of insiders represented shareholder interests as well as those with a higher percentage of outsiders for this purpose. ${ }^{1332}$

One-and-a-half decades later, Helland and Sykuta $(2005)^{1333}$ found that firms with a higher proportion of inside directors or gray directors ${ }^{1334}$ on the board were more likely to be the

\footnotetext{
1324 Thomas M Jones, "Corporate Board Structure and Performance: Variations in the Incidence of Shareholder Suits" (1986) 8 Research in Corporate Social Performance and Policy 345. The author examined 78 shareholder suits against the boards of Fortune 500 industrial and service firms for the years 1970 through 1977, with a view to realizing the relationship between board structure and the incidence of shareholder litigation. Ibid at 349 .

1325 This study did not specifically define outside directors.

1326 The author did not give shareholder suits a precise definition.

1327 Jones, shareholder suits, supra note at 351.

${ }^{1328}$ Ibid at $353,356$.

${ }^{1329}$ Idalene F Kesner \& Roy B Johnson, “An Investigation of the Relationship Between Board Composition and Stockholder Suits" (1990) 11 Strategic Management Journal 327 [Kesner \& Johnson]. The authors investigated 56 Delaware cases between 1975 and 1986 in which directors were sued by shareholders for failure to fulfill their fiduciary responsibilities and examined a control group of 56 firms incorporated in Delaware that had not been sued by its shareholders. Ibid at 330-31.

${ }^{1330}$ In this study, inside directors are defined as directors who are also employees of the firm. Outside directors mean directors who are not employees of the company. Ibid at 328.

1331 Ibid at 332.

1332 Ibid at 333-34.

${ }^{1333}$ Eric Helland \& Michael Sykuta, "Who's Monitoring the Monitor? Do Outside Directors Protect Shareholders' Interests?" (2005) 40 The Financial Review 155 [Helland \& Sykuta]. The authors examined 692 cases classified as
} 
target of shareholder litigation ${ }^{1335}$, compared to firms in the control group. ${ }^{1336}$ However, firms being sued had a lower percentage of independent directors on the board. ${ }^{1337}$ In addition, the negative impact of inside directors was even larger as lawsuits went further in the litigation process ${ }^{1338}$ and reached its apex when the plaintiff won. ${ }^{1339}$ The results suggest that boards with a higher insider concentration were less effective in monitoring management and had a higher incidence of losing at trial. ${ }^{1340}$ In addition, a similar result held for gray directors except for cases won by the plaintiff, suggesting that the probability of receiving unfavorable results was unrelated to the proportion of gray directors on the board. ${ }^{1341}$

Contrary to studies previously discussed, Romano (1991) ${ }^{1342}$ observed that board composition was not related to the likelihood of shareholder suits. ${ }^{1343}$ She found that sued companies did not have a significantly lower percentage of outside directors (not defined), ${ }^{1344}$ compared to companies that were not sued. ${ }^{1345}$ Even after being sued, companies did not significantly add outside directors to their boards in response to the litigation, in comparison to their match companies ${ }^{1346}{ }^{1347}$

\section{Analysis}

securities fraud or shareholder litigation and 692 control observations between 1988 and 2000 in the Federal Judicial Center's Federal Court Cases. Ibid at 162.

${ }^{1334}$ In this study, inside directors refer to directors who are employed by the firm. Independent directors are defined as directors who have no additional financial relationships with the firm beyond the directorship. As for grey directors, they are directors who are not employed by the firm but with an ongoing financial relationship with the firm. Ibid at 163. The term "independent directors" here is identical to the term "outside directors" used by the original authors in their study.

${ }^{1335}$ The authors did not give shareholder litigation a precise definition. Ibid at 162.

${ }^{1336}$ Ibid at 164, 168.

${ }^{1337}$ Ibid at 164,166 Table 2.

${ }^{1338}$ The authors examined the correlation between the percentage of three types of directors (inside, gray and independent directors) on the board and the disposition of shareholder suits (as measured by dismissed, settled, tried or won by plaintiff). Ibid at 166-67 Table 2 .

${ }^{1339}$ Ibid at 168 .

${ }^{1340}$ Ibid at 171 .

${ }^{1341}$ Ibid at 168 . It means that the proportion of gray directors was only significantly and negatively related to a higher incidence of shareholder litigation when the cases were dismissed, settled, or tried. The relationship became insignificant when the cases were won by shareholders.

${ }^{1342}$ The author investigated 139 shareholder suits brought between 1966 and 1987 against 535 corporations traded publicly on the NYSE and NASDAQ. Romano, Shareholder Suit, supra note 1323 at 58-59.

${ }^{1343}$ Ibid at 80,83

${ }^{1344}$ Outside directors are not particularly defined in this study.

${ }^{1345} \mathrm{Ibid}$ at 83.

${ }^{1346}$ In order to control for changes that would occur regardless of litigation, Professor Romano constructed a paired sample that matched sued companies by industry type with companies that had not been sued. Ibid at 71 .

${ }^{1347}$ Ibid at 76. 
The above empirical findings do not provide consistent results regarding the impact of board independence, regardless of whether outside or independent directors were examined, on shareholder suits. Jones (1986) and Kesner and Johnson (1990) found that boards with a higher percentage of outside directors were less likely to be the target of shareholder litigation, while Helland and Sykuta (2005) observed similar results for independent directors. Such findings show that the failure of Kesner and Johnson (1990) to look only at the effect of independent directors may not undermine the relevance of the study, because their findings were the same as Helland and Sykuta (2005) that focused on independent directors (i.e. both showing that a firm with a more independent board were less likely to be the target of shareholder litigation). However, Romano (1991) reported that the fraction of outside directors (not defined) on the board had no impact on the likelihood of shareholder suits. Taking the accumulated evidence as a whole, most studies seem to support the view that a firm with a more independent board had a lower likelihood of being the target of shareholder litigation. The results appear to be consistent with the public's expectation that directors who are more independent are more effective in curbing shareholder litigation.

However, Professor Romano provided an alternative explanation for these findings. She attributed this phenomenon to the courts' inclination to defer to the judgment of boards dominated by independent directors. ${ }^{1348}$ A series of cases have demonstrated that courts scrutinized decisions made by insider-dominated boards more closely since the 1980s. When shareholder-plaintiffs perceived that courts were more likely to adjudicate in favor of officers and directors of firms with a majority of independent directors, shareholders of such firms were less willing to bring about such lawsuits. ${ }^{1349}$ This is to say, boards dominated by independent directors may be sued less not because they monitor management more effectively, but merely because independent directors were perceived by courts as more effective (whether they are in fact or not). And knowing this, shareholders bring fewer suits.

In addition, after considering the outcome of the shareholder lawsuits, the results seem to be contradictory. Helland and Sykuta (2005) reported that boards with a higher insider concentration were more likely to lose at trial, while Kesner and Johnson (1990) found that the fraction of inside directors on the board had no impact on the results of lawsuits. There appears

\footnotetext{
${ }^{1348}$ Romano, Insurance Crisis, supra note 544 at 1177; please refer to section 4.1.1.1 Conflict-of-Interest Transactions, 4.1.1.2 Derivative Suits, and 4.1.1.3 Defensive Measures against Hostile Takeovers for further details. ${ }^{1349}$ Ibid at 81; Romano, Insurance Crisis, supra note 544 at 1177 ; Lin, supra note 13 at 938.
} 
to be no consensus about the connection between insider concentration and unfavorable outcomes of shareholder suits.

In sum, a firm with a more independent board seems to have a lower incidence of being sued by their shareholders, but there is no consensus regarding whether a firm with a higher level of board independence had a higher probability of winning the case at trial. It is worth noting that, following Professor Romano's explanation, the lower likelihood of being sued may be due to the perceived effectiveness of independent directors, rather than their real monitoring effect.

\subsubsection{Summary of the Relationship between Board Independence and Discrete Board Tasks}

This section of investigates whether independent directors fulfill their monitoring responsibilities in relation to discrete board tasks. The effectiveness of independent directors seems to vary with the type of board task. With respect to initiating and responding to takeover bids, empirical evidence shows that bidding firms with up to $60 \%$ independent directors earned higher stock returns for shareholders, while target firms with a majority of independent directors were not clearly associated with an increase in shareholder wealth. Target boards with higher percentages of independent directors were more likely to resist greenmail and adopt golden parachutes, and may enhance shareholder wealth when adopting poison pills. Regarding the other (five) board tasks, the results may be summarized as follows: at least a majority of studies show that firms with a higher proportion of independent directors on the board were associated with: (1) a higher sensitivity of CEO turnover to firm performance, (2) larger returns for shareholders during management buyouts, (3) a lower likelihood of financial fraud, and (4) a lower incidence of shareholder suits, respectively. The most discouraging result in terms of the value of director independence was that higher percentages of independent directors on the board had no impact on the level of CEO compensation, and, sometimes might even be related to higher levels of CEO pay. Except for the findings regarding the task of controlling CEO pay, all results are based on the observation of pre-SOX samples. Taken together, boards with a greater fraction of independent directors, in most cases, are more likely to protect shareholder interests in relation to discrete board tasks; however, their effectiveness is not as good as conventional wisdom expected. 


\subsubsection{The Effectiveness of Independent Directors on Specific Board Committees}

The previous sections have discussed the correlation between board independence and overall firm performance, as well as discrete board tasks. Since the review of auditing, executive compensation and director nomination, all tasks involving special expertise or conflicts of interest for management, may be inappropriate for the entire board to handle, most large companies have gradually delegated these missions to board committees since the 1980s. As early as 1999, the NYSE and NASDAQ required that audit committees of listed companies consist solely of independent directors, at least one of whom has financial expertise. Corporate scandals in the early 2000s led to further reforms by the NYSE and NASDAQ that require compensation committees and nominating committees to be composed entirely of independent directors. The assumption behind these requirements is that the presence of independent directors is necessary to ensure the success of these three monitoring committees. This section examines studies that use different indicators to explore the effectiveness of independent directors in these three committees.

\subsubsection{The Audit Committee}

The primary role of the audit committee is to oversee the financial reporting process with the ultimate goal of ensuring the quality of financial statements and financial reporting. ${ }^{1350}$ With a view to fulfilling this objective, conventional wisdom considers that the audit committee should independently appoint, or nominate, external auditors to review the accuracy of financial statements, and that the members of audit committees should be financially literate, meet diligently and be fully independent of management's influence to supervise the process of financial reporting. As early as 1939, the establishment of a standing committee composed of outside directors responsible for such missions had been proposed by the SEC. More than $90 \%$ of the public companies had established and maintained an audit committee by the 1990s and at least two independent directors have been required to sit on the committee by the NYSE since the end of the 1970s. In 2002, the Sarbanes-Oxley Act further required that each public

${ }^{1350}$ Mark L DeFond \& Jere R Francis, “Audit Research after Sarbanes-Oxley” (2005) 24: Supplement Auditing 5 at 17. 
corporation maintain an audit committee composed solely of independent directors and disclose whether at least one of its members qualifies as a financial expert under the SEC's definition.

Although the important role of the audit committee has been emphasized for a long time, accounting scandals and inappropriate earnings management ${ }^{1351}$ still happened from time to time, despite the existence of an audit committee. Financial economists have investigated the effectiveness of audit committees since the 1990s. The existing empirical evidence regarding the effectiveness of audit committees can be roughly classified into two categories: (1) studies that look at the relationship between firm performance and audit committee characteristics, as well the presence of an audit committee; (2) studies that look at the relationship between the quality of financial reporting and the audit committee characteristics, as well as the presence of an audit committee. In the first category, scholars have adopted ROA, ROE, and Tobin's Q as firm performance indicators to examine whether audit committee characteristics (independence, and financial expertise) and its existence are associated with better firm performance. In the second category, financial economists used the incidence of irregularities, internal control problems, analysts' ranking of financial reporting, financial restatements, auditor resignation, corporate fraud, the issuance of going-concern reports, the level of audit fees, and occurrence of earnings management as indices to measure the quality of financial reporting, and tried to identify which audit committee characteristics (existence, independence, financial expertise, size, and meeting frequency) were correlated with greater quality of financial reporting.

Since not all audit committee characteristics are related to independent directors, this thesis only focuses on two audit committee characteristics-independence and financial expertise-and the presence of an audit committee that may affect the monitoring effect of independent directors. The purpose of this part of the thesis is to identify four types of relationship: (1) the relationship between the presence of an audit committee and firm performance, (2) the relationship between the presence of an audit committee and the quality of

\footnotetext{
${ }^{1351}$ Earnings management is a strategy used by the corporate management to adjust the company's earnings. Under Generally Accepted Accounting Principles, a firm is allowed to adjust its earning by using accrual accounting to provide a more accurate picture of its current financial condition because sometime revenues or expenses of transactions are recognized (earned or incurred), but the actual cash has not been received or paid out. The nature of accrual accounting gives managers a great deal of discretion in determining the actual earnings that a firm reports in any given period. Management, to some extent, can control the timing of recognition of revenues and expenses by advancing recognition of sales revenue through credit sales, or delaying recognition of losses by waiting to establish loss reserves. Biao Xie, Wallace N Davidson III \& Peter J DaDalt, "Earnings Management and Corporate Governance: The Role of the Board and the Audit Committee" (2003) 9 Journal of Corporate Finance 295 at 296 [Xie, Davidson \& DaDalt].
} 
financial reporting, (3) the relationship between the two audit committee characteristics and firm performance, and (4) the relationship between the two audit committee characteristics and the quality of financial reporting. The reason for discussing the presence of the audit committee is to identify whether specific audit committee characteristics really influence the efficacy of the audit committee or just the presence of an audit committee ${ }^{1352}$ is sufficient to enhance the quality of financial reporting and firm performance. The ground for investigating the connection between the type of financial expertise and audit committee efficacy is to identify which type of independent directors in the audit committee are more likely to detect management's misconduct in the financial reporting process, because at least one independent director on the audit committee is required to have financial expertise in the post-SOX period. In fact, other audit committee characteristics (such as the number of audit committee members and their meeting frequency), which are not directly related to independent directors, have been found to have no significant impact on the quality of financial reporting as shown by empirical evidence. ${ }^{1353}$ They

${ }^{1352}$ The presence of an audit committee is a vague perception of possible better auditing review. It only means that a firm has a committee responsible for the quality of financial reporting, but the level of independence of the committee and whether the committee has a financial expert is unknown.

${ }^{1353}$ Empirical evidence regarding the impact of audit committee size on financial reporting quality can be divided into two categories: the first category investigated whether an audit committee with a minimum of three members was correlated with the quality of financial reporting; the second category explored whether greater number of audit committee members was associated with higher financial reporting quality.

With respect to the first category, the results of three related studies were consistent. Abbott, Parker and Peters (2004), Bédard, Chtourou and Courteau (2004) and Krishnan (2005) all reported that audit committees with a minimum of three members were not associated with the incidence of financial restatement, the level of earnings management and the likelihood of internal control problems, respectively (all signifying a poorer quality of financial reporting). Lawrence J Abbott, Susan Parker \& Gary F Peters, "Audit Committee Characteristics and Restatements" (2004) 23:1 Auditing: A Journal of Practice \& Theory 69 at 80 [Abbott, Parker \& Peters]; Bédard, Chtourou \& Courteau, supra note 510 at 14-15, 30; Jayanthi Krishnan, "Audit Committee Quality and Internal Control: An Empirical Analysis" (2005) 80:2 The Accounting Review 649 at 671 [Krishnan].

Regarding the second category, the results seem to be inconsistent. Felo, Krishnamurthy and Solieri (2003), Xie, Davidson and DaDalt (2003) and Vafeas (2005) found that the number of audit committee members had no impact on the analysts' ranking of financial reporting, the level of earnings management, and the incidence of reporting a small earnings increase or avoiding a negative earnings surprise, respectively, while Yang and Krishnan (2005) observed that greater number of audit committee members was associated with a lower level of quarterly earnings management (signifying a higher quality of financial reporting). In total, it appears that the number of audit committee members, in most cases, had no impact on the quality of financial reporting. Taken the effect of the two categories together, it appears that the number of audit committee members had no significant impact on the quality of financial reporting. Enlarging or diminishing the size of an audit committee may not influence the effectiveness of an audit committee. Andrew J Felo, Srinivasan Krishnamurthy \& Steven A Solieri, "Audit Committee Characteristics and the Perceived Quality of Financial Reporting: An Empirical Analysis" (April 2003) at 23-24, online: SSRN < http://ssrn.com/abstract=401240 or doi:10.2139/ssrn.401240> [Felo, Krishnamurthy \& Solieri]; Xie, Davidson \& DaDalt, supra note 1351 at 310; Nikos Vafeas, "Audit Committees, Boards and the Quality of Reported Earnings" (2005) 22:4 Contemporary Accounting Research 1093 at 1110 Table 4 [Vafeas 2005]; Joon S Yang \& Jagan Krishnan, "Audit Committee and Quarterly Earnings Management" (2005) 9 International Journal of Auditing 201 at 210-11 [Yang \& Krishnan]. 
are not the concern of this thesis. The following analysis starts with the connection between the two audit committee characteristics and firm performance.

\subsection{The Relationship between Two Audit Committee Characteristics, the Presence of An Audit Committee and Firm Performance}

The most straightforward approach for measuring audit committee effectiveness is whether shareholder wealth or firm value is significantly enhanced. If a certain characteristic of an audit committee can be identified as related to better firm performance, then this characteristic would be considered as an enhancement of audit committee effectiveness. Existing empirical studies have explored the relationship between firm performance and the presence of the audit committee, audit committee independence, as well as its financial experts. The conclusions drawn from these studies regarding the impact of the two audit committee characteristics and the existence of the audit committee were that their impact on firm performance was neutral.

In addition, empirical evidence regarding the correlation between audit committee diligence and financial reporting quality can be classified into two types: the first type examined whether the number of audit committee meetings was correlated with the quality of financial reporting; the second type explored whether audit committee members that meet a certain number of times per year were associated with higher financial reporting quality.

Regarding the first type, the results seem to be inconsistent. Two studies found that more audit committee meetings were associated with indices representing higher financial reporting quality, while three studies reported that the number of audit committee meetings had no connection with indices symbolizing financial reporting quality. More specifically, Xie, Davidson and DaDalt (2003) found that the firms with more audit committee meetings were likely to have less earnings management, while Vafeas (2005) observed that audit committees having more meetings were less likely to report a small earnings increase. In contrast, Felo, Krishnamurthy and Solieri (2003) found that the number of audit committee meetings was not related to the analysts' ranking of financial reporting, while Krishnan (2005) and Yang and Krishnan (2005) observed that the number of audit committee meetings had no impact on the incidence of internal control problems and the level of quarterly earnings management, respectively. Collectively, it seems that audit committee members meeting more frequently would not reduce, and sometimes might enhance, the quality of financial reporting. Xie, Davidson \& DaDalt, ibid at 296, 310, 314; Vafeas 2005, ibid at 1109, 1118; Felo, Krishnamurthy \& Solieri, ibid at 24-25. Krishnan, ibid at 668-71; Yang \& Krishnan, ibid note at 211-12, 215.

With respect to the second type, the results seem to be divergent. Abbott, Parker and Peters (2004) reported that audit committees with four or more meetings annually were correlated with a lower incidence of financial restatement (signifying a higher quality of financial reporting), while Lee, Mande and Ortman (2004) and Bédard, Chtourou and Courteau (2004) found that audit committees with at least three or four meetings per year were unrelated to auditor resignation or earnings management, respectively (implying a lower quality of financial reporting). It appears that audit committees with at least three or four meetings per year, in most cases, may not substantially improve monitoring quality. Combining the effect of both types, audit committees members meeting more frequently were at least harmless and sometimes might enhance the quality of financial reporting. The effectiveness of audit committees appears not to be closely related to their diligence by this measure. Abbott, Parker \& Peters, ibid at 80, 81 Table 2; Ho Young Lee, Vivek Mande \& Richard Ortman, "The Effect of Audit Committee and Board of Director Independence on Auditor Resignation" (2004) 23:2 Auditing: A Journal of Practice \& Theory 131 at 141 [Lee, Mande \& Ortman]; Bédard, Chtourou \& Courteau, ibid at 14-15, 30. 
With respect to the existence of an audit committee, Klein (1998) reported that the presence of an audit committee had no impact on current firm performance (as measured by ROA, Jensen Productivity ${ }^{1354}$, and market return). ${ }^{1355}$ Perhaps, firm performance depends on audit committee characteristics, instead of merely audit committee existence.

Regarding the correlation between audit committee independence and firm performance, four studies found that audit committees with a higher proportion of, or even $100 \%$ of, independent directors had no impact on firm performance, while one study observed that higher firm performance was associated with audit committees composed of a majority of independent directors. More specifically, Klein (1998) reported that current firm performance was not related to the percentage of independent directors on the audit committee, ${ }^{1356}$ while Brick and Chidambaran (2007) ${ }^{1357}$ observed that a fully independent audit committee had no significant connection with firm value (Tobin's Q). ${ }^{1358}$ Brown and Caylor $(2006,2009)$ found that an audit committee consisting entirely of independent directors was not associated with current or subsequent firm performance and firm value (measured by ROA, ROE and Tobin's Q). ${ }^{1359}$ Only Chan and $\mathrm{Li}(2008)^{1360}$ reported that audit committees with $50 \%$ or more independent directors ${ }^{1361}$ were significantly correlated with higher current firm value (Tobin's Q). ${ }^{1362}$ It is

\footnotetext{
${ }^{1354}$ See supra note 1132.

1355 Klein 1998, supra note 501 at 293.

1356 Ibid.

${ }^{1357}$ Ivan E Brick and N K Chidambaran, Board Meetings, Committee Structure, and Firm Performance (November 2007), online: SSRN <http://ssrn.com/abstract=1108241 > [Brick \& Chidambaran]. The authors examined whether a fully independent audit committee, a fully independent compensation committee, and the adoption of a separate nominating committee affected firm value by using a sample of 4,298 firm-year observations from 1999 to 2005. Ibid at 11 .

${ }^{1358}$ Ibid at 32, 50 Table 8 .

${ }^{1359}$ Brown and Caylor examined the correlation between 51 corporate governance provisions and contemporaneous, as well as subsequent firm performance in their 2006 and 2009 studies by using a similar sample composed of 2,363 firms (only 1,868 firms in their 2006 study) from Institutional Shareholder Services database in 2003. Brown \& Caylor 2009, supra note 1032 at 132-33, 141; Brown \& Caylor 2006, supra note 1027 at 414-15, 418-22, 419 Table 3, 421 Table 4, 422 Table 5.

${ }^{1360}$ Kam C Chan \& Joanne Li, “Audit Committee and Firm Value: Evidence on Outside Top Executives as ExpertIndependent Directors" (2008) 16:1 Corporate Governance 16 [Chan \& Li]. The authors examined the correlation between audit committee independence and firm performance (Tobin's Q) by using a sample of Fortune 200 companies in the year 2000. Ibid at 17, 18 .

${ }^{1361}$ In this study, the authors narrowed the definition of independence by excluding blockholder directors, decorating directors (like actors, athletes and educators), gray directors and venture capitalist directors from the scope of independent directors. Ibid at 18. Only directors who are the CEO, ex-CEOs, top executives and former executives of a firm independent of the sample firm are considered independent. Ibid at 22. The reasons for making such a distinction are that: (1) blockholders and venture capitalists have different incentives to monitor; (2) the independence of the decorating and gray directors is questionable; (3) top executives are perceived to be directors with higher quality among other categories. Ibid at 18 .
} 
worth noting that the results of Chan and $\mathrm{Li}$ (2008) are based on a small number of observations, compared to those of Brown and Caylor (2006, 2009) and Brick and Chidambaran (2007). The former only examined 200 firms in the year 2000, ${ }^{1363}$ while the latter investigated roughly 2,000 firms in the year 2003 and 4,298 firm-year observations from 1999 to 2005, respectively. ${ }^{1364}$ The inconsistency may come from the difference of their samples. ${ }^{1365}$ Taken together, it appears that the impact of audit committee independence on firm performance or firm value was weak at best. Increasing the independence of audit committees might not enhance firm performance (or firm value).

As for the effect of audit committee financial expertise ${ }^{1366}$ on firm value, Chan and $\mathrm{Li}$ (2008) reported that there was a correlation with better firm performance only where financial experts served on the audit committee composed of a majority of independent directors. ${ }^{1367}$ Directors with financial expertise alone had no significant impact on firm value. ${ }^{1368}$ Amazingly, the profits for firms associated with having a director with financial expertise on an independent audit committee were almost five times greater than the profits for firms associated with just having an independent audit committee. ${ }^{1369}$ In short, an independent audit committee in combination with one of its members with financial expertise was found to make a positive difference, while either alone did not. Again, the results were drawn from a small number of observations and a specific year. Further research is needed to confirm these findings.

Professor Klein provided an explanation for the insignificant relationship between audit committee independence and firm performance. She thought that variations in the level of audit committee independence are limited due to stock exchanges' requirements (because, for example,

\footnotetext{
${ }^{1362}$ Ibid at 22. It is worth mentioning that the positive relationship between audit committee independence and firm value may have an alternate interpretation if the causality has not been further examined. It is possible that firms performing well add more independent directors to their audit committees, rather than that the more independent audit committees help firms to perform better. One should be very cautious when applying Chan and Li (2008)'s study, because they did not control the problem of causation.

1363 Please refer to supra note 1360.

${ }^{1364}$ Please refer to supra note 1357 and 1359.

${ }^{1365}$ In addition, Chan and Li (2008) used an FIML system equation to control the problem of endogeneity. Chan \& Li, supra note 1360 at 19.

${ }^{1366}$ The authors used the term "finance-trained" to describe directors who possess professional skills in the field of finance, which is roughly equivalent to the term "financial expert" defined by the SEC in its current version. A finance-trained director must meet one or more of the following criteria: (1) a business school professor; (2) a Certified Public Accountant; (3) a director or CEO of a firm in the finance industry; (4) a chief financial officer; (5) an accounting firm partner; (6) an investment firm partner; and (7) a former secretary of Treasury. Ibid at 19.

1367 Ibid at 26, 29.

1368 Ibid at 24, 29.

${ }^{1369}$ Ibid at 26, 29.
} 
the NYSE has required that each listed company have an audit committee composed exclusively of outside directors since 1978) ${ }^{1370}$. As a consequence, the impact of audit committee independence on firm performance is insignificant (because it is difficult to detect). ${ }^{1371}$ From my point of view, a firm's profits are mainly contributed by management's business vision, marketing strategies, and the firm's ability to do research and development. Only a small portion comes from the audit committee's oversight. This may explain the insignificant relationship between firm performance and audit committee independence.

\subsection{The Relationship between Two Audit Committee Characteristics, the Presence of An Audit Committee and the Quality of Financial Reporting}

Since the effectiveness of an audit committee may not be easily demonstrated through firm performance, most financial economists adopt the quality of financial reporting-the mission of the audit committee-to measure the efficacy of an audit committee. So far, researchers have used the incidence of irregularities, internal control problems, analysts' ranking of financial reporting, financial restatements, auditor resignation, corporate fraud, issuance of going-concern reports, the level of audit fees, and the occurrence of earnings management as indices of financial reporting quality to examine the correlation between the quality of financial reporting and audit committee characteristics, as well as the existence of an audit committee. As I noted earlier, only some audit committee characteristics are related to independent directors, ${ }^{1372}$ so this part of the thesis only explores the connection between the indices of financial reporting quality and two audit committee characteristics (independence, and financial expertise) that are associated with the efficacy of independent directors.

\footnotetext{
${ }^{1370}$ Please refer to supra notes 104-109 and accompanying text.

${ }^{1371}$ Klein 1998, supra note 501 at 293. In addition, she considered that the correlation between firm performance and effective oversight may not be captured contemporaneously. The committee itself or its composition may matter, but its consequence may not be seen until a later period. However, the findings of Brown and Caylor (2006 \& 2009) do not support this explanation.

${ }^{1372}$ Many empirical studies also examine whether another two audit committee characteristics- the number of audit committee members and their meeting frequency - have an impact on the quality of financial reporting. Because these two characteristics are not directly related to independent directors and no consistent connection between these two characteristics and the quality of financial reporting has been reported, this thesis discuss the impact of these two characteristics in the footnote. Please refer to supra note 1353 for further details.
} 


\subsection{The Impact of the Presence of an Audit Committee on the Quality of Financial Reporting}

The primary function of the audit committee is to oversee the financial reporting process with the ultimate goal of ensuring the quality of financial statements. If such a function is fulfilled, firms with an audit committee should be observed to have a higher quality of financial reporting. Six studies between 1996 and 2005 investigated the relationship between the presence of an audit committee and the quality of financial reporting. Their results, however, are inconsistent. Four studies reported that the presence of an audit committee was correlated with a higher quality of financial reporting, while two studies found no connection between the existence of an audit committee and the indices of financial reporting quality. More specifically, McMullen (1996) ${ }^{1373}$ found that the presence of an audit committee was associated with fewer incidence of errors and irregularities (as observed by fewer shareholder lawsuits alleging fraud, fewer quarterly earning restatements, fewer SEC enforcement actions, fewer illegal acts and fewer instances of auditor turnover involving an auditor-client accounting disagreement), ${ }^{1374}$ while Uzen, Szewczyk and Varma (2004) reported that the existence of an audit committee was related to a lower likelihood of corporate fraud. ${ }^{1375}$ Moreover, Dechow, Sloan and Sweeney (1996) observed that firms inclined to manipulate earnings were less likely to have audit committees, ${ }^{1376}$ while Beasley et al. (2000) found that firms with fraudulent financial reporting also had a similar tendency. ${ }^{1377}$ It seems that the quality of financial reporting was linked to the presence of an audit committee in these studies.

In contrast, Beasley (1996) reported that the presence of an audit committee did not significantly reduce the incidence of financial statement fraud, ${ }^{1378}$ while Abbott, Park and Parker (2000) observed that there was no significant relationship between the existence of an audit committee and the likelihood of corporate fraud (as measured by SEC sanctions). ${ }^{1379}$ It appears that the presence of an audit committee had no impact on the quality of financial reporting in

\footnotetext{
${ }^{1373}$ Dorothy Ann McMullen, “Audit Committee Performance: An Investigation of the Consequences Associated with Audit Committees" (1996) 15:1 Auditing: A Journal of Practice \& Theory 87 [McMullen].

${ }^{1374}$ Ibid at 100, 101.

${ }^{1375}$ Uzun, Szewczyk \& Varma, supra note 1309 at 39-41. Corporate frauds in this study include fraud on shareholders, fraud on the government, financial reporting fraud and regulatory violations. Ibid at 33.

${ }^{1376}$ Dechow, Sloan \& Sweeney, supra note 1292 at 21.

${ }^{1377}$ Beasley et al, supra note 1302 at 450.

1378 Beasley, supra note 1295 at $458-59$.

1379 Abbott, Park \& Parker, supra note 1305 at 60.
} 
these two studies. Combined with the results in the last paragraph, firms with an audit committee may not necessarily have a higher quality of financial reporting.

It is worth noting that the effectiveness of an audit committee may not solely rely on its existence, but possibly depends on other committee characteristics, such as the level of committee independence and whether its members have financial expertise. As a result, the studies described above cannot provide a clear picture of the effectiveness of the audit committee. Thus, financial economists have not used the correlation between the presence of an audit committee and the quality of financial reporting to examine the effectiveness of the audit committee since 2004.

\subsection{The Impact of the Audit Committee Independence on the Quality of Financial Reporting}

Conventional wisdom holds that members of an audit committee should be independent of management and their firms, in order to impartially monitor the financial reporting process. However, there is an issue regarding how much independence is enough to ensure the quality of financial reporting. The Blue Ribbon Committee in 1998 contended that only a completely independent audit committee is able to hold management accountable, while some scholars argued that a high level of audit committee independence (for example, a majority of audit committee members being independent) is sufficient to lead to a greater quality of financial reporting. The latter groups of scholars consider that the related costs of complete independence might outweigh its potential benefits. Greater search costs, higher liability insurance premiums and the loss of board effectiveness through the replacement of affiliated directors with firmspecific knowledge are typical examples of such costs. ${ }^{1380}$ The results of empirical studies seemingly have provided answers for the controversy about the appropriate level of independence of the audit committee. Audit committees with $100 \%$ independence are more likely to be associated with a higher quality of financial reporting than those without $100 \%$ independence.

\footnotetext{
${ }^{1380}$ Scott N Bronson et al, “Are Fully Independent Audit Committees Really Necessary?” (2009) 28 Journal of Accounting and Public Policy 265 at 267 [Bronson et al].
} 
The existing empirical studies regarding the impact of audit committee independence on financial reporting quality can be classified into three categories by different independence measures: the first category investigated whether an audit committee with $100 \%$ independence was correlated with higher financial reporting quality; the second category examined the connection between the quality of financial reporting and the proportion of independent directors on the audit committee; the third category compared the effect of independence on the quality of financial reporting between audit committees with, and without, $100 \%$ independence (i.e. using multiple independence measures).

In the first category that concentrated on the effect of $100 \%$ independence of the audit committee, most studies show a positive relationship. Five studies found that the presence of a completely independent audit committee was significantly and positively related to indices representing a higher quality of financial reporting, while only one study reported no such connection. In addition, one study observed that firms with a poorer quality of financial reporting were less likely to have fully independent audit committees.

More specifically, Abbott, Park and Parker (2000) found that audit committees composed entirely of independent directors ${ }^{1381}$ were associated with a lower likelihood of SEC sanctions (signifying a higher quality of financial reporting), ${ }^{1382}$ while Lee, Mande and Ortman (2004) ${ }^{1383}$ reported that firms with completely independent ${ }^{1384}$ audit committees had a lower probability of auditor resignation $^{1385}$ (implying a higher quality of financial reporting). ${ }^{1386}$ Abbott, Parker and

\footnotetext{
${ }^{1381}$ Independent directors here are defined as directors without disclosed business ties (other than service on the board) with the firm or its management. Abbott, Park \& Parker, supra note 1305 at 59.

1382 Ibid at 60, 66 Table 2.

${ }^{1383}$ The authors used auditor resignation as an indicator of the quality of financial reporting system to examine its correlation with board and audit committee characteristics (including independence, meeting frequency, financial expertise, ownership and CEO duality) by surveying a sample of 190 auditor-initiated switches and a sample of 190 client-initiated switches during 1996 to 2000. Lee, Mande \& Ortman, supra note 1353 at 134-35.

${ }^{1384} \mathrm{An}$ audit committee member or a board member is considered to be independent if he or she is not an employee or a gray director. A gray director is a former officer or employee of the firm or of a related entity, an interlocking director, a relative of an executive, a person having a business relationship with the firm, or a large customer of or supplier to the company, unless the transaction occurred in the normal course of business. Ibid at 136.

${ }_{1385}$ Auditor resignation often occurs in the context of grave economic circumstances, such as high litigation risk, deteriorating financial health, disagreement with management, internal control weaknesses or financial reporting reliability concerns, and is usually accompanied by a significant and negative stock price reaction. Board members' reputational capital, especially those of audit committee members, usually suffers after the time of the resignation of the firm's auditor. In order to maintain their personal reputation and protect interests of the firm, boards of directors, especially audit committee members, have strong incentives to lower the possibility of auditor resignations. Ibid at 133.

${ }^{1386}$ Ibid at 141, 143.
} 
Peters (2004) ${ }^{1387}$ observed that the incidence of financial restatement ${ }^{1388}$ and the likelihood of corporate fraud ${ }^{1389}$ were both lower for audit committees composed of fully independent ${ }^{1390}$ directors. ${ }^{1391}$ Bédard, Chtourou and Courteau (2004) ${ }^{1392}$ found that earnings management ${ }^{1393}$ was less likely to occur (signifying a better quality of financial reporting) when firms had completely independent ${ }^{1394}$ audit committees. ${ }^{1395}$ Bronson et al. (2009) ${ }^{1396}$, using the issuance of a going-concern report ${ }^{1397}$ as an index of a better quality of financial reporting, reported that financially distressed companies with fully independent ${ }^{1398}$ audit committees were more likely to

${ }^{1387}$ The authors investigated the association between Blue Ribbon Committee (BRC) recommendations (audit committee independence, financial expertise and audit committee size) and the likelihood of financial restatements by surveying 88 restatements of annual reports in the period 1991-1999, together with a matched pairs control group. Abbott, Parker \& Peters, supra note 1353 at 75.

${ }^{1388}$ A financial restatement represents an explicit acknowledge that material omissions or misstatements occurred in prior financial statements. The presence of financial restatements engenders investors' concern and signifies a poorer quality of financial reporting. Ibid at 69 .

${ }^{1389}$ In this study, corporate fraud was measured by fraud alleged by the SEC Accounting and Auditing Enforcement. Ibid at 80 .

${ }^{1390}$ The BRC define independence as exclusion of current and former employees, relatives of management, and persons receiving compensation from the company (except directors' fees). Ibid at 72.

${ }^{1391}$ Ibid at 80,83 .

${ }^{1392}$ The authors examined the relationship between audit committee characteristics (financial expertise, independence, and activities) and the extent of earnings management (as measured by abnormal accruals) by surveying a sample of 300 US firms in 1996. Bédard, Chtourou \& Courteau, supra note 510 at 14.

${ }^{1393}$ With respect to the definition of earnings management, please refer to supra note 1351. Xie, Davidson and DaDalt (2003), supra note 1353 at 296. Since earnings management may impact investors by giving them false information regarding financial statements, the level of earnings management is often used as an indicator to measure the quality of financial reporting by financial economists. Abnormal accruals or discretionary accruals are prevailingly used as a proxy for the magnitude of earnings management in the field of financial economics and financial accountings.

${ }^{1394}$ Independent directors in this study include all directors who have no relation with the firm other than their position as directors. Bédard, Chtourou \& Courteau, supra note 510 at 23.

${ }^{1395}$ Ibid at $14,29$.

${ }^{1396}$ The authors examined whether the level of audit committee independence influenced the likelihood of a firm to receive a going-concern report by extending Carcello and Neal's 2000 and 2003 studies with the same methodology, observation period and sample firms. Bronson et al, supra note 1380 at 268-70.

${ }^{1397}$ External auditors are often considered as public watchdogs over corporate financial statements. When external auditors consider that a company may not remain in existence beyond the foreseeable future, they should issue a going-concern report to express their concerns. (A going-concern report issued by an auditor represents that the company is not expected to remain a going concern.) However, auditors may hesitate to issue a going-concern report, if management implicitly or explicitly suggests that the company will dismiss the auditors if they issue such a report. Since an audit committee's main responsibility is to safeguard the independence of external auditors, whether the external auditor can independently issue opinions regarding a firm's ability to continue as a going concern is an appropriate indicator to test the efficacy of an audit committee. Ibid at 268-69; Joseph V Carcello \& Terry L Neal, “Audit Committee Composition and Audit Reporting” (2000) 75:4 The Accounting Review 453 at 455 [Carcello \& Neal 2000].

${ }^{1398}$ Directors are defined as independent if they are not current or former officers, employees of the company or a related entity, relatives of management, professional advisors to the company, officers of a significant supplier or customers of the company or interlocking directors. Bronson et al, supra note 1380 at $271 \mathrm{n} 14$. 
receive a going-concern report, ${ }^{1399}$ and were more likely to shield auditors from dismissal after issuing new going-concern reports (implying a higher quality of financial reporting). ${ }^{1400}$ In addition, Beasley et al. (2000) observed that firms without financial statement frauds (implying a higher quality of financial reporting) have a higher percentage of fully independent audit committees than firms with financial statement frauds. ${ }^{1401}$ In contrast, Klein (2002) ${ }^{1402}$ found that a wholly independent ${ }^{1403}$ audit committee had no significant impact on the magnitude of earnings management, but an audit committee with a majority of independent directors did (however, Professor Klein did not provide any explanation for the anomalous result). ${ }^{1404}$ Taken together, these results seem to indicate that $100 \%$ of audit committee independence does matter. A firm with a completely independent audit committee was more likely to be associated with a higher quality of financial reporting.

Regarding the second category that focused on the effect of the percentage of independent directors on the audit committee, the results seem to be inconsistent. Seven studies reported that a greater proportion of independent directors on the audit committee was correlated with a higher quality of financial reporting, while six studies observed no such connection. More specifically, Krishnan (2005) ${ }^{1405}$ found that the incidence of internal control problems ${ }^{1406}$ was lower (signifying a better quality of financial reporting) for firms having a

\footnotetext{
1399 Ibid at 275.

${ }^{1400}$ Ibid at 276.

${ }^{1401}$ Beasley et al, supra note 1302 at 450-52.

1402 April Klein, "Audit Committee, Board of Director Characteristics and Earnings Management" (2002) 33 Journal of Accounting and Economics 375 [Klein 2002]. The author examined the correlation between the magnitude of abnormal accruals (the proxy for earnings management) and audit committee independence by using a sample of 692 firm-years of S\&P 500 firms from 1992 to 1993. Ibid at 376, 379.

${ }^{1403}$ Independent directors in this study are defined as directors who have no ties to the firm beyond being a board member. Only current employees of the firm are considered as insiders. Affiliated directors are past employees, relatives of the CEO, or have significant transactions or business relationships with the firms. Ibid at 381. ${ }^{1404}$ Ibid at 376, 389-90, 398.

1405 The author investigated the association between audit committee characteristics (as measured by audit committee size, independence and financial expertise) and the likelihood of an internal control problem by surveying a sample of 128 companies that changed auditors over the period 1994 to 2000. Krishnan, supra note 1353 at $652,656$.

${ }^{1406}$ Internal control problems are measured by reportable conditions or material weaknesses. Reportable conditions are defined as "significant deficiencies in the design or operation of internal control, which could adversely affect the organization's ability to initiate, record, process, and report financial date consistent with the assertions of management in the financial statements," according to SAS No. 60. Ibid at 652. A material weakness is "a reportable condition in which the design or operation of one or more of the internal control components does not reduce to a relatively low level the risk that misstatements caused by error or fraud in amounts that would be material in relation to the financial statements being audited may occur and not be detected within a timely period by employees in the normal course of performing their assigned functions." In a word, material weaknesses are reportable conditions that become very severe. Ibid at 653.
} 
higher proportion of independent directors ${ }^{1407}$ on audit committees, ${ }^{1408}$ while Vafeas (2005) ${ }^{1409}$ reported that audit committees with more outside (independent plus affiliated) directors ${ }^{1410}$ were more likely to have a better earnings quality ${ }^{1411}$ (observed by being less likely to report a small earnings increase and to avoid negative earnings surprises). ${ }^{1412}$ Uzen, Szewczyk and Varma (2004) observed that the likelihood of fraud was lower when firms had a higher proportion of independent directors ${ }^{1413}$ on the audit committee. ${ }^{1414}$ Moreover, Carcello and Neal (2000) ${ }^{1415}$ and Bronson et al. (2009) found that the greater the percentage of independent directors ${ }^{1416}$ on the audit committee, the higher the likelihood that auditors would issue a going-concern report (signifying a higher quality of financial reporting). ${ }^{1417}$ This implies that auditors facing an ambiguous situation were less likely to adopt the client's position (or to render them susceptible

${ }^{1407}$ The author defines non-independent or affiliated directors as current or former officers or employees of the company or of a related entity, relatives of management, professional advisors to the company, officers of significant suppliers or customers of the company, and interlocking directors. Independent directors are directors who are not affiliated or are non-independent. Ibid at 656-57.

${ }_{1408}^{14 b i d}$ at 651, 660 Table 2, 661.

${ }^{1409}$ The author used the likelihood of reporting a marginal earnings increase and the probability of artificially avoiding a negative earnings surprise as proxies for the quality of financial reporting, and investigated whether they were correlated with audit committee characteristics (as measured by independence, expertise, size, meeting frequency, shareholdings, and extra directorship) by surveying a sample of 2251995 Fortune 500 firms from the year 1994 to 2000. Vafeas 2005, supra note 1353 at 1102-03.

${ }^{1410}$ The author did not directly define outside directors. Inside directors are defined as directors who are firm executives, who were employees of the firm within the past three years and their relatives, and who have a fiduciary relation to the firm either directly or through their principal employer. Ibid at 1119.

${ }^{1411}$ The author assumed that firms avoiding an earnings decline and averting a negative earnings surprise may motivate management to manipulate earnings. The quality of financial reporting may, therefore, be decreased. Ibid. at $1098-99$.

${ }^{1412}$ Ibid at $1105,1109,1118$.

${ }^{1413}$ In this study, directors who have no affiliation with the company other than being on the board are considered as independent directors. Directors who have some non-board affiliation with the company are considered as gray directors, such as lawyers, investment bankers, consultants, executives of advertising agencies, former employees and family members. Independent directors in combination with gray directors are called outside directors. Uzen, Szewczyk and Varma, supra note 1309 at 34, 36.

${ }^{1414}$ The authors found that the proportion of outside (independent plus gray) directors on the audit committee was not sensitive to the likelihood of fraud, but observed that the percentage of gray directors on the same committee was correlated with a higher incidence of fraud. Taken together, independent directors on the audit committee, without the interference of gray directors, had a positive impact in reducing the probability of fraud. Ibid. at 41-42.

${ }^{1415}$ The authors investigated the correlation between audit committee independence and the incidence of issuing going-concern reports by surveying a sample of 223 public firms experiencing financial distress during 1994. Carcello \& Neal 2000, supra note 1397 at 457.

${ }^{1416}$ In Carcello and Neal (2000), the authors defined inside and gray directors, instead of independent directors. Inside directors are current officers or employees of the company or of a related entity. Gray directors include former officers or employees of the company or of a related entity, relatives of management, professional advisors to the company (such as consultants, bank officers and legal counsel), officers of significant suppliers or customers of the company, and interlocking directors. Ibid at 458. As for the definition of independent directors in Bronson et al. (2009), please refer to Bronson et al, supra note 1398.

${ }^{1417}$ Carcello \& Neal 2000, ibid at 454, 460, 465; Bronson et al, supra note 1380 at 275. 
to management pressure) when the audit committee had more independent directors. Carcello and Neal (2003) $)^{1418}$ and Bronson et al. (2009) further observed that audit committee members with greater independence ${ }^{1419}$ were more likely to shield auditors from dismissal after issuing new going-concern reports (implying a higher quality of financial reporting). ${ }^{1420}$ In addition, Klein (2002) reported that the probability of earnings management was lower when firms had a higher proportion of independent directors on the audit committee. The correlation was more pronounced when the audit committee had at least a majority of independent directors. However, the correlation became insignificant when all audit committee members were independent. ${ }^{1421}$ Together, the findings of these seven studies showed that audit committees with a greater proportion of independent directors were associated with indices representing a higher quality of financial reporting.

In contrast, Beasley (1996) and Agrawal and Chadha (2005) found that audit committee composition $^{1422}$ did not significantly reduce the incidence of financial statement fraud or the likelihood of earning restatements, respectively. ${ }^{1423}$ Xie, Davidson and DaDalt $(2003)^{1424}$ and Yang and Krishnan (2005) ${ }^{1425}$ observed that audit committee independence ${ }^{1426}$ had no impact on

1418 Joseph V Carcello \& Terry L Neal, "Audit Committee Characteristics and Audit Dismissals Following "New" Going-Concern Reports" (2003) 78:1 The Accounting Review 95 [Carcello \& Neal 2003]. The authors examined the correlation between audit committee characteristics (independence, financial expertise, outside directorship and ownership) and auditor dismissals following new going-concern reports issued by Big 6 firms for 124 firms between 1988 and 1999. Ibid at 101.

${ }^{1419}$ In Carcello and Neal (2003), audit committee independence is measured by the percentage of independent directors on the audit committee. The authors do not directly define independent directors. Directors are considered non-independent, when they are current or former officers or employees of the company or of a related entity, relatives of management, professional advisors to the company, officers of significant suppliers or customers of the company, and interlocking directors. Ibid at 99.

${ }^{1420}$ Ibid at 96-97, 107, 113-114; Bronson et al, supra note 1380 at 276.

${ }^{1421}$ Klein 2002, supra note 1402 at 376, 389-90, 398.

${ }^{1422}$ In Beasley (1996), audit committee composition is measured by the average percentage of outside directors on the audit committee. Beasley, supra note 1295 at 458-59. In Agrawal and Chadha (2005), audit committee composition is measured by the proportion of independent directors on the audit committee. Agrawal \& Chadha, supra note 1313 at 390. It is worth mentioning that Beasley (1996) did not differentiate affiliated directors from outside directors. The monitoring effect of independent directors might, therefore, be offset. If only independent directors had been looked at, the results might have been different.

${ }^{1423}$ Beasley, ibid; Agrawal \& Chadha, ibid at 389-92, 395.

${ }^{1424}$ The authors investigated whether the characteristics of entire board and the audit committee (as measured by its size, meeting frequency and composition) influenced the incidence of earnings management (as proxied by discretionary current accruals) by surveying a sample of around 100 S\&P 500 firms for the years 1992, 1994 and 1996. Xie, Davidson \& DaDalt, supra note 1351 at 302.

${ }^{1425}$ The authors studied the relationship between seven characteristics of audit committees (independence, financial expertise, size, meeting frequency, stock ownership, outside directorships and tenure) and earnings management (as measured by total discretionary accruals and current discretionary accruals) by using a sample of 896 firm-year observations for the years 1996 to 2000. Yang \& Krishnan, supra note 1353 at 201, 207. 
earnings management and quarterly earnings management, respectively. ${ }^{1427}$ Bédard, Chtourou \& Courteau (2004) further found no significant correlation between audit committees with 50-99\% independence and earnings management. ${ }^{1428}$ Moreover, Felo, Krishnamurthy and Solieri $(2003)^{1429}$ reported that the percentage of independent directors ${ }^{1430}$ on the audit committee was not correlated with analysts' ranking of financial reporting. ${ }^{1431}$ In total, results of these six studies revealed that the fraction of independent directors on the audit committee was not related to the indices representing the quality of financial reporting.

Taking the evidence in the second category together, it seems that there is no consistent evidence that a higher percentage of independent directors on the audit committee was always associated with a higher quality of financial reporting. Combined with the findings in the first category, it appears that a wholly independent audit committee was more likely to have a greater monitoring effect. Independent audit committees, even those with a higher proportion of independent directors, may be insufficient to generate a high quality of financial reporting.

As for the third category of studies that compared the difference between audit committees with, and without, $100 \%$ independence, the results seem to be mixed. Bédard, Chtourou and Courteau (2004) found that the presence of 100\%, rather than a majority of (50\%99\%), independent directors on the audit committee was associated with a lower likelihood of earnings management, ${ }^{1432}$ while Klein (2002) reported the opposite results. ${ }^{1433}$

${ }^{1426}$ Audit committee independence is measured by the percentage of independent directors on the audit committee. Ibid at 206; Xie, Davidson \& DaDalt, supra note 1351 at 307. However, Xie, Davidson and DaDalt (2003) and Yang and Krishnan (2005) did not further define independent directors.

${ }^{1427}$ Xie, Davidson \& DaDalt, ibid at 307; Yang \& Krishnan, ibid at 211-12, 215.

${ }^{1428}$ Bédard, Chtourou \& Courteau, supra note 510 at 29.

${ }^{1429}$ The authors examined the correlation between four audit committee characteristics (financial expertise, independence, size and meeting frequency) and the quality of financial reporting (as measured by analysts' ranking) by surveying a sample of 119 firms for the periods of 1992-93 and 1995-96. Felo, Krishnamurthy \& Solieri, supra note 1353 at $15-16$.

${ }^{1430}$ In Felo, Krishnamurthy and Solieri, audit committee members are classified as inside, gray, and independent. Directors are considered insiders, if the firm has employed them within the past five years or if they are immediate family members of individuals who have been employed by the firm within the past five years. Directors are considered gray, if they receive consulting fees from the firm or if they are executives, partners, directors, or controlling shareholders in other firms which have significant business ties with the firm. Directors who are not inside or gray are classified as independent. Ibid at 17-18

${ }^{1431}$ Ibid at 23-25;

1432 Bédard, Chtourou \& Courteau, supra note 510 at 29.

${ }^{1433}$ Klein 2002, supra note 1402 at 376, 389-90, 398. The inconsistency of the two studies might be attributed to the size of their sample firms. The sample firms in Bédard, Chtourou and Courteau (2004) appear to be smaller than those in Klein (2002). Bédard, Chtourou \& Courteau, ibid. 
In contrast, Bronson et al. (2009) observed that 100\% audit committee independence was required for firms to have a higher quality of financial reporting as shown by the likelihood of receiving a going-concern report and protecting auditors from dismissal following the issuance of such a report. In cases of receiving a going-concern report, the authors found that financially distressed firms with completely independent audit committees were more likely to receive going-concern opinions, while similar firms with only one non-independent member on audit committees were not. ${ }^{1434}$ In terms of protecting auditors from dismissal following the issuance of a going-concern report, Bronson et al. (2009) observed that completely independent and not completely independent audit committees both provided protection from auditor dismissal following the issuance of a going-concern opinion (signifying a better quality of financial reporting). ${ }^{1435}$ However, the effect of a completely independent audit committee was stronger than that of an audit committee with only one non-independent member. Overall, audit committees with $100 \%$ independence seem to have a better chance to be related to a higher quality of financial reporting than those without $100 \%$ independence.

Taking the results of the three categories together, the monitoring benefits of audit committees appear not to be fully realized, unless the audit committee was completely independent. It seems that empirical evidence supports SOX's requirement that all audit committee members must be independent from management. It is worth noting that Professor Romano has indicated that the findings of the above studies, as with all regression analysis, cannot demonstrate causation. ${ }^{1436}$ The positive correlation between complete audit committee independence and the quality of financial reporting can be interpreted as audit committee members with complete independence lead to a higher quality of financial reporting-the rationale for SOX and related reforms in this regard. However, the same relationship can also be explained as firms with higher financial reporting quality choose to have a completely independent audit committee. If the latter interpretation explains the study results, the requirement for a completely independent audit committee may be misplaced.

\footnotetext{
${ }^{1434}$ Bronson et al, supra note 1380 at 275, 277.

1435 Ibid at 276-77.

${ }^{1436}$ Romano, Quack Corporate Governance, supra note 11 at 1532.
} 


\subsection{The Relationship between Different Types of Financial Expertise and the Quality of Financial Reporting}

As mentioned earlier, the primary function of the audit committee is to ensure a high quality of financial reporting. It seems obvious that audit committee members should have sufficient knowledge and experience in the field of accounting and finance in order to fulfill their responsibility of supervising the integrity of financial reporting system. As early as 1999, the Blue Ribbon Committee suggested that each member on the audit committee should be financially literate and at least one member should have accounting or related financial management expertise. ${ }^{1437}$ In 2002, these recommendations were legislated by SOX. However, the key issue is how financial expertise is defined. In other words, which type of financial expert can sufficiently protect the integrity of the financial reporting process?

Originally, the Blue Ribbon Committee recommended that financial expertise can be demonstrated by employment experience in accounting, finance, or any other comparable experience, including financial oversight responsibilities (like a CEO). After SOX was enacted, the SEC initially proposed to narrow financial expertise to individuals who had obtained education and experience in accounting or auditing. However, due to severe criticism, the SEC later adopted a more liberal definition of financial expertise that further includes experience in financial statement analysis (such as from working as an investment banker or financial analyst) and experience in financial oversight (such as from working as a CEO or president), in addition to experience in accounting and auditing. ${ }^{1438}$ Since the current SEC version of financial expertise seems roughly equal to the definition of Blue Ribbon Committee in 1999, I treat them the same in the following analysis.

Since different financial expertise may have a different impact on the quality of financial reporting, financial economists, based on the SEC current definition, have further classified financial expertise into three types: (1) accounting expertise; (2) financial statement analysis expertise; and (3) supervisory expertise, and examined which type of financial expertise has a greater impact on the quality of financial reporting. The results seem to reveal that the impact of financial expertise on financial reporting quality depends on how financial expertise is defined.

\footnotetext{
${ }^{1437}$ BRC Report, supra note 232 at $1072-73$.

${ }^{1438}$ Please refer to section 4.1.2.4.1.2.1 Definition of Financial Experts for further details.
} 
The existing empirical evidence regarding this issue can be classified into five categories: (1) findings regarding the relationship between accounting expertise (equivalent to the SEC initial definition) and the quality of financial reporting; (2) findings concerning the correlation between financial analysis expertise and the quality of financial reporting; (3) evidence about the connection between supervisory expertise and the quality of financial reporting; (4) findings regarding the combined impact of accounting and financial analysis expertise on the quality of financial reporting; (5) evidence concerning the combined effect of all three types of financial expertise on the quality of financial reporting (equivalent to the SEC current or the BRC definition).

Regarding the findings of the first category, six studies reported that accounting expertise (equivalent to the SEC initial definition of financial expertise) was significantly associated with indices of a higher financial reporting quality, while only one study found no such connection. More specifically, Agrawal and Chadha (2005) found that the incidence of earnings restatement was significantly lower when firms had an independent director with accounting expertise ${ }^{1439}$ on their audit committees, ${ }^{1440}$ while Qin $(2007)^{1441}$ reported that firms with financial experts on the audit committee under the SEC's initial definition ${ }^{1442}$ were more likely to enjoy a higher quality of reported earnings ${ }^{1443}$ (signifying a higher quality of financial reporting). ${ }^{1444}$ Carecello et al . $(2006)^{1445}$ and Dhaliwal, Naiker and Navissi (2006) ${ }^{1446}$ also observed that audit committees

\footnotetext{
${ }^{1439}$ Directors are considered to have financial (accounting) expertise, if they currently have (or have previously had) work experience as a CPA, CFA or in corporate financial management (for example, as a chief financial officer, treasurer, controller, or vice presidents of finance). This definition is similar in spirit to what the SEC initially adopted. Agrawal \& Chadha, supra note 1313 at 386.

1440 Ibid at 394-95.

${ }^{1441}$ Bo Qin, "The Influence of Audit Committee Financial Expertise on Earnings Quality: U.S. Evidence" (2007), online: SSRN <http://ssrn.com/abstract=799645> [Qin]. The author examined the correlation between two types of financial expertise under the SEC's initial and current definition and earnings quality (the proxy for financial reporting quality) by using a sample of 92 firms in 43 industries from 1998 to 2002. Ibid at 1-2, 17.

${ }^{1442}$ A financial expert under the SEC's initial definition refers to an expert with previous positions, such as public accountants, auditors, principal/chief financial officers, controllers, or principal/chief accounting officers. Ibid at 10. ${ }^{1443}$ The earning quality is measured by returns-earnings relation, which is characterized as "the extent to which accounting earnings can reflect the economic events already reflected in the stock prices." The author estimated it by a regression model of cumulative abnormal returns on unexpected earnings. Ibid at 11-12.

${ }^{1444}$ Ibid at 20.

1445 Joseph V Carcello et al, “Audit Committee Financial Expertise, Competing Corporate Governance Mechanisms, and Earning Management" (February 2006), online: SSRN <http://ssrn.com/abstract=887512 or http://dx.doi.org/10.2139/ssrn.887512> [Carcello et al]. The authors examined the association between different types of audit committee financial experts and earning management by using a sample of 283 firms traded on NYSE, NASDAQ's National Market and NASDAQ's Small Cap Market in the year 2003. Ibid at 2.

${ }^{1446}$ Dan Dhaliwal, Vic Naiker \& Farshid Navissi, "Audit Committee Financial Expertise, Corporate Governance and Accruals Quality: An Empirical Analysis” (May 2006), online: SSRN < http://ssrn.com/abstract=906690 > [Dhaliwal,
} 
having at least one member with accounting expertise ${ }^{1447}$ were correlated with a lower level of earnings management and higher accruals quality ${ }^{1448}$, respectively. ${ }^{1449}$ In addition, Defond, Hann and $\mathrm{Hu}(2005)^{1450}$ and Davidson, Xie and $\mathrm{Xu}(2004)^{1451}$ found a significant and positive market reaction ${ }^{1452}$ surrounding the appointment of accounting experts ${ }^{1453}$ to the audit committee, suggesting that investors perceived accounting and auditing experience as beneficial. ${ }^{1454}$ Only Felo, Krishnamurthy and Solieri (2003) found that the proportion of financial experts (under the SEC's initial definition) ${ }^{1455}$ on the audit committee had no impact on the analysts' ranking of financial reporting quality. ${ }^{1456}$ Taken together, the findings of most studies in the first category

Naiker \& Navissi]. The authors investigated the correlation between three types of audit committee financial expertise (accounting, finance and supervisory expertise) and accruals quality by surveying a sample of 3,510 individuals serving as audit committee members in 1,114 firms from the period 1995 to 1998. Ibid at 10.

${ }^{1447}$ In Carcello et al. (2006), the authors define directors with financial expertise under the SEC's initial definition as accounting financial experts. Directors who current have (or have previously had) work experience as certified public accountants, chief financial officers, vice presidents of finance, financial controllers are considered as accounting financial experts in this study. Carcello et al, supra note 1445 at 7. In Dhaliwal, Naiker and Navissi (2006), the authors define accounting expertise to audit committee members as directors who currently have (or have previously had) work experience as certified public accountants, chief financial officers, vice presidents of finance, financial controllers, or any other major accounting positions. Dhaliwal, Naiker and Navissi (2006), ibid at $11-12$.

${ }^{1448}$ Accruals quality is derived from a modified version of the Dechow and Dichev (2002) model and is measured by the standard deviation of residuals from firm-specific regressions of changes in working capital accruals on lagged, current and future cash flows from operations. Ibid at 11, 42 .

${ }^{1449}$ Carcello et al, supra note 1445 at 3, 23; Dhaliwal, Naiker \& Navissi, ibid at 4, $25,32$.

${ }^{1450}$ Mark L Defond, Rebecca N Hann \& Xuesong Hu, "Does the Market Value Financial Expertise on Audit Committees of Boards of Directors" (2005) 43:2 Journal of Accounting Research 153 [Defond, Hann \& Hu]. The authors investigated three-day cumulative abnormal returns around the announcement of 702 newly-appointed independent directors assigned to audit committees during 1993-2002 in 509 firms. Ibid at 160-62.

${ }^{1451}$ Wallace N Davidson III, Biao Xio \& Weihong Xu, "Market Reaction to Voluntary Announcements of Audit Committee Appointments: The Effect of Financial Expertise" (2004) 23 Journal of Accounting and Public Policy 279 [Davidson, Xio \& Xu]. The authors examined stock market reaction surrounding the appointment of directors to audit committees by surveying 136 voluntary appointment announcements over the period 1990 to 2001. Ibid at 282-84.

${ }^{1452}$ In Defond, Hann and Hu (2005), market reaction is measured by three-day cumulative abnormal returns, while, in Davidson, Xie and Xu (2004), stock market reaction is proxied by two-day cumulative market-adjusted returns. Ibid at 284; Defond, Hann and Hu, supra note 1450 at 158, 166.

${ }^{1453}$ In Defond, Hann and $\mathrm{Hu}$ (2005), accounting financial experts are defined as directors who have experience as a public accountant, auditor, principal or chief financial officer, controller, or principal or chief accounting officer. These categories are chosen based on the suggestions included in the initial version of SOX proposed by the SEC. Defond, Hann and $\mathrm{Hu}$, ibid at 162. In Davidson, Xie and Xu (2004), directors are classified as having auditing and audit firm experience, if they are employed by a CPA firm or work as an audit consultant. Davidson, Xie and Xu, ibid at $285-86$.

${ }^{1454}$ Defond, Hann and Hu, ibid at 166-68; Davidson, Xie and Xu, ibid at 289, 291.

${ }^{1455}$ In addition to the SEC's current definition of financial expertise, the authors also examined whether the stricter definition (SEC initial version) of financial expertise was correlated with the analysts' ranking of financial reporting quality. Under the stricter definition, only individuals who have accounting degrees, accounting certifications, or current or past experience in accounting or finance are considered as financial experts. Felo, Krishnamurthy \& Solieri, supra note 1353 at 29-30.

${ }^{1456}$ Ibid. 
seems to show that accounting (the SEC initial definition) expertise was significantly correlated with indices symbolizing a higher quality of financial reporting.

With respect to the findings in the second category, two studies found that financial analysis expertise had no impact on the quality of financial reporting, while one study reported that financial analysis expertise was related to a higher quality of financial reporting. More specifically, Davidson, Xie and Xu (2004) found that there was no significant market reaction around the appointment of a financial analysis ${ }^{1457}$ expert to the audit committee, ${ }^{1458}$ while Dhaliwal, Naiker and Navissi (2006) reported no significant association between the presence of financial analysis expertise ${ }^{1459}$ on the audit committee and accruals quality. ${ }^{1460}$ In contrast, Carecello et al. (2006) observed that audit committees having at least one non-accounting expert $^{1461}$ (excluding senior business executives) were correlated with a lower level of earnings management. ${ }^{1462}$ Taken together, there is no consistent evidence regarding the impact of finance analysis expertise on the quality of financial reporting for audit committee members.

As for the evidence in category three, three studies consistently reported that supervisory expertise had no impact on the quality of financial reporting. More specifically, Dhaliwal, Naiker and Navissi (2006) found no significant association between the presence of supervisory expertise $^{1463}$ on the audit committee and accruals quality, ${ }^{1464}$ while Carecello et al. (2006) observed that audit committees having at least one supervisory expert ${ }^{1465}$ (but no accounting expert) had no impact on the level of earnings management. ${ }^{1466}$ Defond, Hann and Hu (2005) also reported that there was no significant market reaction around the appointment of a

\footnotetext{
${ }^{1457}$ Directors are classified as having financial statement analysis experience, if they are executives in the investment, investment banking, or commercial banking industry, or work as financial consultants or college professors in finance or accounting. Davidson, Xie and Xu, supra note 1451 at 285-86.

${ }_{1458}^{14}$ Ibid at 289, 290 Table 3.

${ }^{1459}$ The authors define financial analysis expertise to audit committee members as directors who currently have (or have previously had) work experience as investment bankers, financial analysts, or any other financial management roles are considered as having finance expertise. Dhaliwal, Naiker and Navissi, supra note 1446 at 12.

${ }^{1460}$ Ibid at 4, 25, 32.

${ }^{1461}$ Non-accounting financial experts are defined as financial experts who are investment bankers, venture capitalists, private investors, consultants, attorneys, academics retirees, principals and directors, but excluding current or retired senior managers. Carcello et al, supra note 1445 at 25.

${ }_{1462}$ Ibid at 3, 25-26.

${ }^{1463}$ The authors define supervisory financial experts as directors who currently have (or have previously had) work experience as chief executive officers or company presidents. Dhaliwal, Naiker and Navissi, supra note 1446 at 12. ${ }^{1464}$ Ibid at 4, 26, 32.

${ }^{1465}$ A supervisory expert (originally used as a senior business executive by the authors) is defined as a current or retired senior manager in another firm, including a CEO, chairman of the board, president, chief operating officer or vice president. Carcello et al, supra note 1445 at 24.

${ }^{1466} \mathrm{Ibid}$ at 3, 25-26.
} 
supervisory ${ }^{1467}$ expert to the audit committee. ${ }^{1468}$ It appears that the quality of financial reporting was not associated with supervisory expertise on the audit committee.

Regarding the findings in category four, two studies reported that audit committees with financial experts having either accounting or financial analysis expertise (i.e. combining the effect of the two types of financial expertise) were more likely to have a higher quality of financial reporting. More specifically, Krishnan (2005) found that the number of financial experts $^{1469}$ on the audit committee was significantly and negatively related to the incidence of internal control problems, ${ }^{1470}$ while Bédard, Chtourou \& Courteau (2004) observed that the presence of at least one audit committee member with financial expertise ${ }^{1471}$ was correlated with a lower probability of earnings management. ${ }^{1472}$ In comparison with the findings in category one (the significantly positive impact of accounting expertise on financial reporting quality) and the evidence in category two (no consistent effect of financial analysis expertise on financial reporting quality), the results in this category seemingly could be attributed to the audit committee members with accounting expertise, instead of financial analysis expertise.

With respect to the evidence in category five, the results are inconsistent. Four studies found that financial expertise within the SEC current definition (combining the effect of all three types of financial expertise) was significantly associated with a higher quality of financial reporting, while two studies reported no such relationship. More specifically, Abbott, Parker and Peters (2004) reported that audit committees possessing at least one member meeting the BRC definition of financial expert ${ }^{1473}$ were likely to have a lower incidence of financial

\footnotetext{
${ }^{1467}$ Directors are classified as having supervisory (originally used as non-accounting experts by the authors) experience, if they have experience as a CEO or president of a for-profit corporation. Such classification is inferred from the final version of SOX drafted by the SEC. Defond, Hann and Hu, supra note 1450 at 162.

${ }^{1468}$ Ibid at 168 .

${ }^{1469}$ A director is considered having financial expertise, if he/she was a certified public accountant, chartered financial analyst, or had work experience in a financial or accounting position. Krishnan, supra note 1353 at 657.

${ }^{1470}$ Ibid at 651, 660 Table 2, 661.

${ }^{1471}$ The authors adopted a more restrictive definition of financial expert than that of the BRC in this study. Prior experience as a CEO is excluded from the scope of financial expert. Only directors with accounting expertise or financial analysis expertise (such as bankers or venture capitalists) are considered as financial experts in this study. Bédard, Chtourou \& Courteau, supra note 510 at 22.

1472 Ibid at 28-29.

${ }^{1473}$ BRC states that financial expertise may be demonstrated by employment experience in finance or accounting, a CPA certification or comparable experience, or a position as a CEO or other senior officer with financial oversight responsibilities. BRC report, supra note 232 at 1081. In this study, a director who is (or has been) a CPA, investment banker or venture capitalist, served as CFO or controller, or has held a senior management position (CEO, President, EVP, SVP, VP) with financial responsibilities are all considered as having financial expertise. Abbott, Parker \& Peters, supra note 1353 at 76.
} 
restatement, ${ }^{1474}$ while Carecello et al. (2006) observed that an audit committee having at least one financial expert (based on the SEC's current definition) was inclined to have a lower level of earnings management. ${ }^{1475}$ Davidson, Xie and Xu (2004) further found a significantly positive stock price reaction when new members of audit committees had one of the three types of financial expertise currently defined by the SEC, ${ }^{1476}$ while Lee, Mande and Ortman (2004) observed a significant connection between a higher proportion of financial experts ${ }^{1477}$ on the audit committee and lower likelihood of auditor resignation. ${ }^{1478}$ In contrast, Qin (2007) reported no relationship between earnings quality and financial experts under the SEC's current definition, ${ }^{1479}$ while Carcello and Neal (2003) found no significant relationship between the proportion of audit committee members with financial expertise ${ }^{1480}$ and auditor dismissals following the issuance of going-concern reports. ${ }^{1481}$ Taken together, a majority of studies show that financial expertise under the BRC (or the SEC current) definition had a positive impact on the indices representing a higher quality of financial reporting. However, compared with the findings of the above four categories, it appears likely that the improvements in financial reporting quality were mainly attributed to having audit committee members with accounting expertise, rather than financial analysis or supervisory expertise.

Taking the accumulated evidence as a whole, the effect of financial expertise on the quality of financial reporting varied with the type of expertise. Audit committee members with accounting expertise had a dominant effect in enhancing the quality of financial reporting, while directors with finance analysis expertise had no consistent effect on financial reporting quality. Audit committee members with supervisory expertise were not associated with the quality of financial reporting. It seems that the current definition of financial expertise adopted by the

\footnotetext{
1474 Ibid at 80 .

${ }^{1475}$ Carcello et al, supra note 1445 at 3, 22.

${ }^{1476}$ Davidson, Xie \& Xu, supra note 1451 at 280, 286-87, 287 Table 2, 291.

${ }^{1477}$ A financial expert in this study is defined as a director who is a CPA, investment banker, or venture capitalist, served as CEO, Vice-President of Finance, controller, treasurer, or CEO. Lee, Mande \& Ortman, supra note 1353 at $136 \mathrm{n} 14$.

1478 Ibid at $141,143$.

${ }^{1479}$ Qin, supra note 1441 at 20.

${ }^{1480}$ Financial expertise in this study is defined as past employment experience in finance or accounting, requisite professional certification in accounting, or any other comparable experience or background which results in the individual's financial sophistication, including being or having been a CEO or other senior officer with financial oversight responsibilities. Ibid at 98. This definition is equivalent to the 1999 Blue Ribbon Committee definition and the SEC's current definition. Carcello and Neal 2003, supra note 1418 at 99.

${ }^{1481}$ Ibid at $107,113$.
} 
SEC and major stock exchanges is too broad. Future refinements to exclude those who have no accounting expertise may be needed.

It is worth noting that the effect of accounting experts on audit committees may depend on a firm's overall governance environment. Accounting experts alone may not necessarily enhance the quality of financial reporting. Three studies explored this issue and their results appear to be inconsistent. Defond, Hann and $\mathrm{Hu}$ (2005) reported that investors attached a higher value to the appointment of audit committee members with accounting expertise only when the appointing firms had strong corporate governance ${ }^{1482}$ (suggesting that accounting expertise complemented corporate governance), ${ }^{1483}$ while Dhaliwal, Naiker and Navissi (2006) found that accounting experts on the audit committee alone had a positive (but only marginally significant) impact on enhancing the accruals quality; but with the help of strong audit committee governance (high governance scores) ${ }^{1484}$, the positive impact on accruals quality became prominent (implying that accounting expertise complemented audit committee governance). ${ }^{1485}$ However, Carecello et al. (2006) observed that the strength of a firm's governance and accounting experts on the audit committee acted as substitutes for each other. Firms with either at least one accounting expert on the audit committee or strong corporate governance ${ }^{1486}$ experienced reduced likelihood of earnings management. ${ }^{1487}$ Taken together, it is hard to conclude whether the quality of financial reporting can be enhanced by the accounting experts on the audit committee alone. Perhaps further research is needed to clarify the correlation between accounting expertise and the strength of a firm's (or an audit committee's) governance.

\section{Summary of Empirical Evidence regarding the Efficacy of Audit Committee}

\footnotetext{
${ }^{1482}$ The strength of a firm's governance is measured by a composite score by considering board size, board independence, audit committee size, audit committee independence, shareholders' rights and institutional ownerships. Strong corporate governance refers to the firm that has a high composite score. Defond, Hann and Hu (2005), supra note 1450 at 176.

${ }^{1483}$ Ibid at 176, 187.

${ }^{1484}$ The strength of audit committee governance is measured by a composite score of three audit committee characteristics: audit committee size, audit committee independence and audit committee meetings. Strong audit committee governance refers to the audit committee that has a high composite score. Dhaliwal, Naiker and Navissi (2006), supra note 1446 at 14-15.

${ }^{1485}$ Ibid at 25-27, 33.

${ }^{1486}$ In this study, the strength of a firm's governance is measured by a composite score based on board size, board independence, audit committee size, audit committee independence, shareholders' rights and institutional ownership, which is identical to the measure of Defond, Hann and $\mathrm{Hu}$ (2005). Strong corporate governance refers to the firm that has a high composite score. Carcello et al, supra note 1445 at 18-19.

${ }^{1487}$ Ibid at 3, 22-23, 24, 32.
} 
Taking the accumulated evidence together, the mere presence of an audit committee may be insufficient to maintain a high quality of financial reporting. The monitoring benefits of audit committees cannot be consistently realized unless the audit committee is composed entirely of independent directors and has at least one member with accounting expertise. It appears that a requirement for all audit committee members to be independent from management, as mandated by SOX, is justified, but the current definition of financial expertise adopted by the SEC is too broad and needs to be modified.

\subsubsection{The Compensation Committee}

As mentioned previously, CEO compensation should ideally not be so high as to damage shareholder wealth; however, it cannot be so low that it does not provide sufficient incentives for executives to maintain high quality management. The popular scenario for modern corporations to deal with this issue is to establish a compensation package that can ensure quality management by executives and align their interests with those of shareholders. Originally, executive compensation was decided by board members. Since the 1970s, the mission of setting executive pay has been gradually delegated to compensation committees for most large companies. At first, CEOs and other affiliated directors were not excluded from compensation committees. In light of the growing concern regarding conflicts of interest and self-dealing, the complete independence of compensation committees was promoted in the 1980s and was finally adopted as mandatory requirements by major stock exchanges after corporate scandals in the early 2000s.

The effectiveness of compensation committees has been studied by financial economists since the 1990s. They used the relationship between compensation committee independence and the level of executive pay, as well as the sensitivity of CEO pay to firm performance, to evaluate whether independent directors play an active monitoring role in the compensation committee. In addition, some researchers used firm performance as an index to measure the effectiveness of independent directors on the compensation committee. Existing empirical evidence regarding this issue can be analyzed from three perspectives: (1) the association between the existence or the level of independence of the compensation committee and firm performance; (2) the 
relationship between the proportion of independent directors on the compensation committee and the level of CEO compensation; (3) the correlation between compensation committee independence and whether the CEO remuneration is sensitive to corporate performance.

\subsection{The Association between the Existence or the Level of Independence of the Compensation Committee and Firm Performance}

With respect to the connection between the existence of a compensation committee and firm performance, Klein (1998) and Hayes, Mehran and Schaefer (2004) ${ }^{1488}$ both reported that the presence of a compensation committee had no significant impact on firm performance, regardless of whether firm performance was measured by ROA, Jensen Productivity, market return, or market to book ratio. ${ }^{1489}$ The mere existence of a compensation committee did not lead to better firm performance.

Regarding the relationship between the level of compensation committee independence and firm performance, five existing studies reported similar results. Klein (1998) found that compensation committees with a higher proportion of independent directors were only marginally (significant at the 10\% level) and positively associated with one out of three firm performance indicators (market returns), ${ }^{1490}$ while Hayes, Mehran and Schaefer (2004) observed that the percentage of outside directors ${ }^{1491}$ on the compensation committee was not related to firm performance (as measured by market to book ratio). ${ }^{1492}$ The trend remained unchanged when compensation committee independence was increased to 100\%. Brown and Caylor (2006) reported that a compensation committee comprised solely of independent directors was not associated with current or subsequent Tobin's Q (firm value index), ${ }^{1493}$ while they observed similar results when firm performance was measured by ROE and ROA in their 2009 study. ${ }^{1494}$ In addition, Brick and Chidambaran (2007) found that poorly performing firms were more likely

\footnotetext{
${ }^{1488}$ The authors examined variations in the committee structure of boards of directors by using a sample of 509 S\&P 500 firms during 1997 and 1998. Rachel Hayes, Hamid Mehran \& Scott Schaefer, "Board Committee Structure, Ownership, and Firm Performance" (October 2004) at 8-9, online: Washington University at St. Louis $<$ http://apps.olin.wustl.edu/jfi/pdf/HayesMehranSchaefer.pdf > [Hayes, Mehran \& Schaefer].

${ }^{1489}$ Klein 1998, supra note 501 at 293; Hayes, Mehran \& Schaefer, ibid at 19.

${ }^{1490}$ Klein 1998, ibid at 293, 294 Table 4.

${ }^{1491}$ Outside directors in this study are defined as directors who are neither current nor former employees of the firm. Gray directors (who have a certain business or other connection with the firm) are considered as outside directors in this study. Hayes, Mehran \& Schaefer, supra note 1489 at 9.

1492 Ibid at 19, 40-43.

${ }^{1493}$ Brown \& Caylor 2006, supra note 1027 at 419 Table 3, 421 Table 4, 422 Table 5.

${ }^{1494}$ Brown \& Caylor 2009, supra note 1032 at 129-30, 142.
} 
to have a fully independent compensation committee, but having a completely independent compensation committee had no significant impact on subsequent firm value (Tobin's Q). In contrast, firms that performed well were hesitant to change the composition of their compensation committees. ${ }^{1495}$ Taken together, it appears that compensation committee independence had little impact on firm performance. Increasing the independence of compensation committees may not be associated with enhanced firm value.

\subsection{The Relationship between the Proportion of Independent Directors on the Compensation Committee and the Level of CEO Compensation}

The findings seem to be consistent regarding whether a higher percentage of independent directors on the board can lower the level of CEO compensation. Seven studies reported that compensation committees with a higher proportion of independent (or outside) directors had no significant impact on the level of CEO compensation, while one study observed that compensation committees composed entirely of independent directors led to greater total CEO remuneration. More specifically, Vafeas $(2003)^{1496}$ found no correlation between the presence of inside directors ${ }^{1497}$ on the compensation committee and the total CEO compensation ${ }^{1498}$ level, ${ }^{1499}$ while Conyon and He (2004) observed that compensation committees with a higher proportion of insiders ${ }^{1500}$, or CEOs from other firms, had no impact on the level of CEO pay ${ }^{1501}$ or CEO equity incentives ${ }^{1502} \cdot{ }^{1503}$ Daily et al. (1998) ${ }^{1504}$ also reported that compensation committees with

${ }^{1495}$ Brick and Chidambaran, supra note 1357 at 33-34.

${ }^{1496}$ Nikos Vafeas, "Further Evidence on Compensation Committee Composition as A Determinant of CEO Compensation" (2003) 32 Financial Management 53 [Vafeas 2003]. The author examined the correlation between the presence of inside directors on compensation committees and the level of CEO compensation by investigating 271 US firms during the year 1991 to 1997 . Ibid at 57-58.

${ }^{1497}$ Inside directors in this study are defined as directors who are present or were past executives in the companies, and who are employees of subsidiaries. Ibid at 58.

1498 Total CEO compensation includes non-contingent (fixed) and contingent (variable) pay. Ibid at 62.

${ }^{1499} \mathrm{Ibid}$ at 54, 67.

${ }^{1500}$ Inside directors are defined as directors who currently or previously work for the firm. Conyon \& He, supra note 1259 at $47,49,52$.

${ }^{1501}$ CEO compensation is the sum of base salary, annual bonus, long-term incentive, restricted stock, stock-option grants and other compensation. Ibid at 41

${ }_{1502}$ CEO equity incentives are measured by stock and stock options, which directly link CEO wealth to shareholder value. Ibid at 41 .

${ }^{1503}$ Ibid at 46, 48, 49, 52.

${ }^{1504}$ Catherine M Daily et al, "Compensation Committee Composition as a Determinant of CEO Compensation" (1998) 41 Academy of Management Journal 209. The authors investigated a sample of 194 publicly-traded companies from 1992 Fortune 500 firms by examining the correlation between CEO pay and these "captured" directors (as measured by affiliated, interdependent and CEO directors). Ibid at 212. 
a higher proportion of affiliated directors ${ }^{1505}$, interdependent directors ${ }^{1506}$, or CEO directors ${ }^{1507}$ did not lead to higher levels of CEO compensation ${ }^{1508} \cdot{ }^{1509}$ The findings of these three studies seem to show that the level of CEO remuneration was not necessarily higher when compensation committees had more inside directors or directors who are likely to be subject to CEO influence. Such a trend remained unchanged for compensation committees with more independent directors. Anderson and Bizjak (2003) ${ }^{1510}$ found that the level of executive compensation ${ }^{1511}$ was not associated with the proportion of independent directors ${ }^{1512}$ on the compensation committee, ${ }^{1513}$ while Conyon and Kuchinskas (2006) ${ }^{1514}$ reported no significant relationship between total CEO compensation ${ }^{1515}$ and the proportion of non-independent directors ${ }^{1516}$ on the

${ }^{1505}$ In this study, affiliated directors mean non-management directors with personal and/or professional relationships with a firm or its management. Ibid at 210.

${ }^{1506}$ Interdependent directors are defined as directors who are appointed during the tenure of an incumbent CEO. Ibid at 211 .

${ }^{1507} \mathrm{CEO}$ directors are defined as directors who are CEOs of other companies. Ibid.

${ }^{1508} \mathrm{CEO}$ compensation is measured by non-contingent pay (salary and other annual cash compensation) and contingent pay (stock options, bonuses and long-term incentive plans). Ibid at 212.

${ }^{1509} \mathrm{Ibid}$ at 214. The authors examined the one-, two-, and three-year lagged relationships between compensation committee variables in 1991 and CEO pay (in 1992, 1993 and 1994). Therefore, the causation between compensation committee variables and CEO pay can be identified. Ibid at 213.

${ }^{1510}$ Ronald C Anderson \& John M Bizjak, "An Empirical Examination of the Role of the CEO and the Compensation Committee in Structuring Executive Pay" (2003) 27 Journal of Banking \& Finance 1323 [Anderson \& Bizjak]. The authors surveyed a random sample of 110 New York Stock Exchange firms from 1985 to 1998 to examine: how compensation structure affects levels of executive pay and pay sensitivity; whether the CEO's presence on the compensation committee correlates with self-dealing; and how the 1992 and 1993 regulations change pay structure. Ibid at 1329-30.

${ }^{1511}$ CEO compensation is measured by fixed compensation (salary and bonus) and contingent compensation (new options grants and the option portfolio). Ibid at 1327.

${ }^{1512}$ In this study, directors who are employed by the firm, retired from the firm or immediate family members are defined as inside directors. Affiliate directors are defined as directors who have existing or potential business ties to the firm, but are not full time employees, such as consultants, lawyers, financiers and investment banks.

Independent directors are board members whose only business relationship with the firm is their directorship. Ibid at 1326. The authors used the term "outside directors" to represent "independent directors". Ibid at 1330 Table 1. ${ }^{1513}$ Ibid at $1325,1332$.

${ }^{1514}$ Martin J Conyon \& Danielle Kuchinskas, "Compensation Committee in the United States" in Christine A Mallin, ed, Handbook on International Corporate Governance: Country Analyses (Northampton: Edward Elgar 2006) 151 [Conyon \& Kuchinskas]. The authors examined the correlation between CEO compensation and non-independent directors on the compensation committee by surveying approximately 1,500 firms from 1998 to 2003. Ibid at 157 .

${ }^{1515}$ Total compensation is the sum of salaries, bonuses, other cash, restricted stock grants, and Black-Scholes grant value of options. Ibid at 163 Table 9.7.

${ }^{1516}$ Non-independent directors (the original term used by the authors is affiliated directors which include conventional inside and affiliated directors) are defined as directors who are either employees or linked directors. Ibid at 159. Linked directors include directors who were former employees, who provide professional services to the company (such as legal or financial service), who are designated by a significant shareholder or a documented agreement by a group, such as a union, who are material customers or suppliers of the company, who are interlocking, who are a family member of executive officers, and who are a member of the other firm that receives charitable giving from the company. Ibid at 162 Table 9.6. 
compensation committee. ${ }^{1517}$ Newman and Mozes (1999) ${ }^{1518}$ also observed that CEO compensation ${ }^{1519}$ was not significantly higher in firms that had at least one non-independent director $^{1520}$ on the compensation committee than in firms that had an entirely independent compensation committee. ${ }^{1521}$ In comparison with the findings concerning inside and affiliated directors noted in the last paragraph, independent directors were also ineffective in lowering the level of CEO compensation.

The tendency for independent directors to be ineffective was also found when compensation committees were composed entirely of independent directors. Before the enactment of SOX related rules, Anderson and Bizjak (2003) observed that a fully (100\%) independent compensation committee had no impact on the level of CEO compensation. ${ }^{1522}$ After SOX was implemented, Chhaochharia and Grinstein (2009) also reported a similar result. Their findings showed that the level of executive remuneration ${ }^{1523}$ was not significantly different between firms that did not comply with the completely independent compensation committee requirements (prior to the enactment of the new rules) and firms that did comply with the requirements. ${ }^{1524}$ Wan (2009), repeated Chhaochharia and Grinstein's research by excluding two exceptional low compensations, further found that the new stock exchange requirements regarding a compensation committee with complete independence were even associated with greater, rather than lower, CEO compensation. The total of CEO compensation was raised

1517 Ibid at 164-66.

${ }^{1518}$ Harry A Newman \& Hail A Mozes, "Does the Composition of the Compensation Committee Influence CEO Compensation Practice" (1999) 28:3 Financial Management 41 [Newman \& Mozes]. The authors used a sample of 161 Fortune 250 firms in 1992 to examine whether the independence of compensation committees affects CEO compensation. Ibid at 44.

${ }^{1519}$ CEO compensation is measured by salaries, bonuses, other annual compensation, restricted stock awards, longterm incentive payouts and all other compensation. Ibid at 44.

${ }^{1520}$ The authors did not define a non-independent director directly, but provide examples of non-independent directors by using firm A as an example. Non-independent directors in firm A include an employee of firm A, a former employee of firm A, an employee of firm B when firm B has significant business dealings with firm A (such as an attorney whose law firm provides legal work to firm A), a current employee of firm B when the CEO of firm $\mathrm{A}$ is on the board of firm B (an interlocking directorate), and a former employee of firm B when the CEO of firm A is on the board of firm B. Such a definition includes inside directors and affiliated directors in the traditional classification. Ibid at 42-43.

${ }^{1521}$ Ibid at 46, 50 .

1522 Anderson \& Bizjak, supra note 1510 at 1325, 1332.

${ }^{1523}$ CEO compensation includes base salary, bonuses, options (Black-Scholes value), restricted stocks, and other compensation. Chhaochharia and Grinstein 2009, supra note 1263 at 241-42.

${ }^{1524}$ Ibid at 244 . However, the authors found that CEO compensation was reduced by $17 \%$ in the post-regulation period for the firms that did not comply with the board independence requirement, compared to firms that complied with the requirement. Ibid at 232, 244. 
7.25\%. ${ }^{1525}$ Together, these studies show that compensation committees composed entirely of independent directors were not effective in controlling executive pay.

Taking the evidence together, the level of executive compensation was not influenced by the degree of compensation committee independence, regardless of whether the level of compensation committee independence was measured by the proportion of inside directors, the proportion of affiliated directors, the proportion of non-independent directors, the proportion of independent directors, or 100\% independent directors. It appears that independent directors on the compensation committee were not effective in controlling remuneration for executives. However, as I noted earlier, the level of executive compensation should not be the main concern of shareholders. Their major concern should be whether the executive pay fits his/her performance. Shareholders would not be sparing in rewarding CEOs higher remuneration if CEOs can produce higher profits for their investment. Thus, the better indicator to measure the effectiveness of independent directors appears to be their effect on the likelihood that CEO compensation will be structured as pay-for-performance, rather than only the level of CEO remuneration.

\subsection{The Correlation between Compensation Committee Independence and the Sensitivity of CEO Pay to Firm Performance}

With respect to the correlation between compensation committee independence and the sensitivity of pay-for-performance, the results seem to be slightly inconsistent. Three studies found that the level of compensation committee independence had no impact on the sensitivity of CEO compensation to firm performance, while one study reported that less independent compensation committees were more likely to shield CEOs from the impact of poor performance. More specifically, Vafeas (2003) found that the presence of inside directors on the compensation committee had no impact on the level of CEOs' contingent (stock options) compensation (signifying the sensitivity of pay-for-performance), ${ }^{1526}$ while Conyon and He (2004) reported a similar result for compensation committees with a higher fraction of inside directors. ${ }^{1527}$ Anderson and Bizjak (2003) observed that stock options for CEOs (representing pay sensitivity)

\footnotetext{
1525 Wan, supra note 1271 at $5,14$.

${ }^{1526}$ Vafeas 2003, supra note 1496 at 54, 64.

${ }^{1527}$ Conyon \& He, supra note 1259 at 49, 52. The authors used CEO equity incentives, as measured by stock and stock options, to signify the pay sensitivity. Ibid at 41 .
} 
were not significantly different between compensation committees with a higher proportion of independent directors and those consisting of inside directors. ${ }^{1528}$ The results remained the same for compensation committees composed entirely of independent directors. ${ }^{1529}$

In contrast, Newman and Mozes (1999) found that compensation committees with at least one non-independent director were more likely to shield CEOs from the impact of poor performance than those composed fully of independent directors. More specifically, greater CEO compensation was associated with worse firm performance when compensation committees had at least one non-independent director; however, such a negative relationship turned neutral when firm performance became favorable. ${ }^{1530}$ The authors also reported that CEO compensation was not related to firm performance when compensation committees consisted entirely of independent directors. ${ }^{1531}$ Based on this study, it seems that compensation committees with at least one non-independent director were poorer corporate monitors than those with completely independent directors. ${ }^{1532}$ Nevertheless, in combination with the findings discussed in the last paragraph, the level of compensation committee independence generally had no significant impact on the sensitivity of CEO remuneration to firm performance. It appears that independent directors on the compensation committee did not help to ensure that the interests of CEO were aligned with those of shareholders.

\section{Summary of Empirical Evidence regarding the Efficacy of Compensation Committee}

Taking the evidence as a whole, the existence of a compensation committee or the level of compensation committee independence had little impact on firm performance. Higher levels of the compensation committee independence neither lowered the level of CEO pay nor tied CEO remuneration to firm performance. It seems that independent directors on the compensation committee were not effective corporate monitors in establishing CEO compensation. The SOX related reforms, such as the NYSE and NASDAQ's requirements of

\footnotetext{
1528 Anderson and Bizjak, supra note 1510 at 1332-34.

1529 Ibid at 1334.

${ }^{1530}$ Newman and Mozes, supra note 1518 at 46-48, 50.

1531 Ibid at 48.

${ }^{1532}$ The results suggest that completely independent compensation committees are more likely to tie CEO pay to firm performance than those non-completely independent ones, since non-completely independent compensation committees even perform worse.
} 
having a completely independent compensation committee, lack empirical support and may be misplaced.

\subsubsection{The Nominating Committee}

One of the important tasks for the board of directors is to monitor managers and align the interests of management with those of shareholders. Directors shoulder responsibility to review the company's major plans, to evaluate the performance of management teams, to decide on the compensation of top managers, and when appropriate, to dismiss incompetent CEOs. However, a long-standing problem for management-monitoring in practice is that directors are not nominated by shareholders, but rather by the very managers they are supposed to oversee. ${ }^{1533}$ Forty years ago, Professor Mace indicated that CEOs exercise their authority in selecting candidates for the board, in effect, hand-picking nominees, ${ }^{1534}$ while, more recently, Lorsch and MacIver also reported that CEOs wield major influence in nominating new board members. ${ }^{1535}$ Shivdasani and Yermack (1999) further found that stock market reaction to the independent director appointments was significantly negative when the CEO was involved in director selection. ${ }^{1536}$ Due to such allegations, many institutional investors have proposed for a long time that boards of directors should be chosen by a nominating committee composed solely of independent directors without the involvement of the CEO. In 2003, such a suggestion was adopted by the NYSE and NASDAQ as a requirement for their listed corporations.

However, the effectiveness of independent directors in nominating committees has been seldom explored by financial economists, probably due to the lack of proper indicators. So far, only a few empirical studies have addressed this issue. One approach is to examine the relationship between the presence of a nominating committee and firm performance; the other is to investigate the correlation between the level of nominating committee independence and firm performance.

\footnotetext{
${ }^{1533}$ Anil Shivdasani \& David Yermack, "CEO Involvement in the Selection of New Board Members: An Empirical Analysis" (1999) 54:5 Journal of Finance 1829 at 1829 [Shivdasani \& Yermack].

${ }_{1534}^{153}$ See Myles L Mace, Directors: Myth and Reality (Boston: Harvard Business School Press, 1971).

${ }^{1535}$ See Jay L Lorsch \& Elizabeth M MacIver, Pawns or Potentates? The Reality of America's Corporate Boards (Boston: Harvard Business School Press, 1989).

${ }^{1536}$ Shivdasani \& Yermack, supra note 1533 at 1830, 1846, 1852.
} 
Regarding the relationship between the existence of a nominating committee and firm performance, the findings of three studies appear to be divergent. Hayes, Mehran and Schaefer (2004) reported that the presence of a nominating committee had no impact on the market to book ratio (an indicator of firm performance), ${ }^{1537}$ while Chllahan, Millar and Schulman $(2003)^{1538}$ and Brick and Chidambaran (2007) found that the adoption of a separate nominating committee was significantly and negatively related to firm performance (Tobin's Q). ${ }^{1539}$ More specifically, Chllahan, Millar and Schulman (2003) reported that the existence of a separate nominating committee and lack of involvement of the CEO were associated with poorer subsequent firm performance, suggesting that a separate nominating committee may not be beneficial to the company. ${ }^{1540}$ In addition, Brick and Chidambaran (2007) observed that poorly performing firms were more likely to adopt a separate nominating committee, but such decisions had no impact on subsequent firm value within the year of the adoption. ${ }^{154}$ Taken together, it suggests that establishing a nominating committee did not lead to better firm performance. It is possible that the effort made by nominating committee members was not easily captured by firm performance indicators or the presence of a nominating committee was not an appropriate index to represent the function of a nominating committee.

With respect to the impact of the level of nominating committee independence on firm performance, the results appear to be consistent. Hayes, Mehran and Schaefer (2004) found that the degree of nominating committee independence (the proportion of outside directors on the nominating committee) was not related to firm performance (as measured by market to book ratio), ${ }^{1542}$ while the two studies of Brown and Caylor $(2006,2009)$ observed that a nominating committee composed solely of independent directors was not associated with current or subsequent firm performance (as measured by ROA, ROE and Tobin's Q). ${ }^{1543}$ Although Hayes, Mehran and Schaefer (2004) did not distinguish the effect between outside and independent

\footnotetext{
${ }^{1537}$ Hayes, Mehran and Schaefer, supra note 1489 at 19, 40-41 Table 13 Panel A.

${ }^{1538}$ The authors examined the correlation between management participation in the director selection process and corporate performance (Tobin's Q) by surveying 106 Fortune 1000 firms between 1990 and 1993. William T Callahan, James A Millar \& Craig Schulman, "An Analysis of the Effect of Management Participation in Director Selection on the Long-Term Performance of the Firm” (2003) 9:2 Journal of Corporate Finance 169 at 171 [Callahan, Millar \& Schulman].

${ }^{1539}$ Brick \& Chidambaran, supra note 1357 at $31,33$.

${ }^{1540}$ Callahan, Millar \& Schulman, supra note 1538 at 177-78, 180.

${ }^{1541}$ Brick \& Chidambaran, supra note 1357 at $31,33$.

${ }^{1542}$ Hayes, Mehran \& Schaefer, supra note 1489 at 19, 42-43 Table 13 Panel B.

${ }^{1543}$ Brown \& Caylor 2006, supra note 1027 at 419 Table 3, 421 Table 4, 422 Table 5; Brown \& Caylor 2009, supra note 1032 at $130,141-42$.
} 
directors or explore possible lagged effects, the findings of Brown and Caylor (2006, 2009), which have addressed these two problems, reached the same results. In total, nominating committee independence, regardless of its level, seems to have no significant impact on firm performance.

Taking the accumulated evidence together, the mere presence of a nominating committee was not associated with enhanced firm performance. A nominating committee composed of a higher proportion, or even solely, of independent directors also has no significant impact on firm performance. Perhaps, the real effect of independent directors in nominating committees, i.e. reducing management influence in the director selection process, was difficult to capture and might not be reflected in the measurement of firm performance. Further research is needed to determine how independent directors on the nominating committee mitigate management's influence on the director selection.

\subsubsection{Summary of Empirical Evidence regarding the Efficacy of Independent Directors on the Three Key Monitoring Committees}

This section examines the monitoring effect of independent directors on three key board committees, namely the audit, compensation and nominating committees. The results show that the quality of financial reporting was higher when audit committees consisted solely of independent directors and had at least one member with accounting expertise. However, the efficacy of the compensation committee was well below the public's expectation. Compensation committees with higher proportions, or composed entirely, of independent directors were not associated with lowered levels of CEO pay nor with CEO remuneration being tied to firm performance. As for the nominating committee, existing empirical evidence only showed that the level of nominating committee independence was not related to firm performance. Since the real effect of independent directors in nominating committees might not be fully reflected in the measurement of firm performance, more research is needed to determine whether independent directors can mitigate management's influence on director selection. 


\subsubsection{Evidence Regarding Other Governance Mechanisms Influencing the Effectiveness of Independent Directors}

The prior three subsections have explored the connection between director independence and overall firm performance, effectiveness in performing specific board tasks, as well as the efficacy of the three monitoring committees. In addition, other governance mechanisms may directly or indirectly complement, substitute for or diminish the effectiveness of independent directors. Some famous investor institutions ${ }^{1544}$ have proposed that gender and ethnic diversity, smaller boards, separating the CEO from board chair, fewer outside directorships for independent directors, more frequent board meetings, and greater director shareholdings would enhance the effectiveness of director independence; hence, increase shareholder wealth (or enhance shareholder interests). This section investigates the evidence regarding whether these governance mechanisms affect the efficacy of independent directors.

\subsubsection{Gender and Ethnic Diversity}

Greater board diversity in terms of improved female and minority representation has been proposed by major institutional investors ${ }^{1545}$ for a long time. ${ }^{1546}$ They argue that gender and ethnic diversity enriches board independence, which, therefore, enhances a board's ability to monitor management. Firms with diverse boards encourage new perspectives on problem solving and constructive dissent, leading to an improved quality of strategic decision-making. In addition, diverse directors provide access to important constituencies and resources in the external environment, which may raise the survival possibility of the company. The participation of women and minorities on the board also enhances a firm's creativity and

\footnotetext{
${ }^{1544}$ See the text accompanying infra notes 1545,1575 , and 1630.

${ }^{1545}$ For example, Interfaith Center on Corporate Responsibility (ICCR) and TIAA-CRFF have proposed or sponsored shareholder proposals that corporate boards should be composed of individuals who reflect diversity of gender, race and so forth since the late 1990s. National Association of Corporate Directors also made similar recommendations around the same time. David A Carter, Betty J Simkins \& W Gary Simpson, "Corporate Governance, Board Diversity, and Firm Value" (2003) 38 The Financial Review 33 at 34 [Carter, Simkins \& Carter 2003].

${ }^{1546}$ See also Janet McFarland, "Glacial Progress of Women on Canada's Boards Prompts Calls for Reform”, The Globe and Mail (26 November 2012), online: The Globe and Mail <http://www.theglobeandmail.com/report-onbusiness/careers/management/board-games-2012/glacial-progress-of-women-on-canadas-boards-prompts-calls-forreform/article5644350/>.
} 
innovation, which may improve the productivity and performance of the corporation. ${ }^{1547}$ Since board diversity has the above advantages, including women and minorities as independent directors may increase shareholder interests or firm performance. Thus, the connection between board diversity and shareholder interests (or firm performance) is worth exploring.

Approximately ten studies have examined the relationship between women (and/or minority) directors and indices of shareholder interests. However, most findings did not differentiate the effect of women (or minority) directors as independent directors from the effect of those as non-independent directors; only few of them did so. More specifically, most studies only reported whether women (or minority) directors had an impact on the indices of firm (or committee) performance, which combined the effect of women (or minority) independent, affiliated and inside directors on firm (or committee) performance. Without further differentiation, it is difficult to identify the real effect of women (or minority) independent directors on firm (or committee) performance. The following analysis first presents the connection between general female (or ethnic minority) directors and firm performance, and, then, explores whether such findings can be applied to female (or ethnic minority) independent directors.

In addition, some earlier studies did not address the causation between women (or minority) directors and firm performance; therefore, their findings allowed two possible explanations. Taking the positive relationship between women directors and firm performance as an example, it can be interpreted as indicating that more women directors lead to better firm performance; on the other hand, it is possible that better performing firms choose to add more women directors to their boards. Without further investigation, it is hard to decide their causation. The findings of Sharder, Blackburn and Iles (1997) ${ }^{1548}$ and Erhardt, Werbel and Shrader $(2003)^{1549}$ are typical examples.

Nevertheless, these studies have provided useful evidence regarding how women (or minority) directors, including women (or minority) independent directors, affect shareholder interests. This thesis analyzes the impact of female and ethnic minority directors on shareholder

\footnotetext{
${ }^{1547}$ Carter et al 2008, supra note 1033 at 6-9; Toyah Miller \& María del Carmen Triana, "Demographic Diversity in the Boardroom: Mediators of the Board Diversity -Firm Performance Relationship" (2009) 46:5 Journal of Management Studies 755 at 771-75 [Miller \& Triana].

${ }^{1548}$ Charles B Shrader, Virginia B Blackburn \& Paul Iles, "Women in Management and Firm Financial Performance: An Exploratory Study" (1997) 9:3 Journal of Managerial Issues 355 at 365 [Shrader, Blackburn \& Iles]. ${ }^{1549}$ Niclas L Erhardt, James D Werbel \& Charles B Shrader, "Board of Director Diversity and Firm Financial Performance" (2003) 11:2 Corporate Governance 102 at 105-06 [Erhardt, Werbel \& Shrader].
} 
interests from five perspectives: (1) the relationship between ethnic diversity on the board and firm performance; (2) the association between ethnic diversity on the three monitoring (audit, compensation and nominating) committees and firm performance; (3) the correlation between female directors on the board and firm performance; (4) the relationship between female directors on the three monitoring committees and firm performance; (5) the correlation between female directors and other discrete board tasks. Some observations will be made regarding the connection between independent women (or minority) directors and shareholder interests.

\subsection{The Relationship between Ethnic Minority Directors on the Board and Firm Performance}

The impact of ethnic diversity on firm performance is consistent. Three studies, Erhardt, Werbel and Shrader (2003), Carter, Simkins and Simpson (2003) and Carter et al. (2008), found that a higher level of board ethnic diversity (as measured by the presence or the fraction of minority directors on the board) was correlated with better firm performance ${ }^{1550}{ }^{1551}$ Carter et al. (2008) further reported that the causality ran from greater board racial diversity to higher firm performance. ${ }^{1552}$ Moreover, Millar and Triana (2009) observed that board racial diversity indirectly increased firm performance via the improvement of innovation and reputation. ${ }^{1553}$ However, the above findings combined the effect of minority independent and non-independent directors on firm performance. Whether boards with the presence or a higher proportion of minority independent directors were associated with greater firm performance is still unknown.

\subsection{The Association between Ethnic Minority Directors on the Three Monitoring Committees and Firm Performance}

\footnotetext{
${ }^{1550}$ In Erhardt, Werbel \& Shrader (2003), firm performance was measured by return on assets and return on income. Ibid at 106; In Carter, Simkins and Simpson (2003) and Carter et al. (2008), firm performance was measured by Tobin's Q. Carter, Simkins \& Carter 2003, supra note 1545 at 36, 43, 51; Carter et al 2008, supra note 1033 at 17. ${ }^{1551}$ Erhardt, Werbel \& Shrader, ibid at 107; Carter, Simkins \& Carter 2003, ibid at 36, 51; Carter et al 2008, ibid at 20-23.

${ }^{1552}$ Carter et al 2008, ibid at 22-23. The authors conjectured that the causality goes from gender diversity to firm performance, because the results showed that the correlation between gender diversity and firm performance is significant and positive when firm performance is the dependent variable, and this correlation becomes insignificant when gender diversity is the dependent variable. Ibid.

${ }^{1553}$ Miller \& Triana, supra note 1547 at 769, 774-75.
} 
The benefits of having ethnic minority directors have been found to extend to the three monitoring committees. Carter et al. (2008) reported that greater racial diversity in the three monitoring (audit, compensation and nominating) committees resulted in higher firm performance, rather than vice versa. ${ }^{1554}$ It is worth noting that the sample period in Carter $e$ al. (2008) was between 1998 and 2002. ${ }^{1555}$ The NYSE and NASDAQ have required audit committees composed solely of independent directors since 1999. As a result, the positive impact of audit committee minority directors on firm performance seemingly could be mostly attributed to the effort of minority independent directors on the audit committee. However, such an inference could not extend to minority directors on the compensation and nominating committees, because the complete independence of the two committees was not required by the NYSE or NASDAQ until 2003. In short, whether minority independent directors on the compensation committee or the nominating committee had a positive impact on firm performance was unclear, but minority independent directors sitting on the audit committee enhanced corporate performance. Ethnic minorities seem to be good candidates for positions as independent directors to serve on the audit committee.

\subsection{The Correlation between Female Directors on the Board and Firm Performance}

No consistent relationship has been found between female directors on the board and firm performance. Existing findings only focused on the effect of general female (or female outside) directors, rather than the effect of female independent directors. Farrell and Hersch (2005) reported that adding more female outside directors ${ }^{1556}$ to the boards had no significant impact on subsequent firm performance (return on assets), ${ }^{1557}$ while Shrader, Blackburn and Iles (1997) observed that boards with a higher percentage of female directors was not associated with improved firm performance. ${ }^{1558}$ In contrast, Erhardt, Werbel and Shrader (2003), Carter,

\footnotetext{
${ }^{1554}$ Carter et al 2008, supra note 1033 at 23. The authors investigated the correlation between female directors and firm performance by using a sample of Fortune 500 firms in the five year period from 1998 to 2002. Ibid at 18-19. 1555 Ibid at 18.

${ }^{1556}$ Outside directors in this study include independent and affiliated directors. Kathleen A Farrell \& Philip L Hersch, "Addition to Corporate Boards: The Effect of Gender" (2005) 11 Journal of Corporate Finance 85 at 96 [Farrell and Hersch].

1557 Ibid at 101 .

${ }^{1558}$ Shrader, Blackburn \& Iles, supra note 1548 at 364-65. Firm performance was measured by return on assets, return on income, return on sales and return on equity. Ibid at 361 .
} 
Simkins and Simpson (2003), and Carter et al. (2008) found that firms with greater board gender diversity (as measured by the presence or the percentage of female directors on the board) were associated with higher firm performance. ${ }^{1559}$ In addition to the positive correlation, Carter et al. (2008) further indicated that the direction of causation went from board gender diversity to firm performance rather than the inverse direction. ${ }^{1560}$ However, Adams and Ferreira (2009) reported that such a positive relation was not robust, ${ }^{1561}$ and the value of a gender-diverse board depended on the strength of the governance environment in the firm. ${ }^{1562}$ It is worth mentioning that the results of Farrell and Hersch (2005) combined the effect of female independent and affiliated directors on firm performance, while the findings of the rest of studies combined the effect of female independent, affiliated and inside directors on firm performance. This might be the reason why the results were so divergent. The real effect of female independent directors on firm performance is still unknown.

\subsection{The Correlation between Female on the Three Monitoring Committees and Firm Performance}

The influence of committee gender diversity on firm performance varies with the function of the committee. Carter et al. (2008) found that gender diversity had a positive impact on firm performance through women on the audit committee, but did not find a clear indication that firm performance was enhanced through women on the compensation or nominating committees. In addition to the positive impact, Carter et al. (2008) further indicated that the direction of causation went from female audit committee members to firm performance. ${ }^{1563}$ Although the results regarding whether audit committees with female directors were more likely to demand a higher audit effort from their auditors were mixed, ${ }^{1564} \mathrm{Gul}$, Srinidhi and Tsui (2008)

\footnotetext{
${ }^{1559}$ Erhardt, Werbel \& Shrader, supra note 1549 at 107; Carter, Simkins \& Carter 2003, supra note 1545 at 36, 50, 51; Carter et al 2008, supra note 1033 at 21.

1560 Carter et al 2008, ibid at 21-22.

${ }^{1561}$ Renée B Adams \& Daniel Ferreira, "Women in the Boardroom and Their Impact on Governance" (2009) 94 Journal of Financial Economics 291 at 305 [Adams \& Ferreira 2009].

1562 Ibid at 306-07.

1563 Carter et al 2008, supra note 1033 at 22-23.

${ }^{1564}$ Ferdinand A Gul, Bin Srinidhi \& Judy Tsui, "Board Diversity and the Demand for Higher Audit Effort" (February 2008) at 20, online: SSRN <http://ssrn.com/abstract=1359450> [Gul, Srinidhi and Tsui 2008]; Kim Ittonen, Johanna Miettinen \& Sami Vähämaa, "Does Female Representation on Audit Committees Affect Audit Fees?” (2008) at 2, 18-19, 22-23, online: SSRN < http://ssrn.com/abstract=1314243>.
} 
found that audit committees with female directors were more likely to demand higher audit effort from their auditors, while Ittonen, Miettinen and Vähämaa (2008) reported the opposite.

Nevertheless, Gul, Srinidhi and Tsui (2007) observed that audit committees with at least one female director were less likely to manage earnings. ${ }^{1565}$

It is worth noting that the sample periods in Carter et al. (2008) and Gul, Srinidhi and Tsui (2007) were 1998-2002 and 2001-02, ${ }^{1566}$ respectively. The audit committees in these two studies, subject to the 1999 NYSE and NASDAQ listing standards, have been required to consist solely of independent directors in most of the (or entire) sample periods. Therefore, the above positive impact that female directors on the audit committee have on firm performance and the quality of financial reporting seemingly came from the effort of female independent directors on the audit committee. ${ }^{1567}$

\subsection{The Relationship between Female and Other Discrete Board Tasks}

The impact of board gender diversity on discrete board tasks depend on the perspective adopted. Adams and Ferreira (2009) reported that female directors were more likely to dismiss incompetent CEOs and to attend board meetings in carrying out their duties, compared to their male counterparts. ${ }^{1568}$ On the other hand, they found that the proportion of female directors on the board had no significant impact on the proportion of CEO incentive pay ${ }^{1569}$ and the level of CEO compensation. ${ }^{1570}$ It is worth mentioning that the findings of Adams and Ferreira (2009) combined the effect of independent, affiliated and inside female directors on the specific board tasks. The real effect of independent directors on these jobs was still unclear. In addition, Levi, Li and Zhang (2008) reported that each 10\% representation of female directors on the boards of

\footnotetext{
${ }^{1565}$ Ferdinand A Gul, Bin Srinidhi \& Judy Tsui, "Do Female Directors Enhance Corporate Board Monitoring? Some Evidence from Earnings Quality" (September 2007) at 26, online:

$<$ http://www.isb.edu/AccountingResearchConference/File/GulSrinidhiTsui.pdfhttp://www.isb.edu/AccountingResea rchConference/File/GulSrinidhiTsui.pdf > [Gul, Srinidhi and Tsui 2007]. The authors examined the relationship between earnings quality and female directors on the board, as well as on the audit committee by employing a sample of about 1,200 firms during the years 2001-2002. Ibid at 21 .

${ }^{1566}$ Carter et al 2008, supra note 1033 at 18; Gul, Srinidhi and Tsui 2007, supra note 1565 at 21.

${ }^{1567}$ However, we do not know that firm performance or the quality of financial reporting would not have been as good or better if no independence criteria had been imposed.

${ }_{1568}$ Adams \& Ferreira 2009, supra note 1561 at 296, 301, 303.

1569 The proportion of CEO incentive pay is calculated by 1 - (salary + bonus)/ total CEO compensation. Ibid at 304 Table 8.

${ }^{1570} \mathrm{Ibid}$ at 303-04.
} 
corporations that were the targets of takeover bids was associated with a $15 \%$ reduction in the bid premium ${ }^{1571}$ during mergers and acquisition. ${ }^{1572}$ This study further showed that this negative economic impact of female directors was mainly associated with female independent directors rather than inside female directors. ${ }^{1573}$ The findings of this study seem to reveal that firms with more female independent directors may not be necessarily beneficial by this test.

\subsection{Summary}

Taking all the evidence together, whether minority and female independent directors on the board could enhance firm performance is still unclear. Firm performance was more likely to be better when a higher proportion of ethnic minority and female independent directors serve on the audit committee. However, no clear evidence was reported when ethnic minority and female independent directors served on the compensation and nominating committees. Female independent directors on the board were even harmful when their firms were the targets of takeovers. These findings indicated that ethnic minorities and females are good candidates to serve as independent directors on the audit committee, but female independent directors on the board during mergers and acquisitions might not be beneficial to shareholders. It is worth noting that except for Levi, Li and Zhang (2008) with a sample straddling SOX, all studies used pre-SOX samples.

\subsubsection{Director Ownership and Compensation}

As mentioned previously, independent directors are expected to play an active role in monitoring and advising top management. Since vigilant monitoring and advising require a substantial time commitment from independent directors to review a firm's affairs and management's performance, they may not be eager to do it without sufficient financial

\footnotetext{
${ }^{1571}$ It is worth mentioning that whether bid premiums are beneficial to target shareholders are still controversial. Please refer to supra notes 1155-1159 and accompanying text for further details.

${ }^{1572}$ Maurice Levi, Kai Li \& Feng Zhang, "Mergers and Acquisitions: The Role of Gender" (August 2008) at 1, 13, online: SSRN: 〈http://ssrn.com/abstract=1123735〉. The authors investigated whether the gender of corporate directors plays a role in the pricing of and returns on mergers and acquisitions by using a sample of 403 acquisition attempts for the period 1997-2006. Ibid at 7.

${ }^{1573}$ Ibid at $1,14$.
} 
incentives. ${ }^{1574}$ In order to align the interests of directors more closely with those of shareholders, many institutional investors and influential stockholder activists have called for minimum shareholdings or appropriate incentive programs, especially stock-based compensation, for independent directors to increase their willingness to engage in management oversight. ${ }^{1575}$ In the 1990s, stock grants and stock options were introduced to director compensation packages, in addition to the traditional cash retainer and attendance fees. ${ }^{1576}$ However, some scholars have cautioned against such a move, arguing that adopting stock-based compensation for independent directors may hurt shareholders more than it helps them. ${ }^{1577}$ Empirical studies have explored the above issues since the late 1980s. The existing evidence can be organized into three categories: first, the impact of director share ownership on firm performance; second, the influence of director incentive compensation on firm performance; third, the impact of director share ownership and incentive plans on the sensitivity of CEO turnover to firm performance.

\subsection{The Impact of Director Share Ownership on Firm Performance}

No consistent relationship has been found between all director share ownership and firm performance, but independent directors having stock ownership was reported to have a positive impact on firm performance. Two studies found that firms were likely to perform better when their directors had greater stock ownership (as measured by the dollar value of the median director's stock ownership) ${ }^{1578}$, while one study reported mixed results regarding the impact of stock ownership by all directors on firm performance. More specifically, Bhagat and Bolton

${ }^{1574}$ Cordeiro, Veliyath \& Neubaum 2005, supra note 375 at 83.

1575 TIAA-CRFF and the California Public Employees' Retirement System (CalPERS) support the idea that directors should maintain a minimum level of shareholdings in the firms they serve. In addition, the 1995 Blue Ribbon Commission on Director Compensation of the National Association of Corporate Directors recommended that corporations should adopt stock options and other equity-based compensation to align the interests of outside directors with those of shareholders. Ibid at 82; Gerety, Hoi \& Robin, supra note 375 at 47; Nikos Vafeas, "Operating Performance around the Adoption of Director Incentive Plans" (2000) 68 Economics Letters 185 at 185 [Vafeas 2000].

${ }^{1576}$ National Association of Corporate Directors recommended that firms should remunerate their outside directors mainly by stock-based compensation, rather than cash compensation around the year 1995. Cordeiro, Veliyath \& Neubaum 2005, ibid at 84.

${ }^{1577}$ Stock-based compensation can dilute outside stockholder claims by reducing their proportional ownership, earnings and dividends. In addition, directors holding stock grants and options may also initiate stock buyback to achieve price increases that meet a set option exercise price even when firms perform poorly. Ibid at 87; Fich \& Shivdasani 2005, supra note 36 at 2231-32; Cordeiro, Veliyath \& Romal 2007, supra note 502 at 1384.

${ }^{1578}$ The authors take the median director's shareholdings as the ownership measure because this individual can be viewed as having the swing vote in governance-related matters. Bhagat \& Bolton 2008, supra note 1020 at 261. 
(2008) found that director stock ownership was significantly and positively correlated with contemporaneous and subsequent ROA (with a sample period mostly before the enactment of SOX), ${ }^{1579}$ while their 2009 study reported similar results for firms in both pre-SOX and postSOX periods. ${ }^{1580}$ However, Bhagat, Carey and Elson $(1999)^{1581}$ observed that the dollar value of the median director's stock holdings was positively related to the company's subsequent sales growth and income growth, but was negatively associated with ROA and stock return. There is no consensus regarding the impact of stock ownership by all directors on firm performance.

It is worth noting that these findings combined the effect of independent and nonindependent director share ownership on firm performance. They (the results for all directors) may not be applied to independent directors without further investigation, since the findings of Hambrick and Jackson (2000) have shown that the effect of equity holdings on firm performance was different between outside and inside directors (detailed findings are reported in the next paragraph). ${ }^{1582}$ Therefore, the finding of the above three studies cannot demonstrate whether independent directors with higher shareholdings could lead to greater firm performance.

In contrast, four studies reported that independent or outside directors having greater shareholdings were associated with better firm performance. Morck, Shleifer and Vishny (1988) found a significant and positive correlation between outside director share ownership ${ }^{1583}$ and current and next year's firm performance (as measured by Tobin's Q), ${ }^{1584}$ but the correlation was not monotonic. Firm performance increased as outside director share ownership rose from $0 \%$ to $5 \%$ of the total equity. When share ownership rose from $5 \%$ to $25 \%$, firm performance fell. Firm performance increased again as share ownership rose beyond $25 \%{ }^{1585}$ In addition, Hambrick and Jackson (2000) ${ }^{1586}$ reported that outside directors (not defined) ${ }^{1587}$ in firms that

${ }^{1579}$ Bhagat \& Bolton 2008, supra note 1020 at 258, 267, 271.

${ }^{1580}$ Bhagat \& Bolton 2009, supra note 1021 at 19, 44 Table VI.

${ }^{1581}$ Sanjai Bhagat, Dennis C Carey \& Charles M Elson, "Director Ownership, Corporate Performance and Management Turnover" (1999) 54 Bus Law 885 [Bhagat, Carey \& Elson]. The authors investigated the correlation between firm performance and director ownership by using a sample of 449 firms from 1990 to 1995 . Ibid at 904 .

1582 Hambrick \& Jackson, supra note 377 at 115-16.

${ }^{1583}$ In this study, outside director ownership only excludes the holdings of the two top senior inside directors (usually the chairperson and the president), but still includes the holdings of other inside directors (such as vicepresidents). Strictly speaking, the effect of "outside director ownership" is not pure. However, the authors considered that such classification was unlikely to make much difference, since these inside director generally owned very little stock. Morck, Shleifer \& Vishny, supra note 374 at 308.

${ }^{1584}$ Ibid at 302

1585 Ibid at 308 .

${ }^{1586}$ The authors investigated whether the equity holdings of outside directors were associated with subsequent firm performance by using a sample of firms drawn from Project Evergreen for the years 1987, 1992 and 1996. They 
successively outperformed their industries had greater equity holdings than their counterparts in firms that apparently lagged behind their industries. The results held for three different ownership indicators ${ }^{1588}$ and the causation ran from equity holdings to firm performance. ${ }^{1589}$ However, no similar correlation was found for inside directors. ${ }^{1590}$ It demonstrated that the effect of equity holdings on firm performance was indeed different between outside (not defined) and inside directors. Moreover, Klein (1998) reported a positive relationship between corporate performance and the presence of at least one independent director holding at least 5 percent of the firm's equity, ${ }^{1591}$ while Bhagat and Black (2002) observed that independent directors who hold significant stock positions enhanced firm performance, but other independent directors did not. ${ }^{1592}$ Although these two studies did not identify the causation of their findings, the results of similar studies-Morck, Shleifer and Vishny (1988) and Hambrick and Jackson (2000) which did control for causation - appear to suggest that it is that independent directors with greater shareholdings lead to better firm performance, rather than vice versa. Taken together, it seems that firms were more likely to perform better when their independent or outside directors had a higher proportion of shareholdings. ${ }^{1593}$

\subsection{The Impact of Director Incentive Compensation on Shareholder Interests}

The impact of director incentive compensation on firm performance varies with the content of incentive compensation. Three studies found that the adoption of stock-option

targeted firms with excellent performance and firms with poor performance for two five-year periods, 1987-1991 and 1992-1996, and then traced these firms' outside director ownership structure back to the years 1987 and 1992. Hambrick \& Jackson, supra note 377 at 113.

${ }^{1587}$ The authors do not define outside directors in this study. Their findings may represent the effect of either independent or outside directors.

${ }^{1588}$ Outside director ownership is measured by the percentage of firm share owned by outside directors, the dollar value of each outside director's holdings, and the number of outside directors who hold significant stakes.

Hambrick \& Jackson, supra note 377 at 114, 116.

${ }^{1589}$ Ibid.

1590 Ibid at 116.

${ }^{1591}$ Klein 1998, supra note 501 at 277, 293. The author found that the presence of at least one independent director holding at least 5 percent of a firm's equity was marginally related to one out of three firm performance indicators (significant for Jensen Productivity, but not for ROA and market return). Ibid.

${ }^{1592}$ Bhagat \& Black 2002, supra note 1 at 265-66. However, the authors did not describe what "significant stock position" means.

${ }^{1593}$ The findings of Morck, Shleifer and Vishny (1988) and Hambrick and Jackson (2000) controlled the causation between director ownership and firm performance. They both showed that independent (or outside) directors with greater shareholdings lead to better firm performance. 
compensation plans for independent (or outside) directors were significantly and positively associated with better firm performance, while two of the above three studies also reported that stock grants for outside directors had a similar, but weaker, positive impact on firm performance. However, another two studies observed that the adoption of stock-based compensation combining stock grants and stock options for outside directors had no impact on subsequent firm performance. Thus, there is no consensus about whether granting independent directors stock options or stock grants are necessarily beneficial to their firms. In addition, some studies reported that granting stocks or stock options to independent directors increase the likelihood of collusion between executives and independent directors. Monitoring benefits of independent directors' may decrease or even become negative. Overall shareholder wealth may suffer. Collectively, the adoption of incentive compensation plans for independent directors, regardless of whether one focuses on stock options, stock grants or combining both, is not necessarily beneficial to shareholders. In other words, the adoption of incentive compensation plans for independent directors may not necessarily enhance the effectiveness of independent directors. Further details are analyzed in the following subsections.

\subsection{The Impact of Stock Options for Independent Directors on Shareholder Interests}

Fich and Shivdasani (2005) reported that the presence of a stock-option plan for independent directors ${ }^{1594}$ was significantly and positively correlated with several firm performance indicators, ${ }^{1595}$ while Cordeiro, Veliyath and Neubaum $(2005){ }^{1596}$ and Corderio, Veliyath and Romal (2007) ${ }^{1597}$ found a similar relationship between stock options ${ }^{1598}$ for outside

\footnotetext{
${ }^{1594}$ In this study, directors who are full-time employees of the firm are defined as inside directors. Directors who: (1) are associated with the firm, (2) were former employees, (3) have existing family or commercial ties with the firm other than their directorship, and (4) have interlocking directorships with the CEO are designated as gray directors. Directors who do not fit the description for inside or gray are classified as independent directors. Fich \& Shivdasani 2005, supra note 36 at 2233.

${ }^{1595}$ Ibid at 2240, 2243. The authors use market-to-book ratio and three accounting performance measures-return on assets, return on sales and asset turnover-to examine the relationship between the presence of a stock-option plan and firm profitability. The results were quantitatively similar. Ibid.

${ }^{1596}$ The authors investigated the correlation between stock-grant ratio, as well as stock-option ratio and subsequent performance by using a sample 450 S\&P 500 firms during the period 1995-1997. Cordeiro, Veliyath and Neubaum 2005, supra note 375 at 84.

${ }^{1597}$ The authors explored how the correlation between outside director ownership and firm performance was likely to vary with the level of firm's investment opportunities and external monitoring environment by using the same data in Cordeiro, Veliyath and Neubaum (2005). Cordeiro, Veliyath \& Romal 2007, supra note 502 at 1387.
} 
directors (not defined) ${ }^{1599}$ and subsequent firm performance (as shown by stock returns and Jensen's Alpha). ${ }^{1600}$ In addition, Fich and Shivdasani (2005) found that investors and equity analysts responded favorably to the announcement of the adoption of stock-option plans for independent directors. ${ }^{1601}$ They also observed that market reactions (as measured by cumulative abnormal returns) to independent director appointments were significantly negative when firms did not offer stock-option compensation for independent directors. However, the cumulative abnormal returns turned close to zero for firms with stock-option plans. ${ }^{1602}$ Taken together, the adoption of stock-option compensation for independent directors seems to be (or is perceived to be) beneficial to shareholders.

In addition, several factors were reported to influence the effect of stock-option compensation on firm performance. Corderio, Veliyath and Romal (2007) found that the effect of stock-option compensation for outside directors (not defined) on firm performance was significantly stronger when firms had higher investment opportunities and weaker external monitoring environments ${ }^{1603}$, in comparison to firms with lower investment opportunities and stronger monitoring environment. ${ }^{1604}$ Fich and Shivdasani (2005) also observed that the effect of stock-option compensation on firm performance was close to zero when independent directors owned $5 \%$ or more of the firm's outstanding shares. ${ }^{1605}$ These results demonstrated that the effect of stock-option compensation on firm performance was likely to be enhanced if firms had higher investment opportunities, weaker external monitoring environments and less existing director share ownership.

It is worth mentioning that stock options for independent directors may have also been found to have their disadvantages in terms of shareholder wealth. Ronen, Tzur and Yaari

\footnotetext{
${ }^{1598}$ Stock options in this study are calculated by the dollar stock-option compensation to total dollar director compensation. Ibid.

${ }^{1599}$ The authors do not define outside directors in both 2005 and 2007 studies. Outside directors in these two studies seem to include independent and affiliated directors from the context. Cordeiro, Veliyath \& Neubaum 2005, supra note 375 at 84-85; Cordeiro, Veliyath \& Romal 2007, supra note 502 at 1388.

${ }^{1600}$ Cordeiro, Veliyath \& Neubaum 2005, ibid at 86-87; Cordeiro, Veliyath \& Romal 2007, ibid at 1388, 1389 Table 2.

${ }^{1601}$ Fich and Shivdasani 2005, supra note 36 at 2245-46. The authors found a significant and positive three-day mean cumulative abnormal return associated with the announcements of the adoption of stock-option plans.

${ }^{1602}$ Ibid at 2230, 2247, 2250, 2252.

${ }^{1603}$ The level of external monitoring is estimated by a composite index using the measures of: (1) the number of security analysts following the firms; (2) institutional ownership; and (3) firm leverage (measured as long-term debt to total assets which is gathered from Compustat). Cordeiro, Veliyath \& Romal 2007, supra note 502 at 1388.

${ }^{1604}$ Ibid at $1388-90$.

${ }^{1605}$ Fich and Shivdasani 2005, supra note 36 at 2241-42.
} 
$(2006)^{1606}$ found that stock options induced directors to tacitly collude with executives in the manipulation of earnings. ${ }^{1607}$ In addition, Bebchuk, Grinstein and Peyer (2010) and Byard and $\mathrm{Li}$ (2003) reported that independent directors were less likely to constrain CEO total compensation or to reduce CEOs' timing opportunism ${ }^{1608}$, when they also received the same lucky option grants ${ }^{1609}$ as the CEO did. ${ }^{1610}$ Further details were discussed in section 3.2.2.2. Taking the findings in this paragraph together, granting stock options to independent directors may increase the likelihood of collusion between executives and independent directors, and, thus, can undermine independent directors' monitoring integrity. Shareholder wealth may therefore suffer.

In combination with findings in the previous three paragraphs, granting stock options to independent directors has its advantages and disadvantages. The effectiveness of independent directors is not necessarily enhanced by granting them stock options and depends on the circumstances.

\subsection{The Impact of Stock Grants for Independent Directors on Shareholder Interests}

Regarding the connection between stock grants for outside directors and firm performance, Cordeiro, Veliyath and Neubaum (2005) and Corderio, Veliyath and Romal (2007) found that stock grants ${ }^{1611}$ for outside directors (not defined) were only significantly and positively associated with one out of two firm performance measures in their studies. ${ }^{1612}$ In contrast, both studies reported a similar relationship between stock options and two subsequent performance measures. The results seem to show that stock options and stock grants both led to better firm performance, but the effect of stock options for outside directors (not defined) on firm performance appears to be stronger than that of stock grants. However, as noted, Ronen, Tzur \&

\footnotetext{
${ }^{1606}$ Ronen, Tzur \& Yaari, supra note 508 at 360.

${ }^{1607}$ Ibid at 362, 380. The results of Ronen, Tzur and Yaari (2006) were generated from a model designed by the authors, not from empirical research.

${ }^{1608}$ Timing opportunism refers to the opportunistic practice where CEOs increase the value of their option grants by lowering their firms' stock prices on days when they receive option grants. Byard \& Li, supra note 514 at 1.

${ }^{1609}$ Lucky grants in these two studies refer to grants for which the exercise price is based on the lowest trading price of the underlying security during a month. Ibid; Bebchuk, Grinstein \& Peyer, supra note 511 at $2364,2368$.

${ }^{1610}$ Ibid at 1-2, 29; Bebchuk, Grinstein \& Peyer, supra note 511 at 2365, 2387, 2399.

1611 Stock grants are counted by the dollar stock grant compensation to total dollar director compensation. Cordeiro, Veliyath \& Neubaum 2005, supra note 375 at 84.

1612 Ibid at 86.
} 
Yaari (2006) found that stock grants also induced directors to tacitly collude with executives in the manipulation of earnings. ${ }^{1613}$ Therefore, granting outside directors (not defined) corporate stocks, similar to the effect of granting them stock options, does not necessarily benefit their firms and shareholders and depends on the circumstances.

\subsection{The Impact of Incentive Plans Combining Stock Options and Stock Grants on Shareholder Interests}

Two studies reported that outside director compensation combining stock grants and stock options either had no impact on firm performance or were not perceived positively by investors. Hempel and Fay (1994) found that firms with stock-based compensation plans (including stock grants and stock options) for outside directors (not defined) ${ }^{1614} \mathrm{did}$ not perform ${ }^{1615}$ better than firms without such plans, regardless of whether it was the same year or several years following the plan adoption. ${ }^{1616}$ Gerety, Hoi and Robin (2001) ${ }^{1617}$ also observed that stock markets only reacted neutrally to the adoption of incentive plans ${ }^{1618}$ for outside directors ${ }^{1619}{ }^{1620}$ This finding suggests that shareholders did not consider that they significantly benefit from the adoption of incentive compensation (combining stock options and stock grants) for outside directors. ${ }^{1621}$ Therefore, similar to the effect of granting independent directors stock

${ }^{1613}$ Ronen, Tzur \& Yaari, supra note 508 at 362, 380.

1614 The authors do not define "outside directors".

${ }^{1615}$ Firm performance was measured by earnings per share. Paul Hempel \& Charles Fay, "Outside Director Compensation and Firm Performance" (1994) 33:1 Human Resource Management 111 at 119.

1616 Ibid at 123, 127. The authors examined the correlation between board compensation and firm performance by using a sample of 235 Fortune 250 firms for the years 1986 and 1990. Ibid at 113.

1617 The authors used stock market reaction, instead of a firm's accounting performance to assess whether shareholders benefit from the adoption of incentive plans for outside directors by surveying a sample of 289 firms that made incentive compensation proposals for directors during the period 1988 to 1998. Gerety, Hoi \& Robin, supra note 375 at 49.

${ }^{1618}$ Incentive plans in this study include gravy plans, option plans, stock award plans and restricted share plans. Ibid at 53 Table III.

${ }_{1619}$ Outside directors are defined as directors who are not employees in the firm. Ibid at 55 Table IV.

${ }^{1620}$ Three-day cumulative abnormal returns (a proxy for stock market reaction) was only $-0.27 \%$ and statistically insignificant. Ibid at 54.

${ }^{1621}$ Some may argue that the findings of Gerety, Hoi and Robin (2001) are inconsistent with those of Fich and Shivdasani (2005) that investors responded favorably to the adoption of stock-option plans for independent directors. See Fich \& Shivdasani 2005, supra note 36 at 2245-46. The inconsistency between the two studies may be due to the differences in sample size, sample periods, the subjects of the incentive plan (outside directors $v s$. independent directors), and the contents of the incentive plan (stock options plus stock grants $v s$. stock options alone). Gerety, 
options or stock grants, the adoption of incentive compensation (combining stock options and stock grants) for outside directors is not necessarily beneficial.

\subsection{The Relationship between Director Share Ownership (or Incentive Pay) and the Sensitivity of CEO Turnover to Firm Performance}

Empirical results show a positive impact of director share ownership (or incentive pay) on the sensitivity of CEO turnover to firm performance, regardless of whether all directors or independent directors are examined. Bhagat, Carey, and Elson (1999), Bhagat and Bolton (2008) and Bhagat and Bolton (2009) all reported that directors holding greater equity (as measured by the dollar value of the median director's stock ownership) were more likely to replace the CEO when the firm performed poorly. ${ }^{1622}$ Bhagat and Bolton (2009) further found that the results remained unchanged after the implementation of SOX-related reforms. ${ }^{1623}$ However, again, these findings combined the effect of share ownership by independent and non-independent directors on the sensitivity of CEO turnover to firm performance. The results for all directors may not be applicable to independent directors without further investigation. Whether independent directors with higher shareholdings could discipline the poorly performing CEO is still unknown based on the above three studies.

In contrast, Perry (2000) found that board independence and director incentive compensation (including stock grants and stock options) ${ }^{1624}$ both influenced the sensitivity of CEO turnover to firm performance. ${ }^{1625}$ Boards with at least $60 \%$ independent directors (regardless of whether or not they received incentive compensation) and boards with less than $60 \%$ independent directors but having incentive pay were both inclined to remove poorly

Hoi and Robin (2001) focused on 283 proposals of equity-based compensation plans (including stock options and stock grants) for outside directors (including affiliated and independent directors) between 1988 and 1998, while Fich and Shivdasani (2005) concentrated on 112 adoptions of stock-option plans for only independent directors between 1997 and 1999. Ibid at 2244-45; Gerety, Hoi \& Robin, supra note 375 at 54-55.

${ }^{1622}$ Bhagat, Carey \& Elson, supra note 1581 at 909-11; Bhagat \& Bolton 2008, supra note 1020 at 270; Bhagat \& Bolton 2009, supra note 1021 at 23. In Bhagat, Carey, and Elson (1999), the results remained significant for four out of five performance measures (significant for 3-year growth in earnings per share, 1-year stock returns, 3-year stock returns and 5-year stock returns, except for 5-year growth in earnings per share). Bhagat, Carey \& Elson 1999, ibid at 909-11. In Bhagat and Bolton (2008) and Bhagat and Bolton (2009), firm performance was measured by the past two year's stock returns. Bhagat \& Bolton 2008, ibid; Bhagat \& Bolton 2009, ibid.

${ }_{1623}$ Bhagat \& Bolton 2009, ibid at 24.

${ }^{1624}$ Perry, supra note 379 at 4.

1625 Ibid at 19. 
performing CEOs. Only boards with less than $60 \%$ independent directors but without incentive compensation were not associated with linking CEO turnover to firm performance. ${ }^{1626}$ Among the above boards which were sensitive to firm performance in replacing the CEO, the most sensitive one was the board having at least $60 \%$ independent directors in combination with incentive compensation. ${ }^{1627}$ These results suggest that board independence was the key factor in protecting shareholder interests by removing an under-performing CEO. With the addition of director incentive compensation, the effectiveness of independent directors was increased. The findings of Perry (2000) show that the director incentive plans play an active role in improving the monitoring effect of independent directors. In combination with the findings in the last paragraph, it would seem that independent directors were more likely to discipline a poorly performing CEO when they had incentive compensation plans (combining stock options and stock grants).

\subsection{Summary}

Taken together, empirical evidence showed that firms were more likely to perform better when their outside (or independent) directors had greater shareholdings. However, the adoption of stock-based compensation plan for independent (or outside) directors, regardless of whether stock options, stock grants or both were considered, did not necessarily benefit the firm or its shareholders. In addition, the sensitivity of CEO turnover to firm performance was inclined to be enhanced when independent directors were awarded with incentive compensation (combining stock options and stock grants). Since incentive compensation plans with stock grants or stock options in some cases may damage shareholder interests and no empirical evidence so far shows independent directors having greater shareholdings are harmful, firms may consider nominating candidates who hold a certain percentage of share ownership as independent directors, in order to align their interests with those of shareholders. It is worth noting that all studies mentioned in this section used pre-SOX samples.

\footnotetext{
${ }^{1626}$ Ibid.

${ }^{1627}$ Ibid at 17-18, 19.
} 


\subsubsection{Multiple Directorships}

Whether a director holding multiple outside directorships benefits or harms corporate value has been debated for a long time. Supporters of the reputation hypothesis contend that multiple directorships are advantageous because they can enhance directors' experience, broaden their business network and further certify their ability. By serving on many other boards, directors are said to learn about different management styles and strategies used in other firms. They also have more opportunities to get acquainted with executives in other corporations, which therefore expand their business network. In addition, firms usually offer board seats for individuals where the companies they serve as directors or executives enjoyed superior performance in the past. These imply that the more directorships a director holds, the higher quality the director signals. ${ }^{1628}$

On the other hand, proponents of the busyness hypothesis argue that a director's time and effort are limited, so directors holding multiple board seats may be overcommitted and may be unable to perform their monitoring function effectively. Poor managerial oversight may create the potential for many kinds of abuses that destroy firm value. ${ }^{1629}$ In light of the disadvantages of busyness, The National Association of Corporate Directors (NACD) suggests that directors with full-time positions should not serve on more than three or four other boards. The Council of Institutional Investors (CII) contends that full-time directors should not hold more than two outside board seats. ${ }^{1630}$

Since the trend of modern companies is to place more independent directors on their boards, whether a candidate for independent director holding multiple directorships is an asset or disadvantage for the company is an issue worth exploring. Empirical studies have used firm performance, stock market reaction, incidence of fraud litigation, board meeting attendance and the number of committee memberships as proxies to measure the impact of multiple

\footnotetext{
${ }^{1628}$ Ferris, Jagannathan \& Pritchard, supra note 1122 at 1089; Tod Perry \& Urs Peyer, "Board Seat Accumulation by Executives: A Shareholder's Perspective" (2005) 60 The Journal of Finance 2083 at 2084 [Perry \& Peyer]; Fich \& Shivdasani 2006, supra note 1240 at 693; Pornsit Jiraporn, Young Sang Kim \& Wallace N Davidson III, "Multiple Directorships and Corporate Diversification" (2008) 15 Journal of Empirical Finance 418 at 419, 420 [Jiraporn, Kim \& Davidson]; Pornsit Jiraporn et al, “Too Busy to Show Up? Analysis of Directors' Absences” (2009) 49 The Quarterly Review of Economics and Finance 1159 at 1160 [Jiraporn et al]; Pornsit Jiraporn, Manohar Singh \& Chun I Lee, "Ineffective Corporate Governance: Director Busyness and Board Committee Memberships" (2009) 33 Journal of Banking \& Finance 819 at 820 [Jiraporn, Singh \& Lee].

${ }^{1629}$ Ferris, Jagannathan \& Pritchard, ibid at 1088; Perry \& Peyer, ibid; Fich \& Shivdasani 2006, ibid; Jiraporn, Kim \& Davidson, ibid at 419, 421; Jiraporn et al, ibid; Jiraporn, Singh \& Lee, ibid at 820-21.

${ }^{1630}$ Ferris, Jagannathan \& Pritchard, supra note 1122 at 1087.
} 
directorships on the efficacy of independent directors. Existing evidence concerning this issue can be divided into four categories: (1) the impact of independent directors holding multiple directorships on firm value; (2) shareholder reaction to the appointment of a busy independent director; (3) the correlation between committee service and independent directors holding multiple board seats; (4) the relationship between other factors and independent directors holding multiple board seats.

\subsection{The Impact of Independent Directors Holding Multiple Directorships on Firm Value}

Empirical evidence is inconsistent regarding the impact of independent directors holding multiple directorships on firm value. One study reported that outside directors with multiple directorships had no impact on firm performance, while two studies observed that firms with independent directors holding multiple board seats were more likely to perform more poorly. More specifically, Ferris, Jagannathan and Pritchard (2003) ${ }^{1631}$ found that outside directors ${ }^{1632}$ with multiple board seats (as measured by the average number of directorships held by outside directors) ${ }^{1633}$ in 1995 had no significant impact on firm performance (market-to-book ratio) in 1997. ${ }^{1634}$ This result suggests that outside directors holding multiple board seats did not impair future corporate value. In contrast, Fich and Shivdasani (2006) ${ }^{1635}$ reported that the presence of busy ${ }^{1636}$ independent directors ${ }^{1637}$ (regardless of whether measured by proportion or majority) on the board was negatively and significantly related to firm value (market-to-book ratio) for the current period, the next one-year period and the next two-year period. ${ }^{1638}$ The results remained robust after applying different firm performance indicators, including return on assets, sales over

\footnotetext{
${ }^{1631}$ The authors examined the relationship between multiple directorships and firm performance as well as market reaction by using a sample of 3,190 firms for the year 1995. Ibid at 1090-91.

${ }^{1632}$ Outside directors are defined as directors who are not currently employed by the firm. Ibid at $1091 \mathrm{n} 1$.

${ }^{1633}$ Ibid at 1091.

1634 Ibid at $1100-01$.

${ }^{1635}$ The authors examined whether busy boards had an impact on firm performance and CEO turnover by using a sample of 508 Forbes 500 firms in 1992 during the period from 1989 to 1995. Fich \& Shivdasani 2006, supra note 1240 at 695.

1636 The authors consider independent directors busy if they serve on three or more boards, and regard the board busy if 50\% or more of the board's independent directors are busy. Ibid at 695-97.

${ }^{1637}$ In this study, inside directors are full-time employees of the firm. Gray directors are defined as directors: (1) who are associated with the firm, (2) who are former employees, (3) who have existing family or commercial ties with the firm other than their directorship, or (4) who have interlocking directorships with the CEO. Directors who do not fit the description for inside or gray directors are classified as independent directors. Ibid at 695 .

${ }^{1638}$ Ibid at 691, 701, 703-05.
} 
assets (asset turnover ratio) and return on sales. ${ }^{1639}$ The findings of Fich and Shivdasani (2006) suggest that the more busy independent directors serve on the board, the worse the firm performs. The divergent results of the two studies may come from the different definition of "director busyness." Ferris, Jagannathan and Pritchard (2003) used the average number of directorships held by outside directors to measure "director busyness", while Fich and Shivdasani (2006) examined the same concept by using whether an independent director serves on three or more boards and whether a majority of independent directors hold three or more board seats. The approach adopted by Ferris, Jagannathan and Pritchard (2003) may not reveal how busy the whole board is, because there is a wide dispersion in the number of board seats held by independent directors, according to Fich and Shivdasani (2006). ${ }^{1640}$

Two years later, Jiraporn, Kim and Davidson (2008) ${ }^{1641}$ observed that the busyness of independent directors ${ }^{1642}$ was significantly and negatively related to firm value (as proxied by excess value $\left.{ }^{1643}\right),{ }^{1644}$ regardless of whether director busyness was as defined by Ferris, Jagannathan and Pritchard (2003) or Fich and Shivdasani (2006). ${ }^{1645}$ The causality of the results ran from busy independent directors to reduced firm value, rather than vice versa. ${ }^{1646}$ The findings of this study imply that overcommitted independent directors were more likely to diminish firm value. Collectively, after considering the problem of the definition of director busyness in Ferris, Jagannathan and Pritchard (2003), it appears that corporate value was less likely to be enhanced when independent directors held too many directorships.

Moreover, Jiraporn, Kim and Davidson (2008) further found that the impact of multiple directorships on firm performance was influenced by the governance environment (as measured

\footnotetext{
${ }^{1639}$ Ibid at 701-03.

${ }^{1640}$ Ibid at 694; Jiraporn, Kim \& Davidson, supra note 1628 at 422 n 10. It is worth noting that the significant correlation between director busyness and firm value in Fich and Shivdasani (2006) disappeared, if they adopted Ferris, Jagannathan and Pritchard's definition of a busy director. Fich \& Shivdasani 2006, ibid at 701.

${ }^{1641}$ The authors investigated the impact of multiple directors on corporate diversification by surveying a sample of 3,605 firm-year observations from 1998 to 2002. Jiraporn, Kim \& Davidson, supra note 1628 at 422.

1642 The authors did not define independent directors in this study.

${ }^{1643}$ Excess value is an indicator to represent whether the firm is worth more than the sum of its segments. A positive excess value indicates a diversification premium while a negative excess value implies a diversification discount. Jiraporn, Kim \& Davidson, supra note 1628 at 419-21.

1644 Ibid at 427.

1645 The authors employed three approaches to measure the busyness of independent directors. The first measure is the number of outside directorships per independent director. The second measure is the percentage of busy independent directors (holding three or more board seats) on the board. The third measure is whether more than $50 \%$ of independent directors on the board are busy. The first measured was used by Ferris, Jagannathan and Pritchard (2003), while the last two were employed by Fich and Shivdasani (2006). Ibid at 422.

${ }^{1646}$ Ibid at 433.
} 
by the Governance Index ${ }^{1647}$ developed by Gompers et al.) in the firm. More specifically, the variables representing busyness of independent directors were negatively and significantly correlated with firm value for firms with high Governance Index scores (representing poor governance environment); however, such a correlation became insignificant when firms had low Governance Index scores. ${ }^{1648}$ These findings imply that a good governance environment can mitigate the impact of director busyness on firm value; and, as a result, protect the interests of shareholders.

\subsection{Market Reaction to the Appointment of a Busy Independent Director}

Results regarding shareholder reaction to the appointment of a busy (independent) director have been mixed. One study reported a positive investor reaction, while the other found a negative response. More specifically, Ferris, Jagannathan and Pritchard (2003) found a positive, but insignificant, market reaction (as measured by abnormal returns) for announcing an appointment of a busy director ${ }^{1649}$ to the board. ${ }^{1650}$ After dividing their sample into two subsamples ${ }^{1651}$, the authors observed that the market reaction remained unchanged for adding an additional busy director to its board when the firm already had busy directors. However, market reaction became positive and significant when a firm appointed a busy director to its board for the first time. ${ }^{1652}$ Collectively, Ferris, Jagannathan and Pritchard (2003) found that market participants did not consider that the appointment of busy directors impaired firm value.

In contrast, Fich and Shivdasani (2006) reported that the average abnormal returns (a proxy for market reaction) was $-1.04 \%$, if independent directors became busy (holding three or

\footnotetext{
${ }^{1647}$ The Governance Index (G Index) is an index developed by Professors Gompers, Ishii and Metrick to measure the strength of shareholder rights. A higher score for Governance Index signifies that a firm is more insulated from takeovers and its shareholder rights are more suppressed, and therefore its agency problems are expected to be more serious. Ibid at 428-29; Gompers, Ishii \& Metrick, supra note 1191 at 109, 112.

1648 Jiraporn, Kim \& Davidson, ibid.

${ }^{1649}$ A director is considered to be a busy director, if he/she holds three or more directorships in sample firms. Ferris, Jagannathan \& Pritchard, supra note 1122 at 1091, 1103 Table VI.

${ }^{1650}$ Regarding this issue, the authors performed an event study to measure the announcement effect of the appointment of a busy director to a company's board by observing 291 such announcements from 1990 to 1995 in a two-day announcement period. Ibid at 1101.

${ }^{1651}$ The authors divided their sample into two subsamples: (1) firms with busy directors adding an additional busy director to their boards; and (2) firms without busy directors appointing a busy director to the board for the first time. Ibid at $1102-03$.

${ }^{1652}$ Ibid at 1101-03.
} 
more board seats) following the appointment. However, the average abnormal returns became trivial (-0.1\%) and insignificant, if independent directors were not busy following the appointment. ${ }^{1653}$ These results suggest that shareholders more negatively perceived an appointment that caused an independent director to become busy. Moreover, the authors found that the average abnormal returns (market reaction) related to the departure of busy independent directors were larger than those related to the departure of non-busy counterparts. ${ }^{1654}$ Similarly, the average abnormal returns were larger when boards with a majority of independent directors were not busy after the departure of a busy independent director, compared to the situation where a majority of independent directors remained busy. ${ }^{1655}$ These findings imply that the departure of busy independent directors was favored by investors.

It is worth mentioning that the subjects of the above two studies were different. The findings in Ferris, Jagannathan and Pritchard (2003) were focused on general directors (i.e. combining the effect of inside, affiliated and independent directors), while the results in Fich and Shivdasani (2006) were concentrated on independent directors. Had only independent directors been analyzed in Ferris, Jagannathan and Pritchard (2003), the results might have been different. Therefore, the findings of Fich and Shivdasani (2006) appear to be more reliable regarding market reaction to the appointment of a busy independent director.

\subsection{The Correlation between Committee Service and Directors Holding Multiple Board Seats}

Regarding the correlation between committee service and directors holding multiple board seats, the results were consistent for the frequency of service on committees, but inconsistent for service in the monitoring committees ${ }^{1656}$. Ferris, Jagannathan and Pritchard

\footnotetext{
${ }^{1653}$ Fich \& Shivdasani 2006, supra note 1240 at 719-20. The results are based on a sample regarding 818 distinct appointments of a single independent director (not independent directors as a group). Ibid.

${ }^{1654}$ Ibid at 717.

${ }^{1655}$ Ibid at 719 .

${ }^{1656}$ Ferris, Jagannathan and Pritchard (2003) examined the relationship between directors holding multiple board seats and service in the audit and compensation committees, while Jiraporn, Singh and Lee (2009) investigated similar relationship regarding the service in the audit, compensation, nominating and corporate governance committees. Ferris, Jagannathan \& Pritchard, supra note 1122 at 1103-05; Jiraporn, Singh and Lee, supra note 1628 at 825-26.
} 
(2003) and Jiraporn, Singh and Lee (2009) ${ }^{1657}$ both found that directors holding three or more board seats provided more committee service than those holding only one or two directorships. ${ }^{1658}$ Jiraporn, Singh and Lee (2009) further reported that an additional outside directorship was associated with fewer committee memberships until the number of directorships reached three. Beyond this point, each additional outside board seat was associated with an increase in membership of internal board committees. ${ }^{1659}$ However, the findings were mixed for serving on the important monitoring committees. Ferris, Jagannathan and Pritchard (2003) found that busy directors served on the audit and compensation committees with greater frequency, ${ }^{1660}$ while Jiraporn, Singh and Lee (2009) reported the opposite results. ${ }^{1661}$ Collectively, directors with three or more board seats appear to provide more committee service than their non-busy counterparts, but whether they were likely to serve on the two important monitoring committeesaudit and compensation committees-was unclear. It is worth noting that the above results combined the effect of independent, affiliated and inside directors holding multiple board seats on committee service. It may not be extended to independent directors without further investigation.

\subsection{The Relationship between Other Factors and Independent Directors Holding Multiple Board Seats}

Empirical studies have used board meeting attendance, the sensitivity of CEO turnover to firm performance, and securities litigation as indicators to evaluate the impact of directors holding multiple board seats. Jiraporn et al. (2009) ${ }^{1662}$ found that busy directors (as measured by the number of outside directorships held by each director) were more inclined to be absent from

\footnotetext{
${ }^{1657}$ The authors used committee service as an indicator to examine whether holding multiple outside directorships compromises a director's ability to serve on board committees by employing a sample of 1,471 firms (including 41,475 observations) from 1999 to 2003. Jiraporn, Singh and Lee, ibid at 822.

${ }^{1658}$ Ibid at 819, 823; Ferris, Jagannathan \& Pritchard, supra note 1122 at 1103-05.

${ }^{1659}$ Jiraporn, Singh and Lee, ibid.

${ }^{1660}$ Ferris, Jagannathan \& Pritchard, supra note 1122 at 1103-05.

1661 Jiraporn, Singh and Lee, supra note 1628 at 826.

1662 The authors adopted board meeting attendance as a proxy to investigate the impact of multiple directorships on director performance by using a sample of 1,510 firms (7,261 observations) from the year 1998 to 2003. Jiraporn et al, supra note 1628 at 1163 .
} 
board meetings. ${ }^{1663}$ The authors further observed that busy independent directors were likely to miss more board meetings than their inside and affiliated counterparts. ${ }^{1664}$ Although attending board meetings may not necessarily transfer into diligent monitoring, absence from board meetings is a visible way to show that independent directors may not be fulfilling their responsibilities.

In addition, Fich and Shivdasani (2006) found that the sensitivity of CEO turnover to firm performance was significantly lower when independent directors held three or more directorships, compared to those who held less than three. ${ }^{1665}$ CEO turnover became entirely insensitive to firm performance when a majority of independent directors held three or more board seats. ${ }^{1666}$ The findings of above two studies suggest that multiple directorships not only impaired independent directors' diligence with respect to attending board meetings, but also weakened the ability of independent directors to dismiss an unfit CEO.

Empirical findings regarding the impact of multiple directorships on securities litigation (or financial fraud) were not consistent. Ferris, Jagannathan and Pritchard (2003) found that outside directors in firms facing securities lawsuits did not hold more outside board seats than those in firms not being sued, ${ }^{1667}$ while Beasley (1996) reported that the incidence of financial statement fraud was higher when outside directors held more outside directorships. ${ }^{1668}$ Since firms which were sued have not necessarily committed the fraud alleged, this might be the reason why the impact of outside directors holding multiple board seats on the likelihood of a securities lawsuit was not as strong as that on the likelihood of financial fraud.

\subsection{Summary}

Taken together, although nearly half of the evidence relates to director generally, the rest of the findings show that independent (or outside) directors holding three or more board seats

\footnotetext{
${ }^{1663} \mathrm{Ibid}$ at 1165 . The authors reported that the propensity for absence rises by $9.9 \%$ when the number of outside directorships increases from one to two. Ibid. After addressing the potential endogeneity, the authors confirmed that the causality ran from busy directors to attendance, rather than reverse direction. Ibid at 1169.

${ }^{1664}$ Ibid at 1167. The authors argued that the affiliated and inside directors may have different motivations to attend board meetings because their livelihood may be more closely associated with the firm. Ibid.

${ }^{1665}$ Fich and Shivdasani 2006, supra note 1628 at 715-16.

${ }^{1666}$ Ibid at 716.

${ }^{1667}$ Ferris, Jagannathan \& Pritchard, supra note 1122 at 1105-09.

${ }^{1668}$ Beasley, supra note 1295 at 461.
} 
were less likely to be associated with better firm performance, to be perceived favorably by investors, to attend board meetings, to remove incompetent CEOs, and to lower the probability of financial fraud, in comparison with those holding two or fewer board seats. It is manifest that the disadvantages for independent directors holding multiple directorships far outweigh the advantages. Therefore, firms would be wise not to nominate individuals who hold more than two outside directorships as their independent directors, in order to maintain the effectiveness of independent directors. It is worth noting that all studies mentioned in this section used pre-SOX samples.

\subsubsection{Market for Corporate Control (or Barriers to the Market for Corporate Control)}

As noted in the introduction, in addition to independent directors, external oversight mechanisms, including product markets, the market for managers' services, the market for corporate control and capital (securities) markets, as well as other internal mechanisms (such as the presence of controlling shareholders) are claimed to act as constraints on managerial misdeeds. ${ }^{1669}$ The monitoring effect of independent directors may be influenced by these external and internal mechanisms which contribute to the oversight function. Since the early 1980s, scholars have contended that the oversight of independent directors and the market for takeovers are substitute devices for controlling managerial behavior. When independent directors dominate a board, resulting in more effective internal control, the role for the takeover market becomes less important. In contrast, when a corporate board is dominated by insiders (board oversight becomes less effective), the takeover market assumes a more important role in disciplining top management. In other words, the market for takeovers provides a source of external discipline to corporate executives, which substitutes for internal discipline exerted by independent directors. ${ }^{1670}$ In the same way, when the number of antitakeover provisions in a firm's charter or bylaw have been increased to become barriers for the market for corporate

\footnotetext{
${ }^{1669}$ See the text accompanying supra notes 16-18; K J Martijn Cremers \& Vinay B Nair, "Governance Mechanisms and Equity Prices" (2005) 60:6 Journal of Finance 2859 at 2859.

${ }^{1670}$ James A Brickley \& Christopher M James, "The Takeover Market, Corporate Board Composition, and Ownership Structure: The Case of Banking" (1987) 30 J L \& Econ 161 at 162 [Brickley \& James]; Omesh Kini, William Kracaw \& Shehzad Mian, “Corporate Takeovers, Firm Performance, and Board Composition” (1995) 1 Journal of Corporate Finance 383 at 384 [Kini, Kracaw \& Mian]; Fama \& Jensen 1983, supra note 364 at 314-15.
} 
control, a firm would need to increase the number (or the proportion) of the independent directors to its board to monitor management.

Financial economists have studied the interaction between director oversight and takeover market (including the barriers for the market for corporate control) since the late 1980s. Four studies support the substitute hypothesis, while one study reported a complementary relationship between the two governance mechanisms under specific situations. Nevertheless, these five studies consistently show that the market for corporate control (or barriers to the market for corporate control, like firms with antitakeover provisions in place) has an impact on the effectiveness of independent directors. The findings concerning this issue are analyzed as follows.

In the late 1980s, Brickley and James (1987) examined the impact of board independence on the managerial consumption of perquisites ${ }^{1671}$ between states prohibiting corporate acquisitions of commercial banks and states having no statutory impediments to bank acquisitions. ${ }^{1672}$ The authors observed a significantly negative relationship between the managerial consumption of perquisites and the proportion of outside directors ${ }^{1673}$ on the board within the states that prohibited acquisitions, and no consumption of perquisites was found within the states that permitted acquisitions. ${ }^{1674}$ The results demonstrate that more independent boards reduced the managerial consumption of perquisites when the market for takeovers did not operate, suggesting a substitute effect between the market for takeovers and outside directors. ${ }^{1675}$

In the mid-1990s, Kini, Kracaw and Mian (1995) investigated the effect of board composition on the sensitivity of CEO turnover to firm performance surrounding corporate takeovers. ${ }^{1676}$ They reported a significantly negative relationship between pre-takeover firm performance and post-takeover CEO turnover for targets with insider-dominated ${ }^{1677}$ boards.

\footnotetext{
${ }^{1671}$ Managerial consumption of perquisites is measured by excessive expenditures on labor (expenditures beyond those dictated by profit maximization). Brickley \& James, ibid at 175.

1672 The authors investigated a sample of 891 banks, including 502 banks in acquisition states and 389 banks in nonacquisition states during 1979. Ibid at 167.

${ }^{1673}$ In this study, directors who are not officers of the bank are defined as outside directors. Ibid at 166-67.

${ }^{1674}$ Ibid at 163, 179, 180.

${ }^{1675}$ Ibid at 163-64, 180.

${ }^{1676}$ The authors surveyed a sample of 244 successful tender offers from 1958 through 1984. Kini, Kracaw \& Mian, supra note 1670 at $386-87$.

${ }^{1677}$ A board is defined to be insider dominated if the proportion of outside directors is less than $60 \%$, while a board is defined to be outsider dominated if the proportion of outside directors is greater or equal to $75 \%$. Ibid at 397

Table 4. Outside directors in this study are defined as board members who are not full-time employees of the firm. Ibid at 388. With a view to avoiding the effect of misclassifying gray directors (directors who have family ties or
} 
However, they found no significant performance-turnover relation for targets with outsiderdominated boards. ${ }^{1678}$ In other words, the market for takeovers disciplines poorly performing CEOs when board oversight was less effective (dominated by insiders), but such a discipline effect disappeared when board monitoring should have become stronger (dominated by outside directors). The findings seem to support the hypothesis that takeovers and independent directors serve as substitute control mechanisms in disciplining management for poor performance. ${ }^{1679}$ About one-and-a-half decades later, Huang and Zhao (2009) ${ }^{1680}$ conducted similar research to investigate whether the effect of antitakeover legislation ${ }^{1681}$ on the sensitivity of CEO turnover to firm performance ${ }^{1682}$ varies with the level of board independence. The main difference between Kini, Kracaw and Mian (1995) and Huang and Zhao (2009) is that the former focused on the direct impact of the market for takeovers, while the latter concentrated on the effect of antitakeover legislation (the barriers to the market for corporate control). The results showed that only firms with higher (larger than median) proportions of independent directors ${ }^{1683}$ significantly increased the sensitivity of CEO turnover to performance after the passage of antitakeover law, compared to firms with lower (smaller than median) proportions of independent directors in the same situation. ${ }^{1684}$ That is to say, stronger director oversight assumed the role of disciplining incompetent CEOs after the market for corporate control became weaker (the passage of antitakeover legislation). Again, the results suggest that independent directors and the market for takeovers act as substitute mechanisms for checking managerial abuses.

In the middle of the first decade of the 2000s, Gillan, Hartzell, and Starks (2006) explored the relationship between antitakeover provisions in a firm's charter (as measured by G

other affiliations with management or the firm) into outside directors, the authors recomposed the subsamples to exclude approximately one-third of the target firms with a proportion of the board represented by outside directors nearest to the sample median of $67.95 \%$. Ibid at 395-96.

${ }^{1678} \mathrm{Ibid}$ at $386,396,410$.

${ }^{1679}$ Ibid at 399.

1680 Jun Huang \& Shan Zhao, "CEO Turnover and Takeover Threats: New Evidence from Antitakeover Legislation" (18 March 2009), online: SSRN <http://ssrn.com/abstract=1362642 or http://dx.doi.org/10.2139/ssrn.1362642 > [Huang \& Zhao]. The authors investigated 792 large listed firms from 1984-1991. Ibid at 7.

${ }^{1681}$ The effect of antitakeover legislation in this study is measured by whether antitakeover legislation had been passed by the time in the state the firm incorporated. Ibid at 9. Antitakeover legislation in this study includes business combination law, fair price law and control share acquisition law. Ibid at 6. Please refer to Gompers, Ishii \& Metrick, supra note 1191 at 146-48 for further explanations of these laws.

${ }^{1682}$ Firm performance is measured by ROA (return on assets) and RETLAG (a firm's market-adjusted return over the previous calendar year). Ibid at 8 .

${ }_{1683}$ The authors did not define independent directors in the study.

${ }^{1684}$ Huang \& Zhao, supra note 1680 at $12-13$. 
index) ${ }^{1685}$ and corporate internal mechanisms (including board independence). ${ }^{1686}$ They found that firms had a greater number of antitakeover provisions when their level of board independence (the proportion of independent directors ${ }^{1687}$ on the board) increased, suggesting that independent directors undertook the oversight role when the market for corporate control was less effective. In contrast, firms with less independent boards tended to have fewer antitakeover provisions, allowing the market for corporate control to provide greater monitoring. ${ }^{1688}$ The findings appear to show that independent boards serve as a substitute for the market for corporate control.

However, at the same time, Santaló and Diestre (2006) ${ }^{1689}$ reported different results regarding the relationship between the two mechanisms. The authors examined the connection between firm performance (measured by Tobin's Q), independent directors ${ }^{1690}$ and antitakeover provisions ${ }^{1691}$. They found that the effectiveness ${ }^{1692}$ of independent directors, to some extent,

${ }^{1685}$ G Index (Governance Index) is an index developed by Professors Gompers, Ishii and Metrick to proxy for the level of shareholder rights at about 1,500 large firms during the 1990s. G Index varies from 0 to 24 depending on the number of provisions (that restrict shareholders' rights) included in a firm's charter. There are five different types of provisions: (1) tactics for delaying hostile bidders; (2) limits on voting rights; (3) director/officer protection; (4) other takeover defenses; (5) state laws. In this study, the authors used G Index to measure a firm's degree of protection against takeovers. Ibid at 8; Gompers, Ishii \& Metrick, supra note 1191 at 109, 112.

1686 The authors explored the relationship between antitakeover provisions (as measured by G index) and corporate internal mechanisms (including board independence) by using a sample of 2,340 firms from 1997 to 2000 . Gillan, Hartzell, \& Starks, supra note 16 at 4-5.

${ }^{1687}$ Directors who are not affiliated with the company are considered as independent. Ibid at 39 Table 6. However, this study did not further define affiliated directors.

${ }^{1688} \mathrm{Ibid}$ at 14, 18, 20. It is possible that the causation of these findings runs the other direction. However, in this case, it is less likely that a firm with a higher proportion of independent directors causes the presence of more these antitakeover provisions in their charters (since these provisions may encourage management entrenchment). It is more likely that a firm with more antitakeover provisions in their charters chooses to have a higher proportion of independent directors on the board (to undertake the oversight role). In addition, some provisions in $\mathrm{G}$ Index may benefit shareholders, such as cumulative votings and fair-price provisions, although most provisions in $\mathrm{G}$ Index do restrict shareholders' rights. See explanations for these provisions in Gompers, Ishii and Metrick (2003), supra note 1191 at $147-48$.

1689 The authors surveyed a sample of 1,294 firms for the period 1996-2001. Juan Santaló \& Luis Diestre, "When Do Outside Directors Create Corporate Value?" (May 2006) at 13, online: SSRN <http://ssrn.com/abstract=942045> [Santaló \& Diestre].

${ }^{1690}$ In this study, directors who have no personal or professional relationship with the company or management are defined as independent directors. Directors who are former employees, relatives of the CEO, or who have a business relationship with the company are considered as affiliate directors. Directors who currently are employees of the company are defined as inside directors. Ibid at 14.

${ }^{1691}$ The authors used their own index "Antitakeover Index (ATA)", which is almost identical to the G Index (developed by Professors Gompers, Ishii and Metrick) to measure the level of antitakeover. Ibid; see Gompers, Ishii \& Metrick, supra note 1191 at 109, 112.

${ }^{1692}$ In this study, the effectiveness of independent directors was measured by firm performance-Tobin's Q. Santaló \& Diestre, ibid. 
depends on a firm's degree of protection against takeovers. ${ }^{1693}$ When firms had a low level of antitakeover protection, an increase of $10 \%$ in the proportion of independent directors on the board was associated with an increase of $28 \%$ in the market valuation of the firm (Tobin's Q).

On the contrary, when firms had a high degree of antitakeover protection, an increase of $10 \%$ in board independence was linked to a decrease of $10 \%$ in a firm's market value. ${ }^{1694}$ The relationship between independent directors and the antitakeover protection appears to be complementary rather than a substitution under these two situations. ${ }^{1695}$ However, for those firms with a medium degree of antitakeover protection (about two-thirds of the sample firms), no significant connection was found between board independence and firm market value. ${ }^{1696}$ In other words, a firm's degree of protection against takeovers, in most cases, had no significant impact on effectiveness of its independent directors. Independent directors were effective only when the threat of a disciplining takeover was strong. When the threat of takeover turns neutral (weak), board oversight becomes insignificant (even detrimental) to the firms. The authors interpret the results as evidence that the threat of takeover motivates independent directors to discipline ineffective management, since the entire board (including independent directors themselves) would be replaced after a takeover. However, when such a threat becomes weaker, independent directors may not have sufficient incentives to monitor management. ${ }^{1697}$

Taken together, empirical evidence, based on the observation of all pre-SOX samples, demonstrates that the effectiveness of independent directors is affected by the efficacy of the market for corporate control (or antitakeover provisions-the barriers to the market for corporate control). Most studies have shown a substitute effect between independent directors and the takeover market, while one study reported, in most cases, no significant connection between the two mechanisms. Collectively, the efficacy of independent directors on management oversight is related to the level of takeover threat, but whether their relationship is as substitutes or complements is still unclear.

\footnotetext{
1693 Ibid at 4.

${ }^{1694}$ The authors found a positive and significant correlation between the proportion of independent directors on the board and firm performance when firms have a lower level of antitakeover protection (ATA lower than 6). However, the correlation between independent directors and firm performance becomes significantly negative when firms have a higher degree of antitakeover protection (ATA higher than 11). Ibid at 4-5, 19, 27.

1695 Ibid at 4-5.

${ }^{1696}$ See ibid at 37 Table 4. The medium degree of antitakeover protection refers to the ATA between 6 and 11 . Ibid. 1697 Ibid at 1, 28.
} 


\subsubsection{Information Cost}

Independent directors need sufficient information regarding how the firm is operating and being managed in order to perform successful monitoring. ${ }^{1698}$ However, information asymmetry between the CEO and independent directors or between inside directors and independent directors has been noted for several decades. In the early 1990s, Professor Jensen indicated that outside directors usually possess far less information than the CEO, since the CEO controls the agenda and the flow of information to outside directors. ${ }^{1699}$ In the new millennium, Adams and Ferreira (2007) further argued that the CEO has a greater incentive to conceal information from outside directors because a higher level of board independence increases management's fear of losing control and private benefits. ${ }^{1700}$ Similarly, Harris and Raviv (2008) argued that inside directors may not be willing to reveal to the board full or completely accurate information about the firm when the board is controlled by outside directors. ${ }^{1701}$ Empirical evidence in the new millennium supports the above arguments of imbalance in information distribution between independent directors and management. Nowak and McCabe (2003) found that independent directors perceived that the CEO and other executives had controlling power over corporate information, ${ }^{1702}$ while Fu and $\mathrm{Yu}$ (2010) reported that information asymmetry ${ }^{1703}$ between managers and independent directors did not change between the pre-SOX and post-SOX period. The latter findings further show that information advantages possessed by management against independent directors remained high after the enactment of SOX. ${ }^{1704}$ Since independent

\footnotetext{
1698 Nicola Faith Sharpe, "The Cosmetic Independence of Corporate Board” (2011) 34 Seattle U L Rev 1435 at 1451 , 1453.

1699 Jensen, Industrial Revolution, supra note 403 at 864.

${ }^{1700}$ Renée Adams \& Daniel Ferreira, “A Theory of Friendly Boards” (2007) 62:1 The Journal of Finance 217 at 217 , 242.

${ }^{1701}$ Milton Harris \& Arthur Raviv, "A Theory of Board Control and Size” (2008) 21:4 The Review of Financial Studies 1797 at 1798 [Harris \& Raviv].

${ }^{1702}$ Margaret Nowak \& Margaret McCabe, "Information Costs and the Role of the Independent Corporate Director" (2003) 11:4 Corporate Governance 300 at 302-03. The authors examined the perceptions of directors in Australian publicly-listed companies regarding their access to information for their role as directors by interviewing 45 directors. Ibid at 302.

${ }^{1703}$ The authors used the abnormal buy-and-hold returns associated with trades initiated by independent directors and managers over various investment horizons as a proxy for the level of inside information they possess. The difference in returns signifies the magnitude of information asymmetry between managers and independent directors. Huijing Fu \& Xiaoyun Yu, "Is Board Structure One-Size-Fits-All? The Unintended Informational Consequence of the Sarbanes-Oxley Act” (8 August 2010) at 10-11, online: SSRN <http://ssrn.com/abstract=1107676> [Fu and Yu]. ${ }^{1704}$ The authors found that managers earned higher returns than independent directors during both the pre-SOX and post-SOX period, suggesting that there was no change in formation asymmetry from the pre-SOX to post-SOX period. Ibid. at 17-18.
} 
directors may not be able to monitor the CEO and management effectively without full and accurate information about the firm, the effect of information costs on independent directors' efficacy is worth exploring.

Financial economists used the availability of corporate information to measure the costs of acquiring corporate information. Existing studies adopted analysts' forecasts and the returns of selling the company's stock to explore independent directors' costs of becoming informed. In Duchin, Matsusaka and Ozbas (2010), researchers used the number of analysts ${ }^{1705}$, the dispersion of analysts' forecasts, and analysts' forecast error ${ }^{1706}$ as indices to measure the costs of acquiring corporate information for independent directors. Greater analyst following means more corporate information is available to independent directors. A wider dispersion of analysts' forecasts suggests it is more difficult for independent directors to become informed about the firm. Larger forecast errors also indicate greater challenges for independent directors to evaluate the firm. ${ }^{1707}$ The authors found that firm performance (as measured by Tobin's Q, ROA and stock return) depended on how costly it was for independent directors to acquire information about the firm. ${ }^{1708}$ When the cost of acquiring information was low, adding independent directors to the board was associated with better firm performance. In contrast, when the cost of acquiring information was high, an increase in the percentage of independent directors was connected with worse firm performance. ${ }^{1709}$ These findings, based on the observation of a sample straddling SOX, suggest that the effectiveness of independent directors (presented by firm performance) depends on corporate information availability. Independent directors do a better job of monitoring when information costs are low.

\footnotetext{
${ }^{1705}$ The authors count the number of analysts who posted earnings forecasts for the firm in a given year. Greater analyst following means more information is available to independent directors. Duchin, Matsusaka and Ozbas, supra note 429 at 201.

${ }^{1706}$ The forecast error is measured by the absolute difference between the mean analyst earnings forecast and the actual earnings. Ibid at 202.

1707 Ibid at 201-202.

${ }^{1708}$ Ibid at 196, 204, 212.

${ }^{1709}$ More specifically, for firms in the lowest information cost quartile, each additional $10 \%$ representation of independent directors to the board was associated with $1.3 \%$ higher ROA, $8.1 \%$ higher Tobin's Q, and 3.8\% higher annual stock returns during 2000 to 2005. In contrast, for firms in the highest information cost quartile, each additional $10 \%$ representation of independent directors to the board was associated with $1.7 \%$ lower ROA, $15.8 \%$ lower Tobin's Q, and 2.4\% lower annual stock returns during the sample period. Ibid at 204.
} 
On the other hand, Ravina and Sapienza (2010), with a pre-SOX sample, investigated whether independent directors ${ }^{1710}$ have enough corporate information to monitor management by analyzing their trading behavior in the company's stock. ${ }^{1711}$ If the difference between the returns earned by firm's executives and independent directors is small or trivial, it shows that independent directors have similar corporate information to that possessed by a firm's executives. If the difference is large, there is information asymmetry between managers and independent directors. The authors found that the returns for executives were slightly larger than those for independent directors, but the difference between executives and independent directors was relatively small over most time periods. ${ }^{1712}$ However, the authors reported that governance quality (as measured by $\mathrm{G}$ index ${ }^{1713}$ ), in some cases, affected the level of corporate information collected by independent directors. The gap in stock returns between executives and independent directors was larger in firms with the weakest ${ }^{1714}$ governance, while it disappeared for firms with the best governance. But in most cases, the difference between executives and independent directors was insignificant. ${ }^{1715}$ The findings of Ravina and Sapienza (2010) suggest that independent directors, in general, had access to information comparable to executives, but they acquired less information than insiders in poorly governed firms.

Taking the evidence of two studies together, the efficacy of independent directors depends on costs of acquiring information about the firm, and the quality of corporate governance affects the availability of corporate information collected by independent directors. With a view to maintaining the effectiveness of independent directors, fostering a full and complete information environment for them seems to be necessary.

\footnotetext{
${ }^{1710}$ In this study, independent directors are defined as directors who have no past or present business or familial ties to the firm or the executives nor own large blocks of corporate stock. Enrichetta Ravina \& Paola Sapienza, "What Do Independent Directors Know? Evidence from Their Trading" (2010) 23:3 The Review of Financial Studies 962 at 965 [Ravina \& Sapienza].

${ }^{1711}$ The authors analyzed open market trades between executives and independent directors in almost 15,000 firms from 1986 to 2003. Ibid at 966-67.

${ }_{1712}$ Ibid at $963,974,979-80$. The results remained robust by using a variety of alternative specifications. Ibid at 963, 981-82,

${ }^{1713} \mathrm{G}$ Index is an index developed by Gompers, Ishii and Metrick (2003) to proxy for the level of shareholder rights in about 1,500 large firms during the 1990s. G Index varies from 0 to 24 depending on the number of provisions included in a firm's charter. More provisions (i.e. higher $\mathrm{G}$ index) indicate more restricted shareholder rights. Ibid at 986. See Gompers, Ishii \& Metrick, supra note 1191 at 109, 112.

${ }^{1714}$ The authors classify corporations into ten groups by their $\mathrm{G}$ index: those with a $\mathrm{G}$ index less than or equal to 5 , equal to $6,7,8,9,10,11,12,13$, and greater than or equal to 14 . Firms with $\mathrm{G}$ index 6,5 or lower are considered as the best governed firms, while firms with $\mathrm{G}$ index 14 or higher are defined as the worst governed firms. Ibid at 986. ${ }^{1715}$ Ibid at 963-64, 986, 1001.
} 


\subsubsection{Leadership Structure}

For the past two decades, finance, accounting and management practitioners and academics have been trying to determine whether a firm should bestow CEO and board chair duties on one individual or whether a firm should have different people holding the two positions, with a view to enhancing shareholder interests. Proponents of combining the positions of the $\mathrm{CEO}$ and board chair contend that CEOs playing a dual role is beneficial to shareholders, because it can (1) provide a clear-cut leadership structure for strategy formation and implementation, (2) minimize the potential rivalry and information sharing costs between the CEO and the chairperson, (3) allow the corporation to respond more quickly to market conditions, and (4) provide an incentive mechanism for new CEOs during a management transition. ${ }^{1716}$ In contrast, proponents of separating the two positions argue that allowing the CEO to be the board chair is detrimental to investors, since it would (1) violate the principle of the separation of decision-management and decision-control (like asking students to grade their own homework), and (2) hamper a board's ability to effectively monitor management headed by the CEO. ${ }^{1717}$ Because arguments from both sides seem to be persuasive to some extent, financial economists have been trying to find evidence to decide which type of leadership structure is better for shareholders.

\subsection{The Connection between Firm Performance and Different Types of Leadership Structure (Without Considering the Impact of Independent Directors)}

\footnotetext{
${ }^{1716}$ Brian K Boyd, “CEO Duality and Firm Performance: A Contingency Model” (1995) 16 Strategic Management Journal 301 at 301 [Boyd, CEO Duality]; B Ram Baliga, R Charles Moyer \& Ramesh S Rao, "CEO Duality and Firm Performance: What's the Fuss” (1996) 17 Strategic Management Journal 41 at 42 [Baliga, Moyer \& Rao]; P Someshwar Rao \& Clifton R Lee-Sing, "Governance Structure, Corporate Decision-Making and Firm Performance in North America" in Ronald J Daniels \& Randall Morck, eds, Corporate Decision-Making in Canada (Calgary, Alta: University of Calgary Press, 1995) at 63 [Rao \& Lee-Sing]; Steven Balsam, John Puthenpurackal \& Arun Upadhyay, "The Determinants and Performance Impact of Outside Board Leadership" (22 December 2011) at 7 , online: SSRN <http://ssrn.com/abstract=1361255> [Balsam, Puthenpurackal \& Upadhyay]; Rechner \& Dalton, supra note 417 at 155; Brickley, Coles \& Jarrell, supra note 417 at 194-95; Aiyesha Dey, Ellen Engel, \& Xiaohui Liu, "Determinants and Implications of Board Leadership Structure", Chicago Booth Research Paper No. 09-23 (1 June 2009) at 1, online: SSRN < http://ssrn.com/abstract=1412827> [Dey, Engel \& Liu].

${ }^{1717}$ Rechner \& Dalton, ibid; Boyd, CEO Duality, ibid at 302; Baliga, Moyer \& Rao, ibid; Balsam, Puthenpurackal \& Upadhyay, ibid at 6.
} 
The most popular and straightforward approach to this issue is to examine the connection between the two types of leadership structure and overall firm performance. However, the results regarding the impact of the leadership structure on firm performance seem to be mixed. Rechner and Dalton (1991) and Pi and Timme (1993) observed that firms separating the CEO from the board chair outperformed firms combining the two positions, ${ }^{1718}$ while Balsam, Puthenpurackal and Upadhyay (2011) reported similar results for firms having an outside director as board chair ${ }^{1719}$, compared to firms having inside board chair ${ }^{1720} .^{1721}$ In contrast, Brickley, Coles and Jarell (1997) documented an opposite result. They found that firms with the CEO playing a dual role had the same or even better performance, in comparison with firms that separated the positions of CEO and board chair. ${ }^{1722}$ Other studies, like Boyd (1995), Baliga, Moyer and Rao (1996), Chen, Lin and Yi (2008), and Dey, Engel and Liu (2009), reported that firm leadership structure had no significant impact on firm performance, ${ }^{1723}$ while Palmon and Wald (2002) and Faleye (2007) observed that the optimal corporate leadership structure depended on a firm's needs and characteristics. ${ }^{1724}$ It is hard to conclude which type of leadership structure was more beneficial to shareholders. Probably because of the mixed results, studies in the new millennium started to explore the determinants of leadership structure in more detail and the impact of these determinants on firm performance. The results show that the impact of the leadership structure on firm performance varied with firm features (size, complexity and diversity), CEO characteristics (age and tenure) and ownership structure (insider

\footnotetext{
${ }^{1718}$ Rechner \& Dalton, ibid at 157; Lynn Pi \& Stephen G Timme, “Corporate Control and Bank Efficiency” (1993) 17 Journal of Banking and Finance 515 at 525, 529.

${ }^{1719}$ Outside board chair in this study refers to a firm having a non-inside board chair. Inside board chair means the board chair who is the CEO or a retired employee, including a former CEO, or relatives of senior firm employees. Balsam, Puthenpurackal \& Upadhyay, supra note 1716 at 14.

${ }^{1720}$ See ibid.

${ }_{1721}^{17 b i d}$ at 16-17, 20-23, 34, 44 Table 1 Panel C.

${ }^{1722}$ Firm performance in this study is measured by return on capital and median stock return. Brickley, Coles, \& Jarrell, supra note 417 at 210-11.

${ }^{1723}$ Boyd, CEO Duality, supra note 1716 at 307; Baliga, Moyer \& Rao, supra note 1716 at 46-47, 49-50; Chia-Wei Chen, J Barry Lin \& Bingsheng Yi, "CEO Duality and Firm Performance-An Endogenous Issue" (2008) 6:1 Corporate Ownership \& Control 58 at 59, 63-64; Dey, Engel, \& Liu, supra note 1716 at 3,20.

1724 Olubunmi Faleye, "Does One Hat Fit All? The Case of Corporate Leadership Structure" (2007) 11:3 Journal of Management and Governance 239 at 241, 256 [Faleye]. In Palmon and Wald (2002), the authors found that shareholder reaction to the announcement of firms switching from a combined CEO/board chair title to a split title varied with firm size. Oded Palmon \& John K Wald, "Are Two Heads Better Than One? The Impact of Changes in Management Structure on Performance by Firm Size" (2002) 8 Journal of Corporate Finance 213 at 218-19 [Palmon $\&$ Wald]. However, the authors also reported that the impact of firm size on firm performance became insignificant when firms switched from a split title to a combined CEO/board chair title. Ibid at 215, 219, 225.
} 
vs. institutional ownership). ${ }^{1725}$ It seems that the optimal leadership structure is not one-size-fitsall.

\subsection{The Relationship between Different Types of Leadership Structure and the Efficacy of Independent Directors}

Since the main function of independent directors is to hold management accountable and protect shareholder interests, if independent directors under a specific type of leadership structure are more likely to fulfill their function, firms should adopt this type of structure to better serve their shareholders. Among the existing studies, few have investigated the correlation between the types of leadership structures and the role of independent directors. The findings of existing studies can be compiled into two categories: first, the relationship between an independent board chair and firm performance; second, the relationship between board independence and leadership structure.

First, with respect to the correlation between an independent board chair and firm performance, Balsam, Puthenpurackal and Upadhyay (2011) ${ }^{1726}$ reported that outside board chairs were significantly and positively related to firm performance (Tobin's Q) ${ }^{1727}$ and the causation ran from the outside board chair to firm performance, rather than vice versa. ${ }^{1728}$ The correlation remained unchanged for four different regression models. ${ }^{1729}$ After the authors further explored whether the impact of an outside board chair depends on the board chair's affiliation, they found that affiliated outside board chair was positively and significantly related to ROA and Tobin's Q (firm performance indicators) in both OLS and firm fixed effect regression models, while the association between an independent board chair and firm

\footnotetext{
${ }^{1725}$ Balsam, Puthenpurackal \& Upadhyay (2011) found that outside board chairs were more valuable when firms had higher external monitoring costs and less complexity and their CEOs had less bargaining power, while Faleye (2007) observed that the CEO playing a dual role was more beneficial when firms were more complex and their CEOs enjoyed a higher reputation. Balsam, Puthenpurackal \& Upadhyay, supra note 1716 at 23-26; Faleye, ibid at 241, 256. In addition, Palmon and Wald (2002) reported that large firms benefited and small firms suffered when firms switched from CEO duality to non-duality, while Linck, Netter and Yang (2008) found that firms were more likely to combine the two positions when the firms were larger and their CEOs were older and served longer in the companies. Palmon \& Wald, ibid at 218-19; Linck, Netter \& Yang, supra note 679 at 320-21.

${ }^{1726}$ The authors examined the impact of different types of board chair on firm performance (Tobin's Q) by surveying a sample of 1,125 firms from 1996 to 2005, including 1,516 outside chair firm-years corresponding to 532 unique firms. Balsam, Puthenpurackal \& Upadhyay, ibid at 13-14.

${ }^{1727}$ Ibid at $21-23,34$.

${ }^{1728}$ Ibid at 31-32.

${ }^{1729}$ Ibid at 21-23, 34.
} 
performance was also positive and significant in all specifications but the OLS specification with Tobin's Q. ${ }^{1730}$ The impact of affiliated outside chair on firm performance is stronger than that of independent board chair. The results suggest that non-inside board chairs, regardless of whether they are independent or affiliated, are beneficial to shareholders.

In addition, Grinstein and Valles (2008) ${ }^{1731}$ further observed that firms appointing an independent director as board chair were usually associated with poor firm performance (as measured by stock returns) in prior periods. However, firm performance was significantly improved within one year after the independent director took the board chair. ${ }^{1732}$ Combined with the findings in the last paragraph, it appears that independent directors serving as board chairs are effective in enhancing shareholder interests. Both studies had sample periods straddling SOX.

Second, regarding the connection between board independence and the two types of leadership structures, empirical evidence seems to show a substitution effect between board independence and a separate board chair. Grinstein and Valles (2008) found that the percentage of independent directors on the board was significantly and negatively related to a separate board chair, ${ }^{1733}$ while Linck, Netter and Yang (2008) ${ }^{1734}$ reported a significantly positive correlation between the proportion of outside directors ${ }^{1735}$ on the board and CEO's filling both roles. ${ }^{1736}$ Balsam, Puthenpurackal and Upadhyay (2011) also observed that the significant and positive association between an outside board chair and firm performance became less pronounced after the implementation of SOX and related rules. ${ }^{1737}$ The findings of Grinstein and Valles (2008) imply that firms with more independent boards were less likely to split the CEO and chairman role, since the monitoring of independent directors helped reduce agency problems and, therefore,

\footnotetext{
${ }^{1730}$ Ibid at 26-27, 34, 57 Table 9.

${ }^{1731}$ The authors explored the determinants of decisions to separate the CEO from the board chair by using a sample of about 1,000 S\&P 1,500 firms in the year 2000 and 2004. Yaniv Grinstein \& Yearim Valles, "Separating the CEO from the Chairman Position: Determinants and Changes after the New Corporate Governance Regulation" (March 2008) at 3, online: SSRN < http://ssrn.com/abstract=1108368> [Grinstein \& Valles].

${ }^{1732}$ Ibid at 26-27, 44 Table 13.

${ }^{1733}$ Ibid at 18, 33 Table 3, 35 Table 5.

${ }^{1734}$ The authors investigated how firm characteristics were associated with board structure, including leadership structure, by using a sample of nearly 7,000 firms over the period 1990 through 2004. Linck, Netter \& Yang, supra note 679 at 314 .

1735 Ibid at 311 .

${ }^{1736}$ Ibid at 320, 321 Table 4.

${ }^{1737}$ Balsam, Puthenpurackal \& Upadhyay, supra note 1716 at 28 . The authors found that a firm with an outside chair was significantly and positively associated with enhanced firm performance in both pre-SOX and post-SOX periods. However, the monitoring benefits of an outside board chair became lower in the post-SOX period. Ibid.
} 
there would be less benefit from such separation. ${ }^{1738}$ Similarly, the results of Linck, Netter and Yang (2008) appear to suggest that firms with a unitary leadership structure were more likely to have more independent boards, because boards may need more independent directors to counterbalance the CEO's influence. ${ }^{1739}$ In the same way, the findings of Balsam, Puthenpurackal and Upadhyay (2011) suggest that monitoring benefits of having an outside board chair become lower because more independent directors on the board are required in the post-SOX period. ${ }^{1740}$ All three studies had sample periods straddling SOX.

\subsection{Summary}

Taken together, looking at the relationship between firm performance and leadership structure seemingly cannot provide a clear answer regarding which type of leadership structure is better for shareholders. If a firm decides to separate the positions of CEO and board chair, the appointment of either an independent or affiliated director, instead of an inside director, as the board chair would lead to better subsequent firm performance. Furthermore, there is a substitution effect between board independence and a separate board chair. The level of board independence increased where CEOs play dual roles, but decreased with a separation between the CEO and board chair. To put it in a nutshell, the type of leadership structure seems to have an impact on the monitoring effect of independent directors. When a firm's board chair is an outsider, the monitoring effect of independent directors becomes less likely to be needed. The monitoring effect of an outside board chair seems to overlap with that of independent directors to some extent. Nevertheless, appointing an independent board chair remains beneficial to shareholders, since there is a connection between better firm performance and an independent board chair.

\subsubsection{Board Size (The Number of Directors)}

\footnotetext{
${ }^{1738}$ Grinstein \& Valles, supra note 1731 at 18.

${ }^{1739}$ Linck, Netter \& Yang, supra note 679 at 320.

${ }^{1740}$ Balsam, Puthenpurackal \& Upadhyay, supra note 1716 at 28.
} 
The issue regarding how many directors serving on the board is most effective and productive has been explored by financial economists for more than a decade. Conventional wisdom believes that large boards operate less effectively than small boards, because the coordination costs are higher and free-rider problems ${ }^{1741}$ are more serious among members of large boards. ${ }^{1742}$ In the early 1990s, Lipton and Lorsch contended that "[w]hen a board has more than ten members it becomes more difficult for them all to express their ideas and options", 1743 while Jensen argued that "[w]hen boards get beyond seven or eight people they are less likely to function effectively and are easier for the CEO to control." ${ }^{1744}$ Although many studies have addressed this issue, no study so forth has investigated how many independent directors on the board would be most effective. Generally, the number of independent directors on the board increased with the total number of board members. Thus, the findings of studies that have examined the ideal number of the entire board, to some extent, may be looked at for evidence of the ideal number of the independent board members.

According to empirical findings, financial economists used two approaches to explore the optimal size of a corporate board. First, they examined the connection between board size and firm performance. If boards with a certain number of directors are significantly and stably associated with better firm performance, the number would be considered as an optimal size for the boards. Second, they explored the determinants of board size and, then, identified how these determinants were related to the number of board members. The results of empirical studies are analyzed by two approaches as follows.

Regarding the correlation between board size and firm performance, the results seem to be mixed. Yermack (1996) ${ }^{1745}$ and Coles, Daniel and Naveen (2008) ${ }^{1746}$ (before dividing firms

\footnotetext{
${ }^{1741}$ A free-rider problem means that when there are more independent directors on the board, each independent director views the importance of his/her contribution as being reduced; hence, expends less effort in specializing his/her expertise. Harris \& Raviv, supra note 1701 at 1799; Lin, supra note 13 at 952-53.

1742 See Lehn, Patro \& Zhao, supra note 679 at 3.

${ }^{1743}$ Martin Lipton \& Jay W Lorsch, “A Modest Proposal for Improved Corporate Governance” (1992) 48 Bus Law 59 at 65 [Lipton \& Lorsch].

1744 Jensen, Industrial Revolution, supra note 403 at 865.

${ }^{1745}$ The author investigated whether the number of directors has an impact on firm value by using a sample of 452 Forbes 500 firms over the period 1984 to 1991. Yermack 1996, supra note 1098 at 189.

1746 The authors reexamined the appropriateness of the conventional wisdom that smaller and more independent boards are better boards by using a sample of 8,165 firm-year observations over the period 1992 to 2001 . Coles, Daniel \& Naveen, supra note 679 at 335.
} 
into complex and simple firms) found that board size ${ }^{1747}$ was significantly and negatively related to firm performance (as measured by Tobin's Q). ${ }^{1748}$ In other words, boards with more (fewer) members were inclined to have poorer (better) firm performance. However, Ning, Davidson and Zhong (2007) ${ }^{1749}$ reported the opposite results. They observed that board size was marginally (at $10 \%$ level) and positively associated with return on assets (a proxy for firm performance). ${ }^{1750}$ In addition, the results became more divergent after Coles, Daniel and Naveen (2008) divided firms into complex and simple firms ${ }^{1751}$. They found that complex firms benefited, but simple firms suffered, when their board size became larger. The benefits of having larger boards in complex firms were driven by adding outside directors ${ }^{1752}$ to the board. ${ }^{1753}$ Taken together, there seems to be no optimal board size that can increase firm performance for all companies.

Probably because of these divergent results, studies in the new millennium started to investigate the determinants of board size, in addition to the correlation between the number of directors and firm performance. The results demonstrated that the optimal number of board members varied with firm characteristics (firm size ${ }^{1754}$, firm complexity ${ }^{1755}$, and growth

\footnotetext{
${ }^{1747}$ Board size in Yermack (1996) is measured by the number of directors on the board as of the annual meeting date during each fiscal year. Yermack, supra note 1098 at 191 Table 1. Coles, Daniel and Naveen (2008) followed Yermack (1996)'s methodology to examine the relationship between board size and Tobin's Q by using a similar specification in their own sample. Coles, Daniel \& Naveen, ibid at 340.

${ }^{1748}$ Yermack observed an inverse and significant association between board size and firm value (as measured by Tobin's Q) in both OLS and fixed-effects regression models. The association appears to have a convex shape, implying that the largest proportion of lost value occurs when boards grow from small to medium size. Yermack, ibid at 194, 200. Coles, Daniel and Naveen (2008) also reported a similar result. Coles, Daniel \& Naveen, ibid. ${ }^{1749}$ The authors explored the determinants of board size by using a sample of 473 randomly-selected listed firms over a 12-year period from 1988 to 1999. Ning, Davidson \& Zhong, supra note 679 at 49.

${ }^{1750}$ Ibid at 55.

${ }^{1751}$ The authors used diversification, firm size and financial leverage as proxies for firm complexity. The level of firm complexity was calculated by factor scores based on the number of segments, log (sales) and leverage. Firms with above-median factor scores were termed "complex" and those below median were termed "simple." Coles, Daniel \& Naveen, supra note 679 at 332-33.

${ }^{1752}$ The authors did not define inside or outside directors in their study. See ibid at 353.

${ }^{1753}$ The results showed that adding more outside directors to the board enhanced firm performance for complex firms but decreased firm value for simple firms. In economic terms, when the number of outside directors increased by one, firm value was enhanced by $\$ 290$ million for complex firms but was reduced by $\$ 21$ million for simple firms. The results remained robust by using different regression models. Ibid at 344 .

${ }^{1754}$ In Lehn, Patro and Zhao (2003), firm size is defined as market value of equity. Lehn, Patro \& Zhao, supra note 679 at 17. In Boone et al., firm size is measured as the natural log of the market value of equity as of each fiscal year-end. Boone et al, supra note 679 at 76. In Ning, Davidson and Zhong (2007), firm size is defined as the book value of total debt over the market value of firm's equity. Ning, Davidson \& Zhong, supra note 679 at 50 . In Linck, Netter and Yang (2008), firm size is measured by the logarithm of market value of equity. Linck, Netter \& Yang, supra note 679 at 313,321 Table 4.

${ }^{1755}$ Boon et al. (2007) uses firm size, firm age and the number of business segments as proxies for firm complexity, while Coles, Daniel and Naveen (2008) adopts firm size, diversification and financial leverage as proxies to measure firm complexity. Linck, Netter and Yang (2008) uses firm size, the proportion of debt in capital structure, the
} 
opportunities ${ }^{1756}$ ), costs of monitoring ${ }^{1757}$, managers' opportunities to consume private benefits ${ }^{1758}$, and ownership incentives ${ }^{1759}$. More specifically, firms were inclined to have larger boards, when they were larger, ${ }^{1760}$ more complex, ${ }^{1761}$ and with higher opportunities for managers to pursue private benefits ${ }^{1762}$. In contrast, firms were more likely to have smaller boards when they had higher monitoring costs, ${ }^{1763}$ or their CEOs or outside directors ${ }^{1764}$ had higher shareholdings ${ }^{1765}$. In other words, firm characteristics, monitoring costs, opportunities for

number of business segments and firm age to represent firm complexity. Boone et al, ibid at 71; Coles, Daniel \& Naveen, supra note 679 at 332; Linck, Netter \& Yang, ibid at 311.

${ }^{1756}$ Both Lehn, Patro and Zhao (2003) and Ning, Davidson and Zhong (2007) used the ratio of the market to book value of assets and the ratio of property plant and equipment to total assets to measure growth opportunities. Lehn, Patro \& Zhao, supra note 679 at 17-18; Ning, Davidson \& Zhong, supra note 679 at 50. However, the effect of growth opportunities on board size seems to be mixed. Lehn, Patro and Zhao (2003) observed that growth opportunities were negatively related to board size, while Ning, Davidson and Zhong (2007) found the opposite. Lehn, Patro \& Zhao, ibid at 19, 23; Ning, Davidson \& Zhong, ibid at 55.

${ }^{1757}$ Boon et al. (2007) used (the log of) market-to-book ratio, high R\&D expenditures, return variance and CEO ownership as proxies for costs of monitoring, while Linck, Netter and Yang (2008) adopted market-to-book ratio, the level of R\&D spending and stock return to represent costs of monitoring and advising. Boone et al, supra note 679 at 71, 80; Linck, Netter \& Yang, supra note 679 at 311-12.

${ }^{1758}$ Boon et al. (2007) hypothesized that the optimal number of board members depends on the monitoring costs and manager's opportunities to consume private benefits, so they examined the relationship between board size and monitoring costs, as well as manager's opportunities to consume private benefits. Managers' opportunities to pursue private benefits are measured by three variables: free cash flow, industry concentration and whether management is insulated from market for corporate control by using takeover defenses (as measured by G index, see Gompers, Ishii \& Metrick, supra note 1191 at 109, 112). Monitoring costs are measured by (the log of) market-to-book ratio, high $\mathrm{R} \& \mathrm{D}$ expenditures, return variance and CEO ownership. Boone et al, ibid at 71, 80 .

${ }^{1759}$ Linck, Netter and Yang (2008) used insider incentive alignment and outsider incentive alignment as proxies for ownership incentives. Insider incentive alignment is measured by the percentage of shares held by the CEO, while outsider incentive alignment is measured by the percentage of shares held by outside directors. Linck, Netter \& Yang, supra note 679 at 312.

${ }^{1760}$ Four studies, exploring the determinants of board size, all observed that the number of board of directors increased when firm size became larger. Lehn, Patro \& Zhao, supra note 679 at 18, 23; Ning, Davidson \& Zhong, supra note 679 at 55; Boone et al, supra note 679 at 78-80; Linck, Netter \& Yang, ibid at 320.

${ }^{1761}$ Boon et al. (2007), Coles, Daniel and Naveen (2008) and Linck, Netter and Yang (2008) all reported that firm complexity was positively associated with board size, suggesting that board size increased when firm operations grew, matured and became more complex. Boone et al, ibid at 79-80; Coles, Daniel \& Naveen, supra note 679 at 339-40; Linck, Netter \& Yang, ibid. Although the proxies for firm complexity in these three studies were slightly different, it did not change the trend that complex firms were more likely to have larger boards.

${ }^{1762}$ Boon et al. (2007) found that board size was positively correlated with managers' opportunities for private benefits, suggesting that board size expanded when managers had more opportunities to pursue their private benefits. Boone et al, ibid note at 81 .

${ }^{1763}$ Boon et al. (2007) and Linck, Netter and Yang (2008) both found that firms' monitoring costs were negatively related to board size, suggesting that the costs of monitoring were reduced when boards became larger. Since the proxies for costs of monitoring in both studies were almost the same, it demonstrated a trend that firms with lower costs of monitoring were inclined to have larger boards. Boone et al, ibid; Linck, Netter \& Yang, supra note 679 at 320 .

${ }^{1764}$ Outside directors are defined as directors who are non-executive directors. Linck, Netter \& Yang, ibid at 311, 315 Table 2, 319.

${ }^{1765}$ Linck, Netter and Yang (2008) reported that CEO ownership and outside director ownership were both negatively related to board size, suggesting that boards became smaller when the CEO and outside directors had more firm shares. Ibid at 320. Perhaps the higher ownership incentives have aligned interests of the CEO and 
managers to consume private benefits, and ownership incentives decided the number of board members. Thus, there seems to be no ideal board size that fits all companies.

Since the number of independent directors is closely associated with the number of board members, as mentioned previously, the findings regarding the ideal number of the entire board may, to some extent, be applied to the situation regarding the ideal number of the independent board members. The optimal number of independent board members may also depend on firm characteristics, monitoring costs, opportunities for managers to consume private benefits, and ownership incentives. If this is the case, there is also no perfect number of independent directors that can always be associated with better performance of independent directors for all corporations.

\subsubsection{Board Meeting Frequency (Board Diligence)}

Board meeting frequency is often considered as an indicator of board diligence, a measure to test whether directors are industriously carrying out their duties. Some scholars contend that board meeting time is an important opportunity for improving the effectiveness of a board. Directors who meet more frequently are more likely to perform their duties in accordance with shareholders' interests. ${ }^{1766}$ On the contrary, some researchers argue that more frequent board meetings are not necessarily useful, because the limited time independent directors spend together is used mostly for routine tasks rather than exchanging meaningful ideas regarding how to control over management. Unless firms encounter difficulties, such as financial or performance problems, more board meetings may not be an efficient and proactive approach to improving corporate governance. In this view, high frequency of board meetings usefully serves as a fire-fighting device in the presence of problems, rather than an enhancer of corporate governance. ${ }^{1767}$ Due to conflicting views concerning the nature of board meetings, the impact of board meetings on shareholders' interests is worth exploring.

outside directors with those of shareholders; hence, reduced the need for outside monitors to sit on the board. Ibid at 326.

${ }^{1766}$ See Jay A Conger, David Finegold \& Edward E Lawler III, “Appraising Boardroom Performance” (1998) 76 Harvard Business Review 136 and Lipton \& Lorsch, supra note 1743.

${ }^{1767}$ See Jensen, Industrial Revolution, supra note 403. Nikos Vafeas, "Board Meeting Frequency and Firm Performance" (1999) 53 Journal of Financial Economics 113 at 114 [Vafeas 1999]. 
So far, existing studies have not directly investigated the connection between independent directors' meeting frequency and their efficacy. Since modern listed corporations have at least $50 \%$ of independent directors on their boards, the effectiveness of an entire board, to some extent, represents the efficacy of independent directors, except for the decisions made in executive sessions or made by the three monitoring committees. If more frequent meetings are associated with indicators signifying enhancement of shareholder interests (such as better firm performance or greater sensitivity of CEO turnover to firm performance), it, to some extent, suggests that diligence of independent directors benefits shareholders. As a result, firms should require a minimum number of board meetings in order to improve shareholder interests.

The existing evidence regarding the impact of board meeting frequency on shareholder interests can be organized into four categories: (1) the relationship between prior firm performance and the number of board meetings; (2) the association between the number of board meetings and subsequent firm performance; (3) the correlation between board meeting frequency and board meeting fees, as well as directors' attendance; (4) the relationship between board meeting frequency and board independence.

First, with respect to the relationship between prior firm performance and board meeting frequency ${ }^{1768}$, the results seem to be non-linear. The findings were consistent when firms increased board activity in response to poor performance. Vafeas (1999) ${ }^{1769}$ and Ryan, Wang and Wiggins (2009) ${ }^{1770}$ reported that board members met more frequently when firms performed poorly in the prior year, ${ }^{1771}$ while Brick and Chidambaran (2007) observed a similar correlation

\footnotetext{
${ }^{1768}$ Board meeting frequency is measured by the number of board meetings in a fiscal year in Vafeas (1999) and Ryan, Wang and Wiggins (2009). Vafeas 1999, ibid at 119; Harley E Ryan, Lingling Wang \& Roy A Wiggins, "Board-of-Director Monitoring and CEO Tenure" (25 February 2009) at 2, online: SSRN <http://ssrn.com/abstract=992857> [Ryan, Wang \& Wiggins]. In Brick and Chidambaran (2007), the authors adopted the number of director-days as an additional proxy to measure the level of board activity, in addition to the definition used by Vafeas (1999) and Ryan, Wang and Wiggins (2009). Brick \& Chidambaran, supra note 1357 at 3 , 11,12 . The number of director-days is measured by the product of the number of board meetings and the number of independent directors on the board. Ibid.

1769 The author explored the determinants of board diligence (as measured by the number of meeting held by the board of directors annually) and the relationship between firm performance and board diligence by using a sample of 307 Forbes firms over the period 1990 to 1994. Vafeas 1999, ibid at 119.

${ }^{1770}$ The authors investigated the determinants of board meeting frequency, and the relationship between board meeting frequency and CEO tenure, firm performance, as well as CEO turnover by surveying a sample of 1,324 S\&P 1,500 firms from 1995 to 2002. Ryan, Wang \& Wiggins, supra note 1768 at 13-15.

${ }^{1771}$ Vafeas 1999, supra note 1767 at 127; Ryan, Wang \& Wiggins, ibid at 21. In Vafeas (1999), the results held regardless of whether firm performance was measured by excess returns, adjusted ROA or raw returns. Vafeas 1999 , ibid at 127. It is worth mentioning that the relation held for only prior year performance, but not for prior two year performance. Ibid at 126 Table 3. In Ryan, Wang and Wiggins (2009), the authors used industry-adjusted return on assets (ROA) in the prior year as a measure of firm performance. Ryan, Wang \& Wiggins, ibid at 20.
} 
but further extended the presence of poor performance to the prior two years. ${ }^{1772}$ However, the results became inconsistent when boards responded to good performance. Vafeas (1999) found that boards were reluctant to decrease meeting frequency during good years, ${ }^{1773}$ while Ryan, Wang and Wiggins (2009) observed that boards became less active following good performance. ${ }^{1774}$ It appears that boards increased their monitoring intensity following periods of poor performance, but might not necessarily reduce their monitoring level when firms performed well in the previous period.

Second, regarding the association between the number of board meetings and subsequent firm performance, the results seem to be mixed. Vafeas (1999) reported that firms strongly recovered in the year of abnormally high meeting intensity and in the two subsequent years, ${ }^{1775}$ while Ryan, Wang and Wiggins (2009) found that firm performance did not improve after abnormally high numbers of board meetings. ${ }^{1776}$ In contrast, Ryan, Wang and Wiggins (2009) observed that firm performance improved over the three-year period following abnormally low meeting frequency. ${ }^{1777}$ Taken together, firm performance was not necessarily enhanced after intensive monitoring in the form of board meetings, ${ }^{177}$ and one study found that firms performed well after low board meeting frequency. ${ }^{1779}$ It seems that no general conclusion can be made regarding the number of board meetings that benefits shareholders.

Third, as for the correlation between board meeting frequency and board meeting fees, Vafeas (1999) and Ryan, Wang and Wiggins (2009) both observed that the intensity of board meetings was not significantly related to board meeting fees, ${ }^{1780}$ while Brick and Chidambaran (2007) reported a mixed effect of board meeting fees on board meeting frequency. ${ }^{1781}$ Taken together, it appears that higher board meeting fees did not increase the frequency of board meetings. However, board meeting fees do seem to effectively mitigate directors' attendance

\footnotetext{
${ }^{1772}$ Brick \& Chidambaran, supra note 1357 at 26-27. The authors used industry adjusted annual common stock return as a firm performance indicator. Ibid at 21. It is worth mentioning that the result was only significant in one of the two test models, implying that the evidence for the result was not so robust. Ibid at 26-27.

${ }^{1773}$ Vafeas 1999, supra note 1767 at 132.

${ }^{1774}$ Ryan, Wang \& Wiggins, supra note 1768 at 34, Appendix Table IX.

${ }^{1775}$ Vafeas 1999, supra note 1767 at 136.

${ }^{1776}$ Ryan, Wang \& Wiggins, supra note 1768 at 33-34.

1777 Ibid at 34.

1778 This conclusion was drawn from the findings of Vafeas (1999) and Ryan, Wang \& Wiggins (2009).

1779 This conclusion was drawn from the findings of Ryan, Wang \& Wiggins (2009) only, since no finding in Vafeas (1999) was related to firm performance after low meeting frequency.

${ }^{1780}$ Ryan, Wang \& Wiggins, supra note 1768 at Appendix Table 3; Vafeas 1999, supra note 1767 at 127.

${ }^{1781}$ The authors found a positive relationship between board meeting fees and board meeting frequency in the fixed effect regression, but observed a negative correlation in the pooled regression. Ibid at 42 Table 2.
} 
problems. Adams and Ferreira (2008) observed that directors were less likely to be absent from board meetings when firms provided higher meeting fees. ${ }^{1782}$ It appears that even small financial rewards can motivate directors to attend board meetings.

Finally, with respect to the relationship between board meeting frequency and board independence, the results seem to be divergent. Brick and Chidambaran (2007) reported that boards with a higher percentage of independent directors were associated with higher frequency of board meetings, ${ }^{1783}$ while Ryan, Wang and Wiggins (2009) observed fewer board meetings for boards with a greater fraction of inside directors. ${ }^{1784}$ Vafeas (1999) found that board meeting frequency was not related to whether the board had a majority of independent directors. ${ }^{1785}$ Collectively, it seems that the correlation between board diligence and board independence was unclear. Further research is needed to clarify the relationship between board meeting frequency and board independence.

Taken together, empirical evidence showed that firms increased their board meeting frequency following poor performance, but boards did not necessarily lower their monitoring level when firms performed well in the past. After intensive monitoring through frequent meetings, firm performance was not necessarily enhanced, and firms were inclined to perform well following low board meeting frequency. These results may suggest that board members meet more frequently usually due to the presence of problems, rather than as part of diligent management-monitoring. Since high board meeting frequency is not necessarily associated with better firm performance, it may be improper to require independent directors or entire boards to have a minimum number of meetings in a certain period. The effectiveness of independent directors (or entire boards) appears to be unrelated to the frequency of their meetings.

\subsubsection{Summary of Evidence regarding Other Governance Mechanisms Influencing the Efficacy of Independent Directors}

\footnotetext{
${ }^{1782}$ Renée B Adams \& Daniel Ferreira, "Do Directors Perform for Pay” (2008) 46 Journal of Accounting and Economics 154 at 164.

${ }^{1783}$ Brick and Chidambaran, supra note 1357 at 42 Table 2.

${ }^{1784}$ Ryan, Wang \& Wiggins, supra note 1768 at 21.

${ }^{1785}$ Vafeas 1999, supra note 1767 at 124 . Independent directors are defined as directors who are not management, consultants, executives in other financial firms or lawyers. Ibid at 125 Table 3.
} 
This section (section 5.1.6) explored whether the seven governance mechanisms (outside directorship, director share ownership, the market for corporate control, information costs, firm leadership structure, board size and board meeting frequency) and two director characteristics (gender and race) influenced the efficacy of independent directors in the United States.

With respect to the impact of director characteristics, the results show that ethnic minorities and females as independent directors on an audit committee were associated with better firm performance. However, the findings indicate that female independent directors on the board during mergers and acquisitions might not be beneficial to shareholders.

Regarding the influence of the seven governance mechanisms on the effectiveness of independent directors, empirical evidence first shows that a firm with independent directors having greater shareholdings was likely to have better firm performance. Firms with incentive compensation (combining stock grants and stock options) for independent directors were inclined to maintain the sensitivity of CEO turnover to firm performance. However, there is no general consensus about whether stock options and stock grants for independent directors are beneficial to the firm and shareholders. As a result, firms may consider nominating candidates who hold a certain percentage of ownership as independent directors in order to align their interests with those of shareholders.

As for the impact of independent directors holding multiple directorship on their effectiveness, the findings demonstrate that boards with independent (or outside) directors holding three or more board seats were less likely to be associated with better firm performance, to be perceived favorably by investors, to have high attendance at board meetings, to remove incompetent CEOs, and to lower the probability of financial fraud, in comparison with those holding two or fewer board seats. The disadvantages for independent directors holding multiple directorships far outweigh their advantages.

In regard to the connection between the market for corporate control and the efficacy of independent directors, most studies found that the level of board independence was negatively related to the level of takeover threat, while one study reported that the effectiveness of independent directors, in some circumstances, was positively associated with the level of takeover threat. Collectively, the efficacy of independent directors as monitors of management depends on the level of takeover threat, but how they interact is still uncertain. 
With respect to the impact of information availability on the effectiveness of independent directors, the findings reveal that: (1) the efficacy of independent directors depends on the costs of acquiring information; and (2) the quality of corporate governance affects the availability of corporate information collected by independent directors. With a view to maintaining the effectiveness of independent directors, a firm should foster a full and complete information environment for their independent directors.

In regard to the relationship between corporate leadership structure (separating the roles of $\mathrm{CEO}$ from board chair vs. the CEO playing a dual role) and the efficacy of independent directors, the evidence revealed that the type of leadership structure has an impact on the monitoring effect of independent directors. The level of board independence increases with CEO's playing the role of board chair and decreases with the separation between the CEO and board chair. In addition, empirical evidence shows a correlation between better firm performance and an independent board chair, suggesting that appointing an independent board chair is beneficial to shareholders.

As for the connection between the number of directors and their efficacy, the results showed that the optimal number of directors serving on a board seems to vary with firm characteristics, costs of monitoring, opportunities for managers to pursue their private benefits, and ownership incentives. Firms were inclined to have larger boards, when they were larger, more complex, and when they had greater opportunities for managers to pursue private benefits. In contrast, firms were more likely to have smaller boards, when they had higher monitoring costs or their CEOs or outside directors had higher shareholdings. Since the number of independent directors is closely associated with the number of board members, the findings regarding the ideal size of the entire board may, to some extent, be extended to the ideal number of independent board members. To this extent, there is no perfect number of independent directors that can always be associated with better performance of independent directors for all corporations.

Regarding the relationship between meeting frequency and effectiveness of boards of directors, the findings showed that directors met more frequently usually as a result of the presence of problems rather than engaging in diligent management-monitoring. In addition, firm performance was not necessarily improved following more frequent board meetings. Since most modern listed corporations consist of at least $50 \%$ of independent directors on the board, the 
findings regarding meeting frequency of the entire board may, to some extent, be extended to the relationship between meeting frequency and effectiveness of independent board members. As a result, it may be unwise to require a board dominated by independent directors to have a minimum number of board meetings in a certain period because it is not necessarily beneficial.

Briefly stated, shareholder interests (or wealth) were more likely to be protected (or enhanced) when independent directors: (1) owned a certain amount of firm shares; (2) held less than three outside directorships; (3) were ethnic minorities or females serving on the audit committee; (4) had a low cost to collect corporate information; and (5) held the position of board chair in a firm. The first three findings are based on the observation of pre-SOX samples, while the last two results include samples straddling SOX.

\subsubsection{Summary for US Empirical Evidence}

In this section, the author has explored the empirical evidence regarding the effectiveness of independent directors in the United States. The first part examined the relationship between board independence and overall firm performance. The results show that firms with a higher proportion of independent directors did not experience better current or future firm performance before the enactment of SOX. Firm performance might even be worse. In contrast, in the postSOX period, firms with a higher proportion of independent directors, in some circumstances, were associated with enhanced current and future performance.

The second part investigated whether independent directors fulfilled their monitoring responsibilities in discrete board tasks. Except for the task of controlling CEO pay, at least a majority of empirical studies of each board task discussed reveal that a firm with a higher proportion of independent directors on the board was associated with a positive result, including higher sensitivity of CEO turnover to firm performance, larger returns for shareholders during management buyouts, a lower incidence of the firm being sued, and lower likelihood of financial fraud, respectively. However, the level of board independence had no impact on restraining the level of CEO compensation. As for the task associated with takeovers, bidding firms with a higher proportion of independent directors were more likely to have less-negative stock returns for shareholders, while target firms with a higher percentage of independent directors were inclined to adopt golden parachutes. Collectively, firms with higher levels of board 
independence, in most cases, were more likely to protect shareholder interests, but their efficacy is not as good as conventional wisdom expected. These positive results are based on the observation of pre-SOX samples.

The third part examined the monitoring effect of independent directors in the audit, compensation, and nominating committees. The results, based on pre-SOX samples, demonstrate that the quality of financial reporting was higher when audit committees consisted solely of independent directors and had at least one member with accounting expertise. However, independent directors on the compensation committee were not effective in lowering the level of CEO pay (in both pre-SOX and post-SOX periods) or tying CEO remuneration to firm performance (in pre-SOX period). Existing empirical evidence only showed that the level of nominating committee independence was not related to firm performance. Since the real effect of independent directors in nominating committees might not be fully reflected in the measurement of firm performance, more research is needed to determine the effectiveness of independent directors in the function of director nomination.

The final part explored whether seven governance variables (the number of outside directorships, director share ownership, the market for corporate control, information costs, firm leadership structure, board size and board meeting frequency) and two director characteristics (gender and race) had an impact on the efficacy of independent directors. The evidence reveals that shareholder interests (or wealth) were more likely to be protected (or enhanced), when independent directors: (1) owned a certain amount of firm shares; (2) held less than three outside board seats; (3) were an ethnic minority or female serving on the audit committee; (4) had a low cost to collect corporate information; (5) held the position of board chair in a firm. The first three findings are based on the observation of pre-SOX samples, while the last two results include samples straddling SOX. However, the findings did not show that the number of independent directors or their meeting frequency had any significant impact on their efficacy.

Reviewing the whole range of empirical evidence, firms with a higher proportion of independent directors on the board, in some circumstances, were associated with better firm performance in the post-SOX period and were likely to fulfill their monitoring responsibilities in discrete board tasks generally. Overall, however, the performance of independent directors was not as uniformly effective as conventional wisdom expected. When an audit committee was composed entirely of independent directors, the firm was more likely to experience higher 
quality of financial reporting. However, there was no similar benefit when the compensation and nominating committees were comprised solely of independent directors. With a view to improving the efficacy of independent directors, firms may consider limiting the number of outside directorships on which they can serve, lowering costs of collecting the firm's information, requiring them to have minimum share ownership, and/or nominating those who are ethnic minorities or female to serve on the audit committee, based on the existing empirical evidence.

\subsection{Empirical Studies in Canada}

Unlike the United States, empirical studies related to the effectiveness of independent directors are relatively few in Canada. Of the approximately 30 existing studies, half of them focus on the correlation between board independence and overall firm performance measured by financial or accounting indicators. The rest can be roughly divided into four categories. First, there is one study exploring whether board independence plays a role in adopting additional governance mechanisms to check managerial abuses and reduce agency costs. Second, several studies investigated the relationship between director independence and the quality of financial reporting-the most important monitoring function of independent directors. Third, some studies examined whether independent directors fulfill their responsibilities in one of the main board tasks-setting appropriate remuneration for management. Fourth, the remaining group explored whether other governance mechanisms (for example, controlling shareholders, CEO playing the role of board chair, and board size) or director characteristics (such as gender) influence the efficacy of independent directors. However, unlike the United States, almost no research has investigated the relationship between board independence and discrete board tasks, and almost no studies have directly explored the efficacy of the three key monitoring committees, the audit, compensation and nominating committees, which are required or recommended to be composed entirely of independent directors. The following analysis starts with studies that examined the connection between board independence and overall firm performance.

\subsubsection{Board Independence and Overall Firm Performance}


If independent directors are really effective corporate monitors, their monitoring effect should be reflected through measures of shareholder interests (or wealth) and be captured by certain objective indicators. In the US, overall firm performance has been used as a prevailingly proxy for measuring the effectiveness of director independence since the 1980s. In Canada, following in the steps of US researchers, scholars also use financial indices, such as ROE, ROA and Tobin's Q, as performance indicators to evaluate their correlation with board independence. Similar to the status of the Blue Ribbon Committee in the USA, the Dey Committee ${ }^{1786}$ played a significant role in promoting director independence in Canada. However, in comparison with the divergent results of US studies regarding the relationship between board independence and overall firm performance, Canadian empirical evidence seems to show more consistently that board independence generally had little impact on firm performance. The following paragraphs compile the results of related Canadian studies by the time sequence of their samples.

\subsubsection{The Relationship between Outside Directors and Firm Performance Before 1994}

Before the importance of director independence was promoted by the Dey Committee, three studies had reported that board composition was not related to better firm performance. Rao and Lee-Sing (1995) ${ }^{1787}$ found that the more inside directors on the board, the higher the profitability for the Canadian firms. ${ }^{1788}$ Since directors who are not insiders are considered outside directors, the findings suggest that firms with more outside directors on the board might even perform worse. ${ }^{1789}$

\footnotetext{
${ }^{1786}$ Influenced by the Cadbury Report in England, the Toronto Stock Exchange (TSX) appointed a committee chaired by Peter Dey in 1993 to assess the corporate governance practices of publicly-held Canadian firms. Please refer to section 2.1.2 and subsection 2.1.2.1 for further details regarding the Cadbury Report and Dey Report.

${ }^{1787}$ The authors compared the impact of six governance mechanisms (concentration of ownership, institutional investors, inside ownership, inside directors, CEO duality and board size) on firm performance (as measured by ROE, ROA, growth of sales, growth of assets, labor growth and capital growth) between Canada and the United States by using a sample of 766 Canadian firms and 3,000 American corporations for the period 1988 to 1993. Rao \& Lee-Sing, supra note 1716 at $67,70,76$.

${ }^{1788}$ The authors reported that inside director ratio was significantly and positively associated with current ROE and ROA. The inside director ratio is calculated by the ratio of inside directors (officers of the firm who also sit on the board) to the total number of directors. Ibid at 53, 67 .

${ }^{1789}$ Ibid at 67, 68 Table 5.
} 
In contrast, Gagnon and St-Pierre (1995) ${ }^{1790}$ reported that board independence (as measured by the ratio of outsiders to insiders ${ }^{1791}$ ) was significantly and positively related to ROA (a proxy for firm performance) under diffuse ownership ${ }^{1792}$; however, such a correlation did not hold under either inside concentrated ${ }^{1793}$ or outside concentrated ownership ${ }^{1794} .^{1795}$ There seems no consistent impact of board independence on firm performance according to Gagnon and StPierre (1995).

During the same period, Amoako-Adu and Smith (1995) ${ }^{1796}$ conducted a study that examined the correlation between three firm performance measures: (1) Tobin's Q; (2) ROA; (3) asset turnover ${ }^{1797}$ and four categories of outside directors ${ }^{1798}$ : (1) outside financial directors (narrow definition); (2) outside financial directors (broader definition); (3) directors in the same line of business ${ }^{1799}$; and (4) other outside directors ${ }^{1800}$. Outside financial directors under the narrow definition include directors who are only current employees from financial institutions, while outside financial directors under the broader definition include directors who are either employees or directors from financial institutions. ${ }^{1801}$

\footnotetext{
${ }^{1790}$ The authors investigated the determinants of board composition and the correlation between board composition and firm performance (ROA) by employing a sample of 258 Canadian firms for the period from 1978 to 1991. JeanMarie Gagnon \& Josée St-Pierre, "Alternative Mechanisms for Corporate Governance and Board Composition" in Ronald J Daniels \& Randall Morck, eds, Corporate Decision-Making in Canada (Calgary, Alta : University of Calgary Press, 1995) at 149, 166 [Gagnon \& St-Pierre].

${ }^{1791}$ A director is defined as an inside director, if he/ she is an employee, or ex-employee of a firm, or of one of its subsidiaries. Directors who are not inside directors are classified as outside directors. Ibid at 167.

${ }^{1792}$ Diffuse ownership is defined as when three or fewer of the main shareholders or directors do not own 20 percent or more of the voting rights. Ibid.

${ }^{1793}$ Inside concentrated ownership signifies that directors own 20 percent or more of voting rights. Ibid.

${ }^{1794}$ Outside concentrated ownership means that three or fewer of the main shareholders own 20 percent or more of the voting rights. Ibid.

${ }^{1795}$ Ibid at 175, 180-81 Table 9, 179.

${ }^{1796}$ The authors evaluated whether the presence of outside financial directors enhanced the value of a corporation by surveying 150 Canadian public companies listed on the Toronto Stock Exchange over the period 1984 to 1993. Ben Amoako-Adu \& Brian F Smith, "Outside Financial Directors and Corporate Governance" in Ronald J Daniels \& Randall Morck, eds, Corporate Decision-Making in Canada (Calgary, Alta: University of Calgary Press, 1995) at 406-07 [Amoako-Adu \& Smith].

${ }^{1797}$ Asset turnover is calculated as the average annual ratio of the market capitalization of common equity to the book value of common equity. Ibid at 414 Table 5 .

${ }^{1798}$ This study defines inside directors as directors who are employees and officers of a firm or related corporations or shareholders who control at least $10 \%$ of the votes of a firm. Directors who are not inside directors are classified as outside directors. Ibid at 404.

${ }^{1799}$ Directors in the same line of business mean directors who are directors or officers of firms operating in the same industry. Ibid.

${ }^{1800}$ Other outside directors are defined as all directors who are not insiders, outside financial directors or same-lineof-business directors, including politicians, academics, public sector employees, consultants and lawyers. Ibid.

${ }^{1801}$ Ibid at 404, 406.
} 
The authors found that there was no significant relationship between three firm performance measures and the proportion of total outside directors on the board. After the composition of outside directors was further analyzed, neither the presence of outside financial directors (narrow definition) nor the presence of other outside directors were associated with any firm performance indicator. Only outside financial directors (broader definition) were significantly and positively related to one out of three performance indicators (Tobin's Q), while directors from the same industry were significantly and negatively correlated with one out of three performance indicators (asset turnover). ${ }^{1802}$ Collectively, there was no convincing evidence that outside directors from financial institutions or from the same line of business enhanced the value of a corporation, nor was there evidence that outside directors, in general, improved firm performance. ${ }^{1803}$ But outside directors who are employees or directors from financial institutions had some positive impact on firm value.

Taking the evidence of the three studies together, Gagnon and St-Pierre (1995) and Amoako-Adu and Smith (1995) found that outside directors had little impact on firm performance in general, while Rao and Lee-Sing (1995) reported that firms with a higher proportion of outside directors might even perform more poorly. The evidence with samples before 1994 does not show that outside directors were effective corporate monitors. It is worth noting that the findings of these three studies only look at the effect of outside directors (i.e. combining the effect of independent and affiliated directors). Had only independent directors been examined, the results might have been different.

\subsubsection{The Relationship between Unrelated Directors and Firm Performance After the Dey Report}

In 1994, the Dey committee proposed 14 guidelines for improved corporate governance; the primary prescription was that corporate boards consist of at least $50 \%$ of unrelated directors $^{1804}$. One year later, the TSE adopted the Dey guidelines as its listing requirements

\footnotetext{
${ }^{1802}$ Ibid at 410, 411 Table 3, 412 Table 4, 414 Table 5.

1803 Ibid at 413 .

${ }^{1804}$ Unrelated directors are defined as directors who are independent of management and are free from any interest and any business or any other relationship which could, or could reasonably be perceived to materially interfere with the director's ability to act in the best interests of the company, other than interests and relationships arising from shareholdings. Dey Report, supra note 196 at 4.
} 
whereby corporations had to specify, in either the annual report or proxy statement, whether their corporate governance practices were different from the guidelines, and, if they were, to explain the difference. ${ }^{1805}$ As noted, this type of reform is often characterized as a "comply-or-explain" approach in corporate governance.

Panasian, Prevost and Bhabra (2008) ${ }^{1806}$, examining the impact of the TSX requirements (the Dey guidelines) on firm performance, reported that firms voluntarily in compliance with the board independence guideline of the Dey committee (or those that were always ${ }^{1807}$ in compliance) did not have better firm performance (presented by the level of Tobin's Q) than those noncompliant firms. ${ }^{1808}$ More specifically, there was no significant difference in firm performance between boards with less than $50 \%$ of unrelated directors and boards with more than $50 \%$ of unrelated directors. In contrast, the authors found that firms with poorer performance were inclined to choose compliance with the new board independence guideline, while firms with better performance and ex ante noncompliant board composition preferred to remain noncompliant after the issuance of the Dey report. ${ }^{1809}$ In other words, poorly performing firms were more likely to increase their proportion of independent directors on the board to at least $50 \%$, but well performing firms were reluctant to change their board composition in compliance with the Dey recommendation. The study concluded that insider-dominated boards were optimal for some firms. Such findings were consistent with the voluntary nature of the guidelines, since firms should choose a board composition which is the most beneficial to their shareholders. ${ }^{1810}$ Collectively, these results seem to support the view of Boon et al. (2007) that board composition evolves in accordance with a firm's governance environments; ${ }^{1811}$ as a result, a higher level of board independence may not be ideal for all companies.

\footnotetext{
${ }^{1805}$ Christine Panasian, Andrew K Prevost \& Harjeet S Bhabra, "Voluntary Listing Requirements and Corporate Performance: The Case of the Dey Report and Canadian Firms" (2008) 43 The Financial Review 129 at 130, 133 [Panasian, Prevost \& Bhabra].

${ }^{1806}$ The authors examined whether firms voluntarily in compliance with the board independence guideline had better subsequent performance than those incompliant firms by investigating 300 of the largest Canadian firms listed on the TSX in 1995 for the period 1993 to 1997. Ibid at 134-35.

1807 "Always" here refers to firms that were always in compliance with the Dey Committee (board independence) guideline through the pre- and post-guideline periods, in comparison with those that comply with the guideline after the recommendation of Dey Committee.

${ }^{1808}$ Ibid at 142.

${ }^{1809} \mathrm{Ibid}$ at 143.

${ }^{1810} \mathrm{Ibid}$ at 142 .

${ }^{1811}$ Ibid at 140.
} 
Regarding whether the performance of compliant firms was improved in the post-Dey period, the authors observed that poorly performing firms that complied with the board independence guideline experienced significantly improved firm valuation, in comparison with those noncompliant poorly-performing firms. ${ }^{1812}$ It seems that encouraging greater board independence achieved the intended effect - poorly performing firms gained benefits from intensive monitoring. ${ }^{1813}$ However, the results also revealed that firms that were performing well and chose to ignore the Dey recommendations continued to perform strongly in the post-Dey period, ${ }^{1814}$ which reinforces the notion that insider-dominated boards are optimal for some firms. Thus, it may not be appropriate for regulators to require a board to have a minimum proportion of independent directors. Interestingly, adding an another unrelated director to the board did not generate any extra improvement in firm performance if the firm already had a majority of unrelated directors on the board, ${ }^{1815}$ suggesting that the advantages of board independence have upper limit-50\%.

Taken together, it seems that only poorly performing firms benefited from increasing their board independence, while the well-performing firms did not. However, firm performance could not be further improved after the percentage of unrelated directors on the board crossed the $50 \%$ threshold. This study showed that the benefit of board independence had reached its peak at 50\% and the TSE's comply-or-explain policy was an appropriate approach.

Using the same sample period as Panasian, Prevost and Bhabra (2008), Erickson et al. $(2005)^{1816}$ investigated whether an improvement in board independence (proportion of outside directors) enhances firm value (as measured by adjusted Tobin's Q) in the presence of controlling shareholders. They found that such firms with poor performance tended to add outside directors ${ }^{1817}$ to their boards in the next year, ${ }^{1818}$ but greater board independence did not

\footnotetext{
${ }^{1812}$ Ibid at 148-50, 154. The authors attributed this result to that boards in the post-Dey era became better at identifying new independent directors with more experience and better reputation. Ibid at 150.

1813 Ibid at 154 .

1814 Ibid at 153 .

1815 Ibid at 150,154 .

1816 The authors examined whether an improvement in board composition increases firm value under concentrated ownership by using a sample of 66 Canadian firms collected from the Global Vantage database for the period between 1993 and 1997. Erickson et al, supra note 676 at 394-96.

${ }^{1817}$ Directors who are not inside directors are considered as outside directors. The authors define company officers, family members of the controlling shareholders and related company officers as inside directors. Ibid at 396.

${ }^{1818}$ Ibid at 392, 402, 403 Table 7, 409.
} 
lead to better performance in the following year. ${ }^{1819}$ The finding implies that Canadian outside directors were not effective monitors in a concentrated ownership environment or that the monitoring effect of independent directors was unnecessary in light of monitoring by controlling shareholders. It is worth mentioning that this study observed that the presence of outside directors who are officers of financial institutions or who also sit on the audit committee do increase firm value. ${ }^{1820}$ Similar results have also been reported by Amoako-Adu and Smith (1995) that outside directors who are directors from financial institutions had some positive impact on firm performance (measured by Tobin's Q). However, the same study found no similar effect for outside directors who are current employees of financial institutions. These findings suggest that outside directors with financial expertise benefit their firms, but there is no conclusive evidence regarding which type of financial expertise is beneficial.

\subsubsection{The Relationship between Outside Directors and Firm Performance Regarding SOEs}

In addition to the relationship between independent directors and firm performance in private corporations, researchers also explored such a correlation in state-owned enterprises (SOEs). However, the results were mixed regarding the impact of outside directors on firm performance.

Bozec (2003) $)^{1821}$ found no significant relationship between firm performance ${ }^{1822}$ indicators and the proportion of outside directors ${ }^{1823}$ on the board, suggesting that board independence had no significant impact on the performance of SOEs. ${ }^{1824}$ However, after considering the effect of market competition ${ }^{1825}$ (when some of these SOEs faced competition), the author observed that the percentage of outside directors on the board was significantly and

\footnotetext{
${ }^{1819}$ Ibid at 400 Table 5, 400-01, 409. The results showed that the more outside directors were added to the board the worse these firms performed. Ibid.

${ }^{1820}$ Ibid at 392, 401, 403, 409.

${ }^{1821}$ The author investigated the correlation between firm performance and board independence, as well as the presence of audit, compensation and nominating committees by using a sample of 25 state-owned enterprises (SOEs) selected from the 500 largest companies in Canada as listed by the Financial Post covering the period from 1976 to 2000. Richard Bozec, Boards of Directors, Market Discipline and Firm Performance (Ottawa: Faculty of Administration, University of Ottawa, 2003) at 16 [Bozec].

${ }^{1822}$ In this study, firm performance is measured by return on sales, return on assets, sale efficiency, net income efficiency and assets turnover. Ibid at 35 Table 1.

${ }_{1823}$ Outside directors here are defined as board members who are non-executive directors. Ibid.

${ }^{1824}$ Ibid at 26, 28, 41 Table 7.

${ }^{1825}$ Market competition is measured by whether the SOE is a natural or geographic monopoly. Ibid at 19.
} 
negatively related to four out of five firm performance measures, implying that the more outside directors the poorer the firm performance. ${ }^{1826}$ The result appears to contradict the conventional wisdom that firms with a higher proportion of outside directors should perform better. ${ }^{1827}$

Interestingly, a similar study conducted by Bozec and Dia (2007), ${ }^{1828}$ investigating the impact of board independence on firm performance in 14 Canadian SOEs, ${ }^{1829}$ had opposite results. The authors found that the proportion of outside directors ${ }^{1830}$ on the board was positively related to firm performance (firm technical efficiency) ${ }^{1831}$ when SOEs were exposed to market competition $^{1832}$, suggesting that SOEs with a more independent board are more effective at coping with a complex and uncertain environment. ${ }^{1833}$ However, without the impact of market discipline, no significant correlation was found between board independence and firm technical efficiency. ${ }^{1834}$ The results of Bozec and Dia (2007) suggest that board independence is important for SOEs when they are subject to market competition (i.e. they are in a position similar to private firms). The contradictory results between the two studies might come from the use of different firm performance indicators. Bozec (2003) used accounting indices (ROS, ROA, sale efficiency, net income efficiency and assets turnover), while Bozec and Dia (2007) adopted firm technical efficiency.

It is worth noting that the results of Bozec (2003) and Bozec and Dia (2007) should not be overemphasized, because their samples merely contain 25 and 14 SOEs, respectively, which may be generalized to SOEs in Canada and may not represent the whole business sector. ${ }^{1835}$

\footnotetext{
${ }^{1826}$ Ibid at 27, 41 Table 7.

1827 The author provided a possible explanation for the results that inside directors possess superior information that can lead to more effective evaluation of top managers, while independent directors are usually part-time and may sit on a number of other boards. Therefore, it may be difficult for independent directors to understand the complexities of the company and to access enough information to make correct decisions. Ibid at 9.

${ }^{1828}$ Richard Bozec \& Mohamed Dia, "Board Structure and Firm Technical Efficiency: Evidence from Canadian State-owned Enterprises" (2007) 177 European Journal of Operational Research 1734 [Bozec \& Dia].

${ }^{1829}$ The sample of SOEs in this study was selected from the 500 largest Canadian firms in 1985 as listed by the Financial Post covering the period from 1976 to 2001. Ibid at 1738.

${ }^{1830}$ Outside directors here are defined as board members who are non-executive directors. Ibid at 1136,1740 Table 2.

${ }^{1831}$ Firm performance in this study is measured by firm technical efficiency (currently CCR or BCC models). Regarding the further detail of the CCR model, please refer to A Charnes, W W Cooper \& E Rhodes, "Measuring the Efficiency of Decision-Making Units" (1978) 2:6 European Journal of Operational Research 429. As for the BCC model, please refer to R D Banker, A Charnes \& W W Cooper, "Some Models for Estimating Technical and Scale Efficiencies in Data Envelopment Analysis" (1984) 30:9 Management Science 1078.

${ }^{1832}$ Market competition is measured by whether the SOE is a natural or geographic monopoly. Ibid at 1739.

${ }^{1833}$ Ibid at 1735, 1746, 1746 Table 7, 1747.

${ }^{1834}$ Ibid at 1745 .

${ }^{1835}$ Ibid at 1747; Bozec, supra note 1821 at 31.
} 


\subsubsection{The Correlation between ROB Board Composition Scores and Firm Performance After 2002}

In addition to the correlation between a singular director independence indicator (such as board independence or committee independence) and firm performance, some studies measure director independence by using composite indices in exploring the relationship between board composition and firm performance.

In Canada, the Report on Business (ROB), published by the Globe and Mail, has developed a composite index to rate corporate governance for firms represented on the TSX/S\&P index since 2002. The ROB corporate governance index is based on a set of best practices inspired by corporate governance guidelines and the recommendations of regulators, institutional investors and associations in the US and Canada. Taking the year 2002 as an example, the overall corporate governance index, with a maximum value of 100, was obtained by adding four sub-indices: (1) board composition (a maximum of 40 marks); (2) shareholdings and compensation (regarding the CEO and directors) (a maximum of 23 marks); (3) shareholder rights (a maximum of 22 marks); and (4) governance-related disclosure (a maximum of 15 marks). Each sub-index contains several criteria with arbitrary weights for each criterion. ${ }^{1836}$ The Board Composition sub-index evaluates director autonomy, including board independence (a maximum of 8 marks), the independence of the audit, compensation and nominating committees (a maximum of 13 marks), whether a firm's CEO is separated from the board chair (a maximum of 5 marks), relationships among directors (a maximum of 5 marks), and others (a maximum of 9 marks). The weights of the indexes and sub-indexes are slightly different in different years. Details regarding ROB Corporate Governance Indices in 2002 are provided in Appendix 28.

After the Globe and Mail released the ranking of corporate governance for the largest Canadian firms in 2002, some scholars employed the ROB corporate governance composite and sub-indices to explore whether firms with a higher ROB overall governance ranking or Board Composition scores are associated with better firm performance. The results of five related studies show that firms with higher ROB overall governance scores did not necessarily have

\footnotetext{
${ }^{1836}$ Janet McFarland, "How ROB Created the Rating System”, The Globe and Mail (7 October 2002) B6.
} 
better firm performance, while only one study reports that firms with higher ROB overall governance scores were related to lower cost of equity capital. With respect to the connection between ROB Board Composition scores and firm performance, five out of six studies found that firms with higher ROB Board Composition scores did not necessarily perform better, and sometimes might even perform worse. Only one study observed that firms with higher ROB Board Composition scores enjoyed lower cost of equity capital.

More specifically, Jog \& Dutta (2004) ${ }^{1837}$ found that the total corporate governance scores and Board Composition scores were significantly and negatively related to ROA, but were not associated with the other two performance indicators (market-to-book value ratio and a firm's monthly return), suggesting that firms with higher ROB total governance scores or Board Composition scores may even perform worse. Collectively, the authors concluded that no systematic relationship was found between ROB governance scores, either in aggregate or by individual components, and various performance measures. ${ }^{1838}$

Klein, Shapiro and Young (2005) also examined the relationship between firm performance (as measured by Tobin's Q) and ROB governance indices for 263 of the largest Canadian firms in 2002, and further explored whether such a correlation varies with ownership structure (as measured by family, institutional/corporate, government, mixed and widely held). ${ }^{1839}$ They reported that the ROB total corporate governance scores had no connection with Tobin's Q, regardless of the ownership structure. ${ }^{1840}$ The results suggest that firms with a higher overall governance ranking did not necessarily have better performance and such a finding was not influenced by the firm's ownership type.

As for the correlation between the Board Composition sub-index and firm performance, the authors observed that Board Composition alone was insignificantly related to Tobin's Q, and it became significantly and negatively associated with Tobin's Q when the effect of all four sub-

\footnotetext{
1837 The authors examined the connection between ROB governance indices and firm performance (as measured by market-to-book ratio, ROA, and a firm's monthly return), as well as CEO pay by using a sample of 270 largest Canadian firms in 2002. Vijay Jog \& Shantanu Dutta, "Corporate Governance, Performance and CEO Pay" (February 2004) at 10, online: SSRN <http://ssrn.com/abstract=507502> [Jog \& Dutta].

${ }^{1838}$ Ibid at 12-13, 15, 31 Table 6.

${ }^{1839}$ Peter Klein, Daniel Shapiro \& Jeffrey Young, "Corporate Governance, Family Ownership and Firm Value: the Canadian Evidence" (2005) 13:6 Corporate Governance 769 at 770, 772 [Klein, Shapiro \& Young]. Firms with at least 10 percent or more of voting rights controlled by families, institutions/corporations, or government are defined as family, institutional/corporate, or government control, respectively. Firms with two owners having shares of more than 10 percent and involving government are classified as mixed control. Corporations with no equity owners that controlled 10 percent or more of the voting rights are assigned to the widely-held category. Ibid at 772 . ${ }^{1840}$ Ibid at 775.
} 
indices were all included. ${ }^{1841}$ The findings imply that markets perceived that firms with higher levels of director independence was not associated with enhanced firm value, and sometimes might be connected with lower firm value. With respect to whether the correlation between Board Composition and firm performance depends on ownership structure, the authors found that Board Composition had no significant effect on firm performance for widely-held firms, while higher Board Composition scores were related to inferior firm performance for familyowned firms. ${ }^{1842}$ The results suggest that director independence was not an effective governance mechanism in Canadian family-control firms. Thus, the authors concluded that the impact of Board Composition on firm performance varied with ownership structure. ${ }^{1843}$

Two years later, Adjaoud, Zeghal and Andaleeb (2007) ${ }^{1844}$ also investigated the relationship between firm performance and ROB governance indices by using four accountingbased indices (return on equity, return on investments, earnings per share, and market-to-book value ratio) and two value-creation based indices (EVA and MVA) ${ }^{1845}$ as performance indicators for the 219 largest Canadian firms in 2002. ${ }^{1846}$ The reason for using different types of performance measures is for comparison purposes, since some studies have shown that valuecreation based indices are more reliable and complete than those traditional performance measures. ${ }^{1847}$ The authors observed that there was no significant difference in firm performance between firms with higher and firms with lower total governance marks, when firm performance

${ }^{1841}$ Ibid.

${ }^{1842}$ Ibid at 777-78.

${ }^{1843}$ Ibid at 778. The impact of Board Composition on firm performance was neutral for widely-held firms, but it turned negative when firms were family-owned.

${ }^{1844}$ Fodil Adjaoud, Daniel Zeghal \& Syed Andaleeb, "The Effect of Board's Quality on Performance: A Study of Canadian Firms" (2007) 15:4 Corporate Governance 623 [Adjaoud, Zeghal \& Andaleeb].

${ }^{1845}$ EVA, economic value added, calculates the dollar amount of the difference between a company's net profit after taxes and the total cost of capital employed, including the cost of equity. Ibid at 627. MVA (market value added) calculates the dollar amount of the difference between a company's market value of outstanding shares and the total cost of capital employed. Ibid at 629. According to the authors, EVA and MVA are more closely associated with shareholder wealth and firm values than the traditional accounting measures, such as earnings and cash from operations. Ibid.

${ }^{1846}$ Ibid at $625-26,631$. The main difference between this study and Klein, Shapiro \& Young (2005) is that the latter only employed Tobin's $Q$ as a performance indicator, while this study used four accounting-based indices (ROI, ROE, EPS and market-to-book ratio) and two value creation-based indices (EVA and MVA) to measure firm performance.

${ }^{1847}$ Ibid at 627-29. For example, Elais (2006), using a sample of about 1,000 American firms over the peiod 19902002, found that EVA outperformed total shareholder return and Tobin's Q in explaining shareholder wealth. See Wajeeh Elali, "Contemporaneous Relationship between EVA and Shareholder Value" (2006) 2 International Journal of Business Governance and Ethics 237. In addition, Stewart (1994) mentioned that EVA is almost 50\% better than its closest accounting-based competitor in explaining changes in shareholder wealth. Bennett Stewart, "EVA: Fact and Fantasy?" (1994) 7:2 Journal of Applied Corporate Finance 71 at 75. 
was evaluated by four accounting-based measures. However, they found that firms with higher governance rankings significantly outperformed firms with lower governance rankings, when firm performance was assessed by the two value creation-based measures. ${ }^{1848}$ Such findings suggest that a firm's governance quality was correlated with value creation.

With respect to the relationship between the ROB Board Composition sub-index and firm performance, Board Composition was reported to be negatively related to all six firm performance measures. More specifically, Board Composition was significantly and negatively associated with three out of four accounting-based indices ${ }^{1849}$ and one out of two value creationbased indexes (MVA). ${ }^{1850}$ The results show that firms with a higher Board Composition ranking were more likely to perform poorly, implying that greater director independence may not be beneficial to large Canadian firms.

Two years later, Gupta, Kennedy and Weaver (2009) ${ }^{1851}$ conducted similar research by investigating data over a longer period (four-year time series) and measuring firm performance through three separate sets of metrics: market valuation (market-to-book ratio and Tobin's Q), firm performance (ROA) and market reaction (two-day and 11-day stock returns around the publication date of ROB rankings). ${ }^{1852}$ The authors found that neither the firm value measures (Tobin's Q and market-to-book ratio) nor market reaction measures (two-day and 11-day stock returns) were correlated with composite governance scores. Only a firm's operation performance measure (ROA) was reported to be significantly and positively related to the total governance rankings. ${ }^{1853}$ There was no consistently significant association between the composite corporate governance scores as published by ROB and various measures of firm performance.

Regarding the correlation between firm performance and the ROB Board Composition sub-index, Board Composition seems to have no impact on firm value, regardless of how firm

\footnotetext{
${ }^{1848}$ Ibid at 629, 631 Table 6.

${ }^{1849}$ Board composition was significantly and negatively related to ROI at the five percent level, and was associated with ROE and EPS at 10 percent level. Ibid at 632 Table 7.

${ }^{1850}$ Ibid at 631 .

${ }^{1851}$ The authors examined whether firms with higher ROB governance scores had greater firm value by surveying 158 Canadian largest firms from 2002 to 2005. Parveen P Gupta, Duane B Kennedy \& Samuel C Weaver, "Corporate Governance and Firm Value: Evidence from Canadian Capital Market" (2009) 6:3 Corporate Ownership \& Control 293 at 294, 296 [Gupta, Kennedy \& Weaver].

1852 Ibid at 297.

${ }^{1853}$ Ibid at 299-300, 304-05 Table 3 to Table 5.
} 
performance was measured. ${ }^{1854}$ However, after reviewing it annually, the authors found that the higher the Board Composition ranking, the lower Tobin's Q or the market-to-book ratio the firm had for the years 2002 and 2004. The results seem to be consistent with the findings reported by Klein, Shapiro and Young (2005) for 2002. ${ }^{1855}$ The authors concluded that there was no consistent relationship between Board Composition ranking and firm performance.

In light of the concern that the traditional measures may not accurately and stably evaluate firm performance, Bozec and Bozec (2011) adopted an alternative measure of firm performance, cost of equity capital, to examine the correlation between ROB governance index and firm performance. ${ }^{1856}$ They observed that both ROB total index and Board Composition sub-index were negatively and significantly related to the cost of equity capital ${ }^{1857}$, suggesting that better firm governance practices and higher levels of director independence are associated with a decreased cost of capital. ${ }^{1858}$

In the wake of 2008 financial crisis, Toledo and Bocatto (2012) ${ }^{1859}$ investigated whether the relationship between the quality of governance (as measured by the ROB governance scores) and firm performance has been changed. ${ }^{1860}$ The authors found that firms with higher ROB governance scores presented lower stock returns, but found no connection with other performance indicators-ROA and Tobin's Q. ${ }^{1861}$ The findings show a lack of market reward for the adoption of higher standards of corporate governance. ${ }^{1862}$ With respect to whether board composition had an impact on firm performance, no significant correlation was found between the ROB Board Composition scores and three firm performance indicators (stock returns, ROA

\footnotetext{
${ }^{1854}$ Ibid at 299.

1855 Ibid.

${ }^{1856}$ The authors used panel data for 155 Canadian firms over a four-year period from 2002 to 2005 . Yves Bozec \& Richard Bozec, "Overall Governance and Cost of Capital: Evidence From Canada Using Panel Data” (2011) 6:1 J of Global Business Management 1.

${ }^{1857}$ The cost of equity capital was measured by the weighted-average cost of capital (WACC), including the cost of equity and the after-tax cost of debt. Ibid.

${ }^{1858}$ Ibid.

${ }^{1859}$ The authors examined the connection between the ROB governance scores and firm performance (including Tobin's Q, returns on assets, and stock returns) by using a sample of 156 corporations listed in TSX in 2009. Eloisa Perez de Toledo \& Evandro Bocatto, "Does Corporate Governance Matter After All? Quality of Governance and the Value of Canadian Firms After 2008" (12 January 2012) at 11, online: SSRN

$<$ http://ssrn.com/abstract=1985672> [Toledo \& Bocatto].

1860 Ibid at 4.

${ }^{1861}$ Ibid at 16, 24 Table 6, 25 Table 7.

${ }^{1862}$ Ibid at 19.
} 
and Tobin's Q), ${ }^{1863}$ suggesting that higher levels of director independence did not benefit listed firms.

In total, five of six studies ${ }^{1864}$ show that firms with higher ROB overall corporate governance scores, in general, did not have better performance, while only Bozec and Bozec (2011) reported that the cost of equity capital was lower when firms had higher ROB overall corporate governance scores. Similarly, Jog and Dutta (2004), Gupta, Kennedy and Weaver (2009), and Toledo and Bocatto (2012) found that firms with higher ROB Board Composition scores did not experience enhanced performance, while Klein, Shapiro and Young (2005) and Adjaoud, Zeghal and Andaleeb (2007) reported that firm performance might be even worse in some circumstances. Only Bozec and Bozec (2011) observed that the cost of equity capital was lower when firms had higher ROB Board Composition scores. In general, shareholders did not benefit from higher levels of independence on the board or on the committees. Professors Gupta, Kennedy and Weaver provide a possible explanation that the governance scores developed by the ROB did not adequately capture the true state of overall corporate governance or director independence of the sample firms; ${ }^{1865}$ however, from my point of view, it is also probable that director independence was not the major determinant of firm performance in Canada.

\subsubsection{The Connection between SOX Director Independence Requirements and Firm Performance for Cross-Listing Small Canadian Firms}

After SOX had been in place for a couple of years, Switzer (2007) examined whether the correlation between governance mechanisms (including board independence) and firm performance (measured by Tobin's Q) for 94 Canadian TSX/S\&P Small-Cap firms was influenced by cross-listing in the US and the compliance with SOX-related reforms during the years 1997 to 2004 . $^{1866}$ His findings showed no significant correlation between the proportion of outside directors ${ }^{1867}$ on the board and Tobin's $Q,{ }^{1868}$ suggesting that board independence was not

\footnotetext{
${ }^{1863}$ Ibid at 15, 23 Table 5.

1864 The five studies here are Jog and Dutta (2004), Klein, Shapiro and Young (2005), Adjaoud, Zeghal and Andaleeb (2007), Gupta, Kennedy and Weaver (2009), as well as Toledo \& Bocatto (2012).

1865 Ibid at 301.

${ }^{1866}$ Lorne N Switzer, “Corporate Governance, Sarbanes-Oxley, and Small-cap Firm Performance” (2007) 47 The Quarterly Review of Economics and Finance 651 at 656 [Switzer].

${ }^{1867}$ Outside directors are defined as board members who are not employed by the firm. See ibid at 657 Table 1.

${ }^{1868}$ Ibid at 660, 662 Table 4.
} 
a powerful governance mechanism in enhancing firm value for small Canadian firms. However, such findings did not separate the sample into pre-2002 and post-2002 periods to examine the effect of SOX. As shown in Bhagat and Bolton (2008) and Bhagat and Bolton (2009), ${ }^{1869}$ the impact of independent directors on firm performance is significantly different between pre-SOX and post-SOX periods. The positive impact of SOX board-independence reforms on firm performance might be moderated by the negative effect of board independence on firm performance in the pre-SOX period. Further research is needed to understand the real impact of SOX on the performance of Canadian small-cap firms.

In addition, the author found that cross-listing in the US per se had no significant impact on firm value for Canadian small firms. However, after becoming compliant with new SOXrelated listing requirements, these small firms had an incremental market valuation gain of between $15.7 \%$ and $34 \%$, implying that the benefits for mandatory compliance with SOX for small firms outweighed its costs. ${ }^{1870}$ However, since SOX included a variety of reforms, it is difficult to determine whether the director independence requirements on their own have a positive impact on firm value for Canadian small cross-listed firms.

\subsubsection{Analysis}

Taking the accumulated evidence together, it shows that, in Canada, firms with a higher level of board independence (or a majority of independent directors on the board) generally did not experience better performance and might even perform worse than firms without independent boards. Before the Dey Report was published, Gagnon and St-Pierre (1995) and Amoako-Adu and Smith (1995) found that the percentage of outside directors on the board had little impact on firm performance, while Rao and Lee-Sing (1995) reported that firms with a higher proportion of outside directors might even perform worse. After the TSX recommended that listing companies should have a majority of unrelated directors on the board in 1995, Panasian, Prevost and Bhabra (2008) observed that firms with a majority of independent directors on the board, in general, did not have better firm performance than those without the same board composition, and only poorly performing firms that chose to comply with the board independence guideline

\footnotetext{
${ }^{1869}$ Bhagat \& Bolton 2008, supra note 1020 at 258, 266 Table 4, 271; Bhagat \& Bolton 2009, supra note 1021 at 4.

${ }^{1870}$ Switzer, supra note 1866 at 664.
} 
experienced enhanced firm valuation in comparison with those noncompliant poorly-performing firms that did not do so. Erickson et al. (2005) reported that firms with poor performance tended to add outside directors to their boards in the next year, but greater board independence did not lead to better performance in the future.

In the wake of the emergence of ROB corporate governance rankings in 2002, Jog and Dutta (2004), Gupta, Kennedy and Weaver (2009) and Toledo and Bocatto (2012) found that firm performance was not necessarily enhanced for firms with higher ROB Board Composition scores, while Klein, Shapiro \& Young (2005) and Adjaoud, Zeghal \& Andaleeb (2007) observed that firm performance might be even worse for those with a higher level of director independence as measured by the Board Composition index. Only Bozec and Bozec (2011) reported that higher ROB Board Composition scores were associated with lower cost of equity capital. The ineffectiveness of independent directors was also reflected in the mixed results regarding the impact of outside directors on firm performance in SOEs (when facing market competition). Bozec (2003) found that the more outside directors on the board, the poorer the firm performance, while Bozec and Dia (2007) observed the opposite. This tendency was consistent with the study of small-cap firms by Switzer (2007), who reported an insignificant impact of outside directors on firm performance over the years 1997 to 2004. Ostensibly, firms with more independent boards did not necessarily perform better, and might even perform worse, than those less independent ones.

It is worth noting that the problems of endogeneity (mainly causation), possible lagged effects and the definition of independent director, which emerged in the US empirical studies, were also concerns related to Canadian empirical studies. As mentioned in the US part, findings of some studies cannot demonstrate causation. The impact of board independence on firm performance is unclear without further investigation. In addition, a "lagged effect" may exist between board independence and firm performance, so the finding that there is no contemporaneous correlation between director independence and firm performance does not exclude the possibility that a relationship may occur across different periods. The results of these studies need further examination to confirm their reliability. As well, the results of some studies might not represent the real effect of independent directors on firm performance because their results did not distinguish the effect between outside and independent directors. In fact, affiliated directors, who have business ties with a firm, may neutralize the monitoring effect of 
truly independent directors, which results in an understatement of the effect of independent directors. Had only independent directors been investigated, the results might have been different.

Moreover, ROB Board Composition scores cannot reflect the real level of board independence. Taking the 2002 ROB Board Composition scores for example, board independence only occupies $20 \%$ of the ROB Board Composition scores. The independence of the audit, compensation and nominating committees, whether the firm's CEO is separated from the board chair, relationships among directors, and other factors also constitute $32.5 \%, 12.5 \%$, $12.5 \%$ and $22.5 \%$ of the ROB Composition scores, respectively. ${ }^{1871}$ As a result, the connection between ROB Board Composition scores and firm performance may not be indicative of the relationship between independent directors on the board and firm performance.

Collectively, there are fourteen Canadian empirical studies exploring the relationship between board independence and firm performance. Thirteen of them, more or less, are tainted by aforementioned weakness. Seven studies ${ }^{1872}$ only looked at the effect of outside directors, while the other six studies ${ }^{1873}$ used ROB Board Composition scores to measure board independence. Three ${ }^{1874}$ of the thirteen studies did not examine the possible lagged effects, while two ${ }^{1875}$ of them merely examined state-owned enterprises and thus might not be applicable to private firms. Consequently, the results of these thirteen studies may not be fully reliable. The problems of the 13 Canadian empirical studies are compiled in Appendix 29. Nevertheless, to the extent that the findings of these studies are considered reliable, they still show that

\footnotetext{
${ }^{1871}$ See section 5.2.1.4 and supra text accompanying note 1836.

1872 Seven studies-Gagnon and St-Pierre (1995), Amoako-Adu and Smith (1995), Rao and Lee-Sing (1995), Bozec (2003), Erickson et al. (2005), Bozec and Dia (2007), and Switzer (2007)-did not distinguish the effect between independent and outside directors.

${ }^{1873}$ Six studies-Jog and Dutta (2004), Klein, Shapiro \& Young (2005), Adjaoud, Zeghal \& Andaleeb (2007), Gupta, Kennedy and Weaver (2009), Bozec and Bozec (2011) and Toledo and Bocatto (2012)-used ROB Board Composition scores to represent board independence.

1874 Three studies-Amoako-Adu and Smith (1995), Jog and Dutta (2004), and Gupta, Kennedy and Weaver (2009)did not control the problem of lagged effects, while five studies-Gagnon and St-Pierre (1995), Erickson et al. (2005), Switzer (2007), Panasian, Prevost and Bhabra (2008), and Toledo and Bocatto (2012)-did. Gagnon \& St-Pierre, supra note 1790 at 160; Erickson et al, supra note 676 at 393; Panasian, Prevost \& Bhabra, supra note 1805 at 134, 137; Switzer, supra note 1866 at 659-60; Toledo \& Bocatto, supra note 1859 at 6-7, 13.

1875 Please refer to Bozec (2003) and Bozec \& Dia (2007) in section 5.2.1.3.
} 
Canadian firms with higher board independence were not associated with enhanced firm performance. ${ }^{1876}$

Of the fourteen studies, only the findings of Panasian, Prevost and Bhabra (2008), showing that poorly-performing firms chose to comply with the board independence guideline experienced improved firm valuation (compared to those noncompliant poorly-performing firms), controlled for the problem of endogeneity, lagged effects and definition of independent directors. ${ }^{1877}$ However, the same study also found that firms with a majority of independent directors on the board, in general, did not have better firm performance than those without the same board composition. ${ }^{1878}$ It appears that not every firm benefits from having a majority of independent directors on the board.

Since the findings of most studies regarding the relationship between board independence and firm performance in Canada suffer from methodological problems and the study with high reliability only endorsed the efficacy of independent directors in some circumstances, it is difficult to conclude that boards composed of a majority of independent directors are beneficial to their firms in Canada. More research is needed to understand the real impact of board independence on firm performance.

\subsubsection{Board Independence and Other Monitoring Mechanisms}

Since explorations of board independence and firm performance has not provided conclusive results regarding whether independent directors are effective monitors, Professors Anand, Milne and Purda used an alternative approach-focusing on board actions (rather than firm performance) to examine the efficacy of independent directors in management oversight. The rationale is that if independent directors have incentives to act as diligent monitors, they would be expected to equip themselves with additional tools (governance mechanisms) to

\footnotetext{
${ }^{1876}$ Although Bozec and Bozec (2011) reported that higher director independence was associated with lower cost of equity capital, a firm with lower cost of equity capital may not necessarily generate higher returns for its shareholders.

${ }^{1877}$ Panasian, Prevost \& Bhabra, supra note 1805 at 134, 137.

${ }^{1878}$ It is worth noting that some well-performing firms chose to maintain their board independence below $50 \%$, while some poorly-performing firms chose to increase their board independence above 50\%. Perhaps, it makes firm performance, in general, no significant difference between firms with and without a majority of independent directors on the board.
} 
facilitate this role. ${ }^{1879}$ Professors Anand, Milne and Purda investigated whether independent boards ${ }^{1880}$ are more likely to adopt seven governance mechanisms ${ }^{1881}$, compared to nonindependent boards, to assist them in checking managerial abuses by surveying information circulars of about 1,200 firms listed on Toronto Stock Exchange during the years 1999 to 2003. ${ }^{1882}$ They found that generally there is no significant difference between independent and non-independent boards in voluntarily adopting governance mechanisms designed to enhance their monitoring capabilities, ${ }^{1883}$ but independent boards place special emphasis on management oversight through the presence of independent audit and compensation committees. ${ }^{1884}$ The findings suggest that the presence of a majority of independent directors on the board does not guarantee enhanced compliance with best practices. ${ }^{1885}$

\subsubsection{Director Independence and the Quality of Financial Reporting}

In addition to firm performance and board actions, the quality of financial reporting is also an important indicator measuring the effectiveness of independent directors. In modern capital market, investors rely on quality financial statements to make their investment decisions. A firm without a transparent and reliable financial reporting process will be punished by market participants ultimately. In order to survive in the competitive market, ensuring the quality of financial reporting has become one of the main missions of the modern corporations. Since some firms delegate such a mission to the audit committee, the board or audit committee members shoulder the responsibility of reviewing financial statements and establishing an internal control system to make certain that the goal is achieved.

\footnotetext{
1879 Anand, Milne \& Purda, supra note 7 at 814-15.

${ }^{1880}$ In this study, a board is defined as independent if it includes either a majority of independent directors or an independent chair. Ibid at 818, 835, 839, 841, 844, 845.

${ }^{1881}$ The authors explored the connection between board independence and seven governance mechanisms, including a completely independent audit committee, a completely independent compensation committee, ability to independently hire advisors, formal training for new board members, adoption of a code of ethics, certification of financial statements, and the presence of a financial expert on the audit committee. Ibid at 821-22.

1882 Ibid at 809,838 .

${ }^{1883}$ Ibid at 810-11, 824, 830-31, 836-37.

${ }^{1884}$ Firms with a majority of independent directors on the board are more likely to staff their audit and compensation committees solely with independent directors, compared to those without a majority of independent directors. Ibid at $810,832-33,835$.

1885 Ibid at 837 .
} 
As early as 1995, the TSE recommended that listed companies establish an audit committee composed entirely of outside directors. Since 2004, National Instrument 52-110 has required that reporting issuers have an audit committee and its members should be financially literate and fully independent of management. However, whether independent directors on the board or on the audit committee can effectively ensure the quality of financial reporting has not been systematically explored in Canada. So far, only a few studies have examined the correlation between board or audit committee characteristics and measures of the quality of financial reporting, such as interaction with auditors, earnings management, and accounting irregularities, for Canadian firms. The existing evidence seems to show that director independence and financial expertise, either on the board or on the audit committee, have a certain positive impact on the quality of financial reporting, but it is not as strong as conventional wisdom would expect. These empirical results can be analyzed from three perspectives: (1) the correlation between the proportion of independent directors on the board and financial reporting quality; (2) the relationship between the proportion of independent directors on the audit committee and the quality of financial reporting; (3) the connection between the presence or the number of financial experts (or directors with financial literacy) on the audit committee (or on the board) and the quality of financial reporting.

First, regarding the relationship between the proportion of independent directors on the board and financial reporting quality, the results are inconsistent. Smaili and Labelle (2009) ${ }^{1886}$ found that boards with a higher proportion of independent directors ${ }^{1887}$ were associated with not only a lower occurrence but also less severe accounting irregularities ${ }^{1888}$ (representing a higher

\footnotetext{
${ }^{1886}$ The authors used the occurrence of accounting irregularities as an indicator of the quality of financial reporting to examine its connection with board independence, audit committee independence, financial expertise, and CEO duality, by surveying a sample of 107 firms identified as accounting irregularities by the Ontario Securities Commission (OSC) from 2001 to 2005. Nadia Smaili \& Réal Labelle, "Preventing and Detecting Accounting Irregularities: The Role of Corporate Governance" (7 January 2009) at 5, 12, online: SSRN < http://ssrn.com/abstract=1324143> [Smaili \& Labelle].

${ }^{1887}$ The authors use the term "unrelated" directors to describe what most studies call "independent" directors in their study. However, they do not specifically define unrelated directors in the study. From the context, the authors seem to divide directors into three categories: unrelated directors, affiliated directors and inside directors. Ibid at 26 Table 2.

${ }^{1888}$ The accounting irregularities, according to the gravity of violation of the OSC Financial Statement Filing Requirements, can be divided into three levels: first, the lowest level, the firms are put on a "Re-filing and errors list" after making the corrections; second, the middle level, the firms are issued a full cease trade order (CTO) or a CTO limited to management and insiders; third, the most severe level, the firms are cited for fraudulent financial statements by the OSC. Ibid at 5, 12 .
} 
quality of financial reporting), ${ }^{1889}$ while Niu $(2006){ }^{1890}$ reported that firms with higher ROB

Board Composition scores, combining the effect of board independence, committee

independence and the separation of CEO and board chair, were less likely to manipulate earnings

(as measured by abnormal accruals) and more likely to have quality earnings (both signifying a better quality of financial reporting). ${ }^{1891}$ In contrast, Park and Shin (2004) ${ }^{1892}$ found that firms with a higher proportion of outside directors ${ }^{1893}$ on the board did not experience reductions in the frequency of earnings management ${ }^{1894}$ (an indicator of financial reporting quality). ${ }^{1895}$ However, they observed that outside directors from financial intermediaries ${ }^{1896}$ or from institutional investors were inclined to curb income-increasing earnings management when (unmanaged)

${ }^{1889} \mathrm{Ibid}$ at $18-19,22,29$ Table 4.

${ }^{1890}$ The author examined: (1) the relationship between the scores of Report of Business (ROB) governance indices (including sub-indices) and the level of earnings management (as measured by abnormal accruals), and (2) the relationship between the scores of Report of Business (ROB) governance indices (including sub-indices) and earnings quality (as measured by return-earnings association) by employing a sample of around 520 firm-year observations for S\&P/TSX composite index firms from years 2002 to 2005. Flora F Niu, "Corporate Governance and the Quality of Accounting Earnings: A Canadian Perspective" (2006) 2:4 International Journal of Managerial Finance 302 at $311-12$ [Niu].

${ }^{1891}$ Ibid at 312-13, 315, 322.

1892 The authors examined the effect of board independence (as measured by the proportion of outside directors on the board) on the practice of earnings management (as measured by abnormal accruals) by using a sample of 202 Canadian firms from 1991 to 1997. Yun W Park \& Hyun-Han Shin, "Board Composition and Earnings Management in Canada" (2004) 10 Journal of Corporate Finance 431 at 438 [Park \& Shin]. Accruals, in the field of accounting, means the recognition of revenue when earned or expenses when incurred regardless of when cash is received or disbursed. See Venture Line Accounting Terms, online: Venture Line

$\langle$ http://www.ventureline.com/glossary A.asp〉. Accrual manipulation occurs when managers distort accruals in order to manipulate earnings. See ibid at $434,440$.

${ }^{1893}$ In this study, directors who are company officers, family members of the controlling shareholder, and related company officers are considered as insider directors. In contrast, outside directors include unrelated company officers, officers of financial institution, former bankers, lawyers, academics, consultants, corporate directors and former politicians. Ibid.

${ }^{1894}$ Corporate executives have incentives to manipulate a firm's earnings so that the results of financial statements can match their desired objectives. Although Generally Accepted Accounting Principles allow a firm to adjust its earnings, earnings management, to some extent, obscures a firm's real performance and lessens the ability of shareholders to make informed decisions. Generally, the higher the level of earnings management the lower the quality of financial reporting. Therefore, some scholars used the gravity of earnings management as an index to measure the quality of financial reporting. Ibid at 434; Xie, Davidson \& DaDalt, supra note 1351 at 296; Bédard, Chtourou \& Courteau, supra note 510 at 15-16.

${ }^{1895}$ Park \& Shin, supra note 1892 at 445, 449, 455. The authors addressed four possible reasons to explain why outside directors were not effective in curbing earnings management in Canada. First, outside directors generally lack financial sophistication and access to relevant information to detect and correct earnings management. Second, outside directors in Canada may not have sufficient incentives to supervise management because they lack ownership interests in the company they monitor. Third, the presence of dominant shareholders in many corporations may make it difficult for outside directors to effectively curb inappropriate earnings management. Finally, the Canadian labor market for outside directors may not be well developed, so adding outside directors to the board may not improve corporate governance, especially in a jurisdiction where ownership is highly concentrated. Ibid at 455-56.

${ }^{1896}$ In this study, financial intermediaries include commercial banks, insurance companies, investment banks, mutual funds and pension funds. Ibid 447. 
earnings were below the target. ${ }^{1897}$ It showed that outside directors with financial expertise or acting on behalf of institutional shareholders were effective monitors in reducing the likelihood of earnings management. ${ }^{189}$ Interestingly, Smaili and Labelle (2009) reported that boards with non-affiliated blockholders (holders of blocks of shares representing at least $10 \%$ of outstanding shares), ${ }^{1899}$ or their representatives, were more likely to be associated with fewer and less severe accounting irregularities, ${ }^{1900}$ suggesting that significant shareholders were effective in monitoring management. Taken together, it seems that having a higher level of board independence was at worst harmless and may be related to a higher quality of financial reporting.

It is worth mentioning that the effect of outside directors from financial intermediaries on earnings management reported by Park and Shin (2004) was not significantly different after the issuance of the Toronto Stock Exchange's Corporate Governance Guidelines of 1994, in comparison with the effect in the pre-guideline period. ${ }^{1901}$ Although there was a small increase in the proportion of independent directors on the board after the implementation of the Guidelines (from $57 \%$ in 1993 to $66 \%$ in 1997), ${ }^{1902}$ there is no evidence that boards were more actively involved in mitigating the level of earnings management, suggesting that a more independent board is not necessarily more effective in improving the quality of financial reporting.

Second, the results regarding the correlation between the proportion of independent directors on the audit committee and the quality of financial reporting are inconsistent. Scarbrough, Rama and Raghunandan (1998) ${ }^{1903}$ found that audit committees with $100 \%$ outside directors ${ }^{1904}$ were more likely to be engaged in internal auditing activities ${ }^{1905}$, including meeting at least three times a year with the chief internal auditor and reviewing the results of internal

\footnotetext{
${ }^{1897}$ Ibid at 447-49, 455 .

1898 Ibid at 456.

${ }^{1899}$ A non-affiliated blockholder in the study is defined as a shareholder who owns more than $10 \%$ of corporate shares and does not have any material relationship with the corporation. Smaili \& Labelle, supra note 1886 at 26 Table 2, 27 Table 3.

${ }^{1900}$ Ibid at 19, 33 Table 6.

${ }^{1901}$ Park \& Shin, supra note 1892 at 452, 455.

1902 Panasian, Prevost \& Bhabra, supra note 1805 at 135.

1903 The authors examined whether the audit committee composition had an impact on the committee's interaction with internal auditing activities by using a sample of 72 Canadian firms in the late 1990s. D Paul Scarbrough, Dasarathe V Rama \& K Raghunandan, "Audit Committee Composition and Interaction with Internal Auditing: Canadian Evidence" (1998) 12:1 Accounting Horizons 51 at 55 [Scarbrough, Rama \& Raghunandan].

${ }^{1904}$ Outside directors are defined as board members who are non-employee directors. Ibid.

1905 The committee's interaction with internal auditing activities is measured by: (1) audit committee involvement in decisions to dismiss the chief internal auditor; (2) meetings between the audit committee and the chief internal auditor; and (3) audit committee review of the internal auditing plan and the results of internal auditing. Ibid at 54.
} 
auditing (signifying a better quality of financial reporting), ${ }^{1906}$ while Smaili and Labelle (2009) observed that the proportion of independent directors on the audit committee had no connection with the occurrence of accounting irregularities. ${ }^{1907}$ Although Niu (2006) reported that firms with higher ROB Board Composition scores, reflecting the effect of the audit committee independence, were less likely to manipulate earnings, ${ }^{1908}$ it may not be appropriate to conclude that greater audit committee independence was associated with a lower level of earnings management, since fully independent audit committees only occupied $15 \%$ of the Board Composition scores. In total, audit committees with a higher proportion of independent or outside directors were at worst harmless and might be related to a higher quality of financial reporting. Such findings are similar to, but not as strong as, the evidence regarding the impact of board independence on the quality of financial reporting.

Third, with respect to the connection between financial expertise or financial literacy ${ }^{1909}$ and the quality of financial reporting, the results are slightly inconsistent. Smaili and Labelle (2009) found that audit committees with a greater number of financial experts ${ }^{1910}$ were associated with fewer and less severe accounting irregularities (implying a better quality of financial reporting), ${ }^{1911}$ while Park and Shin (2004) reported that the boards with outside directors from financial institutions were related to a lower level of earnings management (signifying a better quality of financial reporting). ${ }^{1912}$ However, against conventional wisdom, Smaili and Labelle (2009) observed that the proportion of audit committee members with financial literacy ${ }^{1913}$ had no impact on the occurrence or gravity of accounting irregularities. ${ }^{1914}$ In sum, directors with

\footnotetext{
${ }^{1906}$ Ibid at 58, 61 .

1907 Smaili \& Labelle, supra note 1886 at 19, 33 Table 6.

${ }^{1908} \mathrm{Niu}$, supra note 1890 at 312-13, 315, 322.

1909 According to National Policy 52-110, an individual is considered financially literate, if he or she has the ability to read and understand a set of financial statement that present a breadth and level of complexity of accounting issues that are generally comparable to the breadth and complexity of the issues that can reasonably be expected to be raised by the issuer's financial statements. It is not necessary for an audit committee member to have a comprehensive knowledge of GAAP and GAAS to be considered having financial literacy. Companion Policy 52110 CP to Multiple Instrument 52-110 Audit Committee, OSC CP 52-110, s 4.1, 27 OSCB 3264 (26 March 2004), at 3266.

${ }^{1910}$ The authors use the number of directors with a professional designation in accounting or finance (CA, CMA, CGA or CFA) or with a specialized university diploma in accounting or in finance to measure financial expertise. Smaili \& Labelle, supra note 1886 at 10.

${ }^{1911}$ Ibid at 19, 33 Table 6.

1912 Park \& Shin, supra note 1892 at 447, 455.

1913 The authors use the number of directors with an MBA or a BAA in administration or with experience in finance or in accounting to measure financial literacy. Smaili \& Labelle, supra note 1886 at 10.

${ }^{1914}$ Ibid at 19, 33 Table 6.
} 
financial expertise either on the board or on the audit committee were more likely to be related to a higher quality of financial reporting, but directors with only financial literacy seem to have no such effect. It appears that the current National Policy NI 52-110 which requires that all audit committee members should be financially literate, rather than at least one of them having financial expertise, may be insufficient to maintain the quality of financial reporting.

Taking the accumulated evidence together, boards or audit committees with a higher percentage of independent or outside directors were likely to be associated a higher quality of financial reporting in some circumstances; the effect of having independent directors on the board was seemingly stronger than that on the audit committee. In addition, the quality of financial reporting was more likely to be better when boards or audit committees had members with financial expertise; however, such an effect could not be reached if these members were only financially literate.

\subsubsection{Director Independence and Executive Compensation}

Besides firm performance and the quality of financial reporting, executive compensation is also often used as an indicator to measure the efficacy of independent directors. As mentioned in the US section, executive remuneration ideally should not be too high or it may damage shareholder wealth. However, it cannot be too low or it may not provide sufficient incentives for executives to maintain management quality. The better scenario is to establish a compensation package that can align the interests of executives with those of shareholders. Since boards of directors or members of compensation committees, especially independent directors, are in charge of setting executive pay, the correlation between independent directors and executive compensation seems to be a good indicator to measure the effectiveness of Canadian independent directors. The existing evidence seems to show that boards or compensation committees with a higher proportion of independent directors neither lowered the level of executive compensation nor tended to tie executive pay to firm performance. Empirical evidence related to this topic is analyzed as follows.

First, regarding the relationship between the level of CEO compensation and the proportion of independent or outside directors on the board or compensation committee, two 
related studies reached similar results. Jog and Dutta (2004) ${ }^{1915}$ found that board independence, as measured by the proportion of insiders on the board, was not related to the level of CEO compensation ${ }^{1916},{ }^{1917}$ while Sapp (2008) ${ }^{1918}$ observed that boards with a higher percentage of independent directors ${ }^{1919}$ had no impact on the level of total CEO pay. ${ }^{1920}$ Sapp (2008) further reported that compensation committees with a higher proportion of independent directors were even related to higher levels of CEO compensation. ${ }^{1921}$ It seems that Canadian independent or outside directors, either on the board or compensation committee, were unable to restrain remuneration for their executives. Interestingly, the findings revealed that the presence of a controlling shareholder ${ }^{1922}$ was correlated with a lower level of executive compensation, fewer stock options, and a smaller gap between the CEO and other executives, suggesting that controlling shareholders, instead of independent directors, played an important role in restraining CEO remuneration. ${ }^{1923}$

Second, with respect to whether Canadian independent directors are able to tie executive pay to firm performance, the results are slightly inconsistent. One study found that the presence of outside directors was not related to the sensitivity of CEO pay to firm performance, while the other observed that independent directors had a certain positive impact on such sensitivity. Another two studies reported that executive compensation was insensitive to firm performance, but without mentioning the role of independent directors in such a relation.

1915 The authors investigated the interaction between three firm performance indicators (market-to-book ratio, return on assets and the firm's monthly return ) and six corporate governance mechanisms (director ownership, blockholder ownership, board size, proportion of inside directors, CEO pay, and CEO duality) by using a sample of 270 largest Canadian firms in 2002. Jog and Dutta, supra note 1837 at 10, 11, 29 Table 1 and 34 Table 10.

1916 The authors do not give "CEO compensation" a definition.

${ }^{1917}$ The authors found no significant connection among the six governance mechanisms, except for the positive relationship between the proportion of inside directors and director ownership. It implies that the proportion of inside directors was not associated with CEO pay. Ibid. at 14-15, 32 Table 8, 33 Table 9.

${ }^{1918}$ The author investigated how the compensation of top five executives was influenced by firm size, industry, firm performance and four governance mechanisms (as measured by ownership and characteristics of a board, compensation committee and CEO) through using a sample of 416 Canadian publicly-listed firms from 2000 to 2005. Stephen G Sapp, “The Impact of Corporate Governance on Executive Compensation” (2008) 14:4 European Financial Management 710 at 714 [Sapp].

1919 The author does not define "independent directors" in this study.

${ }^{1920}$ Ibid at 740. CEO compensation is measured by the sum of salary, bonus, long-term incentive plan and all other annual compensation. Ibid at 721 Figure 1.

${ }^{1921}$ Ibid.

${ }^{1922}$ A controlling shareholder in this study is defined as the largest shareholder who has either at least twice the voting rights of the next largest shareholder or at least $10 \%$ equity ownership. Ibid at 730 .

1923 Ibid at 730, 742 . 
More specifically, Switzer (2007) found that pay-for-performance sensitivity of CEO compensation was not significantly related to the proportion of outside directors ${ }^{1924}$ on the board, ${ }^{1925}$ while Schiehll and Bellavance (2009) ${ }^{1926}$ observed that firms with a greater proportion of independent directors ${ }^{1927}$, in some circumstances, aligned CEO interests with shareholder wealth by employing non-financial performance measures ${ }^{1928}$ in the CEO's compensation package. ${ }^{1929}$ In addition, Jog and Dutta (2004), and Sapp (2008) reported that CEO compensation was insensitive to firm performance. More precisely, the former found no significant relationship between CEO pay and three performance measures. ${ }^{1930}$ The latter observed that executive compensation was not related to two out of three performance measures (excess total shareholder return relative to the average return in that industry and the average industry return), but was significantly and negatively associated with return on assets (implying that executives were paid even more when their firms performed poorly). ${ }^{1931}$ Since executive compensation is supposed to be established by boards of directors, especially independent directors, the findings of Jog and Dutta (2004) and Sapp (2008) indirectly confirmed the findings of Switzer (2007) that the sensitivity of pay-for-performance was not influenced by board independence. In total, independent directors in Canada seemingly do not do a good job of tying CEO remuneration to firm performance.

\footnotetext{
${ }^{1924}$ Outside directors are defined as board members who are not employed by the firm. Switzer, supra note 1866 at 657 Table 1.

${ }^{1925}$ Ibid at 660, 662 Table 4.

${ }^{1926}$ The authors examined the correlation between the use of non-financial performance measures in the CEO bonus plan and the proportion of unrelated directors on the board by using a sample of 132 Canadian firms listed on the Toronto Stock Exchange at the end of 2000. Eduardo Schiehll \& Francois Bellavance, "Boards of Directors, CEO Ownership, and the Use of Non-Financial Performance Measures in the CEO Bonus Plan" (2009) 17:1 Corporate Governance 90 at 93 [Schiehll \& Bellavance].

${ }^{1927}$ Independent directors (refer to what the authors call unrelated directors in this study) are defined as directors who are independent of management and free of any interest, business, or other relationship that could, or could materially interfere with, a director's ability to monitor management, which is the same as the definition in the Dey Report. Ibid at $104 \mathrm{n} 10$.

${ }^{1928}$ In addition to financial performance indicators, non-financial performance information, such as market share, customer satisfaction, and productivity rates, may provide more accurate information regarding the factors that drive firm value contributed by a CEO. As a result, the use of non-financial performance measures in the CEO remuneration plan better reflects a CEO's contribution to firm value, and more closely connects a CEO's incentives with shareholder wealth. Ibid at 90-91.

${ }^{1929}$ The authors found that the use of non-financial performance measures in the CEO bonus plan was associated with greater proportion of unrelated directors on the board when firms had higher growth opportunities. However, such relationship did not exist when firms only had lower growth opportunities. Ibid. at 97, 99, 100-01.

${ }^{1930}$ Jog \& Dutta, supra note 1837 at 15-16, 34 Table 10.

${ }^{1931}$ Sapp, supra note 1918 at 729.
} 
Taken together, boards or compensation committees with a higher proportion of independent (or outside) directors in Canada neither restrained the level of CEO compensation, nor tied CEO pay to firm performance. It appears that Canadian independent directors were unable to align the interests of CEOs with those of shareholders. In contrast, the presence of a controlling shareholder seems to play an important role in lowering the level of executive compensation.

\subsubsection{Evidence Regarding Other Mechanisms Influencing the Effectiveness of Independent Directors}

The prior three sections have explored the effectiveness of Canadian independent directors through examining the connection between director independence and overall firm performance, $\mathrm{CEO}$ compensation, and the quality of financial reporting. In addition, other governance mechanisms may directly or indirectly complement, substitute for or diminish the effectiveness of independent directors. In other words, the connection between independent directors and shareholder wealth (or interests) may be influenced by the presence of other governance factors, such as ownership structure, gender diversity, the number of directors, and whether the CEO is also the board chair. The following subsections investigate whether, or how, these governance factors affect the efficacy of independent directors.

\subsubsection{The Relationship between the Presence of Controlling Shareholders and Independent Directors}

Canadian firms are often characterized by concentrated ownership, mostly in the hands of wealthy families. Ownership concentration refers to the situation where a firm's main voting rights (the rights to elect the board of directors and to influence or dictate decisions that require shareholder approval) are directly or indirectly controlled by one shareholder or a group of shareholders. ${ }^{1932}$ According to Gadhoum's 2006 survey, more than $40 \%$ of Canadian firms had a controlling shareholder owning more than $20 \%$ of voting rights, in comparison with only around

${ }^{1932}$ Erickson et al, supra note 676 at 388; Bozec \& Bozec, supra note 676 at 183. 
$20 \%$ of firms with similar ownership structure in the United States. ${ }^{1933}$ Highly concentrated ownership provides opportunities for controlling shareholders to entrench their interests through the use of control-enhancing mechanisms, such as dual (or multiple) class shares ${ }^{1934}$, pyramidal control $^{1935}$ and cross-holdings ${ }^{1936} \cdot{ }^{1937}$ Approximately 25\% of Canadian listed companies adopted dual (or multiple) class shares, while $33 \%$ and $8 \%$ of the listed companies gained control of other firms through pyramid structures and cross-holdings, respectively, according to Gadhoum's 2006 survey and Attig's 2007 study. ${ }^{1938}$ The use of control-enhancing mechanisms allow dominant shareholders to maintain control of firms through voting rights while only retaining a small fraction of the equity claims on firms' cash flows (cash-flow rights). ${ }^{1939}$ The separation of control (voting rights) from cash-flow rights, manifestly against the "one share, one vote" rule, fosters an environment in which controlling shareholders may make decisions beneficial to themselves without bearing the full cost. ${ }^{1940}$ Firm performance and the effectiveness of

${ }^{1933}$ Yoser Gadhoum, "Power of Ultimate Controlling Owners: A Survey of Canadian Landscape" (2006) 10 Journal of Management Governance 179 at 180, 197 Table V [Gadhoum]; Michael R King \& Eric Santor, "Family Values: Ownership Structure, Performance and Capital Structure" (2008) 32 Journal of Banking \& Finance 2423 at 2424 [King \& Santor].

${ }^{1934}$ Dual (multiple) class shares refer to a firm that has issued two (or more) classes of stock with differential voting rights. One class of common stock typically has more votes per share (the superior class) than the other (the inferior class). Lucian A Bebchuk, Reinier Kraakman \& George G Triantis, "Stock Pyramids, Cross-Ownership, and Dual Class Equity: The Mechanisms and Agency Costs of Separating Control from Cash-Flow Rights" in Randall K Morck ed Concentrated Corporate Ownership (Chicago: The University of Chicago Press, 2000) at 297 [Bebchuk, Kraakman \& Triantis]; Jennifer Francis, Katherine Schipper \& Linda Vincent, "Earnings and Dividend Informativeness: When Cash Flow Rights Are Separated from Voting Rights" (December 2003) at 2, online: Northwestern University <www.kellogg.northwestern.edu/faculty/vincentl/htm/dualclass.pdf $>$.

1935 Pyramidal control refers to an entity (usually a group of corporations) whose ownership structure displays a topdown chain of control starting with an ultimate owner (at the apex) and with successive lower layers of firms. The ultimate owner, through such structure, has more opportunities to orchestrate corporate behavior to extract private benefits. Najah Attig, Klaus Fischer \& Yoser Gadhoum, "On the Determinants of Pyramidal Ownership: Evidence on Dilution of Minority Interests" (March 2004) at 2, EFA 2004 Maastricht Meetings Paper No 4592, online: SSRN 〈http://ssrn.com/abstract=434201 or doi:10.2139/ssrn.434201 > [Attig, Fischer \& Gadhoum]; Bebchuk, Kraakman \& Triantis, ibid at 298.

${ }^{1936}$ Cross-holding is defined as a condition that exists when a firm has a controlling shareholder and owns shares in other firms that belong to its chain of control. The controlling shareholder may completely control the assets or important decisions of a firm, but only holds a small fraction of the cash-flow rights in this firms. Gadhoum, supra note 1933 at 185; Bebchuk, Kraakman \& Triantis, ibid at 299-300.

${ }^{1937}$ Walid Ben-Amar \& Paul André, "Separation of Ownership from Control and Acquiring Firm Performance: The Case of Family Ownership in Canada" (2006) 33: 3 \& 4 Journal of Business Finance \& Accounting 517 at 518 [Ben-Amar \& André]; Bebchuk, Kraakman \& Triantis, supra note 1934 at 295, 297-99; Najah Attig, "Excess Control and the Risk of Corporate Expropriation: Canadian Evidence" (2007) 24 Canadian Journal of Administrative Sciences 94 at 97 [Attig]; King \& Santor, supra note 1933 at 2424; Gadhoum, supra note 1933 at $180-81,185$.

${ }^{1938}$ Gadhoum, ibid at 180-81; Attig, ibid at 97, 98 Table 1.

1939 Bebchuk, Kraakman \& Triantis, supra note 1934 at 295; Gadhoum, ibid at 189; Ben-Amar \& André, supra note 1937 at 520.

${ }^{1940}$ See Ben-Amar \& André, ibid. 
independent directors in Canada may be influenced by ownership concentration, since independent directors safeguard minority shareholders' interests against misappropriation by controlling shareholders, and influential shareholders may also perform the role of management monitoring.

Most empirical studies exploring the impact of controlling shareholders focused on the relationship between ownership concentration and firm performance. Only three studies examined the connection between controlling shareholders and independent directors. This thesis briefly states how ownership concentration influenced firm performance and discusses in detail the impact of the presence of controlling shareholders on the effectiveness of independent directors.

\subsection{The Impact of Ownership Concentration on Firm Performance}

The findings regarding the connection between ownership concentration and firm performance are inconsistent, but no study shows a positive relationship. Erickson et al. (2005) and Panasian, Prevost and Bhabra (2008) found that firms with a dominant shareholder were more likely to be associated with poorer performance (lower Tobin's Q), ${ }^{1941}$ while Rao and LeeSing (1995) and Attig (2007) found that ownership concentration had no connection with firm performance. ${ }^{1942}$ In addition, King and Santor (2008) observed no significant difference in firm performance (Tobin's Q) between family-owned firms and widely-held firms. ${ }^{1943}$ There seems to be no common thread running through the studies regarding the relationship between ownership concentration and firm performance.

The results were also similar when control-enhancing mechanisms were employed by controlling shareholders. Four studies ${ }^{1944}$ reported that firms under higher levels of control (i.e. dominant shareholders' voting rights larger than cash-flow rights) were more likely to suffer

\footnotetext{
${ }^{1941}$ Erickson et al, supra note 676 at 400; Panasian, Prevost \& Bhabra, supra note 1805 at 142. The difference between the two studies is that the existence of a dominant shareholder had a significant negative effect on Tobin's Q in Erickson et al. (2005), but only had a weak negative impact on Tobin's Q in Panasian, Prevost and Bhabra (2008).

1942 Rao \& Lee-Sing, supra note 1716 at 61, 71 Table 7; Attig 2007, supra note 1937 at 99, 102 Table 4.

1943 King \& Santor, supra note 1933 at 2424, 2429, 2431.

${ }^{1944}$ Please refer to Attig, Fischer and Gadhoum (2004), Erickson et al. (2005), Attig (2007), King and Santor (2008).
} 
poor performance, ${ }^{1945}$ while Bozec and Laurin (2008) and Ben-Amar and André (2006) found no negative correlation between high levels of control and firm performance. ${ }^{1946}$ In combination with the findings in the last paragraph, a firm was unlikely to be associated with enhanced firm performance when it had a controlling shareholder, regardless of whether control-enhancing mechanisms were used. In comparison with mere existence of a controlling shareholder, firms were more likely to have poorer performance when control-enhancing mechanisms were used.

\subsection{The Impact of the Presence of Controlling Shareholders on the Effectiveness of Independent Directors}

So far, three studies have explored the relationship between the presence of controlling shareholders and independent directors. Two of them examined the correlation between controlling shareholders and independent directors, while one of the two studies and the remaining one further investigated whether the effectiveness of independent directors was influenced by the presence of controlling shareholders.

The two studies show that the presence of a controlling shareholder was associated with reductions in the number or proportion of independent directors in a firm. More specifically, Erickson et al. (2005) found that the proportion of outside directors on the board was significantly and negatively associated with the presence of voting rights held by controlling shareholders, ${ }^{1947}$ while Bozec and Bozec $(2007)^{1948}$ reported that ROB Board Composition scores (including board independence [8/40], committee independence [13/40] and directors meeting without management present [2/40]) were significantly and negatively related to

\footnotetext{
1945 Attig, Fischer \& Gadhoum, supra note 1935 at 19; Erickson et al, supra note 676 at 400; Attig, supra note 1937 at 99-100, 102 Table 4; King \& Santor, supra note 1933 at 2424, 2431.

${ }^{1946}$ Ben-Amar and André (2006) reported that investors did not perceive (as measured by three-day abnormal returns) that the separation of ownership and control led to firm value destruction during the merger and acquisition situation. Ben-Amar and André, supra note 1937 at 533-34. In addition, Bozec and Laurin (2008) found that the separation of ownership and control per se did not cause poor performance. Bozec \& Laurin, supra note 1012 at 37. It was the large separation of control and ownership, in combination with the opportunity for dominant shareholders to expropriate, that led firms to display poor performance. Bozec \& Laurin, ibid at 26, 39, 44.

${ }^{1947}$ Erickson et al, supra note 676 at 402, 403 Table 7.

1948 The authors explored the correlation between ownership concentration, separation of ownership and control, and ROB total and sub-index governance rankings by using a sample of 244 Canadian listed firms in 2002 . Bozec \& Bozec, supra note 676 at 185.
} 
ownership concentration ${ }^{1949}$, especially when a dominant shareholder held more than $25 \%$ of voting rights. ${ }^{1950}$ The finding that firms with controlling shareholders tend to have fewer independent directors could have at least two different explanations. On the one hand, it could mean that fewer independent directors are needed because controlling shareholders who control management and the election of directors do not need independent directors to hold management accountable. To the extent that management is generally held accountable to shareholders in this way, that is a positive result and the monitoring of independent directors is less important. ${ }^{1951}$ On the other hand, firms with fewer independent directors might actually create a risk for minority shareholders because management might benefit the controlling shareholder at their expense. Controlling shareholders might prefer fewer independent directors because it gives them a free hand to benefit themselves. ${ }^{1952}$ Interestingly, no significant correlation was reported between the presence of control-enhancing mechanisms and the level of board independence. ${ }^{1953}$ Taken together, these findings observed a negative correlation between the presence of controlling shareholders and the proportion of independent directors on the board, but had not come to conclusions regarding whether the presence of a controlling shareholder affect the efficacy of independent directors.

The findings of Anand, Milne and Purda (2010) and Erickson et al. (2005) provide an insight regarding this issue. Anand, Milne and Purda (2010) observed that the presence of controlling shareholders reduced the ability of an independent board ${ }^{1954}$ to adopt other governance mechanisms in assisting them to monitor management, ${ }^{1955}$ suggesting that the monitoring effect of independent directors was compromised by controlling shareholders. In addition, Erickson et al. (2005) reported that adding more outside directors to the board was not

\footnotetext{
${ }^{1949}$ Ibid at 189 . Ownership concentration is measured by the voting rights directly and indirectly held by the largest shareholder. Ibid at 186.

${ }^{1950}$ Ibid at 190, 191 Table 7.

${ }^{1951}$ Bozec \& Bozec, supra note 676 at 193. Sapp (2008) reported that the presence of a controlling shareholder was correlated with a lower level of executive compensation; however, a compensation committee with a higher proportion of independent directors was associated with higher level of CEO remuneration. These results seem to suggest that controlling shareholders played an important role in restraining CEO remuneration. However, Professor Sapp considers that the apparently lower compensation for the CEO might be a result of the CEO obtaining value in other ways such as dividends from their holdings, perquisites or even income from other affiliated firms. As a result, the lower CEO compensation may not be the effect of the presence of a controlling shareholder. Sapp, supra note 1918 at 730, 730 n 16, 742.

${ }^{1952}$ Park \& Shin, supra note 1892 at 455, Erickson et al, supra note 676 at 402.

${ }^{1953}$ Erickson et al, ibid at 403; Bozec \& Bozec, supra note 676 at 191, 191 Table 7, 192 Table 8.

${ }^{1954}$ An independent board refers to a board that has a majority of independent directors or has an independent chair. Anand, Milne \& Purda, supra note 7 at 818.

${ }^{1955}$ Ibid at 810, 834-35, 837.
} 
associated with enhanced firm value (Tobin's Q) in the presence of dual class shares, but outside directors who came from a financial institution or served on the audit committee reduced some loss of firm value from the existence of dual class shares. ${ }^{1956}$ The findings of Erickson et al. (2005) imply that outside directors with financial expertise would partially alleviate the negative impact of existence of controlling shareholders through dual classes of shares on firm value.

Taking the evidence in this subsection together, firms with controlling shareholders, regardless of whether control-enhancing mechanisms are employed, were likely to be associated with poorer firm performance. When a firm has a controlling shareholder, the monitoring effect of independent directors is likely to be compromised. Nevertheless, outside directors with financial expertise can partially alleviate the negative impact of the existence of control shareholders through dual classes of shares on firm value. In short, the existence of a controlling shareholder seems not only to reduce the number (or proportion) of independent directors in a firm but also to mitigate the monitoring effect of independent directors.

\subsubsection{Gender Diversity}

As mentioned in the US section, gender diversity enriches board independence, which may enhance a board's ability to monitor management and make greater profits for shareholders. However, the unique ownership structure and different governance environment in Canada may cause a different effect of gender diversity on shareholder interests. Francoeur, Labelle and Sinclair-Desgagné (2008) investigated whether the participation of women officers and directors enhanced financial performance (as measured by monthly abnormal returns) by using a sample of 230 of the Financial Post's 500 largest Canadian firms from 2001 to $2003 .{ }^{1957}$ The authors found that firms with a higher proportion of women officers generated positive abnormal returns of $6 \%$ over a three-year period, but no significant abnormal returns were created for firms with a higher proportion of women directors. ${ }^{1958}$ It seems that placing or adding female directors to Canadian boards had no significant impact on corporate value. However, the latter finding included the effect of both independent and non-independent female directors on firm

\footnotetext{
${ }^{1956}$ Erickson et al, supra note 676 at 408.

1957 Claude Francoeur, Réal Labelle \& Bernard Sinclair-Desgagné, “Gender Diversity in Corporate Governance and Top Management” (2008) 81 Journal of Business Ethics 83 at 86-87 [Francoeur, Labelle \& Sinclair-Desgagné].

${ }^{1958}$ Ibid at $84,93$.
} 
performance. The real effect of female independent directors on firm performance is still unknown. Further research is needed to understand the contribution of female independent directors on firm performance in Canada.

\subsubsection{Board Size}

In Canada, the issue of how many directors constitute an efficient board has been debated since the establishment of the Dey Committee in 1993. Large boards may bring a diversity of views and experience, increase the opportunity for a broad geographic representation, and provide extensive director resources for constituting board committees to deal with complex issues. ${ }^{1959}$ However, beyond a certain threshold of board size, the high coordination costs and free-rider problems ${ }^{1960}$ may also lower the efficiency of decision-making, which would lead to poorer firm performance. As a result, the Dey Report suggested that every board should undertake a program to reduce the number of directors to a number which facilitates more effective decision-making. ${ }^{1961}$ As to the optimal number of independent directors on the board, no study, so far, investigates how many independent directors on the board would be most effective. Generally, the number of independent directors on the board increases with the total number of board members. Thus, the findings of studies that have examined the ideal number of the entire board, to some extent, may provide some insight regarding the ideal number of the independent board members.

Of the aforementioned Canadian empirical studies, some also explored the correlation between board size and firm performance. Their findings seem to show that the number of directors on the board had no significant impact on firm performance. Rao and Lee-Sing (1995) found that board size was not related to firm performance (as measured by ROA and ROE), ${ }^{1962}$ while Jog and Dutta (2004) observed a similar result by using market-to-book ratio, ROA and monthly return as firm performance indicators. ${ }^{1963}$ Panasian, Prevost and Bhabra (2008) also

\footnotetext{
${ }^{1959}$ Rao \& Lee-Sing, supra note 1716 at 63.

${ }^{1960}$ Harris \& Raviv, supra note 1701 at 1799.

${ }^{1961}$ Dey Report, supra note 196 at 4 Guideline (7).

1962 Rao \& Lee-Sing, supra note 1716 at 67, 71 Table 7.

1963 The authors found that firms with smaller number of directors on the board were associated with better firm performance, but such an association disappeared after accounting for endogeneity. It implies that the correlation between board size and firm performance was unstable. Jog \& Dutta, supra note 1837 at 16, 34 Table 10.
} 
reported that board size had no impact on firm value (Tobin's Q) and the compliance with the TSX board independence guidelines. ${ }^{1964}$ In addition, a mixed relationship between board size and firm performance was found to exist in state-owned enterprises. Bozec (2003) found a mixed relationship between board size and firm performance, ${ }^{1965}$ while Bozec and Dia (2007) reported no connection between board size and firm performance. ${ }^{1966}$ Taking the accumulated evidence together, it appears that the number of directors on the board did not have a significant impact on firm performance.

Since the number of independent directors is closely associated with the number of board members as mentioned previously, the findings regarding the ideal number of the entire board, to some extent, may be applicable to the ideal number of independent board members. However, since there seems to be no perfect board size, it is impossible to conclude that there is an ideal number of independent directors on the board that would improve the efficacy of independent directors for all corporations in Canada.

\subsubsection{Leadership Structure}

The advantages and disadvantages of a CEO holding the board chair have been explored by financial economists for nearly two decades in the US. There seems to be no conclusive evidence in the US regarding whether a unitary or dual leadership structure is better for shareholders. In Canada, the Dey Committee recommended that boards should either appoint a non-executive to chair the board, or adopt alternate structures and procedures to ensure that the board can function independently of management. ${ }^{1967}$ Since the main function of independent directors is to hold management accountable and protect shareholder interests, if independent directors under a specific type of leadership structure are more likely to fulfill this function, firms should adopt this type of leadership structure to enhance shareholder interests. However, the impact of leadership structure on the effectiveness of independent directors is still unclear.

\footnotetext{
${ }^{1964}$ Panasian, Prevost \& Bhabra, supra note 1805 at 141 Table 2 Panel A, 142 Table 2 Panel B.

1965 The author found that board size was significantly and negatively related to return on sales, sales efficiency and assets turnover, but had no significant relationship with return on assets and net income efficiency. Bozec, supra note 1821 at 25,41 Table 7 .

${ }^{1966}$ Bozec \& Dia, supra note 1828 at 1745 . When these state-owned enterprises faced market competition, the relatioinship between board size and firm performance turned significantly and positively in three out of four regression models. Ibid at 1746-47.

${ }^{1967}$ Dey Report, supra note 196 at 5 Guideline (13), 39-40 Separate Chair and CEO.
} 
Among the Canadian empirical studies, some explored the relationship between CEOs chairing the board and firm performance. Their findings revealed that a CEO holding the board chair had no connection with firm performance. ${ }^{1968}$ However, these studies did not further investigate whether the relationship between board independence and firm performance varies with leadership structure, except for Switzer (2007). Switzer (2007) observed that firms with a unitary leadership structure (CEOs who also hold the board chair) were inclined to have more outside directors on their boards, but the adoption of a unitary leadership structure had no significant impact on their firm value (Tobin's Q). ${ }^{1969}$ Altogether, there is no clear Canadian evidence that a CEO playing a dual role or separating a CEO from the board chair has a significant impact on independent directors' monitoring effect.

\subsubsection{Summary for Canadian Empirical Evidence}

In this section, I have explored the empirical evidence regarding the effectiveness of independent directors in Canada. The first part examined the relationship between board independence and overall firm performance. The findings showed that Canadian firms with a higher proportion of independent or outside directors did not experience enhanced firm performance and, sometimes, might even experience poorer firm performance. However, most studies suffer from methodological problems and the most reliable study only endorsed the efficacy of independent directors in some circumstances. Consequently, it is difficult to draw any strong conclusions regarding whether boards composed of a majority of independent directors are beneficial to their firms in Canada.

\footnotetext{
${ }^{1968}$ Rao and Lee-Sing (1995) found that leadership structure was not related to firm performance (as measured by ROA and ROE), while Switzer (2007) and Panasian, Prevost and Bhabra (2008) reported that CEO playing dual role had no impact on firm value (Tobin's Q). Panasian, Prevost and Bhabra (2008) further observed that the separation of CEO from board chair had no connection with its compliance with the TSX board independence guideline. In addition, the results of studies regarding the relationship between CEO playing a dual role and firm performance in state-owned enterprises further confirmed this trend. Bozec (2003) found that a CEO holding the board chair was only significantly and negatively associated with two out of five firm performance indicators, while Bozec and Dia (2007) observed an unclear directional sign between CEO playing a dual role and firm efficiency. Taken together, there seems no significant connection between firm performance and firms in which the CEO is also the board chair. Rao \& Lee-Sing, supra note 1716 at 67, 71 Table 7; Switzer, supra note 1866 at 662 Table 4; Panasian, Prevost \& Bhabra, supra note 1805 at 141 Table 2 Panel A, 142 Table 2 Panel B; Bozec, supra note 1821 at 26, 38 Table 4; Bozec \& Dia, supra note 1828 at 1745 Table 6, 1746, 1746 Table 7.

${ }^{1969}$ Switzer, ibid at 660, 662 Table 4.
} 
The second part investigated the relationship between director independence and the quality of financial reporting-the most important monitoring function of independent directors. The results indicated that the presence of independent directors, either on the board or audit committee was associated with better financial reporting quality in some circumstances. In addition, independent directors with financial expertise were likely to have a positive influence on the quality of financial reporting; however, independent directors with only financial literacy seem to have no such effect.

The third part examined whether independent directors fulfill their monitoring responsibilities in one of the main board tasks (or compensation committee tasks)-setting appropriate remuneration for executives. The findings revealed that Canadian boards or compensation committees with a higher proportion of independent or outside directors neither restrained the level of CEO compensation, nor were effective at tying CEO pay to firm performance. In contrast, the presence of a controlling shareholder seems to play an important role in restraining the level of executive compensation.

The final part explored whether the four governance mechanisms (ownership concentration, gender, board size, and leadership structure) influence the efficacy of independent directors. The evidence shows that firms with ownership concentration were likely to be associated lower corporate value. When a firm's significant ownership was in the hands of a controlling shareholder, the number and the monitoring effect of independent directors in the firm were likely to be reduced. However, existing evidence did not provide a clear picture regarding the impact of gender and leadership structure on the effectiveness of independent directors.

Taken as a whole, the empirical evidence suggests that independent directors in Canada, except for improving the quality of financial reporting in some circumstances and where they have financial expertise, were ineffective at enhancing shareholder interests. It is possible that the existence of controlling shareholders reduces the monitoring effects of independent directors in some cases. 


\section{Chapter Six}

\section{An Analysis of the Effectiveness of Independent Directors in North America}

As mentioned in chapter four, laws and regulations in the United States and Canada have relied on independent directors as corporate monitors since the mid-1990s to address agency costs. Empirical studies in management science and financial economics have provided some evidence regarding whether independent directors are effective in protecting shareholder interests or enhancing shareholder wealth, though the implications of the evidence, analyzed in chapter five, are not straightforward. What can the legal community learn from the empirical findings regarding the efficacy of independent directors as corporate monitors? To go a step further, what message does the empirical evidence bring to North American regulators regarding their policies that rely on independent directors' oversight role? This chapter addresses these issues from four perspectives: (1) whether empirical findings support the current legal measures regarding the oversight role of independent directors? (2) if not, what are the possible reasons? (3) are there other factors that may enhance or impair the efficacy of independent directors not identified by current measures? (4) should current laws, regulations and courts' reliance concerning independent directors be modified according to existing empirical findings? In general, empirical evidence seems to show that independent directors are only beneficial for some firms and in some specific situations. As a result, regulators should adopt measures to make independent directors more effective and allow a greater flexibility for firms to tailor their level of board independence according to their particular firm characteristics. As well, courts may need to look at the social and other ties between independent directors and their CEOs more closely when reviewing director behaviors in the board room.

\subsection{Whether Empirical Findings Support the Current Measures Relying on Independent Directors as Corporate Monitors?}

As analyzed in chapter four, regulators in the United States and Canada currently rely on independent directors as corporate monitors through four types of measures: (1) requiring or 
recommending a board comprised of a majority of independent directors; (2) requiring or recommending that a board establishes audit, compensation and nominating committees composed solely of independent directors; (3) requiring audit committee members to have certain knowledge or expertise; (4) requiring or recommending that a board hold executive sessions with attendance of only non-management or independent directors and designate an independent lead director or board chair (only in Canada). With a view to enhancing the effectiveness of independent directors, regulators in both countries have also increased the standards for director independence. If these five measures regarding independent directors are the right prescriptions for holding management accountable, their effects should be reflected in or at least not contradicted by the empirical evidence. Whether empirical findings support the current measures relying on independent directors is an important indicator to decide whether independent directors are effective corporate monitors and what government policy should be in that regard.

It is worth noting that there are several differences between two jurisdictions, including the legal environment and the distribution of share ownership. In the United States, listed corporations have to comply with all of these requirements without any discretion, while the issuers in Canada enjoy the flexibility to decide whether to comply with them, except for the requirements regarding the audit committee and the definition of independent directors. Shareholder structure in the United States is also distinct from that in Canada. Only around 20\% of US firms had a controlling shareholder owning more than $20 \%$ of voting rights; however, more than $40 \%$ of Canadian firms had similar ownership structure, according to a 2006 survey. ${ }^{1970}$

Also the number of empirical studies regarding independent directors is different between the two countries. In particular, there is a wide gap between the two countries regarding the number of empirical studies targeting the first three measures discussed above, including board independence, committee independence and financial knowledge for audit committee members. In the United States, around 80 studies have directly examined the efficacy of independent directors regarding these three measures, ${ }^{1971}$ while there are only approximately 21 studies

\footnotetext{
${ }^{1970}$ See supra note 1933.

${ }^{1971}$ In addition, there are more than 60 empirical studies examining the impact of other governance mechanisms (or director characteristics) on the effectiveness of independent directors.
} 
concerning similar issues in Canada. ${ }^{1972}$ Furthermore, around two-thirds of Canadian studies (14 studies) concentrated mainly on the effect of board independence. ${ }^{1973}$ That is to say, very few studies have explored the effect of the remaining measures regarding independent directors in Canada. Moreover, almost no research has investigated the effect of a lead director or executive sessions in the two countries. Overall, not all current requirements or recommendations relating to independent directors have been examined by empirical studies. Since the legal environment, shareholder ownership structure, the number of studies and the breadth of focus of the studies are all different between the United States and Canada, the following analysis regarding whether empirical findings support current measures relying on independent directors as corporate monitors is presented separately.

\subsubsection{In the United States}

As noted earlier, the main purpose of having independent directors is to hold management accountable with a view to protecting shareholder interests and enhancing shareholder wealth. In principle, whether independent directors are effective in doing so may also be determined by observing the relationship between the presence of independent directors and shareholder wealth or the promotion of shareholder interests. Traditionally, overall firm performance is considered as a straightforward and objective index to represent shareholder wealth, because shareholder wealth would usually be increased when a firm performs better. However, despite the researchers' best efforts; it is difficult to isolate the effect of director independence from many other factors that affect firm performance. ${ }^{1974}$ Thus, some scholars have sought to investigate the connection between independent directors (on the board or committees) and specific monitoring tasks, especially transactions (or decisions) involving potential conflicts of interest between management and shareholders. The following analysis examines: (1) whether there is empirical support for the existence of a positive relationship between four measures ${ }^{1975}$ that rely on

\footnotetext{
1972 See supra section 5.3.

1973 See supra section 5.3.1.

${ }^{1974}$ Lin, supra note 13 at 925; Gordon, The Rise of Independent Directors, supra note 1 at 1500.

${ }^{1975}$ The four types of measures relying on independent directors as corporate monitors are: (1) requiring a board comprised of a majority of independent directors; (2) requiring that a board establishes audit, compensation and nominating committees composed solely of independent directors; (3) requiring at least one of the audit committee
} 
independent directors and firm performance, as well as board (or committee) tasks; (2) whether current standards for director independence are sufficient to protect independent directors from the CEO's influence; and (3) whether courts' reliance on independent directors as corporate monitors has empirical support.

\subsubsection{Whether a Board Composed of a Majority of Independent Directors Is More Likely to Benefit Shareholders}

Conventional wisdom believes that the more independent the board, the less the opportunity management has to increase their own wealth at the expense of shareholders. Although a board composed of a majority of independent directors was not required by stock exchanges until 2003, most large publicly-held corporations had adopted this practice by the end of the 1990s. Empirical studies examining whether independent directors on the board are effective in fulfilling a monitoring role focused on the relationship between board independence and firm performance and those that investigated how board independence affects board behavior on discrete tasks, such as replacing the CEO, or defending against a takeover bid. Their results seem to show that a board composed of a majority of independent directors only acts as an effective corporate monitor in some circumstances.

\subsection{Whether a Board Composed of a Majority of Independent Directors Is More Likely to Perform Better}

As I mentioned in section 5.1.3, the results of 21 empirical studies regarding the relationship between board independence and overall firm performance appear divergent at a glance. Five studies found that boards with a higher proportion of independent directors were correlated with better firm performance, while five studies observed the opposite results. Another 11 studies reported that firm performance was unrelated to the fraction of independent directors on the board. It seems that there is no common thread running through the results of these empirical studies.

members to have financial expertise; (4) requiring a board to hold executive sessions with attendance of only nonmanagement or independent directors. 
As I discussed in section 5.1.2, there are three factors that may influence the reliability of some empirical findings regarding the relationship between the presence of independent directors and firm performance: (1) the definitions of director relationships with the corporation do not focus on independent directors consistently; (2) the impact of SOX and related reforms may enhance the monitoring effect of independent directors so that pre-Sox studies may not be reliable evidence of the impact of independent directors currently; (3) issues related to the nature and direction of causation and possible lagged effects between independent directors and their effectiveness indicators are not addressed.

First, some studies did not differentiate effects between independent and outside directors (i.e. results combining the effect of affiliated and independent directors), so their findings may not demonstrate the real effect of independent directors on firm performance. Six studies had this kind of problem. ${ }^{1976}$

Second, SOX and related reforms have fostered a better environment for independent directors to exercise independent judgment, such as by requiring executive sessions and that the three main monitoring committees be composed entirely of independent directors. Consequently, independent directors may be more effective in protecting shareholder interests in the post-SOX period than in the pre-SOX period. Studies that do not differentiate their results between preSOX and post-SOX period may not truly detect whether independent directors are effective corporate monitors after the implementation of SOX. ${ }^{1977}$ Of the 21 studies investigated, 17 studies examined only pre-SOX samples, while four studies ${ }^{1978}$ had samples straddling the implementation of SOX. However, one ${ }^{1979}$ of the four studies did not differentiate the effects between pre-SOX and post-SOX periods, while another one ${ }^{1980}$ used an untraditional benchmark - the year 2000, rather than 2002 (or 2003) - to differentiate the impact of SOX reforms. Thus, only two studies ${ }^{1981}$ properly distinguished the effects between pre-SOX and post-SOX. The one that did not differentiate the effect between pre-SOX and post-SOX periods

\footnotetext{
${ }^{1976}$ Chaganti, Mahajan and Sharma (1985), Schellenger, Wood and Tashakori (1989), Fosberg (1989), Hermalin and Weisbach (1991), Agrawal and Knoeber (1996), and Ferris, Jagannathan and Pritchard (2003) did not differentiate the effect of affiliated directors from that of outside directors. See section 5.1.3.3 regarding the group two studies and Schellenger, Wood and Tashakori (1989) in section 5.1.3.1.

1977 See supra text accompanying notes 1015-1022.

${ }^{1978}$ The four studies are Chhaochharia and Grinstein (2007) and Bhagat and Bolton (2009) in section 5.1.3.1, Bhagat and Bolton (2008) in section 5.1.3.2, and Duchin, Matsusaka and Ozbas (2010) in section 5.1.3.3.

${ }^{1979}$ Please refer to Bhagat and Bolton (2008) in section 5.1.3.2.

${ }^{1980}$ Please refer to Duchin, Matsusaka and Ozbas (2010) in section 5.1.3.3.

${ }^{1981}$ Please refer to Chhaochharia and Grinstein (2007) and Bhagat and Bolton (2009) in section 5.1.3.1.
} 
used a sample period (1990-2004) that was mostly before the implementation of SOX, so its result may only demonstrate the pre-SOX effect.

Third, results of empirical studies simply showing a positive or negative correlation between the presence of independent directors and firm performance cannot demonstrate causation (without further investigation). A positive correlation may be because firms with better firm performance choose to have a higher proportion of independent directors, rather than because firms with a higher proportion of independent director are likely to achieve enhanced firm performance. Similarly, a negative correlation between independent directors and firm performance may because firms with poorer firm performance add more independent directors to their boards, rather than because firms with a higher proportion of independent directors are more likely to have poorer firm performance. As a result, without further examination, whether independent directors are effective in improving firm performance is not demonstrated by a simple conclusion of a significant association between the presence of independent directors and firm performance. ${ }^{1982}$ Moreover, the impact of independent directors on firm performance may take some time to be seen. In other words, the effect of board independence on firm performance may not happen in the same year, but may occur in the following years. Thus, empirical studies reporting no contemporaneous connection between independent directors and firm performance may miss an important relationship if lagged effects have not been examined. ${ }^{1983}$ Of the five studies reporting a positive relationship, one study did not examine the causation between independent directors and firm performance, ${ }^{1984}$ while the results of another study were not subject to concerns about causation because it examined the market reaction to independent director appointment. ${ }^{1985}$ In contrast, five studies reporting a negative correlation all investigated causation. Of the 11 studies that reported no current connection, seven studies did not explore possible lagged effects. ${ }^{1986}$ In total, eight (out of 21) studies did not explore either causation or lagged effects.

\footnotetext{
1982 See supra text accompanying notes 1026-1029

1983 See supra text accompanying notes 1033-1037.

${ }^{1984}$ See Schellenger, Wood and Tashakori (1989) in section 5.1.3.1.

1985 See Rosenstein and Wyatt (1990) in section 5.1.3.1.

${ }^{1986}$ Schellenger, Wood and Tashakori (1989), Fosberg (1989), Hermalin and Weisbach (1991), Mehran (1995), Yermack (1996), and Fogel and Geier (2007), and Duchin, Matsusaka and Ozbas (2010) appeared to neglect the possible time lag between board independence and firm performance. See section 5.1.3.3 regarding studies in group one and group two.
} 
In addition to these three factors, another two elements affect the interpretation of empirical results regarding the efficacy of independent directors. The first element is that the evidence of two studies showing a positive association between independent directors and enhanced corporate performance may be considered unpersuasive. The findings of Baysinger and Butler (1985) were questioned because it took too long (almost ten years) for the benefits of independent director monitoring to manifest themselves on firm performance. ${ }^{1987}$ The results of Rosenstein and Wyatt (1990) were also criticized. A $0.2 \%$ stock price increase in response to the appointment of an additional independent director was statistically significant, but it was economically small. As well, the finding was based on a perception of investors, since it only measured market reaction during the appointment period, rather than long-term firm performance. $^{1988}$

The second element is that the findings of two studies ${ }^{1989}$ were not related to the efficacy of independent directors. The two studies only examined whether prior firm performance affected later board composition, but did not investigate whether the level of board independence influenced later firm performance. The issue of whether independent directors on the board are effective in enhancing current or future firm performance was not addressed. (The problems of the above 14 studies are compiled in the Appendix 30)

After eliminating studies that are tainted by these weakness, only the findings of five studies with (or mostly with) pre-SOX samples and two studies with post-SOX samples are not subject to these concerns. Of the five studies with pre-SOX samples, two studies found no significant correlation between board independence and current or future firm performance, ${ }^{1990}$ while three studies reported that more independent board might have even worsened current and future firm performance. ${ }^{1991}$ In contrast, two studies ${ }^{1992}$ with post-SOX samples observed that firms with a majority of, or a higher proportion of, independent directors on the board, were associated with better firm performance. However, Chhaochharia and Grinstein (2007) reported that the enhanced firm performance was only for large and medium-sized firms (not for small-

\footnotetext{
${ }^{1987}$ Bhagat \& Black, 2002, supra note 1 at 236; Fosberg, supra note 1052 at 25.

1988 Bhagat \& Black 1999, supra note 25 at 941; Bhagat \& Black 2002, ibid at 237; Hermalin \& Weisbach 2003, supra note 1012 at 13.

${ }^{1989}$ See Hermalin and Weisbach (1988) in 5.1.3.2 and Klein (1998) in section 5.1.3.3.

${ }^{1990}$ See Brown and Caylor (2006), and Brown and Caylor (2009) in section 5.1.3.3.

1991 See Bhagat and Black (1999), Bhagat and Black (2002), and Bhagat and Bolton (2008) in section 5.1.3.2.

${ }^{1992}$ See Chhaochharia and Grinstein (2007) and Bhagat and Bolton (2009) in section 5.1.3.1.
} 
sized firms), ${ }^{1993}$ while the results of Bhagat and Bolton (2009) were significant in relation to only one out of three performance indicators. ${ }^{1994}$ Taken together, independent directors were not associated with better firm performance in the pre-SOX period, but, in some circumstances, became effective in enhancing firm value after the implementation of SOX. It seems that SOX and related reforms, focusing on director independence, achieved some of the expected effects, though not as effectively as conventional wisdom would have anticipated.

It is worth noting that only Chhaochharia and Grinstein (2007) supported the requirement of having a majority of independent directors on the board, while Bhagat and Bolton (2009) did not demonstrate an optimal threshold of board independence (only reported that a higher level of board independence was associated with better firm performance) ${ }^{1995}$. As a result, whether current threshold of board independence-50\%-is optimal for all firms is still unclear. In combination with the analysis in the last paragraph, a mandatory requirement for a board composed of a majority of independent directors has some empirical support, but has not fully justified by existing empirical evidence.

The lack of a strong connection between board composition and performance may be because firm performance is not an ideal indicator to measure the efficacy of independent directors. Generally, firm performance depends on multiple factors, rather than solely on board independence. Factors like executives' business vision, marketing strategies, research and development, as well as independent directors' oversight all influence corporate performance. Since it is difficult to isolate the effect of board independence from other possible factors that affects firm performance, some researchers explored the efficacy of independent directors by investigating the connection between board independence and specific board tasks, especially those involving conflicts of interest between management and shareholders. The next subsection discusses whether independent directors are effective corporate monitors in relation to these particular activities.

\subsection{Whether a Board Composed of a Majority of Independent Directors Is More Likely to Protect Shareholder Interests in Relation to Discrete Board Tasks}

\footnotetext{
1993 See supra text accompanying notes 1060-1061.

${ }_{1994}$ See supra text accompanying notes 1067-1070.

${ }^{1995}$ Bhagat \& Bolton, 2009, supra note 1067 at 3-4, 17, 25, 38 Table III, 39 Table IV.
} 
As I discussed in section 5.1.4, existing empirical studies have explored the relationship between board independence and six types of specific board tasks: (1) responding to takeover bids; (2) evaluating management buyouts; (3) replacing incompetent CEOs; (4) setting executive compensation; (5) preventing financial fraud; and (6) reducing shareholder suits. The first four events manifestly involve conflicts of interest between management and shareholders, while the last two are closely related to the protection of shareholder interests. Preliminarily speaking, more than a half of empirical studies in each aforementioned board task show that firms with a higher proportion of, or a majority of, independent directors on the board were positively related to performance indicators for each board task, except for restraining the level of executive compensation.

It is worth noting that factors influencing the reliability of empirical studies regarding the relationship between board independence and firm performance may also influence the reliability of studies concerning the connection between board independence and specific board tasks. Thus, whether the definition of independent director, the impact of SOX, and the problem of causation and lagged effects have an impact on the results regarding relationships between board independence and specific board tasks is worth discussing. As noted earlier, unlike the relationship between board independence and firm performance, scholars put less emphasis on the impact of causation and lagged effects when interpreting the results between board independence and specific board tasks. No study of the six board tasks examined the problem of causation or lagged effects. However, not addressing causation or lagged effects does not mean there are no such issues in these studies. The results of these studies may have an alternative interpretation or risk missing an important connection between independent directors and the performance of board tasks. So far, only one scholar suggested that the causation between board independence and preventing financial fraud may have an alternative interpretation. Except for the studies related to the task of preventing financial fraud, this thesis will not comment on studies that did not control causation or lagged effects regarding board tasks due to the complexity of the two issues. The following analysis mostly focuses on whether the definition of independent directors and the impact of SOX affect the reliability of the studies regarding the connection between independent directors and the performance of board tasks.

First, in the task of responding to takeover bids, all (11) studies focused on pre-SOX samples, while two studies only looked at the effect of outside directors and another two studies 
did not define "outside director". The two studies ${ }^{1996}$ that did not define "outside director" do not really matter, because a similar study ${ }^{1997}$ found that the same results held for both outside and independent directors and the term "outside director" is sometimes used to describe what is currently called "independent director" before the new millennium. However, the results of another two studies ${ }^{1998}$ reporting that greater board independence was associated with a higher likelihood of resisting greenmail may not be reliable, because these two studies did not differentiate between outside and independent directors. Collectively, except for the findings of the two studies regarding greenmail, the results of the other nine studies were not subject to the above reliability concern. These studies showed that the efficacy of board independence varied depending on whether bidding firms or target firms are examined, and the type of defensive tactics adopted by the target board. In bidding firms, boards with up to $60 \%$ of independent directors were associated with less negative returns to shareholders than boards without such a composition during tender offers. ${ }^{1999}$ However, in target firms, there is no conclusive evidence that boards with a majority of independent directors would be more likely to increase shareholder wealth. ${ }^{2000}$ Where target boards adopted poison pills, shareholder wealth at least was not reduced, and, in some cases, was enhanced, if the target was controlled by independent directors. ${ }^{2001}$ In addition, target boards with a higher percentage of independent directors were more likely to adopt golden parachutes, but such an adoption did not expand the size of individual payments and was perceived by shareholders in a positive way. ${ }^{2002}$ Taken together, it appears that independent directors generally meet the expectation of protecting shareholder interests in response to takeover bids, except in studies that looked at the shareholder wealth of target boards subject to tender offers. ${ }^{2003}$

Second, in the task of evaluating management buyouts, the only study regarding this task explored only a pre-SOX sample and focused on independent directors. The results show that

\footnotetext{
${ }^{1996}$ Please refer to Singh and Harianto (1989a) and Singh and Harianto (1989b) in subsection 5.1.4.1.3.3.

${ }^{1997}$ Please refer to Cochran, Wood and Jones (1985) in subsection 5.1.4.1.3.3.

1998 Please refer to Kosnik (1987) and Kosnik (1990) in subsection 5.1.4.1.3.2.

1999 Byrd \& Hickman, supra note 363 at 199, 207, 213-216.

${ }^{2000}$ Cotter, Shivdasani and Zenner (1997) found that a majority of independent directors serving on the target board extracted higher tender offer premiums, while Bange and Mazzeo (2004) demonstrated contradictory results. See subsection 5.1.4.1.2.

${ }^{2001}$ See subsection 5.1.4.1.3.1.

${ }^{2002}$ See subsection 5.1.4.1.3.3.

${ }^{2003}$ Further details were discussed in section 5.1.4.1.
} 
firms with a majority of independent directors tended to enhance shareholder wealth during going-private situations, but might not be effective in unit management buyouts. ${ }^{2004}$

Third, in the task of replacing incompetent CEO, all (seven) studies focused on independent directors, while two of them had sample periods straddling SOX. One ${ }^{2005}$ of the two studies clearly compared the effects between pre-SOX and post-SOX, while the other studyBhagat and Bolton (2008) — did not differentiate the effect between pre-SOX and post-SOX periods. Since most of the sample periods in Bhagat and Bolton (2008) were before the enactment of SOX-related reforms, their positive results at most could only reflect the situation in the pre-SOX period. Taken together, the empirical evidence show that in the pre-SOX period, most (five $\mathrm{e}^{2006}$ out of seven) studies reported that independent directors were an effective mechanism in maintaining the sensitivity of CEO turnover to firm performance, but the positive connection between board independence and the sensitivity of CEO turnover to firm performance became insignificant (shown by one study) in the post-SOX period. ${ }^{2007}$

Fourth, in the task of controlling the level of executive compensation, three studies with pre-SOX samples focused on outside directors, while two studies comparing effects between preSOX and post-SOX looked at independent directors. The results of the three pre-SOX studies ${ }^{2008}$ that only looked at outside directors appear to be reliable, because they did not contradict the findings of the two studies ${ }^{2009}$ that compared the effects between pre-SOX and post-SOX. ${ }^{2010}$ All five studies suggest that independent directors (or outside) directors were ineffective in controlling the level of CEO compensation. ${ }^{2011}$ Collectively, the five studies involving the task of setting executive compensation appear not to be subject to the reliability concern. They show that a firm with a higher level of board independence, regardless of whether measured by the proportion of, or $100 \%$ independent or outside directors, on the board, was ineffective in controlling the level of CEO compensation in either pre-SOX or post-SOX periods.

\footnotetext{
${ }^{2004}$ Further details were discussed in section 5.1.4.4.

2005 Please refer to Bhagat and Bolton (2009) in section 5.1.4.2.

${ }^{2006}$ Please refer to Weisbach (1988), Perry (1999), Fich and Shivdasani (2006), Bhagat and Bolton (2008), and Bhagat and Bolton (2009) in section 5.1.4.2.

${ }^{2007}$ Further details were discussed in section 5.1.4.2.

${ }^{2008}$ Please refer to Boyd (1994), Core, Holthausen and Larcker (1999) and Conyon and He (2004) in section 5.1.4.3.

${ }^{2009}$ Please refer to Chhaochharia and Grinstein (2009) and Wan (2009) in section 5.1.4.3.

${ }^{2010}$ The three pre-SOX studies reported that the more outside directors on the board the greater CEO compensation was granted, while the two post-SOX studies found that independent directors had no impact on the level of CEO pay.

${ }^{2011}$ Further details were discussed in section 5.1.4.3.
} 
Fifth, in the task of preventing financial fraud, all (six) studies focused on pre-SOX samples, while one study only looked at the effect of outside directors. However, the failure of that study ${ }^{2012}$ to look only at the effect of independent directors might not undermine the relevance of the study, because two later similar studies ${ }^{2013}$ reported that outside and independent directors were both effective in controlling financial fraud. After considering the reliability concern, most (four ${ }^{2014}$ out of six) studies show that firms with more (less) independent boards were less (more) likely to be associated with financial fraud. ${ }^{2015}$ It is worth noting that these results may also be interpreted as suggesting that firms that tend to engage in financial fraud choose to have less independent boards. This is why Professors Bhagat and Black suggest that executives who are prone to commit fraud may resist oversight by independent boards. It may be the executives' propensity for fraud that drives both the likelihood of fraud and the degree of board independence. ${ }^{2016}$ Although the above findings may have different interpretations due to the direction of causation, either interpretation suggests that independent directors are more likely to detect fraud and take action against it.

Sixth, in the task of reducing shareholder suits, all (four) studies explored pre-SOX samples, while two of them did not define "outside director" and one of them only looked at the effect of outside directors. The study ${ }^{2017}$ that only looked at the effect of outside directors may not be unreliable, because a latter similar study ${ }^{2018}$ focusing on independent directors reached similar results (both showing that greater board independence was associated with fewer shareholder suits). However, whether independent directors were effective in reducing shareholder suits is unclear for the two studies ${ }^{2019}$ that did not define "outside director", because their results were inconsistent and the undefined "outside director" may represent either independent or the broad category of outside directors. Taken together, two (out of four)

\footnotetext{
${ }^{2012}$ Please refer to Dechow, Sloan and Sweeney (1996) in section 5.1.4.5.

${ }^{2013}$ Please refer to Beasley (1996) and Uzen, Szewczyk and Varma (2004) in section 5.1.4.5.

${ }^{2014}$ Please refer to Dechow, Sloan and Sweeney (1996), Beasley (1996), Beasley et al. (2000) and Uzen, Szewczyk and Varma (2004) in section 5.1.4.5.

${ }^{2015}$ Further details were discussed in section 5.1.4.5.

2016 Bhagat \& Black 1999, supra note 25 at 933.

${ }^{2017}$ Please refer to Kesner and Johnson (1990) in section 5.1.4.6.

${ }^{2018}$ Please refer to Helland and Sykuta (2005) in section 5.1.4.6.

${ }^{2019}$ Please refer to Jones (1986) and Romano (1991) in section 5.1.4.6.
} 
studies $^{2020}$ show that firms with more independent board are less likely to experience shareholder litigation. $^{2021}$

After taking the factors that may influence the reliability of studies into account, at least a majority of studies looking at five out of six board tasks show that independent directors play a positive monitoring role based on the observation of pre-SOX samples. Except for the task of controlling CEO compensation, firms with more independent directors on the board were likely to protect shareholder interests in relation to the five specific board tasks based on the observation of pre-SOX samples. Since the findings regarding the four ${ }^{2022}$ out of five board tasks have shown a positive result regarding independent directors' monitoring effect, they are likely to be reliable evidence even though none are post-SOX studies.

However, there seems to be no consensus regarding how much board independence is enough to perform these discrete board tasks. Some studies observed that the independence threshold to gain the efficacy of independent directors was $60 \%,{ }^{2023}$ while some studies found that it was 50\%. ${ }^{2024}$ Many studies reported simply that "a higher proportion" of independent directors on the board were sufficient to reach a significant result. ${ }^{2025}$ The optimal threshold of board independence appears to vary with firms and board tasks. It is not clear whether a board composed of a majority of independent directors can reach positive results. Nevertheless, the empirical results have demonstrated that the policy of requiring a more independent board is appropriate, and some findings do clearly support the effectiveness of the 50\% threshold. Collectively, the requirement for a board to be composed of a majority of independent directors has some empirical support, but it has not fully justified by existing empirical evidence exploring discrete board tasks.

\footnotetext{
${ }^{2020}$ Please refer to Kesner and Johnson (1990) and Helland and Sykuta (2005) in section 5.1.4.6.

${ }^{2021}$ Further details were discussed in section 5.1.4.6.

${ }^{2022}$ Except for the studies involving the tasks of controlling the level of executive compensation and replacing incompetent CEO, all studies (of the other four board tasks) used pre-SOX samples.

${ }^{2023}$ Please refer to Byrd and Hickman (1992) in subsection 5.1.4.1.1, and Weisbach (1988) and Perry (2000) in subsection 5.1.4.2.

${ }^{2024}$ Please refer to Brickley, Cole and Terry (1994) in subsection 5.1.4.1.3.1, and Fich and Shivdasani (2006) in section 5.1.4.2.

${ }^{2025}$ See Bhagat and Bolton (2008) and Bhagat and Bolton (2009) in section 5.1.4.2.
} 


\subsubsection{Whether the Level of Independence in the Audit, Compensation and Nominating Committees Has a Significant Impact on Shareholder Interests}

In addition to board independence, advocates of independent committees contend that a board's three key committees, namely the audit, compensation and nominating committees, should be composed solely of independent directors with the responsibility for ensuring the quality of financial reporting, setting proper executive compensation and nominating directors without management interference. Existing empirical studies, like those involving board independence, also used firm performance and the performance of discrete committee tasks as indicators to evaluate the efficacy of independent directors in these three key committees. Empirical evidence shows that committee independence has little impact on firm performance, while the relationship between committee independence and the effective performance of committee tasks seems to vary with the committee. A completely independent audit committee has a strong connection with the achievement of its committee mission (ensuring the quality of financial reporting). However, there is no evidence of a significant relationship between compensation committee independence and the level of executive compensation, or sensitivity of CEO pay to firm performance. The association between nominating committee independence and its committee tasks seems to be unclear as well.

\subsection{Whether the Level of Audit Committee Independence Has an Impact on Shareholder Interests}

The key responsibility of the audit committee is to select the company's outside auditors, to supervise the required audits of the company's financial statements, and to monitor the performance of the company's internal control system. The level of the committee independence is considered one of the key characteristics that determine the success of the audit committee. An audit committee composed of at least two independent directors has been required since the late 1970s. US stock exchanges included a completely independent audit committee as a listing requirement in 1999 and SOX made it a legal requirement in 2003. Empirical studies have examined its effect through indicators of firm performance and financial reporting quality. The 
results demonstrate that the level of audit committee independence was closely related to the indicators of financial reporting quality, but had no impact on firm performance.

More specifically, regarding the connection between the level of audit committee independence and firm performance, four studies found that audit committee independence had little impact on firm performance, while only one study - Chan and Li (2008) reported a positive connection between committee independence and firm value. ${ }^{2026}$ Since the results of Chan and Li (2008) were based on only a small number of observations, and Klein (1998) and Brick and Chidambaran (2007) did not explore possible lagged effects, their results may not be fully reliable. Nevertheless, the findings of Brown and Caylor (2006, 2009), with high reliability, have shown that an audit committee consisting entirely of independent directors was not associated with current or subsequent firm performance. Consequently, it would seem that the level of audit committee independence has no identifiable impact on firm performance.

With respect to whether the quality of financial reporting depends on the level of audit committee independence, empirical evidence shows that the level of audit committee independence did matter. Audit committees composed entirely of independent directors were more likely to be associated with a good quality of financial reporting than those without 100\% independence. More specifically, five studies found that the presence of a completely independent audit committee was significantly related to indices representing a higher quality of financial reporting, while only one study reported no such connection. ${ }^{2027}$ Moreover, one study observed that firms with a poorer quality of financial reporting were less likely to have fully independent audit committees. ${ }^{2028}$ However, for firms without $100 \%$ independent audit committees, seven studies reported that a greater proportion of independent directors on the audit committee were correlated with a higher quality of financial reporting, while six studies observed no such connection. ${ }^{2029}$ In addition, among studies that compared the difference between audit committees with and without $100 \%$ independence, two out of three studies showed that the effect of a complete independent audit committee is stronger than that of an audit committee without $100 \%$ independence. ${ }^{2030}$ Taken together, it appears that the monitoring benefits of the audit

\footnotetext{
${ }^{2026}$ The four studies are Klein (1998), Brick and Chidambaran (2007) and Brown and Caylor (2006, 2009). See supra text accompanying notes 1356-1362.

${ }^{2027}$ See supra text accompanying notes 1381-1401 .

${ }^{2028}$ Beasley et al, supra note 1302 at 450-52.

${ }^{2029}$ See supra text accompanying notes 1405-1431.

${ }^{2030}$ See supra text accompanying notes 1432-1435 .
} 
committee were most likely to be fully realized, if the audit committee was completely independent.

It is worth noting that the problem of causation, possible lagged effects, the impact of SOX-related reforms and the definition of independent director, which emerged in the studies regarding board independence, may also be the concerns of the studies involving independent directors on the audit committee. Studies discussed in this section all focused on independent directors and pre-SOX samples, and no study investigated the issues of causation or lagged effects. Since empirical findings have shown a positive result regarding the relationship between independent directors and the quality of financial reporting, they are likely to be reliable evidence despite the lack of post-SOX studies. Not addressing causation or lagged effects does not mean there are no such issues in these studies. The results of these studies may have an alternative interpretation or risk missing an important connection between audit committee independence and the quality of financial reporting. One scholar has indicated that the findings of the above studies, as with all regression analysis that simply shows a positive (or negative) correlation, do not demonstrate causation. ${ }^{2031}$ The positive correlation between complete audit committee independence and the quality of financial reporting can have two possible explanations. One is that having an entirely independent audit committee leads to a higher quality of financial reporting-supporting the rationale for SOX and related reforms in this regard. Another possible explanation is that firms with a higher financial reporting quality choose to have a completely independent audit committee. ${ }^{2032}$ If the latter interpretation explains the study results, the requirement for audit committee independence may be misplaced. From my point of view, listed corporations value the quality of financial reporting with a view to earning the trust of their investors. It is less likely that a company would really care much about whether its audit committee is completely independent, except for its impact on the quality of its financial

\footnotetext{
${ }^{2031}$ Romano, Quack Corporate Governance, supra note 11 at 1532.

${ }^{2032}$ It is worth noting that the above empirical studies exploring relationship between audit committee independence and the quality of financial reporting all used pre-SOX sample periods (most studies adopted sample periods before the enactment of a completely independent audit committee required by the NYSE and NASDAQ in 1999). Almost no study examined the same issue by using a post-SOX sample because the degree of variability in audit committee independence is trivial after the enactment of SOX (every listed corporation should have an entirely independent audit committee). Except for comparing the effect of the same firms before and after SOX, it may be difficult for a researcher to find an impact of audit committee independence on the quality of financial reporting or firm performance. See Chan \& Li, supra note 1360 at 17; David Fingold, George S Benson \& David Hecht, "Corporate Boards and Company Performance: Review of Research in Light of Recent Reforms" (2007) 15:5 Corporate Governance 865 at 874 [Fingold, Benson \& Hecht].
} 
reporting. Consequently, it seems that the more likely direction of causation is that companies would put in place completely independent audit committees with a view to achieving better financial reporting.

In total, since the main purpose of having an audit committee is to ensure the quality of financial reporting, rather than directly improving firm performance, the above findings and analysis demonstrate that the requirement for all audit committee members to be completely independent of management and the company enjoys strong empirical support.

\subsection{Whether the Level of Compensation Committee Independence Has an Impact on Shareholder Interests}

The main mission of the compensation committee is to establish an executive compensation package that can encourage high quality management by executives and align their interests with those of shareholders. The level of the committee's independence is often considered as the key characteristic that affects its success. However, a completely independent compensation committee was not required by law or listing requirements until 2003. Empirical studies have examined its effect through firm performance indices, the level of executive compensation, and the sensitivity of CEO remuneration to firm performance. The findings show that the level of compensation committee independence was not related to firm performance, the level of executive compensation or the sensitivity of CEO pay to firm performance.

With respect to the relationship between compensation committee independence and firm performance, five studies ${ }^{2033}$, all with pre-SOX samples, consistently reported that compensation committee independence had little or no impact on firm performance. Although two of these studies $^{2034}$ did not examine possible lagged effects, and one ${ }^{2035}$ of them did not differentiate the effect between outside and independent directors, the same results held for the remaining three studies $^{2036}$ that were not subject to these defects. It is unclear whether the lack of connection between compensation committee independence and firm performance would change in the postSOX period. Since the main mission of a compensation committee is to set up an appropriate

\footnotetext{
${ }^{2033}$ Please refer to Klein (1998), Hayes, Mehran and Schaefer (2004), Brown and Caylor (2006, 2009), and Brick and Chidambaran (2007) in section 5.1.5.4.

${ }^{2034}$ Please refer to Klein (1998) and Hayes, Mehran and Schaefer (2004) in section 5.1.5.4.

2035 Please refer to Hayes, Mehran and Schaefer (2004) in section 5.1.5.4.

${ }^{2036}$ Please refer to Brown and Caylor (2006, 2009), and Brick and Chidambaran (2007) in section 5.1.5.4.
} 
compensation package for executives, rather than enhancing firm performance, the impact of compensation committee independence on firm performance is not the main concern regarding the efficacy of independent directors.

Regarding the impact of compensation committee independence on the level of CEO pay, seven studies ${ }^{2037}$ found that the level of compensation committee independence had no significant impact on the level of CEO compensation, regardless of whether their sample periods were before or after the enactment of SOX related reforms, ${ }^{2038}$ or whether the level of compensation committee independence was measured by the proportion of inside directors, ${ }^{2039}$ the proportion of affiliated directors, ${ }^{2040}$ the proportion of non-independent directors, ${ }^{2041}$ the proportion of independent directors, ${ }^{2042}$ or $100 \%$ independent directors. ${ }^{2043}$ After stock exchanges required stricter compensation committee independence in 2003, Wan (2009) even observed that compensation committees composed entirely of independent directors was associated with greater total CEO remuneration. ${ }^{2044}$ The results suggest that the level of compensation committee independence had no impact on the level of remuneration for executives. It is worth noting that the effect of independent directors on controlling executive compensation may need some time to be seen. The findings of no connection between independent directors and the level of executive pay may be because possible lagged effects have not been examined. None of the seven studies explored possible lagged effects. However, no scholar, so far, has raised concerns about the failure to examine lagged effects.

As for the connection between compensation committee independence and the sensitivity of CEO compensation to firm performance, four studies, all with pre-SOX samples, found that the level of compensation committee independence had no impact on the sensitivity of CEO compensation to firm performance, ${ }^{2045}$ regardless of whether the level of compensation

\footnotetext{
${ }^{2037}$ Please refer to Daily et al. (1998), Newman and Mozes (1999), Vafeas (2003), Anderson and Bizjak (2003), Conyon and $\mathrm{He}$ (2004), Conyon and Kuchinskas (2006), and Chhaochharia and Grinstein (2009) in section 5.1.5.4.

${ }^{2038}$ Only Chhaochharia and Grinstein (2009) used a post-SOX sample, while the remaining six studies adopted preSOX samples. See supra text accompanying notes 1496-1521.

${ }^{2039}$ Please refer to Vafeas (2003) and Conyon and He (2004) in section 5.1.5.4.

${ }^{2040}$ Please refer to Daily et al. (1998) in section 5.1.5.4.

${ }^{2041}$ Please refer to Newman and Mozes (1999) and Conyon and Kuchinskas (2006) in section 5.1.5.4.

${ }^{2042}$ Please refer to Anderson and Bizjak (2003) in section 5.1.5.4.

${ }^{2043}$ Please refer to Newman and Mozes (1999), Anderson and Bizjak (2003), and Chhaochharia and Grinstein (2009) in section 5.1.5.4.

${ }^{2044}$ Wan, supra note 1271 at $5,14$.

2045 Please refer to Newman and Mozes (1999), Vafeas (2003), Anderson and Bizjak (2003), Conyon and He (2004) in section 5.1.5.4. See supra text accompanying notes 1526-1532.
} 
committee independence was measured by the proportion of inside directors, ${ }^{2046}$ the proportion of independent directors, ${ }^{2047}$ the proportion of non-independent directors, ${ }^{2048}$ or completely independent directors. ${ }^{2049}$ In addition, one of the above studies, Newman and Mozes (1999), reported that less independent compensation committees were more likely to shield CEOs from the impact of poor performance than completely independent compensation committees in some circumstances. ${ }^{2050}$ The findings of Newman and Mozes (1999) imply that the monitoring effect of a completely independent compensation committee is still better than that of a non-completely independent compensation committee, although a completely independent compensation committee, in general, had no impact on the sensitivity of CEO compensation to firm performance. Collectively, independent directors on the compensation committee did not help to ensure that the interests of CEO were aligned with those of shareholders in the pre-SOX period. It is unclear whether such a situation has been changed after the implementation of SOX. However, no connection between the level of compensation committee independence and the sensitivity of CEO compensation to firm performance may be because possible lagged effects have not be investigated.

Taken together, compensation committees with higher levels of, or complete, independence were not related to enhanced firm performance or tying CEO remuneration to firm performance in the pre-SOX period, and were not associated with lower levels of CEO pay in the pre-SOX or post-SOX period. Sometimes, a completely independent compensation committee was even correlated to greater CEO compensation. It is no wonder that several high-profile corporations on the edge of bankruptcy during the 2008 financial crisis, such as AIG, still intended to issue a large bonuses to their executives, even only shortly after they received bailouts worth billions of dollars from the US government. These corporations, subject to the NYSE listing requirements, all had a compensation committee composed entirely of independent directors. The empirical evidence appears not to support a requirement that the compensation committee should be composed entirely of independent directors.

\footnotetext{
${ }^{2046}$ Please refer to Vafeas (2003), Anderson and Bizjak (2003) and Conyon and He (2004) in section 5.1.5.4.

${ }^{2047}$ Please refer to Anderson and Bizjak (2003) in section 5.1.5.4.

${ }^{2048}$ Please refer to Newman and Mozes (1999) in section 5.1.5.4.

2049 Please refer to Newman and Mozes (1999) and Anderson and Bizjak (2003) in section 5.1.5.4.

${ }^{2050}$ Newman \& Mozes, supra note 1518 at 46-48.
} 


\subsection{Whether the Level of Nominating Committee Independence Has an Impact on Shareholder Interests}

The key responsibilities of the nominating committee are to search for qualified director candidates consistent with the board's criteria and nominate directors who are truly independent of management. The level of committee independence is often considered the main characteristic that affects the success of the nominating committee. Stock exchanges have required listing corporations to have a completely independent nominating committee since 2003. However, existing evidence, focusing on pre-SOX samples, shows that nominating committee independence, regardless of its level, has no significant impact on firm performance. So far, empirical studies have not developed other useful indicators to evaluate the connection between nominating committee independence and the tasks of the committee.

More specifically, Brown and Caylor $(2006,2009)$ found that a nominating committee comprised solely of independent directors was not associated with current or subsequent firm performance indicators, ${ }^{2051}$ while Hayes, Mehran and Schaefer (2004) observed that the degree of nominating committee independence (as measured by the proportion of outside directors on the nominating committee) was not related to firm performance. ${ }^{2052}$ Chllahan, Millar and Schulman (2003) even reported that the existence a separate nominating committee (without management participation) was connected with poorer subsequent firm performance. ${ }^{2053}$ Although the findings of Hayes, Mehran and Schaefer (2004) did not differentiate between outside and independent directors or explore possible lagged effects, the findings of Brown and Caylor (2006, 2009), addressing the two issues, reached the same results. Taken together, these studies consistently found that nominating committee independence had no positive impact on firm performance.

It is worth noting that the efficacy of independent directors in nominating committees may not be fully reflected in the measurement of firm performance. In fact, firm performance depends on multiple complicated factors and only a part of it may be related to the oversight of independent directors in the nomination process. It may be inappropriate to measure the

\footnotetext{
${ }^{2051}$ See Brown \& Caylor 2006, supra note 1027 at 419 Table 3, 421 Table 4, 422 Table 5; Brown \& Caylor 2009 , supra note 1032 at $130,141-42$.

${ }^{2052}$ See Hayes, Mehran and Schaefer (2004) in 5.2.3.3. Although Hayes, Mehran and Schaefer (2004) did not distinguish the effect between outside and independent directors and explore the possible lagged effect, the findings of Brown and Caylor (2006, 2009), which addressed the two problems, reached the same results.

${ }^{2053}$ Callahan, Millar \& Schulman, supra note 1538 at 178, 180.
} 
contribution of independent directors in stifling CEO's influence during the director selection process by only using firm performance as an indicator. More innovative and nuanced indicators are needed to figure out the real impact of independent directors on director nominating procedure. Thus, whether the independence of nominating committee can increase the likelihood of having independent and unbiased director nominees remains unknown.

In summary, only requiring a completely independent audit committee gained strong empirical support. Existing empirical research did not support requiring a compensation committee composed solely of independent directors and could not provide clear answers regarding the impact of nominating committee independence on director nomination.

\subsubsection{Whether Financial Literacy and the Types of Financial Expertise Affect the Quality of Financial Reporting}

In addition to independence, audit committee members should have certain knowledge and experience in the field of accounting and finance in order to fulfill their responsibility of supervising the integrity of the financial reporting system. Stock exchanges require that all audit committee members should have the ability to read and understand a company's financial statements (financial literacy) and at least one audit committee member should have financial management expertise. ${ }^{2054}$ Initially, the SEC proposed that only individuals who had obtained education and experience in accounting or auditing should be qualified as financial experts. However, under severe criticism, the SEC later expanded the range of financial expertise to include experience in financial statement analysis (such as would result from working as an investment banker or financial analyst) and experience in financial oversight (such as from working as a CEO or president), in addition to the experience in accounting and auditing. ${ }^{2055}$ The concern is which type of financial expertise is more likely to ensure the quality of financial reporting.

Empirical studies examined the connection between three different types of financial expertise and the financial reporting quality, and found that the improvement in financial

\footnotetext{
${ }^{2054}$ See supra text accompanying notes 826-829. Perhaps, requiring audit committee members to be financially literate has been taken for granted, so there is no research investigating the connection between financial literacy and the quality of financial reporting.

${ }^{2055}$ Please refer to subsection 4.1.2.4.1.2.1 for further details.
} 
reporting quality mainly came from independent directors who have accounting expertise, rather than financial analysis or supervisory expertise. More specifically, six studies reported that the accounting expertise was significantly associated with indices of a higher financial reporting quality, ${ }^{2056}$ while only one study found no such connection. ${ }^{2057}$ With respect to the effect of financial analysis expertise, two studies found that financial analysis expertise had no impact on the indices of financial reporting quality, ${ }^{2058}$ while one study reported that financial analysis expertise was related to an index of a higher quality of financial reporting. ${ }^{2059}$ As for the effect of supervisory expertise, three studies consistently reported that supervisory expertise had no impact on the indices of financial reporting quality. ${ }^{2060}$ Taken together, audit committee members with accounting expertise seem to have a dominant effect in enhancing the quality of financial reporting, while those with financial analysis expertise had no consistent effect. Audit committee members with supervisory expertise had no impact on the quality of financial reporting.

Some empirical findings that combine the effect of the above two or three types of financial expertise show different results. They reported that financial experts: (1) having either accounting or financial analysis expertise ${ }^{2061}$ or (2) within the current SEC definition (having any of three types of financial expertise), ${ }^{2062}$ still had a certain connection with the indices representing a higher quality of financial reporting. However, in light of the findings in the last paragraph, it appears that the improvements in financial reporting quality were likely and mainly attributable to having audit committee members with accounting expertise, rather than financial analysis or supervisory expertise.

As noted in chapter five, the definition of independent directors, the impact of SOXrelated reforms, and the problems of causation and lagged effects may influence the reliability of studies examining the relationship between different types of financial expertise and financial reporting quality. Studies discussed in this section all focused on independent directors on the audit committee and pre-SOX samples, and no studies investigated the issues of causation or lagged effects. The positive results that independent directors with accounting expertise were

\footnotetext{
2056 See supra text accompanying notes 1439-1456.

${ }^{2057}$ Felo, Krishnamurthy \& Solieri, supra note 1353 at 29-30.

2058 See supra text accompanying notes 1457-1460.

${ }^{2059}$ Carcello et al., supra note 1445 at 3, 25-26.

${ }^{2060}$ See supra text accompanying notes 1463-1468. Further details were discussed in subsection 5.1.5.1.2.3.

${ }^{2061}$ See supra text accompanying notes 1469-1472.

2062 See supra text accompanying notes 1473-1481.
} 
associated with higher quality of financial reporting are likely to be applicable in the post-SOX, because there was nothing in the SOX reforms that would likely affect the significance of the type of expertise that would be useful. Moreover, not addressing causation or lagged effects does not mean there are no such issues in these studies. The results of these studies may have an alternative interpretation or risk missing an important correlation between different types of financial expertise and the quality of financial reporting. Nevertheless, addressing causation and lagged effects, except for studies regarding firm performance, is out of the scope of this thesis.

Collectively, the results seem to demonstrate that the current definition of financial expertise adopted by the SEC-under which any of the three types of expertise qualifies as financial expertise-is too broad and not supported by empirical evidence. The SEC may need to consider excluding those who have no accounting expertise to act as financial experts in the audit committee.

\subsubsection{Whether the Current Definition of Director Independence Is Sufficient to Prevent Independent Directors from the CEO's Influence}

As early as mid-1990s, Byrd and Hickman (1992) and Brickley, Cole and Terry (1994) indicated that independent directors (who have no business connection with the firm) were more likely to protect shareholder wealth than outside directors (which include both independent directors and affiliated directors-who have business relationship with the firm) in response to takeover bids. They found that market reacted positively when bidding firms had a majority of independent directors on the board or when target boards adopted a poison pill with a majority of independent directors. However, market reaction turned negative if only a majority of outside directors served on the board. ${ }^{2063}$ These findings show that a business relationship between a director and the company (like an affiliated director) is perceived as impairing his/her monitoring ability in protecting shareholder interests.

In response to corporate scandals in the beginning of new millennium, the NYSE and NASDAQ also focused on different types of relationships between a director and his/her firm when defining an independent director. Both exchanges provide a bright-line test-with six

\footnotetext{
${ }^{2063}$ Further details were discussed in subsections 5.1.4.1.1 and 5.1.4.1.3.1.
} 
preclusions $^{2064}$ that exclude a director from being considered independent in specific circumstances - in addition to offering a broadly worded definition for "director independence" and leaving the authority to the board to determine whether a director is independent. However, the six preclusions only focus on directors' financial ties and familial ties with the company without considering their social, sponsorship or professional ties with the CEOs. ${ }^{2065}$ Corporations or their executives can easily nominate or use their influence to secure the nomination of directors who are independent according to the specific requirements of the regulatory definition, but who may still be unduly influenced by management, although the general standards for director independence would still apply. ${ }^{2066}$

Two recent empirical studies, examining samples straddling SOX, have shown that independent directors with social ties to the firm's CEOs, including graduating from the same education institution, having the same academic discipline or the same industry of primary employment, both serving in the military, and being a member of an organization of which the CEO is also a member, were less effective in enhancing shareholder wealth and in fulfilling their monitoring roles. More specifically, Hwang and Kim (2009) found that firms with independent directors with such connections to their CEOs were more inclined to award a higher level of compensation to their CEOs, and exhibited a lower sensitivity of CEO pay to performance and of CEO turnover to performance relationships. Dey and Liu (2010) also reported that firms experienced poorer financial performance and a lower quality of financial reporting, when they added independent directors with the above social ties to the CEO to the board. ${ }^{2067}$ These findings demonstrate that certain social connections between independent directors and the CEOs impaired the effectiveness of independent directors in holding management accountable. Current definitions of director independence, especially the design of the preclusions, are insufficient to ensure that independent directors are free from the CEO's influence.

\footnotetext{
${ }^{2064}$ The six preclusions include employment relationships, compensation relationships, relationships with auditors, business relationships, immediate family relationships and cross compensation committee links. Further details have been discussed in subsection 4.1.2.1.4.2.

${ }^{2065}$ Fairfax, Inside Director, supra note 216 at 149-50; Fink, supra note 428 at 457; Developments in the Law, supra note 428 at 2198.

${ }^{2066}$ Duchin, Matsusaka \& Ozbas, supra note 429 at 196; Cosenza, supra note 391 at 15.

${ }^{2067}$ Hwang \& Kim, supra note 464 at 139; Dey \& Liu, supra note 463 at 4 . Further details were discussed in section 3.2.1.3.
} 


\subsubsection{Summary regarding Whether Empirical Findings Support Current Measure Relying on Independent Directors in the United States}

In summary, among the measures designed to enhance the effect of monitoring boards in the United States, only the requirement for an audit committee composed entirely of independent directors found strong empirical support based on pre-SOX samples. Empirical studies show that boards with a majority of independent directors benefited shareholders through more effective performance in most of (five of six) board tasks discussed in the pre-SOX period and through improved firm performance in some circumstances in the post-SOX period. In contrast, the level of compensation committee independence had no significant association with firm performance or the sensitivity of CEO pay to firm performance in the pre-SOX period, and was not associated with the level of executive remuneration in either the pre-SOX or post-SOX period. In addition, empirical findings, based on pre-SOX samples, reveal that audit committee members with accounting expertise, but not those with financial analysis or supervisory expertise, were able to enhance the quality of financial reporting. Empirical studies also show that certain social connections between independent directors and the CEO can impair the effectiveness of independent directors in holding management accountable. However, existing empirical studies could not provide clear answers regarding whether nominating committee independence has an impact on management oversight and no study, so far, explores the impact of the presence of an independent lead director or executive sessions on shareholder wealth or interests. In short, only the requirements of a completely independent audit committee and an independent board received empirical support. Empirical findings show that independent directors without social ties with their CEOs or having accounting expertise are more effective corporate monitors in the United States and it would be desirable for the applicable rules to take this into account in definitions of independent directors.

\subsubsection{In Canada}

The Canadian Securities Administrators have endorsed the same five measures that form part of US rules, namely (1) an independent board; (2) all members in three key committees being independent; (3) financial literacy of audit committee members; (4) executive sessions and 
an independent board chair; and (5) requirements for director independence, as ways to support the role of the monitoring board. However, there are two important differences between the United States and Canada. First, there is no requirement regarding financial expertise for audit committee members. Second, only measures regarding the audit committee and the definition of independent director are mandatory. Listing corporations have the discretion to decide whether to follow the other measures regarding independent directors, but they have to explain any noncompliance.

Unlike the United States, empirical studies regarding the effectiveness of independent directors in Canada are relatively few. There is no evidence, so far, exploring whether (1) maintaining a completely independent nominating committee, (2) holding executive sessions, (3) having a lead director, and (4) directors meeting current definition of independent director are more likely to hold management accountable or are associated with higher returns. Thus, the following subsections only analyze whether the measures related to board independence, audit committee independence, compensation committee independence, and the financial literacy of audit committee members are empirically supported. Generally, empirical findings did not show that independent directors in Canada were effective in protecting shareholder interests or holding management accountable, except for those on the audit committee and those with financial expertise.

\subsubsection{Whether a Board Comprised of a Majority of Independent Directors Is More Likely to Benefit Shareholders}

As mentioned in the US discussion (6.1.1.1), some empirical studies used firm performance as an index to examine the efficacy of board independence, while some research adopted specific board tasks as indicators to do a similar evaluation. Since there are drawbacks to evaluating the efficacy of independent directors by focusing only on the impact of firm performance or specific board tasks, both approaches are needed to provide a full picture of whether independent directors are effective corporate monitors. However, existing Canadian empirical studies have used only firm performance to evaluate the impact of board independence. Consequently, their findings may not truly reflect the efficacy of independent directors on the board. 
Of 14 Canadian empirical studies examined, 12 of them showed that a higher level of board independence was not necessarily correlated with better performance and, sometimes, might even be associated with worse performance. More specifically, eight studies ${ }^{2068}$ reported that board independence (regardless of whether measured by the percentage of outside directors, ${ }^{2069}$ a majority of unrelated directors, ${ }^{2070}$ or Global and Mail ROB Board Composition scores ${ }^{2071}$ ) had no significant impact on firm performance. The findings included sample periods before $^{2072}$ and after ${ }^{2073}$ the recommendation of an independent board was adopted by TSX (listing rules), as well as a sample comprised solely of state-owned enterprises. ${ }^{2074}$ In contrast, four studies ${ }^{2075}$ found that firms with a higher level of board independence performed more poorly, including studies with sample periods before ${ }^{2076}$ and after $^{2077}$ the TSX's adoption of the recommendation of having an independent board, as well as a study with only small-cap firms. ${ }^{2078}$ Only three studies ${ }^{2079}$ found that greater level of board independence is beneficial. Panasian, Prevost and Bhabra (2008) observed that poorly performing firms experienced improved firm valuation from an increase of board independence after a majority of independent directors on the board was recommended by the Dey Committee, ${ }^{2080}$ while Bozec and Dia (2007) reported that state-owned enterprises with a higher proportion of outside directors were related to

\footnotetext{
${ }^{2068}$ See Gagnon and St-Pierre (1995), and Amoako-Adu and Smith (1995) in section 5.3.1.1., Erickson et al. (2005), and Panasian, Prevost and Bhabra (2008) in section 5.3.1.2, Jog and Dutta (2004), Gupta, Kennedy and Weaver (2009), and Toledo and Bocatto (2012) in section 5.3.1.4, as well Switzer (2007) in section 5.3.1.5.

${ }^{2069}$ See Gagnon and St-Pierre (1995), and Amoako-Adu and Smith (1995) in section 5.3.1.1, Erickson et al. (2005) in section 5.3.1.2, as well as Switzer (2007) in section 5.3.1.5.

${ }^{2070}$ Panasian, Prevost \& Bhabra, supra note 1805 at 143.

${ }^{2071}$ See Jog and Dutta (2004), Gupta, Kennedy and Weaver (2009) and Toledo and Bocatto (2012) in section 5.3.1.4.

${ }^{2072}$ See Gagnon and St-Pierre (1995), and Amoako-Adu and Smith (1995) in section 5.3.1.1.

${ }^{2073}$ See Erickson et al. (2005) and Panasian, Prevost and Bhabra (2008) in section 5.3.1.2, and Jog and Dutta (2004), Gupta, Kennedy and Weaver (2009) and Toledo and Bocatto (2012) in section 5.3.1.4.

${ }^{2074}$ See Bozec (2003) in section 5.3.1.3.

${ }^{2075}$ See Rao and Lee-Sing (1995) in section 5.3.1.1, Bozec (2003) in section 5.3.1.3, Klein, Shapiro \& Young (2005), and Adjaoud, Zeghal \& Andaleeb (2007) in section 5.3.1.4.

${ }^{2076}$ See Rao and Lee-Sing (1995) in section 5.3.1.1.

2077 See Klein, Shapiro \& Young (2005), and Adjaoud, Zeghal \& Andaleeb (2007) in section 5.3.1.4.

${ }^{2078}$ See Switzer (2007) in section 5.3.1.5.

${ }^{2079}$ See Bozec and Dia (2007) in section 5.2.1.3, Panasian, Prevost and Bhabra (2008) in section 5.2.1.2, and Bozec and Bozec (2011) in section 5.2.1.4. It is worth mentioning that Panasian, Prevost and Bhabra (2008) have been counted once when calculating the number of studies that found no connection between board independence and firm performance. Here it is counted again as studies that reported a connection between greater level of board independence and better firm performance. Therefore the total number of studies is still 14 instead of 15 .

${ }^{2080}$ However, the authors in the same study observed that firms with a majority of independent directors on the board, in general, did not have better firm performance than those without the same board composition. Panasian, Prevost \& Bhabra, supra note 1805 at 142, 154.
} 
better firm performance when facing market competition. ${ }^{2081}$ Bozec and Bozec (2011) also found that firms with higher director independence were associated with lower cost of equity capital. On balance, the studies in this area do not consistently show that firms with more independent directors were beneficial from the perspective of firm performance in Canada.

As mentioned, the problems of endogeneity (mainly causation), possible lagged effects and the definition of independent director, which emerged in the US empirical studies, are also concerns regarding Canadian empirical studies. Moreover, ROB Board Composition scores do not reflect the real level of board independence because board independence only occupies $20 \%$ of the ROB Board Composition scores. The results of 14 empirical studies might not truly demonstrate whether a board comprised of a majority of independent directors can benefit shareholders, if these concerns were not properly addressed.

Regarding these concerns, of the eight studies which found no connection between board independence and firm performance, three of them did not control the problem of lagged effects, ${ }^{2082}$ while seven of them either did not distinguish between outside and independent directors or adopted ROB Board Composition scores to represent board independence. ${ }^{2083}$ Consequently, the findings of the seven (out of eight) studies might not be fully reliable. Only the findings of Panasian, Prevost and Bhabra (2008) were not subject to these defects.

With respect to four studies reporting that greater board independence was associated with poorer firm performance, three of them did not control for the problem of causation, ${ }^{2084}$ while all of them either did not distinguish between outside and independent directors or adopted ROB Board Composition scores to represent board independence. ${ }^{2085}$ The results of these four studies might also be unreliable as indicators of the impact of independent directors.

\footnotetext{
${ }^{2081}$ Bozec \& Dia, supra note 1828 at 1746, 1746 Table $7,1747$.

2082 Three studies, Amoako-Adu and Smith (1995), Jog and Dutta (2004), and Gupta, Kennedy and Weaver (2009), did not control the problem of lagged effects, but five studies, Gagnon and St-Pierre (1995), Erickson et al. (2005), Switzer (2007), Panasian, Prevost and Bhabra (2008), and Toledo and Bocatto (2012), did. Gagnon \& St-Pierre, supra note at 160; Erickson et al, supra note 676 at 393; Panasian, Prevost \& Bhabra, supra note 1805 at 134, 137; Switzer, supra note at 659-60; Toledo \& Bocatto, supra note at 6-7, 13.

${ }^{2083}$ Four studies-Gagnon and St-Pierre (1995), Amoako-Adu and Smith (1995) Erickson et al. (2005), and Switzer (2007)-did not distinguish between independent and outside directors, while three studies - Jog and Dutta (2004), Gupta, Kennedy and Weaver (2009), and Toledo and Bocatto (2012)-used ROB Board Composition scores to represent board independence.

${ }^{2084}$ Bozec \& Dia, supra note at 1745; Bozec, supra note 1821 at 19; Erickson et al, supra note 676 at 393, $405-07$.

${ }^{2085}$ Two studies, Rao and Lee-Sing (1995) and Bozec (2003), did not distinguish the effect between independent and outside directors, while two studies, Klein, Shapiro \& Young (2005) and Adjaoud, Zeghal \& Andaleeb (2007), used ROB Board Composition scores to represent board independence.
} 
In regard to three studies reporting that greater level of board independence is beneficial, Bozec and Dia (2007) merely examined 14 state-owned enterprises and focused on outside (rather than independent) directors. ${ }^{2086}$ Their results may not be applied to private firms and independent directors. Although Bozec and Bozec (2011) reported that a firm with higher director independence was associated with lower cost of equity capital, a firm with lower cost of equity capital may not necessarily generate higher returns for its shareholders. Only the findings of Panasian, Prevost and Bhabra (2008), showing that poorly-performing firms experienced improved firm valuation by choosing an independent board, ${ }^{2087}$ have controlled for the problem of causation, lagged effects and definition of independent director. ${ }^{2088}$ However, the same study also found that firms with a majority of independent directors on the board, in general, did not have better firm performance than those without the same board composition. ${ }^{2089}$ The most that can be said is that not every firm benefits from having a majority of independent directors on the board.

Although the findings of most studies regarding the relationship between board independence and firm performance in Canada are unreliable in one way or another, they have shown the ineffectiveness of independent directors. Since there is only one study-Panasian, Prevost and Bhabra (2008) — with high reliability that endorsed the efficacy of an independent board for poorly performing firms, it may be inappropriate to conclude the impact of board independence on firm performance. More research is needed to confirm the results, but there is little strong support for reliance on independent directors as corporate monitors.

\subsubsection{Whether Completely Independent Audit and Compensation Committees Have a Significant Impact on the Achievement of Their Committee Missions}

Influenced by SOX, Canadian Securities Administrators, in 2004, adopted a requirement that each issuer maintain a completely independent audit committee and a recommendation that every listed company have a compensation committee composed entirely of independent

\footnotetext{
${ }^{2086}$ Bozec \& Dia, supra note 1828 at 1736, 1740 Table 2, 1745.

${ }^{2087}$ The authors observed that poorly performing firms that complied with the board independence guideline (with a majority of independent directors on the board) experienced significantly improved firm valuation, in comparison with those noncompliant poorly-performing firms. Panasian, Prevost \& Bhabra, supra note 1805 at 148-50, 154.

${ }^{2088}$ Ibid at $134,137$.

2089 Ibid at 142.
} 
directors. The purpose of doing so is to ensure the quality of financial reporting, and establish appropriate executive compensation. Unlike empirical studies analyzed in the US part, research concerning Canadian firms only used the performance of committee tasks, rather than both committee tasks and firm performance, as indicators to evaluate the efficacy of independent directors in the audit and compensation committees. The empirical results show that audit committees with a higher proportion of independent (or outside) directors were at worst harmless and may be related to a higher quality of financial reporting, while compensation committees with a higher proportion of independent directors would even reward higher compensation to CEO. However, no study examines the impact of a fully independent audit or compensation committee on the achievement of its committee mission, respectively. Further research is needed to investigate such an impact.

More specifically, Scarbrough, Rama and Raghunandan (1998) found that audit committees composed of $100 \%$ outside directors were more likely to be engaged in internal auditing activities (signifying a better quality of financial reporting), ${ }^{2090}$ while Smaili and Labelle (2009) observed that higher proportions of independent directors on the audit committee had no connection with reducing the occurrence of accounting irregularities (representing a higher quality of financial reporting). ${ }^{2091}$ The findings of Scarbrough, Rama and Raghunandan (1998) may not represent the effect of independent directors because they only focused on the effect of outside directors. The ineffectiveness of independent directors found in the study by Smaili and Labelle (2009) may be because not all audit committee members are independent. As analyzed in subsection 5.1.5.1.2.2, ${ }^{2092}$ US studies have shown that audit committees composed entirely of independent directors had a much higher possibility of enjoying a good quality of financial reporting than those without $100 \%$ independence. In other words, the impact of independent directors on the quality of financial reporting may not be fully realized unless all audit committee members are independent. Had Smaili and Labelle (2009) examined the connection between a completely independent audit committee and the occurrence of accounting irregularities, their results might have been different.

\footnotetext{
${ }^{2090}$ Scarbrough, Rama \& Raghunandan, supra note 1903 at 54.

${ }^{2091}$ Smaili \& Labelle, supra note 1886 at 19, 33 Table 6.

${ }^{2092}$ Five out of six studies found that the presence of a completely independent audit committee was significantly related to indices representing a higher quality of financial reporting, while only seven out of thirteen studies reported that audit committees with a greater proportion of independent directors (i.e. not 100\% independent) could reach similar results. The level of audit committee independence did matter. Further details were analyzed in subsection 5.1.5.1.2.2.
} 
Niu (2006) also reported that firms with higher ROB Board Composition scores were less likely to manipulate earnings. ${ }^{2093}$ However, it may not be appropriate to conclude that greater audit committee independence was associated with a lower level of earnings management because only $15 \%$ of the scores represent the effect of the audit committee independence.

Collectively, existing empirical studies do not provide a clear answer regarding the impact of a completely independent audit committee on the quality of financial reporting. Further research is needed to realize whether the quality of financial reporting depends on all audit committee members being independent.

With respect to the findings concerning whether more independent directors on the compensation committee are more likely to appropriately control executive remuneration, the only study-Sapp (2008) - exploring this issue reported that compensation committees with a higher proportion of independent directors were more likely to reward higher compensation to CEOs, ${ }^{2094}$ while other related findings — Jog and Dutta (2004) and Sapp (2008) — found that the proportion of outside or independent directors on the board was not associated with the level of CEO compensation, ${ }^{2095}$ Although the latter may not be applicable to independent directors on the compensation committee, these studies all together provide no evidence that Canadian firms with higher proportions of independent or outside directors, either on the board or compensation committee, were better at restraining remuneration for their executives.

As mentioned earlier, the ineffectiveness of independent directors in controlling the level of CEO compensation may be because not all compensation committee members are independent. The US empirical evidence has shown that the impact of independent directors on the quality of financial reporting may not be fully realized unless all audit committee members are independent. Although such findings may not be entirely applicable to Canadian independent directors on the compensation committee, it provides a reminder that an impact of a fully independent compensation committee should be investigated; otherwise an important connection may be missed.

As for whether Canadian independent directors on the compensation committee do a better job of tying executive pay to firm performance, none of the existing studies explores this

\footnotetext{
${ }^{2093}$ Niu, supra note 1890 at 312-13, 315, 322.

${ }^{2094}$ Sapp, ibid.

${ }^{2095}$ Jog \& Dutta, supra note 1837 at 14-15, 32 Table 8, 33 Table 9; Sapp, supra note 1918 at 740.
} 
issue. Three related studies ${ }^{2096}$ found that the sensitivity of executive pay to firm performance was not influenced by the level of board independence. ${ }^{2097}$ Although these studies may not be applicable to independent directors on the compensation committee, at least these studies demonstrate that Canadian independent directors were not effective in aligning the interests of CEOs with those of shareholders through compensation. In combination with the findings in the last paragraph, empirical evidence only confirms that compensation committees with a higher proportion of independent directors were unable to control the level of their executive compensation. More research is needed to explore whether there is a connection between the sensitivity of executive pay to firm performance and independent directors on the compensation committee, as well as whether the control of executive pay and the sensitivity of pay-forperformance depend on all compensation committee members being independent.

Finally, as mentioned in chapter five, the problem of causation and lagged effects may affect the reliability of studies discussed in this section. No studies in this section investigated the issues of causation or lagged effects. However, not addressing causation or lagged effects does not mean there are no such issues in these studies. The results of these studies may have an alternative interpretation or risk missing an important connection between audit committee independence and the quality of financial reporting, as well as between compensation committee independence and the mission of setting appropriate executive compensation. Addressing causation or lagged effects, however, is out of the scope of this thesis.

\subsubsection{Whether Financial Expertise and Financial Literacy Affect the Quality of Financial Reporting}

As stated previously, independent directors on an audit committee should have certain knowledge and experience in the field of accounting and finance in order to fulfill their responsibility of supervising and ensuring the integrity of a firm's financial reporting system. Financial literacy and financial expertise are popularly considered as the core ability for independent directors to perform such monitoring jobs. However, the Canadian Securities Administrators, choosing not to follow the United States' approach that includes both

\footnotetext{
${ }^{2096}$ Please refer to Jog and Dutta (2004), Switzer (2007), and Sapp (2008) in section 5.2.4.

${ }^{2097}$ Further details were discussed in section 5.2.4.
} 
characteristics as mandatory, only require that every audit committee member must be financially literate. Existing empirical evidence shows, however, that only financial expertise, rather than financial literacy, is associated with a higher quality of financial reporting.

More specifically, Smaili and Labelle (2009) found that firms with an audit committee populated with greater number of financial experts had a lower likelihood of accounting irregularities (implying a better quality of financial reporting), ${ }^{2098}$ while Park and Shin (2004) reported that the boards with outside directors from financial institutions were related to a lower level of earnings management (signifying a better quality of financial reporting). ${ }^{2099}$ However, against conventional wisdom, Smaili and Labelle (2009) observed that the proportion of audit committee members with financial literacy had no impact on the occurrence of accounting irregularities. $^{2100}$ Perhaps, audit committee members with only financial literacy are not sufficient to deter accounting irregularities. In total, directors with financial expertise either on the board or on the audit committee were more likely to enhance the quality of financial reporting, but directors with only financial literacy seem to have no such effect. It appears that the current NI 52-110 which only requires that all audit committee members must be financially literate, rather than both financially literate and financial experts, is not empirically supported.

The lack of a sufficient number of related studies is a concern regarding this conclusion. The above findings regarding financial literacy and financial expertise are only presented by two empirical studies, and one of them_-Park and Shin (2004) — only looked at the effect of outside directors (which may represent the effect of independent directors). More research is needed to confirm whether the effect of financial expertise on financial reporting quality is indeed better than the impact of financial literacy on financial reporting quality. As well, no study examined the issues of causation or lagged effects in this section. Not addressing causation or lagged effects does not mean there are no such issues in these studies. However, these two issues are out of the scope of this thesis.

\subsubsection{Summary regarding Whether Empirical Findings Support the Current Measures Relying on Independent Directors in Canada}

\footnotetext{
${ }^{2098}$ Smaili \& Labelle, supra note 1886 at 19, 33 Table 6.

2099 Park \& Shin, supra note 1892 at 447, 455.

${ }^{2100}$ Smaili \& Labelle, supra note 1886 at 19, 33 Table 6.
} 
In summary, among the four measures designed to enhance the effect of monitoring boards in Canada, financial literacy of audit committee members did not gain empirical support, while empirical evidence only endorsed an independent board in some circumstances. Audit committee members with financial expertise were more likely to enhance the quality of financial reporting, but there was no such effect when they had only financial literacy. Firms with a majority of independent directors on the board, in general, did not perform better than those without that board composition, but poorly performing firms that chose to have an independent board experienced significantly improved firm valuation, in comparison with those not doing so.

In contrast, existing empirical studies do not provide a clear answer regarding the impact of a completely independent audit committee on the quality of financial reporting, or the connection between a completely independent compensation committee and the sensitivity of executive pay to firm performance or the level of executive compensation. Audit committees with a higher proportion of independent or outside directors were at worst harmless and might be related to a higher quality of financial reporting. Compensation committees with a higher proportion of independent directors were even associated with a greater level of executive remuneration. Since the above results regarding the four measures are based on a limited number of studies, more research is needed to confirm such conclusions.

\subsection{The Possible Explanations for the Inconsistency Between Empirical Evidence and the Expectation of Independent Directors}

Independent directors have long been considered a cure for agency problems. Laws and regulations in North America have adopted intensive measures relying on independent directors to fulfill a monitoring role. However, there seems to be a big gap between such expectations and empirical findings. Scholars have addressed six possible causes for the inconsistency, but they did not provide evidence to support these causes. ${ }^{2101}$ The first five reasons address both board independence and committee independence, while the last one only explains board independence.

\footnotetext{
${ }^{2101}$ Bhagat \& Black, 1999, supra note 25 at 952-53; Bhagat \& Black, 2002, supra note 1 at 266-67; Gordon, Independent Directors, supra note 1 at 1506-09.
} 
First, one possible explanation is that existing independent directors are simply not independent enough. ${ }^{2102}$ In other words, independent directors as traditionally defined may not be truly independent of the corporation or its management. Currently, the authority to determine whether a director is independent is left to the entire board. Stock exchanges provide a brightline test that excludes a director from being considered independent in specific circumstances. However, these preclusions only focus on directors' financial ties and familial ties with the company or the chief executive without considering social, sponsorship or professional ties. ${ }^{2103}$ Corporations or their chief executives with a desire to select directors who are attached to them could develop strategies to circumvent these regulations. Top executives can easily influence the board or nominating committee to secure the nomination of directors who are independent according to regulatory definitions, but still unduly dominated by management. ${ }^{2104}$ Similar critiques of independent directors were set out in section 3.2.1.

For example, the independence of Enron's board of directors was substantially compromised by certain under-the-table connections, especially sponsorship relationships, ${ }^{2105}$ as mentioned in subsection 3.2.1.1. Two Delaware lower court decisions, In re Oracle Derivative Litigation and Bean v. Martha Stewart, also demonstrated that non-financial ties and friendships could impede director independence and cause bias that would preclude a director from objectively evaluating corporate decisions, as analyzed in subsection 3.2.1.2. ${ }^{2106}$ In addition, two recent empirical studies-Hwang and Kim (2009) and Dey and Liu's (2010), as discussed in subsection 3.2.1.3, showed that firms with independent directors who have social ties to the firms' CEOs, including ties related to their educational institution attended, regional origin, military service, and professional similarity, were inclined to have poorer financial performance, award a higher level of compensation to their CEOs, exhibit a lower sensitivity of CEO pay to firm performance and of CEO turnover to performance, and have a lower quality of financial reporting. ${ }^{2107}$ These examples consistently demonstrate that existing definitions of independent directors may be too lax. The monitoring benefits of independent directors may be less for those who meet only these definitions.

\footnotetext{
${ }^{2102}$ Tung, supra note 1028 at 1176; Bhagat \& Black 1999, ibid at 952; Bhagat \& Black 2002, ibid at 266; Clark, Morality Tale, supra note 13 at 300.

${ }^{2103}$ See supra note 428.

${ }^{2104}$ Duchin, Matsusaka \& Ozbas, supra note 429 at 196; Cosenza, supra note 391 at 15.

${ }^{2105}$ See supra text accompanying notes 434-439 for further details.

${ }^{2106}$ See supra text accompanying notes 440-461 for further details.

${ }^{2107}$ See supra text accompanying notes $463-476$ for further details.
} 
Second, there may not be sufficient incentives to motivate independent directors in carrying out their monitoring duties. ${ }^{2108}$ Ostensibly, current corporate governance has rewards (compensation) and legal sanctions (liability) to encourage independent directors to engage in active oversight and deter them from shirking their obligations. However, neither of these factors may create strong incentives. Independent directors seldom acquire a great enough equity interest to generate a strong incentive in monitoring management, ${ }^{2109}$ and stock options for independent directors may compromise their ability to constrain the CEO's compensation. ${ }^{2110}$ Professors Black, Cheffins and Klausner also found that independent directors, in the past two and a half decades, rarely made out-of-pocket payments for breaches of the duty of loyalty (fiduciary duty in Canada) or the duty of care either in the United States or Canada. ${ }^{2111}$ Independent directors may have no connection with the company or management, but no strong incentives urge them to curb management's abuses diligently. Similar critiques of independent directors were discussed in chapter three (section 3.2.2 and section 3.2.3).

Third, the returns to having independent directors on the board (or committee) may diminish as the number of independent directors increases. ${ }^{2112}$ In other words, the benefits of retaining independent directors may not be the more the better. Director independence may well be positive for shareholder value, but, above a critical proportion, the returns may be diminishing, and sometimes may even be negative. ${ }^{2113}$ Independent directors, starting from the 1990s, have populated at least two-thirds or even three-quarters of board seats of publicly-held companies in the United States. ${ }^{2114}$ It may be that current firms may have too many independent directors. Several empirical studies have reached similar results. For example, Baysinger and Butler (1985) reported that firm performance was improved by adding independent directors up to the point where independent directors account for around $30 \%$ of the board. Beyond this percentage, adding more independent directors will result in diminishing firm performance. ${ }^{215}$ Byrd and Hickman (1992) also observed a similar relationship between the fraction of independent

\footnotetext{
${ }^{2108}$ Bhagat \& Black 2002, supra note 1 at 266.

${ }^{2109}$ Gordon, The Rise of Independent Directors, supra note 1 at 1488.

${ }^{2110}$ Bebchuk, Grinstein and Peyer, supra note 511 at 2365, 2387, 2399; Byard \& Li, supra note 514 at 2.

${ }^{2111}$ Black, Cheffins \& Klausner, Liability, supra note 528 at 1055; Black \& Cheffins \& Klausner, Liability Across Countries, supra note 529 at 1451.

${ }^{2112}$ Gordon, The Rise of Independent Directors, supra note 1 at 1507.

2113 Ibid; Baysinger \& Butler 1984, supra note 1041 at 573-75; Byrd \& Hickman, supra note 363 at 213-16.

${ }^{2114}$ Bhagat \& Black 2002, supra note 1 at 232; Gordon, ibid at 1474 Figure 1, 1475 .

2115 Baysinger \& Butler 1984, supra note 1041 at 573-75.
} 
directors and bidding firms' stock price returns when the percentage of independent directors on the board achieved $60 \% .^{2116}$ The optimal level of board independence appears to vary with different situations. For this reason, requiring a firm to have a specific proportion of independent directors on the board (or on a specific committee) may not be necessarily beneficial.

Fourth, the success of other corporate governance mechanisms may reduce the need for independent directors. ${ }^{2117}$ In fact, independent directors are only one of several mechanisms that may affect corporate governance. Product markets, the market for managers' services, the market for corporate control, capital markets, as well as the presence of controlling shareholders, are claimed to act as constraints against managerial misdeeds. ${ }^{2118}$ When a corporation operates in an environment where other governance mechanisms are effective, there may be less need for independent directors to play such monitoring roles. ${ }^{2119}$ Further details were discussed in the introduction of this thesis. Empirical findings have shown that independent directors are not always needed as corporate monitors when the market for corporate control is active. ${ }^{2120}$ Canadian empirical evidence demonstrates that the level of board independence was significantly and negatively associated with ownership of dominant shareholders. It suggests that independent directors and controlling shareholders may act as substitutes in corporate governance. ${ }^{2121}$ The monitoring effect of independent directors may be difficult to detect by empirical studies or may simply be redundant where other control mechanisms are effective.

Fifth, independent directors with particular characteristics may be more effective than others. ${ }^{2122}$ For example, US empirical evidence has demonstrated that firms were more likely to perform better when their independent directors had a higher proportion of shareholdings, ${ }^{2123}$ and when ethnic minorities or females served as audit committee members. ${ }^{2124}$ In addition, independent directors holding less than three outside directorships are reported to be more likely

\footnotetext{
${ }^{2116}$ Byrd \& Hickman, supra note 363 at 213-16.

${ }^{2117}$ Lin, supra note 13 at $957-58$.

${ }^{2118}$ VanDuzer, supra note 15 at 528-30; Jones, supra note 15 at 119-20; Fama, Agency Problems, supra note 15 at 294-95; Winter, supra note 15 at 264-66.

2119 Ibid.

${ }^{2120}$ See section 5.1.6.4 for evidence regarding the market for corporate control. As for the relationship between controlling shareholders and independent directors, see Erickson et al, supra note 676 at 402, 403 Table 7; Bozec \& Bozec, supra note 676 at 189.

${ }^{2121}$ Bozec \& Bozec, supra note 676 at 189.

${ }^{2122}$ Bhagat \& Black 2002, supra note 1 at 267; Bhagat \& Black 1999, supra note 25 at 953; Lin, supra note13 at 939.

${ }^{2123}$ See section 5.1.6.2.

${ }^{2124}$ See supra text accompanying notes 1550-1573. Further details were discussed in sections 5.1.6.1 and 5.1.6.2.
} 
to enhance firm performance and remove incompetent CEOs. ${ }^{2125}$ Since some empirical studies did not focus on the differential effects of particular kinds of independent directors, their results may not reflect the real monitoring effect of independent directors. In other words, the reason independent directors are not so effective may be that firms did not nominate individuals with the "right" characteristics to serve as independent directors. With a view to enhancing boards" (or committees') monitoring effect, searching for factors that may improve the efficacy of independent directors becomes one of the vital matters in today's corporate governance.

Sixth, there may be no "one-size-fits-all" board composition for every firm. Optimal level of board independence may vary across firms. ${ }^{2126}$ In fact, there exists a potential trade-off between different attributes that insider and independents bring to a board. ${ }^{2127}$ Firms may benefit from better monitoring resulting from a higher percentage of independent directors on the board; however, simultaneously, they may suffer from poorer strategic planning and operational advice due to a lower proportion of inside directors or affiliated directors. ${ }^{2128}$ The benefits of having independent directors come at the costs of retaining inside or affiliated directors. The right balance between independent and affiliated (or inside) directors may vary across firms and business sectors. Studies that do not account for such differences may not provide an accurate picture of the role of independent directors. Similar arguments were addressed in section 3.2.5.2.

Many scholars have observed that firm-specific characteristics may have caused corporations to have different needs for independent directors since the start of the new millennium. ${ }^{2129}$ Empirical evidence has shown that at least six factors are significantly correlated with the effect of board independence, namely firm size, firm complexity, growth opportunities, R\&D intensity, managers' opportunities for private benefits ${ }^{2130}$, and CEO's influence and the constraints of such influence. ${ }^{2131}$ In other words, the optimal level of board independence varied with a broad combination of firm-specific characteristics and operating environments. Firms were inclined to have more independent boards when they were larger, more complex and had less CEO influence (more constraints on CEO influence). In contrast,

\footnotetext{
${ }^{2125}$ Further details were discussed in section 5.1.6.3.

2126 Tung, supra note 1028 at 1176; Bhagat \& Black 1999, supra note 25 at 955.

${ }^{2127}$ Gordon, The Rise of Independent Directors, supra note 1 at 1506; Bhagat \& Black, 1999, ibid at 951.

${ }^{2128}$ Bhagat \& Black 1999, ibid at 955-56.

${ }^{2129}$ Gordon, Independent Directors, supra note 1 at 1506-07.

${ }^{2130}$ This factor refers to the opportunities for managers to increase their own wealth at the shareholders' expense. Boone et al, supra note 679 at 80; Linck, Netter \& Yang, supra note 679 at 311.

${ }^{2131}$ Please refer to section 5.1.5.8 of this thesis.
} 
firms with high growth opportunities seemingly did not choose boards with higher independence. ${ }^{2132}$ Consequently, there may be no ideal level of board independence that fits all companies. Since firms are expected to move toward their optimal governance structure in a competitive market, their different needs for independent directors may reduce the utility of regression analysis of a large sample of diverse firms regarding the effectiveness of independent directors.

Based on these analyses, the current measures regarding independent directors seem to have room for improvement. The next section discusses the impact of other control mechanisms and director characteristics on the efficacy of independent directors through the analysis of empirical evidence. The subsequent section develops the specific policy implications that flow from the empirical findings.

\subsection{Other Factors That May Affect the Effectiveness of Independent Directors Have Not Been Addressed by Current Laws or Regulations}

As mentioned previously, other factors beyond those contemplated in current laws and regulations may also impact the effectiveness of independent directors. The empirical findings compiled in chapter five have identified some governance mechanisms and director characteristics that may directly or indirectly complement, substitute for or diminish the effectiveness of independent directors. As noted, the definition of independent director, the impact of SOX-related reforms, and the problems of causation and lagged effects may influence the reliability of these studies. The following summary considers the impact of the definition of independent director, SOX effects, and causation and lagged effects raised by scholars (referring to the relationship between independent directors and firm performance). Since the governance culture, legal environment and shareholder structure is different between the United States and Canada, the following summary regarding these factors will be discussed separately.

\subsubsection{In the United States}

${ }^{2132}$ See supra text accompanying notes 687-691. Further details were discussed in section 3.2.5.3. 
In chapter five, this thesis analyzed nine factors that may affect the efficacy of independent directors in the United States, including four director characteristics (female gender, minority ethnicity, ownership interests in corporations they serve, and outside directorships), two governance environment factors (antitakeover provisions and costs of acquiring corporate information), and three governance mechanisms (leadership structure, the number of independent directors, and board diligence). The impact of these factors on the effectiveness of independent directors is compiled as follows.

\section{Ethnic-minority Independent Directors Are Valuable Only When They Serve on the Audit Committee}

First, there may be benefits associated with having independent ethnic-minority directors on the board but they may not be present in all circumstances. The benefits of having independent ethnic-minority directors may only arise when these directors serve on the audit committee. Four studies observed that the presence or a higher proportion of minority directors on the board was correlated with better firm performance, but these findings combined the effect of independent and non-independent minority directors on firm performance. Whether boards with minority independent directors could lead to greater firm performance is still unknown. In contrast, Carter et al. (2008) found that firm performance was more likely to be enhanced when a higher proportion of independent ethnic minority directors serve on the audit committee, and the causation ran from independent ethnic minority directors to firm performance. ${ }^{2133}$ However, there was no clear evidence showing similar relationship when such directors served on the compensation and nominating committees. ${ }^{2134}$ All studies mentioned used pre-SOX samples. In short, the results, based on the observation of a pre-SOX sample, indicate that the more ethnic minorities serve as independent directors on the audit committee the better a firm performs.

\section{Female Independent Directors Are Valuable Only When They Serve on the Audit Committee}

Second, the benefits of having female independent directors may not arise in all cases, but may only be realized when they serve on the audit committee. There are no consistent findings among five studies regarding the relationship between the presence of female directors on the board and firm performance. Levi, Li and Zhang (2008) even found that female independent

${ }^{2133}$ Carter et al. 2008, supra note 1033 at 23.

${ }^{2134}$ See text in subsection 5.1.6.1.2. 
directors on the board were harmful when their firms were the targets of takeovers. ${ }^{2135}$ In contrast, Carter et al. (2008) reported that firm performance was more likely to be enhanced when a higher proportion of female independent directors serve on the audit committee, and the causation ran from female independent directors to firm performance, rather than vice versa. ${ }^{2136}$ In addition, Gul, Srinidhi and Tsui (2007) observed that audit committees with at least one female independent director were less likely to manage earnings. ${ }^{2137}$ However, similar to the findings regarding ethnic minority directors, Carter et al. (2008) could not find a clear indication that firm performance was enhanced through female independent directors on the compensation or nominating committees. Except for Levi, Li and Zhang (2008) with a sample straddling SOX, all studies used pre-SOX samples. Taken together, the benefits of having women as independent directors are clearly shown only in their role as audit committee members.

\section{Independent Directors with Greater Shareholdings Are More Likely to Benefit the Firms They} Serve

Third, independent directors with greater shareholdings are more likely to benefit the firms they serve. Four studies reported that independent directors with greater shareholdings were closely associated with better firm performance, and two of them confirmed that the causation ran from greater shareholdings to better firm performance, rather than vice versa. ${ }^{2138}$ However, there seems to be no general consensus about whether incentive based compensation, consisting of stock options, stock grants, or both, enhances the effectiveness of independent directors measured by firm performance. Three studies observed that firms with stock options or stock grants for independent (or outside) directors were more likely to be associated with better firm performance, ${ }^{2139}$ while two studies found no such effect for firms with stock options and stock grants for their outside directors. ${ }^{2140}$ Another three studies even reported that stock options may increase the likelihood of collusion between executives and independent directors. ${ }^{2141}$ In addition, Perry (2000) found that the sensitivity of CEO turnover to firm performance was

\footnotetext{
${ }^{2135}$ Levi, Li \& Zhang, supra note 1572 at 1, 13-14.

${ }^{2136}$ Carter et al. 2008, supra note 1033 at 21. Like the findings regarding ethnic minority, a clearly similar connection was not found when they served on the compensation and nominating committee.

${ }^{2137}$ Gul, Srinidhi \& Tsui 2007, ibid. at 26.

${ }^{2138}$ See supra text accompanying notes 1583-1593.

2139 See supra text accompanying notes 1594-1602.

2140 See supra text accompanying notes 1614-1620.

${ }^{2141}$ See supra text accompanying notes 1606-1610.
} 
inclined to be enhanced when independent directors were awarded with incentive compensation (combining stock options and stock grants). ${ }^{2142}$ All these results are based on the observation of pre-SOX samples. Taken together, empirical evidence only clearly supports nominating candidates who hold a certain percentage of shares as independent directors. Doing so is likely to align their interests with those of shareholders.

\section{Independent Directors Holding Two or Fewer Outside Board Seats Are More Likely to Benefit Shareholders}

Fourth, independent directors holding two or fewer outside board seats are more likely to benefit shareholders. Fich and Shivdasani (2006) and Jiraporn, Kim and Davidson (2008) observed that firms with a majority of independent directors holding three or more board seats were more likely to perform more poorly than those with a majority of independent directors holding fewer than three board seats. ${ }^{2143}$ Similar results were found by Jiraporn, Kim and Davidson (2008) when the director busyness is measured by the percentage of independent directors holding three or more board seats. The causation of these findings ran from busy independent directors to poorer firm performance, rather than vice versa. In addition, Fich and Shivdasani (2006) reported that the sensitivity of CEO turnover to firm performance was significantly lower when independent directors held three or more directorships, compared to those holding less than three, ${ }^{2144}$ while Beasley (1996) observed that the incidence of financial statement fraud was higher when outside directors held more than two outside directorships, in comparison with those holding less than two. ${ }^{2145}$ Jiraporn et al. (2009) also found that busy ${ }^{2146}$ independent directors were likely to miss more board meetings than their inside and affiliated counterparts. $^{2147}$ All studies mentioned in this paragraph used pre-SOX samples. On the basis of this evidence, firms should nominate individuals who hold two or fewer outside directorships as their independent directors, with a view to protecting shareholder interests.

\footnotetext{
${ }^{2142}$ See supra text accompanying notes 1624-1627.

${ }^{2143}$ Fich \& Shivdasani 2006, supra note 1240 at 691, 701, 703-05; Jiraporn, Kim \& Davidson, supra note 1628 at 428-29.

${ }^{2144}$ Fich \& Shivdasani 2006, supra note 1240 at 715-16.

${ }^{2145}$ Beasley, supra note 1295 at 461.

${ }^{2146}$ Whether an outside director is busy is measured by the number of outside directorship held by each director. Jiraporn et al., supra note 1628 at 1163 .

${ }^{2147}$ Ibid at 1167.
} 


\section{How the Degree of Protection against Takeovers Affects the Effectiveness of Independent Directors} is Unclear

Fifth, whether the degree of protection against takeovers affects the effectiveness of independent directors (in enhancing shareholder wealth) needs further research. Several empirical studies have reported that market for corporate control and the oversight of independent directors act as substitute devices for controlling managerial behavior. When the degree of protection against takeovers (barriers to the market for corporate control, such as poison pills) is high, independent directors assume a role in disciplining top management. However, the findings of Santaló and Diestre (2006) did not support this substitute relationship. They observed that an increase of board independence was linked to a decrease in a firm's market value (Tobin's Q) when firms had a high degree of antitakeover protection. On the contrary, when firms had a low level of antitakeover protection, an increase of independent directors on the board was associated with an increase in the market valuation of the firm. ${ }^{2148}$ For those firms with a medium degree of antitakeover protection, no significant connection was found between board independence and firm market value. ${ }^{2149}$ All four studies used pre-SOX samples. Taken together, there seems no consensus regarding the connection between the degree of protection against takeovers and the effectiveness of independent directors in enhancing shareholder wealth.

\section{The Effectiveness of Independent Directors in Enhancing Firm Value Depends on the Costs of}

\section{Acquiring Corporate Information}

Six, the effectiveness of independent directors in enhancing firm value depends on the costs of acquiring corporate information. Duchin, Matsusaka and Ozbas (2010), with a sample straddling SOX, found that adding independent directors to the board was associated with better firm performance when the costs of acquiring corporate information were low. However, when the costs of acquiring information turned high, an increase in the percentage of independent directors was connected with worse firm performance. ${ }^{2150}$ Ravina and Sapienza (2010), with a

\footnotetext{
${ }^{2148}$ Santaló \& Diestre, supra note 1689 at 4-5, 19, 27.

${ }^{2149}$ See ibid at 37 Table 4.

${ }^{2150}$ More specifically, for firms in the lowest information cost quartile, each additional $10 \%$ representation of independent directors to the board increased 1.3\% ROA, 8.1\% Tobin's $\mathrm{Q}$, and 3.8\% annual stock returns during 2000 to 2005. In contrast, for firms in the highest information cost quartile, each additional $10 \%$ representation of independent directors to the board reduced 1.7\% ROA, 15.8\% Tobin's Q, and 2.4\% annual stock returns during the sample period. Ibid at 204.
} 
pre-SOX sample, also reported that independent directors were not timely informed (acquired less information than executives) when firms had poor governance. Collectively, the evidence shows that the costs of acquiring corporate information affect the effectiveness of independent directors in protecting shareholder interests. Independent directors are beneficial only when it is not difficult for them to collect the corporate information they need.

\section{A Firm with a Board Chair Who Is an Independent Director Is More Likely to Be Associated with Higher Shareholder Wealth}

Seven, a firm with a board chair who is an independent director is more likely to be associated with higher shareholder wealth, compared to a firm with an inside director who serves on the same position. Balsam, Puthenpurackal and Upadhyay (2011) found that affiliated and independent directors serving as board chairs were significantly and positively related to firm performance (Tobin's Q), ${ }^{2151}$ and the causation ran from outside board chairs to firm performance, rather than vice versa. ${ }^{2152}$ But the effect of affiliated chair on firm performance is better than that of independent board chair. ${ }^{2153}$ Grinstein and Valles (2008) also observed that firm performance was significantly improved after an independent director took the board chair of a poorly-performing firm within one year. ${ }^{2154}$ Both studies had samples straddling SOX. Taken together, it appears that the value of having an independent board chair was empirically supported but there were even greater benefits associated with an affiliated chair.

\section{No Optimal Number of Independent Directors and No Optimal Meeting Frequency for Independent Directors}

Eight, no study, so far, directly explores how many independent directors should serve on the board and how often independent directors should meet to provide the most benefit for shareholders. This thesis tries to gain some insight from studies that examined the relationship between shareholder interests and the number of board members, as well as the meeting frequency of board members. Existing evidence shows that: (1) there is no perfect number of board members that fits all corporations; and (2) board members meet more frequently usually due to the presence of problems but more frequent meetings are not necessarily related to better

${ }^{2151}$ Balsam, Puthenpurackal \& Upadhyay, supra note at 21-23, 34.

2152 Ibid at 31-32.

${ }^{2153}$ Ibid at 26-27, 34, 57 Table 9.

${ }^{2154}$ Grinstein \& Valles, supra note 1731 at 26-27, 44 Table 13. 
firm performance. These findings may, in some circumstances, allow an inference to be made that: (1) there is no optimal number of independent directors that fits all companies; and (2) independent directors meeting more frequently may not necessarily lead to better firm performance.

In summary, the above empirical evidence has shown that shareholder interests are more likely to be well protected when: (1) ethnic minority or female serve as independent directors on the audit committee; (2) independent directors have a certain level of shareholdings; (3) independent directors hold less than three outside board seats; (4) the costs for independent directors to acquire firm information are low; (5) an independent director serves as a board chair (compared to the CEO). Therefore, firms may consider nominating candidates with these characteristics as independent directors, and fostering an environment that the costs of acquiring corporate information are low. It is worth noting that these results, except for those regarding information costs and an independent board chair, were based on the observation of pre-SOX samples. Nevertheless, these results are likely to be reliable in the post-SOX period, because it is likely that SOX related reforms improved the governance environment generally. There would be no reason to think that SOX reforms would make independent directors with these characteristics less effective. This thesis will address the implications of these findings for existing regulations in the section 6.4.

\subsubsection{In Canada}

Empirical studies have also searched for factors that may affect the effectiveness of Canadian independent directors; however, the results are limited. So far, only the relationship between the number (or the proportion) of independent directors on the board and the presence of controlling shareholders, as well as a board's leadership structure, have been studied. As discussed in more detailed below, other research findings do not provide clear answers regarding whether independent directors with a specific characteristic or under a specific governance mechanism would be more likely to protect shareholder interests. 
First, the presence of controlling shareholders may be related to fewer or a lower proportion of independent directors on the board. ${ }^{2155}$ Erickson et al. (2005) found that the proportion of outside directors on the board was significantly and negatively associated with the presence of voting rights held by controlling shareholders, ${ }^{2156}$ while Bozec and Bozec (2007) reported that the ROB Board Composition scores were significantly and negatively related to the level of ownership concentration, especially when a dominant shareholder held more than $25 \%$ of voting rights. ${ }^{2157}$ The findings that firms with controlling shareholders tend to have fewer independent directors could have at least two different interpretations. It is possible that controlling shareholders who control management and the election of directors do not need independent directors to hold management accountable because they monitor management by themselves. On the contrary, it may be that controlling shareholders tend to take advantage of their power to increase their own wealth at the expense of minority shareholders; therefore, preferring fewer independent directors who may restrain their abuses. ${ }^{2158}$

Second, board leadership structure may influence the number of independent directors. Switzer (2007) observed that firms with a unitary leadership structure (CEOs who also hold the board chair) were inclined to have more outside directors on their boards. ${ }^{2159}$ Such findings imply that leadership structure may affect independent directors' monitoring effect, since a firm may need more independent directors to counterbalance the CEO's influence when its CEO also holds the board chair. It appears that leadership structure and independent directors may act as substitutes in holding management accountable in some circumstances. ${ }^{2160}$ However, existing research does not directly explore whether independent directors are more likely to protect shareholders under different types of leadership structure. The real impact of the leadership structure on the efficacy of independent directors remains unknown.

Third, the impact of female independent directors on firm value is still unclear. So far, only Francoeur, Labelle and Sinclair-Desgagné (2008) have conducted studies on this issue. The authors found that adding female directors to Canadian boards had no significant impact on

\footnotetext{
${ }^{2155}$ See Bozec \& Bozec, supra note 676 at 189.

${ }^{2156}$ Erickson et al, supra note 676 at 402, 403 Table 7.

${ }^{2157}$ Bozec \& Bozec, supra note 676 at 190.

${ }^{2158}$ Park \& Shin, supra note 1892 at 455; Erickson et al, supra note 676 at 402.

${ }^{2159}$ Switzer, supra note 1866 at 660, 662 Table 4.

${ }^{2160}$ The findings can also be interpreted as that a powerful CEO and board chair would seek to reduce their own power by having more outside directors on the board. Maybe such a CEO is not threatened by outside directors because he or she has so much power.
} 
corporate value. $^{2161}$ Since their findings included the effect of both independent and nonindependent female directors on firm performance, the real effect of female independent directors on firm performance remains unknown. Further research is needed to understand the contribution of female independent directors on firm performance.

In summary, unlike the findings in the United States, no study, so far, has reported that Canadian independent directors with specific characteristics (such as gender or higher shareholdings) would be more likely to protect shareholder interests. However, existing studies have demonstrated that: (1) there are fewer (or lower proportion of) independent directors on the board when there is a controlling shareholder; and (2) when a firm's CEO also holds the board chair, the number of independent directors increases. Since more than $40 \%$ of Canadian firms have a controlling shareholder, independent directors may be less needed in enhancing shareholder wealth or holding management accountable in Canada.

\subsection{Policy Implications}

As discussed above, empirical evidence, both in the United States and in Canada, does not strongly support current measures relying on independent directors as corporate monitors, except for evidence concerning audit committee independence in the United States. These pessimistic findings and possible explanations raise a concern about whether current laws and regulations regarding independent directors are appropriately designed, as well as whether courts' reliance on independent directors is misplaced. Since the nature of reliance on independent directors as corporate monitors is different between the United States and Canada (mandatory requirements vs. comply-or-explain), the suggestions for policy change are discussed separately for the two countries.

\subsubsection{In the United States}

As mentioned earlier, the United States regulators rely on independent directors as corporate monitors through highly-detailed legislation, regulations and stock exchange listing

${ }^{2161}$ Francoeur, Labelle \& Sinclair-Desgagné, supra note 1957 at 84, 93. 
requirements. Unlike Canada, five current measures regarding independent directors in the United States are all mandatory: (1) a majority of independent directors on the board; (2) three key monitoring committees-audit, compensation and nominating committees-composed entirely of independent directors; (3) at least one audit committee member with financial expertise; (4) holding executive sessions with attendance only by non-management or independent directors; and (5) following detailed criteria to determine whether a director is independent. Except for the effect of holding executive sessions, empirical studies have provided some evidence regarding whether these measures are able to protect shareholder interests and hold management accountable. However, the varied empirical support in response to the five measures suggests that some of them may need to be adjusted. Whether and how the measures need adjustment is analyzed in the following six sections. In addition, US courts may need to consider factors that may impair independent directors' monitoring effect (identified by empirical research) when reviewing decisions made by independent directors.

\subsubsection{The Criteria to Determine Whether a Director Is Independent Should Be Tightened}

The criteria to determine whether a director is independent should be tightened. More specifically, the social and other relationships between a director and the company's CEO should be taken into account when determining whether a director is independent. Both the NYSE and NASDAQ leave the authority to the board to determine whether a director is independent. In order to deal with the issue of determining "director independence", ${ }^{2162}$ the two exchanges provide a bright-line test-setting out six preclusions ${ }^{2163}$ for boards to exclude a director from being considered independent in specific circumstance. However, as mentioned in sections 3.2.1 and 6.2, the current six preclusions only focus on directors' financial ties and familial ties with the company but do not consider their social, sponsorship or professional ties with the CEOs. Although the general standards regarding director independence still apply, a corporation or its

\footnotetext{
${ }^{2162}$ Because both exchanges employ a broadly worded definition for "director independence", such as "no material relationship with the company" adopted by the NYSE and "no relationship would interfere with the exercise of independent judgment in carrying out the duties of a director" used by the NASDAQ, they develop a bright-line test for boards to determine whether a director is independent. See NYSE Manual, supra note 5, §303A.02(a) and NASDAQ Rule, supra note 5, §4200(a)(15).

${ }^{2163}$ The six preclusions include employment relationships, compensation relationships, relationships with auditors, business relationships, immediate family relationships and cross compensation committee links. Further details were discussed in subsection 4.1.2.1.4.2.
} 
executives can easily secure the nomination of directors who are independent according to the six preclusions in the regulatory definitions, but are still unduly influenced by management. Two recent empirical studies, with samples straddling SOX discussed in sections 3.2.1.3 and 6.2, have shown that firms having independent directors with social ties to the firm's CEOs were inclined to experience poorer financial performance, award a higher level of compensation to their CEOs, exhibit a lower sensitivity of CEO pay-for-performance and CEO turnover-toperformance relationships, and have a lower quality of financial reporting. ${ }^{2164}$

Since the impact of such social connections on independent directors' oversight was found in relation to a number of variables, regulators may need to consider adding one preclusion that excludes a director to be considered independent when he/she has certain social ties with the company's CEO, with a view to improving the efficacy of independent directors. In other words, the NYSE and NASDAQ may need to modify their Listed Company Manual 303A.02(b) and Market Rules 5605(a)(2), respectively, to include a preclusion such that certain social connections between a director and the CEO may eliminate the director from being considered independent.

Instead of adding a preclusion, the NYSE and NASDAQ may also consider modifying their Listed Company Manual 303A.02(a) and Market Rules 5605(a)(2), respectively, to direct boards to consider social, sponsorship or professional ties between director nominees and the CEOs when making their decisions regarding the application of the general standards about director independence.

\subsubsection{The Requirement of Having a Majority of Independent Directors on the Board Needs to Be Adjusted}

US regulators may need to consider adding supporting measures to make independent directors more effective on the board and adopting Canadian or British comply-or-explain approach in which having a majority of independent directors is only a recommendation. The purposes of mandating an independent board are to protect shareholder interests and hold management accountable. However, empirical studies have shown that firms with higher proportions (or a majority) of independent directors only performed better than those with lower

${ }^{2164}$ Hwang \& Kim, supra note 464 at 139; Dey \& Liu, supra note 463 at 4. 
proportions in some circumstances. ${ }^{2165}$ In addition, there is still some evidence demonstrating that firms with higher proportions (or a majority) of independent directors did not make a difference in relation to six specific board tasks. ${ }^{2166}$ Overall, it seems that the requirement of all corporations to have a board with a majority of independent directors is not fully justified by the empirical evidence.

As analyzed in section 6.2, the inconsistency between the requirement of an independent board and its empirical support may come from: (1) the current threshold of board independence that is not optimal for some firms; (2) the social ties between CEO and independent directors; (3) firms that do not nominate individuals with the "right" characteristics to serve as independent directors; or/and (4) the poor quality of governance environment provided by the firms they serve. Except for social ties, which have been proposed in section 6.4.1.1 as one of the preclusions to determine whether a director is independent, regulators may consider adopting supporting measures to enhance the effectiveness of independent directors and allowing firms to tailor their level of board independence according to their needs as discussed below.

\subsection{Problems of the Requirement of Having a Majority of Independent Directors on the Board}

The current threshold of board independence may not be optimal for some firms. As mentioned in section 3.2.5.3, the optimal level of board independence varies with a broad combination of firm-specific characteristics and operating environments. Firms were inclined to have more independent boards when they were larger, more complex, and had less CEO influence. In contrast, firms with high growth opportunities did not choose boards with higher independence. There seems to be no ideal level of board independence that fits all firms.

In addition, the optimal level of board independence seems to vary with different situations and may not necessarily be 50\%. As analyzed in sections 5.1.3.1, 5.1.4.1.1, and 6.2, Baysinger and Butler (1985) reported that firm performance reached its apex when independent directors was around 30\% of the board, while in Byrd and Hickman (1992) the bidding firms'

${ }^{2165}$ See section 5.2 .1 of this thesis.

${ }^{2166}$ In general, at least half of the studies in relation to most (five out of six) board tasks show that firms with a greater fraction of independent directors on the board had a positive impact on protecting shareholder interests, but firms with a higher level of board independence were unable to control CEO compensation. See section 5.2.2 of this thesis. 
stock price returns came to the highest when the percentage of independent directors on the board achieved $60 \%$. As a result, requiring all firms to have a majority of independent directors on the board may not be beneficial.

As analyzed in sections 3.2.5.2 and 6.2, there exists a trade-off between the different attributes that inside and independent directors bring to a board. Firms may benefit from better monitoring brought by a higher percentage of independent directors on the board, but, at the same time, they may suffer from poorer strategic planning and operational advice due to a lower proportion of inside directors or affiliated directors. Since the right balance among inside, affiliated, and independent directors may vary across firms and business sectors, when regulators require mandatory board independence, firms that need less board independence are forced to have some redundant independent directors on the board. For firms that want to take advantage of insiders' special expertise, they have to increase their board size; resulting in having too many independent directors on the board or depriving the board of valuable inside directors. ${ }^{2167}$

As mentioned in the introduction, product markets, the market for managers' services, the market for corporate control, capital markets, as well as the presence of controlling shareholders, are claimed to act as constraints against managerial misdeeds. When a corporation operates in an environment where other governance mechanisms are effective, there may be less need for independent directors to serve as a disciplinary check against managerial abuses. Therefore, requiring all firms to have a majority of independent directors on the board without considering the success of other control mechanisms in some firms may lead to welfare loss for these firms.

\subsection{The US Regulators May Consider Adopting the Comply-or-explain Approach}

Due to these concerns, the US regulators may consider Canadian or British comply-orexplain approach in which board composition is only a recommendation. Listed corporations would enjoy discretion to choose their own optimal level of board independence according to their specific needs. Investors can obtain explanations through public disclosure regarding why a company adopted a board composition different from what regulators recommended. The market will judge whether a corporation's approach is optimal.

${ }^{2167}$ See Lin, supra note 13 at $966-67$. 
As well, the costs associated with a comply-or-explain approach are likely to be lower than those with a mandatory requirement. According to Professor Anand, there are, at least, three different types of costs, namely design, enforcement and compliance costs, associated with mandatory and comply-or-explain approaches. ${ }^{2168}$ Usually, the costs for a regulator to design corporate governance rules are similar between mandatory and comply-or-explain approach. ${ }^{2169}$ However, the enforcement costs between the two approaches are significantly different. The regulator in a mandatory system has to examine whether firms have complied with substantive corporate governance rules, while the regulator in a comply-or-explain system only has to ensure that disclosure is adequate. Although the latter still has a role in ensuring that disclosure is accurate and complete, the costs of this process are likely less than those of examining firms' governance regimes as a whole in a mandatory system. ${ }^{2170}$ Regarding the compliance costs, firms under the comply-or-explain approach are likely to bear lower compliance costs than those under the mandatory approach as well, since these firms can choose not to comply with the measures that are excessively costly for them. They can tailor their governance structures according to their specific firm characteristics and avoid incurring excessive compliance costs. ${ }^{2171}$ But firms under the mandatory approach have no such flexibility. Collectively, the costs of a comply-or-explain approach are likely less than the cost of a mandatory system. This is mainly because of reduced compliance costs on the company's side and reduced enforcement costs on the regulator's side. The mandatory approach may yield slightly better compliance, but its costs are likely much higher. ${ }^{2172}$

Some may argue that there is less assurance that firms under the comply-or-explain system will follow the recommendation (guidelines) because no penalty attaches to those who fail to comply, in comparison with firms under a mandatory system. ${ }^{2173}$ In fact, listed firms' corporate governance practices are under market scrutiny. Firms have strong incentives to comply with voluntary guidelines that investors deem desirable. If they decide not to comply with some of them, they have to provide a compelling, rational explanation. Otherwise, they

\footnotetext{
${ }^{2168}$ Anita Indira Anand, “An Analysis of Enabling vs. Mandatory Corporate Governance: Structures Post-SarbanesOxley" (2006) 31 Del J Corp L 229 at 238.

${ }^{2169}$ Ibid at 245.

${ }^{2170}$ Ibid at 249.

${ }^{2171}$ Ibid at 245 .

${ }^{2172} \mathrm{Ibid}$ at 244.

${ }^{2173} \mathrm{Ibid}$ at 230, 240.
} 
may suffer investor repulsion. ${ }^{2174}$ Therefore, Professor Anand concluded that the comply-orexplain approach is likely to yield a high level of compliance at lower cost than the mandatory approach. $^{2175}$

A high level of compliance for firms adopting the comply-or-explain approach in fact was found in another study. Professors Purda, Milne and Anand observed a general increase in the voluntary adoption of governance practices following the implementation of the comply-orexplain system (Dey Committee guidelines) by the Toronto Stock Exchange. ${ }^{2176}$ They found that a high percentage of Canadian firms voluntarily implemented corporate governance guidelines recommended by the Toronto Stock Exchange as well as some SOX-like governance mechanisms between the years 1999 to $2003 .^{2177}$ The findings appear to confirm the feasibility and effectiveness of the comply-or-explain approach.

Taken together, the comply-or-explain approach may be regarded as a better alternative when empirical evidence does not strongly support the efficacy of having an independent board. The NYSE and NASDAQ may need to consider changing their Listed Company Manual 303A.01 and Market Rules 5605(b)(1) requiring an independent board, respectively, to only a recommendation. Disclosure would be required for firms not following the recommendation.

\subsection{Regulators May Consider Adopting Supporting Measures to Enhance the Effectiveness of Independent Directors}

In addition to the inappropriateness of the current threshold of board independence, the characteristics of independent directors and the governance environment in some firms may contribute to the ineffectiveness of independent directors. Empirical studies have reported that nominating individuals with the "right" types of characteristics to serve as independent directors and improving a firm's overall governance environment may make independent directors more effective. More specifically, empirical evidence has demonstrated that firms were more likely to perform better when their independent directors had a certain proportion of shareholdings, ${ }^{2178}$

\footnotetext{
2174 Ibid at 246, 248.

2175 Ibid at 230.

2176 Anand, Milne \& Purda, supra note 7 at 810, 824.

2177 Ibid at 823-24.

${ }^{2178}$ See section 5.1.6.2.
} 
and when ethnic minorities or females served as audit committee members. ${ }^{2179}$ In addition, independent directors holding less than three outside directorships were reported to be associated with enhanced firm performance and higher probability of removing incompetent CEOs. ${ }^{2180}$ The findings regarding these specific director characteristics were generated from a large data set ${ }^{2181}$ and are not contradicted by opposing evidence. Regulators should encourage firms to recruit individuals who have these characteristics to serve as independent directors, with a view to making independent directors more effective. The recruitment of directors with these characteristics may be encouraged through the comply-or-explain approach, because the complyor-explain approach is likely to yield a high level of compliance at lower cost than the mandatory approach. In other words, the NYSE and NASDAQ may consider adding a new clause under their Listed Company Manual 303A.00 (Corporate Governance Standards) and Market Rules 5600 (Corporate Governance Requirements), respectively, or somewhere else, which states that, in making director nomination, the board or its nominating committee must consider whether a nominee: (1) has a certain shareholdings of the company; (2) holds more than two outside directorships; and (3) is a female or ethnic minority serving on the audit committee and disclose the basis for any director nomination.

Moreover, empirical evidence shows that independent directors are beneficial only when their firms can provide complete information to their directors at low cost. ${ }^{2182}$ Regulators may encourage firms to foster an environment in which independent directors are well informed in order to fully realize their oversight function. Based on the same consideration as the

\footnotetext{
2179 See supra text accompanying notes 1550-1573.

${ }^{2180}$ See section 5.1.6.3.

${ }^{2181}$ Four studies reported that independent or outside directors having greater shareholdings were associated with better firm performance. Morck, Shleifer and Vishny (1988) had 3711980 Fortune 500 firms in their sample, while Klein (1998) included 485 firms from 1992-93 in her sample. Bhagat and Black (2002) examined 928 firms from 1991 to 1993 in their sample, but Hambrick and Jackson (2000) did not mention the number of their sample. Morck, Shleifer \& Vishny, supra note 374 at 311; Klein 1998, supra note 501 at 281; Bhagat \& Black 2002, supra note 1 at 240; Hambrick \& Jackson, supra note 377 at 113-14. Regarding the positive effect of independent female and ethnic minority directors, Carter et al. (2008) included Fortune 500 firms from 1998 to 2002 in their sample, while Gul, Srinidhi and Tsui (2007) had around 750 firms from 2001to 2002. Carter et al 2008, supra note 1033 at 18; Gul, Srinidhi and Tsui 2007, supra note 1565 at 21 . With respect to the findings regarding outside directorships, Fich and Shivdasani (2006) had 508 Fortune 500 firms from 1989 to 1995 in their sample, while the sample of Jiraporn, Kim and Davidson (2008) included 3,605 firm years observation from 1998 to 2002. Jiraporn, Singh and Lee (2009) employed a sample of 1,471 firms including 41,475 observations from 1999 to 2003, while Beasley (1996) investigated 75 fraud and 75 non-fraud firms between 1980 and 1981. Fich \& Shivdasani 2006, supra note 1240 at 695; Jiraporn, Kim \& Davidson, supra note 1628 at 422; Jiraporn, Singh and Lee, supra note 1628 at 822 ; Beasley, supra note 1295 at 448.

${ }^{2182}$ See section 5.1.6.5.
} 
recruitment of directors with specific characteristics, the establishment of a well-informed environment should also be done through the comply-or-explain approach. ${ }^{2183}$ The NYSE and NASDAQ should consider adding a new clause under their Listed Company Manual 303A.00 (Corporate Governance Standards) and Market Rules 5600 (Corporate Governance Requirements), respectively, or somewhere else, which states that listed companies must ensure that information flow to board members should be sufficient to support understanding of the company's business and the critical issues the company faces and disclose how this be fulfilled.

\subsubsection{The Requirement That the Audit Committee Be Composed Entirely of Independent Directors Should Be Maintained}

The key responsibility of the audit committee is to ensure a firm's financial reporting quality. Empirical evidence has shown that audit committees composed entirely of independent directors were more likely to be associated with a good quality of financial reporting than those without $100 \%$ independence. Such strong empirical support suggests that the current requirement regarding complete audit committee independence is justified. Although the findings are based on the observation of pre-SOX samples, the positive results regarding independent directors' monitoring effect seem unlikely to be reduced, because the monitoring environment prepared for independent directors has been largely enhanced in the post-SOX period.

However, as noted earlier, a positive correlation between complete audit committee independence and the quality of financial reporting allows two possible explanations. One is that having an audit committee composed entirely of independent members leads to a higher quality of financial reporting. The other is that firms with a higher financial reporting quality choose to have a completely independent audit committee. If the latter interpretation explains the study results, the mandate of audit committee independence may be misplaced. Further research may be needed to clarify the real effect of audit committee independence.

\footnotetext{
${ }^{2183}$ There two studies involving the cost of acquiring corporate information. Duchin, Matsusaka and Ozbas (2010) examined nearly 2,900 firms from 1996 to 2005, while Ravina and Sapienza (2010) analyzed almost 15,000 firms from 1986 to 2003. Duchin, Matsusaka \& Ozbas, supra note 429 at 200-01; Ravina \& Sapienza, supra note 1710 at 966-67.
} 
It is worth mentioning that requiring proof of causation in regression analysis to evaluate the correctness of a particular public policy is a very high standard that most public policies might not meet. There is no obvious reason that a firm would pursue a completely independent audit committee when the firm has enjoyed a high quality of financial reporting. It is likely that firms would put in place completely independent audit committees with a view to achieving better financial reporting. Consequently, unless further research finds an unexpected causation between the audit committee independence and the quality of financial reporting, the current requirement of complete audit committee independence should be maintained.

\subsubsection{The Definition of a Financial Expert Should Be Tightened}

The current definition of a financial expert seems too broad. The goal of having a financial expert on the audit committee is to provide enhanced financial reporting oversight and additional protection for investors. However, a strong connection has not been found between committee members with some types of expertise meeting the current definition of financial experts and the indicators representing better quality of financial reporting. ${ }^{2184}$ On the contrary, existing empirical studies demonstrated that the improvements in the financial reporting quality were mainly attributed to having audit committee members with accounting expertise, rather than financial analysis or supervisory expertise. ${ }^{2185}$ It appears that the current definition of financial experts adopted by the SEC is not sufficient to achieve the goal of improving financial reporting. With a view to protecting investors and ensuring the quality of financial reporting, the definition of financial experts should be narrowed to only individuals who have accounting expertise, instead of other two types of expertise. Although these findings are based on the observation of pre-SOX samples, the positive results of independent directors' accounting expertise are likely to be applicable in the post-SOX period, because nothing in the SOX reforms would likely impair the significance of this type of expertise that are beneficial to their firms.

From my observation, the pool of available candidates having accounting expertise in the United States may not be as small as listed companies have perceived. So far, there are

${ }^{2184}$ See section 5.2.3.1.2.3 of this thesis.

2185 Ibid. 
approximately 2,800 and 3,400 corporations listed on the NYSE and NASDAQ, respectively. ${ }^{2186}$ Assuming that each of them needs one candidate with accounting expertise to serve on the audit committee, corporations listed on the two stock exchanges need at least 6,200 financial experts to fulfill the requirement. According to the American Institute of Certified Public Accountants' (AICPA) 2010-2011 annual report, AICPA has more than 330,000 regular (voting) members ${ }^{2187}$ since 2002, and approximately $80 \%$ of them have had experience in public accounting, business or industry. ${ }^{2188}$ Deducting those who reside outside of the United States, the pool of available candidates is still obviously far beyond the need of the market. Therefore, requiring a listed corporation to nominate an individual with accounting expertise as an audit committee member seems not a severe or unreasonable request. The SEC should consider tightening the definition of a financial expert.

\subsubsection{The Requirement That the Compensation Committee Be Composed Entirely of Independent Directors May Need to Be Changed to Only a Recommendation and Supporting Measures May Also Be Needed}

Regulators in the United States may need to consider: (1) adopting the comply-or-explain approach in which a completely independent compensation committee is only a recommendation; and (2) adding supporting measures to make independent directors more effective on the compensation committee. The key mission of the compensation committee is to establish an executive compensation package that can ensure the quality of executives and align their interests with those of shareholders. However, empirical findings consistently show that firm performance, the level of executive compensation, and the sensitivity of CEO remuneration to

\footnotetext{
${ }^{2186}$ See New York Stock Exchange, Frequently Asked Questions, online: NYSE <http://www.nyse.com/content/faqs/1050241764950.html >; NASDAQ OMX, About Us, online: NASDAQ, <http://www.nasdaqomx.com/aboutus/>.

${ }^{2187}$ To qualify as an AICPA member, one has to meet one of the following criteria:

(1) hold a valid and current CPA license and have passed either the Uniform CPA exam or the International Qualification Examination (IQEX);

(2) held a CPA license in the past that was not revoked for disciplinary reasons and have passed either the Uniform CPA exam or the International Qualification Examination (IQEX);

(3) have completed the requirements for CPA licensure as defined by the Uniform Accountancy Act (UAA), but have never been licensed. See AICPA, membership, online: AICPA <http://www.aicpa.org/Membership/Join/Pages/RegularMember.aspx >.

${ }^{2188}$ AICPA, 2010-2011 Annual Report at 27, online: AICPA, <http://www.aicpa.org/About/AnnualReports/Pages/2010-2011AICPAAnnualReport.aspx $>$.
} 
firm performance were not affected by the degree of compensation committee independence, regardless of whether the studies were based on only pre-SOX samples or samples comparing the pre-SOX and post-SOX period. ${ }^{2189}$ It appears that the inability to establish appropriate compensation for executives may not be attributed to the level of compensation committee independence, but to other factors. Therefore, the requirement of a completely independent compensation committee may need to be adjusted.

As discussed in section 6.4.1.2.2, the comply-or-explain approach is likely to yield a high level of compliance at lower cost than the mandatory approach. This is mainly because: (1) listed companies can choose not to comply with the measure that are excessively costly for them (and only need to disclose the reasons of not doing so); (2) regulators bear only the costs of ensuring whether the disclosure is accurate and complete, instead of the costs of examining whether every firm follows the mandatory rules; and (3) listed companies have strong incentives to comply with voluntary guidelines that investors deem desirable. As a result, the a comply-orexplain approach in which a completely independent compensation committee is only a recommendation may be a better alternative when empirical evidence does not support the efficacy of a completely independent compensation committee. The NYSE and NASDAQ may need to consider changing their Listed Company Manual 303A.05(a) and Market Rules 5605(d)(1)(B) and 5605(d)(2)(B) requiring a completely independent compensation committee, respectively, to only a recommendation. Disclosure would be required for firms not following the recommendation.

In addition, as analyzed previously, the gap between the expectation of independent directors on the compensation committee and what the empirical evidence shows may come from: (1) the compensation package (mainly stock options) for independent directors that may compromise independent directors' ability to constrain the CEO's compensation; (2) the social ties between CEO and independent directors; (3) firms that do not nominate individuals with the "right" characteristics to serve as independent directors; or/and (4) the poor quality of governance environment provided by the firms they serve. Regulators may also need to adopt measures to overcome the possible deficiencies.

As mentioned in section 3.2.2 and section 5.1.6.2.2.1, stock-option compensation for independent directors may have negative impact on their monitoring integrity. Bebchuk,

\footnotetext{
${ }^{2189}$ See section 5.2.3.2 of this thesis.
} 
Grinstein and Peyer (2010) and Byard and Li (2003) found that independent directors were less likely to constrain the CEO's total compensation or reduce the CEO's timing opportunism ${ }^{2190}$, respectively, when they also received lucky option grants ${ }^{2191} \cdot{ }^{2192}$ US regulators may consider placing restrictions on the sale of stock until after the director's departure from the compensation committee with a view to reducing the negative impact of stock compensation on the effectiveness of independent directors. ${ }^{2193}$

As for the tactics to deal with the social ties between the CEO and independent directors, this thesis has made a proposal in section 6.4.1.1 that current criteria to determine whether a director is independent should be tightened, regardless of whether a director serves on the committee or the board only. With respect to the strategies to solve the problems of nominating the right type of independent directors and governance environment, as proposed in section 6.4.1.2, regulators should encourage firms to recruit individuals who hold less than three outside directorships or/and own a higher proportion of shareholdings, and to foster an environment in which independent directors are well informed, with a view to making independent directors more effective.

\subsubsection{The Requirement That the Nominating Committee Be Composed Entirely of Independent Directors May Need to Be Changed to Only a Recommendation}

Regulators in the United States may need to consider: (1) adopting the comply-or-explain approach in which a completely independent nominating committee is only a recommendation; and (2) adding supporting measures to make independent directors more effective on the nominating committee. The mandate of the nominating committee is to search for qualified director candidates consistent with the board's criteria and nominate independent directors who are truly independent of management. However, most existing empirical evidence shows that the level of nominating committee independence was not related to firm performance, ${ }^{2194}$ while

\footnotetext{
${ }^{2190}$ Timing opportunism refers to the opportunistic practice where CEOs increase the value of their option grants by lowering their firms' stock prices on days when they receive option grants. Byard \& Li, supra note 514 at 1-2, 29.

${ }^{2191}$ Lucky grants in this study are defined as grants for which the exercise price is based on the lowest trading price of securities during a month. Bebchuk, Grinstein and Peyer, supra note 511 at 2364, 2368.

2192 Ibid at 2365, 2387, 2399; Byard \& Li, supra note 514 at 2.

${ }^{2193}$ Brown, supra note 416 at 1123, 1125; Cosenza, supra note 391 at 26.

${ }^{2194}$ See Brown \& Caylor 2006, supra note 1027 at 419 Table 3, 421 Table 4, 422 Table 5; Brown \& Caylor 2009, supra note 1032 at 130, 141-42; Hayes, Mehran \& Schaefer, supra note at 19, 42-43 Table 13 Panel B.
} 
one study even reported that a nominating committee without management participation was connected with poorer firm performance. ${ }^{2195}$ Altogether, it seems that the degree of nominating committee independence may not be the critical factor that determines the effectiveness of the nominating committee.

As discussed in section 6.4.1.2.2, the comply-or-explain approach is likely to yield a high level of compliance at lower cost than the mandatory approach. When empirical evidence does not clearly support the efficacy of a completely independent nominating committee, it may be a better alternative to adopt a comply-or-explain approach in which a completely independent nominating committee is only a recommendation due to the lower costs. Consequently, the NYSE and NASDAQ may need to consider changing their Listed Company Manual 303A.04(a) and Market Rules 5605(e)(1)(B) requiring a completely independent nominating committee, respectively, to only a recommendation. Disclosure would be required for firms not following the recommendation.

The lack of empirical support for the nominating committee independence may be attributed to four possible reasons that: (1) firm performance may not be an ideal indicator to measure the efficacy of nominating committees; (2) there are the social ties between CEO and independent directors; (3) firms do not nominate individuals with the "right" characteristics to serve as independent directors; or/and (4) firms do not cultivate a high quality governance environment for independent directors.

Regulators or the academic community may need to conduct further research using innovative indicators to explore the real impact of independent directors on director nominations. In addition, as proposed in section 6.4.1.1, current criteria to determine whether a director is independent should be tightened in order to reduce the negative impact of social connection between the $\mathrm{CEO}$ and independent directors. As well, regulators should encourage firms to recruit individuals who hold less than three outside board seats or/and own a certain proportion of shareholdings, and to foster an environment in which independent directors are well informed, with a view to making independent directors more effective, as proposed in section 6.4.1.2.

${ }^{2195}$ Callahan, Millar \& Schulman, supra note 1538 at 178, 180. 


\subsubsection{Courts May Need to Examine Relevant Factors That May Impair Independent Directors' Monitoring Effect When Reviewing Decisions Made by Independent Directors}

As discussed in section 4.1.1, US state courts defer to decisions made by independent directors with respect to situations involving risks of managerial abuse, including conflict-ofinterest transactions, takeover bid cases, and decisions about whether to make a claim on behalf of the corporation when a shareholder seeks permission to bring a derivative action. Empirical research has identified some factors that may influence independent directors' monitoring effect, such as social ties, the existence of a controlling shareholder, share ownership, and outside directorships. However, not every factor identified is relevant or known to a court and can be subject to judicial review.

This thesis suggests that courts should consider looking at factors (identified by empirical research) that may only impair, ${ }^{2196}$ rather than enhance, independent directors' monitoring effect, especially those that have been investigated by some courts, when they review decisions made by independent directors . For example, social ties, including friendship, sponsorship and professional connection, between independent directors and the CEO have been identified that they may impair the efficacy of independent directors to hold executive accountable (as shown by awarding greater CEO compensation, experiencing poorer financial performance and a lower quality of financial reporting). ${ }^{2197}$ For example, when a court considers a special litigation committee's decision to refuse to pursue a suit, it may need to look at whether there are social ties between the committee members (usually independent directors) and management (who are alleged to have engaged in wrong doing) that would impair committee members to exercise their objective and unbiased judgment. Two Delaware lower court decisions have indicated that nonfinancial ties and friendship could impede director independence and cause bias that would preclude a director from objectively evaluating corporate decisions. ${ }^{2198}$ Lawyers should be

\footnotetext{
${ }^{2196}$ For example, the existence of social ties between independent directors and executives only impair, rather than enhance, the monitoring effect of independent directors shown by having poorer firm performance and a lower quality of financial reporting. However, independent directors having a certain proportion of the company's shareholdings may enhance, rather than lower, the company's firm performance. As a result, the former-social ties is a factor that may impair independent directors' monitoring effect, but the latter-independent directors' share ownership is not (because it is an enhancer of firm performance).

${ }^{2197}$ Further details were discussed in section 3.2.1.3.

${ }^{2198}$ Further details were discussed in section 3.2.1.2.
} 
encouraged to make submissions to a court regarding factors identified by empirical research as relevant and needing to be examined.

\subsubsection{In Canada}

As I noted earlier, Canadian Securities Administrators (CSA) have relied on five measures regarding independent directors as a check on managerial abuses, including (1) a majority of independent directors on the board; (2) three key monitoring committees-the audit, compensation and nominating committees-composed entirely of independent directors; (3) all audit committee member having financial literacy; (4) designating an independent board chair or a lead director and holding executive sessions with attendance of only independent directors; and (5) criteria to determine whether a director is independent. However, there exist two major differences between the regulations of the two countries. First, the CSA does not require any audit committee member to have financial expertise. Second, the above measures are implemented through a comply-or-explain approach in Canada, except for measures regarding the audit committee and how to determine whether a director is independent, which are mandatory. This approach, compared to the United States' mandatory compliance approach, provides more flexibility for Canadian listed corporations to tailor their board and committee independence according to their specific needs. So far, there is no Canadian empirical evidence regarding the efficacy of Canadian independent directors on the nominating committee, in holding executive sessions, when being designated as a board chair or a lead director, or the appropriateness of the criteria to determine whether a director is independent. Nevertheless, existing empirical findings seem to suggest that some of the remaining CSA's requirements and recommendations may not be appropriate. The recommended adjustments are discussed in the following four sections. In addition, Canadian courts may need to consider factors that may impair independent directors' monitoring effect (identified by empirical research) when reviewing recommendations made by a special committee composed of independent directors.

\subsubsection{The Recommendation of Having a Majority of Independent Directors on the Board Should Be Maintained}


The recommendation of an independent board may seem inappropriate because empirical evidence show that firms with a higher level of board independence did not have better firm performance and, sometimes, might even perform worse. ${ }^{2199}$ However, as noted earlier, some studies did not take the problems of endogeneity or possible lagged effects into account, or used Global and Mail ROB Board Composition Scores to represent the level of board independence, and most studies did not differentiate the effect of independent directors from that of outside directors, ${ }^{2200}$ so their findings may not reflect the real impact of board independence on firm performance. Nevertheless, Panasian, Prevost and Bhabra (2008), having controlled for the problems of endogeneity, possible lagged effects and the definition of independent directors, observed that poorly performing firms benefited (i.e. experienced enhanced firm performance) from an increase of board independence (from below 50\% to over 50\%), although they still found that firms with a majority of independent directors on the board, in general, did not perform better than those without the same board composition. ${ }^{2201}$

In addition to firm performance, the relationship between board independence and discrete board tasks, such as responding to takeover bids, replacing incompetent CEOs, and preventing financial fraud, is often used to measure the efficacy of independent directors. Existing Canadian studies, so far, have seldom explored such types of relationships. It may be inappropriate to evaluate the efficacy of independent directors by only looking at the evidence between board independence and firm performance. Moreover, the presence of controlling shareholders may also mitigate the effectiveness of independent directors, as empirical evidence has demonstrated. Taken together, existing empirical evidence does not provide a clear picture regarding whether firms with a majority of independent directors on the board are really effective in protecting shareholder interests. Further research is needed to explore the correlation.

In terms of firm performance, although not every firm benefited from having a majority of independent directors on the board, as long as some (e.g. poorly performing) firms could benefit (i.e. experience enhanced firm performance) from an increase of board independence (from below $50 \%$ to over 50\%), the recommendation of an independent board is justified. Findings of Panasian, Prevost and Bhabra (2008) have demonstrated such results. Firms that do not experience enhanced firm performance from having an independent board may choose not to

\footnotetext{
${ }^{2199}$ See section 5.3.1 of this thesis.

2200 See section 5.2.1.6.

${ }^{2201}$ Panasian, Prevost \& Bhabra, supra note 1805 at 142, 154.
} 
comply with the recommendation but to provide their explanations. This is the main advantage of adopting the comply-or-explain approach: benefits of having an independent board can be realized (for compliant firms) and, simultaneously, listed corporations have more flexibility to tailor their board independence according to their specific needs. From this perspective, the current recommendation of having a majority of independent directors is not clearly inappropriate and should be maintained.

As analyzed in the US part, the ineffectiveness of the US independent directors may result from: (1) social ties between CEO and independent directors; (2) firms that do not nominate individuals with the "right" characteristics to serve as independent directors; or/and (3) the poor quality of governance environment provided by the firms they serve. Although existing Canadian studies have not explored these issues, the effectiveness of Canadian independent directors may also be affected by these factors. Further research is needed to understand the impact of these factors.

\subsubsection{The CSA Should Require or Recommend That at Least One Member of the Audit Committee Be a Financial Expert}

Unlike the United States, current Canadian regulations only require that all audit committee members must be financially literate, but do not require or recommend that at least one of the audit committee members must have financial expertise. However, existing Canadian empirical studies found that directors with financial expertise, either on the board or on the audit committee, were more likely to enhance the quality of financial reporting, ${ }^{2202}$ but directors with only financial literacy have no such effect. ${ }^{2203}$ Two similar studies also reported similar results. Erickson et al. (2005) reported that the presence of outside directors who are officers of financial institutions on the board was more likely to reduce some loss of firm value from the existence of dual class shares, ${ }^{2204}$ while Park and Shin (2004) reported that the boards with outside directors from financial institutions were associated with a lower level of earnings management. ${ }^{2205}$ It

\footnotetext{
${ }^{2202}$ Scarbrough, Rama \& Raghunandan, supra note 1903 at 54; Smaili \& Labelle, supra note 1886 at 19, 33 Table 6; Niu, supra note 1890 at 312-13, 315, 322.

${ }^{2203}$ Smaili \& Labelle, supra note 1886 at 19, 33 Table 6.

${ }^{2204}$ Erickson et al, supra note 676 at 408.

${ }^{2205}$ Park \& Shin, supra note 1892 at 447, 455.
} 
appears that only audit committee members with financial expertise, instead of financial literacy, are able to financially hold management accountable.

However, one remaining question is which type of expertise should be considered as financial expertise. US empirical evidence has demonstrated that an audit committee member having only accounting expertise was strongly associated with a higher quality of financial reporting. The effect was weak or non-existent when an audit committee member had only financial analysis or supervisory expertise. In contrast, the definition of financial expertise is inconsistent between Canadian studies. One study defined financial expertise as a director who has a professional designation in accounting or finance, or a specialized university diploma in accounting or in finance, ${ }^{2206}$ which is roughly equivalent to "accounting expertise" in the US context. The other two studies refer to a director who is an officer from a financial intermediary, such as a bank, an insurance company or mutual fund. ${ }^{2207}$ Further research is needed to figure out which type of financial expertise for audit committee members can really enhance a firm's financial reporting quality.

Altogether, in order to ensure the quality of financial reporting, Canadian securities regulators may need to consider following the US-requiring at least one audit committee member with financial expertise - or encouraging listed firms to nominate a financial expert to serve as an audit committee member. In other words, Canadian securities regulators may need to supplement the current section 3.1 (4) of the NI 52-110 "every audit committee member must be financially literate" to add that "and at least one of them must have financial expertise" or to include the recommendation of at least one of the audit committee members should have financial expertise into the NP 58-201 Corporate Governance Guidelines-the "comply-orexplain" regime in combination with a definition of "financial expertise" in the relevant context.

\subsubsection{The Requirement of Having an Audit Committee Composed Entirely of Independent Directors May Not Need to Be Changed, But Further Research Is Needed}

As analyzed in sections 5.2.3 and 6.1.2.2, existing Canadian empirical evidence did not show a strong connection between independent directors on the audit committee and the quality

\footnotetext{
${ }^{2206}$ Smaili \& Labelle, supra note 1886 at 10.

${ }^{2207}$ Erickson et al, supra note 676 at 408; Park \&Shin, supra note 1892 at 447.
} 
of financial reporting. One study found that audit committees with $100 \%$ of outside directors were more likely to be engaged in internal auditing activities (signifying a better quality of financial reporting), ${ }^{2208}$ while the other observed that the proportion of independent directors on the audit committee had no connection with the occurrence of accounting irregularities (representing a lower quality of financial reporting). ${ }^{209}$ Consequently, the requirement of having an audit committee composed entirely of independent directors is only supported by empirical findings in some circumstances.

It is worth noting that the latter study only reported no connection between the proportion of independent directors on the audit committee and the occurrence of accounting irregularities, but did not examine the impact of a fully independent audit committee on the occurrence of accounting irregularities. Since the US empirical evidence has shown that the impact of independent directors on the quality of financial reporting may not be fully realized unless all audit committee members are independent, the findings of the latter study may not reflect the real impact of a fully independent audit committee on the occurrence of accounting irregularities. Further research is needed to confirm the relationship between a completely independent audit committee and the quality of financial reporting in Canadian firms.

In addition, the lack of strong empirical support for the requirement may be because financial expertise was not mandatory for any audit committee member. As I mentioned in the last section, current Canadian regulations, unlike the US rules, only require that all audit committee members must be financially literate, but do not require or recommend that at least one of the audit committee members have financial expertise. Canadian audit committee members, compared to their US counterparts, may not have sufficient financial knowledge and experience to detect financial wrongdoing or enhance the financial reporting quality. Had at least one of the audit committee members had financial expertise, the results of the effect of the audit committee might have been different.

Although existing empirical evidence does not strongly support the requirement of having an audit committee composed entirely of independent directors in Canada, the requirement has been supported by the majority view in the theoretical literature and has been endorsed by US

\footnotetext{
${ }^{2208}$ Scarbrough, Rama \& Raghunandan, supra note 1903 at 54.

${ }^{2209}$ Smaili \& Labelle, supra note 1886 at 19,33 Table 6.
} 
empirical findings. Canadian securities regulators should maintain the current rule in the absence of any counter-evidence, but further research confirming this approach would be helpful.

\subsubsection{The Recommendation of Having a Compensation Committee Composed Entirely of Independent Directors May Not Need to Be Changed, But Further Research Is Needed}

The main task of the compensation committee is to design an executive remuneration package that can well align interests of executives with those of shareholders. However, the only study exploring this issue reported pessimistic results - compensation committees with a higher proportion of independent directors were more likely to reward higher remuneration to CEOs. Similar research also reveals that the proportion of independent or outside directors on the board had no significant impact on restraining the level of CEO compensation or tying executive pay to firm performance. ${ }^{2210}$ The recommendation of having a compensation committee composed entirely of independent directors seems not to be supported by empirical evidence.

It is worth noting that the ineffectiveness of independent directors on the compensation committee may be because the members of the compensation committee are not all independent. US empirical evidence has found that the effect of independent directors on the audit committee may not be entirely realized unless all the audit committee members are independent. The effectiveness of independent directors on the compensation committee may also depend on $100 \%$ independence. Since the impact of a fully independent compensation committee on the level of CEO compensation or on the sensitivity of executive pay to firm performance has not been examined, the current findings may not represent the real effect of the CSA's recommendation. Further research is needed to explore the connection between a fully independent compensation committee and the level of CEO compensation, as well as the sensitivity of executive pay to firm performance.

Nevertheless, currently, a compensation committee composed entirely of independent directors is only a recommendation. Firms are allowed to adjust their proportion of independent directors on the compensation committee, so long as they provide an explanation. Although firms still bear the costs of explanation for non-compliance, these costs are relatively low in comparison with those associated with mandatory requirements. Because the recommendation

${ }^{2210}$ Jog \& Dutta, supra note 1837 at 14-15, 32 Table 8, 33 Table 9; Sapp, supra note 1918 at 740. 
has been supported by the majority view in the theoretical literature, the Canadian securities regulators should maintain the current recommendation, unless and until empirical studies report otherwise.

\subsubsection{Ontario Courts May Need to Examine Relevant Factors That May Impair Independent Directors' Monitoring Effect When Reviewing Recommendations Made by Independent Directors}

As discussed in section 4.2.3, Ontario courts defer to recommendations made by a special committee composed of independent directors in cases involving conflicts of interest and oppression remedy. However, the number of cases relying on independent directors in Canada is relatively few. Most significantly, only few factors that may influence the efficacy of independent directors in Canada have been identified in Canadian research.

As noted previously, not every factor identified will be relevant or known to a court and can be subject to judicial review. This thesis, following the approach adopted in section 6.4.1.7, suggests that Ontario courts should consider looking at factors (identified by empirical research) that may impair, rather than enhance, independent directors' monitoring effect. For example, empirical research has indicated that the presence of controlling shareholders may compromise independent directors' monitoring effects, resulting the adoption of fewer other governance mechanisms to assisting them to monitor management. ${ }^{2211}$ When an Ontario court reviews a special committee's recommendation in an oppression remedy case, it may need to look at whether the controlling shareholder took advantage of his/her power to pursue his/her interests at the expense of minority shareholders, if there is a controlling shareholder. This approach was illustrated in Brant Investments Ltd. v. KeepRite Inc., where an Ontario court considered the impact of a major shareholder on the efficacy of independent directors when reviewing the appropriateness of a recommendation made by the KeepRite's special committee (composed of independent directors) regarding acquiring assets from some subsidiaries of its major shareholder. $^{2212}$ Lawyers in future cases should similarly seek to get the court to consider that factors identified by empirical research are relevant and needs to be examined.

2211 Anand, Milne \& Purda, supra note 7 at 810, 834-35, 837.

${ }^{2212}$ KeepRite, supra note 995 at 58,63, 74, 106. See also text in section 4.2.3. 


\section{Chapter Seven}

\section{Conclusion}

Whether independent directors are really effective corporate monitors in North America and whether it is a good policy to rely on independent directors to hold management accountable have been major concerns in corporate governance for several decades. This thesis, after reviewing more than 160 empirical studies in the field of management science and financial economics, concludes that the effectiveness of independent directors in management oversight varies with the types of their tasks, differs from firm to firm, and depends on the characteristics of independent directors, the firm's governance environment, as well as the success of other governance mechanisms. With a view to making independent directors more effective, regulators in the United States and Canada need to adjust some current governance rules and adopt supporting measures in light of these empirical findings. Courts in both countries may need to consider factors that may impair independent directors' monitoring effect (identified by empirical research) when reviewing decisions or recommendations made by independent directors. As well, further research is needed to understand better how to improve the efficacy of independent directors.

\subsection{What Did Empirical Evidence Say About the Effectiveness of Independent Directors}

Generally, independent directors in North America are not as effective in monitoring management as conventional wisdom expected. Boards with a majority of independent directors, in some circumstances, enhance firm performance (in the post-SOX period) and fulfill certain board tasks effectively in the United States, but have not been shown to be related to improved firm performance in Canada. Audit committees composed entirely of independent directors appear to be effective in ensuring the quality of financial reporting in the United States, but this effect has not been fully demonstrated in Canada. Compensation committees comprised fully of independent directors neither constrain the level of executive compensation nor tie CEO pay to firm performance, regardless of whether it is the United States or Canada that is examined. In addition, audit committee members in the United States having accounting expertise, rather than 
financial analysis or supervisory expertise, are associated with a higher quality of financial reporting, while audit committee members in Canada having financial expertise, instead of financial literacy, are associated with similar results. Most US results were based on the observation of pre-SOX samples, except for the findings regarding firm performance and compensation committee. Collectively, except for a completely independent audit committee in the US, requirements or recommendations regarding independent directors in both countries did not have fully, or even have no, empirical support. Independent directors seem not to play the kind of effective role as corporate monitors that North America laws, policy and courts rely on them to perform. Nevertheless, research to date suggests that independent directors in the United States perform better than those in Canada. Regulators in both countries may need to take some steps to make independent directors more effective.

\subsection{What Regulators Can Do to Make Independent Directors More Effective}

Existing US empirical evidence has demonstrated several causes that may jointly or separately affect the effectiveness of independent directors, including: (1) the presence of social connections between the CEO and independent directors, (2) lack of appropriate and sufficient incentives, (3) neglecting the importance of particular characteristics of independent directors, (4) poor governance environments, including the high costs of acquiring corporate information, (5) diminishing returns of having independent directors on the board, (6) the success of other corporate governance mechanisms, (7) the need for board independence varying across firms, and (8) methodological problems of research. The first four causes seem to be applicable to all firms, while the fifth to the seventh causes seem to be related to some firms that have less need for board independence. US regulators may need to take the following three steps in response to these problems.

First, US regulators may need to modify current rules (ex. NYSE Manual §303A.02(b), NASDAQ Rule $\$ 5605(a)(2))$ to prevent a director who has social connections with the CEO from being considered independent. ${ }^{2213}$ In addition, the SEC may need to consider narrowing the

\footnotetext{
${ }^{2213}$ The NYSE and NASDAQ may need to modify their Listed Company Manual 303A.02(b) and Market Rules 5605(a)(2), respectively, to include a preclusion such that certain social connections between a director and the CEO may eliminate the director from being considered independent.
} 
qualification of a financial expert to an individual who has accounting expertise. Existing empirical evidence has provided solid foundation to support for such revisions.

Second, US regulators may consider adopting measures: (1) to encourage firms to recruit individuals who hold less than three outside board seats, or/and who own a certain proportion of the company's shares to serve as independent directors; ${ }^{2214}$ and (2) to foster a governance environment in which independent directors are well informed and their interests can better align with their shareholders, ${ }^{2215}$ because empirical findings have demonstrated that in these circumstances independent directors were more likely to be associated with better firm performance.

Third, US regulators may consider adopting the comply-or-explain approach in which an independent board, a completely independent compensation committee, and a completely independent nominating committee are only recommendations accompanied by a requirement to explain any non-compliance, ${ }^{2216}$ because: (1) empirical evidence did not (or not fully) support these three current requirements; (2) the need for board independence varies with firms and industries, and the $50 \%$ threshold of board independence may not be optimal for all firms.

Compared to US regulators, Canadian regulations may need fewer modifications, because most of their measures are under the comply-or-explain regime, although most empirical evidence did not strongly support these rules. Another reason is that many CSA measures have not benefited from empirical research.

Nevertheless, based on studies done to date, regulators in Canada may need to require or recommend that at least one audit committee member has financial expertise, instead of only all

\footnotetext{
${ }^{2214}$ The NYSE and NASDAQ may consider adding a new clause under their Listed Company Manual 303A.00 (Corporate Governance Standards) and Market Rules 5600 (Corporate Governance Requirements), respectively, or somewhere else, which states that, in making director nomination, the board or its nominating committee must consider whether a nominee: (1) has a certain shareholdings of the company; and (2) holds more than two outside directorships.

${ }^{2215}$ The NYSE and NASDAQ may consider adding a new clause under their Listed Company Manual 303A.00 (Corporate Governance Standards) and Market Rules 5600 (Corporate Governance Requirements), respectively, or somewhere else, which states that listed companies must ensure that information flow to board members should be sufficient to support the understanding of the company's business and the critical issues the company faces and disclose how this be fulfilled.

${ }^{2216}$ The NYSE and NASDAQ may need to consider: (1) modifying their Listed Company Manual 303A.01 and Market Rules 5605(b)(1), respectively, regarding the requirement of an independent board; (2) modifying their Listed Company Manual 303A.05(a) and Market Rules 5605(d)(1)(B) and 5605(d)(2)(B), respectively, regarding a completely independent compensation committee; and (3) modifying their Listed Company Manual 303A.04(a) and Market Rules 5605(e)(1)(B), respectively, regarding a completely independent nominating committee. All these three measures are suggested to change from a currently mandatory requirement to only a recommendation. In addition, disclosure is required if listed corporations choose not to follow these recommendations.
} 
audit committee members having financial literacy, ${ }^{2217}$ since empirical evidence has shown that audit committee members who have only financial expertise were associated with a higher quality of financial reporting, but having financial literacy was not.

\subsection{Where Further Research Is Needed in the United States and Canada}

As analyzed previously, existing empirical findings do not provide complete answers regarding whether independent directors are really effective, because some findings were flawed or inconsistent, and some areas have not been studied. Researchers may conduct further studies to understand the real effect of independent directors.

In the United States, the requirement of holding executive sessions has not been examined and the requirement to have a nominating committee composed entirely of independent directors, so far, has no proper indicators to measure its validity. In addition, the causation between independent directors in the audit committee and the quality of financial reporting is not clear. Most importantly, the impact of most SOX-related reforms has not been examined. These issues need further research to produce clear results.

In comparison with the United States, more studies are needed in relation to the role of Canadian independent directors. First, the effect of three current CSA recommendations has not been examined, including a nominating committee composed entirely of independent directors, holding executive sessions, and designating an independent board chair or a lead director. Second, whether all members of the audit and compensation committees should be independent in order to realize the monitoring effect of the two committees needs to be confirmed. Third, there is no study exploring whether a director who has social connections with the CEO should not be considered independent, which type of financial expertise on the audit committee is more beneficial, or on the relationship between board independence and the specific board tasks. Fourth, more research is needed to understand the impact of controlling shareholders on the efficacy of independent directors. Finally, it would be helpful to have some US studies done in

\footnotetext{
${ }^{2217}$ Canadian securities regulators may need to supplement the current section 3.1 (4) of the NI 52-110 as "every audit committee member must be financially literate and at least one of them must have financial expertise" or include the recommendation of "at least one of the audit committee members should have financial expertise" into the NP 58-201 Corporate Governance Guidelines - the "comply-or-explain" regime, in combination with a definition of "financial expertise" in the relevant context.
} 
Canada, including: (1) whether an independent director who holds less than three outside board seats is more beneficial; (2) whether an independent director who owns a certain proportion of the company's shares is better for the company; (3) whether the costs of acquiring a company's information affect their independent directors' efficacy. All these issues need further research to confirm their impact on the effectiveness of independent directors. Until more such work is done, our understanding of the real role of independent directors will remain fragmentary and our laws and policies that rely on the monitoring role of independent directors will be based on contested theory rather than hard evidence. 


\section{Appendix 1}

\section{Summary of US Empirical Studies Regarding the Relationship between Board Independence and Firm Performance}

Table A: Studies Reporting a Positive Relationship between Board Independence and Firm Performance

\begin{tabular}{|c|c|c|c|c|}
\hline Studies & Sample & $\begin{array}{l}\text { Measure of Board } \\
\text { Independence }\end{array}$ & $\begin{array}{l}\text { Measure of } \\
\text { Firm } \\
\text { Performance }\end{array}$ & Findings \\
\hline $\begin{array}{l}\text { Baysinger \& } \\
\text { Butler (1985) }\end{array}$ & $\begin{array}{l}266 \text { major US corporations } \\
\text { listed in Forbes during the } \\
1970-80 \text { period }\end{array}$ & $\begin{array}{l}\text { Proportion of } \\
\text { independent directors } \\
\text { on the board }\end{array}$ & ROE & $\begin{array}{l}\text { Firms with a higher proportion of independent } \\
\text { directors in the early } 1970 \text { s enjoyed better ROE in } \\
\text { the late } 1970 \text { s }\end{array}$ \\
\hline $\begin{array}{l}\text { Schellenger, } \\
\text { Wood \& } \\
\text { Tashakori } \\
(1989)\end{array}$ & $\begin{array}{l}526 \text { randomly selected firms } \\
\text { listed on both the Compustat } \\
\text { Industrial tape and CRSP } \\
\text { daily price files in } 1986\end{array}$ & $\begin{array}{l}\text { Proportion of outside } \\
\text { directors on the board }\end{array}$ & $\begin{array}{l}\text { Market } \\
\text { returns, } \\
\text { ROA, ROE, } \\
\& \text { RET }\end{array}$ & $\begin{array}{l}\text { The proportion of outside directors had a significant } \\
\text { and positive relationship with current market } \\
\text { returns and ROA, but had no association with ROE } \\
\text { and RET. }\end{array}$ \\
\hline $\begin{array}{l}\text { Rosenstein \& } \\
\text { Wyatt (1990) }\end{array}$ & $\begin{array}{l}1251 \text { announcements of an } \\
\text { independent director } \\
\text { appointment for firms listed } \\
\text { on the NYSE or the AMEX } \\
\text { from } 1981 \text { to } 1985\end{array}$ & $\begin{array}{l}\text { Announcement of the } \\
\text { appointment of an } \\
\text { additional independent } \\
\text { director }\end{array}$ & $\begin{array}{l}\text { abnormal } \\
\text { returns for } \\
\text { shareholders }\end{array}$ & $\begin{array}{l}\text { Abnormal returns for shareholders increased by } \\
0.2 \% \text { during the two-day announcement period. }\end{array}$ \\
\hline $\begin{array}{l}\text { Chhaochharia } \\
\text { \& Grinstein } \\
(2007)\end{array}$ & $\begin{array}{l}1,101 \text { S\&P } 1500 \text { firms } \\
\text { between November } 2001 \text { and } \\
\text { October } 2002\end{array}$ & $\begin{array}{l}\text { A majority of } \\
\text { independent directors } \\
\text { on the board }\end{array}$ & $\begin{array}{l}\text { Abnormal } \\
\text { returns for } \\
\text { shareholder }\end{array}$ & $\begin{array}{l}\text { The announcement of the new rules regarding board } \\
\text { independence was associated with higher abnormal } \\
\text { returns for large and medium-sized firm. }\end{array}$ \\
\hline $\begin{array}{l}\text { Bhagat \& } \\
\text { Bolton (2009) }\end{array}$ & $\begin{array}{l}\text { 1,500 large US firms from } \\
1998 \text { to } 2007\end{array}$ & $\begin{array}{l}\text { Proportion of } \\
\text { independent directors } \\
\text { on the board }\end{array}$ & $\begin{array}{l}\text { ROA } \\
\text { (current, next } \\
\text { one year and } \\
\text { next two } \\
\text { year), } \\
\text { Tobin's Q, } \\
\text { and stock } \\
\text { returns }\end{array}$ & $\begin{array}{l}\text { (1) Pre-SOX period (1998-2001): the proportion of } \\
\text { independent directors had significant and } \\
\text { negative relationship with current and future } \\
\text { ROA, but had no association with Tobin's Q } \\
\text { and stock returns. } \\
\text { (2) Post-SOX period (2003-2007): the proportion } \\
\text { of independent directors had a significant and } \\
\text { positive relationship with current and future } \\
\text { ROA, but had no association with Tobin's Q } \\
\text { and stock returns. }\end{array}$ \\
\hline
\end{tabular}




\section{Appendix 1 (continued)}

Table B: Studies Reporting a Negative Relationship between Board Independence and Firm Performance

\begin{tabular}{|c|c|c|c|c|}
\hline Studies & Sample & $\begin{array}{l}\text { Measure of Board } \\
\text { Independence }\end{array}$ & $\begin{array}{l}\text { Measure of } \\
\text { Firm } \\
\text { Performance }\end{array}$ & Findings \\
\hline $\begin{array}{l}\text { Hermalin \& } \\
\text { Weisbach } \\
(1988)\end{array}$ & $\begin{array}{l}142 \text { firms listed on NYSE } \\
\text { from } 1972 \text { to } 1983\end{array}$ & $\begin{array}{l}\text { Proportion of outside } \\
\text { directors on the board }\end{array}$ & $\begin{array}{l}\text { the change of } \\
\text { EBIT \& } \\
\text { stock returns }\end{array}$ & $\begin{array}{l}\text { Firms with performance in the bottom decile } \\
\text { increased their proportion of outside directors by } \\
\text { around } 1 \% \text { in the following year. }\end{array}$ \\
\hline $\begin{array}{l}\text { Agrawal \& } \\
\text { Knoeber } \\
(1996)\end{array}$ & $\begin{array}{l}383 \text { Forbes } 800 \text { firms in } \\
1987\end{array}$ & $\begin{array}{l}\text { Proportion of outside } \\
\text { directors on the board }\end{array}$ & Tobin's Q & $\begin{array}{l}\text { There was a significant and negative relationship } \\
\text { between the proportion of outside directors and } \\
\text { current Tobin's Q. }\end{array}$ \\
\hline $\begin{array}{l}\text { Bhagat \& } \\
\text { Black (1999) }\end{array}$ & $\begin{array}{l}928 \text { large US Firms from } \\
1985 \text { to } 1995\end{array}$ & $\begin{array}{l}\text { Board independence } \\
\text { (proportion of } \\
\text { independent directors } \\
\text { minus proportion of } \\
\text { inside directors) }\end{array}$ & $\begin{array}{l}\text { Tobin's Q, } \\
\text { ROA, ratio } \\
\text { of sales to } \\
\text { assets, } \\
\text { operating } \\
\text { margin \& } \\
\text { sales per } \\
\text { employee }\end{array}$ & $\begin{array}{l}\text { Firms with poor performance (Tobin's Q, ROA, } \\
\text { ratio of sales to assets \& sales per employee) from } \\
1988 \text { to } 1990 \text { added independent directors to their } \\
\text { boards in } 1991 \text {, but their performance was not } \\
\text { enhanced (ROA), or even became worse (Tobin's } \\
\text { Q, ratio of sales to assets \& sales per employee), } \\
\text { during the } 1991 \text { to } 1993 \text { period. }\end{array}$ \\
\hline $\begin{array}{l}\text { Bhagat \& } \\
\text { Black (2002) }\end{array}$ & $\begin{array}{l}928 \text { large US Firms from } \\
1985 \text { to } 1995\end{array}$ & $\begin{array}{l}\text { Board independence } \\
\text { (proportion of } \\
\text { Independent directors } \\
\text { minus proportion of } \\
\text { inside directors) }\end{array}$ & $\begin{array}{l}\text { Tobin's Q, } \\
\text { ROA \& ratio } \\
\text { of sales to } \\
\text { assets }\end{array}$ & $\begin{array}{l}\text { Firms with poor performance (Tobin's Q, ROA \& } \\
\text { ratio of sales to assets) from } 1988 \text { to } 1990 \text { added } \\
\text { independent directors to their boards in } 1991 \text {, but } \\
\text { their performance was not enhanced (ROA \& ratio } \\
\text { of sales to assets), or even became worse (Tobin's } \\
\text { Q), during the } 1991 \text { to } 1993 \text { period. }\end{array}$ \\
\hline $\begin{array}{l}\text { Bhagat \& } \\
\text { Bolton }(2008)\end{array}$ & $\begin{array}{l}\text { More than } 10,000 \text { firms } \\
\text { during the period } 1990 \text { to } \\
2004\end{array}$ & $\begin{array}{l}\text { Proportion of } \\
\text { independent directors } \\
\text { on the board }\end{array}$ & $\begin{array}{l}\text { ROA (in } \\
\text { current and } \\
\text { next year), } \\
\text { Tobin's Q \& } \\
\text { stock return }\end{array}$ & $\begin{array}{l}\text { There was a significant and negative relationship } \\
\text { between the proportion of independent directors } \\
\text { and current and future ROA \& Tobin's Q. }\end{array}$ \\
\hline
\end{tabular}




\section{Appendix 1 (continued)}

Table C: Studies Reporting No Relationship between Board Independence and Firm Performance

\section{Panel 1: Studies That Do Not Differentiate between Independent Directors from Outside Directors or Do Not Control for Possible Lagged Effect}

\begin{tabular}{|c|c|c|c|c|}
\hline Studies & Sample & $\begin{array}{l}\text { Measure of Board } \\
\text { Independence }\end{array}$ & $\begin{array}{c}\text { Measure of Firm } \\
\text { Performance }\end{array}$ & Findings \\
\hline $\begin{array}{l}\text { Chaganti, } \\
\text { Mahajan \& } \\
\text { Sharma (1985) }\end{array}$ & $\begin{array}{l}\text { Comparing } 21 \text { pairs of failed and } \\
\text { non-failed retailing firms between } \\
1970 \text { and } 1976\end{array}$ & $\begin{array}{l}\text { Proportion of outside } \\
\text { directors on the board }\end{array}$ & $\begin{array}{l}\text { Whether filing for } \\
\text { bankruptcy }\end{array}$ & $\begin{array}{l}\text { There was no significant difference in the } \\
\text { proportion of outside directors between firms } \\
\text { filing for bankruptcy and firms not filing for } \\
\text { bankruptcy, }\end{array}$ \\
\hline Fosberg (1989) & $\begin{array}{l}\text { Comparing around } 200 \text { firms with } \\
\text { and without a majority of outside } \\
\text { directors on their boards between } \\
1979 \text { and } 1983\end{array}$ & $\begin{array}{l}\text { Proportion of outside } \\
\text { directors on the board }\end{array}$ & $\begin{array}{l}\text { ROE, ratio of } \\
\text { sales to total } \\
\text { assets }\end{array}$ & $\begin{array}{l}\text { The proportion of outside directors was not } \\
\text { related to ROE, as well as ratio of sales to total } \\
\text { assets. }\end{array}$ \\
\hline $\begin{array}{l}\text { Hermalin \& } \\
\text { Weisbach } \\
(1991)\end{array}$ & $\begin{array}{l}142 \text { firms traded on the NYSE } \\
\text { during the period from } 1971 \text { to } \\
1983\end{array}$ & $\begin{array}{l}\text { Proportion of outside } \\
\text { directors on the board }\end{array}$ & Tobin's Q & $\begin{array}{l}\text { The proportion of outside directors was not } \\
\text { related to Tobin's Q. }\end{array}$ \\
\hline Mehran (1995) & $\begin{array}{l}153 \text { randomly selected } \\
\text { manufacturing firms during the } \\
\text { period from } 1973 \text { to } 1983\end{array}$ & $\begin{array}{l}\text { Proportion of } \\
\text { independent directors on } \\
\text { the board }\end{array}$ & $\begin{array}{l}\text { Tobin's Q \& } \\
\text { ROA }\end{array}$ & $\begin{array}{l}\text { The proportion of independent directors was not } \\
\text { associated with current ROA \& Tobin's Q. }\end{array}$ \\
\hline $\begin{array}{l}\text { Yermack } \\
(1996)\end{array}$ & $\begin{array}{l}452 \text { large industrial firms during } \\
1984 \text { to } 1991 \text { period }\end{array}$ & $\begin{array}{l}\text { Proportion of } \\
\text { independent directors on } \\
\text { the board }\end{array}$ & $\begin{array}{l}\text { ROA, ROS, ratio } \\
\text { of sale to assets \& } \\
\text { Tobin's Q }\end{array}$ & $\begin{array}{l}\text { The proportion of independent directors was not } \\
\text { associated with current ROA, ROS, and ratio of } \\
\text { sale to assets, but was significantly and negatively } \\
\text { related to current Tobin's Q. }\end{array}$ \\
\hline $\begin{array}{l}\text { Ferris, } \\
\text { Jagannathan \& } \\
\text { Pritchard } \\
(2003)\end{array}$ & $\begin{array}{l}\text { Around 3,000 firms between } 1995 \\
\text { and } 2002\end{array}$ & $\begin{array}{l}\text { Proportion of outside } \\
\text { directors on the board }\end{array}$ & $\begin{array}{l}\text { A firm's market- } \\
\text { to-book ratio }\end{array}$ & $\begin{array}{l}\text { There was no association between board } \\
\text { independence in } 1995 \text { and a firm's market-to- } \\
\text { book ratio in } 1997 .\end{array}$ \\
\hline $\begin{array}{l}\text { Fogel \& Geier } \\
(2007)\end{array}$ & $\begin{array}{l}254 \text { public firms in the year } 2000 \\
\text { across fifty separate industries and } \\
\text { different equity capitalizations }\end{array}$ & $\begin{array}{l}\text { Proportion of } \\
\text { independent directors on } \\
\text { the board }\end{array}$ & ROE & $\begin{array}{l}\text { Worse and best ROE firms in each of fifty } \\
\text { industries had about the same proportion of } \\
\text { independent directors on their boards. }\end{array}$ \\
\hline $\begin{array}{l}\text { Duchin, } \\
\text { Matsusaka \& } \\
\text { Ozbas (2010) }\end{array}$ & $\begin{array}{l}\text { Approximately } 2,900 \text { firms } \\
\text { covering the period from } 1996 \text { to } \\
2005\end{array}$ & $\begin{array}{l}\text { Proportion of } \\
\text { independent directors on } \\
\text { the board }\end{array}$ & $\begin{array}{l}\text { ROA, Tobin's Q } \\
\text { and stock returns }\end{array}$ & $\begin{array}{l}\text { An increase in the percentage of independent } \\
\text { directors did not significantly improve or harm } \\
\text { current ROA, Tobin's Q \& stock returns between } \\
2000 \text { and } 2005 \text {. }\end{array}$ \\
\hline
\end{tabular}




\section{Appendix 1 (continued)}

Table C (continued): Studies Reporting No Relationship between Board Independence and Firm Performance

Panel 2: Studies That Control the Problems of Endogeneity and Possible Lagged Effect

\begin{tabular}{|c|c|c|c|c|}
\hline Studies & Sample & $\begin{array}{l}\text { Measure of Board } \\
\text { Independence }\end{array}$ & $\begin{array}{l}\text { Measure of } \\
\text { Firm } \\
\text { Performance }\end{array}$ & Findings \\
\hline Brown \& Caylor (2006) & $\begin{array}{l}\text { 2,363 firms from } \\
\text { Institutional Shareholder } \\
\text { Services database in } 2003\end{array}$ & $\begin{array}{l}\text { Whether a board } \\
\text { composed of a } \\
\text { majority of } \\
\text { independent directors }\end{array}$ & Tobin's Q & $\begin{array}{l}\text { There was no association between boards } \\
\text { composed of a majority of independent } \\
\text { directors and current and next year's } \\
\text { Tobin's Q. }\end{array}$ \\
\hline Brown \& Caylor (2009) & $\begin{array}{l}\text { 2,363 firms from } \\
\text { Institutional Shareholder } \\
\text { Services database in } 2003\end{array}$ & $\begin{array}{l}\text { Whether a board } \\
\text { composed of a } \\
\text { majority of } \\
\text { independent directors }\end{array}$ & ROA \& ROE & $\begin{array}{l}\text { There was no association between boards } \\
\text { composed of a majority of independent } \\
\text { directors and current and next year's ROA } \\
\text { and ROE. }\end{array}$ \\
\hline
\end{tabular}

Panel 3: A Study Only Controls a Part of the Problem of Endogeneity

\begin{tabular}{|l|l|l|l|l|}
\hline \multicolumn{1}{|c|}{ Studies } & \multicolumn{1}{|c|}{ Sample } & $\begin{array}{c}\text { Measure of Board } \\
\text { Independence }\end{array}$ & $\begin{array}{c}\text { Measure of } \\
\text { Firm } \\
\text { Performance }\end{array}$ & $\begin{array}{l}\text { Findings } \\
\text { Klein (1998) }\end{array}$ \\
\hline $\begin{array}{l}\text { R61 corporations listed on } \\
\text { the S\&P in 1992 and 1993 }\end{array}$ & $\begin{array}{l}\text { Proportion of } \\
\text { independent directors } \\
\text { on the board } \\
\text { Productivity \& } \\
\text { market returns }\end{array}$ & $\begin{array}{l}\text { There was no association between board poorer Jensen Productivity in the past } \\
\text { but } \\
\text { led to greater fraction of independent } \\
\text { directors on the board. }\end{array}$ \\
\hline
\end{tabular}




\section{Appendix 2}

\section{Summary of US Empirical Studies Investigating the Relationship between Board Independence and the Effects of}

\section{Takeover Bids}

Table A: Studies Regarding the Relationship between Board Independence and Shareholder Wealth in Bidding Firms

\begin{tabular}{|l|l|l|l|l|}
\hline \multicolumn{1}{|c|}{ Studies } & \multicolumn{1}{|c|}{ Sample } & \multicolumn{1}{c|}{$\begin{array}{c}\text { Measure of Board } \\
\text { Independence }\end{array}$} & $\begin{array}{l}\text { Measure of } \\
\text { Shareholder Wealth }\end{array}$ & \multicolumn{1}{c|}{ Findings } \\
\hline $\begin{array}{l}\text { Byrd \& } \\
\text { Hickman } \\
(1992)\end{array}$ & $\begin{array}{l}128 \text { acquisition bids made by } \\
111 \text { firms listed on the NYSE } \\
\text { or American Stock Exchange } \\
\text { during the period from 1980 to } \\
1987\end{array}$ & $\begin{array}{l}\text { Proportion of } \\
\text { independent directors on } \\
\text { the board }\end{array}$ & Abnormal returns & $\begin{array}{l}\text { A curvilinear relationship between the proportion of } \\
\text { independent directors on the board and bidding firms } \\
\text { abnormal returns. This relationship was positive over } \\
\text { most of the range (from 0\% to 60\%), but was } \\
\text { significantly negative when independent directors } \\
\text { held more than 60\% of board seats. }\end{array}$ \\
\hline
\end{tabular}

Table B: Studies Regarding the Relationship between Board Independence and Shareholder Interests (or Wealth) in Target

\begin{tabular}{|c|c|c|c|c|}
\hline Studies & Sample & $\begin{array}{l}\text { Measure of Board } \\
\text { Independence }\end{array}$ & $\begin{array}{c}\text { Measure of } \\
\text { Shareholder Interests } \\
\text { (or Wealth) }\end{array}$ & Findings \\
\hline $\begin{array}{l}\text { Cotter, } \\
\text { Shivdasani \& } \\
\text { Zenner (1997) }\end{array}$ & $\begin{array}{l}169 \text { tender offer targets traded } \\
\text { on the NYSE, AMEX, or } \\
\text { NASDAQ from } 1988 \text { to } 1992\end{array}$ & $\begin{array}{l}\text { Whether a board } \\
\text { composed of a majority } \\
\text { of independent } \\
\text { directors (an } \\
\text { independent board) }\end{array}$ & Shareholder gains $^{2218}$ & $\begin{array}{l}\text { (1) Shareholder gains were roughly } 20 \% \text { higher for } \\
\text { targets with independent boards than they were } \\
\text { for other targets. } \\
\text { (2) Targets with a majority of independent directors } \\
\text { extracted both higher initial tender offer } \\
\text { premiums and higher revised bid premiums than } \\
\text { targets without independent boards. }\end{array}$ \\
\hline $\begin{array}{l}\text { Bange \& } \\
\text { Mazzeo (2004) }\end{array}$ & $\begin{array}{l}436 \text { proposed negotiated } \\
\text { mergers and bypass offers } \\
\text { (tender offers) that were listed } \\
\text { on the NYSE and AMEX } \\
\text { between } 1979 \text { and } 1990\end{array}$ & $\begin{array}{l}\text { Whether a board } \\
\text { composed of a majority } \\
\text { of independent } \\
\text { directors }\end{array}$ & Initial offer premium & $\begin{array}{l}\text { Target with a majority of independent directors } \\
\text { received a lower initial offer premium and had lower } \\
\text { likelihood of the success of the initial offer. }\end{array}$ \\
\hline
\end{tabular}

\footnotetext{
${ }^{2218}$ The target shareholder gain is the percentage price change from 30 days before the first tender offer rumor to the final tender bid price if the bid is successful,
} or to the stock price 90 days after the resolution of the tender offer if the bid is not successful. 
Appendix 2 (continued)

Table C: Studies Regarding the Impact of Board Independence on Takeover Defenses and Shareholder Wealth in Target Firms

Panel 1: The Adoption of Poison Pills

\begin{tabular}{|c|c|c|c|c|}
\hline Studies & Sample & $\begin{array}{l}\text { Measure of Board } \\
\text { Independence }\end{array}$ & $\begin{array}{c}\text { Measure of Board } \\
\text { Task }\end{array}$ & Findings \\
\hline $\begin{array}{l}\text { Brickley, Cole } \\
\text { \& Terry } \\
(1994)\end{array}$ & $\begin{array}{l}247 \text { publicly-traded firms } \\
\text { that adopted poison pills over } \\
\text { the period } 1984 \text { to } 1986\end{array}$ & $\begin{array}{l}\text { Proportion of } \\
\text { independent directors } \\
\text { on the board }\end{array}$ & $\begin{array}{l}\text { Average } \\
\text { abnormal returns } \\
\text { during the } \\
\text { adoption of a } \\
\text { poison pill }\end{array}$ & $\begin{array}{l}\text { Average abnormal returns were significantly } \\
\text { positive }(0.94 \%) \text { when the company had a } \\
\text { majority of independent directors on the board, } \\
\text { and were significantly negative }(-0.31 \%) \text { when it } \\
\text { did not. }\end{array}$ \\
\hline $\begin{array}{l}\text { Mallette \& } \\
\text { Fowler (1992) }\end{array}$ & $\begin{array}{l}226 \text { firms with poison pills } \\
\text { and } 447 \text { firms without such } \\
\text { pills listed on Standard \& } \\
\text { Poor's COMPUSTAT } 1988 \\
\text { Industrial Files between } 1985 \\
\text { and } 1988\end{array}$ & $\begin{array}{l}\text { Proportion of } \\
\text { independent directors } \\
\text { on the board }\end{array}$ & $\begin{array}{l}\text { The likelihood of } \\
\text { adoption of } \\
\text { poison pills }\end{array}$ & $\begin{array}{l}\text { No significant relationship between the } \\
\text { proportion of independent directors and the } \\
\text { probability that a firm will adopt a poison pill }\end{array}$ \\
\hline
\end{tabular}

\section{Panel 2: The Payment of Greenmail}

\begin{tabular}{|c|c|c|c|c|}
\hline Studies & Sample & $\begin{array}{l}\text { Measure of Board } \\
\text { Independence }\end{array}$ & $\begin{array}{l}\text { Measure of Board } \\
\text { Task }\end{array}$ & Findings \\
\hline Kosnik (1987) & $\begin{array}{l}53 \text { listed companies paying } \\
\text { greenmail and } 57 \text { listed } \\
\text { corporations resisting } \\
\text { greenmail between } 1979 \text { and } \\
1983\end{array}$ & $\begin{array}{l}\text { Proportion of outside } \\
\text { directors on the } \\
\text { board }\end{array}$ & Resist greenmail & $\begin{array}{l}\text { Boards which effectively resisted greenmail had } \\
\text { a higher proportion of outside directors than did } \\
\text { boards of companies that paid greenmail }\end{array}$ \\
\hline Kosnik (1990) & The same as the above & $\begin{array}{l}\text { The same as the } \\
\text { above }\end{array}$ & $\begin{array}{l}\text { The same as the } \\
\text { above }\end{array}$ & $\begin{array}{l}\text { The same as the above (but by using a different } \\
\text { statistical method) }\end{array}$ \\
\hline
\end{tabular}


Appendix 2 (continued)

\section{Table C: Studies Regarding the Impact of Board Independence on Takeover Defenses and Shareholder Wealth in Target Firms (continued)}

\section{Panel 3: The Adoption of Golden Parachutes}

\begin{tabular}{|c|c|c|c|c|}
\hline Studies & Sample & $\begin{array}{l}\text { Measure of Board } \\
\text { Independence }\end{array}$ & $\begin{array}{l}\text { Measure of } \\
\text { Board Task }\end{array}$ & Findings \\
\hline $\begin{array}{l}\text { Cochran, Wood } \\
\text { \& Jones (1985) }\end{array}$ & $\begin{array}{l}52 \text { corporations selected } \\
\text { from Fortune } 500 \text { firms } \\
\text { as of } 1982\end{array}$ & $\begin{array}{l}\text { Proportion of independent } \\
\text { or outside directors on the } \\
\text { board }\end{array}$ & $\begin{array}{l}\text { The adoption of } \\
\text { golden } \\
\text { parachutes }\end{array}$ & $\begin{array}{l}\text { The probability of giving management golden parachutes } \\
\text { was higher when firms had a higher percentage of } \\
\text { independent or outside directors. }\end{array}$ \\
\hline $\begin{array}{l}\text { Singh \& } \\
\text { Harianto } \\
(1989 a)\end{array}$ & $\begin{array}{l}79 \text { Fortune } 500 \text { firms that } \\
\text { adopted golden } \\
\text { parachutes as of } \\
\text { December } 1985\end{array}$ & $\begin{array}{l}\text { Proportion of outside } \\
\text { directors (not defined) on } \\
\text { the board }\end{array}$ & $\begin{array}{l}\text { The adoption of } \\
\text { golden } \\
\text { parachutes }\end{array}$ & $\begin{array}{l}\text { Firms that adopted golden parachutes had a higher } \\
\text { proportion of outside directors on the boards than those that } \\
\text { did not adopt golden parachutes. }\end{array}$ \\
\hline $\begin{array}{l}\text { Singh \& } \\
\text { Harianto } \\
(1989 b)\end{array}$ & $\begin{array}{l}\text { The same as Singh and } \\
\text { Harianto (1989a) }\end{array}$ & $\begin{array}{l}\text { (1) Proportion of outside } \\
\text { directors (not defined) } \\
\text { on the board } \\
\text { (2) proportion of outside } \\
\text { directors (not defined) } \\
\text { on the compensation } \\
\text { committee }\end{array}$ & $\begin{array}{l}\text { Coverage and } \\
\text { size of golden } \\
\text { parachutes }\end{array}$ & $\begin{array}{l}\text { (1) The number of executives covered by golden parachutes } \\
\text { was significantly and positively correlated with the } \\
\text { proportion of outside directors who sat on the } \\
\text { compensation committee (but was not related to the } \\
\text { proportion of outside directors on the board). } \\
\text { (2) No significant relationship was found between the size } \\
\text { of golden parachutes and the fraction of outside } \\
\text { directors on the board or on a compensation committee. }\end{array}$ \\
\hline $\begin{array}{l}\text { Davidson, } \\
\text { Pilger \& } \\
\text { Szakmary } \\
(1998)\end{array}$ & $\begin{array}{l}86 \text { firms selected from } \\
\text { The Investor } \\
\text { Responsibility Research } \\
\text { Center (IRRC) between } \\
\text { June } 1984 \text { and January } \\
1990\end{array}$ & $\begin{array}{l}\text { Proportion of independent } \\
\text { directors on the board }\end{array}$ & $\begin{array}{l}\text { Abnormal } \\
\text { returns during } \\
\text { the adoption of } \\
\text { golden } \\
\text { parachutes }\end{array}$ & $\begin{array}{l}\text { (1) Board composition had no impact on abnormal returns } \\
\text { during the adoption of golden parachutes. } \\
\text { (2) Firms whose share price reacted positively to the } \\
\text { parachute announcement had compensation committees } \\
\text { with majority control by independent directors. } \\
\text { (3) Firms whose share price reacted negatively to the } \\
\text { announcement had compensation committees that were } \\
\text { numerically dominated by inside and affiliated } \\
\text { directors. }\end{array}$ \\
\hline
\end{tabular}




\section{Appendix 3}

\section{Summary of US Empirical Studies Investigating the Relationship between Board Independence and CEO Turnover}

\begin{tabular}{|c|c|c|c|c|}
\hline Studies & Sample & $\begin{array}{l}\text { Measure of Board } \\
\text { Independence }\end{array}$ & $\begin{array}{c}\text { Measure of Board } \\
\text { Task }\end{array}$ & Findings \\
\hline $\begin{array}{l}\text { Mikkelson \& } \\
\text { Partch (1997) }\end{array}$ & $\begin{array}{l}227 \text { firms listed in the NYSE or } \\
\text { AMEX during the period } \\
\text { between } 1984 \text { and } 1988 \text {, and } \\
218 \text { firms listed on the same } \\
\text { exchange during the period } \\
\text { from } 1989 \text { to } 1993\end{array}$ & $\begin{array}{l}\text { Proportion of } \\
\text { independent directors } \\
\text { on the board }\end{array}$ & CEO turnover & $\begin{array}{l}\text { The proportion of independent directors on the board } \\
\text { had no impact on CEO turnover. }\end{array}$ \\
\hline $\begin{array}{l}\text { Geddes \& } \\
\text { Vinod (1997) }\end{array}$ & $\begin{array}{l}367 \text { corporations from } 1974 \text { to } \\
1983\end{array}$ & $\begin{array}{l}\text { Proportion of } \\
\text { independent directors } \\
\text { on the board }\end{array}$ & CEO turnover & $\begin{array}{l}\text { The proportion of independent directors on the board } \\
\text { had no impact on CEO turnover. }\end{array}$ \\
\hline $\begin{array}{l}\text { Weisbach } \\
(1988)\end{array}$ & $\begin{array}{l}367 \text { NYSE firms between } 1974 \\
\text { and } 1983\end{array}$ & $\begin{array}{l}\text { Whether a board has at } \\
\text { least } 60 \% \text { of } \\
\text { independent directors }\end{array}$ & $\begin{array}{l}\text { Sensitivity of CEO } \\
\text { turnover to firm } \\
\text { performance }\end{array}$ & $\begin{array}{l}\text { CEO turnover was more sensitive to firm } \\
\text { performance when firms had at least } 60 \% \\
\text { independent directors on the board, in comparison } \\
\text { with those dominated by inside directors (with less } \\
\text { than } 40 \% \text { of independent directors). }\end{array}$ \\
\hline Perry (2000) & $\begin{array}{l}677 \text { CEO turnover events } \\
\text { between } 1992 \text { and } 1995\end{array}$ & $\begin{array}{l}\text { Whether a board has at } \\
\text { least } 60 \% \text { of } \\
\text { independent directors }\end{array}$ & $\begin{array}{l}\text { Sensitivity of CEO } \\
\text { turnover to firm } \\
\text { performance }\end{array}$ & $\begin{array}{l}\text { Firms with at least } 60 \% \text { of independent directors } \\
\text { were associated with a higher likelihood of CEO } \\
\text { turnover when firms performed poorly. }\end{array}$ \\
\hline $\begin{array}{l}\text { Fich \& } \\
\text { Shivdasani } \\
(2006)\end{array}$ & $\begin{array}{l}508 \text { Forbes } 500 \text { firms in } 1992 \\
\text { during the period from } 1989 \text { to } \\
1995\end{array}$ & $\begin{array}{l}\text { Whether a board has a } \\
\text { majority of } \\
\text { independent directors }\end{array}$ & $\begin{array}{l}\text { Sensitivity of CEO } \\
\text { turnover to firm } \\
\text { performance }\end{array}$ & $\begin{array}{l}\text { Firms with a majority of independent directors were } \\
\text { associated with a higher likelihood of CEO turnover } \\
\text { when firms performed poorly. }\end{array}$ \\
\hline $\begin{array}{l}\text { Bhagat \& } \\
\text { Bolton }(2008)\end{array}$ & $\begin{array}{l}\text { More than } 10,000 \text { firms during } \\
\text { the period } 1990 \text { to } 2004\end{array}$ & $\begin{array}{l}\text { Proportion of } \\
\text { independent directors } \\
\text { on the board }\end{array}$ & $\begin{array}{l}\text { Sensitivity of CEO } \\
\text { turnover to firm } \\
\text { performance }\end{array}$ & $\begin{array}{l}\text { Firms with a higher proportion of independent } \\
\text { directors were associated with a higher likelihood of } \\
\text { CEO turnover when firms performed poorly. }\end{array}$ \\
\hline $\begin{array}{l}\text { Bhagat \& } \\
\text { Bolton (2009) }\end{array}$ & $\begin{array}{l}\text { Around } 1,500 \text { US large firms } \\
\text { from } 1998 \text { to } 2007\end{array}$ & $\begin{array}{l}\text { Proportion of } \\
\text { independent directors } \\
\text { on the board }\end{array}$ & $\begin{array}{l}\text { Sensitivity of CEO } \\
\text { turnover to firm } \\
\text { performance }\end{array}$ & $\begin{array}{l}\text { (1) Pre-SOX: firms with a higher proportion of } \\
\text { independent directors were associated with a } \\
\text { higher likelihood of CEO turnover when firms } \\
\text { performed poorly. } \\
\text { (2) Post-SOX: no significant relationship between } \\
\text { the proportion of independent directors and the } \\
\text { sensitivity of CEO turnover to firm performance }\end{array}$ \\
\hline
\end{tabular}




\section{Appendix 4}

\section{Summary of US Empirical Studies Investigating the Relationship between Board Independence and Executive} Compensation

Table A: Studies Regarding the Relationship between Board Independence and the Level of Executive Compensation

\begin{tabular}{|c|c|c|c|c|}
\hline Studies & Sample & $\begin{array}{l}\text { Measure of Board } \\
\text { Independence }\end{array}$ & $\begin{array}{l}\text { Measure of } \\
\text { Performance }\end{array}$ & Findings \\
\hline Boyd (1994) & $\begin{array}{l}193 \text { firms in } 12 \text { industry } \\
\text { groups in } 1980\end{array}$ & $\begin{array}{l}\text { Proportion of inside } \\
\text { directors on the } \\
\text { board }\end{array}$ & $\begin{array}{l}\text { The level of CEO } \\
\text { compensation }\end{array}$ & $\begin{array}{l}\text { Firms with a higher proportion of inside } \\
\text { directors on the board were associated with } \\
\text { lower CEO compensation. }\end{array}$ \\
\hline $\begin{array}{l}\text { Core, } \\
\text { Holthausen \& } \\
\text { Larcker } \\
\text { (1999) }\end{array}$ & $\begin{array}{l}205 \text { publicly-traded US firms } \\
\text { between } 1982 \text { and } 1984\end{array}$ & $\begin{array}{l}\text { Proportion of outside } \\
\text { directors on the } \\
\text { board; proportion of } \\
\text { less independent } \\
\text { outside directors on } \\
\text { the board }\end{array}$ & $\begin{array}{l}\text { The level of CEO } \\
\text { compensation }\end{array}$ & $\begin{array}{l}\text { (1) Firms with a higher proportion of inside } \\
\text { directors on the board were associated with } \\
\text { lower CEO compensation. } \\
\text { (2) Firms with a higher proportion of less } \\
\text { independent outside directors }{ }^{2219} \text { were } \\
\text { associated with higher CEO compensation. }\end{array}$ \\
\hline $\begin{array}{l}\text { Conyon \& He } \\
(2004)\end{array}$ & $\begin{array}{l}455 \text { US firms completing an } \\
\text { initial public offering in } 1999\end{array}$ & $\begin{array}{l}\text { Proportion of inside } \\
\text { directors on the } \\
\text { board }\end{array}$ & $\begin{array}{l}\text { The level of CEO } \\
\text { compensation }\end{array}$ & $\begin{array}{l}\text { Firms with a higher proportion of inside } \\
\text { directors were associated with lower total CEO } \\
\text { compensation. }\end{array}$ \\
\hline $\begin{array}{l}\text { Chhaochharia } \\
\text { \& Grinstein } \\
(2009)\end{array}$ & $\begin{array}{l}865 \text { firms in the S\&P } 1500 \\
\text { index for the years } 2000 \text { to } \\
2005\end{array}$ & $\begin{array}{l}\text { A majority of } \\
\text { independent directors } \\
\text { on the board }\end{array}$ & $\begin{array}{l}\text { The level of CEO } \\
\text { compensation }\end{array}$ & $\begin{array}{l}\text { CEO compensation was lower by } 17 \% \text { in the } \\
\text { post-SOX period for firms that did not comply } \\
\text { with board independence requirement in the pre- } \\
\text { SOX period, compared to firms that complied } \\
\text { with the requirement before the enactment of } \\
\text { SOX. }\end{array}$ \\
\hline Wan (2009) & $\begin{array}{l}865 \text { firms in the S\&P } 1500 \\
\text { index for the years } 2000 \text { to } \\
2005\end{array}$ & $\begin{array}{l}\text { A majority of } \\
\text { independent directors } \\
\text { on the board }\end{array}$ & $\begin{array}{l}\text { The level of CEO } \\
\text { compensation }\end{array}$ & $\begin{array}{l}\text { Board independence requirements had no impact } \\
\text { on CEO total compensation and the results of } \\
\text { Chhaochharia \& Grinstein (2009) were driven } \\
\text { by two unusually low CEO pay packages. }\end{array}$ \\
\hline
\end{tabular}

\footnotetext{
${ }^{2219}$ The less independent outside directors refer to outside directors: (1) who are appointed by the CEO; (2) who are gray directors and (3) who are interlocked.
} 


\section{Appendix 4 (continued)}

Table B: The Relationship between Board Independence and the Sensitivity of CEO Pay to Firm Performance

\begin{tabular}{|l|l|l|l|l|}
\hline \multicolumn{1}{|c|}{ Studies } & \multicolumn{1}{|c|}{ Sample } & $\begin{array}{l}\text { Measure of Board } \\
\text { Independence }\end{array}$ & $\begin{array}{l}\text { Measure of } \\
\text { Board Task }\end{array}$ & \multicolumn{1}{|c|}{ Findings } \\
\hline $\begin{array}{l}\text { Mehran } \\
(1995)\end{array}$ & $\begin{array}{l}\text { 153 manufacturing firms } \\
\text { during the period from } \\
1973 \text { to } 1983\end{array}$ & $\begin{array}{l}\text { Proportion of } \\
\text { independent } \\
\text { directors on the } \\
\text { board }\end{array}$ & $\begin{array}{l}\text { Sensitivity of } \\
\text { executive pay to } \\
\text { the use of } \\
\text { equity-based } \\
\text { compensation } \\
\text { measure }\end{array}$ & $\begin{array}{l}\text { Firms with a higher proportion of } \\
\text { independent directors on the board had a } \\
\text { higher percentage of their executives' } \\
\text { compensation in an equity-based form }(i . e . \\
\text { sensitive to firm performance). }\end{array}$ \\
\hline
\end{tabular}




\section{Appendix 5}

Summary of US Empirical Studies Investigating the Relationship between Board Independence and Management Buyouts

\begin{tabular}{|l|l|l|l|l|}
\hline Studies & Sample & $\begin{array}{c}\text { Measure of } \\
\text { Board } \\
\text { Independence }\end{array}$ & $\begin{array}{l}\text { Measure of } \\
\text { the } \\
\text { Performance } \\
\text { of } \\
\text { Management } \\
\text { Buyouts }\end{array}$ & \multicolumn{1}{|c|}{ Findings } \\
$\begin{array}{l}\text { Lee } e t \\
\text { al. } \\
(1992)\end{array}$ & $\begin{array}{l}58 \text { going-private } \\
\text { transactions and 74 unit } \\
\text { management buyouts for } \\
\text { firms listed on the NYSE } \\
\text { and AMEX over the } \\
\text { years 1983 to 1989 }\end{array}$ & $\begin{array}{l}\text { A majority of } \\
\text { independent } \\
\text { directors on } \\
\text { the board }\end{array}$ & $\begin{array}{l}\text { Cumulative } \\
\text { abnormal } \\
\text { returns }\end{array}$ & $\begin{array}{l}\text { (1) In going-private transactions: firms with a majority of } \\
\text { independent directors on the board were associated } \\
\text { with larger cumulative abnormal returns, compared to } \\
\text { those dominated by non-independent directors. }\end{array}$ \\
(2) $\begin{array}{l}\text { In unit management buyouts: firms with a majority of } \\
\text { independent directors on the board were associated } \\
\text { with positive cumulative abnormal returns, but the } \\
\text { correlation is insignificant. }\end{array}$ \\
\hline
\end{tabular}




\section{Appendix 6}

\section{Summary of US Empirical Studies Investigating the Relationship between Board Independence and Financial Fraud}

\begin{tabular}{|c|c|c|c|c|}
\hline Studies & Sample & $\begin{array}{l}\text { Measure of Board } \\
\text { Independence }\end{array}$ & $\begin{array}{c}\text { Measure of } \\
\text { Performance }\end{array}$ & Findings \\
\hline $\begin{array}{l}\text { Dechow, } \\
\text { Sloan\& } \\
\text { Sweeney } \\
(1996)\end{array}$ & $\begin{array}{l}92 \text { firms subject to accounting } \\
\text { enforcement actions by the SEC for } \\
\text { alleged violation of GAAP and } 92 \text { control } \\
\text { firms similar in industry and size between } \\
\text { April } 1982 \text { and December } 1992\end{array}$ & $\begin{array}{l}\text { A majority of } \\
\text { outside directors on } \\
\text { the board }\end{array}$ & $\begin{array}{l}\text { Earnings } \\
\text { manipulation }\end{array}$ & $\begin{array}{l}\text { Firms inclined to manipulate earnings were less } \\
\text { likely to have outsider-dominated boards, } \\
\text { compared to those without such a board. }\end{array}$ \\
\hline $\begin{array}{l}\text { Beasley } \\
(1996)\end{array}$ & $\begin{array}{l}75 \text { publicly-traded firms which had } \\
\text { financial statement fraud reported } \\
\text { and } 75 \text { no-fraud publicly-traded firms } \\
\text { during } 1980 \text { to } 1991\end{array}$ & $\begin{array}{l}\text { Proportion of } \\
\text { independent } \\
\text { directors on the } \\
\text { board }\end{array}$ & $\begin{array}{l}\text { Financial statement } \\
\text { fraud }\end{array}$ & $\begin{array}{l}\text { Firms experiencing financial statement fraud had } \\
\text { a significantly lower proportion of independent } \\
\text { directors on the board, compared to firms without } \\
\text { such fraud. }\end{array}$ \\
\hline $\begin{array}{l}\text { Beasley et } \\
\text { al. }(2000)\end{array}$ & $\begin{array}{l}66 \text { companies accused of fraudulent } \\
\text { financial reporting by the SEC and a } \\
\text { control group from } 1987 \text { to } 1997\end{array}$ & $\begin{array}{l}\text { A majority of } \\
\text { independent } \\
\text { directors on the } \\
\text { board }\end{array}$ & $\begin{array}{l}\text { Fraudulent financial } \\
\text { reporting }\end{array}$ & $\begin{array}{l}33 \% \text { of firms accused of fraud had a majority of } \\
\text { independent directors, while } 74 \% \text { of firms without } \\
\text { fraud allegations had a majority of independent } \\
\text { directors in the three industries }\end{array}$ \\
\hline $\begin{array}{l}\text { Abbott, Park } \\
\text { \& Parker } \\
(2000)\end{array}$ & $\begin{array}{l}78 \text { firms that were sanctioned by the SEC } \\
\text { for fraud or aggressive accounting and } 78 \\
\text { non-sanctioned firms between } 1980 \text { and } \\
1996\end{array}$ & $\begin{array}{l}\text { Proportion of } \\
\text { independent } \\
\text { directors on the } \\
\text { board }\end{array}$ & $\begin{array}{l}\text { Sanction by the } \\
\text { SEC for fraud or } \\
\text { aggressive } \\
\text { accounting }\end{array}$ & $\begin{array}{l}\text { No significant relationship between the } \\
\text { percentage of independent directors on the board } \\
\text { and the sanction by the SEC for fraud or } \\
\text { aggressive accounting. }\end{array}$ \\
\hline $\begin{array}{l}\text { Uzen, } \\
\text { Szewczyk \& } \\
\text { Varma } \\
(2004)\end{array}$ & $\begin{array}{l}133 \text { pairs of firms with and without fraud } \\
\text { matched by industry and size during the } \\
\text { period } 1978 \text { through } 2001\end{array}$ & $\begin{array}{l}\text { Proportion of } \\
\text { outside or } \\
\text { independent } \\
\text { directors on the } \\
\text { board }\end{array}$ & Corporate fraud $^{2220}$ & $\begin{array}{l}\text { The percentage of outside and independent } \\
\text { directors were both lower for firms with fraud } \\
\text { than firms without fraud. }\end{array}$ \\
\hline $\begin{array}{l}\text { Agrawal \& } \\
\text { Chadha } \\
(2005)\end{array}$ & $\begin{array}{l}159 \text { firms that restated earnings and an } \\
\text { industry-size matched sample of control } \\
\text { firms from } 2000 \text { to } 2001\end{array}$ & $\begin{array}{l}\text { Proportion of } \\
\text { independent } \\
\text { directors on the } \\
\text { board }\end{array}$ & $\begin{array}{l}\text { Incidence of } \\
\text { earning } \\
\text { restatements }\end{array}$ & $\begin{array}{l}\text { (1) No significant relationship between the } \\
\text { proportion of independent directors and the } \\
\text { incidence of earning restatements. } \\
\text { (2) Firms that had an independent director with } \\
\text { financial expertise on their board or audit } \\
\text { committee had a lower incidence of earning } \\
\text { restatements. }\end{array}$ \\
\hline
\end{tabular}

${ }^{2220}$ Corporate fraud in this study includes fraud of shareholders, fraud of the government, financial reporting fraud and regulatory violations. 


\section{Appendix 7}

\section{Summary of US Empirical Studies Investigating the Relationship between Board Independence and Shareholder Suits}

\begin{tabular}{|c|c|c|c|c|}
\hline Studies & Sample & $\begin{array}{l}\text { Measure of Board } \\
\text { Independence }\end{array}$ & $\begin{array}{l}\text { Measure of Firm } \\
\text { Performance }\end{array}$ & Findings \\
\hline Jones (1986) & $\begin{array}{l}78 \text { shareholder suits against } \\
\text { the boards of Fortune } 500 \\
\text { industrial and service firms } \\
\text { for the years } 1970 \text { through } \\
1977\end{array}$ & $\begin{array}{l}\text { Proportion of outside } \\
\text { directors (not defined) } \\
\text { on the board }\end{array}$ & $\begin{array}{l}\text { The incidence of } \\
\text { shareholder suits }\end{array}$ & $\begin{array}{l}\text { Firms with less than } 60 \% \text { of outside directors } \\
\text { (not defined) were more likely to be sued than } \\
\text { those with } 60 \% \text { or more outside directors (not } \\
\text { defined) on the board. }\end{array}$ \\
\hline $\begin{array}{l}\text { Kesner \& } \\
\text { Johnson } \\
(1990)\end{array}$ & $\begin{array}{l}56 \text { Delaware shareholder } \\
\text { suits between } 1975 \text { and } 1986 \\
\text { in which directors were sued } \\
\text { by shareholders for failure to } \\
\text { fulfill their fiduciary } \\
\text { responsibilities and a control } \\
\text { group of } 56 \text { firms (not been } \\
\text { sued) }\end{array}$ & $\begin{array}{l}\text { Proportion of outside } \\
\text { directors on the board }\end{array}$ & $\begin{array}{l}\text { The incidence of } \\
\text { shareholder } \\
\text { suits, and the } \\
\text { outcome of the } \\
\text { suits }\end{array}$ & $\begin{array}{l}\text { (1) Firms that were sued by their shareholders } \\
\text { tended to have a greater (lower) proportion } \\
\text { of inside (outside) directors than those firms } \\
\text { that were not sued. } \\
\text { (2) Firms receiving favorable outcomes of } \\
\text { shareholder suits did not inevitably have a } \\
\text { larger proportion of outside directors than } \\
\text { those receiving unfavorable outcomes. }\end{array}$ \\
\hline $\begin{array}{l}\text { Helland and } \\
\text { Sykuta (2005) }\end{array}$ & $\begin{array}{l}692 \text { shareholder suits } \\
\text { classified as securities fraud } \\
\text { or shareholder litigation and } \\
692 \text { control observations } \\
\text { between } 1988 \text { and } 2000 \text { in } \\
\text { the Federal Judicial Center's } \\
\text { Federal Court Cases }\end{array}$ & $\begin{array}{l}\text { Proportion of inside, } \\
\text { gray, and independent } \\
\text { directors on the board }\end{array}$ & $\begin{array}{l}\text { The incidence of } \\
\text { shareholder } \\
\text { suits, and the } \\
\text { outcome of the } \\
\text { suits }\end{array}$ & $\begin{array}{l}\text { (1) Firms with a higher proportion of inside } \\
\text { directors or gray directors were more likely } \\
\text { to be suited, compared to firms in the } \\
\text { control group. } \\
\text { (2) Firms being sued had a lower percentage of } \\
\text { independent directors on the board. } \\
\text { (3) Firms with a higher proportion of inside } \\
\text { directors had a higher incidence of losing at } \\
\text { trial. }\end{array}$ \\
\hline $\begin{array}{l}\text { Romano } \\
\text { (1991) }\end{array}$ & $\begin{array}{l}139 \text { shareholder suits brought } \\
\text { between } 1966 \text { and } 1987 \\
\text { against } 535 \text { corporations } \\
\text { traded publicly on the NYSE } \\
\text { and NASDAQ }\end{array}$ & $\begin{array}{l}\text { Proportion of outside } \\
\text { directors (not defined) } \\
\text { on the board }\end{array}$ & $\begin{array}{l}\text { The incidence of } \\
\text { shareholder suits }\end{array}$ & $\begin{array}{l}\text { Sued companies did not have a significantly } \\
\text { lower percentage of outside directors (not } \\
\text { defined), compared to companies that were not } \\
\text { sued. }\end{array}$ \\
\hline
\end{tabular}




\section{Appendix 8}

\section{Summary of US Studies Investigating the Impact of Audit Committee Independence on the Quality of Financial Reporting}

Table A: Studies Regarding the Relationship between Audit Committees with $100 \%$ Independence and the Quality of Financial Reporting

\begin{tabular}{|c|c|c|c|}
\hline Studies & Sample & $\begin{array}{l}\text { Measure of the Quality } \\
\text { of Financial Reporting }\end{array}$ & Findings \\
\hline $\begin{array}{l}\text { Beasley et al. } \\
(2000)\end{array}$ & $\begin{array}{l}66 \text { companies accused of fraudulent } \\
\text { financial reporting by the SEC and a } \\
\text { control group from } 1987 \text { to } 1997\end{array}$ & Financial statement fraud & $\begin{array}{l}\text { Firms without financial statement frauds had a higher } \\
\text { percentage of fully independent audit committees than firms } \\
\text { with financial statement frauds. }\end{array}$ \\
\hline $\begin{array}{l}\text { Abbott, Park \& } \\
\text { Parker (2000) }\end{array}$ & $\begin{array}{l}78 \text { firms that were sanctioned by the } \\
\text { SEC for fraud or aggressive accounting } \\
\text { and } 78 \text { non-sanctioned firms between } \\
1980 \text { and } 1996\end{array}$ & $\begin{array}{l}\text { Sanction by the SEC for } \\
\text { fraud or aggressive } \\
\text { accounting }\end{array}$ & $\begin{array}{l}\text { The presence of an audit committee which excludes employees } \\
\text { and affiliated directors was associated with a lower probability } \\
\text { of SEC sanction. }\end{array}$ \\
\hline $\begin{array}{l}\text { Lee, Mande \& } \\
\text { Ortman (2004) }\end{array}$ & $\begin{array}{l}190 \text { auditor-initiated changes in auditor } \\
\text { and a sample of } 190 \text { client-initiated } \\
\text { changes in auditor during } 1996 \text { to } 2000\end{array}$ & Auditor resignation & $\begin{array}{l}\text { The presence of a completely independent audit committee was } \\
\text { negatively and significantly related to the likelihood of auditor } \\
\text { resignation. }\end{array}$ \\
\hline $\begin{array}{l}\text { Abbott, Parker \& } \\
\text { Peters (2004) }\end{array}$ & $\begin{array}{l}88 \text { restatements of annual reports in the } \\
\text { period 1991-1999, together with a } \\
\text { matched pairs control group }\end{array}$ & $\begin{array}{l}\text { Incidence of financial } \\
\text { restatement and the } \\
\text { likelihood of corporate } \\
\text { fraud }\end{array}$ & $\begin{array}{l}\text { The presence of a completely independent audit committee was } \\
\text { significantly and negatively related to the incidence of financial } \\
\text { restatement and the likelihood of corporate fraud. }\end{array}$ \\
\hline $\begin{array}{l}\text { Bédard, Chtourou } \\
\& \text { Courteau (2004) }\end{array}$ & 300 US firms in 1996 & Earnings management & $\begin{array}{l}\text { The presence of a completely independent audit committee was } \\
\text { associated with a significant reduction in the likelihood of } \\
\text { earnings management. }\end{array}$ \\
\hline $\begin{array}{l}\text { Bronson et al. } \\
\text { (2009) }\end{array}$ & $\begin{array}{l}208 \text { firms with a high level of financial } \\
\text { distress during } 1994 \text { and } 53 \text { going- } \\
\text { concern firms with auditor dismissals } \\
\text { prior to the issuance of their next } \\
\text { annual report during } 1988 \text { to } 1999\end{array}$ & $\begin{array}{l}\text { The likelihood of issuing } \\
\text { a going-concern report, } \\
\text { and protection of } \\
\text { auditors from dismissal } \\
\text { after issuing new-going } \\
\text { concern reports }\end{array}$ & $\begin{array}{l}\text { Financially distressed companies with fully independent audit } \\
\text { committees: } \\
\text { (1) were more likely to receive a going-concern report (the } \\
\text { likelihood of receiving a going-concern report is higher). } \\
\text { (2) were more likely to shield auditors from dismissal after } \\
\text { issuing new going-concern reports. }\end{array}$ \\
\hline Klein (2002) & $\begin{array}{l}692 \text { firm-years of S\&P } 500 \text { firms from } \\
1992 \text { to } 1993\end{array}$ & Earnings management & $\begin{array}{l}\text { Firms with wholly independent audit committees had no impact } \\
\text { on the likelihood of earnings management. However, the } \\
\text { presence of a majority of independent directors on } \\
\text { the audit committee was associated with a lower } \\
\text { likelihood of earnings management. }\end{array}$ \\
\hline
\end{tabular}




\section{Appendix 8 (continued)}

\section{Table B: Studies Regarding the Relationship between the Proportion of Independent Directors on the Audit Committee and}

the Quality of Financial Reporting

\section{Panel 1: Studies Reporting Positive Results}

\begin{tabular}{|c|c|c|c|}
\hline Studies & Sample & $\begin{array}{l}\text { Measure of the Quality } \\
\text { of Financial Reporting }\end{array}$ & Findings \\
\hline $\begin{array}{l}\text { Carcello \& } \\
\text { Neal }(2000)\end{array}$ & $\begin{array}{l}223 \text { public firms experiencing financial } \\
\text { distress during } 1994\end{array}$ & $\begin{array}{l}\text { The likelihood that } \\
\text { auditors would issue a } \\
\text { going-concern report }\end{array}$ & $\begin{array}{l}\text { The likelihood that auditors would issue a going-concern report } \\
\text { was higher when the proportion of independent directors on the } \\
\text { audit committee was higher. }\end{array}$ \\
\hline $\begin{array}{l}\text { Carcello \& } \\
\text { Neal (2003) }\end{array}$ & $\begin{array}{l}62 \text { clients receiving going-concern reports } \\
\text { that dismissed their auditors and } 62 \text { clients } \\
\text { receiving going-concern reports that } \\
\text { retained their auditors between } 1988 \text { and } \\
1999\end{array}$ & $\begin{array}{l}\text { Protection of auditors } \\
\text { from dismissal after } \\
\text { issuing new-going } \\
\text { concern reports }\end{array}$ & $\begin{array}{l}\text { The likelihood to shield auditors from dismissal after issuing } \\
\text { new going-concern reports was higher when the proportion of } \\
\text { independent directors on the audit committee was higher. }\end{array}$ \\
\hline $\begin{array}{l}\text { Bronson et al. } \\
\text { (2009) }\end{array}$ & $\begin{array}{l}208 \text { firms with a high level of financial } \\
\text { distress during } 1994 \text { and } 53 \text { going-concern } \\
\text { firms with auditor dismissals prior to the } \\
\text { issuance of their next annual report during } \\
1988 \text { to } 1999\end{array}$ & $\begin{array}{l}\text { The likelihood of issuing } \\
\text { a going-concern report, } \\
\text { protection of auditors } \\
\text { from dismissal after } \\
\text { issuing new-going } \\
\text { concern reports }\end{array}$ & $\begin{array}{l}\text { Financially distressed companies with a higher proportion of } \\
\text { independent directors on their audit committees: } \\
\text { (1) were more likely to receive a going-concern report (the } \\
\text { likelihood of receiving a going-concern report is higher) } \\
\text { (2) were more likely to shield auditors from dismissal after } \\
\text { issuing new going-concern reports }\end{array}$ \\
\hline Klein (2002) & $\begin{array}{l}692 \text { firm-years of S\&P } 500 \text { firms from } \\
1992 \text { to } 1993\end{array}$ & Earnings management & $\begin{array}{l}\text { The likelihood of earnings management was lower when firms } \\
\text { had a higher proportion of independent directors on the audit } \\
\text { committee. The correlation was more pronounced when the } \\
\text { audit committee had at least a majority of independent directors. }\end{array}$ \\
\hline $\begin{array}{l}\text { Uzen, } \\
\text { Szewczyk \& } \\
\text { Varma (2004) }\end{array}$ & $\begin{array}{l}133 \text { pairs of firms with and without fraud } \\
\text { matched by industry and size during the } \\
\text { period } 1978 \text { through } 2001\end{array}$ & Corporate fraud & $\begin{array}{l}\text { The likelihood of corporate fraud was lower when firms had a } \\
\text { higher proportion of independent directors on the audit } \\
\text { committee. }\end{array}$ \\
\hline $\begin{array}{l}\text { Krishnan } \\
(2005)\end{array}$ & $\begin{array}{l}128 \text { companies that changed auditors over } \\
\text { the period } 1994 \text { to } 2000\end{array}$ & $\begin{array}{l}\text { Incidence of internal } \\
\text { control problems }\end{array}$ & $\begin{array}{l}\text { The incidence of internal control problems was lower when } \\
\text { firms had a higher proportion of independent directors on audit } \\
\text { committees. }\end{array}$ \\
\hline Vafeas (2005) & $\begin{array}{l}2251995 \text { Fortune } 500 \text { firms from the year } \\
1994 \text { to } 2000\end{array}$ & $\begin{array}{l}\text { Earnings quality } \\
\text { (whether a firm is likely } \\
\text { to report a small earnings } \\
\text { increase and avoid } \\
\text { negative earnings } \\
\text { surprises) }\end{array}$ & $\begin{array}{l}\text { The likelihood to have a better earnings quality (observed by } \\
\text { being less likely to report a small earnings increase and to avoid } \\
\text { negative earnings surprises) was higher when the percentage of } \\
\text { outside directors on audit committee members was higher. }\end{array}$ \\
\hline
\end{tabular}




\section{Appendix 8 (continued)}

Table B: Studies Regarding the Relationship between the Proportion of Independent Directors on the Audit Committee and the Quality of Financial Reporting (Continued)

\section{Panel 2: Studies Reporting Neutral Results}

\begin{tabular}{|c|c|c|c|}
\hline Studies & Sample & $\begin{array}{l}\text { Measure of the } \\
\text { Quality of Financial } \\
\text { Reporting }\end{array}$ & Findings \\
\hline $\begin{array}{l}\text { Beasley } \\
(1996)\end{array}$ & $\begin{array}{l}75 \text { fraud and } 75 \text { no-fraud publicly- } \\
\text { traded firms during the period from } \\
1980 \text { to } 1991\end{array}$ & $\begin{array}{l}\text { Financial statement } \\
\text { fraud }\end{array}$ & $\begin{array}{l}\text { The percentage of outside directors on the audit } \\
\text { committee was not associated with the likelihood of } \\
\text { financial statement fraud. }\end{array}$ \\
\hline $\begin{array}{l}\text { Xie, Davidson } \\
\text { \& DaDalt } \\
(2003)\end{array}$ & $\begin{array}{l}\text { around } 100 \mathrm{~S} \& \mathrm{P} 500 \text { firms for the } \\
\text { years } 1992,1994 \text { and } 1996\end{array}$ & $\begin{array}{l}\text { Earnings } \\
\text { management }\end{array}$ & $\begin{array}{l}\text { The percentage of independent directors on the audit } \\
\text { committee was not associated with the likelihood of } \\
\text { earnings management. }\end{array}$ \\
\hline $\begin{array}{l}\text { Felo, } \\
\text { Krishnamurthy } \\
\text { \& Solieri } \\
(2003)\end{array}$ & $\begin{array}{l}119 \text { firms for the periods of } 1992- \\
93 \text { and } 1995-96\end{array}$ & $\begin{array}{l}\text { Analysts' ranking of } \\
\text { financial reporting }\end{array}$ & $\begin{array}{l}\text { The percentage of independent directors on the audit } \\
\text { committee was not correlated with analysts' ranking } \\
\text { of financial reporting. }\end{array}$ \\
\hline $\begin{array}{l}\text { Bédard, } \\
\text { Chtourou \& } \\
\text { Courteau } \\
(2004)\end{array}$ & 300 US firms in 1996 & $\begin{array}{l}\text { Earnings } \\
\text { management }\end{array}$ & $\begin{array}{l}\text { There was no significant correlation between audit } \\
\text { committees with 50-99\% independence and earnings } \\
\text { management. }\end{array}$ \\
\hline $\begin{array}{l}\text { Yang \& } \\
\text { Krishnan } \\
(2005)\end{array}$ & $\begin{array}{l}896 \text { firm-year observations for the } \\
\text { years } 1996 \text { to } 2000\end{array}$ & $\begin{array}{l}\text { Quarterly earnings } \\
\text { management }\end{array}$ & $\begin{array}{l}\text { The percentage of independent directors on the audit } \\
\text { committee was not associated with the likelihood of } \\
\text { quarterly earnings management. }\end{array}$ \\
\hline $\begin{array}{l}\text { Agrawal \& } \\
\text { Chadha (2005) }\end{array}$ & $\begin{array}{l}159 \text { firms that restated earnings } \\
\text { and an industry-size matched } \\
\text { sample of control firms from } 2000 \\
\text { to } 2001\end{array}$ & Earning restatements & $\begin{array}{l}\text { The percentage of independent directors on the audit } \\
\text { committee was not associated with the likelihood of } \\
\text { earning restatements. }\end{array}$ \\
\hline
\end{tabular}




\section{Appendix 8 (continued)}

Table C: Studies Comparing the Impact between Audit Committees with and Without 100\% Independence on the Quality of Financial Reporting

\begin{tabular}{|c|c|c|c|c|}
\hline Studies & Sample & $\begin{array}{l}\text { The Level of Audit } \\
\text { Committee } \\
\text { Independence }\end{array}$ & $\begin{array}{l}\text { Measure of the Quality } \\
\text { of Financial Reporting }\end{array}$ & Findings \\
\hline \multirow[t]{2}{*}{ Klein (2002) } & \multirow[t]{2}{*}{$\begin{array}{l}692 \text { firm-years of S\&P } 500 \\
\text { firms from } 1992 \text { to } 1993\end{array}$} & $\begin{array}{l}50 \%-99 \% \\
\text { independence }\end{array}$ & \multirow[t]{2}{*}{ Earnings management } & $\begin{array}{l}\text { The presence of a majority of independent directors } \\
\text { on the audit committee was associated with a lower } \\
\text { likelihood of earnings management. }\end{array}$ \\
\hline & & $100 \%$ independence & & $\begin{array}{l}\text { However, an audit committee composed fully of } \\
\text { independent directors was not associated with the } \\
\text { likelihood of earnings management. }\end{array}$ \\
\hline \multirow{2}{*}{$\begin{array}{l}\text { Bédard, } \\
\text { Chtourou \& } \\
\text { Courteau } \\
\text { (2004) }\end{array}$} & \multirow{2}{*}{$\begin{array}{l}300 \text { US firms in } 1996 \text { (the firm } \\
\text { size of Bédard, Chtourou \& } \\
\text { Courteau (2004) is smaller than } \\
\text { that of Klein (2002)) }\end{array}$} & $\begin{array}{l}50 \%-99 \% \\
\text { independence }\end{array}$ & \multirow[t]{2}{*}{ Earnings management } & $\begin{array}{l}\text { The presence of 50-99\% of independent directors on } \\
\text { the audit committee was not associated with the } \\
\text { likelihood of earnings management. }\end{array}$ \\
\hline & & $100 \%$ independence & & $\begin{array}{l}\text { Audit committees composed } 100 \% \text { of independent } \\
\text { directors were associated with a lower likelihood of } \\
\text { earnings management. }\end{array}$ \\
\hline \multirow[t]{4}{*}{$\begin{array}{l}\text { Bronson et al. } \\
(2009)\end{array}$} & \multirow[t]{2}{*}{$\begin{array}{l}208 \text { firms with a high level of } \\
\text { financial distress during } 1994\end{array}$} & $\begin{array}{l}\text { With only one non- } \\
\text { independent } \\
\text { director }\end{array}$ & \multirow[t]{2}{*}{$\begin{array}{l}\text { The likelihood of } \\
\text { issuing a going- } \\
\text { concern report }\end{array}$} & $\begin{array}{l}\text { Financially distressed firms with only one non- } \\
\text { independent member on audit committees were not } \\
\text { associated with the likelihood of receiving a going- } \\
\text { concern report. }\end{array}$ \\
\hline & & $100 \%$ independence & & $\begin{array}{l}\text { Financially distressed firms with completely } \\
\text { independent audit committees were more likely to } \\
\text { receive going-concern report. }\end{array}$ \\
\hline & \multirow{2}{*}{$\begin{array}{l}53 \text { going-concern firms with } \\
\text { auditor dismissals prior to the } \\
\text { issuance of their next annual } \\
\text { report during } 1988 \text { to } 1999\end{array}$} & $\begin{array}{l}\text { With only one non- } \\
\text { independent } \\
\text { director }\end{array}$ & \multirow{2}{*}{$\begin{array}{l}\text { Protection of auditors } \\
\text { from dismissal after } \\
\text { issuing new-going } \\
\text { concern reports }\end{array}$} & \multirow{2}{*}{$\begin{array}{l}\text { Complete and non-complete independent audit } \\
\text { committee both provided protection of auditors from } \\
\text { dismissal following the issuance of a going-concern } \\
\text { opinion. } \\
\text { However, the effect of a completely independent } \\
\text { audit committee was stronger than that of an audit } \\
\text { committee with only one non-independent member. }\end{array}$} \\
\hline & & $\begin{array}{l}100 \% \\
\text { independence }\end{array}$ & & \\
\hline
\end{tabular}




\section{Appendix 9}

\section{Summary of US Empirical Studies Investigating the Relation between Different Types of Financial Expertise and the Quality of Financial Reporting}

Table A: Studies Regarding the Relationship between Accounting Expertise (Equivalent to the SEC Initial Definition) and the Quality of Financial Reporting

\begin{tabular}{|c|c|c|c|}
\hline Studies & Sample & $\begin{array}{l}\text { Measure of the Quality of Financial } \\
\text { Reporting }\end{array}$ & Findings \\
\hline $\begin{array}{l}\text { Felo, } \\
\text { Krishnamurthy } \\
\& \text { Solieri (2003) }\end{array}$ & $\begin{array}{l}119 \text { firms for the periods of } 1992-93 \\
\text { and } 1995-96\end{array}$ & Analysts' ranking of financial reporting & $\begin{array}{l}\text { The proportion of financial experts on the audit } \\
\text { committee had no impact on analysts' ranking of } \\
\text { financial reporting quality. }\end{array}$ \\
\hline $\begin{array}{l}\text { Davidson, Xie } \\
\& \mathrm{Xu}(2004)\end{array}$ & $\begin{array}{l}136 \text { appointment announcements of a } \\
\text { director to an audit committee over the } \\
\text { period } 1990 \text { to } 2001\end{array}$ & $\begin{array}{l}\text { Market reaction (two-day cumulative } \\
\text { market-adjusted return) to the appointment } \\
\text { of an audit committee member with } \\
\text { financial expertise }\end{array}$ & $\begin{array}{l}\text { There is a significant and positive market reaction } \\
\text { regarding the appointment of an accounting } \\
\text { expert to the audit committee. }\end{array}$ \\
\hline $\begin{array}{l}\text { Defond, Hann } \\
\& \mathrm{Hu}(2005)\end{array}$ & $\begin{array}{l}\text { the announcement of } 702 \text { newly- } \\
\text { appointed independent directors } \\
\text { assigned to audit committees during } \\
1993-2002 \text { for } 509 \text { firms }\end{array}$ & $\begin{array}{l}\text { Market reaction (three-day cumulative } \\
\text { abnormal returns) to the appointment of an } \\
\text { audit committee member with financial } \\
\text { expertise }\end{array}$ & $\begin{array}{l}\text { There is a significant and positive market reaction } \\
\text { regarding the appointment of an accounting } \\
\text { expert to the audit committee. }\end{array}$ \\
\hline $\begin{array}{l}\text { Agrawal \& } \\
\text { Chadha (2005) }\end{array}$ & $\begin{array}{l}159 \text { firms that restated earnings and an } \\
\text { industry-size matched sample of } \\
\text { control firms from } 2000 \text { to } 2001\end{array}$ & Earning restatements & $\begin{array}{l}\text { Audit committees having a member with } \\
\text { accounting expertise were associated with a lower } \\
\text { incidence of earnings restatement. }\end{array}$ \\
\hline $\begin{array}{l}\text { Carcello et al. } \\
\text { (2006) }\end{array}$ & $\begin{array}{l}283 \text { firms traded on NYSE, Nasdaq's } \\
\text { National Market and Nasdaq's Small } \\
\text { Cap Market in the year } 2003\end{array}$ & Earnings management & $\begin{array}{l}\text { Audit committees having at least one member } \\
\text { with accounting expertise were correlated with a } \\
\text { lower level of earnings management. }\end{array}$ \\
\hline $\begin{array}{l}\text { Dhaliwal, } \\
\text { Naiker \& } \\
\text { Navissi (2006) } \\
\end{array}$ & $\begin{array}{l}3,510 \text { individuals serving as audit } \\
\text { committee members in } 1,114 \text { firms } \\
\text { from the period } 1995 \text { to } 1998\end{array}$ & Earnings management (accruals quality) & $\begin{array}{l}\text { Audit committees having at least one member } \\
\text { with accounting expertise were correlated with a } \\
\text { higher accruals quality. }\end{array}$ \\
\hline Qin (2007) & $\begin{array}{l}92 \text { firms in } 43 \text { industries from } 1998 \text { to } \\
2002\end{array}$ & Earnings quality & $\begin{array}{l}\text { Audit committees having members with financial } \\
\text { experts under the SEC's initial definition }{ }^{2221} \text { were } \\
\text { more likely to enjoy a higher quality of reported } \\
\text { earnings. }\end{array}$ \\
\hline
\end{tabular}

\footnotetext{
${ }^{2221}$ A financial expert under the SEC's initial definition refers to an expert with previous positions, such as public accountants, auditors, principal/chief financial officers, controllers, or principal/chief accounting officers.
} 


\section{Appendix 9 (continued)}

Table B: Studies Regarding the Relationship between Financial Analysis Expertise and the Quality of Financial Reporting

\begin{tabular}{|c|c|c|c|}
\hline Studies & Sample & $\begin{array}{l}\text { Measure of the Quality of Financial } \\
\text { Reporting }\end{array}$ & Findings \\
\hline $\begin{array}{l}\text { Davidson, Xie } \\
\& \mathrm{Xu}(2004)\end{array}$ & $\begin{array}{l}136 \text { appointment announcements of } \\
\text { a director to an audit committee } \\
\text { over the period } 1990 \text { to } 2001\end{array}$ & $\begin{array}{l}\text { Market reaction (two-day cumulative } \\
\text { market-adjusted return) to the } \\
\text { appointment of an audit committee } \\
\text { member with financial expertise }\end{array}$ & $\begin{array}{l}\text { There was no significant market reaction to } \\
\text { the appointment of a financial analysis expert } \\
\text { to the audit committee. }\end{array}$ \\
\hline $\begin{array}{l}\text { Dhaliwal, } \\
\text { Naiker \& } \\
\text { Navissi (2006) }\end{array}$ & $\begin{array}{l}3,510 \text { individuals serving as audit } \\
\text { committee members in } 1,114 \text { firms } \\
\text { from the period } 1995 \text { to } 1998\end{array}$ & $\begin{array}{l}\text { Earnings management (accruals } \\
\text { quality) }\end{array}$ & $\begin{array}{l}\text { There was no significant association between } \\
\text { the presence of financial analysis expertise } \\
\text { on the audit committee and accruals quality. }\end{array}$ \\
\hline $\begin{array}{l}\text { Carcello et al. } \\
(2006)\end{array}$ & $\begin{array}{l}283 \text { firms traded on NYSE, } \\
\text { Nasdaq's National Market and } \\
\text { Nasdaq's Small Cap Market in the } \\
\text { year } 2003\end{array}$ & Earnings management & $\begin{array}{l}\text { Audit committees with at least one non- } \\
\text { accounting expert (excluding senior business } \\
\text { executives) were correlated with a lower } \\
\text { level of earnings management. }\end{array}$ \\
\hline
\end{tabular}

Table C: Studies Regarding the Relationship between Supervisory Expertise and the Quality of Financial Reporting

\begin{tabular}{|c|c|c|c|}
\hline Studies & Sample & $\begin{array}{c}\text { Measure of the Quality of Financial } \\
\text { Reporting }\end{array}$ & Findings \\
\hline $\begin{array}{l}\text { Defond, Hann } \\
\& \mathrm{Hu}(2005)\end{array}$ & $\begin{array}{l}\text { The announcement of } 702 \text { newly- } \\
\text { appointed independent directors } \\
\text { assigned to audit committees } \\
\text { during 1993-2002 for } 509 \text { firms }\end{array}$ & $\begin{array}{l}\text { Market reaction (three-day cumulative } \\
\text { abnormal returns) to the appointment } \\
\text { of an audit committee member with } \\
\text { financial expertise }\end{array}$ & $\begin{array}{l}\text { There was no significant market reaction to } \\
\text { the appointment of a supervisory expert to } \\
\text { the audit committee. }\end{array}$ \\
\hline $\begin{array}{l}\text { Carcello et al. } \\
(2006)\end{array}$ & $\begin{array}{l}283 \text { firms traded on NYSE, } \\
\text { Nasdaq's National Market and } \\
\text { Nasdaq's Small Cap Market in the } \\
\text { year } 2003\end{array}$ & Earnings management & $\begin{array}{l}\text { There was no significant association between } \\
\text { the presence of at least one supervisory } \\
\text { expert (but no accounting expert) on the audit } \\
\text { committee and the level of earnings } \\
\text { management. }\end{array}$ \\
\hline $\begin{array}{l}\text { Dhaliwal, } \\
\text { Naiker \& } \\
\text { Navissi (2006) }\end{array}$ & $\begin{array}{l}3,510 \text { individuals serving as audit } \\
\text { committee members in } 1,114 \text { firms } \\
\text { from the period } 1995 \text { to } 1998\end{array}$ & $\begin{array}{l}\text { Earnings management (accruals } \\
\text { quality) }\end{array}$ & $\begin{array}{l}\text { There was no significant association between } \\
\text { the presence of supervisory expertise on the } \\
\text { audit committee and accruals quality. }\end{array}$ \\
\hline
\end{tabular}




\section{Appendix 9 (continued)}

Table D: Studies Regarding the Combined Effect of Accounting and Financial Analysis Expertise and the Quality of Financial Reporting

\begin{tabular}{|c|c|c|c|}
\hline Studies & Sample & $\begin{array}{l}\text { Measure of the } \\
\text { Quality of } \\
\text { Financial } \\
\text { Reporting }\end{array}$ & Findings \\
\hline $\begin{array}{l}\text { Krishnan } \\
(2005)\end{array}$ & $\begin{array}{l}128 \text { companies that } \\
\text { changed auditors over the } \\
\text { period } 1994 \text { to } 2000\end{array}$ & $\begin{array}{l}\text { Incidence of } \\
\text { internal control } \\
\text { problems }\end{array}$ & $\begin{array}{l}\text { The number of financial experts }{ }^{2222} \text { (including who have } \\
\text { accounting or financial analysis expertise) on the audit } \\
\text { committee was significantly and negatively related to the } \\
\text { incidence of internal control problems. }\end{array}$ \\
\hline $\begin{array}{l}\text { Bédard, } \\
\text { Chtourou \& } \\
\text { Courteau } \\
(2004)\end{array}$ & 300 US firms in 1996 & $\begin{array}{l}\text { Earnings } \\
\text { management }\end{array}$ & $\begin{array}{l}\text { The presence of at least one audit committee member with } \\
\text { financial expertise } \\
\text { or financial analysis expertise) was correlated with a lower } \\
\text { probability of earnings management. }\end{array}$ \\
\hline
\end{tabular}

\footnotetext{
${ }^{2222}$ Directors were considered having financial expertise, if they were a certified public accountant, chartered financial analyst, or had work experience in a financial or accounting position. This definition is similar in spirit to what the SEC initially adopted.

${ }^{2223}$ The authors adopted a more restrictive definition of financial expert than that of the Blue Ribbon Committee in this study. Prior experience as a CEO does not count as financial expertise. Only directors with accounting expertise or finance expertise (such as bankers or venture capitalists) are considered as financial experts.
} 


\section{Appendix 9 (continued)}

\section{Table E: Studies Regarding the Combined Effect of All Three Types of Financial Expertise and the Quality of Financial} Reporting

\begin{tabular}{|c|c|c|c|}
\hline Studies & Sample & $\begin{array}{l}\text { Measure of the Quality of Financial } \\
\text { Reporting }\end{array}$ & Findings \\
\hline $\begin{array}{l}\text { Davidson, Xie } \\
\& \mathrm{Xu}(2004)\end{array}$ & $\begin{array}{l}136 \text { appointment announcements of a } \\
\text { director to an audit committee over the } \\
\text { period } 1990 \text { to } 2001\end{array}$ & $\begin{array}{l}\text { Market reaction (two-day cumulative } \\
\text { market-adjusted return) to the } \\
\text { appointment of an audit committee } \\
\text { member with financial expertise }\end{array}$ & $\begin{array}{l}\text { There was a significantly positive stock price reaction } \\
\text { when new members of audit committees had one of the } \\
\text { three types of financial expertise as currently defined } \\
\text { by the SEC. }\end{array}$ \\
\hline $\begin{array}{l}\text { Lee, Mande \& } \\
\text { Ortman (2004) }\end{array}$ & $\begin{array}{l}190 \text { auditor-initiated changes in auditor } \\
\text { and a sample of } 190 \text { client-initiated } \\
\text { changes in auditor during } 1996 \text { to } 2000\end{array}$ & Auditor resignation & $\begin{array}{l}\text { Audit committees with a higher proportion of financial } \\
\text { experts (having one of the three types of financial } \\
\text { expertise) were associated with a lower likelihood of } \\
\text { auditor resignation. }\end{array}$ \\
\hline $\begin{array}{l}\text { Abbott, Parker } \\
\& \text { Peters (2004) }\end{array}$ & $\begin{array}{l}88 \text { restatements of annual reports in the } \\
\text { period 1991-1999, together with a } \\
\text { matched pairs control group }\end{array}$ & $\begin{array}{l}\text { The incidence of financial } \\
\text { restatement and the likelihood of } \\
\text { corporate fraud }\end{array}$ & $\begin{array}{l}\text { Audit committees possessing at least one member } \\
\text { meeting the BRC definition of financial expert }{ }^{2224} \text { were } \\
\text { associated with a lower incidence of financial } \\
\text { restatement. }\end{array}$ \\
\hline $\begin{array}{l}\text { Carcello et al. } \\
\text { (2006) }\end{array}$ & $\begin{array}{l}283 \text { firms traded on NYSE, Nasdaq's } \\
\text { National Market and Nasdaq's Small } \\
\text { Cap Market in the year } 2003\end{array}$ & Earnings management & $\begin{array}{l}\text { Audit committees having at least one financial expert } \\
\text { (with one of the three types of financial expertise) were } \\
\text { associated with a lower level of earnings management. }\end{array}$ \\
\hline $\begin{array}{l}\text { Carcello \& Neal } \\
(2003)\end{array}$ & $\begin{array}{l}62 \text { firms receiving going-concern } \\
\text { reports that dismissed their auditors } \\
\text { and } 62 \text { firms receiving going-concern } \\
\text { reports that retained their auditors } \\
\text { between } 1988 \text { and } 1999\end{array}$ & $\begin{array}{l}\text { Protection of auditors from dismissal } \\
\text { after issuing new-going concern } \\
\text { reports }\end{array}$ & $\begin{array}{l}\text { There was no significant relationship between the } \\
\text { proportion of audit committee members with (one of } \\
\text { the three types of) financial expertise and auditor } \\
\text { dismissals following the issuance of going-concern } \\
\text { reports. }\end{array}$ \\
\hline Qin (2007) & $\begin{array}{l}92 \text { firms in } 43 \text { industries from } 1998 \text { to } \\
2002\end{array}$ & Earnings quality & $\begin{array}{l}\text { There was no relationship between earnings quality and } \\
\text { financial experts under the SEC's current definition } \\
\text { (i.e. with one of the three types of financial expertise). }\end{array}$ \\
\hline
\end{tabular}

\footnotetext{
${ }^{2224}$ BRC states that financial expertise may be demonstrated by employment experience in finance or accounting, a CPA certification or comparable experience, or a position as a CEO or other senior officer with financial oversight responsibilities. In this study, a director who is (or has been) a CPA, investment banker or venture capitalist, served as CFO or controller, or has held a senior management position (CEO, President, EVP, SVP, VP) with financial responsibilities are all considered as having financial expertise.
} 


\section{Appendix 10}

\section{Summary of US Empirical Studies Investigating the Relationship between Compensation Committee Independence and the Missions of the Committee}

Table A: Studies Regarding the Impact of Compensation Committee Independence on the Level of CEO Compensation

\begin{tabular}{|c|c|c|c|c|}
\hline Studies & Sample & $\begin{array}{l}\text { Measure of Compensation } \\
\text { Committee Independence }\end{array}$ & Measure of Executive Compensation & Findings \\
\hline $\begin{array}{l}\text { Daily et al. } \\
\text { (1998) }\end{array}$ & $\begin{array}{l}194 \text { publicly-traded } \\
\text { companies from } \\
1992 \text { Fortune } 500 \\
\text { firms }\end{array}$ & $\begin{array}{l}\text { Proportion of affiliated, } \\
\text { interdependent, and } C E O \\
\text { directors on the } \\
\text { compensation committee }\end{array}$ & $\begin{array}{l}\text { The sum of non-contingent pay (salary } \\
\text { and other annual cash compensation) } \\
\text { and contingent pay (stock options, } \\
\text { bonuses and long-term incentive plans) }\end{array}$ & $\begin{array}{l}\text { Compensation committees with a higher proportion of } \\
\text { affiliated directors, interdependent directors }{ }^{2225} \text {, or CEO } \\
\text { directors were not associated with the level of CEO } \\
\text { compensation. }\end{array}$ \\
\hline $\begin{array}{l}\text { Newman \& } \\
\text { Mozes (1999) }\end{array}$ & $\begin{array}{l}161 \text { Fortune } 250 \\
\text { firms in } 1992\end{array}$ & $\begin{array}{l}\text { The presence of at least one } \\
\text { inside director on the } \\
\text { compensation committee }\end{array}$ & $\begin{array}{l}\text { The sum of salaries, bonuses, other } \\
\text { annual compensation, restricted stock } \\
\text { awards, long-term incentive payouts } \\
\text { and all other compensation. }\end{array}$ & $\begin{array}{l}\text { CEO compensation was not significantly higher in firms } \\
\text { that had at least one non-independent director on the } \\
\text { compensation committee than in firms that had an entirely } \\
\text { independent compensation committee. }\end{array}$ \\
\hline Vafeas (2003) & $\begin{array}{l}271 \text { US firms during } \\
\text { the year } 1991 \text { to } \\
1997\end{array}$ & $\begin{array}{l}\text { The presence of inside } \\
\text { directors on the } \\
\text { compensation committee }\end{array}$ & $\begin{array}{l}\text { The sum of non-contingent (fixed) and } \\
\text { contingent (variable) pay }\end{array}$ & $\begin{array}{l}\text { The presence of inside directors on the compensation } \\
\text { committee was not associated with the total CEO } \\
\text { compensation level. }\end{array}$ \\
\hline $\begin{array}{l}\text { Anderson \& } \\
\text { Bizjak (2003) }\end{array}$ & $\begin{array}{l}110 \text { New York } \\
\text { Stock Exchange } \\
\text { firms from } 1985 \text { to } \\
1998\end{array}$ & $\begin{array}{l}\text { Proportion of independent } \\
\text { directors on the } \\
\text { compensation committee }\end{array}$ & $\begin{array}{l}\text { The sum of fixed compensation (salary } \\
\text { and bonus) and contingent } \\
\text { compensation (new options grants and } \\
\text { option portfolio) }\end{array}$ & $\begin{array}{l}\text { The proportion of independent directors on the } \\
\text { compensation committee was not associated with the level } \\
\text { of executive compensation. }\end{array}$ \\
\hline $\begin{array}{l}\text { Conyon \& He } \\
(2004)\end{array}$ & $\begin{array}{l}455 \text { US firms } \\
\text { completing an } \\
\text { initial public } \\
\text { offering in } 1999 \\
\end{array}$ & $\begin{array}{l}\text { Proportion of inside } \\
\text { directors on the board }\end{array}$ & $\begin{array}{l}\text { The sum of base salary, annual bonus, } \\
\text { long-term incentive, restricted stock, } \\
\text { stock-option grants and other } \\
\text { compensation. }\end{array}$ & $\begin{array}{l}\text { Compensation committees with a higher proportion of } \\
\text { insiders or CEOs from other firms were not associated with } \\
\text { the level of CEO pay or CEO equity incentives. }\end{array}$ \\
\hline $\begin{array}{l}\text { Conyon \& } \\
\text { Kuchinskas } \\
(2006)\end{array}$ & $\begin{array}{l}\text { Approximately } \\
1,500 \text { firms from } \\
1998 \text { to } 2003 \\
\end{array}$ & $\begin{array}{l}\text { Proportion of non- } \\
\text { independent directors on the } \\
\text { compensation committee }\end{array}$ & $\begin{array}{l}\text { The sum of salaries, bonuses, other } \\
\text { cash, restricted stock grants, and Black- } \\
\text { Scholes grant value of options }\end{array}$ & $\begin{array}{l}\text { The proportion of non-independent directors on the } \\
\text { compensation committee was not associated with the level } \\
\text { of total CEO compensation. }\end{array}$ \\
\hline $\begin{array}{l}\text { Chhaochharia } \\
\text { \& Grinstein } \\
(2009)\end{array}$ & $\begin{array}{l}865 \text { firms in the } \\
\text { S\&P } 1500 \text { index for } \\
\text { the years } 2000 \text { to } \\
2005\end{array}$ & $\begin{array}{l}\text { Compensation committee } \\
\text { composed entirely of } \\
\text { independent directors }\end{array}$ & $\begin{array}{l}\text { The sum of base salary, bonuses, } \\
\text { options (Black-Scholes value), } \\
\text { restricted stocks, and other } \\
\text { compensation }\end{array}$ & $\begin{array}{l}\text { The level of executive remuneration was not significantly } \\
\text { different between firms that did not comply with the } \\
\text { complete independent compensation committee } \\
\text { requirements (prior to the enactment of the new rules) and } \\
\text { firms that did comply with the requirements. }\end{array}$ \\
\hline Wan (2009) & $\begin{array}{l}865 \text { firms in the } \\
\text { S\&P } 1500 \text { index for } \\
\text { the years } 2000 \text { to } \\
2005\end{array}$ & $\begin{array}{l}\text { Compensation committee } \\
\text { composed entirely of } \\
\text { independent directors }\end{array}$ & $\begin{array}{l}\text { The sum of base salary, bonuses, } \\
\text { options (Black-Scholes value), } \\
\text { restricted stocks, and other } \\
\text { compensation }\end{array}$ & $\begin{array}{l}\text { The new stock exchange requirements regarding a } \\
\text { compensation committee with complete independence were } \\
\text { associated with greater CEO compensation. The total of } \\
\text { CEO compensation was } 7.25 \% \text { higher. }\end{array}$ \\
\hline
\end{tabular}

${ }^{2225}$ Interdependent directors are defined as directors who are appointed during the tenure of an incumbent CEO. 


\section{Appendix 10 (Continued)}

Table B: Studies Regarding the Correlation between Compensation Committee Independence and the Sensitivity of CEO Compensation to Firm Performance

\begin{tabular}{|c|c|c|c|c|}
\hline Studies & Sample & $\begin{array}{l}\text { Measure of } \\
\text { Compensation } \\
\text { Committee } \\
\text { Independence }\end{array}$ & $\begin{array}{l}\text { Measure of Sensitivity of Pay- } \\
\text { for-performance }\end{array}$ & Findings \\
\hline $\begin{array}{l}\text { Newman \& } \\
\text { Mozes (1999) }\end{array}$ & $\begin{array}{l}161 \text { Fortune } 250 \\
\text { firms in } 1992\end{array}$ & $\begin{array}{l}\text { The presence of at least } \\
\text { one inside director on } \\
\text { the compensation } \\
\text { committee }\end{array}$ & $\begin{array}{l}\text { The change in annual and } \\
\text { long-term CEO compensation } \\
\text { (salaries, annual bonuses, } \\
\text { restricted stock awards, long- } \\
\text { term incentive payouts and } \\
\text { stock options) between } 1991 \\
\text { and } 1992\end{array}$ & $\begin{array}{l}\text { (1) Compensation committees with at least } \\
\text { one non-independent director were more } \\
\text { likely to shield CEOs from the impact of } \\
\text { poor performance than those composed } \\
\text { of fully independent directors. } \\
\text { (2) CEO compensation was not related to } \\
\text { firm performance when compensation } \\
\text { committees consisted entirely of } \\
\text { independent directors. }\end{array}$ \\
\hline Vafeas (2003) & $\begin{array}{l}271 \text { US firms } \\
\text { during the year } \\
1991 \text { to } 1997\end{array}$ & $\begin{array}{l}\text { The presence of inside } \\
\text { directors on the } \\
\text { compensation } \\
\text { committee }\end{array}$ & $\begin{array}{l}\text { CEO contingent compensation } \\
\text { ( stock options) }\end{array}$ & $\begin{array}{l}\text { The presence of inside directors on the } \\
\text { compensation committee was not associated } \\
\text { with the level of CEO contingent } \\
\text { compensation. }\end{array}$ \\
\hline $\begin{array}{l}\text { Anderson \& } \\
\text { Bizjak (2003) }\end{array}$ & $\begin{array}{l}110 \text { New York } \\
\text { Stock Exchange } \\
\text { firms from } 1985 \\
\text { to } 1998\end{array}$ & $\begin{array}{l}\text { Proportion of } \\
\text { independent directors on } \\
\text { the compensation } \\
\text { committee }\end{array}$ & $\begin{array}{l}\text { CEO contingent compensation } \\
\text { (new options grants and option } \\
\text { portfolio) }\end{array}$ & $\begin{array}{l}\text { Stock options for CEOs were not } \\
\text { significantly different between compensation } \\
\text { committees with a higher proportion of } \\
\text { independent directors and those consisting of } \\
\text { inside directors. }\end{array}$ \\
\hline $\begin{array}{l}\text { Conyon \& He } \\
(2004)\end{array}$ & $\begin{array}{l}455 \text { US firms } \\
\text { completing an } \\
\text { initial public } \\
\text { offering in } 1999\end{array}$ & $\begin{array}{l}\text { Proportion of inside } \\
\text { directors on the } \\
\text { compensation } \\
\text { committee }\end{array}$ & $\begin{array}{l}\text { CEO equity incentives (stock } \\
\text { and stock-option) }\end{array}$ & $\begin{array}{l}\text { The proportion of inside directors on the } \\
\text { compensation committee was not associated } \\
\text { with the level of CEO equity incentives. }\end{array}$ \\
\hline
\end{tabular}




\section{Appendix 11}

\section{Summary of US Empirical Studies Investigating the Correlation between Nominating Committee Characteristics and}

the Missions of the Committee

Table A: Studies Regarding the Correlation between the Existence of Nominating Committee and Firm Performance

\begin{tabular}{|l|l|l|l|}
\hline \multicolumn{1}{|c|}{ Studies } & \multicolumn{1}{|c|}{ Sample } & $\begin{array}{l}\text { Measure of Firm } \\
\text { Performance }\end{array}$ & \multicolumn{1}{|c|}{ Findings } \\
\hline $\begin{array}{l}\text { Hayes, Mehran \& } \\
\text { Schaefer (2004) }\end{array}$ & $\begin{array}{l}\text { 509 S\&P 500 firms } \\
\text { from 1997 to 1998 }\end{array}$ & $\begin{array}{l}\text { Market to book } \\
\text { ratio }\end{array}$ & $\begin{array}{l}\text { The presence of a nominating committee was not associated with } \\
\text { firm performance. }\end{array}$ \\
\hline $\begin{array}{l}\text { Chllahan, Millar \& } \\
\text { Schulman (2003) }\end{array}$ & $\begin{array}{l}\text { 106 Fortune 1000 } \\
\text { firms between 1990 } \\
\text { and 1993 }\end{array}$ & Tobin's Q & $\begin{array}{l}\text { The presence of a separate nominating committee and lack of } \\
\text { involvement by the CEO were associated with poorer firm } \\
\text { performance }\end{array}$ \\
\hline $\begin{array}{l}\text { Brick \& Chidambaran } \\
\text { (2007) }\end{array}$ & $\begin{array}{l}\text { 4298 firm-year } \\
\text { observations from } \\
\text { 1999 to 2005 }\end{array}$ & $\begin{array}{l}\text { Tobin's Q } \\
\text { nominating committee, but such decisions had no impact on } \\
\text { subsequent firm value within the year of the adoption. }\end{array}$ & \\
\hline
\end{tabular}

Table B: Studies Regarding the Correlation between Nominating Committee Independence and Firm Performance

\begin{tabular}{|c|c|c|c|c|}
\hline Studies & Sample & $\begin{array}{l}\text { Measure of Nominating } \\
\text { Committee Independence }\end{array}$ & $\begin{array}{c}\text { Measure of Firm } \\
\text { Performance }\end{array}$ & Findings \\
\hline $\begin{array}{l}\text { Hayes, Mehran } \\
\& \text { Schaefer } \\
(2004)\end{array}$ & $\begin{array}{l}509 \text { S\&P } 500 \text { firms from } \\
1997 \text { to } 1998\end{array}$ & $\begin{array}{l}\text { Proportion of outside } \\
\text { directors on the } \\
\text { nominating committee }\end{array}$ & $\begin{array}{l}\text { Market to book } \\
\text { ratio }\end{array}$ & $\begin{array}{l}\text { The proportion of outside directors on the } \\
\text { nominating committee was not related to market } \\
\text { to book ratio. }\end{array}$ \\
\hline $\begin{array}{l}\text { Brown \& } \\
\text { Caylor }(2006)\end{array}$ & $\begin{array}{l}2,363 \text { firms from } \\
\text { Institutional Shareholder } \\
\text { Services database in } \\
2003\end{array}$ & $\begin{array}{l}\text { A nominating committee } \\
\text { comprised solely of } \\
\text { independent directors }\end{array}$ & Tobin's Q & $\begin{array}{l}\text { A nominating committee comprised solely of } \\
\text { independent directors was not associated with } \\
\text { current or subsequent firm performance (Tobin's } \\
\text { Q). }\end{array}$ \\
\hline $\begin{array}{l}\text { Brown \& } \\
\text { Caylor (2009) }\end{array}$ & $\begin{array}{l}\text { 2,363 firms from } \\
\text { Institutional Shareholder } \\
\text { Services database in } \\
2003\end{array}$ & $\begin{array}{l}\text { A nominating committee } \\
\text { comprised solely of } \\
\text { independent directors }\end{array}$ & ROA \& ROE & $\begin{array}{l}\text { A nominating committee comprised solely of } \\
\text { independent directors was not associated with } \\
\text { current or subsequent firm performance (ROA, } \\
\text { ROE). }\end{array}$ \\
\hline
\end{tabular}




\section{Appendix 12}

\section{Summary of US Empirical Studies Investigating the Impact of Female and Ethnic Minority on the Effectiveness of}

Independent Directors

Table A: Studies Regarding the Relationship between Ethnic Minority Directors on the Board and Firm Performance

\begin{tabular}{|c|c|c|c|c|}
\hline Studies & Sample & $\begin{array}{l}\text { Measure of Ethnic } \\
\text { Minority Directors on } \\
\text { the Board }\end{array}$ & $\begin{array}{l}\text { Measure of } \\
\quad \text { Firm } \\
\text { Performance }\end{array}$ & Findings \\
\hline $\begin{array}{l}\text { Erhardt, } \\
\text { Werbel \& } \\
\text { Shrader (2003) }\end{array}$ & $\begin{array}{l}112 \text { large US firms in } \\
1993 \text { and } 1998\end{array}$ & $\begin{array}{l}\text { Proportion of minority } \\
\text { (African, Hispanic, } \\
\text { Asian and Native } \\
\text { American) and female } \\
\text { on the board }\end{array}$ & $\begin{array}{l}\text { ROA, return } \\
\text { on investment }\end{array}$ & $\begin{array}{l}\text { There was a positive and significant } \\
\text { relationship between the proportion of } \\
\text { minority directors on the board and ROA } \\
\text { and ROI. }\end{array}$ \\
\hline $\begin{array}{l}\text { Carter, } \\
\text { Simkins \& } \\
\text { Simpson } \\
(2003)\end{array}$ & $\begin{array}{l}638 \text { Fortune } 1000 \\
\text { firms in the year } 1997\end{array}$ & $\begin{array}{l}\text { The presence or the } \\
\text { proportion of African } \\
\text { Americans, Asians and } \\
\text { Hispanics on the board }\end{array}$ & Tobin's Q & $\begin{array}{l}\text { There was a positive and significant } \\
\text { relationship between the proportion (and the } \\
\text { presence) of minority directors on the board } \\
\text { and Tobin's Q. }\end{array}$ \\
\hline $\begin{array}{l}\text { Carter et al. } \\
(2008)\end{array}$ & $\begin{array}{l}\text { Almost all Fortune } \\
500 \text { firms in the five } \\
\text { year period from } 1998 \\
\text { to } 2002\end{array}$ & $\begin{array}{l}\text { The presence or the } \\
\text { proportion of Asians, } \\
\text { Latinos and African } \\
\text { Americans on the board }\end{array}$ & Tobin's Q & $\begin{array}{l}\text { There was a positive and significant } \\
\text { relationship between the proportion of } \\
\text { minority directors on the board and Tobin's } \\
\text { Q. The causation goes from the ethnic } \\
\text { minorities on the board to Tobin's Q. }\end{array}$ \\
\hline $\begin{array}{l}\text { Millar \& } \\
\text { Triana }(2009)\end{array}$ & $\begin{array}{l}326 \text { Fortune } 500 \text { firms } \\
\text { between } 2002 \text { and } \\
2005\end{array}$ & $\begin{array}{l}\text { Proportion of minority } \\
\text { directors on the board }\end{array}$ & $\begin{array}{l}\text { Firm } \\
\text { innovation, } \\
\text { firm reputation }\end{array}$ & $\begin{array}{l}\text { Board racial diversity indirectly increased } \\
\text { firm performance via the improvement of } \\
\text { innovation and reputation. }\end{array}$ \\
\hline
\end{tabular}




\section{Appendix 12 (Continued)}

Table B: Studies Regarding the Relationship between Ethnic Minority Directors on the Three Monitoring Committees and Firm Performance

\begin{tabular}{|c|c|c|c|c|}
\hline Studies & Sample & $\begin{array}{l}\text { Measure of the } \\
\text { Monitoring Committee } \\
\text { Independence }\end{array}$ & $\begin{array}{l}\text { Measure of } \\
\text { Firm } \\
\text { Performanc } \\
\text { e }\end{array}$ & Findings \\
\hline $\begin{array}{l}\text { Carter et al. } \\
(2008)\end{array}$ & $\begin{array}{l}\text { Almost all } \\
\text { Fortune } 500 \\
\text { firms in the } \\
\text { five year } \\
\text { period from } \\
1998 \text { to } 2002\end{array}$ & $\begin{array}{l}\text { Whether the audit/ } \\
\text { compensation/nominati } \\
\text { ng committee was } \\
\text { comprised solely of } \\
\text { independent directors }\end{array}$ & Tobin's Q & $\begin{array}{l}\text { (1) There was a positive and significant relationship } \\
\text { between the percentage of minority directors on the } \\
\text { three monitoring committees and Tobin's Q. The } \\
\text { causation goes from the committee ethnic minorities } \\
\text { to Tobin's Q. } \\
\text { (2) Only the positive impact of audit committee } \\
\text { minority directors on firm performance could be } \\
\text { mostly attributed to the effort of minority } \\
\text { independent directors on the audit committee, since } \\
\text { the audit committee has been required to be } \\
\text { composed entirely of independent directors since } \\
1999 \text { (similar requirements for the compensation and } \\
\text { nominating committees start from 2003). }\end{array}$ \\
\hline
\end{tabular}




\section{Appendix 12 (Continued)}

Table C: Studies Regarding the Correlation between Female Directors on the Board and Firm Performance

\begin{tabular}{|c|c|c|c|c|}
\hline Studies & Sample & $\begin{array}{c}\text { Measure of Female } \\
\text { Directors on the Board }\end{array}$ & $\begin{array}{l}\text { Measure of Firm } \\
\text { Performance }\end{array}$ & Findings \\
\hline $\begin{array}{l}\text { Shrader, } \\
\text { Blackburn \& } \\
\text { Iles (1997) } \\
\end{array}$ & $\begin{array}{l}200 \text { US firms with the } \\
\text { largest market value in } \\
1992\end{array}$ & $\begin{array}{l}\text { Proportion of female on } \\
\text { the board }\end{array}$ & $\begin{array}{l}\text { ROA, ROE, } \\
\text { return on } \\
\text { income }\end{array}$ & $\begin{array}{l}\text { There was no significant correlation between the } \\
\text { proportion of women on the board and firm } \\
\text { performance. }\end{array}$ \\
\hline $\begin{array}{l}\text { Erhardt, Werbel } \\
\text { \& Shrader } \\
(2003)\end{array}$ & $\begin{array}{l}112 \text { large US firms in } \\
1993 \text { and } 1998\end{array}$ & $\begin{array}{l}\text { Proportion of female on } \\
\text { the board }\end{array}$ & $\begin{array}{l}\text { ROA, return on } \\
\text { investment }\end{array}$ & $\begin{array}{l}\text { There was a positive and significant relationship } \\
\text { between the proportion of female directors on } \\
\text { the board and ROA and ROI. }\end{array}$ \\
\hline $\begin{array}{l}\text { Carter, Simkins } \\
\text { \& Simpson } \\
(2003)\end{array}$ & $\begin{array}{l}638 \text { Fortune } 1000 \text { firms } \\
\text { in the year } 1997\end{array}$ & $\begin{array}{l}\text { The presence or the } \\
\text { Proportion of female } \\
\text { directors on the board }\end{array}$ & Tobin's Q & $\begin{array}{l}\text { There was a positive and significant relationship } \\
\text { between the proportion (and the presence) of } \\
\text { female directors on the board and Tobin's Q. }\end{array}$ \\
\hline $\begin{array}{l}\text { Carter et al. } \\
(2008)\end{array}$ & $\begin{array}{l}\text { Almost all Fortune } 500 \\
\text { firms in the five year } \\
\text { period from } 1998 \text { to } \\
2002\end{array}$ & $\begin{array}{l}\text { The presence or the } \\
\text { Proportion of female } \\
\text { directors on the board }\end{array}$ & Tobin's Q & $\begin{array}{l}\text { There was a positive and significant relationship } \\
\text { between the percentage of female directors on } \\
\text { the board and Tobin's Q. The causation goes } \\
\text { from the female directors to Tobin's Q. }\end{array}$ \\
\hline $\begin{array}{l}\text { Farrell \& } \\
\text { Hersch (2005) }\end{array}$ & $\begin{array}{l}309 \text { Fortune } 500 \text { firms } \\
\text { from } 1990 \text { to } 1999\end{array}$ & $\begin{array}{l}\text { Proportion of female } \\
\text { outside directors on the } \\
\text { board, female directors } \\
\text { added to the board }\end{array}$ & $\begin{array}{l}\text { ROA, market } \\
\text { reaction } \\
\text { (cumulative } \\
\text { abnormal return) }\end{array}$ & $\begin{array}{l}\text { (1) Firms adding more female outside directors } \\
\text { to their boards had no significant impact on } \\
\text { their subsequent firm performance. } \\
\text { (2) There was no significant wealth impact } \\
\text { around the announcement date of a woman } \\
\text { being added to the board. }\end{array}$ \\
\hline $\begin{array}{l}\text { Adams \& } \\
\text { Ferreira (2009) }\end{array}$ & $\begin{array}{l}\text { 1,939 S\&P 500, S\&P } \\
\text { MidCaps and S\&P } \\
\text { SmallCap firms }(8,253 \\
\text { firm-year) from } 1996 \text { to } \\
2003\end{array}$ & $\begin{array}{l}\text { Proportion of female } \\
\text { directors on the board }\end{array}$ & Tobin's Q & $\begin{array}{l}\text { There was no consistent relationship between } \\
\text { the proportion of female directors on the board } \\
\text { and Tobin's Q between different regression } \\
\text { models, and the value of a gender-diverse board } \\
\text { depended on the strength of the governance } \\
\text { environment in the firm. }\end{array}$ \\
\hline
\end{tabular}




\section{Appendix 12 (Continued)}

Table D: Studies Regarding the Correlation between Female Directors on Three Monitoring Committees and Firm Performance

\begin{tabular}{|c|c|c|c|c|}
\hline Studies & Sample & $\begin{array}{c}\text { Measure of the } \\
\text { Monitoring Committee } \\
\text { Independence }\end{array}$ & $\begin{array}{l}\text { Measure of } \\
\text { Firm } \\
\text { Performanc } \\
\mathrm{e} \\
\end{array}$ & Findings \\
\hline $\begin{array}{l}\text { Carter et al. } \\
(2008)\end{array}$ & $\begin{array}{l}\text { Almost all } \\
\text { Fortune } 500 \\
\text { firms in the } \\
\text { five year } \\
\text { period from } \\
1998 \text { to } 2002\end{array}$ & $\begin{array}{l}\text { Whether the audit/ } \\
\text { compensation/nominati } \\
\text { ng committee was } \\
\text { comprised solely of } \\
\text { independent directors }\end{array}$ & Tobin's Q & $\begin{array}{l}\text { (1) Female directors had a positive impact on firm } \\
\text { performance when they served on the audit } \\
\text { committee, but there was no clear evidence that firm } \\
\text { performance was enhanced when they served on the } \\
\text { compensation committee and nominating } \\
\text { committees. } \\
\text { (2) The positive impact of audit committee female } \\
\text { directors on firm performance could be mostly } \\
\text { attributed to the effort of female independent } \\
\text { directors on the audit committee, since the audit } \\
\text { committee has been required to be composed } \\
\text { entirely of independent directors since } 1999 \text { (similar } \\
\text { requirements for the compensation and nominating } \\
\text { committees start from 2003). }\end{array}$ \\
\hline
\end{tabular}




\section{Appendix 12 (Continued)}

Table E: Studies Regarding the Correlation between Female Directors on the Audit Committee and the Task of the Audit

\section{Committee}

\begin{tabular}{|c|c|c|c|c|}
\hline Studies & Sample & $\begin{array}{l}\text { Measure of the Female } \\
\text { Directors on the Audit } \\
\text { Committee }\end{array}$ & $\begin{array}{l}\text { Measure of } \\
\text { the Audit } \\
\text { Committee } \\
\text { Task }\end{array}$ & Findings \\
\hline $\begin{array}{l}\text { Gul, Srinidhi \& } \\
\text { Tsui (2007) }\end{array}$ & $\begin{array}{l}\text { about } 750 \text { US firms } \\
(1,508 \text { firm-years) for } \\
\text { the period } 2001 \text { to } \\
2002\end{array}$ & $\begin{array}{l}\text { At least one female } \\
\text { director on the audit } \\
\text { committee }\end{array}$ & $\begin{array}{l}\text { Earnings } \\
\text { management }\end{array}$ & $\begin{array}{l}\text { (1) Audit committees with at least one female director } \\
\text { were less likely to manage earnings. } \\
\text { (2) The lower earnings management could be } \\
\text { attributed to the effort of female independent } \\
\text { directors on the audit committee because the audit } \\
\text { committee has been required to be composed } \\
\text { entirely of independent directors since } 1999 .\end{array}$ \\
\hline $\begin{array}{l}\text { Gul, Srinidhi \& } \\
\text { Tsui (2008) }\end{array}$ & $\begin{array}{l}\text { about } 900 \text { US firms } \\
(2,784 \text { firm-years) for } \\
\text { the period } 2001 \text { to } \\
2003\end{array}$ & $\begin{array}{l}\text { The presence (or the } \\
\text { proportion) of non- } \\
\text { executive female director } \\
\text { on the audit committee }\end{array}$ & Audit fees & $\begin{array}{l}\text { Audit fees were higher (demanding higher audit effort } \\
\text { from their auditors) in corporations with female } \\
\text { directors on the audit committee. }\end{array}$ \\
\hline $\begin{array}{l}\text { Ittonen, } \\
\text { Miettinen \& } \\
\text { Vähämaa } \\
\text { (2008) }\end{array}$ & $\begin{array}{l}\text { S\&P } 500 \text { firms from } \\
2006 \text { to } 2008 \text { ( } 941 \\
\text { firm-year } \\
\text { observations) }\end{array}$ & $\begin{array}{l}\text { Female audit committee } \\
\text { chair, additional female } \\
\text { director on the audit } \\
\text { committee }\end{array}$ & Audit fees & $\begin{array}{l}\text { Audit fees were lower in corporations with female } \\
\text { audit committee chairs and/or at least additional female } \\
\text { director on the audit committee. }\end{array}$ \\
\hline
\end{tabular}




\section{Appendix 12 (Continued)}

Table F: Studies Regarding the Relationship between Female Directors and Other Discrete Board Tasks

\begin{tabular}{|l|l|l|l|l|}
\hline \multicolumn{1}{|c|}{ Studies } & \multicolumn{1}{|c|}{ Sample } & $\begin{array}{c}\text { Measure of the } \\
\text { Female Directors on } \\
\text { the Audit Committee }\end{array}$ & $\begin{array}{l}\text { Measure of } \\
\text { the Board } \\
\text { Task }\end{array}$ & \multicolumn{1}{|c|}{ Findings } \\
\hline $\begin{array}{l}\text { Adams \& } \\
(2009)\end{array}$ & $\begin{array}{l}\text { 1,939 S\&P 500, S\&P } \\
\text { MidCaps and S\&P } \\
\text { SmallCap firms (8,253 } \\
\text { firm-year) from 1996 } \\
\text { to 2003 }\end{array}$ & $\begin{array}{l}\text { Proportion of female } \\
\text { directors on the } \\
\text { board }\end{array}$ & $\begin{array}{l}\text { CEO } \\
\text { turnover, } \\
\text { attendance, } \\
\text { the level of } \\
\text { CEO pay }\end{array}$ & $\begin{array}{l}\text { (1) Female directors were more likely to dismiss } \\
\text { incompetent CEOs and to attend board } \\
\text { meetings in carrying out their duties, } \\
\text { compared to their male counterparts. } \\
\text { (2) The proportion of female directors on the } \\
\text { board had no significant impact on the } \\
\text { proportion of CEO incentive pay and the level } \\
\text { of CEO compensation. }\end{array}$ \\
\hline $\begin{array}{l}\text { Levi, Li \& } \\
\text { Zhang (2008) }\end{array}$ & $\begin{array}{l}403 \text { acquisition } \\
\text { attempts from 1997 to } \\
2006\end{array}$ & $\begin{array}{l}\text { Proportion of } \\
\text { independent female } \\
\text { directors on the } \\
\text { board }\end{array}$ & $\begin{array}{l}\text { Bid } \\
\text { premium } \\
\text { during } \\
\text { acquisition }\end{array}$ & $\begin{array}{l}\text { Each 10\% representation of independent female } \\
\text { directors on the target boards reduced the bid } \\
\text { premium by 15\% during mergers and acquisition. }\end{array}$ \\
\hline
\end{tabular}




\section{Appendix 13}

Summary of US Empirical Studies Investigating the Impact of Director Ownership on the Effectiveness of Independent Directors

Table A: Studies Regarding the Relationship between Director Ownership and Firm Performance

\begin{tabular}{|l|l|l|l|l|}
\hline \multicolumn{1}{|c|}{ Studies } & \multicolumn{1}{|c|}{ Sample } & $\begin{array}{l}\text { Measure of the } \\
\text { Director } \\
\text { Ownership }\end{array}$ & $\begin{array}{l}\text { Measure of } \\
\text { Firm } \\
\text { Performance }\end{array}$ & \multicolumn{1}{|c|}{ Findings } \\
\hline $\begin{array}{l}\text { Bhagat, Carey } \\
\text { \& Elson } \\
(1999)\end{array}$ & $\begin{array}{l}449 \text { firms from 1990 to } \\
1995\end{array}$ & $\begin{array}{l}\text { Dollar value of } \\
\text { the median } \\
\text { director's stock } \\
\text { holdings }\end{array}$ & $\begin{array}{l}\text { Sales growth, } \\
\text { income } \\
\text { growth, ROA } \\
\text { and stock } \\
\text { return }\end{array}$ & $\begin{array}{l}\text { The dollar value of the median director's stock } \\
\text { holdings was positively related to company's } \\
\text { subsequent sales growth and income growth, but } \\
\text { was not associated with ROA and stock return. }\end{array}$ \\
\hline $\begin{array}{l}\text { Bhagat \& } \\
\text { Bolton (2008) }\end{array}$ & $\begin{array}{l}\text { More than 10,000 } \\
\text { firms during the period } \\
1990 \text { to 2004 }\end{array}$ & $\begin{array}{l}\text { Dollar value of } \\
\text { the median } \\
\text { director's stock } \\
\text { holdings }\end{array}$ & $\begin{array}{l}\text { ROA } \\
\text { Dollar value of } \\
\text { the median } \\
\text { director's stock } \\
\text { holdings }\end{array}$ & $\begin{array}{l}\text { ROA dollar value of the median director's stock } \\
\text { holdings was significantly and positively } \\
\text { correlated with contemporaneous and subsequent } \\
\text { ROA. }\end{array}$ \\
\hline $\begin{array}{l}\text { Bhagat \& } \\
\text { Bolton }(2009)\end{array}$ & from 1998 to 2007 large US firms & $\begin{array}{l}\text { The dollar value of the median director's stock } \\
\text { holdings was significantly and positively } \\
\text { correlated with contemporaneous and subsequent } \\
\text { ROA in both pre-SOX and post-SOX period. }\end{array}$ \\
\hline
\end{tabular}




\section{Appendix 13 (Continued)}

Table B: Studies Regarding the Relationship between Independent Director Ownership and Firm Performance

\begin{tabular}{|c|c|c|c|c|}
\hline Studies & Sample & $\begin{array}{c}\text { Measure of the Director Equity } \\
\text { Holdings }\end{array}$ & $\begin{array}{l}\text { Measure of } \\
\text { Firm } \\
\text { Performance }\end{array}$ & Findings \\
\hline $\begin{array}{l}\text { Morck, Shleifer } \\
\text { \& Vishny (1988) }\end{array}$ & $\begin{array}{l}371 \text { Fortune } 500 \\
\text { firms in the year } \\
1980\end{array}$ & Outside director ownership ${ }^{2226}$ & Tobin's Q & $\begin{array}{l}\text { (1) There was a significant correlation between outside } \\
\text { director share ownership and current and next year's } \\
\text { Tobin's Q, but the correlation was not monotonic. } \\
\text { (2) Firm performance increased as outside director share } \\
\text { ownership rose from } 0 \% \text { to } 5 \% \text {. When share ownership } \\
\text { rose from } 5 \% \text { to } 25 \% \text {, firm performance fell. Firm } \\
\text { performance increased again as share ownership rose } \\
\text { beyond } 25 \% \text {. }\end{array}$ \\
\hline $\begin{array}{l}\text { Hambrick \& } \\
\text { Jackson }(2000)\end{array}$ & $\begin{array}{l}\text { firms drawn from } \\
\text { Project Evergreen } \\
\text { for the years } 1987 \text {, } \\
1992 \text { and } 1996\end{array}$ & $\begin{array}{l}\text { (1) Percentage of firm share } \\
\text { owned by outside directors } \\
\text { (not defined), } \\
\text { (2) Dollar value of each outside } \\
\text { director's (not defined) } \\
\text { holdings and } \\
\text { (3) The number of outside } \\
\text { directors (not defined) who } \\
\text { hold significant stakes }\end{array}$ & $\begin{array}{l}\text { Star Firms } \\
\text { vs. Laggard } \\
\text { Firms }^{2228}\end{array}$ & $\begin{array}{l}\text { Outside directors (not defined) in firms that successively } \\
\text { outperformed their industries (Star Firms) had greater equity } \\
\text { holdings than their counterparts in firms that apparently } \\
\text { lagged behind their industries (Laggard Firms). }\end{array}$ \\
\hline Klein (1998) & $\begin{array}{l}461 \text { corporations } \\
\text { listed on the } S \& P \text { in } \\
1992 \text { and } 1993\end{array}$ & $\begin{array}{l}\text { at least one independent director } \\
\text { holding at least } 5 \% \text { of the firm's } \\
\text { equity }\end{array}$ & $\begin{array}{l}\text { ROA, Jensen } \\
\text { Productivity \& } \\
\text { market returns }\end{array}$ & $\begin{array}{l}\text { Firms with the presence of at least one independent director } \\
\text { holding at least } 5 \text { percent of the firm's equity were } \\
\text { associated with (one out of three) firm performance } \\
\text { indicators (Jensen Productivity). }\end{array}$ \\
\hline $\begin{array}{l}\text { Bhagat \& Black } \\
(2002)\end{array}$ & $\begin{array}{l}928 \text { large US Firms } \\
\text { from } 1985 \text { to } 1995\end{array}$ & $\begin{array}{l}\text { independent director ownership } \\
\text { (not defined) }\end{array}$ & $\begin{array}{l}\text { Tobin's Q, } \\
\text { ROA, ratio of } \\
\text { sales to assets }\end{array}$ & $\begin{array}{l}\text { Firms with independent directors who hold significant stock } \\
\text { positions were associated with enhanced firm performance } \\
\text { (significant in ROA and ratio of sales to assets). }\end{array}$ \\
\hline
\end{tabular}

${ }^{2226}$ Outside director ownership in this study only excludes the holdings of the two top senior inside directors (usually the chairperson and the president), but still includes the holdings of other inside directors (such as vice-presidents).

${ }^{2227}$ A Star Firm is defined as a firm with total returns to shareholders (TRS) at least $10 \%$ above the median TRS for the firm's sector for two five-year periods, 1987 to 1991 and 1992 to 1996.

${ }^{2228}$ A Laggard Firm refers to a company with a TRS at least $10 \%$ below the median TRS for the company's sector for the same two five-year periods. 


\section{Appendix 13 (Continued)}

\section{Table C: Studies Regarding the Impact of Director Incentive Compensation on Shareholder Interests}

\section{Panel 1: The (Positive) Impact of Stock Options on Firm Performance}

\begin{tabular}{|c|c|c|c|c|}
\hline Studies & Sample & $\begin{array}{c}\text { Measure of the Director } \\
\text { Stock Options }\end{array}$ & $\begin{array}{c}\text { Measure of Firm } \\
\text { Performance }\end{array}$ & Findings \\
\hline $\begin{array}{l}\text { Fich \& } \\
\text { Shivdasani } \\
(2005)\end{array}$ & $\begin{array}{l}774 \text { Fortune } \\
1000 \text { firms } \\
\text { from } 1997 \text { to } \\
1999\end{array}$ & $\begin{array}{l}\text { (1) The presence of a stock- } \\
\text { option plan for } \\
\text { independent directors; } \\
\text { (2) The announcements of } \\
\text { the adoption of stock- } \\
\text { option plans for } \\
\text { independent directors; } \\
\text { (3) The appointment of an } \\
\text { independent director } \\
\text { with stock-option } \\
\text { compensation }\end{array}$ & $\begin{array}{l}\text { The value of } \\
\text { market-to-book } \\
\text { ratio, ROA, } \\
\text { ROS, and asset } \\
\text { turnover, } \\
\text { cumulative } \\
\text { abnormal } \\
\text { returns }\end{array}$ & $\begin{array}{l}\text { (1) The presence of a stock-option plan for } \\
\text { independent directors was significantly and } \\
\text { positively correlated with the value of market-to- } \\
\text { book ratio, ROA, ROS, and asset turnover. } \\
\text { (2) The three-day mean cumulative abnormal returns } \\
\text { were significantly and positively associated with } \\
\text { the announcements of the adoption of stock-option } \\
\text { plans for independent directors. } \\
\text { (3) The cumulative abnormal returns (market } \\
\text { reactions) to the appointments of independent } \\
\text { directors were significantly negative when firms } \\
\text { did not offer stock-option compensation for } \\
\text { independent directors. However, the cumulative } \\
\text { abnormal returns turned close to zero for firms } \\
\text { with stock-option plans. }\end{array}$ \\
\hline $\begin{array}{l}\text { Cordeiro, } \\
\text { Veliyath \& } \\
\text { Neubaum } \\
(2005)\end{array}$ & $\begin{array}{l}450 \mathrm{~S} \& \mathrm{P} 500 \\
\text { firms during } \\
\text { the period } 1995 \\
\text { to } 1997\end{array}$ & $\begin{array}{l}\text { Outside director stock option } \\
\text { ratio (the ratio of dollar stock } \\
\text { option compensation }{ }^{2229} \text { to } \\
\text { total dollar director } \\
\text { compensation) }\end{array}$ & $\begin{array}{l}\text { Stock returns, } \\
\text { Jensen's } \\
\text { Alpha }\end{array}$ & $\begin{array}{l}\text { Outside director stock option ratio was significantly } \\
\text { and positively related to stock returns and Jensen's } \\
\text { Alpha. }\end{array}$ \\
\hline $\begin{array}{l}\text { Cordeiro, } \\
\text { Veliyath \& } \\
\text { Romal (2007) }\end{array}$ & $\begin{array}{l}450 \mathrm{~S} \& \mathrm{P} 500 \\
\text { firms during } \\
\text { the period } 1995 \\
\text { to } 1997\end{array}$ & $\begin{array}{l}\text { Outside director stock option } \\
\text { ratio (the ratio of dollar stock } \\
\text { option compensation to total } \\
\text { dollar director compensation) }\end{array}$ & $\begin{array}{l}\text { Stock returns, } \\
\text { Jensen's Alpha }\end{array}$ & $\begin{array}{l}\text { Outside director stock option ratio was significantly } \\
\text { and positively related to stock returns and Jensen's } \\
\text { Alpha. }\end{array}$ \\
\hline
\end{tabular}

${ }^{2229}$ Director stock option compensation is calculated as the number of options awarded multiplied by the per-share option value estimated using the BlackScholes option pricing model.

${ }^{2230}$ Jensen's Alpha is measured by the excess return on the stock over the benchmark S\&P 500 index using the market model. 


\section{Appendix 13 (Continued)}

Table C (Continued): Studies Regarding the Impact of Director Incentive Compensation on Shareholder Interests

\section{Panel 2: The (Negative) Impact of Stock Options on the Effectiveness of Independent Directors}

\begin{tabular}{|c|c|c|c|c|}
\hline Studies & Sample & $\begin{array}{l}\text { Measure of the } \\
\text { Director Stock } \\
\text { Options }\end{array}$ & $\begin{array}{l}\text { Measure of the } \\
\text { Effectiveness of } \\
\text { Independent } \\
\text { Directors }\end{array}$ & Findings \\
\hline $\begin{array}{l}\text { Bebchuk, } \\
\text { Grinstein \& } \\
\text { Peyer (2010) }\end{array}$ & $\begin{array}{l}19,306 \text { CEO } \\
\text { grant events in } \\
5,819 \text { firms and } \\
25,888 \text { director } \\
\text { grant events in } \\
6,441 \text { firms } \\
\text { between } 1996 \\
\text { and } 2005\end{array}$ & $\begin{array}{l}\text { Whether directors } \\
\text { get a grant the } \\
\text { same date as their } \\
\text { CEO }\end{array}$ & $\begin{array}{l}\text { The control of the } \\
\text { CEO's total } \\
\text { compensation }\end{array}$ & $\begin{array}{l}\text { The CEO's total compensation for the year was } \\
\text { higher by } 11 \% \text { when independent directors also } \\
\text { received the lucky option grants }{ }^{2231} \text { on the same } \\
\text { date as the CEO did. }\end{array}$ \\
\hline $\begin{array}{l}\text { Byard \& Li } \\
(2003)\end{array}$ & $\begin{array}{l}12,142 \text { firm- } \\
\text { years between } \\
1992 \text { and } 2002\end{array}$ & $\begin{array}{l}\text { The Black- } \\
\text { Scholes value of a } \\
\text { CEO's option } \\
\text { grants divided by } \\
\text { the CEO's total } \\
\text { compensation }\end{array}$ & $\begin{array}{l}\text { The control of a } \\
\text { CEO's timing } \\
\text { opportunism }\end{array}$ & $\begin{array}{l}\text { The positive association between the magnitude of } \\
\text { timing opportunism }{ }^{2232} \text { and the importance of } \\
\text { option compensation }{ }^{2233} \text { to CEOs became weaker } \\
\text { (stronger) when outside directors receive a lower } \\
\text { (higher) proportion of their compensation in } \\
\text { options. }\end{array}$ \\
\hline
\end{tabular}

\footnotetext{
${ }^{2231}$ A lucky option grant refers an option grant for which the exercise price is based on the lowest trading price of the underlying security during a month.

2232 Timing opportunism refers to the opportunistic practice where CEOS increase the value of their option grants by lowering their companies' stock prices on days when they receive option grants.

${ }^{2233}$ The importance of option compensation to CEOs is measured by the percentage of options in total CEO compensation.
} 


\section{Appendix 13 (Continued)}

Table C (Continued): Studies Regarding the Impact of Director Incentive Compensation on Shareholder Interests

\section{Panel 3: The Impact of Stock Grants on Firm Performance}

\begin{tabular}{|l|l|l|l|l|}
\hline Studies & Sample & $\begin{array}{l}\text { Measure of the Director } \\
\text { Stock Grant Compensation }\end{array}$ & $\begin{array}{l}\text { Measure of } \\
\text { Firm } \\
\text { Performanc } \\
\text { e }\end{array}$ & Findings \\
\hline $\begin{array}{l}\text { Cordeiro, } \\
\text { Veliyath \& } \\
\text { Neubaum }\end{array}$ & $\begin{array}{l}\text { 450 S\&P 500 } \\
\text { firms during the } \\
\text { period 1995 } \\
\text { to1997 }\end{array}$ & $\begin{array}{l}\text { Outside director stock } \\
\text { grant ratio (the ratio of } \\
\text { dollar stock grant } \\
\text { compensation } 2234 \text { to total } \\
\text { dollar director } \\
\text { compensation) }\end{array}$ & $\begin{array}{l}\text { Stock } \\
\text { returns, } \\
\text { Jensen's } \\
\text { Alpha }\end{array}$ & $\begin{array}{l}\text { Outside director stock grant ratio was } \\
\text { positively associated with stock returns and } \\
\text { Jensen's Alpha, but only the relationship with } \\
\text { stock grant was significant. }\end{array}$ \\
\hline $\begin{array}{l}\text { Cordeiro, } \\
\text { Veliyath \& } \\
\text { Romal (2007) }\end{array}$ & $\begin{array}{l}\text { 450 S\&P 500 } \\
\text { firms during the } \\
\text { period 1995 to } \\
1997\end{array}$ & $\begin{array}{l}\text { Outside director stock } \\
\text { grant ratio (the ratio of } \\
\text { dollar stock grant } \\
\text { compensation to total } \\
\text { dollar director } \\
\text { compensation) }\end{array}$ & $\begin{array}{l}\text { Stock } \\
\text { returns, } \\
\text { Jensen's } \\
\text { Alpha }\end{array}$ & $\begin{array}{l}\text { The same as Cordeiro, Veliyath \& Neubaum } \\
\text { (2005)) }\end{array}$ \\
\hline
\end{tabular}

\footnotetext{
${ }^{2234}$ Director stock grant compensation is calculated as the number of shares of stock awarded multiplied by the per-share price (averaged over the year).
} 


\section{Appendix 13 (Continued)}

Table C (Continued): Studies Regarding the Impact of Director Incentive Compensation on Shareholder Interests

Panel 4: The Impact of Incentive Plans Combining Stock Options and Stock Grants on Shareholder Interests

\begin{tabular}{|l|l|l|l|l|}
\hline Studies & Sample & $\begin{array}{l}\text { Measure of the Director } \\
\text { Incentive } \\
\text { Compensation }\end{array}$ & $\begin{array}{l}\text { Measure of } \\
\text { Firm } \\
\text { Performance }\end{array}$ & Findings \\
\hline $\begin{array}{l}\text { Fempel \& } \\
\text { Fay (1994) }\end{array}$ & $\begin{array}{l}235 \text { Fortune 250 } \\
\text { firms } 2235 \text { for the } \\
\text { years 1986 and } \\
1990\end{array}$ & $\begin{array}{l}\text { Stock grants and stock } \\
\text { options }\end{array}$ & $\begin{array}{l}\text { Earnings per } \\
\text { share (EPS) }\end{array}$ & $\begin{array}{l}\text { Firms with stock-based compensation plans } \\
\text { (including stock grants and stock options) for } \\
\text { outside directors (not defined) did not } \\
\text { perform better than firms without such plans, } \\
\text { regardless of whether it was the same year or } \\
\text { several years following the plan adoption. }\end{array}$ \\
\hline $\begin{array}{l}\text { Gerety, Hoi \& } \\
\text { Robin (2001) }\end{array}$ & $\begin{array}{l}289 \text { firms that } \\
\text { made incentive } \\
\text { pompensation } \\
\text { proposals for } \\
\text { the period 1988 } \\
\text { to 1998 }\end{array}$ & $\begin{array}{l}\text { The sum of gravy plans, } \\
\text { option plans, stock } \\
\text { restricted share plans }\end{array}$ & $\begin{array}{l}\text { Three-day } \\
\text { cumulative } \\
\text { abnormal } \\
\text { returns }\end{array}$ & $\begin{array}{l}\text { Stock markets reacted (three-day cumulative } \\
\text { abnormal returns) neutrally (negatively (- } \\
\text { 0.27\%) but insignificantly) to the adoption of } \\
\text { incentive plans for } \text { outside directors. }\end{array}$ \\
\hline
\end{tabular}

\footnotetext{
${ }^{2235}$ It is worth mentioning that only six of 237 firms in 1986 and 42 of 244 firms in 1990 reported stock based compensation for outside* directors.
} 


\section{Appendix 13 (Continued)}

Table D: Studies Regarding the Relationship between Director Ownership and the Sensitivity of CEO Turnover to Firm Performance

\begin{tabular}{|l|l|l|l|l|}
\hline \multicolumn{1}{|c|}{ Studies } & \multicolumn{1}{|c|}{ Sample } & $\begin{array}{l}\text { Measure of the Director } \\
\text { Ownership }\end{array}$ & $\begin{array}{l}\text { Measure of the } \\
\text { Sensitivity of CEO } \\
\text { Turnover to Firm } \\
\text { Performance }\end{array}$ & \multicolumn{1}{|c|}{ Findings } \\
\hline $\begin{array}{l}\text { Bhagat, Carey } \\
\text { \& Elson } \\
(1999)\end{array}$ & $\begin{array}{l}449 \text { firms } \\
\text { from } 1990 \text { to } \\
1995\end{array}$ & $\begin{array}{l}\text { Dollar value of the } \\
\text { median director's stock } \\
\text { holdings }\end{array}$ & $\begin{array}{l}\text { Firm performance } \\
\text { (growth in EPS, } \\
\text { stock returns) times } \\
\text { percentage holding } \\
\text { of median director }\end{array}$ & $\begin{array}{l}\text { Directors holding greater equity } \\
\text { (measured by the dollar value of the } \\
\text { median director's stock holdings) were } \\
\text { associated with higher probability of CEO } \\
\text { turnover for poorly performing firms. }\end{array}$ \\
\hline $\begin{array}{l}\text { Bhagat \& } \\
\text { Bolton }(2008)\end{array}$ & $\begin{array}{l}\text { more than } \\
\text { during the } \\
\text { period } 1990 \text { to } \\
2004\end{array}$ & $\begin{array}{l}\text { Dollar value of the } \\
\text { median director's stock } \\
\text { holdings }\end{array}$ & $\begin{array}{l}\text { Past 2 years' stock } \\
\text { returns times the } \\
\text { dollar value of the } \\
\text { median director's } \\
\text { stock holdings }\end{array}$ & $\begin{array}{l}\text { Directors holding greater equity } \\
\text { (measured by the dollar value of the } \\
\text { median director's stock holdings) were } \\
\text { associated with higher probability of CEO } \\
\text { turnover for poorly performing firms. }\end{array}$ \\
\hline $\begin{array}{l}\text { Bhagat \& } \\
\text { Bolton }(2009)\end{array}$ & $\begin{array}{l}\text { US firms from } \\
\text { 1998 to } 2007\end{array}$ & $\begin{array}{l}\text { Dollar value of the } \\
\text { median director's stock } \\
\text { holdings }\end{array}$ & $\begin{array}{l}\text { Past 2 years' stock } \\
\text { returns times the } \\
\text { dollar value of the } \\
\text { median director's } \\
\text { stock holdings }\end{array}$ & $\begin{array}{l}\text { Directors holding greater equity } \\
\text { (measured by the dollar value of the } \\
\text { median director's stock holdings) were } \\
\text { associated with higher probability of CEO } \\
\text { turnover for poorly performing firms, } \\
\text { regardless of results in the pre-SOX or } \\
\text { post-SOX period. }\end{array}$ \\
\hline
\end{tabular}




\section{Appendix 13 (Continued)}

Table E: Studies Regarding the Relationship between Board Independence, Director Incentive Plan and CEO Turnover

\begin{tabular}{|c|c|c|c|c|}
\hline Studies & Sample & $\begin{array}{l}\text { Measure of Board } \\
\text { Independence }\end{array}$ & $\begin{array}{l}\text { Measure of Director } \\
\text { Incentive Plan }\end{array}$ & Findings \\
\hline Perry (2000) & $\begin{array}{l}677 \text { CEO } \\
\text { turnover } \\
\text { events } \\
\text { between } 1992 \\
\text { and } 1995\end{array}$ & $\begin{array}{l}\text { Whether a board } \\
\text { has at least } 60 \% \\
\text { of independent } \\
\text { directors. }\end{array}$ & $\begin{array}{l}\text { Stocks, restricted } \\
\text { stock or stock } \\
\text { options }\end{array}$ & $\begin{array}{l}\text { (1) The likelihood of CEO turnover was higher } \\
\text { when: } \\
\text { A. boards had at least } 60 \% \text { independent directors } \\
\text { (regardless of whether or not they received } \\
\text { incentive compensation); } \\
\text { B. boards had less than } 60 \% \text { independent } \\
\text { directors but had no incentive pay; } \\
\text { (2) Only boards with less than } 60 \% \text { independent } \\
\text { directors but without incentive compensation } \\
\text { were not associated with linking CEO turnover to } \\
\text { firm performance. }\end{array}$ \\
\hline
\end{tabular}




\section{Appendix 14}

\section{Summary of US Empirical Studies Investigating the Impact of Multiple Directorships on the Effectiveness of Independent Directors}

\section{Table A: Studies Regarding the Impact of Independent Directors Holding Multiple Directorships on Firm Value}

\begin{tabular}{|c|c|c|c|c|}
\hline Studies & Sample & $\begin{array}{l}\text { Measure of Busyness of } \\
\text { Independent Directors }\end{array}$ & $\begin{array}{l}\text { Measure of Firm } \\
\text { Performance }\end{array}$ & Findings \\
\hline $\begin{array}{l}\text { Ferris, } \\
\text { Jagannathan \& } \\
\text { Pritchard (2003) }\end{array}$ & $\begin{array}{l}3,190 \text { firms in the year } \\
1995\end{array}$ & $\begin{array}{l}\text { The average number of } \\
\text { directorships held by an } \\
\text { outside director }\end{array}$ & $\begin{array}{l}\text { The value of market-to- } \\
\text { book ratio }\end{array}$ & $\begin{array}{l}\text { Outside directors with multiple board seats (measured by } \\
\text { the average number of directorships held by outside } \\
\text { directors) in } 1995 \text { had no significant impact on the value } \\
\text { of market-to-book ratio (firm performance) in } 1997 \text {. }\end{array}$ \\
\hline $\begin{array}{l}\text { Fich \& Shivdasani } \\
\text { (2006) }\end{array}$ & $\begin{array}{l}508 \text { Forbes } 500 \text { firms } \\
\text { in } 1992 \text { during the } \\
\text { period from } 1989 \text { to } \\
1995\end{array}$ & $\begin{array}{l}\text { (1) } \begin{array}{l}\text { Proportion of } \\
\text { independent directors } \\
\text { serves on three or more }\end{array} \\
\text { boards; } \\
\text { (2) Whether a majority of } \\
\text { independent directors } \\
\text { hold three or more } \\
\text { board seats }\end{array}$ & $\begin{array}{l}\text { The value of market-to- } \\
\text { book ratio; ROA; sales over } \\
\text { assets (asset turnover ratio); } \\
\text { and return on sales }\end{array}$ & $\begin{array}{l}\text { (1) The variables representing busyness of independent } \\
\text { directors (regardless of whether measured by the } \\
\text { proportion or a majority of such directors) were negatively } \\
\text { and significantly related to firm value (market-to-book } \\
\text { ratio) for the current period, the next one-year period and } \\
\text { the next two-year period. } \\
\text { (2) The results remained robust after applying different firm } \\
\text { performance indicators, including ROA, asset turnover } \\
\text { ratio, and return on sales. }\end{array}$ \\
\hline $\begin{array}{l}\text { Jiraporn, Kim \& } \\
\text { Davidson (2008) }\end{array}$ & $\begin{array}{l}\text { 3,605 firm-year } \\
\text { observations from } \\
1998 \text { to } 2002\end{array}$ & $\begin{array}{l}\text { (1) The average number of } \\
\text { directorships held by } \\
\text { an outside director } \\
\text { (2) Proportion of } \\
\text { independent directors } \\
\text { serves on three or more } \\
\text { boards; } \\
\text { (3) Whether a majority of } \\
\text { independent directors } \\
\text { hold three or more } \\
\text { board seats }\end{array}$ & Excess value $^{2236}$ & $\begin{array}{l}\text { (1) The variables representing busyness of independent } \\
\text { directors were significantly and negatively related to } \\
\text { excess value (a firm value indicator), regardless of } \\
\text { whether director busyness was as defined by Ferris, } \\
\text { Jagannathan and Pritchard (2003) or Fich and Shivdasani } \\
\text { (2006). } \\
\text { (2) The variables representing busyness of independent } \\
\text { directors were negatively and significantly correlated with } \\
\text { firm value for firms with high G Index scores } \\
\text { (representing poor governance environment), but such a } \\
\text { correlation became insignificant when firms had low G } \\
\text { Index scores. }\end{array}$ \\
\hline
\end{tabular}

\footnotetext{
${ }^{2236}$ Excess value is an indicator to represent whether the firm is worth more than the sum of its segments. A positive excess value indicates a diversification premium while a negative excess value implies a diversification discount.

2237 The Governance Index (G Index) is an index developed by Professors Gompers, Ishii and Metrick to measures the strength of shareholder rights. A higher score for Governance Index signifies that a firm is more insulated from takeovers and its shareholder rights are more suppressed, and therefore its agency problems are expected to be more serious.
} 


\section{Appendix 14 (Continued)}

Table B: Studies Regarding Market Reaction to the Appointment of a Busy Independent Director

\begin{tabular}{|c|c|c|c|c|}
\hline Studies & Sample & $\begin{array}{c}\text { Measure of Busyness } \\
\text { of Independent } \\
\text { Directors }\end{array}$ & $\begin{array}{c}\text { Measure of } \\
\text { Market } \\
\text { Reaction } \\
\end{array}$ & Findings \\
\hline $\begin{array}{l}\text { Ferris, } \\
\text { Jagannathan } \\
\text { \& Pritchard } \\
(2003)\end{array}$ & $\begin{array}{l}291 \text { announcement } \\
\text { of appointing an } \\
\text { busy director to a } \\
\text { company's board } \\
\text { from } 1990 \text { to } 1995\end{array}$ & $\begin{array}{l}\text { Whether a director } \\
\text { holds three or more } \\
\text { directorships }\end{array}$ & $\begin{array}{l}\text { Abnormal } \\
\text { returns }\end{array}$ & $\begin{array}{l}\text { (1) Market reaction for announcing an appointment of a busy } \\
\text { director to the board was a positive but insignificant. } \\
\text { (2) After dividing the sample into two subsamples, the } \\
\text { market reaction remained unchanged for adding an } \\
\text { additional busy director to its board when the firm } \\
\text { already had busy directors. However, market reaction } \\
\text { became positive and significant when a firm appointed a } \\
\text { busy director to its board for the first time. }\end{array}$ \\
\hline $\begin{array}{l}\text { Fich \& } \\
\text { Shivdasani } \\
(2006)\end{array}$ & 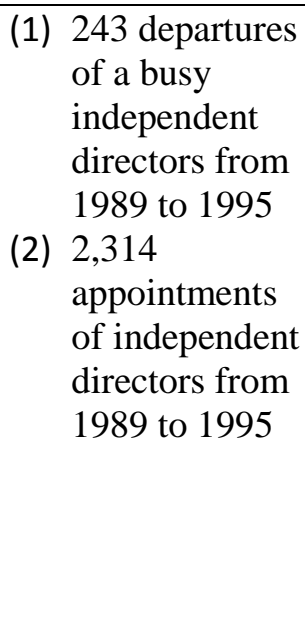 & $\begin{array}{l}\text { Whether an } \\
\text { independent director } \\
\text { holds three or more } \\
\text { directorships }\end{array}$ & $\begin{array}{l}\text { Abnormal } \\
\text { returns }\end{array}$ & $\begin{array}{l}\text { (1) The average abnormal returns (market reaction) was } \\
\text { negative }(-1.04 \%) \text {, if independent directors became busy } \\
\text { (holding three or more board seats) following the } \\
\text { appointment. However, the average abnormal returns } \\
\text { became trivial }(-0.1 \%) \text { and insignificant, if independent } \\
\text { directors were not busy following the appointment. } \\
\text { (2) The average abnormal returns related to the departure of } \\
\text { busy independent directors were larger than those related } \\
\text { to the departure of non-busy counterparts. } \\
\text { (3) The average abnormal returns were larger when boards } \\
\text { with a majority of independent directors were not busy } \\
\text { after the departure of a busy independent director, } \\
\text { compared to the situation where a majority of } \\
\text { independent directors remained busy. }\end{array}$ \\
\hline
\end{tabular}




\section{Appendix 14 (Continued)}

Table C: Studies Regarding the Correlation between Committee Services and Directors Holding Multiple Board Seats

\begin{tabular}{|c|c|c|c|c|}
\hline Studies & Sample & $\begin{array}{c}\text { Measure of } \\
\text { Busyness of } \\
\text { Independent } \\
\text { Directors }\end{array}$ & $\begin{array}{c}\text { Measure of } \\
\text { Committee Service }\end{array}$ & Findings \\
\hline $\begin{array}{l}\text { Ferris, } \\
\text { Jagannathan } \\
\text { \& Pritchard } \\
(2003)\end{array}$ & $\begin{array}{l}3,190 \text { firms in } \\
\text { the year } 1995\end{array}$ & $\begin{array}{l}\text { Whether a } \\
\text { director holds } \\
\text { three or more } \\
\text { directorships }\end{array}$ & $\begin{array}{l}\text { (1) The participation } \\
\text { of board } \\
\text { committees } \\
\text { (2) The participation } \\
\text { of the audit and } \\
\text { compensation } \\
\text { committees }\end{array}$ & $\begin{array}{l}\text { Directors holding three or more board seats: } \\
\text { (1) provided more committee service than those } \\
\text { holding only one or two directorships; } \\
\text { (2) served on audit and compensation committees } \\
\text { with greater frequency. }\end{array}$ \\
\hline $\begin{array}{l}\text { Jiraporn, } \\
\text { Singh \& Lee } \\
(2009)\end{array}$ & $\begin{array}{l}1,471 \text { firms } \\
(41,475 \\
\text { observations }) \\
\text { from } 1999 \text { to } \\
2003\end{array}$ & $\begin{array}{l}\text { Whether a } \\
\text { director holds } \\
\text { three or more } \\
\text { directorships }\end{array}$ & $\begin{array}{l}\text { (1) The participation } \\
\text { of board } \\
\text { committees } \\
\text { (2) The participation } \\
\text { of the audit and } \\
\text { compensation } \\
\text { committees }\end{array}$ & $\begin{array}{l}\text { (1) The number of outside directorships was related } \\
\text { to the number of internal board committees on } \\
\text { which the director served. An additional outside } \\
\text { directorship was associated with fewer committee } \\
\text { memberships until the number of directorships } \\
\text { reached three. Beyond this point, each additional } \\
\text { outside board seat was associated with an } \\
\text { increase in membership of internal board } \\
\text { committees. } \\
\text { (2) The more outside board seats a director held the } \\
\text { less likelihood the director served on the audit } \\
\text { and compensation committees. }\end{array}$ \\
\hline
\end{tabular}




\section{Appendix 14 (Continued)}

Table D: Studies Regarding the Relationship between Other Factors and Independent Directors Holding Multiple Board Seats

\begin{tabular}{|c|c|c|c|c|}
\hline Studies & Sample & $\begin{array}{c}\text { Measure of } \\
\text { Busyness of } \\
\text { (Independent) } \\
\text { Directors }\end{array}$ & $\begin{array}{l}\text { Measure of the } \\
\text { Effectiveness of } \\
\text { Independent } \\
\text { Directors }\end{array}$ & Findings \\
\hline Beasley (1996) & $\begin{array}{l}75 \text { publicly-traded firms } \\
\text { which had financial } \\
\text { statement fraud reported } \\
\text { and } 75 \text { no-fraud } \\
\text { publicly-traded firms } \\
\text { during } 1980 \text { to } 1991\end{array}$ & $\begin{array}{l}\text { The mean number } \\
\text { of additional } \\
\text { directorships held } \\
\text { by outside directors }\end{array}$ & $\begin{array}{l}\text { The incidence of } \\
\text { financial statement } \\
\text { fraud }\end{array}$ & $\begin{array}{l}\text { The incidence of financial statement fraud was } \\
\text { higher when outside directors held more outside } \\
\text { directorships. }\end{array}$ \\
\hline $\begin{array}{l}\text { Ferris, } \\
\text { Jagannathan \& } \\
\text { Pritchard } \\
(2003) \\
\end{array}$ & $\begin{array}{l}133 \text { sued firms during } \\
1996,1997 \text { and } 1998 \\
\text { (and a matched sample } \\
\text { of non-sued firms) }\end{array}$ & $\begin{array}{l}\text { The mean number } \\
\text { of directorships } \\
\text { held by outside } \\
\text { directors }\end{array}$ & $\begin{array}{l}\text { Outside directors } \\
\text { were sued in } \\
\text { securities fraud } \\
\text { class actions } \\
\end{array}$ & $\begin{array}{l}\text { Outside directors in firms facing securities lawsuits } \\
\text { did not significantly hold more outside board seats } \\
\text { than those in firms not being sued. }\end{array}$ \\
\hline $\begin{array}{l}\text { Fich \& } \\
\text { Shivdasani } \\
(2006)\end{array}$ & $\begin{array}{l}\text { 2,844 CEO-year } \\
\text { observations drawn from } \\
508 \text { Forbes } 500 \text { firms } \\
\text { from } 1989 \text { to } 1995\end{array}$ & $\begin{array}{l}\text { Whether an } \\
\text { independent } \\
\text { director holds three } \\
\text { or more } \\
\text { directorships }\end{array}$ & $\begin{array}{l}\text { The sensitivity of } \\
\text { CEO turnover to } \\
\text { firm performance }\end{array}$ & $\begin{array}{l}\text { (1) The sensitivity of CEO turnover to firm } \\
\text { performance was significantly lower when } \\
\text { independent directors held three or more } \\
\text { directorships, compared to those who held less } \\
\text { than three directorships. } \\
\text { (2) CEO turnover became entirely insensitive to } \\
\text { firm performance when a majority of } \\
\text { independent directors held three or more } \\
\text { directorships. }\end{array}$ \\
\hline $\begin{array}{l}\text { Jiraporn et al. } \\
(2009)\end{array}$ & $\begin{array}{l}1510 \text { firms ( } 7261 \\
\text { observations) from the } \\
\text { year } 1998 \text { to } 2003\end{array}$ & $\begin{array}{l}\text { The number of } \\
\text { outside } \\
\text { directorships held } \\
\text { by each director }\end{array}$ & $\begin{array}{l}\text { Board meeting } \\
\text { attendance }\end{array}$ & $\begin{array}{l}\text { (1) The likelihood of missing board meetings was } \\
\text { higher when directors held more outside } \\
\text { directorships. } \\
\text { (2) Independent directors holding more outside } \\
\text { directorships were likely to miss board } \\
\text { meetings than their inside and affiliated } \\
\text { counterparts. }\end{array}$ \\
\hline
\end{tabular}




\section{Appendix 15}

\section{Summary of US Empirical Studies Investigating the Relationship between Market (or the Barriers to the Market) for Corporate Control and Board Independence}

\begin{tabular}{|c|c|c|c|c|}
\hline Studies & Sample & $\begin{array}{l}\text { Measure of Market for } \\
\text { Corporate Control }\end{array}$ & $\begin{array}{l}\text { Measure of Board } \\
\text { Independence }\end{array}$ & Findings \\
\hline $\begin{array}{l}\text { Brickley \& } \\
\text { James (1987) }\end{array}$ & $\begin{array}{l}502 \text { banks in acquisition } \\
\text { states and } 389 \text { banks in } \\
\text { non-acquisition states } \\
\text { during } 1979\end{array}$ & $\begin{array}{l}\text { A comparison between } \\
\text { states that prohibited } \\
\text { acquisitions and states } \\
\text { that permitted } \\
\text { acquisitions }\end{array}$ & $\begin{array}{l}\text { Proportion of outside directors } \\
\text { on the board }\end{array}$ & $\begin{array}{l}\text { The lower (higher) the managerial consumption of perquisites, the } \\
\text { higher (lower) the proportion of outside directors on the board } \\
\text { within the states that prohibited acquisitions. However, no } \\
\text { consumption of perquisites was found within the states that } \\
\text { permitted acquisitions. }\end{array}$ \\
\hline $\begin{array}{l}\text { Kini, Kracaw } \\
\text { \& Mian } \\
(1995)\end{array}$ & $\begin{array}{l}168 \text { successful tender } \\
\text { offers from } 1958 \\
\text { through } 1984\end{array}$ & Tender offers & $\begin{array}{l}\text { A board is defined to be insider } \\
\text { dominated if the proportion of } \\
\text { outside directors is less than } \\
60 \% \text { and to be outsider } \\
\text { dominated if the proportion of } \\
\text { outside directors is greater or } \\
\text { equal to } 75 \%\end{array}$ & $\begin{array}{l}\text { The lower (higher) the pre-takeover firm performance, the higher } \\
\text { (lower) the post-takeover CEO turnover for targets with insider- } \\
\text { dominated boards. However, there was no significant } \\
\text { performance-turnover relation for targets with outsider-dominated } \\
\text { boards. }\end{array}$ \\
\hline $\begin{array}{l}\text { Gillan, } \\
\text { Hartzell, \& } \\
\text { Starks (2006) } \\
\end{array}$ & $\begin{array}{l}\text { of } 2,340 \text { firms from } \\
1997 \text { to } 2000\end{array}$ & $\begin{array}{l}\text { The number of anti- } \\
\text { takeover provisions in a } \\
\text { firm's charter }\end{array}$ & $\begin{array}{l}\text { Proportion of independent } \\
\text { directors on the board }\end{array}$ & $\begin{array}{l}\text { The fewer (greater) the number of antitakeover provisions a firm } \\
\text { had, the lower (higher) the level of a firm's board independence. }\end{array}$ \\
\hline $\begin{array}{l}\text { Santaló \& } \\
\text { Diestre } \\
(2006)\end{array}$ & $\begin{array}{l}1,294 \text { firms for the } \\
\text { period } 1996 \text { to } 2001\end{array}$ & $\begin{array}{l}\text { The level of } \\
\text { antitakeover protection } \\
\text { was measured by G } \\
\text { Index (developed by } \\
\text { Professors Gompers, } \\
\text { Ishii and Metrick) }\end{array}$ & $\begin{array}{l}\text { Proportion of independent } \\
\text { directors on the board }\end{array}$ & $\begin{array}{l}\text { (1) When firms had a low level of antitakeover protection, an } \\
\text { increase of } 10 \% \text { in the proportion of independent directors on } \\
\text { the board was associated with an increase of } 28 \% \text { in the } \\
\text { market valuation of the firm (Tobin's Q). } \\
\text { (2) When firms had a high degree of antitakeover protection, an } \\
\text { increase of } 10 \% \text { in board independence was linked to a } \\
\text { decrease of } 10 \% \text { in a firm's market value. } \\
\text { (3) When firms with a medium degree of antitakeover protection, } \\
\text { no significant connection was found between board } \\
\text { independence and firm market value. }\end{array}$ \\
\hline $\begin{array}{l}\text { Huang \& } \\
\text { Zhao (2009) }\end{array}$ & $\begin{array}{l}792 \text { large listed firms } \\
\text { from } 1984 \text { to1991 }\end{array}$ & $\begin{array}{l}\text { The passage of } \\
\text { antitakeover legislation } \\
\text { (the barriers to the } \\
\text { market for corporate } \\
\text { control) }\end{array}$ & $\begin{array}{l}\text { Whether the proportion of } \\
\text { independent directors on the } \\
\text { board is higher than the median } \\
\text { in sample firms }\end{array}$ & $\begin{array}{l}\text { Only firms with higher (larger than median) proportions of } \\
\text { independent directors significantly increased the sensitivity of CEO } \\
\text { turnover to performance after the passage of antitakeover law, } \\
\text { compared to firms with lower (smaller than median) proportions of } \\
\text { independent directors in the same situation. }\end{array}$ \\
\hline
\end{tabular}




\section{Appendix 16}

Summary of US Empirical Studies Investigating the Relationship between Information Cost and the Effectiveness of Independent Directors

\begin{tabular}{|c|c|c|c|c|}
\hline Studies & Sample & $\begin{array}{c}\text { Measure of } \\
\text { Information Cost }\end{array}$ & $\begin{array}{l}\text { Measure of the } \\
\text { Effectiveness of } \\
\text { Independent } \\
\text { Directors }\end{array}$ & Findings \\
\hline $\begin{array}{l}\text { Duchin, } \\
\text { Matsusaka \& } \\
\text { Ozbas (2010) }\end{array}$ & $\begin{array}{l}2,897 \text { firms }(15,820 \\
\text { firm-year } \\
\text { observations) from } \\
1996 \text { to } 2005\end{array}$ & $\begin{array}{l}\text { The number of } \\
\text { analysts, the } \\
\text { dispersion of } \\
\text { analysts' } \\
\text { forecasts, and } \\
\text { analysts' forecast } \\
\text { error }\end{array}$ & $\begin{array}{l}\text { Firm performance } \\
\text { (measured by } \\
\text { ROA, Tobin's Q, } \\
\text { and annual stock } \\
\text { returns) }\end{array}$ & $\begin{array}{l}\text { (1) When the cost of acquiring information was } \\
\text { low, adding independent directors to the } \\
\text { board was associated with better firm } \\
\text { performance. } \\
\text { (2) When the cost of acquiring information was } \\
\text { high, an increase in the percentage of } \\
\text { independent directors was connected with } \\
\text { worse firm performance. }\end{array}$ \\
\hline $\begin{array}{l}\text { Ravina and } \\
\text { Sapienza } \\
(2010)\end{array}$ & $\begin{array}{l}52,799 \text { transactions } \\
(305,349 \text { made by } \\
\text { executives, } 196,211 \\
\text { made by independent } \\
\text { directors) from } 1986 \text { to } \\
2003\end{array}$ & $\begin{array}{l}\text { A comparison of } \\
\text { stock returns } \\
\text { between } \\
\text { executives and } \\
\text { independent } \\
\text { directors }\end{array}$ & $\begin{array}{l}\text { Whether stock } \\
\text { returns earned by } \\
\text { independent } \\
\text { directors are } \\
\text { equal to those of } \\
\text { executives }\end{array}$ & $\begin{array}{l}\text { (1) The stock returns for executives were } \\
\text { slightly larger than those for independent } \\
\text { directors, but the difference between } \\
\text { executives and independent directors was } \\
\text { relatively small over most time periods. } \\
\text { (2) In firms with the weakest governance (G } \\
\text { Index scores greater than or equal to 14), } \\
\text { the gap in stock returns between executives } \\
\text { and independent directors was larger, but it } \\
\text { disappeared for firms with the best } \\
\text { governance (G Index less than or equal to } \\
\text { 5). In most cases, the difference between } \\
\text { executives and independent directors was } \\
\text { insignificant. }\end{array}$ \\
\hline
\end{tabular}




\section{Appendix 17}

Summary of US Empirical Studies Investigating the Relationship between the Types of Leadership Structure and the Effectiveness of Independent Directors

Table A: Studies Regarding the Relationship between the Types of Leadership Structure and Firm Performance

Panel 1: Firms with the CEO Playing Dual Role

a. Associated with Enhanced Firm Performance

\begin{tabular}{|l|l|l|l|}
\hline \multicolumn{1}{|c|}{ Studies } & \multicolumn{1}{|c|}{ Sample } & $\begin{array}{c}\text { Measure of Firm } \\
\text { Performance }\end{array}$ & \multicolumn{1}{c|}{ Findings } \\
\hline $\begin{array}{l}\text { Brickley, Coles } \\
\text { and Jarell } \\
(1997)\end{array}$ & 661 Forbes Firm in 1988 & $\begin{array}{l}\text { Return on capital, } \\
\text { median stock return }\end{array}$ & $\begin{array}{l}\text { Firms with CEO playing dual role had the same or } \\
\text { even better firm performance, in comparison with } \\
\text { firms that separated the positions of CEO and board } \\
\text { chair. }\end{array}$ \\
\hline
\end{tabular}

b. Associated with Poorer Firm Performance

\begin{tabular}{|l|l|l|l|}
\hline \multicolumn{1}{|c|}{ Studies } & \multicolumn{1}{|c|}{ Sample } & $\begin{array}{c}\text { Measure of Firm } \\
\text { Performance }\end{array}$ & \multicolumn{1}{c|}{ Findings } \\
\hline $\begin{array}{l}\text { Pi \& Timme } \\
(1993)\end{array}$ & $\begin{array}{l}\text { 112 banks (93 firms whose } \\
\text { CEOs also hold board } \\
\text { chair, 19 firms whose } \\
\text { board chairs are not their } \\
\text { CEOs) from 1989 to 1990 }\end{array}$ & $\begin{array}{l}\text { ROA, percentage } \\
\text { production cost } \\
\text { efficiency }\end{array}$ & $\begin{array}{l}\text { Firms with CEOs who also hold the board chair had } \\
\text { lower ROA and cost efficiency than those separating } \\
\text { the CEO from the board chair. }\end{array}$ \\
\hline
\end{tabular}




\section{Appendix 17 (Continued)}

Table A (Continued): Studies Regarding the Relationship between the Types of Leadership Structure and Firm Performance

\section{Panel 2: Firms Separating CEO from Board Chair}

\section{a. Associated with Enhanced Firm Performance}

\begin{tabular}{|l|l|l|l|}
\hline \multicolumn{1}{|c|}{ Studies } & \multicolumn{1}{|c|}{ Sample } & \multicolumn{1}{|c|}{$\begin{array}{l}\text { Measure of Firm } \\
\text { Performance }\end{array}$} & \multicolumn{1}{|c|}{ Findings } \\
\hline $\begin{array}{l}\text { Rechner \& Dalton } \\
(1991)\end{array}$ & $\begin{array}{l}\text { 250 Fortune 500 firms } \\
\text { during the period 1978 to } \\
1983\end{array}$ & $\begin{array}{l}\text { ROE, return on investment } \\
\text { and profit margin }\end{array}$ & $\begin{array}{l}\text { Firms separating the CEO from the board chair outperformed firms } \\
\text { combining the two positions. }\end{array}$ \\
\hline
\end{tabular}

b. Associated with Neutral Firm Performance

\begin{tabular}{|c|c|c|c|}
\hline Studies & Sample & $\begin{array}{l}\text { Measure of Firm } \\
\text { Performance }\end{array}$ & Findings \\
\hline Boyd (1995) & $\begin{array}{l}192 \text { firms in } 12 \text { industry } \\
\text { group in the year } 1980\end{array}$ & Return on investment (ROI) & $\begin{array}{l}\text { Firms with the CEO holding the board chair was correlated with lower } \\
\text { subsequent firm performance (ROI), but the effect is insignificant. }\end{array}$ \\
\hline $\begin{array}{l}\text { Baliga, Moyer \& } \\
\text { Rao (1996) }\end{array}$ & $\begin{array}{l}111 \text { Fortune } 500 \text { firms from } \\
1980 \text { to } 1991\end{array}$ & $\begin{array}{l}\text { ROE, ROA, operating cash } \\
\text { flow/total assets, and } \\
\text { operating cash flow/ sales, } \\
\text { cumulative abnormal returns }\end{array}$ & $\begin{array}{l}\text { (1) There was no significant market reaction (cumulative abnormal } \\
\text { returns), regardless of the change from CEO duality to non-duality } \\
\text { or vice versa. } \\
\text { (2) There was little evidence of firm performance changes around } \\
\text { changes in the leadership structure (CEO duality to non-duality). }\end{array}$ \\
\hline $\begin{array}{l}\text { Chen, Lin \& Yi } \\
\text { (2008) }\end{array}$ & $\begin{array}{l}\text { More than } 1,000 \mathrm{~S} \& \mathrm{P} 1,500 \\
\text { firms from } 1999 \text { to } 2003\end{array}$ & Tobin's Q & $\begin{array}{l}\text { Firms with the CEO holding board chair had no significant } \\
\text { impact on firm performance (Tobin's Q). }\end{array}$ \\
\hline $\begin{array}{l}\text { Dey, Engel and Liu } \\
(2009)\end{array}$ & $\begin{array}{l}643 \text { firms (405 firms with } \\
\text { CEO duality, } 102 \text { firms } \\
\text { separating CEO from the } \\
\text { board chair, and } 136 \text { firms } \\
\text { altering their leadership } \\
\text { structure) from } 2001 \text { to } 2006\end{array}$ & $\begin{array}{l}\text { Adjusted ROA, average } \\
\text { market-adjusted returns, } \\
\text { cumulative abnormal returns }\end{array}$ & $\begin{array}{l}\text { (1) There was no significant difference in firm performance (measured } \\
\text { by adjusted ROA and average returns) between firms combining } \\
\text { the positions of CEO and board chair and firms separating the two } \\
\text { roles. } \\
\text { (2) The market did not have a differential reaction between firms } \\
\text { separating board chair from CEO and firms combining the two } \\
\text { roles. }\end{array}$ \\
\hline
\end{tabular}


Appendix 17 (Continued)

Table B: Studies Regarding the Relationship between the Types of Outside Board Chair and Firm Performance

\begin{tabular}{|c|c|c|c|}
\hline Studies & Sample & $\begin{array}{c}\text { Measure of Firm } \\
\text { Performance }\end{array}$ & Findings \\
\hline $\begin{array}{l}\text { Grinstein \& } \\
\text { Valles (2008) }\end{array}$ & $\begin{array}{l}\text { About } 1000 \text { S\&P } 1500 \\
\text { firms in the year } 2000 \text { and } \\
2004\end{array}$ & Stock returns & $\begin{array}{l}\text { Firms appointing an independent director as board } \\
\text { chair were usually associated with poor firm } \\
\text { performance (as measured by stock returns) in prior } \\
\text { period. However, firm performance was significantly } \\
\text { improved within one year after the independent } \\
\text { director took the board chair. }\end{array}$ \\
\hline $\begin{array}{l}\text { Balsam, } \\
\text { Puthenpurackal } \\
\text { \& Upadhyay } \\
\text { (2011) }\end{array}$ & $\begin{array}{l}1,125 \text { S\&P } 1500 \text { firms } \\
(7,535 \text { firm-year } \\
\text { observations) from } 1996 \text { to } \\
2005\end{array}$ & Tobin's Q, ROA & $\begin{array}{l}\text { (1) Firms with outside board chairs were significantly and } \\
\text { positively related to firm performance (Tobin's Q), and } \\
\text { the causation ran from the outside board chair to firm } \\
\text { performance, rather than vice versa. } \\
\text { (2) Firms with affiliated outside board chair were } \\
\text { positively and significantly associated with ROA and } \\
\text { Tobin's Q in both OLS and firm fixed effect regression } \\
\text { models. } \\
\text { (3) Firms with independent board chair were positive and } \\
\text { significant in all specifications but the OLS } \\
\text { specification with Tobin's Q. In combination with (2), } \\
\text { the impact of affiliated outside chair on firm } \\
\text { performance is stronger than that of independent board } \\
\text { chair on firm performance. }\end{array}$ \\
\hline
\end{tabular}




\section{Appendix 17 (Continued)}

Table C: Studies Regarding the Relationship between Board Independence and Different Types of Leadership Structure

\begin{tabular}{|l|l|l|l|l|}
\hline \multicolumn{1}{|c|}{ Studies } & \multicolumn{1}{|c|}{ Sample } & \multicolumn{1}{c|}{$\begin{array}{c}\text { Measure of Board } \\
\text { Independence }\end{array}$} & $\begin{array}{l}\text { The Type of } \\
\text { Leadership } \\
\text { Structure }\end{array}$ & Findings \\
\hline $\begin{array}{l}\text { Grinstein \& } \\
\text { Valles (2008) }\end{array}$ & $\begin{array}{l}\text { About 1000 S\&P } \\
\begin{array}{l}\text { year firms in the } \\
\text { yean } 2000 \text { and }\end{array}\end{array}$ & $\begin{array}{l}\text { Proportion of } \\
\text { independent directors } \\
\text { on the board } \\
\text { the CEO from } \\
\text { board chair }\end{array}$ & $\begin{array}{l}\text { Firms with more (less) independent } \\
\text { directors on the board were less (more) } \\
\text { likely to split the CEO and chairman roles. }\end{array}$ \\
\hline $\begin{array}{l}\text { Linck, Netter } \\
\text { \& Yang } \\
(2008)\end{array}$ & $\begin{array}{l}\text { Nearly 7,000 } \\
\text { firms from 1990 } \\
\text { to 2004 }\end{array}$ & $\begin{array}{l}\text { Proportion of outside } \\
\text { directors on the board }\end{array}$ & $\begin{array}{l}\text { A firm's CEO } \\
\text { also holds the } \\
\text { board chair }\end{array}$ & $\begin{array}{l}\text { Firms with more (less) outside directors } \\
\text { on the board were more (less) likely to } \\
\text { have CEOs playing dual role. }\end{array}$ \\
\hline
\end{tabular}




\section{Appendix 18}

Summary of US Empirical Studies Investigating the Relationship between the Board Size and the Effectiveness of Independent Directors

Table A: Studies Regarding the Relationship between the Number of Directors (Board Size) and Firm Performance

\begin{tabular}{|l|l|l|l|l|}
\hline \multicolumn{1}{|c|}{ Studies } & \multicolumn{1}{|c|}{ Sample } & Measure of Board Size & $\begin{array}{l}\text { Measure of Firm } \\
\text { Performance }\end{array}$ & \multicolumn{1}{|c|}{ Findings } \\
\hline $\begin{array}{l}\text { Yermack } \\
(1996)\end{array}$ & $\begin{array}{l}\text { 452 Forbes 500 } \\
\text { firms over the } \\
\text { period } 1984 \text { to } \\
1991\end{array}$ & $\begin{array}{l}\text { The log value of the } \\
\text { number of directors on } \\
\text { the board as of the } \\
\text { annual meeting date } \\
\text { during each fiscal year }\end{array}$ & Tobin's Q & $\begin{array}{l}\text { The number of directors on the board was } \\
\text { significantly and negatively related to current } \\
\text { and subsequent firm performance (Tobin's Q). }\end{array}$ \\
\hline $\begin{array}{l}\text { Ning, } \\
\text { Zavidson \& }(2007)\end{array}$ & $\begin{array}{l}473 \text { randomly- } \\
\text { selected listed } \\
\text { firms from 1988 } \\
\text { to 1999 }\end{array}$ & $\begin{array}{l}\text { The log value of the } \\
\text { number of directors on } \\
\text { the board }\end{array}$ & ROA & $\begin{array}{l}\text { The number of directors on the board was } \\
\text { marginally (significant at 10\% level) and } \\
\text { positively associated with ROA. }\end{array}$ \\
\hline $\begin{array}{l}\text { Coles, Daniel } \\
\text { \& Naveen } \\
(2008)\end{array}$ & $\begin{array}{l}\text { observations } \\
\text { over the period } \\
\text { 1992 to 2001 }\end{array}$ & $\begin{array}{l}\text { The log value of the } \\
\text { number of directors on } \\
\text { the board }\end{array}$ & Tobin's Q & $\begin{array}{l}\text { (1) The number of directors on the board was } \\
\text { significantly and negatively related to } \\
\text { Tobin's Q. } \\
\text { After firms were divided into complex and } \\
\text { simple firms, Tobin's Q of complex firms } \\
\text { increased but Tobin's Q of simple firms } \\
\text { decreased, when the board size became } \\
\text { larger. }\end{array}$ \\
\hline
\end{tabular}




\section{Appendix 18 (Continued)}

\section{Table B: Studies Regarding the Determinants of the Number of Directors on the Board (Board Size)}

\begin{tabular}{|c|c|c|c|c|c|c|}
\hline \multirow[t]{2}{*}{ Studies } & \multicolumn{6}{|c|}{ The Relationship between Board Size and Its Determinants } \\
\hline & Firm Size ${ }^{2238}$ & $\begin{array}{c}\text { Firm } \\
\text { Complexity }^{2239}\end{array}$ & $\begin{array}{c}\text { Growth } \\
\text { Opportunities }^{2240}\end{array}$ & $\begin{array}{c}\text { Costs of } \\
\text { Monitoring }^{2241}\end{array}$ & $\begin{array}{c}\text { Managers' Opportunities to } \\
\text { Consume Private } \\
\text { Benefits }^{2242}\end{array}$ & $\begin{array}{l}\text { Ownership } \\
\text { Incentives }^{2243}\end{array}$ \\
\hline $\begin{array}{l}\text { Lehn, Patro \& } \\
\text { Zhao (2003) }\end{array}$ & Positive & N/A & Negative & N/A & N/A & N/A \\
\hline Boon et al. (2007) & Positive & Positive & N/A & Negative & Positive & N/A \\
\hline $\begin{array}{l}\text { Ning, Davidson \& } \\
\text { Zhong (2007) }\end{array}$ & Positive & N/A & Positive & N/A & N/A & N/A \\
\hline $\begin{array}{l}\text { Coles, Daniel \& } \\
\text { Naveen (2008) }\end{array}$ & N/A & Positive & N/A & N/A & N/A & N/A \\
\hline $\begin{array}{l}\text { Linck, Netter \& } \\
\text { Yang (2008) }\end{array}$ & Positive & Positive & N/A & Negative & N/A & Negative \\
\hline
\end{tabular}

${ }^{2238}$ In Lehn, Patro and Zhao (2003), firm size is defined as market value of equity. In Boone et al., firm size is measured as the natural log of the market value of equity as of each fiscal year-end. In Ning, Davidson and Zhong (2007), firm size is defined as the book value of total debt over the market value of firm's equity. In Linck, Netter and Yang (2008), firm size is measured by the logarithm of market value of equity.

${ }^{2239}$ Boon et al. (2007) uses firm size, firm age and the number of business segments as proxies for firm complexity, while Coles, Daniel and Naveen (2008) adopts firm size, diversification and financial leverage as proxies to measure firm complexity. Linck, Netter and Yang (2008) uses firm size, the proportion of debt in capital structure, the number of business segments and firm age to represent firm complexity.

${ }^{2240}$ Both Lehn, Patro and Zhao (2003) and Ning, Davidson and Zhong (2007) used the ratio of the market to book value of assets and the ratio of property plant and equipment to total assets to measure growth opportunities. However, the effect of growth opportunities on board size seems to be mixed. Lehn, Patro and Zhao (2003) observed that growth opportunities were negatively related to board size, while Ning, Davidson and Zhong (2007) found the opposite.

${ }^{2241}$ Boon et al. (2007) used market-to-book ratio, high R\&D expenditures, return variance and CEO ownership as proxies for costs of monitoring, while Linck, Netter and Yang (2008) adopted market-to-book ratio, the level of R\&D spending and stock return to represent costs of monitoring and advising.

2242 Boon et al. (2007) hypothesized that the optimal number of board members depends on the monitoring costs and manager's opportunities to consume private benefits, so they examined the relationship between board size and monitoring costs, as well as manager's opportunities to consume private benefits. Managers' opportunities to pursue private benefits are measured by three variables: free cash flow, industry concentration and whether management is insulated from market for corporate control by using takeover defenses (as measured by G index developed by Gompers, Ishii \& Metrick (2003)).

${ }^{2243}$ Linck, Netter and Yang (2008) used insider incentive alignment and outsider incentive alignment as proxies for ownership incentives. Insider incentive alignment is measured by the percentage of shares held by the CEO, while outsider incentive alignment is measured by the percentage of shares held by outside directors. 


\section{Appendix 19}

\section{Summary of US Empirical Studies Investigating the Relationship between Directors' Meeting Frequency and Their Efficacy}

Table A: Studies Regarding the Correlation between Prior Firm Performance and the Level of Board Meeting Frequency

\begin{tabular}{|c|c|c|c|c|}
\hline Studies & Sample & $\begin{array}{c}\text { Measure of Board Meeting } \\
\text { Frequency }\end{array}$ & $\begin{array}{l}\text { Measure of } \\
\quad \text { Firm } \\
\text { Performance }\end{array}$ & Findings \\
\hline Vafeas (1999) & $\begin{array}{l}307 \text { Forbes firms } \\
\text { over the period } \\
1990 \text { to } 1994\end{array}$ & $\begin{array}{l}\text { (1) The number of board } \\
\text { meetings in a fiscal } \\
\text { year } \\
\text { (2) The difference in board } \\
\text { meetings from the } \\
\text { prior year to the } \\
\text { current year } \\
\text { (3) The difference } \\
\text { between current year } \\
\text { meetings and the } \\
\text { average meeting }\end{array}$ & $\begin{array}{l}\text { Excess returns, } \\
\text { adjusted ROA }\end{array}$ & $\begin{array}{l}\text { Board members met more frequently when } \\
\text { firms performed poorly in the prior year, but } \\
\text { board member did not reduce their meeting } \\
\text { frequency when firms performed well in the } \\
\text { prior year. }\end{array}$ \\
\hline $\begin{array}{l}\text { Brick \& } \\
\text { Chidambaran } \\
(2007)\end{array}$ & $\begin{array}{l}4,298 \text { firm-year } \\
\text { observations } \\
\text { from } 1999 \text { to } \\
2005\end{array}$ & $\begin{array}{l}\text { (1) The number of board } \\
\text { meetings in a fiscal } \\
\text { year } \\
\text { (2) The number of } \\
\text { director-days }\end{array}$ & $\begin{array}{l}\text { Annual } \\
\text { common stock } \\
\text { returns, } \\
\text { Tobin's Q }\end{array}$ & $\begin{array}{l}\text { Board members met more frequently when } \\
\text { firms performed poorly in the prior one or prior } \\
\text { two years by using the fixed effect model, but } \\
\text { the effect disappeared by using the pooled } \\
\text { model. }\end{array}$ \\
\hline $\begin{array}{l}\text { Ryan, Wang } \\
\text { \& Wiggins } \\
(2009)\end{array}$ & $\begin{array}{l}1,324 \text { S\&P } 1,500 \\
\text { firms from } 1995 \\
\text { to } 2002\end{array}$ & $\begin{array}{l}\text { (1) The number of board } \\
\text { meetings in a fiscal } \\
\text { year } \\
\text { (2) The number of board } \\
\text { meeting is more than } \\
\text { one standard error }\end{array}$ & $\mathrm{ROA}$ & $\begin{array}{l}\text { Board members met more frequently following } \\
\text { poor performance (ROA), but they met less } \\
\text { frequently following good performance. }\end{array}$ \\
\hline
\end{tabular}




\section{Appendix 19 (Continued)}

Table B: Studies Regarding the Correlation between the Level of Board Meeting Frequency and Subsequent Firm Performance

\begin{tabular}{|c|c|c|c|c|}
\hline Studies & Sample & $\begin{array}{c}\text { Measure of Board Meeting } \\
\text { Frequency }\end{array}$ & $\begin{array}{l}\text { Measure of } \\
\quad \text { Firm } \\
\text { Performance }\end{array}$ & Findings \\
\hline Vafeas (1999) & $\begin{array}{l}307 \text { Forbes firms } \\
\text { over the period } \\
1990 \text { to } 1994\end{array}$ & $\begin{array}{l}\text { The number of board } \\
\text { meetings in a fiscal year } \\
\text { minus the average of board } \\
\text { meetings }\end{array}$ & $\begin{array}{l}\text { excess returns, } \\
\text { adjusted ROA }\end{array}$ & $\begin{array}{l}\text { Firms strongly recovered in the year of } \\
\text { abnormally high meeting intensity and in the } \\
\text { two subsequent years. }\end{array}$ \\
\hline $\begin{array}{l}\text { Ryan, Wang } \\
\text { \& Wiggins } \\
\text { (2009) }\end{array}$ & $\begin{array}{l}1,324 \mathrm{~S} \& \mathrm{P} 1,500 \\
\text { firms from } 1995 \\
\text { to } 2002\end{array}$ & $\begin{array}{l}\text { Abnormally high (or low) } \\
\text { meeting frequency }\end{array}$ & ROA & $\begin{array}{l}\text { Firm performance did not improve after } \\
\text { abnormally high numbers of board meetings, } \\
\text { but firm performance improved over the three- } \\
\text { year period following abnormally low meeting } \\
\text { frequency. }\end{array}$ \\
\hline
\end{tabular}

\footnotetext{
${ }^{2244}$ If the number of meeting is more than one standard error above (below), it is considered as abnormally high (low) meeting frequency.
} 


\section{Appendix 19 (Continued)}

Table C: Studies Regarding the Correlation between Board Meeting Frequency, Board Meeting Fees and Director Attendance

\begin{tabular}{|c|c|c|c|c|}
\hline Studies & Sample & $\begin{array}{c}\text { Measure of Board Meeting } \\
\text { Frequency (or Director } \\
\text { Attendance) }\end{array}$ & $\begin{array}{c}\text { Measure of } \\
\text { Board Meeting } \\
\text { Fees } \\
\end{array}$ & Findings \\
\hline Vafeas (1999) & $\begin{array}{l}307 \text { Forbes firms } \\
\text { over the period } 1990 \\
\text { to } 1994\end{array}$ & $\begin{array}{l}\text { The number of board } \\
\text { meetings in a fiscal year }\end{array}$ & $\begin{array}{l}\text { Director fees } \\
\text { per board } \\
\text { meeting }\end{array}$ & $\begin{array}{l}\text { Board meeting fees were not significantly } \\
\text { related to the frequency of board } \\
\text { meetings. }\end{array}$ \\
\hline $\begin{array}{l}\text { Brick \& } \\
\text { Chidambaran } \\
(2007)\end{array}$ & $\begin{array}{l}4,298 \text { firm-year } \\
\text { observations from } \\
1999 \text { to } 2005\end{array}$ & $\begin{array}{l}\text { The number of board } \\
\text { meetings in a fiscal year }\end{array}$ & $\begin{array}{l}\text { The fee per } \\
\text { board meeting } \\
\text { to the director }\end{array}$ & $\begin{array}{l}\text { There was a positive relationship between } \\
\text { board meeting fees and board meeting } \\
\text { frequency in the fixed effect regression } \\
\text { model, but the relationship turned negative } \\
\text { in the pooled regression model. }\end{array}$ \\
\hline $\begin{array}{l}\text { Adams \& } \\
\text { Ferreira } \\
(2008)\end{array}$ & $\begin{array}{l}77,135 \text { directorships } \\
\text { in } 2,213 \text { firms from } \\
1996 \text { to } 2003\end{array}$ & $\begin{array}{l}\text { Whether a director } \\
\text { attended fewer than } 75 \% \\
\text { of the meetings }\end{array}$ & $\begin{array}{l}\text { Director fees } \\
\text { per board } \\
\text { meeting }\end{array}$ & $\begin{array}{l}\text { Directors were less likely to be absent } \\
\text { from board meetings when firms provided } \\
\text { higher meeting fees. }\end{array}$ \\
\hline $\begin{array}{l}\text { Ryan, Wang } \\
\text { \& Wiggins } \\
(2009)\end{array}$ & $\begin{array}{l}1,324 \mathrm{~S} \& \mathrm{P} 1,500 \\
\text { firms from } 1995 \text { to } \\
2002\end{array}$ & $\begin{array}{l}\text { The number of board } \\
\text { meetings in a fiscal year }\end{array}$ & $\begin{array}{l}\text { Director fees } \\
\text { per board } \\
\text { meeting }\end{array}$ & $\begin{array}{l}\text { Board meeting fees were not significantly } \\
\text { related to the frequency of board } \\
\text { meetings. }\end{array}$ \\
\hline
\end{tabular}




\section{Appendix 19 (Continued)}

Table D: Studies Regarding the Correlation between Board Meeting Frequency and Board Independence

\begin{tabular}{|l|l|l|l|l|}
\hline \multicolumn{1}{|c|}{ Studies } & \multicolumn{1}{|c|}{ Sample } & $\begin{array}{l}\text { Measure of Board } \\
\text { Meeting Frequency }\end{array}$ & $\begin{array}{c}\text { Measure of Board } \\
\text { Independence }\end{array}$ & \multicolumn{1}{|c|}{ Findings } \\
\hline Vafeas (1999) & $\begin{array}{l}\text { 307 Forbes firms } \\
\text { over the period 1990 } \\
\text { to 1994 }\end{array}$ & $\begin{array}{l}\text { The number of } \\
\text { board meetings in a } \\
\text { fiscal year }\end{array}$ & $\begin{array}{l}\text { Whether the board } \\
\text { has a majority of } \\
\text { independent directors } \\
\text { on the board }\end{array}$ & $\begin{array}{l}\text { Board meeting frequency was not related to } \\
\text { whether the board had a majority of } \\
\text { independent directors on the board. }\end{array}$ \\
\hline $\begin{array}{l}\text { Brick \& } \\
\text { Chidambaran } \\
(2007)\end{array}$ & $\begin{array}{l}\text { 4,298 firm-year } \\
\text { observations from } \\
\text { 1999 to 2005 }\end{array}$ & $\begin{array}{l}\text { The number of } \\
\text { board meetings in a } \\
\text { fiscal year }\end{array}$ & $\begin{array}{l}\text { Proportion of } \\
\text { independent directors } \\
\text { on the board }\end{array}$ & $\begin{array}{l}\text { Board members met more frequently when } \\
\text { firms had a higher proportion of independent } \\
\text { directors on the board. }\end{array}$ \\
\hline $\begin{array}{l}\text { Ryan, Wang } \\
\text { \& Wiggins } \\
\text { (2009) }\end{array}$ & $\begin{array}{l}\text { 1,324 S\&P 1,500 } \\
\text { firms from 1995 to } \\
\text { 2002 }\end{array}$ & $\begin{array}{l}\text { The number of } \\
\text { board meetings in a } \\
\text { fiscal year }\end{array}$ & $\begin{array}{l}\text { Proportion of inside } \\
\text { directors on the } \\
\text { board }\end{array}$ & $\begin{array}{l}\text { Board members met less (more) frequently } \\
\text { when firms had a higher proportion of inside } \\
\text { (outside) directors on the board. }\end{array}$ \\
\hline
\end{tabular}




\section{Appendix 20}

\section{Summary of Canadian Empirical Studies Investigating the Relationship between Board Independence and Firm}

Performance

Table A: Studies Regarding the Relationship between Board Independence and Firm Performance before 1994 (Dey Report)

\begin{tabular}{|c|c|c|c|c|}
\hline Studies & Sample & $\begin{array}{l}\text { Measure of Board } \\
\text { Independence }\end{array}$ & $\begin{array}{l}\text { Measure of } \\
\text { Firm } \\
\text { Performance }\end{array}$ & Findings \\
\hline $\begin{array}{l}\text { Rao \& Lee- } \\
\text { Sing (1995) }\end{array}$ & $\begin{array}{l}766 \text { Canadian } \\
\text { firms for the } \\
\text { period } 1988 \text { to } \\
1993\end{array}$ & $\begin{array}{l}\text { The ratio of inside } \\
\text { directors to the total } \\
\text { number of directors }\end{array}$ & ROA, ROE & $\begin{array}{l}\text { The proportion of inside directors on the board was } \\
\text { significantly and positively related to ROA and ROE. }\end{array}$ \\
\hline $\begin{array}{l}\text { Gagnon \& } \\
\text { St-Pierre } \\
(1995)\end{array}$ & $\begin{array}{l}258 \text { Canadian } \\
\text { firms for the } \\
\text { period from } 1978 \\
\text { to } 1991\end{array}$ & $\begin{array}{l}\text { The ratio of } \\
\text { outsiders to insiders }\end{array}$ & ROA & $\begin{array}{l}\text { (1) Board independence was significantly and } \\
\text { positively related to ROA under diffuse } \\
\text { ownership. } \\
\text { (2) Board independence was not associated with } \\
\text { ROA under either inside concentrated or outside } \\
\text { concentrated ownership. }\end{array}$ \\
\hline $\begin{array}{l}\text { Amoako- } \\
\text { Adu \& Smith } \\
\text { (1995) }\end{array}$ & $\begin{array}{l}150 \text { Canadian } \\
\text { public companies } \\
\text { listed on the TSX } \\
\text { over the period } \\
1984 \text { to } 1993\end{array}$ & $\begin{array}{l}\text { Proportion of outside } \\
\text { directors on the } \\
\text { board }\end{array}$ & $\begin{array}{l}\text { Tobin's Q, } \\
\text { ROA, asset } \\
\text { turnover }\end{array}$ & $\begin{array}{l}\text { (1) The proportion of total outside directors on the } \\
\text { board was not associated with all three firm } \\
\text { performance measures. } \\
\text { (2) Outside financial directors (under broader } \\
\text { definition) }{ }^{2245} \text { were significantly and positively } \\
\text { related to one out of three performance indicators } \\
\text { (Tobin's Q). } \\
\text { (3) Directors from the same industry were } \\
\text { significantly and negatively correlated with one } \\
\text { out of three performance indicators (asset } \\
\text { turnover). }\end{array}$ \\
\hline
\end{tabular}

${ }^{2245}$ Outside financial directors under broader definition include directors who are either employees or directors from financial institutions. 


\section{Appendix 20 (Continued)}

Table B: Studies Regarding the Relationship between Board Independence and Firm Performance between 1994 (Dey Report) and 2002

\begin{tabular}{|c|c|c|c|c|}
\hline Studies & Sample & $\begin{array}{l}\text { Measure of Board } \\
\text { Independence }\end{array}$ & $\begin{array}{l}\text { Measure of } \\
\text { Firm } \\
\text { Performance }\end{array}$ & Findings \\
\hline $\begin{array}{l}\text { Erickson } e t \\
\text { al. }(2005)\end{array}$ & $\begin{array}{l}66 \text { Canadian firms } \\
\text { collected from the } \\
\text { Global Vantage } \\
\text { database for the } \\
\text { period between } 1993 \\
\text { and } 1997\end{array}$ & $\begin{array}{l}\text { proportion of outside } \\
\text { directors on the } \\
\text { board }\end{array}$ & $\begin{array}{l}\text { adjusted } \\
\text { Tobin's Q }\end{array}$ & $\begin{array}{l}\text { Firms (in the presence of dominant shareholders) } \\
\text { with poor performance tended to add outside } \\
\text { directors to their boards in the next year, but greater } \\
\text { board independence did not lead to better } \\
\text { performance in the following year. }\end{array}$ \\
\hline $\begin{array}{l}\text { Panasian, } \\
\text { Prevost \& } \\
\text { Bhabra } \\
(2008)\end{array}$ & $\begin{array}{l}300 \text { largest Canadian } \\
\text { firms listed on the } \\
\text { TSE in } 1995 \text { for the } \\
\text { period } 1993 \text { to } 1997\end{array}$ & $\begin{array}{l}\text { a majority of } \\
\text { independent } \\
\text { directors on the } \\
\text { board }\end{array}$ & Tobin's Q & $\begin{array}{l}\text { (1) There was no significant difference in firm } \\
\text { performance between boards with less than } 50 \% \\
\text { of unrelated directors and boards with more than } \\
50 \% \text { of unrelated directors. } \\
\text { (2) Poorly performing firms were more likely to } \\
\text { increase their proportion of independent directors } \\
\text { on the board to at least } 50 \% \text {, but well performing } \\
\text { firms were reluctant to do so. } \\
\text { (3) Poorly performing firms that increased their } \\
\text { proportion of independent directors on the board } \\
\text { to at least } 50 \% \text { experienced significantly } \\
\text { improved firm valuation, in comparison with } \\
\text { those noncompliant poorly-performing firms. } \\
\text { (4) Firms that performed well and chose not to } \\
\text { increase their proportion of independent directors } \\
\text { on the board to at least } 50 \% \text { continued to perform } \\
\text { strongly in the post-Dey period. }\end{array}$ \\
\hline
\end{tabular}




\section{Appendix 20 (Continued)}

Table C: Studies Regarding the Relationship between Board Independence and Firm Performance for State-Owned Enterprises

\begin{tabular}{|c|c|c|c|c|}
\hline Studies & Sample & $\begin{array}{c}\text { Measure of } \\
\text { Board } \\
\text { Independence }\end{array}$ & $\begin{array}{l}\text { Measure of Firm } \\
\text { Performance }\end{array}$ & Findings \\
\hline Bozec (2003) & $\begin{array}{l}25 \text { state-owned enterprises } \\
\text { (SOEs) selected from the } \\
500 \text { largest Canadian firms } \\
\text { as listed by the Financial } \\
\text { Post covering the period } \\
\text { from } 1976 \text { to } 2000\end{array}$ & $\begin{array}{l}\text { Proportion of } \\
\text { outside } \\
\text { directors on the } \\
\text { board }\end{array}$ & $\begin{array}{l}\text { Return on sales, } \\
\text { ROA, sale } \\
\text { efficiency, net } \\
\text { income efficiency } \\
\text { and assets turnover }\end{array}$ & $\begin{array}{l}\text { (1) There was no significant relationship } \\
\text { between the proportion of outside directors } \\
\text { on the board and firm performance } \\
\text { indicators (without the impact of market } \\
\text { competition). } \\
\text { (2) When the SOEs were exposed to market } \\
\text { competition, the proportion of outside } \\
\text { directors on the board was significantly and } \\
\text { negatively related to four out of five firm } \\
\text { performance measures (except for ROA). }\end{array}$ \\
\hline $\begin{array}{l}\text { Bozec \& Dia } \\
(2007)\end{array}$ & $\begin{array}{l}14 \text { state-owned enterprises } \\
\text { selected from the } 500 \\
\text { largest Canadian firms in } \\
1985 \text { as listed by the } \\
\text { Financial Post covering } \\
\text { the period from } 1976 \text { to } \\
2001\end{array}$ & $\begin{array}{l}\text { Proportion of } \\
\text { outside } \\
\text { directors on the } \\
\text { board }\end{array}$ & $\begin{array}{l}\text { Firm technical } \\
\text { efficiency (CCR or } \\
\text { BCC models) }\end{array}$ & $\begin{array}{l}\text { (1) There was no significant correlation } \\
\text { between the proportion of outside directors } \\
\text { on the board and firm technical efficiency } \\
\text { (without the impact of market discipline). } \\
\text { (2) When the SOEs were exposed to market } \\
\text { competition, the proportion of outside } \\
\text { directors on the board was significantly and } \\
\text { positively related to firm technical } \\
\text { efficiency. }\end{array}$ \\
\hline
\end{tabular}




\section{Appendix 20 (Continued)}

Table D: Studies Regarding the Relationship between ROB Board Composition Scores and Firm Performance after 2002

\begin{tabular}{|c|c|c|c|c|}
\hline Studies & Sample & $\begin{array}{c}\text { Measure of } \\
\text { Board } \\
\text { Independence }\end{array}$ & $\begin{array}{l}\text { Measure of Firm } \\
\text { Performance }\end{array}$ & Findings \\
\hline $\begin{array}{l}\text { Jog \& Dutta } \\
(2004)\end{array}$ & $\begin{array}{l}270 \text { largest } \\
\text { Canadian firms in } \\
2002\end{array}$ & $\begin{array}{l}\text { ROB Board } \\
\text { Composition } \\
\text { scores }\end{array}$ & $\begin{array}{l}\text { ROA, market-to-book value } \\
\text { ratio, a firm's monthly } \\
\text { return }\end{array}$ & $\begin{array}{l}\text { ROB Board Composition scores were significantly and negatively related to } \\
\text { ROA, but were not associated with market-to-book value ratio and a firm's } \\
\text { monthly return. }\end{array}$ \\
\hline $\begin{array}{l}\text { Klein, Shapiro \& } \\
\text { Young (2005) }\end{array}$ & $\begin{array}{l}263 \text { largest } \\
\text { Canadian firms in } \\
2002\end{array}$ & $\begin{array}{l}\text { ROB Board } \\
\text { Composition } \\
\text { scores }\end{array}$ & Tobin's Q & $\begin{array}{l}\text { (1) Board Composition scores alone were insignificantly related to Tobin's Q, } \\
\text { but it was significantly and negatively associated with Tobin's Q when the } \\
\text { effects of all four sub-indices were all included. } \\
\text { (2) The impact of Board Composition scores on firm performance varied with } \\
\text { ownership structure. Board Composition scores were not associated with } \\
\text { firm performance for widely-held firms, but higher Board Composition } \\
\text { scores were related to inferior firm performance for family-owned firms. }\end{array}$ \\
\hline $\begin{array}{l}\text { Adjaoud, Zeghal } \\
\text { \& Andaleeb } \\
(2007)\end{array}$ & $\begin{array}{l}219 \text { largest } \\
\text { Canadian firms in } \\
2002\end{array}$ & $\begin{array}{l}\text { ROB Board } \\
\text { Composition } \\
\text { scores }\end{array}$ & $\begin{array}{l}\text { ROE, return on } \\
\text { investments, earnings per } \\
\text { share, and market-to-book } \\
\text { value ratio) (EVA and } \\
\text { MVA) }\end{array}$ & $\begin{array}{l}\text { ROB Board Composition scores were negatively related to all six firm } \\
\text { performance measures. More specifically, Board Composition was } \\
\text { significantly and negatively associated with three out of four accounting-based } \\
\text { indices (except for market-to-book ratio) and one out of two value creation- } \\
\text { based index (MVA). }\end{array}$ \\
\hline $\begin{array}{l}\text { Gupta, Kennedy } \\
\& \text { Weaver (2009) }\end{array}$ & $\begin{array}{l}158 \text { Canadian } \\
\text { largest firms from } \\
2002 \text { to } 2005\end{array}$ & $\begin{array}{l}\text { ROB Board } \\
\text { Composition } \\
\text { scores }\end{array}$ & $\begin{array}{l}\text { Market valuation (market- } \\
\text { to-book value ratio and } \\
\text { Tobin's Q), firm } \\
\text { performance (ROA) and } \\
\text { market reaction (two-day } \\
\text { and } 11 \text {-day stock returns } \\
\text { around the publication date } \\
\text { of ROB rankings) }\end{array}$ & $\begin{array}{l}\text { (1) ROB Board Composition scores were not associated with all firm } \\
\text { performance measures. } \\
\text { (2) After reviewing it annually, the higher the Board Composition scores, the } \\
\text { lower Tobin's Q or the market-to-book ratio the firm had for the years } \\
2002 \text { and } 2004 \text {. }\end{array}$ \\
\hline $\begin{array}{l}\text { Bozec and Bozec } \\
\text { (2011) }\end{array}$ & $\begin{array}{l}155 \text { Canadian firms } \\
\text { over a four-year } \\
\text { period from } 2002 \text { to } \\
2005\end{array}$ & $\begin{array}{l}\text { ROB Board } \\
\text { Composition } \\
\text { scores }\end{array}$ & $\begin{array}{l}\text { Cost of equity capital, cost } \\
\text { of after-tax debt }\end{array}$ & $\begin{array}{l}\text { ROB Board Composition scores were significantly and negatively related to } \\
\text { the cost of equity capital and after-tax debt. }\end{array}$ \\
\hline $\begin{array}{l}\text { Toledo and } \\
\text { Bocatto (2012) }\end{array}$ & $\begin{array}{l}156 \text { corporations } \\
\text { listed in TSX in } \\
2009\end{array}$ & $\begin{array}{l}\text { ROB Board } \\
\text { Composition } \\
\text { scores }\end{array}$ & $\begin{array}{l}\text { Stock returns, ROA and } \\
\text { Tobin's Q }\end{array}$ & $\begin{array}{l}\text { ROB Board Composition scores were not associated with three firm } \\
\text { performance indicators (stock returns, ROA and Tobin's Q). }\end{array}$ \\
\hline
\end{tabular}

${ }^{2246}$ EVA, economic value added, calculates the dollar amount of the difference between a company's net profit after taxes and the total cost of capital employed, including the cost of equity. MVA (market value added) calculates the dollar amount of the difference between a company's market value of outstanding shares and the total cost of capital employed. 
Appendix 20 (Continued)

Table E: Studies Regarding the Relationship between Board Independence and Firm Performance for Cross-Listing Small Firms

\begin{tabular}{|l|l|l|l|l|}
\hline \multicolumn{1}{|c|}{ Studies } & \multicolumn{1}{|c|}{ Sample } & $\begin{array}{c}\text { Measure of Board } \\
\text { Independence }\end{array}$ & $\begin{array}{c}\text { Measure of Firm } \\
\text { Performance }\end{array}$ & \multicolumn{1}{c|}{ Findings } \\
\hline $\begin{array}{l}\text { Switzer } \\
(2007)\end{array}$ & $\begin{array}{l}\text { 94 Canadian } \\
\text { TSX/S\&P Small- } \\
\text { Cap firms during } \\
\text { the years 1997 to } \\
2004\end{array}$ & $\begin{array}{l}\text { Proportion of outside } \\
\text { directors on the } \\
\text { board }\end{array}$ & Tobin's Q & $\begin{array}{l}\text { There was no significant correlation between } \\
\text { the proportion of outside directors on the board } \\
\text { and Tobin's Q. }\end{array}$ \\
\hline
\end{tabular}




\section{Appendix 21}

Summary of Canadian Empirical Studies Investigating the Relationship between Board Independence and the Adoption of Other Monitoring Mechanisms

\begin{tabular}{|c|c|c|c|c|}
\hline Studies & Sample & $\begin{array}{l}\text { Measure of the } \\
\text { Board } \\
\text { Independence }\end{array}$ & $\begin{array}{c}\text { Measure of Other Monitoring } \\
\text { Mechanisms }\end{array}$ & Findings \\
\hline $\begin{array}{l}\text { Anand, } \\
\text { Milne \& } \\
\text { Purda (2010) }\end{array}$ & $\begin{array}{l}\text { More than } 200 \text { firms } \\
\text { listed on Toronto } \\
\text { Stock Exchange } \\
\text { during the years } \\
1999 \text { to } 2003\end{array}$ & $\begin{array}{l}\text { Whether a board } \\
\text { includes either a } \\
\text { majority of } \\
\text { independent } \\
\text { directors or an } \\
\text { independent chair }\end{array}$ & $\begin{array}{l}\text { Whether a firm has: (1) a } \\
\text { completely independent audit } \\
\text { committee; (2) a completely } \\
\text { independent compensation } \\
\text { committee; ( } 3 \text { ) the ability to } \\
\text { independently hire advisors; (4) } \\
\text { formal training for new board } \\
\text { members; (5) adopted a code of } \\
\text { ethics; (6) its financial } \\
\text { statements certified by its CEO } \\
\text { and CFO; and (7) a financial } \\
\text { expert sitting on the audit } \\
\text { committee. }\end{array}$ & $\begin{array}{l}\text { There is no significant difference } \\
\text { between independent and non- } \\
\text { independent boards in voluntarily } \\
\text { adopting governance mechanisms } \\
\text { designed to enhance their } \\
\text { monitoring capabilities, but } \\
\text { independent boards place special } \\
\text { emphasis on management oversight } \\
\text { though the presence of independent } \\
\text { audit and compensation } \\
\text { committees. }\end{array}$ \\
\hline
\end{tabular}




\section{Appendix 22}

\section{Summary of Canadian Empirical Studies Investigating the Relationship between Director Independence (or Financial}

Expertise) and the Quality of Financial Reporting

Table A: Studies Regarding the Relationship between Board Independence and the Quality of Financial Reporting

\begin{tabular}{|c|c|c|c|c|}
\hline Studies & Sample & $\begin{array}{l}\text { Measure of Board } \\
\text { Independence }\end{array}$ & $\begin{array}{l}\text { Measure of the } \\
\text { Quality of Financial } \\
\text { Reporting }\end{array}$ & Findings \\
\hline $\begin{array}{l}\text { Park \& Shin } \\
(2004)\end{array}$ & $\begin{array}{l}202 \text { Canadian firms } \\
\text { from } 1991 \text { to } 1997\end{array}$ & $\begin{array}{l}\text { Proportion of outside } \\
\text { directors on the } \\
\text { board }\end{array}$ & $\begin{array}{l}\text { Earnings } \\
\text { management }\end{array}$ & $\begin{array}{l}\text { The proportion of outside directors on the } \\
\text { board was not associated with the level of } \\
\text { earnings management. }\end{array}$ \\
\hline Niu (2006) & $\begin{array}{l}\text { Around } 520 \text { firm-year } \\
\text { observations for } \\
\text { S\&P/TSX composite } \\
\text { index firms from years } \\
2002 \text { to } 2005\end{array}$ & $\begin{array}{l}\text { ROB Board } \\
\text { Composition Scores } \\
\text { (only } 20 \% \text { of the } \\
\text { scores is related to } \\
\text { the proportion of } \\
\text { independent } \\
\text { directors on the } \\
\text { board) }\end{array}$ & $\begin{array}{l}\text { The level of earnings } \\
\text { management } \\
\text { (abnormal accruals) } \\
\text { and earnings quality } \\
\text { (return-earnings } \\
\text { association) }\end{array}$ & $\begin{array}{l}\text { Firms with higher ROB Board } \\
\text { Composition scores were associated a } \\
\text { lower level of earnings management and } \\
\text { a higher level of quality earnings. }\end{array}$ \\
\hline $\begin{array}{l}\text { Smaili \& } \\
\text { Labelle } \\
\text { (2009) }\end{array}$ & $\begin{array}{l}107 \text { firms identified as } \\
\text { accounting } \\
\text { irregularities by the } \\
\text { Ontario Securities } \\
\text { Commission from } 2001 \\
\text { to } 2005\end{array}$ & $\begin{array}{l}\text { Proportion of } \\
\text { independent } \\
\text { directors on the } \\
\text { board }\end{array}$ & $\begin{array}{l}\text { The occurrence and } \\
\text { severity of } \\
\text { accounting } \\
\text { irregularities }\end{array}$ & $\begin{array}{l}\text { Firms with a higher proportion of } \\
\text { independent directors on the board were } \\
\text { associated with not only a lower } \\
\text { occurrence of accounting irregularities } \\
\text { but also less severe accounting } \\
\text { irregularities. }\end{array}$ \\
\hline
\end{tabular}




\section{Appendix 22 (Continued)}

Table B: Studies Regarding the Relationship between Audit Committee Independence and the Quality of Financial Reporting

\begin{tabular}{|c|c|c|c|c|}
\hline Studies & Sample & $\begin{array}{l}\text { Measure of the } \\
\text { Audit Committee } \\
\text { Independence }\end{array}$ & $\begin{array}{c}\text { Measure of the } \\
\text { Quality of Financial } \\
\text { Reporting }\end{array}$ & Findings \\
\hline $\begin{array}{l}\text { Scarbrough, } \\
\text { Rama \& } \\
\text { Raghunandan } \\
\text { (1998) }\end{array}$ & $\begin{array}{l}72 \text { Canadian firms in } \\
\text { the late } 1990 \mathrm{~s}\end{array}$ & $\begin{array}{l}\text { Audit committees } \\
\text { with } 100 \% \text { of } \\
\text { outside directors }\end{array}$ & $\begin{array}{l}\text { The likelihood of } \\
\text { engaging in internal } \\
\text { auditing activities }\end{array}$ & $\begin{array}{l}\text { Audit committees with } 100 \% \text { of outside } \\
\text { directors were more likely to be engaged in } \\
\text { internal auditing activities, including meeting } \\
\text { at least three times a year with the chief } \\
\text { internal auditor and reviewing the results of } \\
\text { internal auditing. }\end{array}$ \\
\hline Niu (2006) & $\begin{array}{l}\text { Around } 520 \text { firm- } \\
\text { year observations for } \\
\text { S\&P/TSX composite } \\
\text { index firms from } \\
\text { years } 2002 \text { to } 2005\end{array}$ & $\begin{array}{l}\text { ROB Board } \\
\text { Composition } \\
\text { Scores (only } 15 \% \\
\text { of the scores is } \\
\text { related to the } \\
\text { proportion of } \\
\text { independent } \\
\text { directors on the } \\
\text { audit committee) }\end{array}$ & $\begin{array}{l}\text { The level of earnings } \\
\text { management (as } \\
\text { measured by } \\
\text { abnormal accruals) } \\
\text { and earnings quality } \\
\text { (as measured by } \\
\text { return-earnings } \\
\text { association) }\end{array}$ & $\begin{array}{l}\text { Firms with higher ROB Board Composition } \\
\text { scores were associated a lower level of } \\
\text { earnings management and a higher level of } \\
\text { quality earnings. }\end{array}$ \\
\hline $\begin{array}{l}\text { Smaili \& } \\
\text { Labelle } \\
(2009)\end{array}$ & $\begin{array}{l}107 \text { firms identified } \\
\text { as accounting } \\
\text { irregularities by the } \\
\text { Ontario Securities } \\
\text { Commission from } \\
2001 \text { to } 2005\end{array}$ & $\begin{array}{l}\text { Proportion of } \\
\text { independent } \\
\text { directors on the } \\
\text { audit committee }\end{array}$ & $\begin{array}{l}\text { The occurrence and } \\
\text { severity of } \\
\text { accounting } \\
\text { irregularities }\end{array}$ & $\begin{array}{l}\text { The proportion of independent directors on the } \\
\text { audit committee was not associated with the } \\
\text { occurrence of accounting irregularities. }\end{array}$ \\
\hline
\end{tabular}




\section{Appendix 22 (Continued)}

Table C: Studies Regarding the Relationship between Directors with Financial Expertise (or Financial Literacy) and the Quality of Financial Reporting

\begin{tabular}{|l|l|l|l|l|}
\hline \multicolumn{1}{|c|}{ Studies } & \multicolumn{1}{|c|}{ Sample } & $\begin{array}{l}\text { Measure of Directors } \\
\text { with Financial } \\
\text { Expertise }\end{array}$ & $\begin{array}{c}\text { Measure of the } \\
\text { Quality of Financial } \\
\text { Reporting }\end{array}$ & \multicolumn{1}{|c|}{ Findings } \\
\hline $\begin{array}{l}\text { Park \& Shin } \\
(2004)\end{array}$ & $\begin{array}{l}\text { 202 Canadian firms } \\
\text { from 1991 to 1997 }\end{array}$ & $\begin{array}{l}\text { Whether the } \text { outside } \\
\text { directors come from } \\
\text { financial } \\
\text { intermediaries or } \\
\text { from institutional } \\
\text { investors }\end{array}$ & $\begin{array}{l}\text { Earnings } \\
\text { management }\end{array}$ & $\begin{array}{l}\text { Boards with the presence of directors } \\
\text { from financial institutions were } \\
\text { associated with a lower level of earnings } \\
\text { management. }\end{array}$ \\
\hline $\begin{array}{l}\text { Smaili \& } \\
(2009)\end{array}$ & $\begin{array}{l}\text { 107 firms identified as } \\
\text { accounting } \\
\text { irregularities by the } \\
\text { Ontario Securities } \\
\text { Commission from 2001 } \\
\text { to 2005 }\end{array}$ & $\begin{array}{l}\text { Whether a director } \\
\text { has a professional } \\
\text { designation in } \\
\text { accounting or } \\
\text { finance (CA, CMA, } \\
\text { CGA or CFA) or } \\
\text { with a specialized } \\
\text { university diploma } \\
\text { in accounting or in } \\
\text { finance }\end{array}$ & $\begin{array}{l}\text { The occurrence and } \\
\text { severity of } \\
\text { accounting } \\
\text { irregularities }\end{array}$ & $\begin{array}{l}\text { (1) Audit committees with more financial } \\
\text { experts were associated with fewer } \\
\text { and less severe accounting } \\
\text { irregularities. }\end{array}$ \\
& & & $\begin{array}{l}\text { (2) } \\
\text { The proportion of audit committee } \\
\text { members with financial literacy had } \\
\text { no impact on the occurrence or } \\
\text { gravity of accounting irregularities. }\end{array}$ \\
\hline
\end{tabular}




\section{Appendix 23}

Summary of Canadian Empirical Studies Investigating the Relationship between Director Independence and Executive Compensation

Table A: Studies Regarding the Relationship between Director Independence and the Level of CEO Compensation

\begin{tabular}{|c|c|c|c|c|}
\hline Studies & Sample & $\begin{array}{l}\text { Measure of Director } \\
\text { Independence }\end{array}$ & $\begin{array}{c}\text { Measure of CEO } \\
\text { Compensation }\end{array}$ & Findings \\
\hline $\begin{array}{l}\text { Jog \& Dutta } \\
\text { (2004) }\end{array}$ & $\begin{array}{l}270 \text { largest Canadian } \\
\text { firms in } 2002\end{array}$ & $\begin{array}{l}\text { Proportion of inside } \\
\text { directors on the } \\
\text { board }\end{array}$ & $\begin{array}{l}\text { CEO compensation } \\
\text { is not defined }\end{array}$ & $\begin{array}{l}\text { The proportion of insiders on the board was } \\
\text { not associated with the level of CEO } \\
\text { compensation. }\end{array}$ \\
\hline Sapp (2008) & $\begin{array}{l}416 \text { Canadian } \\
\text { publicly-listed firms } \\
\text { from } 2000 \text { to } 2005\end{array}$ & $\begin{array}{l}\text { Proportion of } \\
\text { independent } \\
\text { directors on the } \\
\text { board, proportion of } \\
\text { independent } \\
\text { directors on the } \\
\text { compensation } \\
\text { committee }\end{array}$ & $\begin{array}{l}\text { The sum of the } \\
\text { salary, bonus, long- } \\
\text { term incentive plan } \\
\text { and all other annual } \\
\text { compensation }\end{array}$ & $\begin{array}{l}\text { (1) The proportion of independent directors } \\
\text { on the board was not associated with the } \\
\text { level of total CEO pay. } \\
\text { (2) Compensation committees with a higher } \\
\text { proportion of independent directors were } \\
\text { associated with higher levels of CEO } \\
\text { compensation. }\end{array}$ \\
\hline
\end{tabular}




\section{Appendix 23 (Continued)}

Table B: Studies Regarding the Relationship between Director Independence and the Sensitivity of CEO Compensation to Firm Performance

\section{Panel 1: Studies Indirectly Exploring this Relationship}

\begin{tabular}{|l|l|l|l|l|}
\hline \multicolumn{1}{|c|}{ Studies } & \multicolumn{1}{|c|}{ Sample } & \multicolumn{1}{c|}{$\begin{array}{c}\text { Measure of Firm } \\
\text { Performance }\end{array}$} & \multicolumn{1}{c|}{$\begin{array}{l}\text { Measure of CEO } \\
\text { Compensation }\end{array}$} & \multicolumn{1}{c|}{ Findings } \\
\hline $\begin{array}{l}\text { Jog \& Dutta } \\
(2004)\end{array}$ & $\begin{array}{l}\text { 270 largest Canadian } \\
\text { firms in 2002 }\end{array}$ & $\begin{array}{l}\text { ROA, market-to-book } \\
\text { value ratio, a firm's } \\
\text { monthly return }\end{array}$ & $\begin{array}{l}\text { CEO compensation is not } \\
\text { defined }\end{array}$ & $\begin{array}{l}\text { There was no significant relationship between CEO } \\
\text { compensation and all three firm performance } \\
\text { measures. }\end{array}$ \\
\hline Sapp (2008) & $\begin{array}{l}\text { 416 Canadian publicly- } \\
\text { listed firms from 2000 to } \\
2005\end{array}$ & $\begin{array}{l}\text { Shareholder returns, } \\
\text { average industry returns, } \\
\text { ROA }\end{array}$ & $\begin{array}{l}\text { The sum of the salary, } \\
\text { bonus, long-term } \\
\text { incentive plan and all } \\
\text { other annual } \\
\text { compensation }\end{array}$ & $\begin{array}{l}\text { Executive compensation was not associated with } \\
\text { shareholder returns and average industry returns, but } \\
\text { was significantly and negatively associated with } \\
\text { ROA. }\end{array}$ \\
\hline
\end{tabular}

\section{Panel 2: Studies Directly Exploring this Relationship}

\begin{tabular}{|l|l|l|l|l|}
\hline \multicolumn{1}{|c|}{ Studies } & \multicolumn{1}{|c|}{ Sample } & $\begin{array}{l}\text { Measure of Director } \\
\text { Independence }\end{array}$ & $\begin{array}{l}\text { Measure of Sensitivity of } \\
\text { CEO Pay to Firm } \\
\text { Performance }\end{array}$ & \multicolumn{1}{|c|}{ Findings } \\
\hline Switzer (2007) & $\begin{array}{l}\text { 94 Canadian TSX/S\&P } \\
\text { Small-Cap firms during } \\
\text { the years 1997 to 2004 }\end{array}$ & $\begin{array}{l}\text { Proportion of outside } \\
\text { directors on the board }\end{array}$ & $\begin{array}{l}\text { Jensen-Murphy pay- } \\
\text { performance sensitivity }\end{array}$ & $\begin{array}{l}\text { The proportion of outside directors on the board was } \\
\text { not associated with the pay-for-performance } \\
\text { sensitivity of CEO compensation. }\end{array}$ \\
\hline $\begin{array}{l}\text { Schiehll \& } \\
\text { Bellavance } \\
(2009)\end{array}$ & $\begin{array}{l}\text { 132 Canadian firms } \\
\text { listed on the Toronto } \\
\text { Stock Exchange at the } \\
\text { end of 2000 }\end{array}$ & $\begin{array}{l}\text { Proportion of } \\
\text { independent directors } \\
\text { on the board }\end{array}$ & $\begin{array}{l}\text { Adoption of non-financial } \\
\text { performance measures } \\
\text { 2247 in }\end{array}$ & $\begin{array}{l}\text { Firms with a greater proportion of independent } \\
\text { directors, in some circumstances, aligned CEO the CEO's } \\
\text { interests with shareholder wealth by employing non- } \\
\text { financial performance measures in establishing the } \\
\text { CEO's compensation package. }\end{array}$ \\
\hline
\end{tabular}

\footnotetext{
${ }^{2247}$ In addition to financial performance indicators, non-financial performance information, such as market share, customer satisfaction, and productivity rates, may provide more accurate information regarding the factors that drive firm value contributed by a CEO. As a result, the use of non-financial performance measures in the CEO remuneration plan better reflects a CEO's contribution to firm value, and more closely connects a CEO's incentives with shareholder wealth.
} 


\section{Appendix 24}

Summary of Canadian Empirical Studies Investigating the Relationship between Female Directors on the Board and Firm Performance

\begin{tabular}{|l|l|l|l|l|}
\hline \multicolumn{1}{|c|}{ Studies } & \multicolumn{1}{|c|}{ Sample } & \multicolumn{1}{c|}{$\begin{array}{c}\text { Measure of the } \\
\text { Female Directors }\end{array}$} & $\begin{array}{c}\text { Measure of Firm } \\
\text { Performance }\end{array}$ & \multicolumn{1}{c|}{ Findings } \\
\hline $\begin{array}{l}\text { Francoeur, } \\
\text { Labelle \& }\end{array}$ & $\begin{array}{l}\text { 230 Financial Post's } \\
\text { 500 largest Canadian } \\
\text { Sinclair- } \\
\text { firms from 2001 to } \\
\text { Desgagné } \\
\text { (2008) }\end{array}$ & $\begin{array}{l}\text { Proportion of } \\
\text { women directors } \\
\text { on the board }\end{array}$ & $\begin{array}{l}\text { Monthly abnormal } \\
\text { returns }\end{array}$ & $\begin{array}{l}\text { There were no significant increased abnormal } \\
\text { returns for firms with a higher proportion of } \\
\text { women directors. }\end{array}$ \\
\hline
\end{tabular}




\section{Appendix 25}

Summary of Canadian Empirical Studies Investigating the Relationship between the Number of Directors on the Board (Board Size) and Firm Performance

\begin{tabular}{|c|c|c|c|c|}
\hline Studies & Sample & $\begin{array}{c}\text { Measure of the Board } \\
\text { Size }\end{array}$ & $\begin{array}{c}\text { Measure of Firm } \\
\text { Performance }\end{array}$ & Findings \\
\hline $\begin{array}{l}\text { Rao \& Lee- } \\
\text { Sing (1995) }\end{array}$ & $\begin{array}{l}766 \text { Canadian firms for the } \\
\text { period } 1988 \text { to } 1993\end{array}$ & $\begin{array}{l}\text { The number of } \\
\text { directors on the board }\end{array}$ & ROA, ROE & $\begin{array}{l}\text { Board size was not associated with firm } \\
\text { performance (ROA and ROE). }\end{array}$ \\
\hline $\begin{array}{l}\text { Jog \& Dutta } \\
(2004)\end{array}$ & $\begin{array}{l}270 \text { largest Canadian firms } \\
\text { in } 2002\end{array}$ & $\begin{array}{l}\text { The number of } \\
\text { directors on the board }\end{array}$ & $\begin{array}{l}\text { ROA, market-to- } \\
\text { book value ratio, } \\
\text { a firm's monthly } \\
\text { return }\end{array}$ & $\begin{array}{l}\text { Firms with smaller number of directors on the } \\
\text { board were associated with better firm } \\
\text { performance (except for market-to-book ratio), } \\
\text { but such an association disappeared after } \\
\text { accounting for endogeneity (in a } 2 \text { SLS } \\
\text { regression model). }\end{array}$ \\
\hline Bozec (2003) & $\begin{array}{l}25 \text { state-owned enterprises } \\
\text { (SOEs) selected from the } \\
500 \text { largest Canadian firms } \\
\text { as listed by the Financial } \\
\text { Post covering the period } \\
\text { from } 1976 \text { to } 2000\end{array}$ & $\begin{array}{l}\text { The number of } \\
\text { directors on the board }\end{array}$ & $\begin{array}{l}\text { ROS, ROA, sale } \\
\text { efficiency, net } \\
\text { income efficiency } \\
\text { and assets } \\
\text { turnover }\end{array}$ & $\begin{array}{l}\text { There was a mixed relationship between board } \\
\text { size and firm performance. Board size was } \\
\text { significantly and negatively related to ROS, } \\
\text { sales efficiency and assets turnover, but was not } \\
\text { associated with ROA and net income efficiency. }\end{array}$ \\
\hline $\begin{array}{l}\text { Bozec \& Dia } \\
(2007)\end{array}$ & $\begin{array}{l}14 \text { state-owned enterprises } \\
\text { selected from the } 500 \text { largest } \\
\text { Canadian firm in } 1985 \text { as } \\
\text { listed by the Financial Post } \\
\text { covering the period from } \\
1976 \text { to } 2001\end{array}$ & $\begin{array}{l}\text { The number of } \\
\text { directors on the board }\end{array}$ & $\begin{array}{l}\text { Firm technical } \\
\text { efficiency (CCR } \\
\text { or BCC models) }\end{array}$ & $\begin{array}{l}\text { There was no significant relationship between } \\
\text { board size and firm technical efficiency in three } \\
\text { out of four regression models. } \\
\text { When SOEs were exposed to market discipline, } \\
\text { board size was significantly and positively } \\
\text { associated with firm technical efficiency. }\end{array}$ \\
\hline $\begin{array}{l}\text { Panasian, } \\
\text { Prevost \& } \\
\text { Bhabra (2008) }\end{array}$ & $\begin{array}{l}300 \text { largest Canadian firms } \\
\text { listed on the TSE in } 1995 \text { for } \\
\text { the period } 1993 \text { to } 1997\end{array}$ & $\begin{array}{l}\text { The number of } \\
\text { directors on the board }\end{array}$ & Tobin's Q & $\begin{array}{l}\text { There was no significant relationship between } \\
\text { board size and firm value (Tobin's Q). }\end{array}$ \\
\hline
\end{tabular}




\section{Appendix 26}

Summary of Canadian Empirical Studies Investigating the Relationship between Leadership Structure, Board Independence and Firm Performance

\begin{tabular}{|l|l|l|l|l|}
\hline \multicolumn{1}{|c|}{ Studies } & \multicolumn{1}{|c|}{ Sample } & $\begin{array}{c}\text { Measure of the } \\
\text { Board } \\
\text { Independence }\end{array}$ & $\begin{array}{l}\text { Measure of Firm } \\
\text { Performance }\end{array}$ & \multicolumn{1}{c|}{ Findings } \\
\hline $\begin{array}{l}\text { Switzer } \\
(2007)\end{array}$ & $\begin{array}{l}\text { 94 Canadian TSX/S\&P } \\
\text { Small-Cap firms during } \\
\text { the years 1997 to 2004 }\end{array}$ & $\begin{array}{l}\text { Proportion of } \\
\text { outside directors on } \\
\text { the board }\end{array}$ & Tobin's Q & $\begin{array}{l}\text { Firms with a unitary leadership structure } \\
\text { (CEOs who also hold the board chair) } \\
\text { were inclined to have more outside } \\
\text { directors on their boards, but the adoption } \\
\text { of a unitary leadership structure had no } \\
\text { significant impact on their firm value } \\
\text { (Tobin's Q). }\end{array}$ \\
\hline
\end{tabular}




\section{Appendix 27}

\section{Summary of Canadian Empirical Studies Investigating the Relationship between Controlling Shareholders and the Efficacy of Independent Directors}

Table A: Studies Regarding the Impact of Ownership Concentration (Existence of Controlling Shareholders) on Firm Performance

\begin{tabular}{|c|c|c|c|c|}
\hline Studies & Sample & $\begin{array}{l}\text { Measure of Ownership } \\
\text { Concentration }\end{array}$ & $\begin{array}{l}\text { Measure of Firm } \\
\text { Performance }\end{array}$ & Findings \\
\hline $\begin{array}{l}\text { Rao \& Lee- } \\
\text { Sing (1995) }\end{array}$ & $\begin{array}{l}766 \text { Canadian firms for the } \\
\text { period } 1988 \text { to } 1993\end{array}$ & $\begin{array}{l}\text { Proportion of voting shares } \\
\text { held by all significant } \\
\text { shareholders ( } 10 \% \text { of } \\
\text { voting rights); the number } \\
\text { of significant shareholders }\end{array}$ & ROA, ROE & $\begin{array}{l}\text { There was no significant relationship } \\
\text { between ownership concentration } \\
\text { and firm performance. }\end{array}$ \\
\hline Attig (2007) & $\begin{array}{l}1,079 \text { publicly traded } \\
\text { Canadian firms in } 1996\end{array}$ & $\begin{array}{l}\text { Proportion of ownership } \\
\text { directly and indirectly held } \\
\text { by the largest shareholders }\end{array}$ & Tobin's Q & $\begin{array}{l}\text { There was no significant relationship } \\
\text { between the proportion of ownership } \\
\text { held by the largest shareholders and } \\
\text { Tobin's Q. }\end{array}$ \\
\hline $\begin{array}{l}\text { King \& } \\
\text { Santor } \\
(2008)\end{array}$ & $\begin{array}{l}613 \text { Canadian firms from } \\
1998 \text { to } 2005\end{array}$ & $\begin{array}{l}\text { An individual or family } \\
\text { group controls } 20 \% \text { or } \\
\text { more of voting rights }\end{array}$ & Tobin's Q, ROA & $\begin{array}{l}\text { There was no significant difference } \\
\text { in firm performance (Tobin's Q) } \\
\text { between family-owned firms and } \\
\text { widely-held firms. }\end{array}$ \\
\hline $\begin{array}{l}\text { Erickson } \text { et } \\
\text { al. }(2005)\end{array}$ & $\begin{array}{l}66 \text { Canadian firms } \\
\text { collected from the Global } \\
\text { Vantage database for the } \\
\text { period between } 1993 \text { and } \\
1997\end{array}$ & $\begin{array}{l}\text { Proportion of voting rights } \\
\text { of the dominant } \\
\text { shareholder }\end{array}$ & $\begin{array}{l}\text { Adjusted } \\
\text { Tobin's Q }\end{array}$ & $\begin{array}{l}\text { The existence of a dominant } \\
\text { shareholder was significantly related } \\
\text { to lower Tobin's Q. }\end{array}$ \\
\hline $\begin{array}{l}\text { Panasian, } \\
\text { Prevost \& } \\
\text { Bhabra } \\
(2008)\end{array}$ & $\begin{array}{l}300 \text { largest Canadian firms } \\
\text { listed on the TSE in } 1995 \\
\text { for the period } 1993 \text { to } \\
1997\end{array}$ & $\begin{array}{l}\text { Equity owned by } \\
\text { blockholders }\end{array}$ & Tobin's Q & $\begin{array}{l}\text { Firms with a dominant shareholder } \\
\text { were more likely (marginally } \\
\text { significant) to be associated with } \\
\text { lower Tobin's Q. }\end{array}$ \\
\hline
\end{tabular}




\section{Appendix 27 (Continued)}

Table B: Studies Regarding the Impact of the Use of Controlling-Enhancing Mechanisms on Firm Performance

\begin{tabular}{|c|c|c|c|c|}
\hline Studies & Sample & $\begin{array}{l}\text { Measure of the Use of } \\
\text { Controlling-Enhancing } \\
\text { Mechanisms }\end{array}$ & $\begin{array}{l}\text { Measure of Firm } \\
\text { Performance }\end{array}$ & Findings \\
\hline $\begin{array}{l}\text { Attig, Fischer } \\
\text { \& Gadhoum } \\
(2004)\end{array}$ & $\begin{array}{l}\text { 1,121 Canadian listed } \\
\text { firms in Stock Guide } 1996\end{array}$ & $\begin{array}{l}\text { The existence of } \\
\text { pyramidal shareholdings }\end{array}$ & Tobin's Q & $\begin{array}{l}\text { Firms affiliated to a pyramidal ownership } \\
\text { underperformed unaffiliated ones in terms of } \\
\text { firm performance (Tobin's Q). }\end{array}$ \\
\hline $\begin{array}{l}\text { Erickson et al. } \\
(2005)\end{array}$ & $\begin{array}{l}66 \text { Canadian firms } \\
\text { collected from the Global } \\
\text { Vantage database for the } \\
\text { period between } 1993 \text { and } \\
1997\end{array}$ & $\begin{array}{l}\text { The existence of dual } \\
\text { class common stock }\end{array}$ & Adjusted Tobin's Q & $\begin{array}{l}\text { The existence of dual class common stock } \\
\text { was significantly related to lower Tobin's Q. }\end{array}$ \\
\hline Attig (2007) & $\begin{array}{l}1,079 \text { publicly traded } \\
\text { Canadian firms in } 1996\end{array}$ & $\begin{array}{l}\text { The firm's largest } \\
\text { shareholder's voting } \\
\text { rights were larger than } \\
\text { his/her cash flow rights }\end{array}$ & Tobin's Q & $\begin{array}{l}\text { Firm performance (Tobin's Q) was lower } \\
\text { when a firm's largest shareholder's voting } \\
\text { rights were disproportionate to his/her cash } \\
\text { flow rights. }\end{array}$ \\
\hline $\begin{array}{l}\text { King \& Santor } \\
(2008)\end{array}$ & $\begin{array}{l}613 \text { Canadian firms from } \\
1998 \text { to } 2005\end{array}$ & $\begin{array}{l}\text { The existence of dual } \\
\text { class common stock }\end{array}$ & Tobin's Q, ROA & $\begin{array}{l}\text { Firms controlled by an individual or family } \\
\text { group through the use of dual-class share } \\
\text { suffered } 17 \% \text { lower Tobin's Q than widely } \\
\text { held firms. }\end{array}$ \\
\hline $\begin{array}{l}\text { Ben-Amar and } \\
\text { André (2006) }\end{array}$ & $\begin{array}{l}327 \text { mergers \& } \\
\text { acquisitions ( } 232 \text { firms) } \\
\text { between } 1998 \text { and } 2002\end{array}$ & $\begin{array}{l}\text { The ratio of (or the } \\
\text { difference between) the } \\
\text { level of voting rights to } \\
\text { the level of cash-flow } \\
\text { rights }\end{array}$ & $\begin{array}{l}\text { Market reaction } \\
\text { (measured by three- } \\
\text { day abnormal } \\
\text { returns) }\end{array}$ & $\begin{array}{l}\text { Investors did not perceive that the separation } \\
\text { of ownership and control led to firm value } \\
\text { destruction during the merger and acquisition } \\
\text { situation. }\end{array}$ \\
\hline $\begin{array}{l}\text { Bozec and } \\
\text { Laurin }(2008)\end{array}$ & $\begin{array}{l}\text { 1,906 firm-year } \\
\text { observations from } 1995 \text { to } \\
1999\end{array}$ & $\begin{array}{l}\text { The degree of the } \\
\text { separation between voting } \\
\text { and cash-flow rights }\end{array}$ & $\begin{array}{l}\text { Tobin's Q, ROA, } \\
\text { ROE, ROI }\end{array}$ & $\begin{array}{l}\text { The separation between voting and cash-flow } \\
\text { rights per se did not cause poor performance. } \\
\text { It was the large separation of voting and } \\
\text { cash-flow rights, in combination with the } \\
\text { opportunity for dominant shareholders to } \\
\text { expropriate, that led firms to display weak } \\
\text { performance. }\end{array}$ \\
\hline
\end{tabular}




\section{Appendix 27 (Continued)}

Table C: Studies Regarding the Relationship between the Presence of Controlling Shareholders and Board Independence

\begin{tabular}{|c|c|c|c|c|}
\hline Studies & Sample & $\begin{array}{c}\text { Measure of Controlling } \\
\text { Shareholders }\end{array}$ & $\begin{array}{l}\text { Measure of Board } \\
\text { Independence }\end{array}$ & Findings \\
\hline $\begin{array}{l}\text { Erickson } \text { et al. } \\
(2005)\end{array}$ & $\begin{array}{l}\text { 66 Canadian firms collected } \\
\text { from the Global Vantage } \\
\text { database for the period between } \\
1993 \text { and } 1997\end{array}$ & $\begin{array}{l}\text { Proportion of voting rights } \\
\text { held by the dominant } \\
\text { shareholder }\end{array}$ & $\begin{array}{l}\text { Proportion of } \\
\text { outside directors on } \\
\text { the board }\end{array}$ & $\begin{array}{l}\text { The level of board independence was significantly } \\
\text { and negatively associated with dominant } \\
\text { shareholder ownership. }\end{array}$ \\
\hline $\begin{array}{l}\text { Bozec \& Bozec } \\
(2007)\end{array}$ & $\begin{array}{l}244 \text { largest Canadian firms } \\
\text { listed in TSX in } 2002\end{array}$ & $\begin{array}{l}\text { Voting rights directly and } \\
\text { indirectly held by the } \\
\text { largest shareholders }\end{array}$ & $\begin{array}{l}\text { ROB Board } \\
\text { Composition Scores }\end{array}$ & $\begin{array}{l}\text { ROB Board Composition scores were } \\
\text { significantly and negatively related to the } \\
\text { presence of controlling shareholders, especially } \\
\text { when a dominant shareholder held more than } 25 \% \\
\text { of voting rights. }\end{array}$ \\
\hline
\end{tabular}

Table D: The Impact of the Presence of Controlling Shareholders on the Effectiveness of Independent Directors - Results Mixed

\begin{tabular}{|l|l|l|l|l|}
\hline \multicolumn{1}{|c|}{ Studies } & \multicolumn{1}{|c|}{ Sample } & $\begin{array}{l}\text { Measure of } \\
\text { Controlling } \\
\text { Shareholders }\end{array}$ & $\begin{array}{l}\text { Measure of the Efficacy } \\
\text { of Independent Directors }\end{array}$ & The existence of \\
Erickson et al. & $\begin{array}{l}\text { 66 Canadian firms } \\
\text { collected from the Global } \\
\text { Vantage database for the } \\
\text { period between 1993 and } \\
1997\end{array}$ & $\begin{array}{l}\text { Firm value (adjusted } \\
\text { stock }\end{array}$ & $\begin{array}{l}\text { The presence of more } \text { outside directors on the board } \\
\text { reduced some loss of firm value (adjusted Tobin's Q) } \\
\text { from the existence of dual class shares, when these } \\
\text { outside directors were from a financial institution or } \\
\text { served on the audit committee (although they did not } \\
\text { benefit the firm overall). }\end{array}$ \\
\hline $\begin{array}{l}\text { Anand, Milne } \\
\& \text { Purda (2010) }\end{array}$ & $\begin{array}{l}\text { More than 200 firms listed } \\
\text { on Toronto Stock } \\
\text { Exchange during the years } \\
\text { 1999 to 2003 }\end{array}$ & $\begin{array}{l}\text { The existence of an } \\
\text { individual or group } \\
\text { who has control of } \\
\text { over 50\% of the } \\
\text { firm's votes }\end{array}$ & $\begin{array}{l}\text { The adoption of other } \\
\text { governance mechanisms } \\
\text { ability of an independent board to adopt other } \\
\text { governance mechanisms in assisting them to monitor } \\
\text { management. }\end{array}$ \\
\hline
\end{tabular}




\section{Appendix 28}

\section{ROB Corporate Governance Index in 2002}

ROB Corporate Governance index in 2002 includes 4 sub-indices, namely Board Composition, Shareholdings and Compensation, Shareholder Rights, and Governance-related Disclosure.

\begin{tabular}{|c|c|}
\hline Sub-Index 1: Board Composition & Criteria: Maximum 40 marks \\
\hline $\begin{array}{l}\text { 1. What percentage of the company's } \\
\text { directors is fully independent? }\end{array}$ & $\begin{array}{l}8 \text { marks for at least two } 66 \% \text { independent directors } \\
4 \text { marks if more than } 50 \% \text { independent } \\
0 \text { marks if more than } 50 \% \text { related directors }\end{array}$ \\
\hline $\begin{array}{l}\text { 2. What percentage of the audit } \\
\text { committee is fully independent? }\end{array}$ & $\begin{array}{l}6 \text { marks if the committee is fully independent } \\
2 \text { if there are one or more related directors } \\
0 \text { if a member of management is on the committee }\end{array}$ \\
\hline $\begin{array}{l}\text { 3. What percentage of the compensation } \\
\text { committee, the committee that } \\
\text { determines executive pay, is fully } \\
\text { independent? }\end{array}$ & $\begin{array}{l}4 \text { marks if fully independent } \\
2 \text { marks if there is one or more related directors who are } \\
\text { not management } \\
0 \text { if a member of management is on the committee }\end{array}$ \\
\hline $\begin{array}{l}\text { 4. What percentage of the nominating } \\
\text { committee, the committee that } \\
\text { recommends new directors, is fully } \\
\text { independent? }\end{array}$ & $\begin{array}{l}3 \text { marks if fully independent } \\
2 \text { marks if there is one or more related directors who are } \\
\text { not management } \\
0 \text { if a member of management is on the committee } \\
0 \text { if no nominating committee }\end{array}$ \\
\hline $\begin{array}{l}\text { 5. Is the role of chairman and CEO split? } \\
\text { If not is there a lead director? }\end{array}$ & $\begin{array}{l}5 \text { marks if jobs are split } \\
2 \text { marks if the chairman is also a related director } \\
3 \text { marks if the jobs are not split, but there is an independent } \\
\text { lead director }\end{array}$ \\
\hline $\begin{array}{l}\text { 6. Are there cosy or clubby relationships } \\
\text { among directors? Are directors } \\
\text { stretched too thin? }\end{array}$ & $\begin{array}{l}\text { Start with a maximum of } 5 \text { marks } \\
\text { Subtract } 3 \text { if CEO or executive chairman of the company } \\
\text { swaps boards with the CEO of another company } \\
\text { Subtract } 2 \text { whenever three or more directors are together } \\
\text { on the board of another public company } \\
\text { Subtract } 2 \text { for any director who is on more than } 8 \text { other for- } \\
\text { profit corporate boards. (Score can be negative) }\end{array}$ \\
\hline $\begin{array}{l}\text { 7. Is the company's CEO busy with } \\
\text { outside commitments? }\end{array}$ & $\begin{array}{l}0 \text { marks if the CEO sits on four or more other boards of } \\
\text { publicly traded companies; } \\
2 \text { marks if three or fewer }\end{array}$ \\
\hline $\begin{array}{l}\text { 8. Does the company have a formal } \\
\text { system to evaluate the performance of } \\
\text { the board and individual directors? }\end{array}$ & 2 marks if yes; 0 marks if no \\
\hline $\begin{array}{l}\text { 9. Do directors sometimes meet without } \\
\text { management present? }\end{array}$ & 2 marks if yes; 0 marks if no \\
\hline $\begin{array}{l}\text { 10. How often does the board meet? How } \\
\text { often do key committees meet? }\end{array}$ & $\begin{array}{l}3 \text { marks if information disclosed and both the board and } \\
\text { audit committee meets at least four times per year } \\
1 \text { mark if they meet less often, or if only partial information } \\
\text { on the number of meetings } \\
0 \text { marks if number of director's meetings not disclosed }\end{array}$ \\
\hline
\end{tabular}




\section{Appendix 28 (Continued)}

\begin{tabular}{|c|c|}
\hline $\begin{array}{l}\text { Sub-Index 2: Shareholding and } \\
\text { Compensation Policy }\end{array}$ & Criteria: Maximum 23 Marks \\
\hline $\begin{array}{l}\text { 1. Are directors required to own stock? (Stock } \\
\text { options don't count) }\end{array}$ & $\begin{array}{l}4 \text { marks if share ownership is mandatory and } \\
\text { equals } \\
\text { at least three times the annual retainer paid to } \\
\text { directors } \\
2 \text { marks if mandatory but ownership requirement } \\
\text { is } \\
\text { lower } \\
0 \text { if ownership not mandatory }\end{array}$ \\
\hline 2. Do the directors own stock? & $\begin{array}{l}4 \text { marks maximum } \\
\text { Subtract a point for each director who has less than } \\
1000 \text { shares after sitting on the board for at least a } \\
\text { year. (Score can be negative) }\end{array}$ \\
\hline $\begin{array}{l}\text { 3. Is the CEO required to own stock? (Stock } \\
\text { options don't count) }\end{array}$ & $\begin{array}{l}3 \text { marks if it is required, or CEO is majority or } \\
\text { controlling shareholder }\end{array}$ \\
\hline 4. Does the CEO own shares? & $\begin{array}{l}3 \text { marks if CEO owns more than } 50,000 \text { shares after } \\
\text { two } \\
\text { years on the job } \\
2 \text { marks if more than } 20,000 \text { shares } \\
0 \text { if less than } 20,000 \text { shares } \\
\text { *if CEO < } 2 \text { years on job, lower ownership levels } \\
\text { qualify } \\
\text { for full marks }\end{array}$ \\
\hline $\begin{array}{l}\text { 5. Are directors in their own separate option } \\
\text { plan? }\end{array}$ & 3 marks if yes or if directors don't get stock options \\
\hline $\begin{array}{l}\text { 6. Does the company give loans to directors or } \\
\text { officers? }\end{array}$ & $\begin{array}{l}6 \text { marks if there are no loans (or company is a bank } \\
\text { and makes loans with interest payable) } \\
0 \text { marks if loans are interest free } \\
\text { Part marks given for loans with interest } \\
\text { Marks decline with size of loan }\end{array}$ \\
\hline
\end{tabular}

\begin{tabular}{|l|l|}
\hline Sub-Index 3: Shareholder Rights Policy & Criteria: Maximum 22 Marks \\
\hline 1. Do all directors stand for re-election annually? & $\begin{array}{l}1 \text { mark for annual election of all directors } \\
0 \text { marks for staggered boards }\end{array}$ \\
\hline $\begin{array}{l}\text { 2. Are employee stock options excessively } \\
\text { dilutive for shareholders? }\end{array}$ & $\begin{array}{l}8 \text { marks if dilution is }<5 \% \text { of outstanding shares } \\
6 \text { marks if dilution is between } 5 \% \text { and } 10 \%\end{array}$ \\
\hline $\begin{array}{l}\text { 3. } \\
\text { Did the company re-price its options in } 2001 \text { or } \\
\text { 2002? (or extend their exercise date, or allow } \\
\text { them to be exchanged for lower-priced }\end{array}$ & $\begin{array}{l}4 \text { marks for no } \\
0 \text { marks for yes }\end{array}$ \\
\hline
\end{tabular}




\begin{tabular}{|l|l|}
\hline options.) & \\
\hline 4. $\begin{array}{l}\text { Are their non-voting or subordinate voting } \\
\text { shares? }\end{array}$ & $\begin{array}{l}8 \text { marks if no } \\
\text { 0 marks if voting control is } 5 \text { times greater than the } \\
\text { ownership stake. Partial marks were given }\end{array}$ \\
\hline
\end{tabular}

\section{Appendix 28 (Continued)}

\begin{tabular}{|c|c|}
\hline Sub-Index 4: Governance-related Disclosure Policy & Criteria: Maximum 15 Marks \\
\hline $\begin{array}{l}\text { 1. Does the company have a full statement of } \\
\text { corporate governance practices? }\end{array}$ & $\begin{array}{l}3 \text { marks if company fully addresses all topics } \\
\text { required } \\
\text { by the Ontario Securities Commission } \\
1 \text { mark if company gives partial answers or } \\
\text { discusses } \\
\text { only some topics } \\
0 \text { marks if there is no statement of corporate } \\
\text { governance practices }\end{array}$ \\
\hline $\begin{array}{l}\text { 2. Does the company fully name and explain } \\
\text { which of its directors are "related" and why? }\end{array}$ & $\begin{array}{l}4 \text { marks for full disclosure of relationships } \\
2 \text { marks if information is missing } \\
1 \text { mark if company lists as "unrelated" someone } \\
\text { ROB } \\
\text { considers to be related }\end{array}$ \\
\hline $\begin{array}{l}\text { 3. Does the company disclose how much it paid } \\
\text { its auditor for consulting and other work? }\end{array}$ & $\begin{array}{l}4 \text { marks for disclosure (minus } 1 \text { if work exceeds the } \\
\text { value of the audit and minus } 2 \text { marks if work is } \\
\text { more } \\
\text { than double the value of the audit) }\end{array}$ \\
\hline $\begin{array}{l}\text { 4. Does the company disclose full biographies of } \\
\text { its board members? }\end{array}$ & 1 mark \\
\hline 5. Does it list other boards its director's sit on? & 1 mark \\
\hline $\begin{array}{l}\text { 6. Does the company disclose attendance records } \\
\text { of its directors at board and committee } \\
\text { meetings? }\end{array}$ & $\begin{array}{l}2 \text { marks for disclosure but minus } 1 \text { for poor } \\
\text { attendance }\end{array}$ \\
\hline
\end{tabular}




\section{Appendix 29}

\section{Problems of 13 Canadian Empirical Studies Exploring the Relationship between Independent Directors and Firm Performance}

\begin{tabular}{|c|c|c|c|}
\hline & \multicolumn{3}{|c|}{$\begin{array}{l}\text { Problems of Canadian Empirical Studies Exploring the Relationship between Independent } \\
\text { Directors and Firm Performance }\end{array}$} \\
\hline & $\begin{array}{l}\text { Definition of Independent } \\
\text { Directors }\end{array}$ & $\begin{array}{l}\text { Not Examine Causation } \\
\text { or Lagged Effect }\end{array}$ & Other Problems \\
\hline $\begin{array}{l}\text { Amoako-Adu \& Smith } \\
\text { (1995) }\end{array}$ & Only looked at outside directors & $\begin{array}{l}\text { Not examined lagged } \\
\text { effects }\end{array}$ & \\
\hline $\begin{array}{l}\text { Gagnon \& St-Pierre } \\
(1995)\end{array}$ & Only looked at outside directors & & \\
\hline $\begin{array}{l}\text { Rao \& Lee-Sing } \\
(1995)\end{array}$ & Only looked at outside directors & & \\
\hline Bozec (2003) & Only looked at outside directors & & $\begin{array}{l}\text { Only looked at state-owned } \\
\text { enterprises }\end{array}$ \\
\hline Jog \& Dutta (2004) & $\begin{array}{l}\text { Used ROB Board Composition } \\
\text { scores to measure board } \\
\text { independence }\end{array}$ & $\begin{array}{l}\text { Not examined lagged } \\
\text { effects }\end{array}$ & \\
\hline Erickson et al. (2005) & Only looked at outside directors & & \\
\hline $\begin{array}{l}\text { Klein, Shapiro \& } \\
\text { Young (2005) }\end{array}$ & $\begin{array}{l}\text { Used ROB Board Composition } \\
\text { scores to measure board } \\
\text { independence }\end{array}$ & & \\
\hline $\begin{array}{l}\text { Adjaoud, Zeghal \& } \\
\text { Andaleeb (2007) }\end{array}$ & $\begin{array}{l}\text { Used ROB Board Composition } \\
\text { scores to measure board } \\
\text { independence }\end{array}$ & & \\
\hline Switzer (2007) & Only looked at outside directors & & \\
\hline Bozec \& Dia (2007) & Only looked at outside directors & & $\begin{array}{l}\text { Only looked at state-owned } \\
\text { enterprises }\end{array}$ \\
\hline $\begin{array}{l}\text { Gupta, Kennedy \& } \\
\text { Weaver (2009) }\end{array}$ & $\begin{array}{l}\text { Used ROB Board Composition } \\
\text { scores to measure board } \\
\text { independence }\end{array}$ & $\begin{array}{l}\text { Not examined lagged } \\
\text { effects }\end{array}$ & \\
\hline Bozec \& Bozec (2011) & $\begin{array}{l}\text { Used ROB Board Composition } \\
\text { scores to measure board } \\
\text { independence }\end{array}$ & & $\begin{array}{l}\text { Firms with lower costs of } \\
\text { equity capital may not } \\
\text { necessarily generate higher } \\
\text { returns for shareholders. }\end{array}$ \\
\hline $\begin{array}{l}\text { Toledo \& Bocatto } \\
\text { (2012) }\end{array}$ & $\begin{array}{l}\text { Used ROB Board Composition } \\
\text { scores to measure board } \\
\text { independence }\end{array}$ & & \\
\hline
\end{tabular}




\section{Appendix 30}

\section{Problems of 14 US Empirical Studies Exploring the Relationship between Independent Directors and Firm Performance}

\begin{tabular}{|c|c|c|c|c|c|}
\hline & \multicolumn{5}{|c|}{$\begin{array}{l}\text { Problems of Empirical Studies Exploring the Relationship between Independent Directors and Firm } \\
\text { Performance }\end{array}$} \\
\hline & $\begin{array}{l}\text { Definition of } \\
\text { Independent } \\
\text { Directors }\end{array}$ & $\begin{array}{l}\text { Not Examine } \\
\text { Causation or } \\
\text { Lagged Effect }\end{array}$ & $\begin{array}{l}\text { Evidence Not } \\
\text { Persuasive }\end{array}$ & $\begin{array}{l}\text { Not Related to the } \\
\text { Efficacy of } \\
\text { Independent } \\
\text { Directors }\end{array}$ & $\begin{array}{l}\text { Not Distinguish Effect } \\
\text { between Pre-SOX and } \\
\text { Post-SOX }\end{array}$ \\
\hline $\begin{array}{l}\text { Baysinger \& Butler } \\
\text { (1985) }\end{array}$ & & & $\begin{array}{l}\text { The lagged effect } \\
\text { took too long }\end{array}$ & & \\
\hline $\begin{array}{l}\text { Schellenger, Wood \& } \\
\text { Tashakori (1989) }\end{array}$ & $\begin{array}{l}\text { Only look at } \\
\text { outside directors }\end{array}$ & $\begin{array}{l}\text { Not explored } \\
\text { causation }\end{array}$ & & & \\
\hline $\begin{array}{l}\text { Rosenstein \& Wyatt } \\
\text { (1990) }\end{array}$ & & & $\begin{array}{l}\text { The effect was } \\
\text { economically small }\end{array}$ & & \\
\hline $\begin{array}{l}\text { Hermalin \& Weisbach } \\
(1988)\end{array}$ & $\begin{array}{l}\text { Only look at } \\
\text { outside directors }\end{array}$ & & & Yes & \\
\hline $\begin{array}{l}\text { Agrawal \& Knoeber } \\
\text { (1996) }\end{array}$ & $\begin{array}{l}\text { Only look at } \\
\text { outside directors }\end{array}$ & & & & \\
\hline $\begin{array}{l}\text { Bhagat \& Bolton } \\
(2008)^{*}\end{array}$ & & & & & $\begin{array}{l}\text { Findings were reliable, } \\
\text { but most of the sample } \\
\text { periods were in pre- } \\
\text { SOX. }\end{array}$ \\
\hline $\begin{array}{l}\text { Chaganti, Mahajan \& } \\
\text { Sharma (1985) }\end{array}$ & $\begin{array}{l}\text { Only look at } \\
\text { outside directors }\end{array}$ & $\begin{array}{l}\text { Not examined } \\
\text { lagged effects }\end{array}$ & & & \\
\hline Fosberg (1989) & $\begin{array}{l}\text { Only look at } \\
\text { outside directors }\end{array}$ & $\begin{array}{l}\text { Not examined } \\
\text { lagged effects }\end{array}$ & & & \\
\hline $\begin{array}{l}\text { Hermalin \& Weisbach } \\
\text { (1991) }\end{array}$ & $\begin{array}{l}\text { Only look at } \\
\text { outside directors }\end{array}$ & $\begin{array}{l}\text { Not examined } \\
\text { lagged effects }\end{array}$ & & & \\
\hline Mehran (1995) & & $\begin{array}{l}\text { Not examined } \\
\text { lagged effects }\end{array}$ & & & \\
\hline Yermack (1996) & & $\begin{array}{l}\text { Not examined } \\
\text { lagged effects }\end{array}$ & & & \\
\hline Klein (1998) & & & & Yes & \\
\hline $\begin{array}{l}\text { Ferris, Jagannathan \& } \\
\text { Pritchard (2003) }\end{array}$ & $\begin{array}{l}\text { Only look at } \\
\text { outside directors }\end{array}$ & & & & \\
\hline Fogel \&Geier (2007) & & $\begin{array}{l}\text { Not examined } \\
\text { lagged effects }\end{array}$ & & & \\
\hline $\begin{array}{l}\text { Duchin, Matsusaka \& } \\
\text { Ozbas (2010) }\end{array}$ & & $\begin{array}{l}\text { Not examine } \\
\text { lagged effects }\end{array}$ & & & $\begin{array}{l}\text { Used year } 2000 \text { to } \\
\text { distinguish Effect } \\
\text { between Pre-SOX and } \\
\text { Post-SOX }\end{array}$ \\
\hline
\end{tabular}

*Note: The findings of Bhagat \& Bolton (2008) are reliable. The only concern of this study is that its results can only represent the impact of independent directors on firm performance in the pre-SOX period because most of its sample period is before the implementation of SOX related reforms. 


\section{Bibliographies}

\section{LEGISLATION: CANADA}

Alberta Business Corporations Act, RSA 2000 cB-9.

Canada Business Corporations Act, RSC 1985, c C-44, as amended by SC 2001, c14.

Ontario Business Corporations Act, RSO 1990, c B16.

Ontario Securities Act, RSO 1990, c S5.

Audit Committees, OSC NI 52-110, 27 OSCB 3252 (26 March 2004).

Companion Policy 52-110CP to National Instrument 52-110 Audit Committee, OSC CP 52-110, 31 OSCB 12200 (19 December 2008).

Continuous Disclosure Obligations-for financial years beginning on or after January 1, 2011, OSC NI 51-102.

Corporate Governance Guidelines, OSC NP 58-201, 28 OSCB 5383 (17 June 2005).

CSA Staff Notice 58-305 - Status Report on the Proposed Changes to the Corporate

Governance Regime, OSC CSA Notice, 32 OSCB 9347 (13 November 2009).

Disclosure of Corporate Governance Practices, OSC NI 58-101, 28 OSCB 3634 (15 April 2005).

Form 58-101F1 Corporate Governance Disclosure, OSC Form 58-101F1, 28 OSCB 3636 (15 April 2005).

Protection of Minority Security Holders in Special Transactions, OSC MI 61-101 (2008) 31 OSCB 1321.

Request for Comment - Proposed Repeal and Replacement of NP 58-201 Corporate

Governance Guidelines, NI 58-101 Disclosure of Corporate Governance Practices, and NI 52110 Audit Committees and Companion Policy 52-110CP Audit Committees, OSC Request for Comment, 31 OSCB 12158 (19 December 2008).

\section{LEGISLATION: UNITED STATES}

Delaware General Corporation Law, Del Code Ann tit 8.

Dodd-Frank Wall Street Reform and Consumer Protection Act, Pub L No 111-203, 124 Stat 1376 (2010).

Internal Revenue Code, 26 USC $\$ 162(\mathrm{~m})$ (1993).

Investment Company Act of 1940, 15 USC (2012).

Michigan Business Corporation Act, Mich Comp Laws Ann §450. §450.1101-450.3192 (West 1973). 
Omnibus Revenue Reconciliation Act of 1993, Pub L No 103-66, 107 Stat 312 (2006).

Sarbanes-Oxley Act of 2002, Pub L No 107-204, 116 Stat 745 (codified in scattered sections of $11,15,18,28$ and 29 USC).

Securities Act of 1933, 15 USC §77a et seq, as amended.

Securities Exchange Act of 1934, 17 USC §78a et seq, as amended.

Exchange Act Rule 10b-5, 17 CFR 240.10b-5 (2008).

Exchange Act Rule 14a-8, 17 CFR §240.14a-8(i)(8) (2010).

Income Tax Regulation, §1.162-27(e)(3)(i); 26 CFR §1.162-27(e)(3)(i).

NASDAQ Stock Market, Rule $§ 5605$ (2009).

New York Stock Exchange Listed Company Manual §303 \& Supplementary material (1983).

New York Stock Exchange, Listed Company Manual §303A (2009).

Regulation S-K, 17 CFR $§ 229.510$ (2008).

TRAP Standards for Compensation and Corporate Governance, 31 CFR pt 30 (2009).

In re McKesson \& Robbins Inc, SEC Securities Exchange Act Release No. 2707 (5 December 1940).

NASDAQ. Press Release, "NASDAQ Submits First Round of Corporate Governance Rule Changes to the SEC; Announces Plan for Additional Issues for Review This Month" (5 June 2002), online: NASDAQ

<http://www.nasdaq.com/newsroom/news/pr2002/ne_section02_121.html >.

NYSE. "New York Stock Exchange Corporate Accountability and Listing Standards

Committee" (6 June 2002), online: NYSE <www.iasplus.com/resource/nysegovf.pdf >.

SEC Accounting Series Release No. 165 (20 December 1974).

SEC Securities Act Release No. 33-4790 (13 July 1965).

SEC Securities Exchange Act Release No. 15384 (6 December 1978).

SEC Securities Exchange Act Release No. 34-14970 (14 July 1978).

SEC Securities Exchange Act Release No. 13346 (9 March 1977).

SEC, Disclosure Required by Sections 404, 406 and 407 of the Sarbanes-Oxley Act of 2002, Exchange Act Release No. 34-47235 (23 January 2003).

SEC, Proposed Rule: Disclosure Required by Sections 404, 406 and 407 of the Sarbanes-Oxley Act of 2002, Exchange Act Release No. 34-46701 (22 October 2002).

Self-Regulatory Organizations, Order Approving Proposed Rule Change by the New York Stock Exchange, Inc. Amending Its Audit Committee Requirements and Notice of Filing and Order 
Granting Accelerated Approval of Amendments No. 1 and No. 2 Thereto, Exchange Act Release No. 34-42233 (14 December 1999).

Self-Regulatory Organizations, Order Approving Proposed Rule Change by the National Association of Securities Dealers, Inc. Amending Its Audit Committee Requirements and Notice of Filing and Order Granting Accelerated Approval of Amendments No. 1 and No. 2 Thereto, Exchange Act Release No. 34-42231 (14 December 1999).

Standards Relating to Listed Company Audit Committee, Exchange Act Release No. 33-8220 (9 April 2003).

Standing Audit Committees Composed of Outside Directors, No. 9548 (23 March 1972).

\section{JURISPRUDENCE: CANADA}

BCE Inc v 1976 Debentureholders, [2008] 3 SCR 560.

Brant Investments Ltd v KeepRite Inc, 1987 CarswellOnt 135 (WL Can).

Canada Deposit Insurance Corp v Canadian Commercial Bank, [1989] 98 AR 353.

Canada Deposit Insurance Corp v Prisco, [1991] 120 AR 35.

CC\&L Dedicated Enterprise Fund (Trustee of) v Fisherman, [2002] 55 OR (3d) 794.

CW Shareholdings Inc v WIC Western International Communications Ltd (1998), 39 OR (3d) 755.Gazit Inc v Centrefund Realty Corp, [2000] OJ No 3070.

Montreal Trust Co of Canada v ScotiaMcLeod Inc, [1995] 26 OR (3d) 48.

Northland Bank v Willson, [1999] 249 AR 201.

Pente Investment Management Ltd v Schneider Corp (1998), 42 OR (3d) 177.

Re Cara Operations Ltd (1999), 22 OSCB 7819.

Re CW shareholdings Inc (1998), 21 OSCB 2899.

Re Ivanhoe III Inc (1999), 22 OSCB 1327.

Re Royal Host Real Estate Investment Trust (1999), 22 OSCB 7819;

Re YBM Magnex International Inc (2003), 26 OSCB 5285.

\section{JURISPRUDENCE: UNITED STATES}

Aronson v. Lewis, 473 A 2d 805 (Del 1984).

Beam ex rel Martha Stewart Living Omnimedia, Inc v Stewart, 833 A 2d 961 (Del Ch 2003).

Escott v BarChris Construction Corp, 283 F Supp 643 (SDNY 1968). 
Grobow v Perot, 539 A 2d 180 (Del 1988).

Grobow v Perot, 539 A2d 180 (Del 1988).

In re Oracle Corp Derivative Litig, 824 A 2d 917 (Del Ch 2003).

Moran v Household Int'l Corp, 500 A 2d 1346 (Del 1985).

Paramount Communications Inc v Time Inc, 571 A 2d 1140 (Del 1990).

Polk v Good, 507 A 2d 531 (Del 1986).

RCM Sec Fund, 928 F 2d 1318 (2d Cir 1991).

Smith v Van Gorkom, 488 A 2d 858 (Del 1985).

Unocal Corp v Mesa Petroleum Co, 493 A 2d 946 (Del Supr 1985).

Weinberger v UOP Inc, 457 A 2d 701 (Del 1983).

Zapata Corp v Maldonado, 430 A 2d 779 (Del 1981).

\section{SECONDARY MATERIAL: MONOGRAPHS}

Bacon, Jeremy. Corporate Directorship Practices: Membership and Committees of the Board (New York: National Industrial Conference Board, 1973).

Corporate Directorship Practices: The Audit Committee (New York: National Industrial Conference Board, 1979).

C. Corporate Directorship Practices: The Nominating Committee and the Director Selection Process (New York: The Conference Board, 1981).

- Membership and Organization of Corporate Boards (New York: The Conference Board, 1990).

Bacon, Jeremy, National Industrial Conference Board \& American Society of Corporate Secretaries. The Corporate Directorship Practices, Business Policy Study, No. 125 (New York: National Industrial Conference Board, 1967).

Berle, Adolf A \& Gardiner C Means. The Modern Corporation and Private Property (New York: Harcourt, Brace \& World, 1932).

Bozec, Richard. Boards of Directors, Market Discipline and Firm Performance (Ottawa: Faculty of Administration, University of Ottawa, 2003).

Clark, Robert Charles. Corporate Law (Boston: Little, Brown, 1986).

Committee on the Financial Aspect of Corporate Governance, The Financial Aspect of Corporate Governance, (London: Gee and Co Ltd, 1992) [Cadbury Report], online: The European Corporate Governance Institute 〈http://www.ecgi.org/codes/documents/cadbury.pdf $>$.

Condon, Mary G Condon, Anita I Anand \& Janis P Sarra. Securities Law in Canada: Cases and Commentary (Toronto: Emond Montgomery Publications, 2005). 
- Securities Law in Canada: Cases and Commentary (Toronto: Emond Montgomery Publications, 2010).

Cox, James D et al. Securities Regulations: Cases and Materials 3rd ed (New York: Aspen, 2001).

Daniels, Ronald J \& Randall Morck, eds, Corporate Decision-Making in Canada (Calgary, Alta : University of Calgary Press, 1995).

Dickson, Paul W. Compensation and Duties of Corporate Directors, Studies in Business Policy, No. 16 (New York: National Industrial Conference Board, 1946).

Dorval, Thierry. The Role of Corporate Governance in Reducing Agency Problems and Assisting Directors in the Discharge of Their Fiduciary Duties (LLD Thesis, University of Ottawa, 2007).

Eisenberg, Melvin A. The Structure of the Corporation: A Legal Analysis (Boston: Little, Brown, 1976).

Gillen, Mark E, Securities Regulation in Canada, 3rd ed (Toronto: Thomson Carswell, 2007).

Janis, Irving. Groupthink: Psychological Studies of Policy Decisions and Fiascoes (Boston: Houghton Mifflin, 1982).

Johnston, David \& Kathleen Doyle Rockwell. Canadian Securities Regulation (Markham, ON: Butterworths, 2006).

Joint Committee on Corporate Governance, Beyond Compliance: Building a Governance Culture (November 2001) [Saucier Report], online: ECGI < http://www.ecgi.org/codes/documents/beyond_compliance.pdf $>$.

Kaura, Belle. "The Corporate Governance Conundrum: Reinventing the Board of Directors and Board Committees" in Poonam Puri \& Jeffrey Larsen eds Corporate Governance and Securities Regulation in the 21st Century (Markham, ON: LexisNexis Butterworths, 2004).

Kinley, John R, National Industrial Conference Board \& American Society of Corporate Secretaries. The Corporate Directorship Practices, Business Policy Study, No. 103 (New York: National Industrial Conference Board, 1962).

Lorsch, Jay L \& Elizabeth M MacIver. Pawns or Potentates? The Reality of America's Corporate Boards (Boston: Harvard Business School Press, 1989).

Mace, Myles L. Directors: Myth and Reality (Boston: Harvard Business School Press, 1971). Marris, Robin. The Economic Theory of Managerial Capitalism (London: Macmillan, 1964). New York Stock Exchange, The Corporate Director and the Investing Public (New York: NYSE, 1962).

Puri, Poonam \& Jeffrey Larsen, eds, Corporate Governance and Securities Regulation in the 21st Century (Markham, ON: LexisNexis Butterworths, 2004).

Senate Commission on Banking, Housing \& Urban Affairs, $96^{\text {th }}$ Congress $2^{\text {nd }}$ Session, Staff Report on Corporate Accountability (1980).

Smith, Roy C \& Ingo Walter, Governing the Modern Corporation: Capital Markets, Corporate Control and Economic Performance (New York: Oxford University Press, 2006). 
Staff Report of the Securities and Exchange Commission. The Financial Collapse of the Penn Central Company, (1972).

The American Law Institute, Principles of Corporate Governance and Structure: Restatement and Recommendations: Tentative Draft No. 1. (1982).

- Principles of Corporate Governance: Analysis and Recommendations, Volume 1 Parts I-VI (1994).

The Standing Committee on Banking, Trade and Commerce, Government of Canada, "The Governance Practices of Institutional Investors" (Ottawa: Government of Canada, 1998) [Kirby Report], online: <http://www.parl.gc.ca/36/1/parlbus/commbus/senate/com-e/bank-e/repe/rep16nov98-e.htm>.

VanDuzer, J Anthony. The Law of Partnerships \& Corporations (Toronto: Irwin Law, 2009).

Yalden, Robert et al. Business Organizations: Principles, Policies and Practice (Toronto: Emond Montgomery Publications, 2008).

\section{SECONDARY MATERIAL: ARTICLES}

American Bar Association Committee on Corporate Laws. "The Corporate Director's Guidebook" (1976) 32 Bus Law 5.

American Bar Association. "Special Study on Market Structure, Listing Standards and Corporate Governance" (2002) 57 Bus Law 1487.

—. "The Corporate Director's Guidebook” (1978) 33 Bus Law 1595.

Anand, Anita Indira. “An Analysis of Enabling vs. Mandatory Corporate Governance: Structures Post-Sarbanes-Oxley” (2006) 31 Del J Corp L 229.

Bainbridge, Stephen M. "A Critique of the NYSE's Director Independence Listing Standards" (2002) 30 Sec Reg L J 370.

Bancroft, Margaret A. "Knowledge Is Power: What Went Wrong in the Mutual Fund Industry" (2006) 1 J Bus \& Tech L 145.

Baxter, Michael St Patrick. "The Fiduciary Obligations of Directors of a Target Company in Resisting an Unsolicited Takeover Bid” (1988) 20 Ottawa L Rev 63.

Baysinger, Barry D \& Henry N Butler. "Revolution Versus Evolution in Corporation Law: The ALI's Project and the Independent Director” (1984) 52 Geo Wash L Rev 557.

Ben-Ishai, Stephanie \& Poonam Puri. “The Canadian Oppression Remedy Judicially Considered: 1995-2001” (2004) Queen's L J 79.

Black, Bernard S. "The Value of Institutional Investor Monitoring: The Empirical Evidence" (1992) 39 UCLA L Rev 895.

Black, Bernard, Brian Cheffins \& Michael Klausner. “Outside Director Liability” (2006) 58 Stan L Rev 1055 at 1060. 
Block, Dennis J, Stephen A Radin \& Michael J Maimone. "Derivative Litigation: Current Law Versus the American Law Institution" (1993) 48 Bus Law 1443.

Blue Ribbon Committee on Improving the Effectiveness of Corporate Audit Committees, "Report and Recommendations of the Blue Ribbon Committee on Improving the Effectiveness of Corporate Audit Committees" (1999) 54 Bus Law 1067.

Borowski, Irwin "Corporate Accountability: The Role of the Independent Director" (1984) 9 J Corp L 455.

Boyer, M Martin. "Three Insights from the Canadian D\&O Insurance Market: Inertia, Information and Insiders" (2008) 14:1 Conn Ins L J 75.

Bratton, William W. “The Economic Structure of the Post-Contractual Corporation” (1992) 87 Nw U L Rev 180.

Brickey, Kathleen F. "From Enron To WorldCom and Beyond: Life and Crime After SarbanesOxley" (2003) 81 Wash U L Q 357.

Brown, Katherine M. "Notes: New Demands, Better Boards: Rethinking Director Compensation in an Era of Heightened Corporate Governance?” (2007) 82 NYU L Rev 1102.

Brown, J Robert. "Criticizing the Critics: Sarbanes-Oxley and Quack Corporate Governance" (2006) 90 Marq L Rev 309.

Brudney, Victor. “The Independent Director- Heavenly City or Potemkin Village?” (1982) 95 Harv L Rev 597.

Bujaki, Merridee \& Bruce J McConomy, “Corporate Governance: Factors Influencing Voluntary Disclosure by Public Traded Canadian Firms" (2002) 1:2 Canadian Accounting Perspectives 105.

Cheffins, Brian R \& Bernard S Black. “Outside Director Liability across Countries” (2006) 84:6 Tex L Rev 1385.

Clark, Robert Charles. "Corporate Governance Changes in the Wake of the Sarbanes-Oxley Act: A Morality Tale for Policymakers Too” (2005) 22 Ga St U L Rev 251.

Clarke, Donald C. "Three Concepts of the Independent Director” (2007) 32 Del J Corp L 73.

Cox, James D. "Managing and Monitoring Conflicts of Interests: Empowering the Outside Directors with Independent Counsel” (2003) 48 Vill L Rev 1077.

Cox, James D \& Harry L Munsinger. "Bias in the Boardroom: Psychological Foundations and Legal Implications of corporate Cohesion” (1985) 48 Law \& Contemporary Problems 83.

Cunningham, Lawrence A. "The Sarbanes-Oxley Yawn: Heavy Rhetoric, Light Reform (And It Just Might Work)” (2003) 35 Conn L Rev 915.

Dallas, Lynn L. "The Relational Board: Three Theories of Corporate Board of Directors" (1996) 22:1 J Corp L 1.

Davidoff, Steven M \& David Zaring. "Regulation by Deal: The Government's Response to the Financial Crisis" (2009) 61:3 Admin L Rev 463.

Developments in the Law - Corporations and Society, (2004) 117 Harv L Rev 2169. 
Dooley, M P \& M D Goldman. "Some Comparisons Between the Model Business Corporation Act and the Delaware General Corporation Law" (2001) 56 Bus Law 737.

Easterbrook, Frank J \& Daniel R Fischel. “The Proper Role of a Target's Management in Responding to a Tender Offer" (1981) 94 Harv L Rev 1161.

Eisenberg, Melvin A. “The Mandatory Structure of Corporate Law” (1989) 89 Colum L Rev 1461 at 1471 .

Elson, Charles M. "Director Compensation and the Management-Captured Board - The History of A Symptom and A Cure" (1996) 50 SMU L Rev 127.

Elson, Charles M \& Christopher J Gyves. "The Enron Failure and Corporate Governance Reform” (2003) 38 Wake Forest L Rev 855.

Fairfax Lisa M. "Sarbanes-Oxley, Corporate Federalism, and the Declining Significance of Federal Reforms on State Director Independence Standards" (2005) 31 Ohio N U L Rev 381.

—. "Spare the Rod, Spoil the Director? Revitalizing Directors' Fiduciary Duty Through Legal Liability” (2005) 42 Hous L Rev 393.

_. "The Uneasy Case for the Inside Director" (2010) 96 Iowa L Rev 127.

Fama, Eugene F. "Agency Problems and the Theory of the Firm" (1980) 88 J Pol Econ 288.

Fama, Eugene F \& Michael C Jensen. "Separation of Ownership and Control” (1983) 26 JL \& Econ 301.

Farrar, John H. "Business Judgment and Defensive Tactics in Hostile Takeover Bids" (1989) 15 Can Bus L J 15.

Fink, Rachel A. "Social Ties in the Boardroom: Changing the Definition of Director Independence to Eliminate 'Rubber-Stamping Boards"' (2006) 79 S Cal L Rev 455.

Fisch, Jill E. “Taking Boards Seriously” (1997) 19 Cardozo L Rev 265.

Fischel, Daniel R. “The Corporate Governance Movement” (1982) 35 Vand L Rev 1259.

Fischel, Daniel R \& Michael Bradley. "The Role of Liability Rules and the Derivative Suit in Corporate Law: A Theoretical and Empirical Analysis" (1986) 71 Cornell L Rev 261.

Garrett, Allison Dabbs. "Themes and Variations: the Convergence of Corporate Governance Practices in Major World Market” (2004) Denv J Int'1 L \& Pol'y 147 at 164.

Gillan, Stuart L \& John D Martin. "Corporate Governance Post-Enron: Effective Reforms, or Closing the Stable Door?” (2007) 13 Journal of Corporate Finance 929.

Gilson, Ronald J \& Reinier Kraakman. "Reinventing the Outside Directors: An Agenda for Institutional Investors" (1991) 43 Stan L Rev 863.

Gordon, Jeffrey N. "The Rise of Independent Directors in the United States, 1950-2005: Of Shareholder Value and Stock Market Prices” (2007) 59 Stan L Rev 1465.

"What Enron Means for the Management and Control of the Modern Business Corporations: Some Initial Reflections” (2002) 69 U Chicago L Rev 1233.

Gorsline, Scott J. "Statutory 'Independent' Directors: A Solution to the Interested Director Problem?” (1989) 66 U Det L Rev 655. 
Grossman, Nadelle. "Director Compliance With Elusive Fiduciary Duties in A Climate of Corporate Governance Reform” (2007) 12 Fordham J Corp \& Fin L 393.

Hamilton, Robert W. "Corporate Governance in America 1950-2000: Major Changes But Uncertain Benefits”, (2000) 25 J Corp L 349.

Heard, James E. "Executive Compensation: Perspective of the Institutional Investor" (1995) 63 U Cin L Rev 749.

Hillman, Amy J, Albert A Cannella \& Ramona L Paetzold. "The Resource Dependence Role of Corporate Directors: Strategic Adaptation of Board Composition in Response to Environmental Change" (2000) 37 Journal of Management Studies 235.

Holmstrom, Bengt \& Steven N Kaplan. "Corporate Governance and Merger Activity in the United States: Making Sense of the 1980s and 1990s" (2001) 15 Journal of Economic Perspectives 121.

Iacobucci, Edward M \& Kelvin E Davis. "Reconciling Derivative Claims and the Oppression Remedy" (2000) 12 Sup Ct L Rev 87.

Ide, R William. "Post-Enron Corporate Governance Opportunities: Creating a Culture of Great Board Collaboration and Oversight" (2003) Mercer L Rev 829.

Jensen, Michael C. "The Modern Industrial Revolution, Exit, and the Failure of Internal Control System" (1993) 48:3 Journal of Finance 831.

Johnson, Jonathan L, Catherine M Daily \& Alan E Ellstrand, "Boards of Directors: A Review and Research Agenda" (1996) 22 Journal of Management 409.

Johnson, Lyman P Q \& Mark A Sides. “The Sarbanes-Oxley Act and Fiduciary Duties” (2004) 30 Wm Mitchell L Rev 1149.

Jones, Renee M. "Law, Norms, and the Breakdown of the Board: Promoting Accountability in Corporate Governance" (2006) 92 Iowa L Rev 105.

Kanji, Naizam. "Business (Mis)judgment: Corporate Governance and the Role of Courts and Securities Regulators in Reviewing Target Defensive Tactics" in Poonam Puri \& Jeffrey Larsen, eds, Corporate Governance and Securities Regulation in the 21st Century (Markham, ON:

LexisNexis Butterworths, 2004).

Karmel, Roberta S. "The Future of Corporate Governance Listing Requirements" (2001) 54 SMU L Rev 325. Rev 534.

"The Independent Corporate Board: A Mean to What End?" (1984) 52 The Geo Wash L

Kershenbaum, Joseph. "Corporate Law - A Snapshot of the Takeover Decade: Polaroid Corp. v. Disney - Whether a Target Corporation Has Third Party Standing to Assert a Violation of the All-Holders Rule" (1991) 13 W New Eng L Rev 63.

Krupsky, Joseph F. “The Role of Investment Company Directors” (1977) 32 Bus Law 1733.

Kurp, Melissa M. “Corporate Takeover Defenses After QVC: Can Target Boards Prevent Hostile Tender Offers Without Breaching Their Fiduciary Duties?” (1994) 26 Loy U Chicago L J 29. 
Langevoort, Donald C. "Selling Hope, Selling Risk: Some Lessons for Law from Behavioral Economics About Stockbrokers and Sophisticated Customers" (1996) 84 Cal L Rev 627.

"The Human Nature of Corporate Boards: Law, Norms, and the Unintended Consequences of Independence and Accountability" (2001) 89 The Geo L J 797 at 798-800.

Lin, Laura. "The Effectiveness of Outside Directors as a Corporate Governance Mechanism: Theories and Evidence" (1996) 90 Nw UL Rev 898.

Lipton, Martin \& Jay W Lorsch. "A Modest Proposal for Improved Corporate Governance" (1992) 48 Bus Law 59.

Lutzy, Jillian M. "Analysis of the Proposed NYSE Corporate Governance and Audit Committee Listing Requirements” (2003) 2 DePaul Bus LJ 99.

Macey, Jonathan R \& Fred S McChesney. "A Theoretical Analysis of Corporate Greenmail” (1985) 95 Yale LJ 13.

MacIntosh, Jeffrey G. "The Poison Pill: A Noxious Nostrum for Canadian Shareholders" (1989) 15 Can Bus LJ 276.

Marchesani, Daniele. "The Concept of Autonomy and the Independent Director of Public Corporations" (2005) 2 Berkeley Bus LJ 315.

Markham, Jerry W. "Regulating Excess Executive Compensation - Why Bother?” (2007) 2 J

Bus \& Tech L 277.

Mathews, Arthur F. "Recent Trends in SEC Requested Ancillary Relief in SEC Level Injunction Actions" (1976) 31 Bus Law 1323.

McFarland, Jeffrey M. “Good News Investors! You've Got A Financial Expert on the Board The Bad News? It Doesn't Mean Anything” (2006) 2 Hastings Bus LJ 165.

Meese, Alan J. "The Team Production Theory of Corporate Law: A Critical Assessment" (200102) 43 Wm \& Mary L Rev 1629 at 1637.

Mizruchi, Mark S. "Berle and Means revisited: The governance and power of large U.S. corporations" (2004) 33:5 Theory and Society 579.

Moscow, Cyril et al. Michigan's Independent Director (1990) 46 Bus Law 57.

Nicholls, Christopher C, "The Bre-X Hoax: A South East Asian Bubble" (1999) 32:2 Can Bus L J 173.

. “The Outside Director: Policeman or Placebo?” (2003) Can Bus L J 323.

O'Connor, Marleen A. "The Enron Board: The Perils of Groupthink" (2003) 71 U Cin L Rev 1233.

Page, Antony. "Unconscious Bias and the Limits of Director Independence" (2009) 2009:1 U Ill L Rev 237.

Patton, Arch \& John C Baker, “Why Won’t Directors Rock the Boat?” (1987) Nov.-Dec. Harvard Business Review 10.

Pearce, John A II \& Richard B Robinson. "Hostile Takeover Defenses that Maximize Shareholder Wealth” (2004) 47 Business Horizons 15. 
Petra, Steven T. "Do Outside Independent Directors Strengthen Corporate Boards" (2005) 5 Corporate Governance 55.

Pillay, Sukanya. "Forcing Canada's Hand? The Effect of the Sarbanes-Oxley Act on Canadian Corporate Governance Reform" (2004) 30:3 Man L J 285.

Pitt, Harvey. “On the Precipice: A Reexamination of Directors' Fiduciary Duties in the Context of Hostile Acquisitions" (1990) 15 Del J Corp L 811.

Prentice, Robert A \& David B Spence. "Sarbanes-Oxley as Quack Corporate Governance: How Wise is the Received Wisdom?" (2007) 95 Geo L J 1843.

Ribstein, Larry E. "Limited Liability and Theories of the Corporation" (1991) 50 Md L Rev 80.

- "Market vs. Regulatory Responses to Corporate Fraud: A Critique of the Sarbanes-

Oxley Act of 2002” (2002) 28 J Corp L 1.

Ricardo-Campbell, Rita. "Comments on the Structure of Ownership and the Theory of the Firm" (1983) 26 JL \& Econ 391.

Romano, Roberta. “A Guide to Takeover: Theory, Evidence, and Regulation” (1992) 9 Yale J on Reg 119.

\section{5 .}

. "Corporate Governance in the Aftermath of the Insurance Crisis" (1990) 39 Emory LJ

—. "The Sarbanes-Oxley Act and the Making of Quack Corporate Governance" (2005) 114 Yale LJ 1521.

Scaldaferri, Ezio. Notes, Mutual Fund Independent Directors: Putting a Leash on the Watchdogs, (1979) 47 Fordham L Rev 568.

Seligman, Joel. “A Modest Revolution in Corporate Governance” (2005) 80 Notre Dame L Rev 1159.

“A Sheep in Wolf's Clothing: The American Law Institute's Principles of Corporate Governance Project” (1987) 55 Geo Wash L Rev 325.

Sharpe, Nicola Faith. "The Cosmetic Independence of Corporate Board” (2011) 34 Seattle U L Rev 1435.

Shleifer, Andrei \& Robert W Vishny. “A Survey of Corporate Governance” 52 (1997) Journal of Finance 737 at 756.

Shu-Acquaye, Florence. "The Independent Board of Directors and Governance in the United States: Where Is This Heading” (2006) 27 Whittier L Rev 725.

Sjostrom, William K Jr. "The Due Diligence Defense Under Section 11 of the Securities Act of 1933” (2006) 44 Brandeis L J 549.

Smith, L Murphy. "Audit Committee Effectiveness: Did the Blue Ribbon Committee Recommendations Make A Difference?” (2006) 3 International Journal of Accounting, Auditing and Performance Evaluation 240.

Soderquist, Larry D. “Toward A More Effective Corporate Board: Reexamining Roles of Outside Directors” (1977) 52 NYUL Rev 1341. 
Solomon, Lewis D. "Restructuring the Corporate Board of Directors: Fond Hope-Faint Promise?" 76 Mich L Rev 581.

Statement of the Business Roundtable, "The Role and Composition of the Board of Directors of the Large Publicly Owned Corporation” (1978) 33 Bus Law 2083.

Strine, Leo E. "Derivative Impact? Some Early Reflections on the Corporation Law Implications of the Enron Debacle" (2002) 57 Bus Law 1371.

Tung, Frederick. "The Puzzle of Independent Directors: New Learning” (2011) 91 BUL Rev 1175.

Velasco, Julian. "Structure Bias and the Need for Substantive Review" (2004) 82 Wash U L Q 821.

Werner, Walter. "Corporation Law in Search of Its Future” (1981) 81 Colum L Rev 1611.

_. "Management, Stock Market and Corporate Reform: Berle and Means Reconsidered" (1977) 77 Colum L Rev 388.

Windolf, Paul. "Corruption, Fraud, and Corporate Governance: A Report on Enron” in Anna Grandori ed Corporate Governance and Firm Organization: Microfoundations and Structural Forms (Oxford; New York: Oxford University Press, 2004).

Winter, Ralph K. "State Law, Shareholder Protection, and the Theory of the Corporation" (1977) $6 \mathrm{~J}$ Legal Stud 251.

Zahra, Shaker A \& John A Pearce II. "Boards of Directors and Corporate Financial Performance: A Review and Integrative Model” (1989) 15 Journal of Management 291.

\section{SECONDARY MATERIAL: EMPIRICAL STUDIES}

Abbott, Lawrence J, Susan Parker \& Gary F Peters. "Audit Committee Characteristics and Restatements" (2004) 23:1 Auditing: A Journal of Practice \& Theory 69.

Abbott, Lawrence, Young Park \& Susan Parker. "The Effect of Audit Committee Activity and Independence on Corporate Fraud” (2000) 26:11 Managerial Finance 55.

Adams, Renée B \& Daniel Ferreira. "A Theory of Friendly Boards” (2007) 62:1 The Journal of Finance 217.

—. "Do Directors Perform for Pay" (2008) 46 Journal of Accounting and Economics 154.

—. "Women in the Boardroom and Their Impact on Governance" (2009) 94 Journal of Financial Economics 291.

Adjaoud, Fodil, Daniel Zeghal \& Syed Andaleeb. "The Effect of Board's Quality on Performance: A Study of Canadian Firms" (2007) 15:4 Corporate Governance 623.

Agrawal, Anup \& Charles R Knoeber. "Firm Performance and Mechanisms to Control Agency Problems between Managers and Shareholders" (1996) 31 Journal of Financial and Quantitative Analysis 377. 
Agrawal, Anup \& Sahiba Chadha. "Corporate Governance and Accounting Scandals" (2005) 48 JL \& Econ 371.

Amoako-Adu, Ben \& Brian F Smith, "Outside Financial Directors and Corporate Governance" in Ronald J Daniels \& Randall Morck, eds, Corporate Decision-Making in Canada (Calgary, Alta: University of Calgary Press, 1995).

Anand, Anita, Frank Milne \& Lynnette Purda. "Monitoring to Reduce Agency Costs: Examining the Behavior of Independent and Non-Independent Boards" (2010) 33 Seattle U L Rev 809.

Anderson, Ronald C \& John M Bizjak. "An Empirical Examination of the Role of the CEO and the Compensation Committee in Structuring Executive Pay" (2003) 27 Journal of Banking \& Finance 1323.

Attig, Najah. "Excess Control and the Risk of Corporate Expropriation: Canadian Evidence" (2007) 24 Canadian Journal of Administrative Sciences 94.

Baliga, B Ram, R Charles Moyer \& Ramesh S Rao. "CEO Duality and Firm Performance: What's the Fuss" (1996) 17 Strategic Management Journal 41.

Bange, Mary M \& Michael A Mazzeo. "Board Composition, Board Effectiveness, and the Observed Form of Takeover Bids" (2004) 17 The Review of Financial Studies 1185.

Banker, R D, A Charnes \& W W Cooper. "Some Models for Estimating Technical and Scale Efficiencies in Data Envelopment Analysis” (1984) 30:9 Management Science 1078.

Baysinger, Barry D \& Henry N Butler. "Corporate Governance and the Board of Directors: Performance Effects of Changes in Board Composition" (1985) 1 JL Econ \& Org 101.

Beasley, Mark S. "An Empirical Analysis of the Relation between the Board of Director Composition and Financial Statement Fraud" (1996) 71 The Accounting Review 443.

Beasley, Mark S et al. "Fraudulent Financial Reporting: Consideration of Industry Traits and Corporate Governance Mechanisms" (2000) 14:4 Accounting Horizons 441.

Bebchuk, Lucian A, Reinier Kraakman \& George G Triantis, "Stock Pyramids, Cross-Ownership, and Dual Class Equity: The Mechanisms and Agency Costs of Separating Control from CashFlow Rights" in Randall K Morck ed Concentrated Corporate Ownership (Chicago: The University of Chicago Press, 2000).

Bebchuk, Lucian A, Yaniv Grinstein \& Urs Peyer. "Lucky CEOs and Lucky Directors" (2010) 65:6 Journal of Finance 2363.

Bédard, Jena, Sonda Marrakchi Chtourou \& Lucie Courteau. "The Effect of Audit Committee Expertise, Independence, and Activity on Aggressive Earnings Management" (2004) 23:2 Auditing: A Journal of Practice \& Theory 13.

Ben-Amar, Walid \& Paul André. "Separation of Ownership from Control and Acquiring Firm Performance: The Case of Family Ownership in Canada" (2006) 33: 3 \& 4 Journal of Business Finance \& Accounting 517.

Bhagat, Sanjai \& Bernard Black. "The Non-Correlation Between Board Independence and LongTerm Firm Performance" (2002) 27 The J Corp L 231.

_. "The Uncertain Relationship Between Board Composition and Firm Performance" (1999) 54 Bus Law 921. 
Bhagat, Sanjai \& Brian Bolton. "Corporate Governance and Firm Performance" (2008) 14 Journal of Corporate Finance 257.

Bhagat, Sanjai, Dennis C Carey \& Charles M Elson. "Director Ownership, Corporate Performance and Management Turnover" (1999) 54 Bus Law 885.

Boone, Audra L et al. "The Determinants of Corporate Board Size and Composition: An Empirical Analysis" (2007) 85 Journal of Financial Economics 66.

Boyd, Brian K. "Board Control and CEO Compensation" (1994) 15 Strategic Management Journal 335.

—. "CEO Duality and Firm Performance: A Contingency Model" (1995) 16 Strategic Management Journal 301.

Bozec, Richard \& Mohamed Dia. "Board Structure and Firm Technical Efficiency: Evidence from Canadian State-owned Enterprises" (2007) 177 European Journal of Operational Research 1734.

Bozec, Yves \& Richard Bozec. "Overall Governance and Cost of Capital: Evidence From Canada Using Panel Data" (2011) 6:1 J of Global Business Management 1.

—. "Ownership Concentration and Corporate Governance Practices: Substitution or Expropriation Effects?" (2007) 24 Canadian Journal of Administration Sciences 182.

Bozec, Yves Bozec \& Claude Laurin. "Large Shareholders Entrenchment and Performance:

Empirical Evidence from Canada" (2008) 35: 1 \& 2 Journal of Business Finance \& Accounting 25.

Brickley, James A \& Christopher M James. "The Takeover Market, Corporate Board Composition, and Ownership Structure: The Case of Banking" (1987) 30 J L \& Econ 161.

Brickley, James A, James S Linck \& Jeffery L Coles. "What Happens to CEOs after They Retire? New Evidence on Career Concerns, Horizon Problems, and CEO Incentives" (1999) 52 Journal of Financial Economics 341.

Brickley, James A, Jeffery L Coles \& Rory L Terry. "Outside Directors and the Adoption of Poison Pills" (1994) 35 Journal of Financial Economics 371.

Brickley, James A, Jeffrey L Coles, \& Gregg Jarrell, "Leadership Structure: Separating the CEO and Chairman of the Board" (1997) 3 Journal of Corporate Finance 189.

Bronson, Scott N et al, “Are Fully Independent Audit Committees Really Necessary?” (2009) 28 Journal of Accounting and Public Policy 265.

Brown, Lawrence D \& Marcus L Caylor. "Corporate Governance and Firm Valuation" (2006) 25 Journal of Accounting and Public Policy 409.

—_. "Corporate Governance and Firm Operating Performance" (2009) 32 Review of Quantitative Finance and Accounting 129.

Byrd, John W \& Kent A Hickman. "Do Outside Directors Monitor Managers?: Evidence from Tender Offer Bids" (1992) 32 Journal of Financial Economics 195. 
Callahan, William T, James A Millar \& Craig Schulman. "An Analysis of the Effect of Management Participation in Director Selection on the Long-Term Performance of the Firm" (2003) 9:2 Journal of Corporate Finance 169.

Carcello, Joseph V \& Terry L Neal. "Audit Committee Characteristics and Audit Dismissals Following "New" Going-Concern Reports" (2003) 78:1 The Accounting Review 95.

Review 453.

"Audit Committee Composition and Audit Reporting" (2000) 75:4 The Accounting

Carter, David A, Betty J Simkins \& W Gary Simpson. "Corporate Governance, Board Diversity, and Firm Value" (2003) 38 The Financial Review 33.

Chaganti, Rajeswararao S et al. "Corporate Board Size, Composition and Corporate Failures in Retailing Industry” (1985) 22 J Mgmt Stud 400.

Chan, Kam C \& Joanne Li. "Audit Committee and Firm Value: Evidence on Outside Top Executives as Expert-Independent Directors" (2008) 16:1 Corporate Governance 16.

Charnes, A, W W Cooper \& E Rhodes. "Measuring the Efficiency of Decision-Making Units" (1978) 2:6 European Journal of Operational Research 429.

Chen, Chia-Wei, J Barry Lin \& Bingsheng Yi, "CEO Duality and Firm Performance-An Endogenous Issue" (2008) 6:1 Corporate Ownership \& Control 58.

Chhaochharia, Vidhi \& Yaniv Grinstein. "CEO Compensation and Board Structure" (2009) 64:1The Journal of Finance 231.

_ . "Corporate Governance and Firm Value: The Impact of the 2002 Governance Rules" (2007) 62:4 Journal of Finance 1789.

Christine Panasian, Andrew K Prevost \& Harjeet S Bhabra, "Voluntary Listing Requirements and Corporate Performance: The Case of the Dey Report and Canadian Firms" (2008) 43 The Financial Review 129.

Cochran, Philip L \& Steven L Wartick. "Golden Parachutes: A Closer Look" (1984) 26 California Management Review 111 at 123.

Cochran, Philip L, Robert A Wood \& Thomas B Jones. "The Composition of Boards of Directors and the Incidence of Golden Parachutes" (1985) 28 Academy of Management Journal 664.

Coles, Jeffrey L, Naveen D Daniel \& Lalitha Naveen. "Boards: Does One Size Fit All" (2008) 87 Journal of Financial Economics 329.

Conger, Jay A , David Finegold \& Edward E Lawler III. "Appraising Boardroom Performance" (1998) 76 Harvard Business Review 136.

Conyon, Martin J \& Danielle Kuchinskas. "Compensation Committee in the United States" in Christine A Mallin, ed, Handbook on International Corporate Governance: Country Analyses (Northampton: Edward Elgar 2006).

Conyon, Martin J \& Lerong He. "Compensation Committees and CEO Compensation Incentives in U.S. Entrepreneurial Firms” (2004) 16 Journal of Management Accounting Research 35. 
Cordeiro, James J, Rajaram Veliyath \& Jane B Romal. "Moderators of the Relationship Between Director Stock-Based Compensation and Firm Performance" (2007) 15:6 Corporate Governance 1384.

Corderio, James J, Rajaram Veliyath \& Donald O Neubaum. "Incentives For Monitors: Director Stock-Based Compensation and Firm Performance" (2005) 21:2 The Journal of Applied Business Research 81.

Core, John E, Robert W Holthauesn \& David F Larcker. "Corporate Governance, Chief Executive Officer Compensation, and Firm Performance” (1999) 51 Journal of Financial Economics 371.

Cosenza, Elizabeth. "The Holy Grail of Corporate Governance Reform: Independence or Democracy?” (2007) 2007:1 BYU L Rev 1.

Cotter, James F, Anil Shivdasani \& Marc Zenner. "Do Independent Directors Enhance Target Shareholder Wealth During Tender Offers?” (1997) 43 Journal of Financial Economics 195.

Cremers, K J Martijn \& Vinay B Nair. “Governance Mechanisms and Equity Prices” (2005) 60:6 Journal of Finance 2859.

Daily, Catherine $\mathrm{M}$ et al. "Compensation Committee Composition as a Determinant of CEO Compensation" (1998) 41 Academy of Management Journal 209.

Davidson, Wallace N III \& Wei Rowe. "Intertemporal Endogeneity in Board Composition and Financial Performance” (2004) 1:4 Corporate Ownership \& Control 49.

Davidson, Wallace N III, Biao Xio \& Weihong Xu. "Market Reaction to Voluntary Announcements of Audit Committee Appointments: The Effect of Financial Expertise" (2004) 23 Journal of Accounting and Public Policy 279.

Davidson, Wallace N III, Theodore Pilger \& Andrew Szakmary. "Golden Parachutes, Board and Committee Composition, and Shareholder Wealth” (1998) 33 The Financial Review 17.

Dechow, Patricia M, Richard G Sloan \& Amy P Sweeney. "Causes and Consequences of Earnings Manipulation: An Analysis of Firms Subject to Enforcement Actions by the SEC" (1996) 13 Contemporary Accounting Research 1.

DeFond, Mark L \& Jere R Francis. “Audit Research after Sarbanes-Oxley” (2005) 24: Supplement Auditing 5.

Defond, Mark L, Rebecca N Hann \& Xuesong Hu. "Does the Market Value Financial Expertise on Audit Committees of Boards of Directors" (2005) 43:2 Journal of Accounting Research 153.

Duchin, Ran, John G Matsusaka \& Oguzhan Ozbas. "When Are Outside Directors Effective?" (2010) 96 Journal of Financial Economics 195.

Elson, Charles M. "Executive Overcompensation-A Board-Based Solution" (1993) 34 BCL Rev 937.

Erhardt, Niclas L, James D Werbel \& Charles B Shrader. "Board of Director Diversity and Firm Financial Performance" (2003) 11:2 Corporate Governance 102.

Erickson, John et al. "Board Composition and Firm Value under Concentrated Ownership: The Canadian Evidence” (2005) 13 Pacific-Basin Finance Journal 387. 
Faleye, Olubunmi. "Does One Hat Fit All? The Case of Corporate Leadership Structure" (2007) 11:3 Journal of Management and Governance 239.

Farrell, Kathleen A \& Philip L Hersch. "Addition to Corporate Boards: The Effect of Gender" (2005) 11 Journal of Corporate Finance 85.

Ferris, Stephen P, Murali Jagannathan and A C Pritchard. "Too Busy to Mind the Business?

Monitoring by Directors with Multiple Board Appointments" (2003) 58:3 The Journal of Finance 1087.

Fich, Eliezer M \& Anil Shivdasani. “Are Busy Boards Effective Monitors?” (2006) 61:2 Journal of Finance 689.

- "The Impact of Stock-Option Compensation for Outside Directors on Firm Value" (2005) 78:6 Journal of Business 2229.

Fingold, David, George S Benson \& David Hecht. "Corporate Boards and Company Performance: Review of Research in Light of Recent Reforms" (2007) 15:5 Corporate Governance 865.

Fogel, Eric M \& Andrew M Geier. "Strangers in the House: Rethinking Sarbanes-Oxley and the Independent Board of Directors" (2007) 32 Del J Corp L 33.

Fosberg, Richard H “Outside Directors and Managerial Monitoring” (1989) 20:2 Akron Business and Economic Review 24.

Francoeur, Claude, Réal Labelle \& Bernard Sinclair-Desgagné. "Gender Diversity in Corporate Governance and Top Management” (2008) 81 Journal of Business Ethics 83.

Gagnon, Jean-Marie \& Josée St-Pierre. "Alternative Mechanisms for Corporate Governance and Board Composition" in Ronald J Daniels \& Randall Morck, eds, Corporate Decision-Making in Canada (Calgary, Alta : University of Calgary Press, 1995).

Geddes, R Richard \& Hrishikesh D Vinod. "CEO Age and Outside Directors: A Hazard Analysis” (1997) 12 Review of Industrial Organization 767.

Gerety, Mason, Chun-Keung Hoi \& Ashok Robin. "Do Shareholders Benefit from the Adoption of Incentive Pay for Directors" (2001) 30:4 Financial Management 45.

Gilson, Stuart C. "Bankruptcy, Boards, Banks, and Blockholders: Evidence on Changes in Corporate Ownership and Control When Firms Default" (1990) 27 Journal of Financial Economics 355.

Gompers, Paul, Joy Ishii, \& Andrew Metrick, "Corporate Governance and Equity Prices” (2003) 118 Quarterly Journal of Economics 107.

Gupta, Parveen P, Duane B Kennedy \& Samuel C Weaver. "Corporate Governance and Firm Value: Evidence from Canadian Capital Market” (2009) 6:3 Corporate Ownership \& Control 293.

Hambrick, Donald C \& Eric M Jackson. "Outside Directors with a Stake: The Linchpin in Improving Governance” (2000) 42:4 California Management Review 111.

Harris, Milton \& Arthur Raviv. "A Theory of Board Control and Size” (2008) 21:4 The Review of Financial Studies 1797. 
Helland, Eric \& Michael Sykuta. "Who's Monitoring the Monitor? Do Outside Directors Protect Shareholders' Interests?” (2005) 40 The Financial Review 155.

Hempel, Paul \& Charles Fay. “Outside Director Compensation and Firm Performance” (1994) 33:1 Human Resource Management 111 at 119.

Hermalin, Benjamin E \& Michael S Weisbach. "Boards of Directors as An Endogenously Determined Institution: A Survey of the Economic Literature" (2003) 9:1 Economic Policy Review 7.

589.

. "The Determinants of Board Composition” (1988) 19:4 RAND Journal of Economics

—. "The Effects of Board Composition and Direct Incentives on Firm Performance" (1991) 20 Financial Management 101.

Hite, Gailen \& Michael Vetsuypens. "Management Buyouts of Divisions and Shareholder Wealth" (1989) 44:4 Journal of Finance 953.

Hwang, Byoung-Hyoun \& Seoyoung Kim. "It Pays to Have Friends" (2009) 93 Journal of Financial Economics 138.

Jiraporn, Pornsit et al. "Too Busy to Show Up? Analysis of Directors' Absences" (2009) 49 The Quarterly Review of Economics and Finance 1159.

Jiraporn, Pornsit, Manohar Singh \& Chun I Lee. "Ineffective Corporate Governance: Director Busyness and Board Committee Memberships" (2009) 33 Journal of Banking \& Finance 819.

Jiraporn, Pornsit, Young Sang Kim \& Wallace N Davidson III. "Multiple Directorships and Corporate Diversification” (2008) 15 Journal of Empirical Finance 418.

Jones, Thomas M. "Corporate Board Structure and Performance: Variations in the Incidence of Shareholder Suits" (1986) 8 Research in Corporate Social Performance and Policy 345.

Kaplan, Steven N \& David Reishus. “Outside Directorships and Corporate Performance” (1990) 27 Journal of Financial Economics 389.

Kesner, Idalene F \& Roy B Johnson. "An Investigation of the Relationship Between Board Composition and Stockholder Suits” (1990) 11 Strategic Management Journal 327.

Kini, Omesh, William Kracaw \& Shehzad Mian. "Corporate Takeovers, Firm Performance, and Board Composition” (1995) 1 Journal of Corporate Finance 383.

Klein, April. "Audit Committee, Board of Director Characteristics and Earnings Management" (2002) 33 Journal of Accounting and Economics 375.

—. "Firm Performance and Board Committee Structure" (1998) 54 JL \& Econ 275.

Klein, Peter, Daniel Shapiro \& Jeffrey Young. "Corporate Governance, Family Ownership and Firm Value: the Canadian Evidence" (2005) 13:6 Corporate Governance 769.

Kosnik, Rita D. "Effects of Board Demography and Directors' Incentives on Corporate Greenmail Decisions” (1990) 33 Academy of Management Journal 129.

—. "Greenmail: A Study of Board Performance in Corporate Governance" (1987) 32 Administrative Science Quarterly 163. 
Krishnan, Jayanthi. "Audit Committee Quality and Internal Control: An Empirical Analysis" (2005) 80:2 The Accounting Review 649.

Lambert, Richard A \& Donald F Larcker. "Golden Parachutes, Executive Decision-making and Shareholder Wealth" (1985) 7 Journal of Accounting and Economics 17.

Lee, Chun I et al. "Board Composition and Shareholder Wealth: The Case of Management Buyouts" (1992) 21 Financial Management 58.

Lee, Ho Young, Vivek Mande \& Richard Ortman. "The Effect of Audit Committee and Board of Director Independence on Auditor Resignation” (2004) 23:2 Auditing: A Journal of Practice \& Theory 131.

Linck, James, Jeffry Netter \& Tina Yang. "The Determinants of Board Structure” (2008) 87 Journal of Financial Economics 308.

Mallette, Paul \& Karen L Fowler. "Effects of Board Composition and Stock Ownership on the Adoption of 'Poison Pills"” (1992) 35 Academy of Management Journal 1010.

McMullen, Dorothy Ann. "Audit Committee Performance: An Investigation of the Consequences Associated with Audit Committees" (1996) 15:1 Auditing: A Journal of Practice \& Theory 87.

Mehran, Hamid "Executive Compensation Structure, Ownership, and Firm Performance" (1995) 38 Journal of Financial Economics 163.

Michael R King \& Eric Santor, "Family Values: Ownership Structure, Performance and Capital Structure" (2008) 32 Journal of Banking \& Finance 2423.

Mikkelson, Wayne H \& M Megan Partch. “The Decline of Takeovers and Disciplinary Managerial Turnover" (1997) 44 The Journal of Financial Economics 205.

Miller, Toyah \& María del Carmen Triana. "Demographic Diversity in the Boardroom: Mediators of the Board Diversity -Firm Performance Relationship" (2009) 46:5 Journal of Management Studies 755.

Mitchell, Mark \& Harold Mulherin. "The Impact of Industry Shocks on Takeover and Restructuring Activity” (1996) 41 Journal of Financial Economics 193.

Morck, Randall, Andrei Shleifer \& Robert W Vishny. "Management Ownership and Market Valuation: An Empirical Analysis" (1988) 20 Journal of Financial Economics 293.

Newman, Harry A \& Hail A Mozes. "Does the Composition of the Compensation Committee Influence CEO Compensation Practice” (1999) 28:3 Financial Management 41.

Ning, Yixi, Wallace N Davidson III \& Ke Zhong. "The Variability of Board Size Determinants: An Empirical Analysis" (2007) Fall/ Winter Journal of Applied Finance 46.

Niu, Flora F. "Corporate Governance and the Quality of Accounting Earnings: A Canadian Perspective" (2006) 2:4 International Journal of Managerial Finance 302.

Nowak, Margaret \& Margaret McCabe. "Information Costs and the Role of the Independent Corporate Director" (2003) 11:4 Corporate Governance 300.

Palmon, Oded \& John K Wald. "Are Two Heads Better Than One? The Impact of Changes in Management Structure on Performance by Firm Size" (2002) 8 Journal of Corporate Finance 213. 
Park, Yun W \& Hyun-Han Shin. "Board Composition and Earnings Management in Canada" (2004) 10 Journal of Corporate Finance 431.

Perry, Tod \& Urs Peyer. "Board Seat Accumulation by Executives: A Shareholder's Perspective" (2005) 60 The Journal of Finance 2083.

Pi, Lynn \& Stephen G Timme. "Corporate Control and Bank Efficiency” (1993) 17 Journal of Banking and Finance 515.

Rao, P Someshwar \& Clifton R Lee-Sing. "Governance Structure, Corporate Decision-Making and Firm Performance in North America" in Ronald J Daniels \& Randall Morck, eds, Corporate Decision-Making in Canada (Calgary, Alta: University of Calgary Press, 1995).

Ravina, Enrichetta \& Paola Sapienza. "What Do Independent Directors Know? Evidence from Their Trading” (2010) 23:3 The Review of Financial Studies 962.

Rechner, L \& Dan R Dalton. "CEO Duality and Organizational Performance: A Longitudinal Analysis” (1991) 12:2 Strategic Management Journal 155.

Romano, Roberta. "The Shareholder Suit: Litigation with Foundation?” (1991) 7 The Journal of Law, Economics \& Organization 55.

Ronen, Joshua Ronen, Joseph Tzur \& Varda Yaari. “The Effect of Directors' Equity Incentives on Earnings Management" (2006) 25 J Acct \& Pub Pol'y 359.

Rosenstein, Stuart \& Jeffrey G Wyatt. "Inside Directors, Board Effectiveness, and Shareholder Wealth" (1997) 44 Journal of Financial Economics 229.

—. "Outside Directors, Board Independence, and Shareholder Wealth" (1990) 26 Journal of Financial Economics 175.

Ryngaert, Michael. "The Effect of Poison Pill Securities on Shareholder Wealth" (1988) 20 Journal of Financial Economics 377.

Sapp, Stephen G. "The Impact of Corporate Governance on Executive Compensation" (2008) 14:4 European Financial Management 710.

Scarbrough, D Paul, Dasarathe V Rama \& K Raghunandan. "Audit Committee Composition and Interaction with Internal Auditing: Canadian Evidence” (1998) 12:1 Accounting Horizons 51.

Schellenger, Michael H, David D Wood \& Ahmad Tashakori, "Board of Director Composition, Shareholder Wealth, and Dividend Policy" (1989) 15:3 Journal of Management 457.

Schiehll, Eduardo \& Francois Bellavance. "Boards of Directors, CEO Ownership, and the Use of Non-Financial Performance Measures in the CEO Bonus Plan” (2009) 17:1 Corporate Governance 90.

Shivdasani, Anil. "Board Composition, Ownership Structure, and Hostile Takeovers" (1993) 16 Journal of Accounting and Economics 167.

Shivdasani, Anil \& David Yermack. "CEO Involvement in the Selection of New Board Members: An Empirical Analysis" (1999) 54:5 Journal of Finance 1829.

Shrader, Charles B, Virginia B Blackburn \& Paul Iles. "Women in Management and Firm Financial Performance: An Exploratory Study" (1997) 9:3 Journal of Managerial Issues 355. 
Singh, Harbir \& Farid Harianto. "Management-Board Relationships Takeover Risk, and the Adoption of Golden Parachutes" (1989) 32 Academy of Management Journal 7.

—. "Top Management Tenure, Corporate Ownership Structure and the Magnitude of Golden Parachutes" (1989) 10 Strategic Management Journal 143.

Switzer, Lorne N. "Corporate Governance, Sarbanes-Oxley, and Small-cap Firm Performance" (2007) 47 The Quarterly Review of Economics and Finance 651.

Uzun, Hatice, Samuel Szewczyk \& Raj Varma. "Board Composition and Corporate Fraud" (2004) May/June Financial Analysts Journal 33.

Vafeas, Nikos. "Audit Committees, Boards and the Quality of Reported Earnings" (2005) 22:4

Contemporary Accounting Research 1093.

__. "Board Meeting Frequency and Firm Performance" (1999) 53 Journal of Financial Economics 113.

. "Further Evidence on Compensation Committee Composition as A Determinant of CEO Compensation" (2003) 32 Financial Management 53.

—. "Operating Performance around the Adoption of Director Incentive Plans" (2000) 68 Economics Letters 185.

Weisbach, Michael S. “Outside Directors and CEO Turnover” (1988) 20 Journal of Financial Economics 431.

Xie, Biao, Wallace N Davidson III \& Peter J DaDalt. "Earnings Management and Corporate Governance: The Role of the Board and the Audit Committee" (2003) 9 Journal of Corporate Finance 295.

Yang, Joon S \& Jagan Krishnan. "Audit Committee and Quarterly Earnings Management” (2005) 9 International Journal of Auditing 201.

Yermack, David. "Higher Market Valuation of Companies with a Small Board of Directors" (1996) 40:2 Journal of Financial Economics 185.

Yoser Gadhoum, "Power of Ultimate Controlling Owners: A Survey of Canadian Landscape" (2006) 10 Journal of Management Governance 179.

\section{SECONDARY MATERIAL: WORKING PAPERS}

Arcot, Sridhar R \& Valentina G Bruno. "In Letter But Not in Spirit: An Analysis of Corporate Governance in the UK" (May 2006), online: SSRN: 〈http://ssrn.com/abstract=819784>.

Attig, Najah, Klaus Fischer \& Yoser Gadhoum. "On the Determinants of Pyramidal Ownership: Evidence on Dilution of Minority Interests" (March 2004), EFA 2004 Maastricht Meetings Paper No 4592, online: SSRN <http://ssrn.com/abstract=434201 or doi:10.2139/ssrn.434201〉.

Bainbridge, Stephen M. “A Question re Compensation Committees Under Dodd Frank 952” (14 September 2010), online: ProfessorBainbridge.Com $<$ http://www.professorbainbridge.com/professorbainbridgecom/2010/09/a-question-recompensation-committees-under-dodd-frank-952.html>. 
_. "Dodd-Frank: Quack Federal Corporate Governance Round II", UCLA School of Law, Law-Econ Research Paper No. 10-12 (7 September 2010), Online: SSRN

$<$ http://ssrn.com/abstract $=1673575>$.

_. "The Corporate Governance Provisions of Dodd-Frank", UCLA School of Law, LawEcon Research Paper No. 10-14 (27 October 2010), online: SSRN < http://ssrn.com/abstract $=1698898>$.

Balsam, Steven, John Puthenpurackal \& Arun Upadhyay. "The Determinants and Performance Impact of Outside Board Leadership" (22 December 2011), online: SSRN <http://ssrn.com/abstract=1361255> .

Beale, Linda M. "In the Wake of Financial Crisis", Wayne State University Law School Research Paper No. 10-07, (2010), online: SSRN <http://ssrn.com/abstract=1681577>.

Bhagat, Sanjai \& Brian J Bolton. "Sarbanes-Oxley, Governance and Performance" (17 March 2009), online: SSRN <http://ssrn.com/abstract=1361815>.

Brick, Ivan E and N K Chidambaran. Board Meetings, Committee Structure, and Firm Performance (November 2007), online: SSRN <http://ssrn.com/abstract=1108241 >.

Broshko, Erinn B \& Kai Li. "Corporate governance Requirements in Canada and the United States: A Legal and Empirical Comparison of the Principles-Based and Rules-Based Approaches", Sauder School of Business Working Paper (February 2006), online: SSRN: $<$ http://ssrn.com/abstract $=892708>$.

Byard, Donal \& Ying Li. “The Impact of Directors' Option Compensation on Their Independence" (September 2005), online: China Center for Financial Research <http://www.ccfr.org.cn/cicf2006/cicf2006paper/20060201123102.pdf > .

Carcello, Joseph V et al. "Audit Committee Financial Expertise, Competing Corporate Governance Mechanisms, and Earning Management" (February 2006), online: SSRN <http://ssrn.com/abstract=887512 or http://dx.doi.org/10.2139/ssrn.887512> .

Carter, David A et al. "The Diversity of Corporate Board Committees and Financial Performance" (2008), online: SSRN < http://ssrn.com/abstract=1106698> .

Coffee, John C. "The Rise of Dispersed Ownership: The Role of Law in the Separation of Ownership and Control”, Columbia Law School, Working Paper No. 182 (January 2001) at 2, online: SSRN <http://ssrn.com/abstract=254097>.

"What Caused Enron?: A Capsule Social and Economic History of the 1990's", Columbia Law and Economics Working Paper No. 214 (29 January 2003), online: SSRN <http://ssrn.com/abstract=373581 or DOI: $10.2139 /$ ssrn.10.2139/ssrn.373581 $>$.

Dey, Aiyesha \& Xiaohui Liu. "Social Connections, Stock-Based Compensation, and Director Oversight” (2010), online SSRN: 〈http://ssrn.com/abstract=1581212>.

Dey, Aiyesha, Ellen Engel, \& Xiaohui Liu. "Determinants and Implications of Board Leadership Structure", Chicago Booth Research Paper No. 09-23 (1 June 2009), online: SSRN < http://ssrn.com/abstract=1412827>. 
Dhaliwal, Dan, Vic Naiker \& Farshid Navissi. “Audit Committee Financial Expertise, Corporate Governance and Accruals Quality: An Empirical Analysis" (May 2006), online: SSRN <http://ssrn.com/abstract=906690 $>$.

Felo, Andrew J, Srinivasan Krishnamurthy \& Steven A Solieri, “Audit Committee Characteristics and the Perceived Quality of Financial Reporting: An Empirical Analysis" (April 2003), online: SSRN < http://ssrn.com/abstract=401240 or doi:10.2139/ssrn.401240>.

Francis, Jennifer, Katherine Schipper \& Linda Vincent. "Earnings and Dividend Informativeness: When Cash Flow Rights Are Separated from Voting Rights" (December 2003), online: Northwestern University 〈www.kellogg.northwestern.edu/faculty/vincentl/htm/dualclass.pdf $>$.

Fu, Huijing \& Xiaoyun Yu. "Is Board Structure One-Size-Fits-All? The Unintended Informational Consequence of the Sarbanes-Oxley Act" (8 August 2010), online: SSRN $\langle\underline{\text { http://ssrn.com/abstract }=1107676}$ > .

Gillan, Stuart L, Jay C Hartzell \& Laura T Starks. "Tradeoffs in Corporate Governance: Evidence from Board Structures and Charter Provisions" (June 2006), online: SSRN <http://ssrn.com/abstract=917544> .

Grinstein, Yaniv \& Yearim Valles, "Separating the CEO from the Chairman Position:

Determinants and Changes after the New Corporate Governance Regulation" (March 2008), online: SSRN < http://ssrn.com/abstract=1108368 $>$.

Gul, Ferdinand A, Bin Srinidhi \& Judy Tsui. "Board Diversity and the Demand for Higher Audit

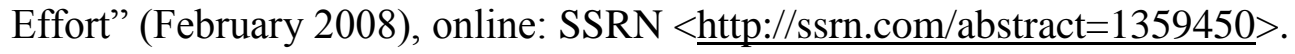

. "Do Female Directors Enhance Corporate Board Monitoring? Some Evidence from Earnings Quality" (September 2007), online:

<http://www.isb.edu/AccountingResearchConference/File/GulSrinidhiTsui.pdfhttp://www.isb.ed u/AccountingResearchConference/File/GulSrinidhiTsui.pdf $>$.

Hayes, Rachel, Hamid Mehran \& Scott Schaefer. "Board Committee Structure, Ownership, and Firm Performance" (October 2004), online: Washington University at St. Louis 〈http://apps.olin.wustl.edu/jfi/pdf/HayesMehranSchaefer.pdf $>$.

Huang, Jun \& Shan Zhao. "CEO Turnover and Takeover Threats: New Evidence from Antitakeover Legislation” (18 March 2009), online: SSRN < $\underline{\text { http://ssrn.com/abstract=1362642 or }}$ http://dx.doi.org/10.2139/ssrn.1362642 >.

Ittonen, Kim, Johanna Miettinen \& Sami Vähämaa. "Does Female Representation on Audit Committees Affect Audit Fees?" (2008), online: SSRN < http://ssrn.com/abstract=1314243>.

Jog, Vijay \& Shantanu Dutta. "Corporate Governance, Performance and CEO Pay" (February 2004), online: SSRN <http://ssrn.com/abstract=507502>.

Lehn, Kenneth, Sukesh Patro \& Mengxin Zhao. "Determinants of the Size and Structure of Corporate Boards: 1935-2000” (November 2003), online: SSRN $\langle$ http://ssrn.com/abstract=470675 or doi:10.2139/ssrn.470675>.

Levi, Maurice, Kai Li \& Feng Zhang. "Mergers and Acquisitions: The Role of Gender" (August 2008), online: SSRN: 〈http://ssrn.com/abstract=1123735>. 
Murphy, Austin. "An Analysis of the Financial Crisis of 2008: Causes and Solutions" (4 November 2008), online: SSRN 〈http://ssrn.com/abstract=1295344〉.

Perry, Tod. "Incentive Compensation for Outside Directors and CEO Turnover" (June 2000) at 17-19, presented at Tuck-JFE Contemporary Corporate Governance Conference, online: SSRN $\langle$ http://ssrn.com/abstract=236033 or doi:10.2139/ssrn.236033〉.

Qin, Bo. "The Influence of Audit Committee Financial Expertise on Earnings Quality: U.S. Evidence" (2007), online: SSRN 〈http://ssrn.com/abstract=799645>.

Roberts, Michael R \& Toni M Whited. "Endogeneity in Empirical Corporate Finance" (30 August 2011), Simon School Working Paper No. FR 11-29, online: SSRN 〈http://ssrn.com/abstract=1748604 or http://dx.doi.org/10.2139/ssrn.1748604〉.

Ryan, Harley E, Lingling Wang \& Roy A Wiggins. "Board-of-Director Monitoring and CEO Tenure" (25 February 2009), online: SSRN <http://ssrn.com/abstract=992857>.

Santaló, Juan \& Luis Diestre. "When Do Outside Directors Create Corporate Value?” (May 2006), online: SSRN 〈http://ssrn.com/abstract=942045>.

Sepe, Simone M. "Making Sense of Executive Compensation" Arizona Legal Studies Discussion Paper No. 10-42 (7 December 2010), online: SSRN <http://ssrn.com/abstract=1721131).

Smaili, Nadia \& Réal Labelle. "Preventing and Detecting Accounting Irregularities: The Role of Corporate Governance" (7 January 2009), online: SSRN < http://ssrn.com/abstract=1324143> .

Toledo, Eloisa Perez de \& Evandro Bocatto. "Does Corporate Governance Matter After All? Quality of Governance and the Value of Canadian Firms After 2008" (12 January 2012), online: SSRN <http://ssrn.com/abstract=1985672〉.

Wallace, James S \& Kenneth R Ferris. "IRC Section 162(m) and the Law of Unintended

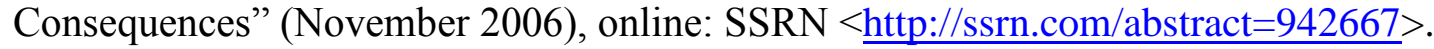

Wan, Kam-Ming. "Can Boards with a Majority of Independent Directors Lower CEO Compensation?" (3 June 2009), online: SSRN: 〈http://ssrn.com/abstract=1421549>.

\section{SECONDARY MATERIAL: OTHER MATERIALS - Canada}

Bagnall, James. "Archive: Nortel's Numbers: Accounting for the Errors" The Ottawa Citizen (10 January 2012).

Committee on Corporate Disclosure. Final Report: Responsible Corporate Disclosure: A Search for Balance, (Toronto: Toronto Stock Exchange, 1997).

Hansell, Carol. "Governance Regulation - The Right Balance" (Paper delivered at the Queen's Business Law Symposium, 2004).

Insurance-Canada.ca. "HUNTERS Completes Secondary Annual Study of D\&O Insurance Limits for the TSX/S\&P 300" Business of Insurance Information in Canada (14 November 2006), online: Insurance-Canada.ca < http://www.insurancecanada.ca/business/canada/HUNTERS-DO-Insurance-Limits-611.php>. 
Levin, J A. “Canadian Corporate Governance Development” (Paper delivered at the Queen's Business Law Symposium, 2004).

McFarland, Janet. "Glacial Progress of Women on Canada's Boards Prompts Calls for Reform", The Globe and Mail (26 November 2012).

—. "How ROB Created the Rating System", The Globe and Mail (7 October 2002) B6.

Munro, Lisa C. "YBM Case Study: Anatomy of A Securities Class Action Settlement" Lerner

LLP, online: Lerners <http://lernersclassactiondefence.ca/@assets/uploads/articles-

25/ybmcasestudyanatomyofasecuritiesclassactionsettlement.pdf $>$.

Osler, Hoskin \& Harcourt LLP. Corporate Governance in Canada: A Guide to the

Responsibilities of Corporate Directors in Canada (2009), online: Osler:

<http://www.osler.com/uploadedFiles/News_and_Resources/Publications/Guides/Corporate_Go vernance_In_Canada/Corporate_Governance_in_Canada_2009_Aug2011.pdf > .

Stuart, Spencer Stuart. "Canadian Spencer Stuart Board Index: Board Trend and Practices of Leading Canadian Companies 2010” (2010), online: Spencer Stuart <http://content.spencerstuart.com/sswebsite/pdf/lib/CSSBI2010.pdf>.

Sussex Circle Inc. Corporate Governance and Accountability in Canada (2002), online:

<http://www.aucc.ca/_pdf/english/programs/cepra/Final\%20report_swain.pdf>.

The Standing Senate Committee on Banking, Trade and Commerce. Navigating Through "The Perfect Storm”: Safeguards to Restore Investor Confidence (June 2003), online: < http://www.parl.gc.ca/37/2/parlbus/commbus/senate/com-e/bank-e/rep-e/rep12jun03-e.pdf>.

Toronto Stock Exchange Committee on Corporate Governance in Canada. Where Were the Directors? (Toronto: Toronto Stock Exchange, 1994).

SECONDARY MATERIAL: OTHER MATERIALS - United States

“The Biggest Bankruptcy Ever” Time (06 July 1970).

AICPA, 2010-2011 Annual Report, online: AICPA, <http://www.aicpa.org/About/AnnualReports/Pages/2010-2011AICPAAnnualReport.aspx $>$.

Andrews, Edmund L \& Peter Baker. "A.I.G. Planning Huge Bonuses After \$170 Billion Bailout" The New York Times (15 March 2009) A1.

Black, Lewis S. Why Corporations Choose Delaware (Delaware Department of State Division of Corporations, 2007), online: Delaware Department of State

<http://corp.delaware.gov/whycorporations_web.pdf $>$.

Buncombe, Andrew. "The WorldCom Scandal: Directors Asked How They Failed to Spot

Fraud" BNET.com (28 June 2002), online: BNET.com

<http://findarticles.com/p/articles/mi_qn4158/is_/ai_n12620440 $>$. 
Cook, Frederic W \& Co Inc. 2011 Director Compensation (November 2011), online: Deloitte <http://www.fwcook.com/alert_letters/2011_Director_Compensation_\%20NonEmployee_Director_Compensation_Across_Industries_and_Size.pdf> .

Feuerstein, Adam. "WorldCom's Watchdogs Were Aslee” TheStreet.com (27 June 2002), online: TheStreet.com < http://www.thestreet.com/tech/adamfeuerstein/10029259.html > .

Heinzl, Mark \& Ken Brown. "Nortel Unveils New Accounting Flubs - Company Details McLean, Bethany. "Why Enron Went Bust” Fortune (24 December 2001).

Mistakes, Says Executives Will Return Millions in Bonus Payments", The Wall Street Journal (12 January 2005) A3.

Hulse, Carl \& David M Herszenhorn. "House Approves 90\% of Tax on Bonuses After Bailouts" The New York Times (20 March 2009).

NASDAQ OMX, About Us, online: NASDAQ, 〈http://www.nasdaqomx.com/aboutus/>.

New York Stock Exchange, Frequently Asked Questions, online: NYSE <http://www.nyse.com/content/faqs/1050241764950.html $>$.

Romero, Simon \& Riva D Atlas. "WorldCom Files for Bankruptcy; Largest U.S. Case", Wall Street Journal (22 July 22 2002) A3.

United States Bankruptcy Court Southern District of New York, First Interim Report of Dick Thornburgh, Bankruptcy Court Examiner (4 November, 2002), online: FindLaw <http://fl1.findlaw.com/news.findlaw.com/hdocs/docs/worldcom/thornburgh1strpt.pdf $>$.

US Department of Justice, News Release, “Fact Sheet: President's Corporate Fraud Task Force Marks Five Years of Ensuring Corporate Integrity" (17 July 2007), online: Department of Justice <http://www.justice.gov/opa/pr/2007/July/07_odag_507.html>.

US The Permanent Subcommittee on Investigations of the Committee on Governmental Affairs United States Senate. The Role of the Board of Directors in Enron's Collapse (S Prt 107-70)

(Washington, DC: United States Government Printing Office, 2002).

Worrell, Kay. Corporate Directors' Compensation 1, Conference Board Report No. 1140-95-RR (1996). 